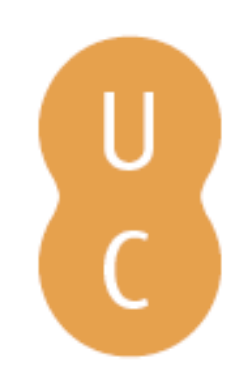

\title{
pommalina
}

\section{Homenaje a la Profesora María Luisa Picklesimer (In memoriam)}

Publicado por: Centro de Estudos Clássicos e Humanísticos da Universidade de Coimbra; Imprensa da Universidade de Coimbra

URL persistente:

URI:http://hdl.handle.net/10316.2/9725

DOI:

DOI:http://dx.doi.org/10.14195/978-989-721-024-2

Accessed : $\quad$ 26-Apr-2023 14:25:38

A navegação consulta e descarregamento dos títulos inseridos nas Bibliotecas Digitais UC Digitalis, UC Pombalina e UC Impactum, pressupõem a aceitação plena e sem reservas dos Termos e Condições de Uso destas Bibliotecas Digitais, disponíveis em https://digitalis.uc.pt/pt-pt/termos.

Conforme exposto nos referidos Termos e Condições de Uso, o descarregamento de títulos de acesso restrito requer uma licença válida de autorização devendo o utilizador aceder ao(s) documento(s) a partir de um endereço de IP da instituição detentora da supramencionada licença.

Ao utilizador é apenas permitido o descarregamento para uso pessoal, pelo que o emprego do(s) título(s) descarregado(s) para outro fim, designadamente comercial, carece de autorização do respetivo autor ou editor da obra.

Na medida em que todas as obras da UC Digitalis se encontram protegidas pelo Código do Direito de Autor e Direitos Conexos e demais legislação aplicável, toda a cópia, parcial ou total, deste documento, nos casos em que é legalmente admitida, deverá conter ou fazer-se acompanhar por este aviso.

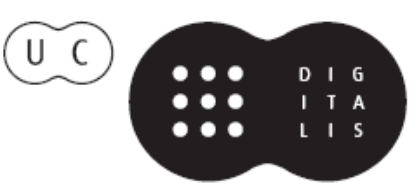




\section{Homenaje a la Profesora María Luisa Picklesimer (In memoriam)}

M.a Nieves Muñoz Martín, José A. Sánchez Marín (eds.) 


\section{Homenaje a la Profesora María Luisa Picklesimer}

(In memoriam)

M. ${ }^{a}$ Nieves Muñoz Martín, José A. Sánchez Marín (eds.) 


\section{Editores}

M. ${ }^{a}$ Nieves Muñoz Martín, José A. Sánchez Marín (eds.)

Título

Homenaje a la Profesora María Luisa Picklesimer

EDITOR

Centro de Estudos Clássicos e Humanísticos da Universidade de Coimbra

Imprensa da Universidade de Coimbra

EDICIÓN

1a/ 2012

Coordinador Científico Editorial

Maria do Céu Fialho

Consejo Editorial

José Ribeiro Ferreira, Maria de Fátima Silva, Francisco de Oliveira e Nair Castro Soares

Director Técnico de la Colección

Delfim F. Leão

Concepción Gráfica y Maquetación

Rodolfo Lopes, Nelson Ferreira

IMPRESIÓN:

Simões \& Linhares, Lda. Av. Fernando Namora, n.o 83 Loja 4. 3000 Coimbra

ISBN: 978-989-721-023-5

ISBN DigitAL: 978-989-721-024-2

DOI: http://dx.doi.org/10.14195/978-989-721-024-2

Depósito Legal: 352437/12

(C) IMPRENSA DA UNIVERISDADE DE COIMBRA

(C) Centro de Estudos Clássicos e Humanísticos da Universidade de Coimbra,

(C) Classica Digitalia Vniversitatis Conimbrigensis (http://classicadigitalia.uc.pt)

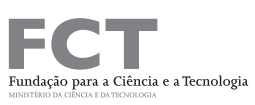

$\mathrm{POCI} / 2010$

Reservados todos los derechos. En términos legales, queda expresamente prohibida la reproducción total o parcial por cualquier medio, ya sea en papel o en edición electrónica, sin autorización expresa de los titulares de los derechos. Queda excluida de esta prohibición la utilización en circuitos académicos orientados a la enseñanza o a la extensión cultural por medio del e-learning. 


\section{ÍNDICE GENERAL}

Prólogo

Recreaciones del Mito de Antígona en el teatro del exilio español de 1939. I:

María Zambrano, La Tumba de AntíGona

J. M. ${ }^{a}$ Camacho Rojo (Universidad de Granada)

El Mito Clásico en los historiadores de Indias

J. M. ${ }^{a}$ Camacho Rojo \& P. P. Fuentes González (Universidad de Granada)

CONSIDERACIONES SOBRE LA SÍNCOPA DE -Ǐ Y -Ǒ EN SÍLABA FINAL CERRADA EN LATÍN

M. del Castillo Herrera (Universidad de Granada)

El Tratado ars musyce indebidamente atribuido a Santo Tomás de Aquino

(Traducción y NOTAS)

P. R. Díaz Díaz (Universidad de Granada)

La presencia de Fedra e Hipólito en la lírica alemana

B. L. Emberger (Universidad de Granada)

BREVITAS, LONGITUDO, ETC., COMO TECNICISMOS PROSÓDicos

F. Fuentes Moreno (Universidad de Granada)

Mito y religión en el DE die natali de Censorino

M. ${ }^{a}$ Del C. Hoces Sánchez (Universidad de Granada)

Los doce trabajos de Hércules en la literatura medieval española

L. Jiménez Justicia (Universidad de Granada)

Mario Vargas Llosa y el escándalo interminable de Fedra

A. López - A. Pociña (Universidad de Granada)

Ecos de los ClÁsicos en el teAtro Rioplatense (siglo XIX)

C. López Rodríguez (Universidad de Granada)

Sílabas LARGAS POR BREVES Y BREVES POR LARGAS: LOS NOMBRES PROPIOS

J. Luque Moreno (Universidad de Granada)

LA FUNCión LITERARIA DE LA TRAdición CLÁSICA EN LAS PRIMERAS NOVELAS DE PALACIO VALDÉS

C. de Miguel Mora (Universidad de Granada)

M. Molina Sánchez (Universidad de Granada) 
E. M. ${ }^{a}$ Morales Rodríguez (Universidad de Granada)

El Mito a LA PALESTRA.

Los juegos antiguos en la poÉtica de Escalígero y en la mitología de Natale Conti

M. ${ }^{a}$ N. Muñoz Martín - J. A. Sánchez Marín (Universidad de Granada)

Memorial de don señor Pedro González de Mendoza al rey Felipe Tercero en RAZÓN DE LA EXPULSIÓN DE LOS MORISCOS CON EL OFICIO Y MISA

L. L. Padilla Mellado (Universidad de Granada)

El encomio a San Hieroteo de la Abadía del Sacromonte: transcripción y TRADUCCIÓN

Paraskevi Gatsioufa (Universidad de Granada)

Reflexiones Sobre LAS SAgAS Míticas EN LA TRAgEDIA GRIEGA

H.F. Pastor Andrés- M. Pastor Muñoz (Universidad de Granada)

La figura de Heracles en algunos autores del siglo IV D.c.

A. J. Quiroga Puertas (Universidad de Granada)

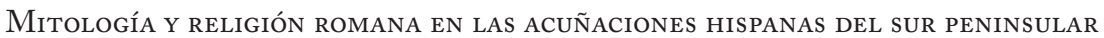

I. D. Ruiz López (Universidad de Granada)

De regresso à Lesbos de Safo

Atardecer en Mitilene de A. Pociña

M. ${ }^{\text {F }}$. de Sousa e Silva (Universidad de Granada) 


\section{Prólogo}

Todas quisimos ser Rhea Silva. Queremos empezar estas páginas evocando la experiencia infantil, de una niña de doce años, que debió afectar profundamente la imaginación de nuestra querida amiga y tal vez la marcara para siempre, según puede deducirse de las emotivas palabras que ella misma escribió ("Vestalis illa" ..., p. 194). Asistía a una función escolar de teatro en su instituto, donde las compañeras de curso, dirigidas por una joven y entusiasta profesora, representaban la trágica historia de la madre del fundador de Roma.

En Enero de 2010, un suceso doloroso golpeó el ánimo y las vidas de quienes contamos tanto tiempo con la presencia de una especial compañera y amiga. De repente nos dejó María Luisa. La rutina de la vida universitaria no logra disipar en muchos de nosotros la añoranza de su persona. Compañía discreta, juicio agudo, pocas veces la vimos decaer, ni en los momentos más difíciles, de sus inquietudes pedagógicas e investigadoras, que algunos compartíamos más estrechamente.

Integrada en nuestros proyectos y Grupo de Investigación desde sus inicios, hemos querido ofrecerle aquí el testimonio de nuestro recuerdo más cariñoso, y la participación de sus colegas y amigos de los Departamentos de Filología Latina, Filología Griega e Historia Antigua de la Universidad de Granada. Este homenaje se suma al que, de modo más inmediato, se le dispensó en la revista que, resultado de la colaboración de estos tres departamentos, siempre contó con su presencia fiel, Florentia Iliberritana. En el número 21 de ésta, que amoldó en parte su estructura a la penosa ocasión, apareció, abriendo la serie de trabajos, el último que María Luisa elaboró. 
El volumen que aquí se ofrece, pronta y generosamente acogido por sus autores, ha sido preparado y editado por el Grupo de Investigación al que perteneció María Luisa, contando con la ayuda del Departamento de Filología Latina, también el de ella. Los editores estimamos como fruto de un profundo conocimiento personal y universitario la imagen que de ella trazó el Profesor Pociña, que hacemos nuestra, unida al recuerdo imborrable de tantas horas vividas en su compañía y afecto. Estamos seguros de que este recuerdo será compartido igualmente por quienes la conocieron en el ámbito personal o profesional.

Hemos querido, además, dejar constancia, ante la comunidad universitaria más próxima, la de Granada, y otra más amplia, de su quehacer incansable de investigadora, cumplido como deber de toda una vida, y realizado a conciencia. Testimonio público y póstumo de una profesora que entendió la calidad universitaria como exigente tarea personal hasta el final de sus días.

Numerosos trabajos avalan los intereses investigadores de la profesora M. ${ }^{\mathrm{a}}$ Luisa Picklesimer. Presentó su tesis doctoral titulada La ascendencia indoeuropea de la figura de Herakles, ya en la línea de los estudios mitológicos, a la que se dedicó de modo preferente, alternándola con otras publicaciones de distintos contenidos: historia legendaria, traducción de textos, literatura clásica y renacentista, teoría poética, estudios de instituciones indoeuropeas y de la mujer en la literatura. Así puede comprobarse en la bibliografía seguidamente relacionada, organizada cronológicamente y que pretendemos que sea exhaustiva. Toda ella se ve enriquecida por la profunda y especial perspectiva adquirida durante toda su vida, apoyada en un manifiesto conocimiento de las fuentes.

1. “Ciane o la conciencia de Plutón”, Estudios Filosóficos 27 (1976) 433-439.

2. "Proserpina. La imagen de la heroína joven en las "Metamorfosis" de Ovidio", Arbor: Ciencia, Pensamiento y Cultura (1976) 341-350.

3. "Hércules fue vencido en Sagunto (comentario a Silio Itálico)", Estudios de Filología Latina en honor de la Profesora Carmen Villanueva Rico, Granada, Universidad, 1980, pp. 147-163.

4. "Una 'leyenda-tipo': la traición por amor”, Sodalitas 2 (1981) 325-345.

5. "El papel de Herakles en el teatro greco-latino", en Actas del I Congreso Andaluz de Estudios Clásicos, Jaén, Instituto de Estudios Giennenses, 1982, pp. 357-360. 
6. "El papel de Herakles en la Alcestis de Eurípides", Sodalitas 3 (1983) 295-312.

7. La ascendencia indoeuropea de la figura de Herakles. Resumen de Tesis Doctoral. Universidad de Granada, Granada 1983.

8. "Hércules en Virgilio", Estudios de Filología Latina 3 (1983) 139-153.

9. “Propercio I,20”, Estudios de Filología Latina 4 (1984) 217-234.

10. "Elementos folklóricos en la mitografía de Herakles", Gallaecia 7-8 (1984) 11-22.

11. "La 'gran guerra' en la tradición indoeuropea”, Actas del II Congreso andaluz de Estudios Clásicos I, Málaga, Universidad, 1988, pp. 239-243.

12. "Hércules en Ovidio", en Studia graecolatina C. Sanmillán in honorem dicata, Granada, Universidad, 1988, pp. 339-348.

13. "La novia que llegó del mar", Florentia Iliberritana 1 (1990) 359-371.

14. "El papel de la mujer en la Guerra Mítica", en La mujer en el mundo mediterráneo antiguo, Granada, Universidad, 1990, pp. 11-26.

15. “Apolo Smintheus y dos cultos de Herakles", Florentia Iliberritana 2 (1991) 409-419.

16. "Vestalis illa", en Estudios de Filologia Latina en honor del Profesor Gaspar Lachica Cassinello, Granada, Universidad, 1991, pp. 193-206.

17. "Tres guerras entre las ciudades aqueas a través del mito", en In memoriam J. Cabrera Moreno, Granada, Universidad, 1992, pp. 387-405.

18. "El tratamiento del mito en la literatura del Humanismo. I", en Humanismo renacentista y mundo clásico, [ed. J.A. Sánchez Marín], Granada, Universidad, 1992, pp. 301-312.

19. "El tratamiento del mito en la literatura del Humanismo. II" en Humanismo renacentista y mundo clásico [ed. J.A. Sánchez Marín], Granada, Universidad, 1992, pp. 313-330.

20. “Teseo, Herakles y el cinturón de la amazona”, Florentia Iliberritana 3 (1992) 503-515.

21. "Hipodamia: el derecho a enamorarse de la mujer mítica", Florentia Iliberritana 4 (1993) 417-435.

22. "La risa de los dioses y el trono trucado de Efesto" Florentia Iliberritana 7 (1996) 265-289.

23. "Tradiciones míticas sobre el origen de la poesía en el De poetica de Viperano" en Humanismo y pervivencia del mundo clásico. Homenaje al 
Profesor Luis Gil, J.M. ${ }^{a}$ Maestre Maestre, J. Pascual Varea, L. Charlo Brea, eds., Cádiz, Instituto de Estudios Turolenses, 1997, pp. 349-356.

24. "La doble función del perro Argos en la Odisea", Florentia Iliberritana 8 (1997) 401-419.

25. "Alusiones mitológicas en el libro $\mathrm{X}$ de Columela", en Estudios sobre Columela, eds. J. M. a Maestre et alii, Cádiz, Universidad, 1997, pp. 159-165.

26. "La seducción por el atuendo en el mito griego" en Moda y sociedad. Estudios sobre: educación, lenguaje e historia del vestido. E.J. García Wiedemann, Ma I. Montoya Ramírez, eds., Granada, Universidad, 1998, pp. 509518.

27. “Antígona: de Sófocles a María Zambrano”, Florentia Iliberritana 9 (1998) 347-376.

28. "El ciclo épico troyano a la luz del Mahabharata", en Religión, Magia y Mitología en la Antigüedad Clásica, J.L. Calvo Martínez, ed., Granada, Universidad, 1998, pp. 167-200.

29. "Valoración de Homero en el De Poetica de Viperano", CongresoInternacional sobre Humanismo y Renacimiento I. Coord. M. Pérez González, León, Universidad, 1998, pp. 591-597.

30. "Ovidio, 11 de junio: la creación literaria de un episodio mítico", en Filología latina hoy. Actualización y perspectivas I, eds. A.M. Aldama et alii, Madrid, Sociedad de Estudios Latinos, 1999, 217-224.

31. "El mar en los Carmina de Giovanni Antonio Viperano", Florentia Iliberritana 10 (1999) 263-286.

32. "Ismene, una figura incomprendida", Florentia Iliberritana 11 (2000) 215225.

33. Carmina, Madrid, Ediciones Clásicas, 2001.

34. "E1 color púrpura (color y función en el mundo indoeuropeo)" en II Jornadas Internacionales sobre moda y sociedad. Las referencias estéticas de la moda. Ma. I. Montoya Ramírez, ed., Granada, Universidad, 2001, pp. 293-304.

35. "De diosas, ninfas y hadas (a propósito de Egeria)", Florentia Iliberritana 13 (2002) 199-224.

36. "El atuendo en la poesía laudatoria: los Carmina de G.A. Viperano", en Moda y Sociedad. La indumentaria: estética y poder. Ma I. Montoya Ramírez, ed., Granada, Universidad, 2002, pp. 393-403. 
37. “Teoría de la bucólica en el De Poetica de Viperano”, en Retórica, poética y géneros literarios. J.A. Sánchez Marín, Ma . N. Muñoz Martín, eds., Granada, Universidad, 2004, pp. 367-386.

38. "La fuente en el bosque (a propósito de las Camenas)", Florentia Iliberritana 15 (2004) 279-313.

39. "Las Musas y Apolo en los poetas latinos", Ad amicam amicissime scripta: Homenaje a la Profesora Dña. María JoséLópez de Ayala, Madrid, UNED, 2005, pp. 359-367.

40. "Una égloga de Viperano dedicada a Benito Arias Montano”, Benito Arias Montano y los humanistas de su tiempo, eds. J. M. ${ }^{a}$ Maestre Maestre et alii, Cáceres, Instituto de Estudios Humanísticos, 2006, pp. 887-898.

41. "Y yo estoy sacrificando (a propósito de Numa I)" Florentia Iliberritana 17 (2006) 225-258.

42. "Dos fundadores y un rey (a propósito de Numa II)", Florentia Iliberritana 18 (2007) 363-397.

43. "El poeta ante su obra", Ágora. Estudos Clássicos em Debate. Júlio César Escalígero 9.1 (2007) 61-98.

44. "E1 Panegírico de Mesala del Corpus Tibullianum", en En Grecia y Roma, II. Lecturas pendientes. A. Pociña Pérez, J.M. García González, eds. Granada, Universidad, 2008, pp. 253-268.

45. “¿Quién fue Franciscus Lupius?”, en La Filología Latina. Mil años más II. P.P. Conde e Isabel Velázquez eds., Sociedad de Estudios Latinos, [Burgos] Fundación Instituto Castellano y Leonés de la Lengua-SELat, 2009, pp. 1151-1161.

46. "Hersilia”, en En Grecia y Roma, III. Mujeres reales y ficticias. A. Pociña Pérez, J.Ma García González, eds. Granada, Universidad, 2009, 349365.

47. "El último exilio de Medea. (Una relectura de Medea en Camariñas de Andrés Pociña)", Florentia Iliberritana 21 (2010) 15-29.

Granada, abril 2012

M. ${ }^{a}$ Nieves Muñoz Martín José A. Sánchez Marín 
(Página deixada propositadamente em branco) 


\title{
Homenaje a la Profesora Maria Luisa Picklesimer
}

\author{
IN MEMORLAM
}




\title{
Recreaciones del mito de Antígona en El teatro del EXILIO ESPAÑOL DE 1939.
}

\author{
I: María Zambrano, La TUMba DE ANTÍGONA ${ }^{\mathrm{I}}$ \\ José María Camacho Rojo \\ Universidad de Granada
}

\begin{abstract}
"El milagro griego es ante todo el prodigioso poetizar del hombre, poetizar siempre aun en la filosofía para apresar adecuadamente lo divino encerrado en el cosmos oscuro, en el cielo adverso, en la tierra gimiente".

(María Zambrano, La luz de la Acrópolis)
\end{abstract}

\section{InTRODUCCIón}

\subsection{El mito de Antígona en la literatura}

Como es sabido, el número de recreaciones, adaptaciones y referencias directas o indirectas al mito de Antígona en la literatura (drama, poesía y prosa) desde la Antigüedad a nuestros días es prácticamente inabarcable. Prueba fehaciente de esta afirmación es el ingente material recogido en los laboriosos y detallados estudios sobre la pervivencia, recepción y recreación de este mito en las literaturas occidentales, trabajos en los que es una constante el reconocimiento por parte de sus autores de la imposibilidad material de hacer un inventario, de recopilar y analizar de modo exhaustivo todas las reescrituras que se han hecho y vienen haciéndose de este mito ${ }^{2}$. Los motivos de tan elevado y variado número de adaptaciones, versiones, recreaciones, $\mathrm{y}$ transmutaciones de Antígona son tan diversos como complejos ${ }^{3}$. Todos somos conscientes de que la Antígona de Sófocles es, según el preciso y acertado juicio de George Steiner, "uno de los hechos perdurables y canónicos en la historia de nuestra conciencia filosófica, literaria y política [...], una obra de arte más cercana a la perfección que cualquier otra producida por el espíritu humano". Pero, al margen de su indiscutida calidad estética, Steiner sugiere una posible clave para entender la eternidad simbólica de Antígona: sólo este texto literario presenta todos los constantes antagonismos propios de la condición del hombre: hombre/mujer, senectud/juventud, individuo/sociedad, vivos/ muertos, hombre/Dios-dioses (Steiner 179). En esta amplitud semántica se encuentra, sin duda, su riqueza significativa y su aparentemente inagotable posibilidad de contemporaneidad, de modo que el texto clásico de Sófocles se convierte en el hipotexto originario, en fuente inagotable de hipertextos que mantienen conexiones esenciales de intertextualidad. 
Los fundamentos mismos de la civilización y del arte occidental son míticos. Habiendo tomado de la Hélade los elementos esenciales de la racionalidad, de las instituciones políticas y de las formas estéticas, hemos tomado también la mitología, de la cual esos elementos adquirieron su validez y su historia simbólica. La literatura griega es la primera que reconocemos y experimentamos como literatura. Su identificación con los mitos es tan directa y fértil que la mitología helénica se ha convertido en un constante y central punto de referencia para la ulterior creación poética y alegoría filosófica. La razón última del eterno retorno del mito radica en que en la tragedia griega la dimensión de la trascendencia es esencial y en el mito se materializa el potencial de finalidad al posponer su realización en virtud de la ambigüedad, del error y del conflicto. En el mito hay que aguardar siempre su significación. Esta expectación no resuelta da origen a la tragedia griega y la deja inagotablemente abierta a nuestras necesidades de comprensión. Es, por tanto, el mito y su trascendencia lo que genera e impone la dinámica de la repetición de las preguntas a través del tiempo ${ }^{4}$.

\subsection{El mito de Antígona en el teatro español contemporáneo}

El fenómeno contemporáneo de adaptaciones dramáticas de mitos clásicos hay que situarlo en la referida tendencia general de los autores de la tradición occidental a recurrir a los temas arquetípicos de la tragedia griega, en especial a partir del período de entreguerras ${ }^{5}$. Al mismo tiempo hay que destacar que en épocas de conflicto y censura los motivos míticos ofrecen la posibilidad de tratar, de manera indirecta, temas que, de otro modo, serían de difícil planteamiento en la literatura. En consonancia con estas dos observaciones se explica el reiterado recurso al mito de Antígona en España después de la Guerra Civil': las obras inspiradas en la heroína clásica se suceden a partir de 1939; la tendencia continúa a lo largo de la dictadura, se extiende hasta la transición y perdura y adquiere nuevas formas y significados con la consolidación de la democracia ${ }^{7}$. De hecho, como bien observa Ragué Arias, "el personaje femenino griego más utilizado en el siglo XX en el teatro español es sin duda Antígona".

\subsection{El mito de Antígona en el teatro español del exilio}

Si estudiamos cronológicamente el desarrollo del mito de Antígona en el teatro español del siglo XX, puede apreciarse con facilidad que en las diferentes versiones producidas en sucesivas etapas se operan transformaciones en la interpretación del dilema político y social que plantea la tragedia en función del contexto histórico y de la matriz ideológica en que se inscribe.

Una de las primeras adaptaciones de la tragedia de Sófocles fue la de José Ma Pemán, obra que constituye un claro ejemplo de la utilización del 
mito por parte del teatro de la dictadura y régimen franquista, en cuyo marco cultural cobra sentido. Situada la acción en la Tebas clásica, la versión no se presenta como una alusión directa a la guerra civil y al contexto de la posguerra: los personajes preservan los nombres de la antigua tragedia, se mantiene el argumento original y se plantea de nuevo el conflicto entre ley religiosa y razón política, elevando los recientes acontecimientos de la historia de España al rango universal de tragedia y equiparando la guerra civil con los hechos heroicos de la época clásica9 ${ }^{9}$.

Un tratamiento diferente del mito ofrecen las sucesivas recreaciones escritas por autores del exilio español republicano de 1939. Con el presente trabajo pretendemos ofrecer una actualización y revisión de la bibliografía existente y de las interpretaciones del empleo del tema de Antígona en el teatro del exilio desde las motivaciones, aportaciones e interpretaciones que cada autor ofrece a partir de su particular y peculiar experiencia del exilio ${ }^{10}$. Se trata, en definitiva, de un estudio general y sintético de la reinterpretación de este mito, como recurso temático común, en los siguientes autores y obras, citadas por orden cronológico de publicación: María Zambrano, La tumba de Antígona (1967); José Bergamín, La sangre de Antígona. Misterio en tres actos (publicada en 1983, aunque escrita en su exilio parisino en 1955), y José Martín Elizondo, Antígona entre muros (publicada en 1988, pero escrita, con el título de Antígona y los perros, durante su exilio en Toulouse en 1969) ${ }^{11}$. Presentamos aquí la primera de las tres partes del estudio, la dedicada a la obra de Zambrano.

\section{María Zambrano: La tumba de Antígona}

\subsection{Texto: ediciones}

Es también Antígona el mito y el personaje de la tragedia de Sófocles que más atención mereció por parte de Zambrano, hasta el punto de que le dedicó su único drama, La tumba de Antígona, una obra escrita durante su exilio en La Pièce, en el Jura francés ${ }^{12}$ y publicada en México en 1967.

La relevancia que Zambrano concedió a este mito se constata en otros textos de la autora. Su primer acercamiento al tema es anterior al drama. Se trata del Delirio de Antígona, un ensayo escrito en Cuba durante los años del exilio y publicado en 1948 en la revista Orígenes ${ }^{13}$, integrado por un prólogo y un «Delirio primero», en el que la autora reflexiona sobre la figura mítica, esbozando algunos de los rasgos y transformaciones respecto a la versión clásica que desarrollaría posteriormente en la obra teatral, cuya alteración y novedad fundamental radica en su desenlace y en la ruptura con el final de la tragedia sofoclea, el suicidio de Antígona en su tumba, acción interpretada tradicionalmente como coherente con el carácter impulsivo y heroico de Antígona por cuanto que, al precipitar de modo voluntario el final de su vida, impedía que Creonte lograra la satisfacción de verla agonizar hasta 
morir ${ }^{14}$. La novedad de esta versión es que la heroína no se suicida ni muere, sino que queda "en el confín de la vida con la muerte" (Zambrano 264). La alteración, en efecto, está ya señalada en el ensayo Delirio de Antígona ${ }^{15}$. Es ratificada luego en el prólogo de la obra, donde Zambrano matiza otras claves de su temprana reflexión: "Antígona, en verdad, no se suicidó en su tumba, según Sófocles, incurriendo en un inevitable error, nos cuenta. Mas ¿podía Antígona darse la muerta, ella que no había dispuesto nunca de su vida? No tuvo siquiera tiempo para reparar en sí misma" (Zambrano 201). Inevitable error "porque Sófocles, como cualquier hombre y mujer de la Antigüedad, estaba en la consuetudinaria creencia de que la única salida ante una situación trágica era la muerte" ${ }^{16}$.

La autora vuelve de nuevo al personaje de Antígona en Delirio y destino, un libro calificado por Maillard como su "biografía personal", publicado en 1989, pero escrito en Cuba casi cuarenta años antes, cuya primera parte cierra Zambrano con un capítulo dedicado a su hermana Araceli, a la que identifica con Antígona. Por último, reflexiona también sobre ella en «El personaje autor: Antígona», texto incluido en El sueño creador (1965), muy cercano por su contenido a la tragedia ${ }^{17}$.

Publicada por primera vez en Méjico, en 1967 [1], la obra ha conocido varias reediciones, alguna con variantes. En 1967 hubo también otra edición, en la Revista de Occidente, en la que faltan los cuatro últimos párrafos [2]. Una bella publicación es la de Litoral, en 1983, que incluye La tumba de Antígona y Diotima de Mantinea [3]. En el tomo I figura un retrato de María Zambrano por José María Prieto, una introducción de Carmen Saval Prados y el texto "La Antígona de María Zambrano" de Julia Castillo. En la sección dedicada a Diotima de Mantinea aparece un dibujo de Pablo Picasso. El tomo II ( Papeles para una poética del ser») es un excelente homenaje en el que colaboran, entre otros, José Ángel Valente, Jorge Guillén, José Luis López Aranguren y Antonio Colinas. Siguió la edición de Senderos (Los intelectuales en el drama de España. La tumba de Antígona), publicada en Barcelona, en 1986, con prólogo especial de la autora, escrito en 1985 [4]. Las últimas ediciones son la publicada por la editorial Mondadori en la colección "Ensayo" (1989) [5] y la versión de Alfredo Castellón editada por la Sociedad General de Autores y Editores en 1997 [6]. Ha sido traducida al italiano por Carlo Ferrucci en 1995, precedida de un ensayo de Rosella Prezzo [7].

\subsection{LA OBRA}

\subsubsection{Tratamiento del tema: Zambrano/Sófocles}

La obra de Zambrano es una versión del mito en la que confluyen su reflexión acerca de la función y el sentido del género trágico y su larga “convivencia” personal con el personaje de Antígona ${ }^{18}$. La pensadora malagueña 
parte de la general aceptación del mito clásico transmitido y consagrado por Sófocles, pero en su obra encontramos tres significativas alteraciones que transcienden al propio personaje: voz (protagonismo), tiempo y espacio.

Voz:"-¿Quieres decir que va a seguir aquí sola, hablando en alta voz, muerta hablando a viva voz para que todos la oigamos? ¿Es que va a tener vida, y voz? -Sí; vida y voz tendrá mientras siga la historia [...] Mientras haya hombres hablará sin descanso [...], en el confín de la vida con la muerte" (Zambrano 264; el subrayado es nuestro). En primer lugar, la autora no muestra el drama de Antígona previo a su enterramiento en vida y decide dar la voz a la heroína, con lo que resuelve, de forma definitiva, el protagonismo de la obra en favor de Antígona, protagonismo que, según algunas interpretaciones, le disputa Creonte en la tragedia clásica. En la obra de Zambrano, por el contrario, la voz protagonista de Antígona es central y absoluta, por lo que, de hecho, el papel de Creonte se ve drásticamente reducido. Con esta alteración, el centro de atención del conflicto se desplaza, en buena medida, de la actitud de la protagonista frente al poder público establecido hacia su propio sacrificio motivado por el amor y la piedad, que cierra el trágico destino de una familia marcada por el incesto. En consecuencia, el nuevo equilibrio planteado redunda en una interpretación existencial que viene a sumarse a la lectura histórica y política de esta obra: "Y su presencia se hace una [...]; una conciencia intangible, una voz que surge una y otra vez. Mientras la historia [...] prosiga [...], Antigona seguirá delirando $[\ldots]^{19}$. Y no será extraño así que alguien escuche este delirio y lo transcriba lo más fielmente posible" (Zambrano 220-221; el subrayado es nuestro).

Tiempo: "Y el suplicio al que Antígona fue condenada parece dado adrede para que tenga tiempo...". La segunda alteración del drama es el ya mencionado rechazo del suicidio de Antígona con la finalidad de darle tiempo 20 , “... un tiempo indefinido para vivir su muerte, para apurarla apurando al par su vida, su vida no vivida y con ella, al par de ella, el proceso trágico de su familia y su ciudad" (Zambrano 205; el subrayado es nuestro). De este modo, Zambrano puede ofrecernos su personal indagación y hallazgo de las claves del personaje, "destacando en ella la fraternidad vivida como pasión absoluta, el sacrificio de la propia vida en nombre de una ética superior a la ley impuesta por el poder y la concepción de la historia personal y colectiva como destino inexorable"21.

Espacio: "Se le dio una tumba [...] Y más que muerte, tránsito" (Zambrano 205; subrayado nuestro). El tercer cambio fundamental es el nuevo espacio en el que se desarrolla la obra. Del palacio real de Tebas en el que Sófocles sitúa la acción pasamos a la tumba en la que la protagonista ha sido enterrada viva. La importancia del espacio en la concepción de la obra lo confirma y corrobora el título mismo, La tumba, convertida aquí "en símbolo del exilio, del no-lugar, 
del lugar que está más allá de la vida y más acá de la muerte”, símbolo mediante el cual Antígona pasa a ser la exiliada arquetípica.

La obra se plantea, por tanto, como la continuación del momento en el que en la tragedia de Sófocles Antígona es encerrada en la cueva-tumba a la espera de su final; pero, al obviarse el suicidio, "Antígona se halla en un estado suspenso entre la vida y la muerte que no ha detenido el tiempo, que ha corrido paralelo a la acción de la tragedia sofoclea”. Se inicia la obra, pues, tras la muerte de Hemón, por lo que las interrelaciones con Antígona (y con Edipo Rey) de Sófocles, aunque implícitas y sugeridas levemente, son imprescindibles para la comprensión del texto de Zambrano. Se abre con un monólogo de Antígona que nos sitúa en la acción: encerrada viva en una cueva que ha de ser su tumba, espera una muerte que no ha de llegar, como se hallaba la sofoclea ${ }^{22}$, hasta que sea consciente del sentido de su muerte. Con la llegada de la noche recuerda a su hermana Ismene que quiso acompañarla, pero a la que Antígona no dejó, como tampoco lo permitió la sofoclea ${ }^{23}$. Se presentan después en su morada los fantasmas de los personajes del mito, los familiares a los que, con su sacrificio, Antígona ha redimido: Edipo ${ }^{24}$, la sombra de Yocasta, los hermanos (Etéocles y Polinices ${ }^{25}$ ), Hemón, Creón y otros "tomados de otras obras como Ana, la nodriza, que representa la inocencia de la infancia en la que no hay consciencia, un personaje que recuerda a la nodriza de Anouilh, o creados como la Harpía que representa lo contrario y define a Antígona como una araña tejedora de razones, marcando el camino que sigue Antígona desde la inocencia hasta la consciencia. Finalmente, Antígona se queda de nuevo sola consigo misma y reflexiona sobre lo que ha acontecido. Se duerme y aparecen en escena dos desconocidos, representación de la lucha entre la vida y la muerte, que quieren llevársela consigo, uno dándole la vida; el otro, la muerte ${ }^{26}$. No pudiendo escapar ni viva ni muerta de su propia historia, sólo el Amor, al que invoca al final de la obra $^{27}$, y la Piedad, móviles también en el caso de la Antígona de Sófocles ${ }^{28}$, pueden ofrecerle descanso ${ }^{29}$.

\subsubsection{Estructura}

\subsubsection{Ensayo/drama: un género literario híbrido}

En el prólogo de La tumba de Antígona Zambrano afirma que "entre todos los protagonistas de la Tragedia griega, la muchacha Antígona es aquella en quien se muestra, con mayor pureza y más visiblemente, la trascendencia propia del género" (202). En el mismo prólogo, inmediatamente después, define la tragedia griega como el género "donde lo divino se entremezcla a lo humano” (206), como el género de la trascendencia ${ }^{30}$, una tragedia que, en el caso de la obra de la pensadora malagueña, se impregna de poesía y pertenece en sentido estricto a la categoría de "poesía dramática", utilizando un 
término que ella misma emplea en ocasiones. Estamos, efectivamente, ante un texto de naturaleza genérica compleja, clasificado a veces dentro del conjunto de su producción filosófica, sin reparar en su condición teatral. El tema de Antígona ha fascinado y cautivado, en efecto, a representantes de ambos géneros, el filosófico y el dramático. El teatro es el más recurrente, pero del mito han tratado también muchos filósofos, Hegel, Kierkegaard y Heidegger, entre otros. Y no faltan los géneros híbridos: ésta es la elección hecha por $Z_{\text {ambrano }}{ }^{31}$. Es la suya una obra atípica, difícil de clasificar en un género bien definido en la literatura occidental (Moraglio 34-35). Sin embargo, a pesar de la inclusión de un fragmento narrativo o prólogo y del marcado carácter lírico de sus monólogos y diálogos, la obra tiene una estructura, como se ha visto, básicamente teatral: ofrece, en efecto, una división en "escenas" y algún ejemplo aislado de acotación. Como señala Nieva de la Paz, la práctica inexistencia de didascalia se suple con la información escénica que proporciona el mismo texto: la palabra crea el espacio (la cueva-tumba), marca también el transcurso del tiempo (el paso del día a la noche) y da entrada a los diversos interlocutores de Antígona (Edipo; Ana, la nodriza; la harpía, los hermanos, Hemón, Creón y los desconocidos).

\subsubsection{Prólogo}

La obra se inicia con un extenso prólogo que pretende explicar su intención y sentido. Este prólogo es interesante desde el punto de vista estructural en tanto en cuanto precede al delirio Antígona, cuya trascripción pretende la autora que sea "lo más fiel posible" (Zambrano 221). Lo es también desde el punto de vista estilístico (ver Irene 75).

\subsubsection{Obra dramática}

En su estructura externa, en tanto que obra dramática, el texto presenta doce partes que, si bien le confieren una teatralidad intrínseca en la forma, caracterizada por las sucesivas alternancias de diálogos y monólogos oníricos de la protagonista, es anómalo en su género. Un análisis atento revela que la obra no tiene realmente una estructura de drama, como en el caso de Sófocles. Zambrano se preocupa del lector y no atiende al público, al oyente/espectador como debe hacer todo escritor de teatro. Prueba de ello es que, siendo indicados los personajes y sus respectivas intervenciones, faltan en el texto referencias a la puesta en escena: descripción de la escenografía o de los personajes y desplazamientos o reacciones que no sean las expresadas verbalmente ${ }^{32}$. Las entradas y salidas de los personajes se deducen del desarrollo de la narración, sin ser explicitadas, al igual que se desconocen sus gestos ${ }^{33}$. De hecho, Zambrano se consideraba una filósofa "del oído" ${ }^{34}$. 


\subsubsection{Género literario, lenguaje y estilo}

El inconfundible lenguaje de Zambrano subraya el carácter poético, lírico, de la obra: se suceden símbolos, metáforas, paradojas y repeticiones que definen una prosa con ritmo auténticamente musical ${ }^{35}$.

En general, Zambrano es considerada por la crítica como una poeta única en su género. Al margen de las influencias recibidas, su obra es una producción absolutamente original en los contenidos y, sobre todo, en el estilo. En Zambrano encontramos una experimental y, al mismo tiempo, perfecta combinación inédita entre dos géneros habitualmente contrastados: filosofía y poesía ${ }^{36}$. El resultado es un estilo híbrido con un notable poder de seducción literario e intelectual. El ensayo filosófico se funde con el simbolismo poético y el aforismo, en un intento de ir más allá de la incomunicación entre varios géneros literarios ${ }^{37}$ (Cerezo Galán, 2004). La tumba de Antígona no es el único ejemplo de esta fusión entre razón filosófica y ritmo musical de la razón poética (Tenenbaum, 2001: 280): Claros del bosque y De la aurora son otros ejemplos de su producción en los que conviven ambos géneros, dando forma a un registro peculiar y particular, el mismo que caracteriza los breves diálogos que Antígona mantiene con el resto de los personajes de la tragedia (Irene, 71). Su pensamiento poético no procede discursivamente, no opera con la argumentación demostrativa de la filosofía tradicional, sino a través de imágenes halladas en el camino de la propia experiencia, en un lenguaje visionario, donde tono, voz, ritmo e incluso el texto fragmentario son significativos y capaces de suscitar una transformación en el lector (Inversi, 1999, Irene, 71). Zambrano usa un lenguaje oracular**** (buscar art. Sobre len oracul en aurora), profético, una forma de escritura específicamente femenina capaz de traducir, como sibila o profeta, las imágenes en palabras que transmiten algo divino (Riveras Carretas 2002: 118), un lenguaje oracular con el que busca hacerse mediadora en la relación que establece con el lector/ espectador (buscar cita de Castillo, 1983,13). Por este motivo, la obra merece ser leída como una poesía experimental, a la búsqueda de un lenguaje nuevo, rico en rigor formal, con estructuras recurrentes en la arquitectura del discurso (PlumierTaquechel 1998, 622):...

\subsubsection{Interpretaciones}

Cualquier interpretación de La tumba de Antígona debe partir, a nuestro juicio, del principio de que es una obra que puede y debe entenderse como histórico-autobiográfica. Tras la experiencia de su exilio, la figura de Antígona fue particularmente simbólica para María Zambrano: la escritora se vio reflejada en la joven griega inocente, envuelta en una historia de guerra y de poder y llevada también al exilio, hasta el punto de que entre la autora y la heroína de Sófocles llegó a entablarse un diálogo que instaura entre ambas una relación y sentimiento de fraternidad: 
"Antígona me hablaba y con naturalidad tanta, que tardé algún tiempo en reconocer que era ella, Antígona, la que me estaba hablando. Recuerdo, indeleblemente, las primeras palabras que en el oído me sonaron de ella: «nacida para el amor he sido devorada por la piedad». No la forcé a que me diera su nombre, caí a solas en la cuenta de que era ella, Antígona, de quien yo me tenía por hermana y hermana de mi hermana que entonces vivía y ella era la que me hablaba; no diría yo la voz de la sangre, porque se no se trata de sangre sino de espíritu que decide, que se hace a través de la sangre derramada históricamente en destino insoslayable que las dos apuramos. Y aun después de tantos años de partida de ella, mi hermana única, de esta tierra, creo que sigo apurando yo sola, aunque sola no se podría porque no es un delirio de soledad, y de ser undelirio sería un delirio de hermandad, de fraternidad" (Zambrano 1986 8).

\subsubsection{Interpretación histórico-política}

Tras la lectura de la obra es inmediata la relación entre la guerra fratricida de Eteocles y Polinices y la guerra civil española, las consecuencias de la misma y las vivencias de Zambrano. Aunque no haya en realidad referencias precisas y correspondencias exactas con el conflicto español (Poumier-Taquechel 1998 [57] 625), sin embargo el dolor de Antígona no es otro que el símbolo del dolor de Zambrano que, como su heroína, está sin patria, en continua búsqueda de respuestas en el fondo de sí misma (Moraglio 76) La realidad política incide hasta tal punto en la vida de la filósofa española que no puede menos que influir indirectamente al menos en su obra, que confiesa por consiguiente la angustia del drama que ha supuesto su vida, pues no en vano es la confesión el género literario propio del hombre en crisis, del que advierte el hecho de que la definición del poder que emerge de los personajes masculinos que encontramos devienen una referencia al hombre occidental contemporáneo. Si bien Zambrano no pretendía posiblemente establecer una relación directa con la historia y no se hace portavoz de la verdad histórica, no faltan referencias a personajes precisos en el curso del prólogo que sirve de introducción al lector en el delirio de Antígona. Cita, en efecto, a Juana de Arco, otra víctima del sacrificio, repetición del drama de Antígona del mismo modo que todos los muertos vivos en nombre de una fe más fuerte que las leyes del estado.

\subsubsection{Interpretación simbólica}

Es la que considera la obra como un símbolo del exilio ${ }^{38}$. Sobre esta interpretación remitimos a la tesis doctoral de Irene Moraglio (77-78).

\subsubsection{Interpretación psicoanalítica}

Una lectura del texto de cariz psicoanalítico la encontramos en el capítulo titulado «La razón de Antígona y su voz (y sus voces)», tal vez, la sección más 
densa del libro Psicoanálisis y arte de ingenio. De Cervantes a María Zambrano, de Emilia Macola y Adone Brandalise (2004 [41]), título sugerente en paralelo con el de Baltasar Gracián, Agudeza y arte de ingenio. La lectura de La tumba de Antígona es tomada como la lectura de un palimpsesto. Se encuentra aquí el texto clásico, pero también el freudiano, el de María Zambrano y el lacaniano, todos leídos intertextualmente. Las autoras parten de la premisa de que, aunque en el siglo XX la literatura vuelve sus ojos a Antígona a menudo por su contenido político, Zambrano va más allá. Lo que se cuestiona es la feminidad, la maternidad, el orden de la ciudad, el padre. Esta lectura de la Antígona de Zambrano permite enlazar a las autoras con el texto lacaniano,

Antígona representa para Zambrano, sin duda, una posición política, pero una posición que no está ni totalmente fuera de la ciudad, ni totalmente dentro. Ocupa un lugar intersticial, lo que puede evocar el lugar que Lacan confiere a Sócrates, un lugar atópico, es decir, un lugar sin-lugar, pues que va a contracorriente y quien va a contracorriente no se encuentra dentro de lo que impone el vínculo social. No hay duda de que Antígona comparte este rasgo y, por supuesto, constituye un auténtico acto ético situarse en ese lugar.

\subsubsection{Obras inspiradas en La tumba de Antígona}

A pesar de su tardío reconocimiento, al que haremos referencia después, la producción literario-filosófica de Zambrano ha gozado de una general aceptación durante el tiempo. Y, como todas las grandes obras, La tumba de Antigona "ha suscitato l'interesse di artista di vario tipo, che hanno così deciso di trarre la propria opera da quella della filosofa spagnola, facendone la principale fonte di ispirazione" ${ }^{39}$.

\subsubsection{Literaratura: teatro}

La prueba más fehaciente de la pervivencia de La tumba de Antígona en el campo de la literatura es la vigencia, el interés que ha suscitado y suscita en el ámbito del teatro. Las versiones y/o adaptaciones del texto de Zambrano para su representación serán analizadas en el siguiente apartado, el dedicado a las representaciones de la obra.

\subsubsection{MúsicA}

María Zambrano fue una gran amante de la música. Pues bien: de la atracción y fascinación que ha producido La tumba de Antígona existen pruebas también en la música. La única pieza teatral de la pensadora fue la fuente de inspiración de su homónima musical, La tumba de Antígona, obra del compositor español Jesús Torres (Zaragoza, 1965). Su estreno, con gran éxito, tuvo lugar en el Auditorio Nacional de Madrid el 13 de febrero de 2004 por parte de la Orquesta Nacional de España, dirigida por su director titular, Josep 
Pons. La obra, cuya partitura fue publicada por la Editorial Tritó de Barcelona, obedecía a un encargo de la propia orquesta ${ }^{40}$, que ofreció una versión limpia y sentida, de manera que el autor y los intérpretes cosecharon calurosas ovaciones. Fue un digno homenaje a María Zambrano, de cuyo nacimiento se cumplía el centenario y que siempre consideró música y poesía como artes gemelas. La revista Archipiélago dedicó el número de marzo de ese año a la escritora y publicó un texto suyo inédito, dedicado a la música ${ }^{41}$, su vocación frustrada ${ }^{42}$.

\subsubsection{Pintura}

Otro ejemplo de la pervivencia de la obra de Zambrano nos lo proporciona la pintura. En lo que atañe a este tema reproducimos las palabras de Irene Moraglio: "Tommasina Squadrita, artista contemporanea italiana, ha realizzato dodice tavole pittoriche generate da un precedente lavoro sull'esilio. Il titolo dell'insieme delle dodici opere è Pensamiento, ma ogni tavola presenta un titolo a sé stante: Aurora, Confesión, Bienaventurados, Destierro, Entrañas, Firma, Guía, Logos Embrionarios $1^{\circ}$ e $2^{\circ}$, più oltre tre tavole specificamente dedicate ad Antigone su diretta ispirazione dall'opera di María Zambrano. La scelta di titoli dimostra come Tommasina Squadrita si sia concentrata su temi che corrispondono a parole chiave del pensiero della filosofa spagnola [...] Dalla parola di María Zambrano [...] si passa quindi all'immagine pura, astratta: ogni artista offre ad Antigone ciò che sente più suo in modo che l'eroina ne faccia la propria forma di espressione e di rinascita" ${ }^{33}$.

\subsection{Representaciones}

Al margen de los juicios sobre el carácter teatral más o menos marcado de la obra, está el hecho indiscutible e incuestionado de que La tumba de Antígona ha sido objeto de interés por parte del teatro ${ }^{44}$. De hecho, la presencia de monólogos en alternancia con diálogos no podía dejar de interesar al arte dramático. La obra de Zambrano puede inspirar, en efecto, diferentes realizaciones escénicas. Esta posibilidad ha sido el motivo desencadenante de varias puestas en escena. En los últimos días de junio y primeros de julio de 1983 se organizó en Almagro (Ciudad Real) un seminario sobre el pensamiento de María Zambrano. Patrocinado por la Fundación Conde de Cabra - Antigua Universidad de Almagro, fue promotor de la idea Jesús Moreno Sanz. Con independencia de la labor de estudio allí realizada, en el convento renacentista de los P. P. Dominicos, hubo diversos actos culturales, entre los que cabe destacar la representación teatral, por parte de J. Mestre y E. Pedregal, de un extracto de La tumba de Antígona de Zambrano ${ }^{45}$.

Como ha quedado dicho, La tumba de Antígona es un texto complejo, potencialmente susceptible de sugerencias y novedosas representaciones escénicas, pues se sitúa en una zona límite de la literatura dramática, en el 
ámbito de lo fronterizo. Y como tal ha sido considerado por algunos creadores de la escena que comparten esta singular predilección por los textos límites. Es el caso del montaje Antígona, realizado por el Teatro-Estudio de Málaga bajo la dirección de Juan Hurtado (Teatro Lope de Vega, Vélez Málaga, 24 de julio de 1984). En su comentario acerca del espectáculo, Miguel Romero Esteo destacaba "su difícil catalogación, que había llevado a unos a negarle su condición teatral, mientras que otros lo consideraron muestra de un nuevo juego teatral (teatro-sinfonía o cantata-teatro). Se combinaban en él múltiples elementos heterogéneos: danza y escultura, palabra y glosolalia, música y sonido en bruto, silencio y explosión sonora”. Romero lo presentó como una 'liturgia trágica fundamentada en el cante jondo', "pero no por vía del flamenco, sino de una reconstrucción de los módulos expresivos de este cante que afectó a música, baile e interpretación de los actores”. La partitura fue obra de Rafael Díez y el elevado coste del espectáculo y la complejidad de su realización fueron la causa de que se llevaran a cabo pocas representaciones ${ }^{46}$.

Otro ejemplo de recreación escénica lo debemos a Alfredo Catellón, quien la realizó por encargo directo de Zambrano y su deseo de ver representada esta obra. Se estrenó el 13/16 de agosto de 1992 en el XXXVIII Festival de Teatro Clásico de Mérida ${ }^{47}$, dedicado monográficamente al mito de Edipo. En esta versión, respetuosa y fiel al espíritu y la letra del texto de Zambrano, se introducen algunas modificaciones orientadas a establecer con mayor claridad la estructura teatral de la obra y a favorecer su representación dramática: se prescinde, en efecto, del prólogo de la autora y se añaden escenas, como la inicial que contextualiza la acción ${ }^{48}$; se remodelan o suprimen algunos de los monólogos, y se cambia el orden de algunas escenas, al tiempo que se incorporan numerosas y pertinentes acotaciones ${ }^{49}$.

Castellón presentó su versión como "un drama intimista que se aleja de los grandes montajes sobre Edipo, y que tiene como eje central el texto escrito por Zambrano, lleno de lirismo y de pureza filosófica" ${ }^{50}$.

E1 24 de enero de 2009, en el marco del XXVI Festival de Teatro de Málaga, tuvo también lugar el estreno de la pieza teatral de Zambrano. Se trata de una versión "en la que la autora hace suya la tragedia de Sófocles rescatando al personaje de su condición de mito y reviviéndolo: Antígona puede, en esta obra, verse a sí misma y hablar del tiempo no vivido pues, según Zambrano, Antígona no se suicidó en su tumba, concediéndole la oportunidad de vivir entre la vida y la muerte, rescatada al fin de la fatalidad y actualizando su universo mítico con aportaciones del psicoanálisis y la fenomenología de los sueños" (Manuel Barrera Martínez [3.2]: 122). Es también una tragedia en la que Zambrano ve reflejados algunos elementos de su propia biografía, como la relación con su hermana o su condición de mujer adelantada a su tiempo y 
transgresora. La obra concluye con una reflexión sobre el amor y la muerte, los dos grandes desconocidos por el hombre.

Según Barrera, la versión de Zambrano es mucho más libre e imaginativa que las de Anouilh y Brecht (más fieles al original de Sófocles), ya que, siguiendo la estela de la Santa Juana de George Bernard Shaw, de 1923, la autora malagueña hace que Antígona reciba en su tumba la visita, imaginada o soñada, de todas las personas que han sido importantes en su vida.

La puesta en escena fue llevada a cabo por una joven compañía fundada por dos actrices de sólida formación, María Bravo y Cristina Segovia. Ambas compaginan su trabajo en el teatro con la no fácil tarea de sacar adelante su productora, «El Círculo de Tiza», nombre brechtiano elegido por ellas para dar respuesta a la necesidad que como artistas sienten de "generar y gestionar su propio producto $[. .$.$] y captar un público más amplio y variado”. El espectáculo$ cuenta, además, con la inestimable colaboración de la compañía milanesa "Elsinor Teatro Stabile d' Innovazione” y de su prestigioso director Franco Palmieri, graduado por la Universidad de Bolonia con una tesis sobre Antropología y Teatro en el sur de Italia, quien precisó que tuvieron que acortar el texto por cuestión de tiempo y que incluyeron un prólogo que explica que la versión del mito ha recorrido toda la historia de la humanidad (Antequltura. Revista Cultural Contemporánea 26/01/2009) Por último, hay que destacar el trabajo de Ángela Boj, la otra actriz que completa el reparto y de Mercedes Castro, adjunta de dirección y corresponsable de la dramaturgia del espectáculo. Como sintetizó el director del montaje, Antígona "es un texto de agua, de sangre, de tierra, de amor, de esperanza, de flores, de violetas y de piedras".

\section{Bibliografía}

En España el reconocimiento de la obra de María Zambrano ha sido lento y tardío. Tal reconocimiento no se inició hasta 1966, año de la publicación del artículo "Los sueños de María Zambrano" de José Luis López Aranguren en la Revista de Occidente $e^{51}$. En la actualidad disponemos de un notable número de estudios sobre su biografía, obra y pensamiento debidos a especialistas en varios campos del conocimiento: la filología (clásica, hispánica, literatura comparada), la filosofía y la crítica literaria, lo que, en ocasiones, no hace fácil el acceso a todos los trabajos existentes (monografías, tesis doctorales, artículos y, sobre todo, actas de congresos o coloquios y obras colectivas). En concreto, la bibliografía en torno a la figura de Antígona en la filosofía de Zambrano es muy abundante. Como dijimos anteriormente, la pretensión de nuestro trabajo no es otra que la de proporcionar un estudio de carácter general que ofrezca una visión panorámica de todas las cuestiones planteadas por el único drama de Zambrano y una actualización de la información bibliográfica sobre esta obra lo más completa posible, aunque no exhaustiva. 
Las publicaciones a las que nos referimos aparecieron, en gran parte, tras haber sido Zambrano nombrada hija adoptiva del Principado de Asturias (1980), su primer reconocimiento oficial; hija predilecta de Vélez-Málaga, su ciudad natal (1981); doctora honoris causa por la Universidad de Málaga (1982); hija predilecta de Andalucía (1985), y, finalmente, por la concesión, en 1981, del Premio Principe de Asturias de Comunicación y Humanidades y, en 198852, del prestigioso Premio Miguel de Cervantes, otorgado por vez primera en la historia a una mujer dedicada a la filosofía. A éstas se añaden las aparecidas con motivo de la celebración del centenario de su nacimiento (2004), que suelen incluir apéndices bibliográficos. Entre los repertorios más completos que contienen las fuentes primarias (obras, artículos, antologías, correspondencia, varios) y bibliografía secundaria (monografías, obras colectivas y publicaciones periódicas), cabe destacar los que señalamos a continuación:

Aurora. Papeles del "Seminario María Zambrano": Información y novedades bibliográfica y culturales en todos los números.

Bernárdez, M. (2004), "Bibliografía de María Zambrano”/“Obra de María Zambrano": <http://www.ensayistas.org/filosofos/spain/zambrano/bibliode.htm>

"Bibliografía de y sobre María Zambrano"(1987), Anthropos 70-71, 82-93.

Cruz Ayuso, C. de la (2004), "Bibliografía de María Zambrano", Letras de Deusto XXXIV (104), 227-265.

Hurtado Pérez, M. E. (1995), "Bibliografía sobre María Zambrano”, Philosophica Malacitana 8, 167-194.

Ortega Muñoz,J. F. (1989), "Bibliografía”, Jábega [Número Monográfico. Homenaje a Maria Zambrano (1904-1991)] 49/3, 70-79.

Palabras de caminante: bibliografía de y sobre María Zambrano (2000), Málaga, Centro "María Zambrano" - UNED.

Seminario Maria Zambrano: "Cronología, bibliografía, bibliografía complementaria, enlaces”, Universidad de Barcelona.

$<$ http://www.ub.edu/smzambrano/index.html>

\subsection{Textos}

\subsubsection{Ediciones y traducciones de La tumba de Antígona}

La tumba de Antígona (1967), México, Siglo XXI Editores (Mínima).

La tumba de Antígona (1967), Revista de Occidente, año V, 2a época, no 54, pp. 273-293.

La tumba de Antigona (1983), Litoral. Revista de la Poesía y el Pensamiento $121,122,123,17-96$.

Senderos (Los intelectuales en el drama de España. La tumba de Antígona) (1986), Barcelona, Anthropos. Editorial del Hombre (Memoria Rota. Exilios y Heterodoxias 8), 199-265. "Prólogo" de la autora (1985), 7-9. Citamos por esta edición.] 
La tumba de Antígona (1989), Madrid, Mondadori (Ensayo. Bolsillo 35). "Introducción" de Julia Castillo, 5-11 (="La tumba de Antígona: tragedia y misericordia”, Papeles de Almagro, 105-110; [cf. 2.3.5])

La tumba de Antigona (1997), versión de Alfredo Castellón, Madrid, Sociedad General de Autores y Editores (SGAE).

La tomba di Antigona. Diotima di Mantinea (1995), traduzione e introduzione di Carlo Ferrucci, con un saggio di Rosella Prerzo ("La scrittura del pensiero in María Zambrano”), Milano, La Tartaruga Edizioni.

\subsubsection{Otros escritos de Zambrano sobre Antígona}

«Delirio de Antígona» (1948), Orígenes (La Habana), no 18, 14-21 ( = buscar en Pino).

Delirio y destino (1998), Madrid, Centro de Estudios Ramón Areces (Comprobar).

El hombre y lo divino (1991), Madrid, Siruela.

"La tragedia: Edipo y Antígona"(1965), El sueño creador, en Obras reunidas, Xalapa (Méjico), Universidad de Veracruz, 81-94 (= "El origen de la tragedia: Edipo" y "El personaje-autor: Antígona”, en Obras reunidas (1971), Madrid, Aguilar, 51-68 = Madrid, Editorial Siruela, 1993, pp. 242-252).

La razón en la sombra. Antología (1993), Madrid, Editorial Siruela. Nueva edición (2004), con prólogo nuevo y textos inéditos, Madrid, Trotta.

\subsubsection{Manuscritos del archivo de la Fundación Zambrano}

M - 440 Antígona. El sacrificio a la luz engendra el ser (1948-1954).

M - 517 Antígona. La República. La Guerra Civil. La historia (ca. 1966).

\subsection{Estudios: transmisión y RECEPCión DEL Mito de Antígona}

\subsubsection{Antígona en la literatura contemporánea}

Bañuls Oller, J. V. - Crespo Alcalá, P. (2008), Antígona(s): mito y personaje. Un recorrido desde los orígenes, Bari, Levante Editori (Kleos 16).

Bosch, M. C. (1979), Antigona en la literatura moderna, Barcelona, Universidad de Barcelona, Secretariado de Publicaciones [Resumen de Tesis de Doctorado].

Duroux, R. - Urdician, S., eds. (2010), Les Antigones contemporaines (de 1945 à nos jours), Clermont Ferrand, Presses Universitaires Blaise Pascal, (Mythographies et sociétés).

Fraisse, S. (1974), Le mythe d'Antigone, Paris, A. Colin.

Molinari, C. (1977), Storia di Antigone (De Sofocle al Living Theatre). Un mito nel teatro occidentale, Bari, De Donato.

Pianacci, R. E. (2008), Antígona: una tragedia latinoamericana, Irvine, Ediciones de Gestos (Historia del Teatro 12). 
Ragué Arias, M. J. (1986), Los personajes femeninos de la tragedia griega en el teatro español del siglo XX, 7 vols., Tesis de Doctorado, Barcelona.

Steiner, G. (1987), Antigones. The Antigone Myth in Western Literature, Art and Thought, New York 1984. - Antigonas. Una poética y una filosofía de la lectura (Antígonas. La travesía de un mito universal por la historia de Occidente), trad. A. L. Bixio, Barcelona, Gedisa.

\subsubsection{Antígona en el teatro español contemporáneo}

Azcue, V. (2009), "Antígona en el teatro español contemporáneo", Acotaciones 23, 33-46.

Bosch Mateu, M. (2010), "El mito de Antígona en el teatro español exiliado”, Acotaciones 24, 83-104.

Pociña, A. - López, A. (2010), "La eterna pervivencia de Antígona", FlorIlib 21, 345-370.

Vilchez de Frutos, M. F. (2006), "Mitos y exilios en la construcción de la identidad colectiva: Antígona en el teatro español contemporáneo", Hispanistica XX 24, 71-124.

\subsubsection{La tumba de Antígona de María Zambrano}

Allaigre-Duny, A. (2004), "L'Antigone de María Zambrano: de la réflexion philosophique à la création poétique", in M.-G. Besse - N. Mékouar-Hertzberg (eds.), Femme et écriture dans la Péninsule Ibérique, vol. 2, Paris, Ed. L'Harmattan, 137-152.

Balcells, J. M. (2004), “María Zambrano y su recreación filosófica de la Antígona”, in Maria Zambrano: raíces de la cultura española, Madrid, 339-358. 11-18.

Berenguer, A. (2007), "Antígona. Un arquetipo de mujer", Antígona 1,

Bonilla, A. B. (2009), "Derivas de Antígona en la escritura de María Zambrano: del saber trágico a la aurora de la razón poética”, in H. Bauzá (comp.), Entre Clio y Caliope. El imaginario mítico: variantes clásicas y proyección contemporánea, Buenos Aires, Academia Nacional de Ciencias, 27-47.

Carchidi, L. (2004), "La tumba de Antígona. María Zambrano e la figura del conflitto e della grazia", in Scrittura e conflitto. Actas del XXII Congreso de la AISPI, Catania-Ragusa, 67-77.

[Edición digital: <http://cvc.cervantes.es/literatura/aispi/pdf/19/I_05.pdf>]

Castillo, J. (1983), "La tumba de Antígona: tragedia y misericordia", in Papeles de Almagro. El pensamiento de Maria Zambrano, Madrid, Zero Zyx, (Por un nuevo saber 11), 105-110.

Duroux, F. (2010), "Antigone dans le noeud des lois", in Les Antigones contemporaines [17], pp. 35-45.

García Marruz, F. (2000), "De Antígona a Nina: del delirio a la esperanza”, 
in Maria Zambrano 1904-1991, Málaga, Diputación Provincial de Málaga, pp. 28-30.

Giner Comín, I. (200I), "El ser de la mujer en la filosofía de María Zambrano", Quimera 206, 55-60.

Inversi, M., ed. (1999), Antigone e il sapere femminile dell' anima: percorsi intorno a María Zambrano, Roma, Edizioni Lavoro.

Jiménez Millán, A. (1990), “Antígona, el sueño del umbral”, in "La tumba de Antigona”, de María Zambrano, Vélez/Málaga, Compañía de Teatro María Zambrano/Vicerrectorado de Extensión Universitaria de Málaga, 20-23.

Johnson, R. (1997), "María Zambrano as Antigone's Sister: Towards an Ethical Aesthetics of Possibility", Anales de la Literatura Española Contemporánea 22/1, 181-194.

La Rubia Prado, F. (1997), "Filosofía y poesía: María Zambrano y la retórica de la reconciliación”, Hispanic Review 65/2,199-216.

Llinares, J. B. (2001), "Noves interpretacions d'Antígona en la filosofía del sg. XX”, in F. De Martino - C. Morenilla (eds.), El fil d' Ariadna, Bari, 217-234.

Macola, E. - Brandalise, A. (2004), Psicoanálisis y arte de ingenio. De Cervantes a María Zambrano, Málaga, Miguel Gómez Ediciones (Itaca 10), 75-122.

Mékouar-Hertzberg, N. (2007), "La dimensión del exilio en La tumba de Antígona de María Zambrano", in E. Larraz (ed.), Exilios/desexilios en el mundo hispánico contemporáneo: los caminos de la identidad (Escrituras y expresiones artísticas del exilio), Bourgogne, Hispanística XX.

Mesa Toré, J. A. (2000), "Antígona, el camino hacia la luz", in María Zambrano 1904-1991, Málaga, Diputación Provincial de Málaga, 26-29.

Moraglio, I. (2003-2004), Antigona, Maria Zambrano, Matbilde Monnier: un unico mito, tre donne a confronto, Tesis de Doctorado, Università degli Studi di Bologna.

Muñiz-Huberman, A. (2002), "María Zambrano: Antígona en el exilio", in R. González Martell (ed.), La literatura y la cultura del exilio republicano español de 1939. Coloquio Internacional: Actas, Barcelona, 149-156. Edición digital: <La literatura y la cultura del exilio republicano español de 1939: II Coloquio Internacional : actas - Biblioteca Virtual Miguel de Cervantes>

Nieva de la Paz, P. (1997), "Mito e historia: tres dramas de escritoras españolas en el exilio [Ma Luisa Algarra, María de la O Lejárraga y María Zambrano]", Hispanistica XX 15, 123-131.

Nieva de la Paz, P. (1999), "La tumba de Antígona (1967): teatro y exilio de María Zambrano”, in M. Aznar Soler (ed.), El exilio teatral republicano de 1939, Sant Cugat del Vallès (Barcelona), Gexel, 287-301. Disponible en edición digital: 
<http://www.cervantesvirtual.com/FichaObra.html?Ref=7229>]

Ortega Muñoz, J. F. (1991), "Antígona, arquetipo de la naturaleza humana", Cor Unum 46/213, 37-48 (= "El paradigma existencial de Antígona”, in María Zambrano 1904-1991 (2000), Málaga, Diputación Provincial de Málaga, 4-12).

Picklesimer, M. L. (1998), “Antígona: de Sófocles a María Zambrano”, FlorIlib 9 347-376.

Pino Campos, L. M. (2005a), "Una Antígona inmortal: recreación zambraniana del personaje de Sófocles", in Id., Estudios sobre María Zambrano: el magisterio de Ortega y las raices grecolatinas de su filosofía, Santa Cruz de Tenerife, Servicio de Publicaciones de la Universidad de La Laguna (Materiales Didácticos Universitarios. Serie Filología 4), 417-431.

Pino Campos, L. M. (2005b), "La trascendencia de Sófocles en la filosofía de María Zambrano”, en Id., Estudios sobre María Zambrano [50], 481-540.

Pino Campos, L.M.(2005c), "La condena de Antígona y el exilio de María Zambrano. Apuntes en torno a la historia sacrificial, I: Delirio de Antígona y Delirio y destino", Actas del Segundo Congreso Internacional del nacimiento de María Zambrano: Crisis cultural y compromiso civil en María Zambrano, Vélez-Málaga, Fundación María Zambrano, 356-372.

Pino Campos, L. M. (2005d), "La condena de Antígona y el exilio de María Zambrano, II: El sueño creador", Postdata. Revista de Artes, Letras y Pensamiento 26 (número especial dedicado al Centenario de María Zambrano, 1904-1991: La palabra o el amor), 119-134.

Pino Campos, L. M. (2005e), "La condena de Antígona y el exilio de María Zambrano: apuntes en torno a la historia sacrificial, III: El Prólogo a La tumba de Antígona", Revista de Filología de la Universidad de La Laguna 23, 247-264.

Pino Campos, L. M. (2007a), "Antígona: ¿rebeldía o sacrificio? Apuntes en torno a la historia sacrificial, IV", in F. Ríos (ed.), Interculturalidad, insularidad, globalización, vol. II, Santa Cruz de Tenerife, Universidad La Laguna, 549568.

Pino Campos, L. M. (2007b), “Antígona: de la piadosa rebelde de Sófocles a la mística inmortal de María Zambrano", Antígona. Revista Cultural de la Fundación María Zambrano 1, 78-95.

Poumier-Taquechel, M. (1998), "Antígona y María Zambrano", Actas del II Congreso Internacional sobre la vida y obra de María Zambrano, Vélez-Málaga, Fundación María Zambrano, 621-638.

Prezzo, R. (1999), "Imágenes del subsuelo: las figuras femeninas en la Antígona de Zambrano”, Aurora 1, 104-112.

Quance, R. A. (2009), "La tumba de Antigona de María Zambrano: política y misterio”, in Á. Encinar - C. Valcárcel (eds.), Escritoras y compromiso: 
literatura española e hispanoamericana de los siglos XX y XXI, Madrid, Visor Libros (Biblioteca filológica hispana 111), 881-896.

Ramond, M. (2010), “Antigone ou l'inscription simbolique des femmes", en Les Antigones contemporaines [17], 47-61.

Romero Esteo, M. (2000), "El mito de Antígona desde el remoto trasfondo mediterráneo", en María Zambrano 1904-1991, Málaga, Diputación Provincial de Málaga, 14-18.

Sanchis, J. (1994), "Desde la tumba de Antígona", Asparkía 3, 75-90.

Santiago Bolaños, M., "El agua del soñar: desde La tumba de Antígona", in Maria Zambrano: los años de Roma (1953-1964) / Maria Zambrano: Gli Anni di Roma (1953-1964). **ow $h t m>]$

[Edición digital: <http://cvc.cervantes.es/literatura/zambrano_roma/default.

Santiago Bolaños, M. (2005), "Recursos del lenguaje en el pensar zambriano: a propósito de La tumba de Antígona", in J. L. Mora García - J. M. Moreno Yuste (coords.), Pensamiento y palabra en recuerdo de María Zambrano (1904-1991): contribución de Segovia a su empresa intelectual, 225-238.

Santiago Bolaños, M. (2010), «María Zambrano dialogue avec Antigone”, in Les Antigones contemporaines, 75-86.

Verdú de Gregorio, J. (1998), "Antígona y el germen de la palabra: la trascendencia del morir", in Id. ¿? Regeneracionismo y Generación del 98: los universos de una crisis, Madrid, Endymion, 287-302.

Volpe Cacciatore, P. (2003), "María Zambrano e il teatro classico", Eikasmos 14, 421-427.

\subsection{Representaciones}

Barrera Benítez, M. (2009a), "El estreno de La tumba de Antígona, de María Zambrano”, Gestos: teoría y práctica del teatro hispánico 48, 157-161.

Barrera Benítez, M. (2009b), "Tiempo para Antígona”, La Ratonera. Revista asturiana de teatro 27, 122-125.

[Edición digital: <http://www.la-ratonera.net/numero27/n27_antigona. html>]

Vilches de Frutos, M. F. (1994), "La temporada teatral española 1991-1992”, Anales de la Literatura Española Contemporánea 19/3, 441-466.

Proporcionamos, por último, algunas direcciones electrónicas que pueden resultar de interés y utilidad para facilitar la consulta de datos sobre la vida, obra y bibliografía de María Zambrano:

Asociación de hispanismo filosófico: <http://www.ahf-filosofia.es/>

Grupo de investigación Creación y Pensamiento de las Mujeres (CiPD) <http://www.ub.edu/cdona/GRC_esp.htm> 
$<$ http://www4.ub.edu/filosofiagenere>

Centro Virtual Cervantes (CVC): <http://cvc.cervantes.es/actcult/ zambrano/>

Ensayistas.org.: <http://www.ensayistas.org/filosofos/spain/zambrano>

Fundación María Zambrano: <http:/www.fundacionmariazambrano. org/>

Fundación Ortega y Gasset: <http://www.ortegaygasset.edu/>

Residencia de Estudiantes: <http://www.residencia.csic.es/>

Seminario María Zambrano (Barcelona): <http://www.ub.es/ smzambrano/>

"La inteligencia desvelada que penetra en la noche, el insomnio de la atención simbolizado en los ojos del búho de Atenea [...], diosa del olivo, bebedora del aceite, del aceite que alimenta la llama de luz suave, aún encendida ella [...] en los templos".

(María Zambrano, El camino recibido) 
${ }^{1}$ In memoriam María Luisa Picklesimer Pardo (1945-2010), experta conocedora del mito clásico, que nos legó una prueba fehaciente de sus cabales reflexiones sobre la Antigona de Sófocles y de María Zambrano y sobre la figura de Ismene en las páginas de la Revista de Estudios de la Antigüedad Clásica de su Universidad de Granada (FlorIlib 9 (1998) 347-376 [49] y 11 (2000) 215-225, respectivamente).

${ }^{2}$ Cf. los estudios de Simone Fraisse (1974 [18]), Cesare Molinari (1977 [19]), Ma del Carmen Bosch (1979 [16]), Ma José Ragué-Arias (1986 [21]), George Steiner (1987 [22]), Rómulo E. Pianacci (2008 [20]) y José Vicente Bañuls Oller - Patricia Crespo Alcalá (2008 [15]), recogidos en el apartado 3.2.1. de la bibliografía. En el índice final de adaptaciones del mito de Antígona del laborioso y sugerente estudio de Bañuls y Crespo se citan 258 obras literarias cuyo referente es la Antígona de Sófocles (Bañuls - Crespo 2008 603-611). Steiner, quien, en el capítulo primero de su conocida obra Antígonas, alude a la "difundida opinión de que la Antígona de Sófocles" es "no sólo la más excelente de las tragedias griegas sino una obra de arte más cercana a la perfección que cualquier otra producida por el espíritu humano" (Steiner 1987 15), cierra su estudio con las siguientes palabras: "Nuevas Antígonas están siendo imaginadas, concebidas, vividas ahora; y lo serán mañana” (Steiner 1987 358). En la introducción al análisis de la presencia y de las numerosas versiones de Antígona en el teatro latinoamericano Pianacci afirma: "Es materialmente imposible mantener un inventario actualizado de los espectáculos que se presentan en relación con el mito de Antígona, ya que es seguro que durante el tiempo de elaboración del presente trabajo, otros muchos se estén desarrollando, estrenando y publicando" (Pianacci 2008 9). En el prefacio de Les Antigones contemporaines [17] se lee: "Antigone n' en finit de nous habiter. Les versions de ce mythe majeur son innombrables: les créateurs, qu'ils soient philosophes, romanciers, poètes, musiciens ou peintres, ne cessent de se pencher sur le destin de cette vierge sacrificielle dont le nom à lui seul symbolise une révolte. La fascination qu'exerce Antigone tient a la ductilité sémantique du mythe, une ductilité qui confere à ce personaje de la tragédie grecque perpétuellement remodelé una signification toujours actuelle" (Duroux Urdician, eds. 2010 [17]).

${ }^{3}$ Parafraseando a Ma Margarita Doncel ("De Sófocles a Luis Rafael Sánchez y otras Antígonas: un canto a la libertad”, Inter-Ethica), cabe preguntarse qué tiene Antígona para hechizar a todos con su fuerza juvenil, por qué subyugan sus verdades absolutas, su toma de conciencia y libertad de acción, por qué provoca a través del tiempo la reflexión poética y reaparece una y otra vez, reactualizándose en todo tipo de textos y, de modo especial, en los dramáticos.

${ }^{4}$ En las consideraciones expuestas compartimos y seguimos la interpretación de Steiner 226-228, quien, como hemos recordado, finaliza su estudio con estas palabras: "lo único de que puedo estar seguro es esto: todo cuanto acabo de decir ya necesita una adición. Nuevas Antígonas están siendo [...] vividas ahora; y lo serán mañana” (cf.n.1). En casi idénticos términos similares, como también hemos señalado, se expresa Pianacci en el comienzo de su estudio: "es seguro que durante el tiempo de elaboración del presente trabajo otros muchos [espectáculos relacionados con el mito de Antígona] se estén desarrollando, estrenando y publicando" (cf. n. 1). Y exactamente lo mismo podemos decir nosotros: en el curso de la elaboración de este artículo hemos podido saber que en la LVII edición del Festival de Teatro Clásico de Mérida del año 2011 ( 7 de julio - 28 de agosto) el mito de Antígona es el tema central. En su programación cuenta con tres versiones diferentes: Antígona de Mérida, versión de Miguel Murillo; Antígona del siglo XXI, versión de Isidro Timón y Emilio del Valle y dirección de éste último; Antígona, versión de Mauricio García Lozano (cf. http://www.festivaldemerida.es/).

${ }^{5}$ Azcue 2009 [23] 34. Cf. L. Díez del Corral, La función del mito clásico en la literatura contemporánea, Madrid, Gredos 1974, 11; D. del Corno, "Appunti sui modi di comunicazione della tragedia greca nel teatro contemporaneo", in A. Cascetta, ed. Sulle orme dell'antico. La tragedia greca e la scena contemporanea, Milano, Vita e Pensiero 1991, 57-67.

${ }^{6}$ Son abundantes los estudios sobre el mito de Antígona en el teatro español contemporáneo. Además del ya citado en n. 1 de Bañuls y Crespo [15], remitimos a los trabajos de Ma José 
Ragué Arias: Los personajes femeninos de la tragedia griega en el teatro español del siglo XX [21]; Els personatges femenins de la tragèdia grega en el teatre català del segle XX, Sabadell, Editorial Ausa 1990; Los personajes y temas de la tragedia griega en el teatro gallego contemporáneo, Sada-A Coruña, Edición do Castro 1991; Lo que fue Troya. Los mitos griegos en el teatro español actual, Madrid, Asociación de Autores de Teatro 1992; El teatro de fin de milenio en España (De 1975 hasta hoy), Barcelona, Editorial Ariel 1996.

${ }^{7}$ Para un listado de las recreaciones y adaptaciones del mito de Antígona en el teatro español contemporáneo, cf., sobre todo, Bañuls - Crespo 2008 [15] 603-611. Cf. también Azcue 2009 [23] 46, n. 2 y Pociña - López 2010 [25] 347-355 ("Notas bibliográficas"). En general, sobre el uso del mito en España a partir de la posguerra, cf. Ma J. Ragué-Arias (2005), "Del mito contra la dictadura al mito que denuncia la violencia y la guerra”, Foro Hispánico 27 11-22.

${ }^{8}$ Ragué-Arias, Lo que fue Troya 1992140.

${ }^{9}$ Cf. Azcue 2009 [23] 34-36.

${ }^{10}$ Sobre el teatro del exilio, cf. M. Aznar Soler, "El exilio republicano español de 1939. Un mapa teatral", Primer Acto 329 (2009), 8-28. Para el tema del exilio español de 1939 y la literatura, cf. J. L. Abellán (1998), El exilio filosófico en América. Los transterrados de 1939, Madrid, Fondo de Cultura Económica de España; M. Aznar Soler, ed. (1998), El exilio literario español de 1939 en Francia, Barcelona-Salamanca, AEMIC/Gexel; M. Aznar Soler, ed. (1999), El exilio teatral republicano de 1939 [46]; X. L. Axeitos - C. Portela, eds. (1999), Sesenta anos despois. Os escritores do exilio repubicano, A Coruña, Ediciós do Castro; Manuel Aznar Soler, ed. (2000), Sesenta años después. Las literaturas de exilio republicano de 1939. Actas del II Congreso Internacional (Bellaterra, 1999), Sant Cugat del Vallés, GEXEL / Associació d'Idees; R. González Martell, ed. (2003), La literatura y la cultura del exilio republicano español de 1939 [45]; A. Alted Vigil - M. Aznar Soler, eds. (2003), Literatura y cultura del exilio español de 1939 en Francia, AEMIC-GEXEL Literatura y cultura del exilio español de 1939 en Francia - Biblioteca Virtual Miguel de Cervantes A. Alted - M. Lluisa, eds. (2003), La cultura del exilio republicano español de 1939. Actas del Congreso Internacional celebrado en el marco del Congreso Plural: Sesenta años después (Madrid-Alcalá-Toledo, diciembre de 1999), Madrid, UNED; M. Aznar Soler, ed. (2006), Escritores, editoriales y revistas del exilio republicano de 1939, Sevilla, Renacimiento (Biblioteca del Exilio, Anejos IX); E. Larraz, ed. (2006), Exilios/desexilios en el mundo hispánico contemporáneo: los caminos de la identidad (Escrituras y expresiones artísticas del exilio [42]; J. Á. Ascunce, ed. (2008), El exilio, un debate para la historia y la cultura, San Sebastián; M. Aznar Soler - J. R. López García, eds., Diccionario bio-bibliográfico de escritores, editoriales y revistas del exilio republicano español de 1939, Sevilla, Renacimiento (Biblioteca del Exilio), en curso de publicación. En general, para una detallada bibliografía sobre el tema de la literatura del exilio español de 1939, remitimos a las publicaciones y actividades del Grupo de Estudios del Exilio Literario (GEXEL), grupo de investigación adscrito al Departamento de Filología Española de la Universidad Autónoma de Barcelona y a la página web del mismo (<http://www.gexel.es/presentacion.html $>$ ), donde se explican sus objetivos y proyectos. Para el uso, en concreto, del mito de Antígona, cf. Vilches de Frutos 2006 [26].

${ }^{11}$ Durante la redacción de este trabajo supimos que durante los días 28 y 29 de octubre de 2009 se celebraron en Madrid, en la Real Escuela Superior de Arte Dramático (RESAD), unas Jornadas sobre el exilio teatral republicano de 1939, setenta años después, en las que Mireia Bosch Mateu presentó una comunicación titulada "El mito de Antígona en el teatro exiliado de Bergamín, José Martín Elizondo y María Zambrano”. Desconocemos si han sido publicadas las actas de estas jornadas. A punto de finalizar nuestro estudio, hemos podido consultar un artículo de la autora que versa sobre el mismo tema: "El mito de Antígona en el teatro español exiliado" (Bosch Mateu 2009 [23]). En él se analizan, por el orden que sigue, las piezas teatrales de Elizondo, Bergamín y Zambrano.

${ }^{12}$ Así lo señala la propia Zambrano en el prólogo especial que escribió para Senderos, fechado en 1985, al justificar el motivo de la inclusión en este libro de la obra dramática: "Se añade La tumba de Antígona, obra publicada en 1967, porque responde a la inspiración del exilio diariamente en París y más tarde en una aldea del Jura francés” (Zambrano 1986 [4] 7).

${ }_{13}$ Orígenes 18 (1948) 14-21 [8]. Recogido en La Cuba secreta y otros ensayos, Madrid, Endymion 1966, 98-106 y en E. Laurenzi (ed.), María Zambrano. Nacer por sí misma, Madrid 
1995, 66-76.

${ }^{14}$ Cf. Pino Campos 2005a [50] 418.

15 "Antígona, según nos cuenta Sófocles, se ahorcó en su cámara mortuoria. Por mucho que nos atemorice el respeto al Autor de su poética existencia [repárese en el uso de la mayúscula al referirse a Sófocles], parece imposible de aceptar tal fin. No; Antígona, la piadosa, nada sabía de sí misma, ni siquiera que podía matarse; esta rápida acción le era extraña y antes de llegar a ella -en el supuesto de que fuera su adecuado final- tenía que entrar en una larga galería de gemidos y ser presa de innumerables delirios; su alma tenía que revelarse y aun rebelarse". En este ensayo Zambrano presenta ya a Antígona, joven, virgen e inocente, como propicia para el sacrificio que pueda purificar las manchas que pesaban sobre el linaje real de Tebas: "En su delirio, ocupará un pequeño lugar su posible vida [...] Lo esencial era la reconciliación de la atormentada familia, la pacificación final y el agotamiento del destino de Edipo, de Yocasta y de sus hijos. Ella había venido a eso: a desatar el nudo del incesto de sus padres y, por ello, no pudo seguir hacia el porvenir casándose con su novio Hemón [...] Toda vida individual, propia, le estaba sustraída a la que no tuvo tiempo de pensar en sí misma” (in La Cuba secreta y otros ensayos, 101).

${ }^{16}$ Pino Campos 2005a 419.

${ }^{17}$ Cf. Nieva de la Paz (1999) [47] 157.

${ }^{18}$ Cf. Nieva de la Paz 1999 [47] 156. A esta "convivencia" alude la autora en el prólogo a la edición de la obra en Senderos, escrito en 1985: "Antígona me hablaba y con naturalidad tanta que tardé algún tiempo en reconocer que era ella, Antígona, la que me estaba hablando". Recuerdo, indeleblemente, las primeras palabras que en el oído me sonaron de ella: «nacida para el amor he sido devorada por la piedad»" (Zambrano 1986 8).

${ }^{19}$ Cf. el final del monólogo inicial de Antígona: "Ahora conozco mi condena: «Antígona, enterrada viva, no morirás, seguirás así, ni en la vida ni en la muerte»" (Zambrano 224).

${ }^{20}$ Cf. J. Castillo (1983), "La tumba de Antígona: tragedia y misericordia", in Papeles de Almagro. Elpensamiento de María Zambrano [32], 107: En La tumba de Antígona es el tiempo lo que María Zambrano le ha concedido a Antígona, personaje de tragedia. Ello no la convierte en personaje de novela [...] porque ese tiempo no es distinto al instante en el que ella se reconoce, libre pero obediente a la fatalidad, víctima de ella, inocente-culpable [...] El solo instante la condujo, como en Sófocles, al suicidio; el tiempo -en que se aúnan filosofía y poesía- que María Zambrano le concede, la conduce a la pasión, a sacrificar no ya su vida, sino su ser, a ese vivir muriendo, del que sólo hay claros ejemplos [...] en la literatura española”.

${ }^{21}$ Cf. Nieva de la Paz (1999) 158, cuyo excelente estudio seguimos en las acertadas consideraciones sobre este tema.

${ }^{22}$ Zambrano, La tumba, 224: "Pero ahora conozco mi condena: «Antígona, enterrada viva, no morirás, seguirás así, ni en la vida ni en la muerte»”.| Cf. Sóf., Ant .850-852: “¡Ay, desdichada de mí!, que no comparto la morada / ni con los hombres, ni con los cadáveres, / ni con los vivos, ni con los muertos" Seguimos la traducción de Luis Gil (Sófocles, Antígona. Edipo rey. Electra, Barcelona, Labor 1975).

${ }^{23}$ Zambrano, La tumba, 228 (el subrayado es nuestro): "Hermana, nosotras tenemos nuestro secreto, lo tuvimos siempre [...] Todos sabían que lo teníamos. Pero nosotras nunca aludíamos a él. Y ahora, yo no sabría tampoco decírtelo. No es de decir. Eso es. Era de jugar, de jugar nuestro juego interminable. Después era de hacer, de hacer eso que yo sola bice: acompañar a nuestro padre; después ir a lavar a nuestro hermano maldecido. Y tú no viniste; y después, sí, ya me acuerdo: tú quisiste morir conmigo. Pero yo no te dejé [...] Y no te condeno a muerte, quiero decir: te condeno a vivir sin mí [...] Pero no, Ismene, no, hermana. Tú no tenías que venir conmigo a lavar a nuestro hermano sin honra, porque, mira, ya está claro, la lavandera soy yo". | Cf. Sóf., Ant. 544-555 (el subrayado es nuestro): "-Ism.: "Por favor, hermana, no me prives de la honra de morir contigo y de cumplir los ritos con el muerto». -Ant.: «No mueras en común conmigo ni te atribuyas aquello en lo que no pusiste la mano. Bastará con que yo muera» [...] -Ism.: "¿Y en qué podría yo ahora serte útil todavía?».-Ant.: «Sálvate. No veo con malos ojos que escapes». -Ism.: «¡Ay, desdichada! ¿He de quedar privada de tu sino?» -Ant.: «Tú escogiste el vivir y yo el morir»”.

${ }^{24}$ Sobre el significado de Edipo en La tumba de Antígona, cf. L. M. Pino Campos (2004), "Héroes trágicos en la obra de María Zambrano: los personajes de Sófocles y el ejemplo de 
Edipo”, in A. Pérez Jiménez - C. Alcalde Martín - R. Caballero Sánchez eds., Sófocles el hombre. Sófocles el poeta. Actas del Congreso Internacional con motivo del XXV centenario del nacimiento de Sófocles (497/496 a.C. - 2003/2004, Málaga, Charta Antiqua, 453-462 (reproducido en sus Estudios sobre María Zambrano [50], 433-441). Pero, además de las referencias contenidas en el drama, la figura de Edipo fue tratada por Zambrano en otros ensayos, "en los que se destacan otros aspectos de su trágica vida y los significados filosóficos, religiosos, literarios e históricos que tuvo en la Grecia antigua y que aún perduran" Cf. al respecto L. M. Pino Campos (2004), "Edipo rey y Edipo mendigo: un héroe trágico en la filosofía de María Zambrano", Laguna 14, 89-118 (reproducido en Estudios sobre Maria Zambrano [50], 443-480): "El padre y hermano de Antígona, Edipo, rey, primero, y mendigo, después, sabio e ignorante a la vez, aparece en Zambrano como el ejemplo más claro de la constante paradoja del hombre, del hecho casi incomprensible de que toda realidad, aunque no lo parezca, es máscara de otra realidad oculta que el hombre es incapaz de ver con sus propios ojos, de comprender con su propia inteligencia. Se cruzan en este punto el sendero racional y apasionado del héroe trágico que quiere y cree conocer la verdad, encarnado en Edipo, y el sendero racional del filósofo que también quiere conocer la verdad, pero duda de que ya la conozca, no cree saberla, y está convencido de que sólo el lógos, desapasionado, impasible dirá Zambrano, le permitirá acceder a ella” (450-451).

${ }^{25}$ En el prólogo a la obra Zambrano hace una aguda e inteligente reflexión sobre la analogía entre Polinices, el hermano de Antígona, y Orestes, el hermano de Electra: "Hoy [...] podemos suponer que el hermano que llegó desde afuera [...] sobre Tebas viniera a rescatarla [...] El hermano de Antígona, que la condujo irresistible, fatalmente a la muerte no pudo llegar, según las paradojas de la tragedia, más que en ansia de llevarla a ella y a su ciudad, hacia la vida. Y así, aunque ninguna alusión encontremos en el texto de Sófocles ni, que sepamos, en ninguna leyenda, llega a la mente la idea de un cierto parentesco, de una cierta analogía entre Polinices, el hermano de Antígona que llega sobre Tebas, y Orestes, el hermano de Electra [...], que llega vengador-liberador para rescatar al par el poder ensombrecido y la hermana víctima de los errores encadenados de todo un linaje [...] Lo que [...] salta a la vista por el contraste entre las dos trágicas situaciones es que se trata de la fraternidad: de una fraternidad que se debate bajo la fatalidad sombría: que es la fraternidad la verdadera protagonista entre las tinieblas legadas por el reino del padre y de la madre -de la madre que no supo ver en el caso de Yocasta lo que Edipo no veía; sustraerse al mal que los excesos de Agamenón le aportaron hiriéndola en su condición de madre y de mujer, en el caso de la oscura, entrañable Clitemnestra-" (Zambrano 210-211).

${ }^{26}$ Zambrano, La tumba, 264: “-Deconocido primero: «He venido aquí en modo diferente a como he bajado a otros lugares como éste [...] Querría llevármela viva, a ella, no a su sombra. Que conociera la vida antes de morir».-Desconocido segundo: «No sabes quién es todavía [...] Tienes que alejarte. Por esta vez te volverás solo».

27 "Deconocido segundo: «Antígona: ven, vamos, vamos». Antígona: «Ah, sí. ¿Dónde? ¿Adónde? Sí, Amor. Amor tierra prometida»" (Zambrano 265).

${ }^{28}$ Cf. Sóf., Ant. 521-523: “-Ant.: «¿Quién sabe si eso es lo piadoso abajo?».-Cr.: «Jamás, ni aun después de muerto, será amigo el enemigo». -Ant.: «No he nacido para compartir el odio, sino el amor»".

${ }^{29}$ Seguimos, a veces literalmente, el contenido según lo exponen Bañuls y Crespo 2008 [15] 369-371.

${ }^{30}$ Acerca de la reflexión de Zambrano sobre los distintos géneros literarios como formas diferenciadas de acceso al conocimiento, cf. M. L. Maillard (1997), María Zambrano. La literatura como conocimiento y participación, Lleida, Universitat de Lleida.

${ }^{31}$ Decíamos antes, siguiendo a Julia Castillo (cf. n. **Tiempo), que en el tiempo que María Zambrano concede a Antígona se aúnan poesía y filosofía: "poesía en ese absolver culpabilidad e inocencia al mismo tiempo que vida y muerte; filosofía, en lo que tiene de alumbramiento: la conciencia, en medio de esa lucidez, de esa cordura en que se unen sueño y vigilia" (Castillo 1983 [32] 108-109).

${ }^{32}$ Cf. Inversi 1992 [36] 82.

${ }^{33}$ Con excepción de una acotación en "El sueño de la hermana": "No estabas allí ni aquí, Ismene, mi hermana. Estabas conmigo. Y era esta tumba [...] Aquí, de este lado (señalando a un 
lugar), un corredor estrecho, y allá, al fondo, una escalerita" (Zambrano 227).

${ }^{34}$ Cf. F. Savater, "La voz de María Zambrano", in Papeles de Almagro. El pensamiento de María Zambrano (1983 [32]) 13: “¿Qué es lo que sabe María Zambrano? Cosas que ha oído y que brotan de nuevo en su voz, reflexionadas, recreadas. "Ya sabes que yo soy del oído», me dice tajante. Ella filósofa de oído frente a la filosofía visual [...], teorética, de nuestra tradición sorda”. Para la oposición vista/oído en Zambrano cf. el apartado "La vista y el oído: algunas lecturas zambranianas de Platón, Aristóteles y Plotino" de la excelente tesis doctoral de Francisco Martínez González, El pensamiento musical de Maria Zambrano, Granada, Universidad de Granada 2008, 195-230.

${ }_{35}$ Cf. F. Martínez González (2008), El pensamiento musical de María Zambrano, 250-285, capítulo dedicado a la palabra; en especial, 250-258 ("Palabra y música"), 277-282 ("Filosofía y poesía) y 283-285 ("Palabra y sueño").

${ }^{36}$ Cf. Comesaña-Santalices, G. M. (1999), "María Zambrano: filosofía y poesía”, Analogía 1, 207-226.

${ }^{37}$ Cf. P. Cerezo Galán, Cerezo Galán, Filosofía y literatura en María Zambrano, Sevilla 2005.

${ }^{38}$ Sobre el significado del exilio, de sus figuras y formas en Zambrano, cf. J. L. Abellán (1998), "María Zambrano. El itinerario de la razón poética", in J. L. Abellán, El exilio filosófico en América. Los transterrados de 1939 (cf. n. ) 257-284; A. Bundgård (2003), "El exilio como patria verdadera en el pensamiento de María Zambrano”, in A. Alted \& M. Lluisa, eds., La cultura del exilio republicano español de 1939, vol. I, Madrid, UNED; 563-569; C. Beorlegui (2004), "El exilio como reflexión filosófica: una sinfonía de acentos (A propósito del centenario del nacimiento de María Zambrano)", Letras de Deusto 104, 13-69; A. Bundgård (2008), "Exilio y transcendencia", Aurora 8, 83-89; J. Verdú de Gregorio (2007), "María Zambrano: (Cuba-Italia): espacios del exilio", Aurora 8, 2007, 90-****. Del 20 al 24 de Julio de 2009 se celebró en VélezMálga, en la sede de la Fundación María Zambrano, el Curso de Verano de la Universidad de Málaga Mujeres en el exilio, dirigido por José Luis Abellán, director del Centro de Estudios sobre el Exilio dependiente de dicha Fundación. El curso finalizó con la ponencia "María Zambrano, filósofa del exilio", a cargo de Juan Fernando Ortega, presidente de la Fundación. Las conferencias impartidas fueron incluidas como temática en el número 5 de la revista Antígona.

${ }^{39}$ I. Moraglio, Antigona, María Zambrano, Matbilde Monnier: un unico mito, tre donne a confronto [44]) 85. Los datos que proporcionamos en esta sección han sido tomados, en parte, de la tesis doctoral de la autora.

${ }^{40}$ En concreto, fue un encargo de Félix Palomero, gerente de la Orquesta Nacional de España. Así lo reconoció el propio autor en una entrevista concedida a Susana Gaviña, publicada en el diario $A B C$ ( $A B C$ Cultural.Madrid,07-/22/2004,p. 40; el subrayado es nuestro): "Félix Palomero, gerente de la orquesta, me propuso este encargo que, según las pautas de la programación de la temporada, debía estar sujeto a un texto. Me propuso dos opciones: el Quijote o Edipo Rey y me decanté por esta última porque yo tenía un texto de María Zambrano, La tumba de Antígona (su única pieza de teatro), que me interesó por su intensidad dramática y por su extraordinario valor poético. Además es una obra en la que se habla del ciclo edípico, de Edipo Rey, Edipo en Colono y Antigona, y en ella desfilan todos sus personajes, a modo de flash-back, y se analizan de una manera muy personal los motivos de esta tragedia familiar". Sobre su especial atracción por la obra de Zambrano declara: "Creo que en ella se realiza un gran canto a la libertad y se muestra la posibilidad de la protagonista para elegir su destino, aunque sabe que éste va a ser trágico. De alguna manera creo que refleja la propia vida de María Zambrano: una relación de hermanas, de torturas nazis, exilio, tiranía...". Acaba matizando que la articulación formal de su obra nació "bajo la sugestión del texto literario. La partitura está dividida en el mismo número de escenas que la obra de Zambrano. Es una puesta en música de los estados anímicos de la protagonista y existe un juego de tensiones y distensiones, muy en función del texto dramático [,,,] Hay un metodismo que recorre toda la obra, con una gran intensidad lírica, que podría equivaler al personaje de Antígona”.

41 "La Música-1955”, Archipiélago. Cuadernos de crítica de la cultura 59 (María Zambrano: la razón sumergida).

${ }^{42}$ Cf. V. Pliego de Andrés, Filomúsica. Revista de Música Culta 50, marzo 2004. También 
Moraglio [44] 86-89 y Bañuls-Crespo [15] 368, n.541. Para el tema de Zambrano y la música, cf., sobre todo, F. Martínez González (2008), El pensamiento musical de María Zambrano, Granada, Universidad de Granada; en especial, los capítulos 2 ("Zambrano y la música: contactos reales", 78-96) y 4 ("Raíces del pensamiento musical zambraniano", 157-249).

${ }^{43}$ Moraglio [44] 86.

${ }^{44}$ Moraglio [44] 79.

${ }^{45}$ Cf. Papeles de Almagro 1983 [32] 5-7, y 124: "Ha sido la primera vez que se hace una lectura en público -teatralizada de alguna forma- de La tumba de Antígona [...] Bien patente quedó [...] que la palabra de María Zambrano es una palabra [...] para ser oída [...], recitada" (Jesús Moreno).

46 “Una fiesta bárbara llamada Antígona”, El Público 17, 1985, 41-42. La información nos es proporcionada por Nieva de la Paz (1999 [47] 296), cuyas precisiones seguimos.

${ }^{47}$ Existe una divergencia entre la fecha de estreno que se ofrece en el encabezamiento de la versión de Castellón (16 de agosto) y la que se deduce de las noticias de prensa sobre el estreno (13 de agosto).

48 "Esta breve escena es una reelaboración de los vv. 806-987 de la tragedia sofoclea, donde Creón da forma al castigo de Antígona (Bañuls - Crespo 2008 [15] 371).

49 Cf. Bañuls-Crespo 2008 [15] 371-372); Nieva de la Paz 1999 [47] 297; Vilches 1994 [70] 464.

${ }^{50}$ A la riqueza del texto de Zambrano se refirió también Eduardo Haro Tecglen, quien manifestó en el prólogo a la versión su admiración por la obra al considerarla una rica y originaria aportación a la larga saga de Antígonas del repertorio teatral universal: "Yo no veo la angustia ni la ansiedad en la Antígona de Sófocles ni en las que he conocido; ni siquiera en las modernas de Cocteau, Anouilh o Brecht. La veo en la de María Zambrano. Y es que veo en ella muchas confesiones personales, de las balas trazadoras que han ido persiguiendo su vida: el exilio, las guerras, las repúblicas, las tiranías, los idiomas" (E. Haro Tecglen, "Antígona, Creón”, in A. Castellón 1997 [6] 8).

${ }^{51}$ Remitimos a las palabras pronunciadas por Jesús Moreno en la mesa redonda del seminario sobre el pensamiento de María Zambrano celebrado en Almagro (Ciudad Real) en el verano de 1983 que contó con la participación de Aranguren: "De María Zambrano puede decirse que ha sido el magisterio ausente, el magisterio que ha faltado en el pensamiento español de la segunda mitad del siglo XX. Es muy de agradecer al profesor José Luis Aranguren el haber sido el primero y más honesto destacador del pensamiento de María Zambrano. Esto ha sido así, en unos años en que nadie, absolutamente nadie, de la Academia Española se dignaba hablar de María Zambrano. J. L. López Aranguren fue el primero, a través de diversos artículos de prensa, que relevó este pensamiento. Por tanto, vaya en nombre de todos nuestro agradecimiento [...] por su honestidad en este tema" (Papeles de Almagro 1983[ 32] 122.

${ }^{52}$ Año en el que, a su vez, se constituye en Vélez-Málaga la Fundación María Zambrano. 


\title{
EL Mito clásico En los Historiadores de INDiAS ${ }^{1}$
}

\author{
José María Camacho Rojo \& Pedro Pablo Fuentes González \\ Universidad de Granada
}

\section{Introducción}

Todo estudio sobre un aspecto concreto en el conjunto de las obras de los historiadores de Indias aconseja una primera selección entre el considerable número de autores que escribieron en los siglos XVI y XVII sobre el descubrimiento y conquista del Nuevo Mundo. Y es que nos encontramos ante un vasto corpus de textos que, bajo la forma de diarios, cartas, relaciones, crónicas e historias propiamente dichas, tienen como motivo común la descripción de la naturaleza de las Indias, de las culturas precolombinas, y la narración de la conquista hispánica. Estos textos nos ofrecen una información variada y de muy diverso valor, pero conviene subrayar desde un principio que, como afirma Mignolo (1981: 380), «la formación discursiva historiográfica acepta por sinónimos», en los siglos XVI y XVII, los nombres de «historia, crónica, anales (y aún relación) para referirse al texto historiográfico» (cf. también p. 384-385 y 402). Ahora bien, no todos los criterios de selección son válidos. Para el estudio del tema que nos ocupa nos ha parecido conveniente utilizar como criterio el tipo de conocimiento historiográfico de los autores, puesto que estimamos que de este modo estarán representadas todas las formas narrativas y, por consiguiente, además del motivo, función y momento en que se introducen los mitos clásicos en la cadena histórica, se podrá determinar el grado de aceptación o rechazo del mito atendiendo al tipo de información de que se vale el historiador.

Pues bien, como medida para valorar la verdad, los historiadores de Indias tomarán la distancia cronológica que media entre los acontecimientos narrados y el momento en que se los narra, de modo que, atendiendo a esta consideración, se pueden distinguir, de nuevo según Mignolo (1981: 387), tres grupos.

Un primer grupo comprende a los escritores que tienen información directa porque son testigos presenciales o agentes de los acontecimientos que narran: el propio Cristóbal Colón (ca. 1451-1506) o Hernán Cortés (1485-1547). A este grupo pertenecen también Gonzalo Fernández de Oviedo (Madrid, 1478 - Santo Domingo, 1557), el gran apologista de los

${ }^{1}$ Este trabajo tiene su origen en una comunicación presentada en el xii Coloquio Internacional de Filología Griega («Influencias de la mitología clásica en la literatura española e hispanoamericana del siglo xvi»), organizado por el profesor J. A. López Férez, y celebrado en Madrid (UNED), los días 7-10 de marzo de 2001. 
conquistadores, con su Historia general y natural de las Indias (1535); el célebre defensor de los indígenas americanos Bartolomé de las Casas (Sevilla, 1474 - Madrid, 1566), autor de una Historia de las Indias, no impresa hasta 1875; Bernal Díaz del Castillo (Medina del Campo, 1492 - Guatemala, 1584), con su Historia verdadera de la conquista de la Nueva España (1568), y Pedro de Cieza de León (1520-1554), autor de la Crónica del Perú (Primera parte: Sevilla, 1553).

El segundo grupo es el de los autores que se basan en información indirecta inmediata, como quienes escriben desde España en el momento en que se realizan los acontecimientos de los cuales informan sus escritos. Es el caso de Pedro Mártir de Anglería (Arona, 1459 - Granada, 1526), autor de las De Orbe Novo decades octo, conocidas como Décadas del Nuevo Mundo (Sevilla, 1511), y Francisco López de Gómara (Gómara [Soria], 1511 - ¿ib.? ca. 1566), escritor de amplia formación humanística, al igual que el anterior, que compuso una Historia general de las Indias y conquista de México (Zaragoza, 1552) a partir de los datos facilitados por Cortés y otros exploradores.

Por último, el tercer grupo es el de los historiadores que se basan en información indirecta mediata, es decir, aquellos que desde España y en un lapso temporal posterior a los hechos que narran, se basan sólo en documentos, como Antonio de Herrera y Tordesillas (1549-1625), el primero de los cronistas de Indias que actúa con una óptica de historiador ajeno personalmente a los hechos que se refieren, autor de una Historia general de los hechos de los castellanos en las islas y tierra firme del mar océano, conocida generalmente como las Décadas, compuesta entre 1601 y 1615; y Juan Cristóbal Calvete de Estella (ca. 15201593), autor de De rebus Indicis (obra inédita hasta 1950).

Como los mitos que aparecen en este variado y extenso corpus de textos son, generalmente, los mismos, se hace aconsejable estudiarlos según su función, esto es, según el cometido que realiza el signo mítico en el texto en que va inmerso. Procederemos, por tanto, a un análisis por temas y no por autores, con el fin de dilucidar si existen o no diferencias en su tratamiento.

\section{Mito clásico e historiografía indiana}

En la historiografía de Indias se encuentran con cierta frecuencia alusiones, referencias y descripciones de mitos clásicos. Para dar una visión de conjunto de los mismos, creemos oportuno establecer una primera división relativa a los tipos de mitos utilizados. Básicamente son de dos clases: los que se refieren a los ámbitos privilegiados del imaginario clásico, aplicados siempre al Nuevo Mundo, y los relacionados con el ámbito heroico-legendario greco-romano, referidos por lo general a los descubridores y conquistadores españoles. 


\section{A. Referentes míticos relativos a los ámbitos privilegiados del imaginario clásico}

La mitologización de las Indias, es decir, la tendencia a ubicar en el Nuevo Mundo una serie de motivos míticos-utópicos tradicionales vino propiciada por la naturaleza extraordinaria de las tierras descubiertas, por su condición de lugar extremo y paradisíaco. En los historiadores, lo real y lo maravilloso se llegan a identificar en ocasiones. Por ello, para describir, explicar y transmitir la imagen de la nueva realidad, los mitos relativos a los ámbitos privilegiados, en el tiempo o en el espacio, del imaginario clásico constituían un referente válido, por ser motivos suficientemente conocidos para gran parte de los lectores a los que se dirigían crónicas e historias. Por otro lado, el elemento utópico característico del espíritu renacentista fue especialmente estimulado por el descubrimiento. La visión utópica de las Indias, que tan fructífera repercusión tendrá en el pensamiento de la época (Moro, Campanella, Bacon), y el fenómeno de la «inversión americana» tienen como primera manifestación la contraposición entre la Edad de Oro y la Edad de Hierro, identificadas con el Nuevo y el Viejo Mundo, respectivamente. Como complementos de este mito e indisolublemente unidos a él, aparecen el tema de la exaltación sin límite de la naturaleza, cuya incidencia llevó a imaginar utopías espaciales que se ubicaron en diversos lugares de las nuevas tierras, y el de la idealización del hombre y los pueblos primitivos. Todo esto conducirá a delinear, en términos generales, la división «estado natural» versus «civilización».

\section{Mitos referidos a un tiempo ideal (utopías temporales): la nostalgia de la Edad de Oro}

Comenzamos por los mitos referidos a un tiempo ideal o utopías temporales, que reflejan la nostalgia de la Edad de Oro. Como es bien sabido, en la Antigüedad clásica el mito de la Edad de Oro alude a un estado de felicidad, la mayor parte de las veces localizado en un pasado remoto, en el que el hombre vive carente de preocupaciones. Esta edad remite a un ámbito ideal que simboliza la armonía, la justicia y la abundancia (Bauzá 1993: 21 ss.). Los testimonios son sobradamente conocidos: Hesíodo (Erga 109123) y Ovidio (Met. I 879 ss.), para no entrar en detalles, son las referencias fundamentales.

La oposición Edad de Oro / Edad de Hierro es una constante en la literatura sobre América de la primera mitad del xvi. Entre los historiadores, el primero que hace mención expresa de la Edad de Oro es Pedro Mártir de Anglería en sus Décadas del Nuevo Mundo. Ya desde la Primera Década, el motivo de la Edad de Oro se afirma claramente. Al comparar a los indios con los itálicos hallados en el Lacio por Eneas, concluye (I 2): 
«Creo yo, empero, que estos isleños de la Española son más felices que aquéllos [...] porque viven desnudos, sin pesas, sin medidas y, sobre todo, sin el mortífero dinero en una verdadera Edad de Oro, sin jueces calumniosos y sin libros, satisfechos con los bienes de la naturaleza, y sin preocupaciones por el porvenir» (p. 23).

El oro se contrapone, pues, al dinero (al hierro); por eso, argumenta Abellán (1979: 384 ss.), al hablar de América como Tierra del Oro, «la palabra "oro" tiene un significado mucho más amplio y elevado que el de la referencia a un simple metal».

Aunque con algunas significativas alteraciones, en los textos de Mártir se reencuentran manifiestamente, como bien observó Lens (1996: 205 ss.), las categorías de la tradición grecorromana. Por ejemplo: cuando refiere el modo de vida de los indios insulares, subraya, entre otras características tradicionalmente aplicadas a la Edad de Oro, que los nativos no conocen la propiedad privada (I 3):

«Es cosa averiguada que aquellos indígenas poseen en común la tierra, como la luz del sol y como el agua, y que desconocen las palabras tuyo y mío, semillero de todos los males. Hasta tal punto se contentan con poco, que en la comarca que habitan antes sobran campos que falta nada a nadie. Viven en plena Edad de Oro, y no rodean sus propiedades con fosos, muros ni setos. Habitan en huertos abiertos, sin leyes, ni libros y sin jueces, y observan lo justo por instinto natural. Consideran malo y criminal al que se complace en ofender a otro» (p. 38).

Y al referir la organización social de los indios, afirma (VII 1):

«Estaban en la edad de oro, no había mío y tuyo, semillas de discordias. El tiempo que les sobraba de sembrar y recoger, lo empleaban en jugar a la pelota, danzar, cazar y pescar. De fueros judiciales, de pleitos, disputas y riñas entre los vecinos, no se hacía mención [...] Lo mismo se observaba en las demás islas, y en todas se contentaban con poco» (p. 423).

Lo hasta ahora dicho está en los textos de nuestros historiadores. No debemos olvidar, sin embargo, que el concepto inverso al de la Edad de Oro, el que interpreta la vida de los indígenas en términos de rudeza y ferocidad, y, en general, contempla la historia de la Humanidad como un progresivo proceso, también lo está, y que tiene asimismo sus antecedentes y su referencia explícita en la otra conceptualización que del hombre primitivo hizo el pensamiento clásico, el de una bestia sin leyes y sin moral, visión que sintetizó Lucrecio en el quinto libro del De rerum natura (925-987). 


\section{Mitos referidos a espacios ideales (utopías espaciales): la exaltación de la naturaleza}

\section{a) Las Indias, locus amoenus}

Tras las utopías temporales, pasamos a los mitos referidos a espacios ideales o utopías espaciales, con su exaltación de la naturaleza. En primer lugar, nos encontramos aquí las Indias como locus amoenus. Entre las visiones utópicas clásicas referidas al espacio destacan los ámbitos privilegiados en los que era posible la eudaimonía. Se trata siempre de lugares placenteros que reciben diversos nombres (Arcadia, Campos Elisios, etc.) y que configuran un espacio idealizado que la retórica englobará bajo el rótulo de locus amoenus (Bauzá 1993: 89-90). El tratamiento de estos motivos clásicos devino un tópico en el Renacimiento, y el tema de la exaltación de la naturaleza recibió gran estímulo a consecuencia del descubrimiento, dando origen a la visión de América como «tierra de la abundancia». El paisaje del Nuevo Mundo fue visto con rasgos que son constantes en todas las descripciones de los primeros historiadores: fertilidad, abundancia y eterna primavera. En este sentido, es famosa la descripción colombina de la Española en la Carta sobre el Descubrimiento (1493):

«En ella hay pinares a maravilla, y hay campiñas grandísimas, y hay miel y muchas maneras de aves y frutas muy diversas [...] La Española es maravilla; las sierras y las montañas y las vegas y las campiñas y las tierras tan hermosas y gruesas para plantar y sembrar, para criar ganados de todas suertes [...] Ésta es para desear, y vista, es para nunca dejar».

Pero para el tema que nos ocupa nos parece paradigmática la descripción que hace P. Mártir de Anglería (III 7) de esta misma isla:

«Sea la descripción particular de la Española lo que vaya al frente de esta narración, ya que es la cabeza y emporio de toda la liberalidad del océano, y que tiene mil y mil ninfas, nereidas hermosas, engalanadas y ricas, que, como a otra Tetis, señora y madre, la rodean y adoran esplendorosamente» (p. 215).

«[...] La Española tiene ambos solsticios casi iguales a los equinoccios [...] Tiene, pues, esta dichosa isla perpetua primavera y perpetuo otoño; allí todo el año tienen hojas los árboles y están verdes los prados; todas las cosas prosperan allí admirablemente» (p. 218).

«[... ¿ ¿Qué mayor felicidad que pasar la vida donde no se vea uno obligado a encerrarse en estrechas habitaciones, con horroroso frío o angustioso calor, ni tenga uno que cargar el cuerpo en invierno con pesados vestidos, o estar quemándose las espinillas continuamente al fuego, que son cosas 
que envejecen a los hombres rápidamente y quebrantan las fuerzas y traen consigo mil clases de enfermedades? Dicen, además, que es saludable el aire, y saludables las aguas de los ríos: como que corren siempre sobre oro; pues no hay ningún río, nigunas montañas, ni llanura que no tengan oro» (p. 219).

En tan gran consideración eran tenidas las excelencias naturales de las nuevas tierras que esta misma consideración sirvió a Las Casas, con ayuda de otros argumentos, para sostener que las Indias no habían sido conocidas por los antiguos. Se basa en que las Indias poseen mayores excelencias que las islas Canarias como para que, de haberse conocido, los antiguos hubieran situado en ellas, y no en las Canarias, los Campos Elisios:

«Y así, no son aquellas islas del nombre de Paraíso dignas, y por esto parece claro ninguna noticia los muy antiguos haber tenido destas Indias [...], porque si la tuvieran, con muy mayor razón pusieran en ellas los Campos Elísios que en las islas de Canaria, ni en España, pues es manifiesta la ventaja, como cien mil partes a una, que a todas las del mundo, en felicidad, templanza de aires, aspecto de los cielos, aguas, frutas, frescura, suelo, disposición de la misma tierra y otras naturales riquezas hacen estas Indias [...]» (BAE XCV 1, p. 381)».

De ahí que, según Las Casas, pueda resultar justificado que Colón concibiera que allí podía encontrarse el Paraíso:

«Y porque allí donde agora el Almirante andara era maravilla la frescura y temperancia de los aires y alegría de la tierra, cielo, aguas y arboledas, que por los ojos vía, no era mucho que por allí concibiese, aunque había navegado hacia el Poniente (puesto que también sentía ser el fin del Oriente), estar, no los Campos Elísios como los gentiles, sino, como católico, el terrenal Paraíso» (ibid.).

\section{b) La fuente de la juventud}

En estos ámbitos idílicos era, pues, posible para el hombre tener una existencia feliz e incluso lograr vencer los achaques de la vejez, por lo que no es extraño que se localizara también en las nuevas tierras la fuente de la juventud. La convicción de la existencia de esta fuente venía, en gran parte, impuesta por la lógica: en las cercanías del Paraíso terrenal, y América lo parecía, se había de hallar semejante prodigio (Gil 1989: I 251-252). En la literatura griega era posible encontrar noticias de la existencia de islas donde se podía detener el paso del tiempo (en la Odisea V 13-281, VII 243-266, Calipso intenta retener a Ulises en la isla de Ogigia con la promesa de la inmortalidad). Referencias a una fuente de la juventud se encontraban en Heródoto, según el cual la mayoría de los etíopes vivían ciento veinte años y se bañaban en una fuente 
cuya agua «era de tan escasa densidad que ningún objeto podía flotar en su superficie», por lo que en ella podía residir «la causa de su longevidad» (III 23). La noticia de la existencia en el Nuevo Mundo de una fuente de la juventud, situada siempre en la tradición más allá de los confines del mundo conocido, fue debida a Juan Ponce de León. Entre los historiadores de Indias el primero que se refiere a una fuente de estas características, seguido por casi todos los cronistas, es Pedro Mártir, (II 10):

«[... a la distancia de trescientas veinticinco leguas de la Española, cuentan que hay una isla [...], que se llama Boyuca o Ananeo, la cual tiene una fuente $\tan$ notable que, bebiendo de su agua, rejuvenecen los viejos. Y [...] tan formalmente se han atrevido a extender esto por toda la corte, que todo el pueblo y no pocos de los que la virtud o la fortuna distingue del pueblo, lo tienen por verdad.

Pues si Vuestra Santidad (scil. el papa León X) me pregunta mi parecer, responderé que yo no concedo tanto poder a la naturaleza madre de las cosas, y entiendo que Dios se ha reservado esta prerrogativa cual no menos peculiar que el escudriñar los corazones de los hombres o sacar las cosas de la nada, como no vayamos a creer la fábula de Medea acerca del rejuvenecimiento de Esón o la de la Sibila de Eritrea, convertida en hojas» (p.159).

En la Séptima Década (VII 7) alude de nuevo a la fuente, situada cerca de la Florida, y a los detalles relativos a ella que le han referido hombres de cierta autoridad que han estado en las Indias (p. 453-455):

«En mis primeras Décadas que corren impresas por el mundo, se dio noticia de una fuente que dicen tiene tal virtud oculta que, usando su agua bebida y en baños, hace rejuvenecer a los ancianos» (p. 453).

Mártir manifiesta su escepticismo al respecto y no duda de que hecho tan excepcional es contrario al parecer de filósofos y médicos, pero también aduce conjeturas a favor:

«Apoyándome yo en el ejemplo de Aristóteles y de nuestro Plinio, me atreveré a dar cuenta y consignar por escrito lo que no vacilan en afirmar de viva voz hombres de suma autoridad [...]

Así, pues, entre las afirmaciones de ellos y los argumentos fuertes de los antiguos sabios, vacilando yo sobre si es posible que, aparte de los milagros divinos, tenga la naturaleza tanta virtud, no apoyándome en las medicinas de Medea, con las cuales fingen los griegos que rejuveneció a su suegro Esón, ni en los versos de Circe con que cambió en animales a los compañeros de Ulises y los volvió, sino enseñando con ejemplos de animales brutos, me propongo argumentar sobre este asunto tan insólito e imposible a juicio de muchos, para 
que no formemos juicio de que hombres tan graves hablaron enteramente sin fundamento» (p. 453-455).

Concluye Mártir manifestando una actitud de confianza en la naturaleza («artífice maravillosa», p. 455), que la acción rejuvenecedora de la fuente podría tal vez explicarse por el misterioso poder de aquélla:

«Así pues, yo no me maravillaría de que las aguas de esta fuente tuvieran alguna virtud aérea y acuosa, desconocida para nosotros [...]» (p. 455).

c) Identificación de las Indias con lugares míticos

Pasamos ahora al problema de la identificación de las Indias con diversos lugares míticos. Esta visión paradisíaca de las nuevas tierras, así como las leyendas y las fantasiosas concepciones cosmográficas de la época hicieron que en los comienzos del descubrimiento las islas se interpretaran y se localizaran en clave mítica. Además de la colombina localización en las comarcas bíblicas de Ofir y Tarsis, las islas fueron pronto identificadas con las Hespérides, en la idea de que se encontraban en el mar Etiópico, entendido como el océano Atlántico frontero de África, por lo que el almirante habría realizado un periplo similar al de Hanón. Esta solución, propugnada por Francisco de Cisneros (Gil 1989: I 72 ss.), fue la defendida por Fernández de Oviedo, quien dedicó un largo capítulo de su Historia general a demostrar, apoyándose en la autoridad del falso Beroso, que las Hespérides, esto es, las islas descubiertas, habían pertenecido en la Antigüedad a Hespero, duodécimo rey de España, y recibido su nombre del mismo:

«[...] a mi parescer, Cristóbal Colon se movió, como sabio e docto e osado varón, a emprender una cosa como ésta, de que tanta memoria dejó a los presentes e venideros, porque conosció, y es verdad, que estas tierras estaban olvidadas. Pero hallólas escriptas; e para mí no dudo haberse sabido e posído antiguamente por los reyes de España [...] En verdad [...] yo tengo estas Indias por aquellas famosas islas Hespérides, así llamadas del duodécimo rey de España, dicho Hespero» (BAE CXVII 1, p. 17).

La credulidad de Fernández de Oviedo fue criticada por Hernando Colón (Historia del Almirante, cap. IX) y con posterioridad por el cronista Antonio de Herrera, pero la más completa refutación se debe a Bartolomé de Las Casas, quien, en los capítulos XV y XVI del libro I de su Historia de las Indias, adujo numerosas razones y argumentos en contra de la identificación de las Hespérides con las Indias y de su pretendida pertenencia a España en tiempos del rey Hespero XII. Las Casas atribuye a Fernández de Oviedo «tanta autoridad, y cuanta cual se suele atribuir a los sueños, o a los que las cosas que aún no son in 
rerum natura adivinan» (p. 53a). Más adelante, continúa negando toda validez a su idea:

«Muchas y en muchas cosas Oviedo alega libros y autoridades que él nunca vió ni entendió, como él no sepa ni entienda latín, y así parece que hizo en esta» (BAE XCV 1, p. 60).

Como ejemplo de los razonamientos de Las Casas en contra de esta idea, citamos el siguiente:

«[...] no había en Grecia ni en otras naciones, harto más políticas y de más sotiles ingenios que las de España, industria de navegar ni cerca y menos lejos, y el primero que juntó flota y señoreó la mar de Grecia fué Minos, como cuenta Tucídides, antiquísimo historiador griego, lib. $1^{\circ}$, columna $2^{a}$, el cual fué antes de Platón, ¿cuánto menos pericia tenía España de navegar en tiempo de Hespero, siendo antes que Troya?; mayormente que no les faltaban guerras, como parece que Hespero defendiéndose contra su hermano Atlante, que le vino con gran ejército a echar del reino, como al fin dél lo echó, las tuvieron muy crueles, y así es manifiesto que no tuvo tiempo en entender en tan prolijos descubrimientos» (BAE XCV 1, p. 54b).

No fue ésta, en fin, relativa a las Hespérides, la única identificación con lugares míticos procedentes de la cultura griega. López de Gómara propuso identificar las Indias con la Atlántida platónica y no con las Hespérides ni Ofir y Tarsis:

«Platón cuenta en los diálogos Timeo y Cricia, que hubo antiguísimamente en el mar Atlántico y Océano grandes tierras, y una isla dicha Atlántide, mayor que África y Asia, afirmando ser aquellas tierras de allí verdaderamente firmes y grandes, y que los reyes de aquella isla señorearon mucha parte de África y de Europa. Empero que con un gran terremoto y lluvia se hundió la isla, sorbiendo los hombres; y quedó tanto cieno, que no se pudo navegar más aquel mar Atlántico. Algunos tienen esto por fábula, y muchos por historia verdadera [...] Pero no hay para qué disputar ni dudar de la isla Atlántide, pues el descubrimiento y conquistas de las Indias aclaran llanamente lo que Platón escribió de aquellas tierras, y en Méjico llaman a el agua atl, vocablo que parece, ya que no sea, al de la isla. Así que podemos decir cómo las Indias son la isla y tierra firme de Platón, y no las Hespérides, ni Ofir y Tarsis, como muchos modernos dicen; ca las Hespérides son las islas de Cabo-Verde y las Gorgonas, que de allí trujo Hanon monas. Aunque con lo de Solino hay alguna duda, por la navegación de cuarenta días que pone. También puede ser que Cuba, o Haiti, o algunas otras islas de las Indias, sean las que hallaron cartagineses, cuya ida y población vedaron a sus ciudadanos, según cuenta Aristóteles o Teofrasto, en las maravillas de natura no oidas. Ofir y Tarsis no se sabe dónde ni cuáles son, 
aunque muchos hombres doctos, como dice San Agustín, buscaron qué ciudad o tierra fuese Tarsis» (BAE XXII, p. 291b-292a).

\section{La visión utópica del hombre primitivo. Pueblos y genios míticos}

Entre los elementos que configuran el mito de la Edad de Oro y la exaltación de la naturaleza se encuentra la idealización de los pueblos primitivos.

\section{a) El mito del buen salvaje}

Es bien sabido que, como complemento de estos mitos, se desarrolló el del «buen salvaje». La utopía del hombre unido a la naturaleza representa un estado en que no se ha producido la degradación del hombre por la civilización. Al margen de algunos textos del propio Colón sobre la bondad, ingenuidad y sencillez de los indígenas, los comienzos del mito se suelen asociar con Bartolomé de las Casas, pero las primeras manifestaciones de la elaboración utópica del «buen salvaje», que alcanzará su formulación más plena con Rousseau, se encuentran ya en Pedro Mártir de Anglería, en el episodio del «filósofo desnudo», claro ejemplo de una idealización del hombre primitivo. Cuenta Mártir (I 3) cómo en la isla de Cuba, «mientras el Almirante oía misa en la playa», se les apareció «cierto varón principal, octogenario y grave, y sin embargo desnudo, con muchos que le acompañaban, el cual, mientras se celebraban los sagrados misterios, asistió admirado con respetuoso rostro y mirada». Y sigue diciendo que, después de ofrecerle un canastillo lleno de frutas, se dirigió a él con estas palabras:

«Nos han contado que tú has recorrido con ejército poderoso todas estas provincias que hasta ahora te eran desconocidas, y que has causado no poco miedo a los pueblos que las habitan. Por lo cual te advierto y amonesto que las almas, cuando salen del cuerpo, tienen dos caminos: uno tenebroso y horrible, preparado para aquellos que molestan y hacen daño al género humano; otro placentero y deleitable, destinado para los que en vida amaron la paz y tranquilidad de las gentes. $\mathrm{Si}$, pues, tienes presente que eres mortal, y que a cada uno le están señalados los méritos futuros según las obras presentes, no harás mal a nadie» (p. 38).

Aunque simplemente como un eco lejano, parece inevitable evocar aquí el encuentro (directo o indirecto) de Alejandro Magno con los gimnosofistas indios, del que la tradición antigua nos ofrece testimonios ya sin duda envueltos en el tópico y la leyenda ( $c f$. Estrabón XV 1, 61, 63-65; Plutarco, Vida de Alejandro 14, 2-3; Arriano, Anábasis VII 1-2; Pap. Genev. 271; Anónimo, Historia de Alejandro Magno III 5-16; Paladio, Sobre los pueblos y los brabmanes de la India $\left.\mathrm{II}^{2}\right)$.

${ }^{2}$ Sobre este episodio legendario, $c f$. Oliver Segura 1991; Id. 1990; Martín García 2008, vol. I, 445-454. 
b) Otros mitos: las amazonas, las sirenas

Conviene, por último, señalar las frecuentes alusiones a pueblos fabulosos, como los cinocéfalos o los hombres con cola. Sin embargo, el asunto que tratamos nos obliga a destacar otros motivos que, aunque no constituyen un material utópico propiamente dicho, pertenecen también al proceso de elaboración mítica de la conquista y descubrimiento: nos referimos a los temas de las amazonas y las sirenas.

Como bien advierte Gil, el mito de las amazonas sufrió a lo largo de los siglos un desplazamiento hacia Oriente: las amazonas, que vivían a orillas del río Termodonte, en la Meótide o mar de Azov (Heródoto IV 110 ss.), acabaron relegadas al Cáucaso o al Caspio y, por último, a los confines de la India, "pero siempre para habitar en parajes acuáticos y estando siempre libres de todo trato con los hombres» (Gil 1989: I 35). No extraña, pues, que Colón, en su Diario, localizara esta leyenda en una isla al este de la Española, de nombre Matininó: «había - dice- una isla adonde no había sino sólo mujeres», precisando que "cierto tiempo del año venían los hombres a ellas de dicha isla de Caribe, que diz que estaba de ellas diez o doce leguas, y si parían niño enviábanlo a la isla de los hombres, y si niña dejábanla consigo» (p. 122 y 132).

La leyenda de las amazonas fue tratada, entre otros, por Pedro Mártir, Pedro de Cieza de León, Fray Gaspar de Carvajal, Fernández de Oviedo y Miguel Cabello Valboa.

En la obra de Pedro Mártir, entre los motivos de carácter mitológico, uno de los mencionados con más frecuencia, quizás el que más, es precisamente el de las amazonas. Las referencias al mito se encuentran ya en la Primera Década (I 2), con motivo del segundo viaje en 1493:

«Comenzó a verse por el Septentrión cierta isla grande, y los que en la primera navegación habían sido llevados a España y librados de los caníbales afirmaron que aquella isla la llamaban sus habitantes Madanina (sic), que la habitan mujeres solas. En el primer viaje habían tenido los nuestros noticias de esta isla. Se ha creído que los caníbales se acercan a aquellas mujeres en ciertos tiempos del año, del mismo modo que los robustos tracios pasaban a ver a las amazonas de Lesbos, según refieren los antiguos, y que de igual manera ellas les envían los hijos destetados a sus padres, reteniendo consigo a las hembras. Cuentan que estas mujeres tienen grandes minas debajo tierra, a las cuales huyen si alguno se acerca a ellas fuera del tiempo convenido; pero si se atreven a seguirlas por la violencia o con asechanzas y acercarse a ellas, se defienden con saetas, creyéndose que las disparan con ojo muy certero. Así me lo cuentan , así te lo digo (p. 20)». 
En la Tercera Década (III 9) trata de explicar el origen de la creencia entre los españoles de la existencia de las amazonas. Así dice que, en ciertas islas, cuando los hombres se marchan:

«[...] las mujeres se defienden varonilmente de los que vayan allá. De aquí me parece que proviene la creencia de que hay en aquel océano islas habitadas sólo por mujeres como me lo persuadió a mí el propio almirante Colón y lo digo en la primera Década (p. 235)».

Hay, pues, en Mártir, en oposición a la falta de espíritu crítico de posteriores cronistas, un intento de explicación histórica, como advertimos en la Década Cuarta (IV 4), donde establece una diferencia entre ciertas sacerdotisas y las amazonas, considerando que las segundas no tienen fundamento real:

«[...] hay otras islas, donde sólo habitan mujeres sin trato de hombres. Piensan algunos que viven a estilo de amazonas. Los que lo examinan mejor, juzgan que son doncellas cenobitas que gustan del retiro, como pasa entre nosotros, y en muchos lugares las antiguas vestales o consagradas a la Diosa Buena. En ciertos tiempos del año pasan hombres a la isla de ellas, no para usos maritales, sino movidos por compasión, para arreglarles los campos y huertos, con el cultivo de los cuales puedan vivir. Mas es fama que hay otras islas habitadas por mujeres, pero violadas, que desde pequeñas les cortan un pecho para que más ágilmente puedan manejar el arco y las flechas, y que pasan allá hombres para unirse con ellas, y que no conservan los varones que les nacen. Esto lo tengo por cuento» (p. 262).

Finalmente, en la Década Séptima, el autor consigna su última referencia a este mito, reafirmando su incredulidad, pese a la coincidencia en este asunto por parte de algunos informantes:

«Añaden también éstos que es verdad lo que se cuenta de la isla habitada solamente por mujeres que a flechazos defienden con bravura sus costas, y que en ciertas temporadas del año pasan allá los caníbales para engendrar, y que desde que están encintas ya no aguantan a los hombres, y que a los niños que les nacen los echan fuera y se guardan las hembras, de lo cual hice mención en las primeras Décadas, y lo dije así como por fábula (p. 471)».

Muchos de los cronistas posteriores a Pedro Mártir se refirieron a las amazonas, uniendo la leyenda al mito clásico. Hernán Cortés, en la cuarta de sus Cartas de relación de la conquista de Méjico, refiere la relación de uno de sus capitanes tras explorar las costas recién descubiertas del «Mar del Sur»:

«[... y y asimismo me trujo relación de los señores de la provincia de Ciguatán, 
que se afirman mucho haber una isla toda poblada de mujeres, sin varón ninguno, y que en ciertos tiempos van de la tierra firme hombres, con los cuales han aceso, y las que quedan preñadas, si paren mujeres las guardan, y si hombres los echan de su compañía» (p. 254).

Fernández de Oviedo nos proporciona numerosas alusiones y referencias a las amazonas en su Historia general y natural de las Indias e insiste en negar su existencia:

«[... y más al mediodía está Matinino, la cual han querido algunos cronistas decir que era poblada de amazonas, e otras fábulas muy desviadas de la verdad, como paresce por sus tractados, e se ha después averiguado que todo es falso por los que hemos visto la isla y las otras de su paraje; y es todo falso lo que désta se ha dicho cuanto a ser poblada de mujeres solamente, porque no lo es ni se sabe, que jamás lo fuese» (BAE CXVII 1, p. 34).

Pero lo que interesa sobre todo es destacar las explicaciones etimológicas que, en al menos dos ocasiones, aduce:

«[...] está [...] más adelante, la punta que llaman de las Mujeres; y más adelante, otra isla que llaman de las Amazonas [...] Estos nombres de punta e islas de Mujeres e Amazonas, les pusieron los primeros descubridores, ignorando lo que quiere decir amazona; porque vieron que estas mujeres destas islas que es dicho, eran todas ellas flecheras y pelean con arcos, así como los indios. Pero amazona no quiere decir sino sin teta; y en lengua griega, a quiere decir sin, e mazón quiere decir teta; y como se escribe que las amazonas pelean con arcos y flechas, pensaban aquellos españoles nuestros que llamaron amazonas a estas mujeres, que el nombre les competía por las armas, e como hombres que no sabían que las amazonas, para el ejercicio del arco se quemaban la teta derecha e dejaban la siniestra para criar sus hijos. De aquellas amazonas fueron reinas Marpesia e Lampedia, e sojuzgaron la mayor parte de Europa, como más largamente lo cuenta Justino en la Abreviación de Trogo Pompeyo» (BAE CXVIII 2, p. 330).

\section{Y posteriormente:}

«Así, los cristianos las comenzaron a llamar amazonas, sin lo ser; porque aquellas que los antiguos llamaron amazonas, fué porque para ejercitar el arco y las flechas, seyendo niñas, les cortaban o quemaban la teta derecha, e no les crescía, e dejaban la siniestra para que pudiesen criar la hija que pariesen; y en griego, a quiere decir sin, mazo quiere decir teta, y por esto amazona quiere decir sin teta» (BAE CXIX 3, p. 122).

Es, por último, especialmente significativo el capítulo XXIV del libro L (BAE CXXI 5, p. 373-402), donde, siguiendo a fray Gaspar de Carvajal, 
relata el descubrimiento del Amazonas por Orellana con las más completas referencias sobre este tema que se pueden hallar en las crónicas de Indias.

Un punto que todos estos textos tienen en común es la referencia al mundo acuático y a las costumbres sociales: periódicamente las mujeres se unen con hombres y, tras dar a luz, si es niña, la retienen; si es varón, lo alejan de sí.

El tema de la aparición de sirenas a los marinos era ya en la época del descubrimiento un tópico. El propio almirante, en su Diario, anotaba en 1493 que «vido tres sirenas que salieron bien alto de la mar, pero no eran tan hermosas como las pintan, que en alguna manera tenían forma de hombre en la cara» (p. 112). Mártir de Anglería refiere también narraciones sobre sirenas en $\mathrm{V}$ 9:

«[...] a unas cien leguas de la colonia de Panamá encontraron una anchura de mar de color negro, en donde nadaban peces del tamaño de los delfines, que cantaban con armonía, como cuentan de las sirenas, y que adormecen del mismo modo» (p. 374).

Advierte a continuación que esto producirá admiración a «los hombres de ánimo estrecho», y, aunque manifiesta su escepticismo, intenta explicar el fenómeno, afirmando, contra la incredulidad de algunos, su fe en el poder de la naturaleza:

«Lo del canto también yo lo tengo por fábula, aunque lo cuentan hombres formales; mas para excusarles, ¿acaso no es sabido que hay tritones con voz [...] y fueron oídos y hallados muertos arrojados a la playa en la parte occidental de España? ¿No canta la rana debajo del agua? ¿Pues qué extraño será que se hallen también otros peces con voz, que nunca se hubiesen oído antes? Cada uno crea lo que le acomode: yo pienso que la naturaleza puede hacer cosas grandes» (p. 374).

\section{B. Referentes míticos del ámbito heroico-legendario clásico}

Otros mitos a los que con frecuencia aluden nuestros historiadores son, como dijimos, los relacionados, en general, con el ámbito heroico-legendario clásico. El empleo de este tipo de mito tiene como finalidad la exaltación y glorificación de los conquistadores. Se pretende con ello hacer a los españoles émulos de los héroes grecolatinos, convirtiendo así la historia en epopeya. Obviamente este uso es muy frecuente en los historiadores apologistas de los conquistadores, cuyo paradigma puede ser Fernández de Oviedo, y, por supuesto, no se encuentra en los defensores de los pueblos indígenas, como Bartolomé de Las Casas, quien, a la inversa, se sirve de este procedimiento, por ejemplo, para encomiar la figura del indio Ciguayo. En este caso, al utilizar 
como referente la guerra de Troya, Las Casas, en coherencia con sus postulados ideológicos, recurre en su comparación al héroe de los vencidos. En efecto, en su Historia de las Indias, cap. CXXVII del libro II, acerca del levantamiento del Ciguayo en la Española, nos dice de éste que, atravesado con una media lanza por un español, «peleaba como un Héctor» ( $B A E \mathrm{XCV} 2$, p. 481). No deja de ser significativo que el único español que merece una comparación heroica por parte de Las Casas sea el propio Emperador Carlos V, al que, en el cap. CXLVIII del mismo libro, que refiere una audiencia, compara con Príamo:

«El obispo de tierra firme se levantó e hizo un preámbulo muy gracioso y elegante [...], diciendo [...] que agora que Dios le había complido su deseo, cognoscía que facies Priami digna erat Imperio; lo que el poeta Homero dijo de la hermosura de Príamo, aquel excelente rey troyano» (BAE XCV 2, p. 533).

Pues bien, para ilustrar mejor este empleo del mito, podemos distinguir entre referentes míticos propiamente dichos y personajes históricos de la Antigüedad mitificados, como Alejandro Magno.

\section{Referentes míticos}

Los referentes míticos más comunes son, como es de esperar, los relativos a viajes legendarios y a héroes civilizadores; es decir, los mitos de Jasón (o Ulises) y Heracles.

\section{a) Mitos relativos a viajes legendarios}

En cuanto a los mitos relativos a viajes legendarios, la imagen de Colón como navegante erudito y como nuevo Tifis proviene de la Historia del Almirante de su hijo Hernando Colón, quien cita a Séneca como referencia del padre:

«El segundo fundamento que dio ánimo al Almirante para la empresa referida, y por el que razonablemente pueden llamarse Indias las tierras que descubrió, fue la autoridad de muchos hombres doctos [...] y Séneca en los Naturales, libro I nos dice que desde las últimas partes de España pudiera pasar un navío a las Indias en pocos días con vientos; y si como algunos quieren, hizo este Séneca las tragedias, podemos decir que a este propósito dijo en el coro de la tragedia de Medea: "Venient annis / secula seris, quibus Occeanus / vincula rerum laxet, et ingens / pateat tellus, Tiphisque novos / detegat orbes. / Nec sit terris ultima Thule"» (p. 64).

López de Gómara reproduce esta referencia, pero haciendo ahora de Tifis la personificación de la navegación: 
«Decir lo que ha de ser mucho antes que sea, es adevinar, y adevino llaman al que acierta lo porvenir, y muchas veces aciertan los que hablan por conjetura y por instinto y razón natural [...] Todo esto digo, considerando lo que dijo Séneca el poeta, en la tragedia Medea, acerca del Nuevo Mundo, que llaman Indias; ca me paresce cuadrar puntualmente con el descubrimiento de las Indias, y que nuestros españoles y Cristóbal Colón lo han sacado verdadero. Dice pues: "Vendrán siglos de aquí a muchos años que afloje las ataduras de cosas el Océano, y que aparezca gran tierra, y descubra Tifis, que es la navegación, nuevos mundos, y no será Tile la postrera de las tierras". Y en latín: Venient annis / Saecula seris, quibus Oceanus / Vincula rerum laxet, et ingens / Pateat tellus, Tiphisque novos / Detegat orbes. / Nec sit terris ultima Thile» (BAE XXII, p. 291b).

La referencia de Séneca se prolonga en la obra de Antonio de Herrera,

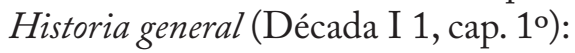

«Las Indias Occidentales eran regiones tan fuera de la imaginación de los hombres, que las pudiese haber, que se tenía por desvarío pensar en ello; porque se creía que se acababa la tierra en las islas de Canaria y que todo lo demás al Poniente era mar, aunque algunos antiguos tocaron algo, acerca de que las había. Séneca, en el fin de su Medea, en el acto II, dice que vendría tiempo en que el Occeano se dejase navegar y se descubriese gran tierra, y viese otro Nuevo Mundo» (II, p. 11).

El viaje de Magallanes y la primera vuelta al mundo realizada por una de sus naves, la Victoria, al mando de Elcano, es comparada por Pedro Mártir (V 7) con la exigua distancia recorrida por la nave de los argonautas en los siguientes términos:

«¿Qué no hubiese inventado la Grecia sobre novedad tan increíble de haberla llevado a cabo uno de los suyos? Venga la nave argonáutica, de cuya llegada al cielo se nos habla supersticiosamente, sin que los que tal hacen se ruboricen ni se rían, a contarnos sus hazañas. Mas ¿en qué consistió ésta sino en arribar desde Argos a Oetes y Medea con sus héroes Hércules, Teseo y Jasón? ¿Acaso sabemos lo que hizo? Las gentes ignoran aún en qué consistió el famoso vellocino de oro, pero, en cambio, los niños han aprendido de cualquier maestrillo que la distancia existente entre Grecia y el Ponto es inferior a la uña de un gigante» (p. 360).

La misma comparación y en términos similares se encuentra en Gómara:

«La nave Argos de Jasón que pusieron en las estrellas, navegó muy poquito en comparación con la nao Victoria [...] Los rodeos, los peligros y trabajos de Ulises fueron nada en respecto de los de Juan Sebastián [...]» (p. 219). 


\section{Y en Fernández de Oviedo:}

«Calle la nao de Argos, pues vimos poco tiempo ha, la nao nombrada la Victoria, que circuyó el universo en el descubrimiento de la Especiería por aquel famoso Estrecho que el capitán Fernando de Magallanes enseñó. Aquel fue el más luengo camino que hasta hoy se sabe que hombres mortales hayan fecho [...] que todo lo que está escripto, e hombres hasta nuestro tiempo han visto, es mucho menos que lo que nuestros españoles han navegado» (BAE CXIX 3, p. 363-364).

Los argonautas siguen siendo el referente mítico, ya tópos, ahora ampliado, en Juan Cristóbal Calvete de Estrella, esta vez ya con relación al valor de los españoles en general en el arte de la navegación. Así, en la Rebelión de Pizarro en el Perú y vida de Don Pedro Gasca:

«Ha llegado tanto el valor de los españoles en navegar, que hay hoy en día muchos vivos de ellos que han dado una vuelta y aun dos al mundo; cosa que parece increíble y que es digna de toda admiración [...] Lo cual fuera tenido en más por los antiguos que la navegación de los Argonautas con su nave Argos, ni que los trabajos ni navegaciones de Ulises; que no es pequeño loor de los españoles, que aunque los cartagineses tuvieron alguna noticia de las tierras y costa del Océano occidental por la navegación que Hanno, su capitán, hizo, fue muy poco o casi nada en comparación de los españoles, y asimismo lo que Platón cuenta en el Timeo que pasó el viejo sacerdote egipcio con Solón, uno de los siete sabios de Grecia. Y ya que fuese algo, sería de la mar del Norte, y no de la del Sur, que tan desconocida fue por los antiguos, y tan dificultosa de hallar, que aun los mismos españoles, con haber dos años que tenían conquistada y poblada la costa del mar del Norte, no sabían de aquella mar del Sur, ni la pudieron descubrir hasta que con gran trabajo, atravesando la tierra, vinieron a hallar aquella mar del Sur tan deseada por ellos» (Crónicas del Perú, vol. IV, BAE CLXVII, p. 287b-298a).

Cf. Id., De rebus Indicis, p. 53:

"Quippequi ea navi Victoria, quam veteres Poetae longe dignius, si id tunc contigisset, quam Argon inter astra collocassent, universum orbis terrae ambitum fuerit circumvectus. Et profeto ea navis Victoria in Hispalensium navalibus reponi atque in perpetuam tantae rei memoriam servari et meruit, et debuit.

Sed Hispanorum res partim Principum culpa, partim scriptorum inscitia, in obscuro iacuere: et Cani quidem cursus majorem in admirationem Graecos duxisset, qua ea, quae de Argonautis, et Ulysse illi ipsi tradiderunt. Non Hannonem Carthaginensium Ducem Graeci et Romani scriptores tantum extulissent: quod florentibus Carthaginis opibus, pervectus a Gadibus ad Arabiae finem, eam oceani oram memoriae prodiderit $[\ldots]$ » 
b) Mitos relativos a trabajos

En cuanto a los mitos relativos a trabajos, las penalidades y la resistencia de los españoles son comparados muy frecuentemente con los trabajos de héroes legendarios, en especial Heracles. Así Mártir de Anglería (V 6), al referir las penalidades de Cortés y sus soldados, hace extensible a los españoles en general la capacidad de sufrimiento:

«Omito aquí muchas cosas particulares que me hacen creer que ni los doce Hércules griegos ni viviente alguno pasó tanto quedando con vida. Tantas desdichas, tantos peligros en los combates, hambres semejantes, creo que no pudiera aguantarlos nadie no siendo español. Este linaje de hombres ha nacido para sufrir cualesquiera trabajos, hambre y sed, calores y fríos y prolongadas vigilias e intemperie, si hay necesidad, a mi juicio, más que otra nación alguna» (p. 345).

Textos de similares características pueden encontrarse en diversos historiadores, pero resultan especialmente significativos, por su afán apologético, algunos de Fernández de Oviedo, como las reflexiones que este introduce tras la descripción de la muerte de algunos de los compañeros de Pánfilo de Narváez:

«Mas aquéstos sin ventura, que con tantos e tan diversos géneros de muertes padescieron, ¿qué se les puede igualar con traerlos su mala dicha e pecados a comerse unos a otros, e a morirse rabiando de hambre e de sed, e de otras enfermedades e trabajos, nunca por hombres padescidos ni tan continuos? [...] Hacedme agora saber, los que habéis leído, si oístes ni supistes otra gente tan desdichada ni tan trabajada ni tan mal aconsejada. Buscad esa peregrinación de Ulixes, o esa navegación de Jasón, o los trabajos de Hércoles, que todo eso es ficciones e metáforas, que entendidas como se deben entender, ni hallaréis de qué os maravillar, ni son comparación igual con los trabajos de estos pecadores que tan infelice camino e fin hicieron. E cualquiera de todos éstos padesció más que los tres capitanes que es dicho, aunque con ellos pongáis a Perseo con su Medusa, si por estos pasos anduvieran que éstos anduvieron» (BAE CXX 4, p. 299).

La referencia a uno o varios mitos está motivada muchas veces, como hemos dicho, por el encomio de un personaje. Sirva de ejemplo el siguiente texto de Fernández de Oviedo, en el que este exalta el valor, generosidad y liberalidad de Diego de Almagro:

«El ser de su persona era tan valerosa cuanto pensarse puede; su esfuerzo no mediocre, sino de un Alcides o Perseo, o el que quisieren escoger de aquellos famosos Hércoles, igualándose a los muy famosos, señalados e osados varones antiguos militares; porque por nescesidad que tuviese, nunca de él se conosció 
temor ni poquedad: antes, en los mayores trabajos e peligros, mirándole los soldados, cobraban nuevas fuerzas e ánimos para resistir su cansancio e hambre e temor» (BAE CXXI 5, p. 127).

En otras ocasiones la alusión al mito figura en los discursos o arengas que los capitanes dirigen a sus soldados, en la idea de que, gracias al sufrimiento de grandes penalidades, se alcanzará la ansiada gloria. Hércules aparece así, de nuevo, como referente en el siguiente discurso de Hernán Cortés, según Mártir de Anglería (V 2):

«¡Qué fama quedará en la posteridad por estas hazañas que jamás se ofrecieron a ninguno de los vivientes! En nuestra patria, nuestros vecinos nos darán más honra que jamás la tuvo Hércules en Grecia por su venida a España, de la cual quedan todavía monumentos. Son muchos más graves nuestros trabajos: también serán mayores los premios. Despertad, pues, y con ánimo valeroso emprended conmigo la empresa comenzada sin dudar de la victoria» (p. 303).

Pero no sólo los conquistadores. También sus mujeres son dignas de encomio por parte de Fernández de Oviedo. Y, como siempre, también aquí el personaje real supera con creces al referente mítico. Después que salió de la prisión de Cortés, Pánfilo de Narváez -dice nuestro historiador-:

«halló a su mujer, María de Valenzuela, que había algunos años que le atendía, en tan buena fama e reputación como pudo estar Penélope; puesto que no tejía e destejía, como aquélla, por la duda que tenía o esperanza de la venida de su marido Ulixes: estotra, certificada de la prisión e trabajos del suyo, granjeaba su hacienda, e la acrescentaba e guardaba para le redimir e ayudar» (BAE CXX 4, p. 285b).

c) Descubridores y conquistadores españoles como civilizadores

Por último, los descubridores y conquistadores españoles son comparados con figuras míticas desde la perspectiva de nuevos civilizadores y propagadores de la religión cristiana. Así, en los dos textos que siguen de Pedro Mártir son equiparados a Saturno y Hércules (I 10):

«Volvamos ya a los nuevos territorios [...] Son tan innumerables, varios y ricos, que nuestros modernos españoles no son menos que Saturno o Hércules, o cualquiera de los antiguos que investigaron nuevas regiones y las pusieron en cultura. ¡Oh, cuán latamente extendida verán los venideros la Religión cristiana! ¡Qué largos viajes podrán hacer ya los hombres! Lo que entiende acerca de estas cosas ni de palabra ni con la pluma me es posible expresarlo» (p. 91).

Y más adelante (III 4): 
«Pululan, germinan, crecen, maduran, se cogen cada día cosas más ricas que las anteriores. Lo que en la antigüedad descubrieron Saturno, Hércules y otros héroes semejantes, ya no es nada. Si algo más descubren los españoles con su incansable trabajo, lo escribiré» (p. 197).

\section{Paradigmas históricos mitificados: Darío, Alejandro, César, Aníbal}

No queremos, por último, dejar de subrayar las numerosas referencias a héroes clásicos casi mitificados. La identificación o comparación de los conquistadores españoles, en especial Cortés, con héroes grecolatinos o del mundo antiguo en general para destacar casi siempre la superioridad de los españoles sobre sus ilustres antecesores es una constante en estos historiadores. Como afirma Reynolds 1962, «era el modo tradicional y casi obligatorio de parangonar a un personaje. Se dirá que así se prolongaba la inmortalidad de los héroes pasados a través de Cortés, al igual que en el proceso los autores (especialmente los poetas) hacían perdurar a sus ascendientes literarios» (Reynolds: 269). Los personajes antiguos más frecuentemente nombrados son, como es de esperar, Alejandro, César, Aníbal o Jerjes, paradigmas del mundo griego, romano, cartaginés y persa, respectivamente. En este sentido, son reiterados los epítetos que designan a los conquistadores como «un nuevo Alejandro» o «un nuevo César» al lado de «un nuevo Aquiles» o «un nuevo Eneas». Sirva de ejemplo, a modo de compilación, el siguiente texto de Fernández de Oviedo, donde se subraya la superioridad de la monarquía española en comparación con los grandes imperios de la Antigüedad:

«Y puesto que de aquesta nasción nuestra, su esfuerzo, su milicia y altos ingenios e grandes excelencias, desde luengos siglos por verdaderos e graves auctores esté predicado y escripto, no por eso se debe preferir ni dejar de poner a su cuenta, con menor, sino con mayor título y fama, lo que en estas Indias han obrado vuestros vasallos españoles, así en el militar ejercicio de las armas en la tierra, como en las amplísimas aguas del mar Océano, como valerosos y experimentados varones [...] Ha resultado haber dado e adquirido a vuestra Majestad otro hemisferio e mitad del mundo, e no menos tierra que todo aquello que los antiguos llamaron Asia, África y Europa [...] ¿Cuál monarquía de los asirios, cuál poder de los sicionios, o del grande Alexandre y sus macedonios, cuál de Darío y de Ciro y los persas, cuál de los de Micenas o de los de Corintio, cuál de los atenienses o tebanos, cuál de los partos o egipcios, cuál potencia de cartagineses o de los romanos, cuyas potencias tan alabadas y famosas son solemnizadas en muchos volúmenes de letras y auctores auténticos y graves?... Todos esos señoríos, e otros que callo, se incluyen en el ártico hemisferio; pero los vuestros, el uno y el otro comprehenden» (BAE CXVIII 2, p. 212). 


\section{Conclusiones}

Para concluir, hemos podido ver, en primer lugar, que la función primordial del uso del mito clásico entre los historiadores de Indias, obviando su base erudita, es la comparativa. El mito sirve de término evocado o referente inferior, por lo general, cualquiera que sea el motivo que sirve de base a la relación de analogía, al término real o comparado (la naturaleza y los hombres de las nuevas tierras, por un lado; los descubridores y conquistadores españoles, por otro).

En segundo lugar, la actitud de los historiadores ante el mito, aunque pueda diferir en función de la formación cultural y del conocimiento historiográfico que posean, es, por lo general, similar: el mito es una fábula inferior si se compara con la verdad, con la realidad vista y vivida por el historiador. Son elocuentes en este sentido las siguientes palabras de Fernández de Oviedo (BAE CXVIII 2, p. 212b-213a):

«No son comparación bastante a vuestros españoles, en las cosas que en estas nuevas tierras han experimentado, las fabulosas novelas de Jasón y Medea con su vellocino dorado. Callen los pregoneros de Theseo aquel laberinto y su Minotauro, pues que, sabida la verdad, esas metáforas, reducidas a la historia cierta, son unas burlas y niñerías si se cotejan y traen a comparación de lo que en estas Indias nuestras se ha visto y se vee cada día en nuestro tiempo; y lo han visto mis ojos y otros muchos a quien en esta edad ni en las venideras no podrán con verdad contradecir envidiosos enemigos de tan valerosa y experimentada nasción y tan jubilada en virtudes».

Por este motivo, aunque el historiador carezca de las dotes con las que los grandes poetas y escritores de la Antigüedad ornamentan y engrandecen a sus personajes y los hechos que se les atribuyen, su obra se justifica sólo por la grandeza, en todos los sentidos, de la materia por él tratada: la materia, es decir, la naturaleza y los hechos descritos suplen al ingenio. De nuevo Fernández de Oviedo:

«Plutarco dice, en la vida que escribió de Alejandre Magno, que yendo contra Darío, cuando llegó a Troya [...] corriendo en torno de la estatua de Aquiles [...] coronó aquella estatua, llamando a Aquiles felice, porque en tanto que fue vivo, hobo tan fiel amigo en Patroclo, e después de la muerte un trompeta tal como Homero. Estas palabras de Alejandre muestran la envidia que hobo de haber tenido Aquiles tan alto escriptor para su historia, e que él para la suya no tenía tal cronista; porque en la verdad, el estilo y elocuencia del auctor de una famosa historia, mucho la engrandesce e sublima por el ornamento de su graciosa pluma e sabio proceder, o mucho le quita e disminuye del propio valor, 
cuando en el tal escriptor no hay la habilidad que se requiere en cosas grandes. Esto falta aquí por cierto, e yo confieso que por tantas e tales e tan diversas materias como son de las que yo aquí tracto, fuera necesario otro ingenio que el mío; pero en confianza desta verdad a que voy arrimado, espero, si yo no basto a tanto ilustrar mi obra, como las que otros grandes varones escribieron, basta para mi consuelo e a la satisfación de quien lee, que la auctoridad que acullá se da a Homero, era supliendo él la materia, e que aqui supla la materia al defecto de mi pluma e ingenio» (BAE CXIX 3, p. 363; la cursiva es nuestra).

En términos similares se expresa también P. de Cieza de León (BAE XXVI, p. 352):

«[...] para decir las admirables cosas que en este reino del Perú ha habido y hay, conviniera que las escribiera un Tito Livio o Valerio, u otro de los grandes escriptores que ha habido en el mundo; y aun estos se vieran en trabajo en lo contar; porque, ¿quién podrá decir las cosas grandes y diferentes que en él son, las sierras altísimas y valles profundos por donde se fue descubriendo y conquistando, los ríos tantos y tan grandes, de tan crecida hondura; tanta variedad de provincias como en él hay, con tan diferentes calidades; las diferencias de pueblos y gentes con diversas costumbres, ritos y cerimonias extrañas, tantas aves y animales, árboles y peces tan diferentes y ignotos? Sin lo cual, ¿quién podrá contar los nunca oidos trabajos que tan pocos españoles en tanta grandeza de tierra han pasado? [...] De todo esto hay tanto que decir, que a todo escriptor cansara en lo escrebir [...] Temeridad parece intentar un hombre de tan pocas letras lo que otros de muchas no osaron».

Y concluye el mismo autor, en el proemio en que declara la intención y división de su obra:

«Bien creo que hubiera otros varones que salieran con el fin deste negocio más al gusto de los lectores, porque siendo más sabios, no lo dudo; mas mirando mi intención, tomarán lo que pude dar, pues de cualquier manera es justo se me agradezca. El antiguo Diodoro Sículo en su proemio dice que los hombres deben sin comparación mucho a los escriptores, pues mediante su trabajo viven los acaescimientos hechos por ellos grandes edades. Y así, llamó a la escriptura Cicerón testigo de los tiempos, maestra de la vida, luz de la verdad. Lo que pido es, que en pago de mi trabajo, aunque vaya esta escriptura desnuda de retórica, sea mirada con moderación; pues a lo que siento, va tan acompañada de verdad» (p. 353).

El último punto de nuestras conclusiones se refiere a las fuentes sobre mitología utilizadas por los historiadores de Indias. Al respecto, en términos generales, podemos afirmar que son muy variadas. Están, por un lado, los propios autores clásicos, manejados, en el caso de los griegos, en traducciones 
latinas; por otro, los manuales mitográficos al uso en la época. Sirva, como ejemplo ilustrativo, el recuento de fuentes mitográficas que se pueden detectar en los primeros capítulos del libro I de la Historia de las Indias de Las Casas, por orden cronológico:

- De fabulosis narrationibus non credendis de Paléfato, autor del s. IV a.C., aunque lo que nos ha llegado de su obra es una compilación bizantina ( $B A E$ $\mathrm{XCV}$ 1, p. 62);

- Fabulae y De poetica astronomia de Higinio, entre los s. I a.C. y I d.C. (p. $61,62)$;

- Biblioteca histórica de Diodoro, del s. I a.C. (p. 56, 58);

- Historia natural de Plinio, del s. I d.C. (p. 53, 58, 59, 63);

- la obra, estrechamente vinculada a ésta, de Solino, del s. III d.C. (p. 53, $59,60,63)$;

- Etymologiae de San Isidoro, del s. vir d.C., (p. 59);

- De genealogia deorum de Juan Bocaccio de finales del s. XIV (p. 55);

- Sobre los dioses de los gentiles de Alonso Fernández de Madrigal (E1 Tostado), cuya primera edición es de 1507 (p. 55, 59).

\section{Bibliografía}

\section{Ediciones}

\subsection{Ediciones de varios autores}

Historiadores primitivos de Indias, vol. I, ed. de E. de Vedia, Madrid, Atlas (BAE XXII), 1946 [contiene: H. Cortés, Cartas de relación; F. López de Gómara, Historia general de las Indias; G. Fernández de Oviedo, Sumario de la natural historia de las Indias, Á. Núñez Cabeza de Vaca, Comentarios].

Historiadores primitivos de Indias, vol. II, ed. de E. de Vedia, Madrid, Atlas (BAE XXVI), 1947 [contiene: B. Díaz del Castillo, Verdadera historia de la conquista de la Nueva España; F. de Jerez, Verdadera relación de la conquista del Perú; P. de Cieza de León, Crónica del Perú; A. de Zárate, Historia del descubrimiento y conquista del Perú].

\subsection{Ediciones particulares}

Cabello Valboa, M. (1951), Miscelánea antártica: una historia del Perú antiguo, Lima, Universidad Nacional Mayor de S. Marcos, Facultad de Letras, Instituto de Etnología.

Calvete de Estrella, J. C. (1950), De rebus Indicis, trad., estudio, notas y prólogo de J. López de Toro, 2 vol., Madrid, CSIC. 
(1964), Rebelión de Pizarro en el Perú y vida de Don Pedro Gasca, en Crónicas del Perú, vol. IV, Madrid (BAE CLXVII), Atlas.

Cieza de León, P. de (2000), La crónica del Perú, ed. de M. Ballesteros, Madrid, Dastin (Crónicas de América 5).

Colón, C. (1982), Los cuatro viajes del Almirante, ed. de I. B. Anzoategui, Madrid, Espasa Calpe (Austral 633).

Colón, H. (1991), Historia del Almirante, ed. de L. Arranz Márquez, 2 vol., Madrid, Historia 16.

Cortés, H. (1993), Cartas de relación, ed., introd. y notas de A. Delgado, Madrid, Castalia.

Díez del Castillo, B. (2000), Historia verdadera de la conquista de la Nueva España, ed. de M. León-Portilla, 2 vol., Madrid, Dastin (Crónicas de América 2-3).

Fernández de Oviedo, G. (1959), Historia general y natural de las Indias, ed. de J. Pérez de Tudela, 5 vol., Madrid, Atlas (BAE CXVII-CXXI).

Herrera, A. de (1934-1957), Historia general de los hechos de los castellanos en las islas y tierrafirme del Mar Océano, con prólogo y notas de A. Ballesteros-Beretta et al., 15 vol., Madrid, Academia de la Historia (citamos por esta edición; cf. también la edición y estudio de M. Cuesta Domingo, 4 vol., Madrid, Universidad Complutense de Madrid, 1991).

Las Casas, B. de (1957-1958), Historia de las Indias, ed. de J. Pérez de Tudela, 2 vol., Madrid, Atlas (BAE XCV-XCVI).

López de Gómara, Fr. (2000), La conquista de México, ed. de J. L. de Rojas, Madrid, Dastin (Crónicas de América 15).

Mártir de Anglería, P. (1989), Décadas del Nuevo Mundo, trad. de J. Torres Asensio [orig.: De Orbe Novo decades], Madrid, Ediciones Polifemo (Crónicas y Memorias 1).

Zárate, A. de (1965), Historia del descubrimiento y conquista del Perú, ed., introd. y notas de D. Mc Mahon, Buenos Aires, Universidad de Buenos Aires (Publicaciones del Instituto de Historia Argentina y Americana 106).

2. Estudios

Abellán, J. L. (1979), Historia crítica del pensamiento español, vol. II: La Edad de Oro, Madrid, Espasa Calpe, 349-525 («El descubrimiento de América»).

Alonso del Real, C. (1961), «Fernández de Oviedo y las Amazonas», Cuadernos Hispanoamericanos 42, p. 33-43 (cf. Id., Realidad y leyenda de las Amazonas, Madrid, Espasa-Calpe [Austral 1396], 1967). 
Álvazez Morán, M. C. (1976), El conocimiento de la mitología clásica en los siglos $X I V$ al XVI, Madrid.

Antelo, A. (1975), «El mito de la Edad de Oro en las letras hispanoamericanas del siglo XVI», Thesaurus 30, 81-112.

Bauzá, H. F. (1993), El imaginario clásico: Edad de Oro, Utopía y Arcadia, Santiago de Compostela, Universidad de Santiago de Compostela. Servicio de Publicacións e Intercambio Científico (Publicacións en Estudios Clásicos 8).

Blok, H. H. (1995), The early Amazons: modern and ancient perspectives on a persistent myth, Leiden-New York, Brill (Religions in the Graeco-Roman World 120).

Boccaccio, G. (1983), Genealogía de los dioses paganos, ed. de M. C. Álvarez \& R. M. Iglesias, Madrid, Ed. Nacional.

Cro, S. (1977), «Las fuentes clásicas de la utopía moderna: el Buen salvaje y las Islas Felices en la historiografía indiana», Anales de Literatura Hispanoamericana 6, 39-51.

(1983), Realidad y utopía en el descubrimiento y conquista de la América Hispana (1492-1682), Madrid, IBP, Troy (Michigan)/Fundación Universitaria Española.

- (1989), «Los cronistas primitivos de Indias y la cuestión de antiguos y modernos», en S. Neumeister (ed.), Actas del IX Congreso Internacional de Hispanistas (18-23 agosto 1986, Berlín), vol. I, Frankfurt am Main, Vervuert Verlagsgesellschaft, 415-424.

Esteve Barba, F. (21992), Historiografía Indiana, Madrid, Gredos (Manuales).

Fabregat Barrios, S. (2003), «Presencia y función de los mitos clásicos en la Historia general y natural de las Indias de Gonzalo Fernández de Oviedo y Valdés», Epos 19, 67-88.

Fernández de Madrigal, A. (el Tostado) (1995), Sobre los dioses de los gentiles, ed. y estudio preliminar de P. Saquero Suárez-Somonte \& T. González Rolán, Madrid, Ed. Clásicas (Series Maior).

Gandía, E. de (1929), Historia y crítica de los mitos y leyendas de la conquista americana, Buenos Aires, Juan Roldán y Compañía Editores.

Gómez Espelosín, F. J. (2006), «La visión mítica del Nuevo Mundo en los historiadores de Indias», en J. A. López Férez (ed.), La mitología clásica en la literatura española. Panorama diacrónico, Madrid, Ediciones Clásicas (Estudios de Filología Griega 11), 327-337.

Gil, J. (1989), Mitos y utopias del Descubrimiento, 3 vol., Madrid, Alianza (Alianza Universidad 577, 585, 596). 
Giuliani, L. (1999), «Las Casas y el rechazo de la Edad de Oro: un recorrido por citas y omisiones de clásicos», en J. V. Bañuls Oller, J. Sánchez Méndez \& J. Sanmartín Sáez (eds.), Literatura iberoamericana y tradición clásica, Valencia, Universitat Autònoma de Barcelona/Universitat de València, 237-242.

Haase, W. \& Reinhold, M. (eds.) (1993), The classical tradition and the Americas, vol. I: European images of the Americas and the classical tradition, Part I, Berlin-New York, W. de Gruyter.

Lacarra, M. J. \& Cacho Blecua, J. M. (1990), Lo imaginario en la conquista de América, Zaragoza, Diputación General de Aragón y Comisión Aragonesa V Centenario.

Lens Tuero, J. (1993), «Bartolomé de Las Casas y la historiografía clásica», en M. Casquero (ed.), Estudios de tradición clásica y bumanística, León, Servicio de Publicaciones de la Universidad de León, 87-104.

(1994), «Los orígenes clásicos de la denominación 'Nuevo Mundo' y la representación colombina del paisaje americano", en El Reino de Granada y el Nuevo Mundo. V Congreso Internacional de Historia de América (Granada, mayo de 1992), vol. III, Granada, Diputación Provincial de Granada, 37-46.

(1996), «La representación de la Edad de Oro desde Hesíodo hasta Pedro Mártir de Anglería», en J. M. García González \& A. Pociña Pérez (eds.), Pervivencia y actualidad de la cultura clásica, Granada, Servicio de Publicaciones de la Universidad de Granada/SEEC (Biblioteca de Estudios Clásicos 7), 171-209.

(1997), «Fernández de Oviedo (Historia General y Natural de las Indias, libro VI, cap. LI) y la etnología clásica», en Anuario de Estudios Americanos 54, 187-198.

Lisi, F. L. (2000), «Culpa y castigo en la crónica del Perú de Pedro Cieza de León», en M. Alganza Roldán, J. M. Camacho Rojo, P. P. Fuentes González \& M. Villena Ponsoda (eds.), Epieikeia: studia Graeca in memoriam Jesús Lens Tuero: homenaje al Profesor Jesús Lens Tuero, Granada, Athos-Pérgamos, 249-261.

Maravall, J. A. (1974), «Utopía y primitivismo en el pensamiento de Las Casas», Revista de Occidente 141, 311-388.

Martín García,J. M. (2008), Los filósofos cínicos y la literatura moral serioburlesca, texto corr. y revis. por C. Macías Villalobos, Tres Cantos, Akal (Akal Clásica 83), vol. I, 445-454.

Martínez, M. (1999), «Las islas de los Bienaventurados: historia de un mito en la literatura griega arcaica y clásica», Cuadernos de Filología Clásica (Estudios Griegos e Indoeuropeos) 9, 243-279. 
Mignolo, W. D. (1981), «El metatexto historiográfico y la historiografía indiana», Modern Language Notes 96, 358-402.

Mund-Dopchie, M. (1990), «L'extrême-Occident de l'Antiquité classique et la découverte du Nouveau Monde: une manipulation de textes a des fins idéologiques», Nouvelle Revue du Seizième Siècle 8, 27-49.

Nava Contreras, M. (2006), La curiosidad compartida: estrategias de la descripción de la naturaleza en los historiadores antiguos y la crónica de Indias, Caracas, Academia Nacional de la Historia.

Oliver Segura,J.P.(1991), «Diálogo del rey Alejandro con el brahmán Dándamis: (PGen. 271)», en F. Gascó \& J. Alvar (eds.), Heterodoxos, reformadores y marginados en la Antigüedad clásica, Sevilla, Secretaría de Publicaciones de la Universidad de Sevilla/Universidad Hispanoamericana de la Rábida, 107-136.

(1990), «Los gimnosofistas indios como modelos del sabio asceta para cínicos y cristianos», en Cristianismo y aculturación en tiempos del Imperio romano, Murcia, Universidad de Murcia (Antigüedad y Cristianismo 7), 53-62.

Paniagua Pérez, J. (2010), «Plinio en las Indias», en Ma I. Viforcos Marinas \& Ma D. Campos Sánchez-Bordona (eds.), Otras épocas, otros mundos, un continuum. Tradición clásica y bumanistica (ss. XVI-XVIII), León, Universidad de León, 339-359.

Reynolds, W. A. (1962), «Hernán Cortés y los héroes de la Antigüedad», Revista de Filología Española 45, 259-271.

Santana Henríquez, G. (2010), «La tradición clásica en los historiadores de la Nueva España: el caso de Fernando de Alva Ixtlilxóchitl», en $\mathrm{M}^{\mathrm{a}} \mathrm{I}$. Viforcos Marinas \& Ma D. Campos Sánchez-Bordona (eds.), Otras épocas, otros mundos, un continuum. Tradición clásica y bumanistica (ss. XVI-XVIII), León, Universidad de León, 360-389.

Valcárcel Martínez, S. (1997), Las crónicas de Indias como expresión y configuración de la mentalidad renacentista, Granada, Diputación Provincial de Granada.

Zulueta, J. M. (1999), «Mitología clásica en las crónicas de Indias», en J. V. Bañuls Oller, J. Sánchez Méndez \& J. Sanmartín Sáez (eds.), Literatura iberoamericana y tradición clásica, Valencia, Universitat Autònoma de Barcelona/Universitat de València, 493-499. 


\title{
CONSIDERACIONES SOBRE LA SÍNCOPA DE - Ĭ Y -Ŏ EN SÍLABA FINAL CERRADA EN LATÍN.
}

\author{
Marina del Castillo Herrera \\ Universidad de Granada
}

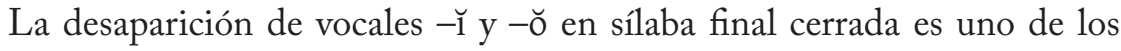
exponentes de un proceso frecuente ya en itálico, cual es la síncopa.

Aunque el origen de la síncopa pudiera estar en el acento de intensidad inicial característico del itálico, establecer cuándo se produce no resulta fácil, sobre todo porque a igualdad de condiciones no siempre tiene lugar.

El problema se agrava si el fenómeno se considera en sílaba final, donde la tendencia fonética podría verse frenada o corregida por la importancia morfológica de la última sílaba de la palabra. Merece, pues, la pena considerar la pérdida de vocales breves en sílaba final, en este caso cerrada, qué hay de fonético y qué de morfológico en los casos implicados y si atendiendo a una y otra perspectiva se puede hablar de un comportamiento coherente, conforme a unas pautas, de la lengua latina.

La complejidad de los hechos la demuestra el planteamiento del problema en los tratados de fonética, donde o bien se insiste en el carácter no generalizado o incluso esporádico del fenómeno ${ }^{1}$ o bien, aun cuando se señalan unas determinadas condiciones que lo propician ${ }^{2}$, se tienen que reconocer las excepciones, sin que además en muchos casos se recojan todas.

Por otro lado, dadas sus repercusiones morfológicas, el fenómeno puede abordarse en la parte de fonética de un manual o directamente en la de morfología.

1. Es frecuente tratar conjuntamente la desaparición de $-\breve{1}$ y $-\breve{o}$ en las secuencias -rŏs /-lŏs, -řss/ -lıs y en la secuencia - $\breve{1} s^{3}$. Por lo que a nosotros respecta, nos ocuparemos de ellas separadamente.

Respecto a los finales -rŏs /-lŏs, -ř̆s/ -lıss, se puede decir que la síncopa tiene lugar cuando la secuencia va precedida por consonante o cuando la secuencia va precedida por una sílaba breve siempre que se trate de una palabra de tres o más sílabas. Es decir:

a) -Cns. -rŏs /-lŏs: *agros > AGER, * nigros > NIGER 
-Cns. -řss/ -liss: imbris > IMBER, * acris > ACER

b) $\Sigma^{4}-\Sigma$ (breve) -rŏs /-lŏs: *puĕros > PUER, *famŭlos > FAMUL

$\Sigma-\Sigma$ (breve) -rı̌s /-lıss: *elěris > CELER, *vigilis > VIGIL.

Así establecido, el corolario de lo que decimos es doble o incluso triple:

c) en estos grupos no se produce la síncopa cuando, en efecto, precede una sílaba breve pero, en cambio, se trata de un bisílabo ${ }^{5}$. Es decir,

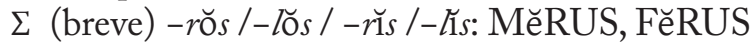

d) en estos grupos no se produce la síncopa cuando, en efecto, se trata de un trisílabo pero, en cambio, precede una sílaba larga ${ }^{6}$. Es decir,

$\Sigma-\Sigma$ (larga) -rŏs /-lŏs / -rŭs /-līs: SECūRIS, AVāRUS, SEVēRUS, así como los adjetivos del tipo FIDēLIS y todos los adjetivos en -TūRUS como MATūRUS.

e) Comprobamos que tampoco se produce la síncopa de la vocal breve cuando precede una sílaba larga, no sólo en los trisílabos sino también en los bisílabos ${ }^{7}$. Es decir,

$\Sigma$ (larga) -rŏs /-lŏs / -ṛ̌s /-liss: VēRUS CLāRUS, PūRUS, así como MOLLIS.

f) Consideración aparte merecen los grupos $-r \breve{o} s,-r \breve{s} s$ de origen secundario, es decir, donde la $r$ procede de una $s$ rotatizada, como UMERUS < *omesos. En este caso, aunque se den las condiciones arriba descritas, no se produce la síncopa de la vocal.

2. En cuanto a los finales en - $\breve{1 s}$, a los que en algunos tratados se añaden

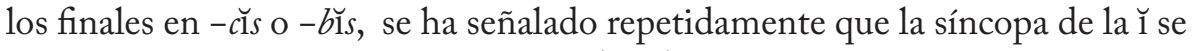
produce, al contrario que en los casos d) y e), cuando se trata de:

g) un bisílabo y la sílaba precedente es larga ${ }^{8}$. Es decir,

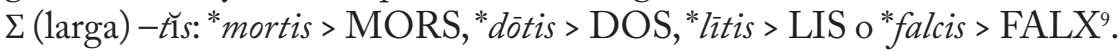

Así establecido, el corolario de lo que decimos es doble:

h) la síncopa de la ĭ no se produce cuando, en efecto, se trata de un bisílabo pero la sílaba precedente es breve. Es decir,

$\Sigma$ (breve) - ťs: SĭTIS, CŭTIS, PŏTIS 
i) la síncopa de la ̌̌ se produce cuando la sílaba precedente es breve pero se trata de un trisílabo. Es decir,

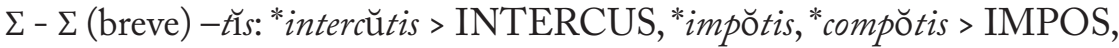
COMPOS.

Constituirían claras excepciones a g) formaciones como VỉTIS ORBIS VECTIS HOSTIS RESTIS PISCIS COLLIS entre los sustantivos y FORTIS, DULCIS o TURPIS, entre los adjetivos ${ }^{10}$.

Aunque nuestro intento de sistematización recoge nada menos que nueve contextos diferentes y parece insistir, una vez más, en la complejidad del fenómeno, es preciso recordar que de ellos el tipo f) es de naturaleza diferente a los demás y que, de momento, de los restantes, c) y d) son complementarios de b) y, por su parte, h) e i) son complementarios de g) ${ }^{11}$. Dicho de otro modo, nuestra propuesta recoge en el fondo no más de tres contextos diferentes, que es nuestra intención relacionar.

3. Es cierto que los casos a) y b) son de naturaleza distinta. En cambio, creemos que a) ager guarda afinidad con c) fẽrus, con g) mors y h) cŭtis. En todos estos casos la síncopa se produce siempre que el resultado no sea un monosílabo breve o, si se quiere, de una determinada estructura prosódica ${ }^{12}$. En el tipo ager la secuencia de consonante más $r$ de la formación originaria conforman un contexto propicio para el desarrollo de una vocal de anaptixis que restituye el número de sílabas y que, por lo tanto, impide la formación de un monosílabo. En el tipo mors es el carácter largo de la sílaba precedente lo que hace posible la síncopa porque, aunque el resultado sea un monosílabo, se trata de un monosílabo largo. El caso de fërus y el de cŭtis son idénticos: la síncopa, de producirse, habría dado lugar a un monosílabo †fẽ $r$ o †cŭs, cuya estructura prosódica pudiera ser diferente a la de mors.

Sería tentador considerar que la síncopa se producía o no en función de que el resultado fuera un monosílabo que se conformara a las condiciones requeridas por el acento latino ${ }^{13}$ : en este caso en concreto, en función de que el resultado fuera un monosílabo largo; pero, si esto es así, es necesario plantearse cuándo un monosílabo es efectivamente largo.

No cabe duda de que son largos los monosílabos cuyo núcleo silábico es largo. Según Allen ${ }^{14}$, por ejemplo, también lo son los que están formados por una vocal breve cerrada por consonante. Por los resultados de los procesos fonéticos sufridos por el latín, éste parece ser el caso de monosílabos formados por una vocal breve cerrada por oclusiva. En efecto, la forma dăt, genuina, no 
parece haber planteado problemas en latín y, por la misma razón, la forma dèt puede sufrir igualmente sin problemas la abreviación en dět. En la misma línea, rèm pudo sufrir la abreviación en rĕ $m$ que, aunque difícil de probar en el verso, parece demostrada por el romance (francés rien) y aparece recogida por los gramáticos (GLKII 23, 13) ${ }^{15}$.

Diferente es, en cambio, el comportamiento de los monosílabos formados por una vocal breve cerrada por consonante continua y diferente podría ser, por tanto, su estatuto. En efecto, aunque hay otras explicaciones ${ }^{16}$, se suele admitir que la $2^{\mathrm{a}} \mathrm{p}$. sing. del presente de indicativo del verbo do era dăs y que por ello alargó ya en época preliteraria en $d \bar{a} s^{17}$. Por la misma razón, palabras del tipo für, cūr, pār, sōl, sāl no habrían llegado ni siquiera a experimentar la abreviación a la que tendían los polisílabos terminados en $-r o-l^{18}$.

Sea como sea, desde época preliteraria,la lengua latina aceptó monosílabos del tipo dăt o la abreviación de monosílabos del tipo rēm en rĕm y, ya en época literaria, la de monosílabos del tipo dèt en dĕt. En cambio, parece no haber tolerado monosílabos del tipo dă o dăs, que ya en época preliteraria podrían haber alargado en $d \bar{a}$ o dās, o la abreviación de für, cūr, pār, sōl, sāl en $\dagger f u ̈ r$,

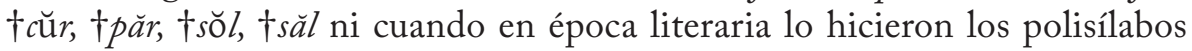
del tipo amōr o uxōr, terminados de la misma manera, ni después. Con este panorama de fondo, un resultado †fẽr $(<f e r u s)$ sería disonante de estructuras prosódicas del tipo für, cūr, pār y un resultado $c \breve{\mathrm{u}} s(<c \breve{\mathrm{u}} t i s)$, de estructuras del tipo dās.

Creemos que la ausencia de dobletes en $-r$ en el nominativo de los monosílabos de tema en $-s$ puede ser un buen ejemplo de las reticencias del latín a una forma sincopada de ferus. En efecto, frente a los bisílabos de tema en $-s$ del tipo arbōs u honōs, con un nominativo anológico de los casos oblicuos analógico en $-r$ arbŏ $r \mathrm{u}$ honŏ $r$, nominativos del tipo flōs o mōs no contaron en latín con la forma alternativa flŏ $r$ o mŏ $r$ (o flör o mōr).

Desde nuestro punto de vista, el adverbio ter < *tris no constituye una evidencia en contra si, como demostraría el derivado terruncius, se trata de un ejemplo de mantenimiento de una doble $r$, no simplificada aún en Plauto (Bacch. 1127), donde probablemente es largo. Problema diferente es determinar por qué ello es así en este caso y no en el de los polisílabos terminados en -er, procedente de -ros o de -ris, cuya sílaba final nunca hizo posición. Quizá la diferencia se deba a que ter es el resultado de un proceso de metátesis *tris > *tirs > terr y no de síncopa ${ }^{19}$. 
En relación con el mantenimiento de consonantes geminadas en final de palabra, quizá debamos plantearnos, en cambio, por qué no se dio la forma $\dagger$ cuss < cuts < cutis de forma paralela a lo que sucedió con miless < *milets, todavía documentado en Plauto. La razón podría estar de nuevo en que cuando se trata de una síncopa no se pasa por un estadio de doble consonante final, como hemos visto que sucedía con los polisílabos terminados en -er, procedente de -ros o de -ris o como sucede en el propio caso de impos o compos < *impotis, compotis.

Queda pendiente el caso e) vèrus. En efecto, no parece que †vèr procedente de vērus no tenga una estructura aceptable desde el punto de vista prosódico. De hecho, contamos con estructuras equiparables como für, cūr, pār o la propia forma de nominativo de vèr, vêris "primavera". Descartada la justificación prosódica, puede que la explicación de que no se haya producido la síncopa sea morfológica y que resida, en concreto, en el hecho de que el latín había asumido un modelo de adjetivos temáticos de dos o más sílabas, terminados en -us o a lo sumo en -ĕr, por referencia al cual adjetivos del tipo †vèr (< vērus) o * †pūr (< pürus) o $\dagger c \bar{a} r(<$ càrus) serían anómalos, como en otro sentido, según veremos, lo sería †mol(l) (< mollis) entre los adjetivos de la tercera declinación.

Queda además justificada la aparente contradicción que suponía el caso g) mors, lìs respecto del caso e) vèrus que, a pesar de tener la misma estructura prosódica que los anteriores (un bisílabo con la primera sílaba larga), no sufre la síncopa. Esta es la razón, por otro lado, de que hayamos considerado la síncopa de la - $\breve{1}$ del grupo - ťs aparte.

4. Distinto de los anteriores es el caso b) puer (< * puĕros) con el que creemos que están relacionados los casos d) avārus e i) impos (<*impŏtis). En todos estos casos la síncopa se produce siempre que el resultado no implique el cambio en la posición del acento o, si se quiere, una formación oxítona. En el caso b) el trisílabo de la formación originaria tenía la penúltima breve, lo que significaba que el acento recaía en la primera sílaba, posición que mantiene también la forma sincopada. Lo mismo sucede en el caso i). En el caso d), en cambio, el trisílabo tiene la penúltima larga, lo que implica que ésta lleva el acento. De producirse la síncopa el acento se tendría que haber retrotraído a la sílaba anterior para evitar una formación oxítona.

5. Habría que explicar entonces por qué, en cambio, sustantivos como animāle sí sufrieron la apócope. En este caso la razón parece ser de orden cronológico: el latín admitió el acento en la última sílaba como resultado de la desaparición de la vocal final de una palabra acentuada en la penúltima 
cuando tal desaparición se produjo en época posterior a la definitiva fijación del acento ${ }^{20}$.

Recordemos además que los adjetivos neutros de estructura fónica paralela, como aequāle o fidèle, no llegaron a sufrir la apócope. Así mismo, formas sustantivadas como vectigal, capital, exemplar convivían con las formas de adjetivo neutro no apocopadas vectigale, capitale, exemplare o con las de adjetivo masculino y femenino vectigalis, capitalis, exemplaris, cuya estructura prosódica no habría permitido en su día la síncopa y cuya función como adjetivos parece haberla frenado en caso de haber sido admisible, prosódicamente hablando.

En efecto, la misma proporción entre forma sincopada : nombre :: forma no sincopada : adjetivo parece darse, por ejemplo entre volucer, nombre, frente a volucris, adjetivo, donde no habría impedimentos prosódicos para la síncopa. En este caso, pues, la fonética se habría visto frenada por la morfología. Y es que la peculiar remodelación que operó el latín para configurar la tercera declinación como grupo flexivo unitario, a partir de temas diversos en su origen, cuales los temas en- $i$ y los temas en consonante fue consecuencia de determinados procesos fonéticos, como, sin ir más lejos, la síncopa de la $̌$ de algunos nominativos y su consiguiente confusión con temas en consonante, pero también de la reutilización de ciertas características de los temas en -i como marca de la flexión de los adjetivos ${ }^{21}$. Esto explicaría volucris (adjetivo) frente a volucer (sustantivo), vectigale (adjetivo) frente a vectigal (sustantivo) o, en otro sentido, que fortis o dulcis no hubieran sufrido la síncopa, a pesar de tener la misma estructura prosódica de fors, mors o falx. Explicaría así mismo el, al parecer, poco éxito de las formas en -er de los adjetivos en $-s_{t r i s^{22}}$.

Cumplida cuenta dan los tratados de morfología de la forma acer, que en la línea de lo dicho precedentemente, como forma adjetival que era, tendría que haberse mantenido en su forma originaria no sincopada acris. De hecho, la forma acer siguió coexistiendo con la forma acris, primero como un simple doblete y luego como forma de femenino, una vez que acer se especializó como forma de masculino: en este caso por presión del modelo del masculino niger.

6. Puede que en este contexto sea también interesante considerar el caso del participio de presente latino. Se suele pensar que una forma como ferens procede de la confluencia de resultados fonéticos de un masculino *fer-ent-s, de un femenino sincopado *fer-enti-s e incluso de un neutro *fer-ent. De haber sido así, la lengua habría renunciado a la forma de femenino o, si se quiere, a la distinción entre femenino y masculino, aunque habría reutilizado los restos de 
esa forma de femenino de tema en - $i$ en el ablativo singular, precisamente para marcar el uso adjetival del participio.

Sin embargo, según venimos viendo, esta síncopa se habría producido contra todo pronóstico, toda vez que se trataba de un trisílabo con la penúltima sílaba larga y, a mayor abundancia, de un adjetivo. Así las cosas, contaríamos con un argumento añadido para la hipótesis de que, como primitivo nombre de acción, el participio de presente no necesitara una distinción de género (y, dicho sea de paso, mucho menos un género neutro). Dicho de otra forma, puede que el latín (y con él todo el itálico) no hubiera dispuesto de forma alguna en $-n t i 5^{23}$ y que en su tendencia a caracterizar los adjetivos de la tercera declinación como temas en $-i$ se valiera de una forma de ablativo singular en $-\bar{\imath}$, propia de adjetivo, no propia de femenino, cuando el participio funcionaba simplemente como tal. 


\section{REFERENCIAS BIBLIOGRÁFICAS}

Allen, W. S.,Accent and Rhythm. Prosodic Features of Latin and Greek: A Study in Theory and Reconstruction, Cambridge, 1973.

__ Vox Latina, Cambridge-London- New York, $1978^{2}$.

Bassols de Climent, M., Fonética latina con un apéndice de Fonemática por Sebastián Mariner, Madrid, 1962.

Bernardi Perini, G., L'accento latino, Bologna, 2010, 5ª riveduta.

Leumann, M.-Hoffmann, J. B., Lateinische Grammatik, I Lateinische Laut-und Formenlebre, München, 1977.

Meiser, G., Historische Laut und Formenlehre der lateinischen Sprache, Darmstadt, 1998.

Molina Yévenes, J., Iniciación a la fonética, fonologia y morfología latinas, edición preparada por E. Borrell Vidal, Barcelona, 1993.

Monteil, P., Eléments de phonétique et de morphologie du latin, Paris, 1970.

Niedermann, E., Precis de phonétique historique du latin, Paris, 1953.

Sihler, A. L., New Comparative Grammar of Greek and Latin, New York-Oxford, 1995.

Sommer, F.-Pfister, R., Handbuch der lateinischen Laut- und Formenlebre, Heidelberg, 1977.

De Vaan, M., Etymological Dictionary of Latin and other Italic Languages, Leiden-Boston, 2008.

Weiss, M., Outline of the Historical and Comparative Grammar of Latin, Ann Arbor, 2009. 
${ }^{1}$ Sommer-Pfister, p. 120: "Die Bedingungen liegen so unklar wie die der Synkope in Mittelsilben"; Niedermann, p. 48: " $i$ et $o$ ont été parfois absorbés dans les groups finaux -ris et -ros"; Sihler, § 73 "Vowel loss is sometimes regular; but it is more commonly a sporadic phenomenon", § 74 "As remarked above, the facts of L vowel loss resist generalization".

${ }^{2}$ Vid. Monteil, p. 103, Sihler, § 74 y, sobre todo, Meiser, § 55.

${ }^{3}$ Sommer-Pfister, p. 120, Niedermann, pp. 47-48, Bassols, pp. 122-123, Monteil, pp. 102103, Sihler § 73-74.

${ }^{4}$ Representa una sílaba, sea de la naturaleza que sea.

${ }^{5}$ Observado por Leumann $\S 106$, por Niedermann, p. 47, para las formaciones en -tis; inexplicable para Sihler, $§ 74.5$.

${ }^{6}$ Observado por Monteil, p. 103.

${ }^{7}$ Observado por Monteil, p. 103.

${ }^{8}$ Cuando a la dental precede $n$ o $r:-n$ dis, $-n$ tis o $-r$ tis, según Sihler, $§ 306.1$; después de sonante y en algunos casos después de vocal larga, según Monteil, p. 191.

${ }^{9}$ Hay incluso quien, como Niedermann. p. 47, incluye ATROX < *atrocis.

${ }^{10}$ Según Monteil, p. 102, en el caso de los adjetivos como fortis o dulcis, no se produce la síncopa como consecuencia de la presión de la forma de neutro singular forte y dulce donde de alguna manera persistía la -i del tema.

${ }^{11} \mathrm{El}$ caso e) puede merecer consideración aparte.

${ }^{12}$ Meiser $\S 55$, establece como condición para que se produzca la síncopa que "der $t$ bzw. $r$ vorausgehende Wortkörper wenigstens zwei Moren unfasst". Creemos que, aunque así formulado se simplifica de una forma muy sugerente la relación de una parte de los contextos, no se llega a la explicación de por qué en los casos en que sólo precedía una mora (o una sílaba breve) no se producía la síncopa.

${ }^{13}$ Véase la formulación hecha por Allen, 1973, p. 177.

${ }^{14} 1973$, p. 51, p. 131.

${ }^{15}$ Allen, Vox Latina, p. 30-31, 119; Weiss, p. 125.

${ }^{16}$ Schrijver, p. 120; De Vaan, ad voc. do.

${ }^{17} C f$. Sihler $\$ 488$ que, aunque cuando tiene que explicar la vocal larga de dā o dās recoge otras explicaciones, reconoce que es más simple considerar que "dă, dăs then became $d \bar{a}$, dās by regular developments involving monosyllables".

${ }^{18}$ No obstante, Monteil, p. 104, admite una primitiva abreviación de la forma originaria *för > * fŏ $r$ con el consiguiente cambio de timbre en *fŭ $r$ y el posterior alargamiento en für, que es la forma documentada en latín. Parece, sin embargo, que, aunque la abreviación de una vocal larga en sílaba final cerrada por consonante distinta de $-s$ es un proceso que arranca de época

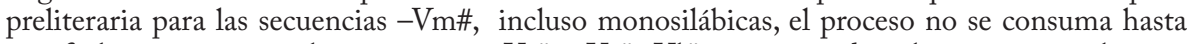
una fecha reciente para las secuencias -Vt\#, -Vr\# -Vl\# y en estos dos últimos casos sólo si se trata de polisílabos. De hecho, últimamente se obvia el estadio de abreviación preliteria supuesto para explicar el cambio de timbre de for a fur entendiendo que éste se produjo directamente de för a für. Así, por ejemplo, Sihler, § 52. 3a, Schrijver, p. 120; De Vaan, ad vocem fur o cur.

${ }^{19}$ Vid. Meisser, 59, 3; Weiss, p. 123.

${ }^{20}$ Bernardi Perini, p. 51; Allen, 1970, p. 87; Weiss, p.110.

${ }^{21}$ Leumann $§ 357,2$.

${ }^{22}$ Weiss, p. 320, notas 82-86.

${ }^{23}$ Este es el parecer de Leumann: "Im Italischen bestehen dafür keine eindeutigen Zeugnisse: Die Rückführung von ptc. fem. ferens auf eine $-\bar{\imath}$-Form (nt-ī >-enti-s > èns)...ist 
nicht zwingend...Sie müsste übrigens auch auf fem. audāx anwendbar sein”, § 354.4 c; ver también $\S 357,3$. Molina Yévenes ( $\$ 236$ ), por su parte, no ve muy clara la forma femenina. Dice, en concreto: "resulta sospechoso que no haya ejemplos de $-i$ - mantenida, como sucede en los sustantivos". También Weiss, p. 197: "Latin, if ever had such a system, has eliminated it". 


\section{El tratado ARs MusYcE indebidamente atribuido a Santo Tomás de Aquino (TRADUCCIÓN Y NOTAS) ${ }^{1}$}

Pedro Rafael Díaz Díaz

Universidad de Granada

\section{Nota de presentación}

El breve tratado técnico de teoría musical que lleva por título Ars musyce, indebidamente atribuido a Santo Tomás de Aquino (en adelante, también nos referiremos a este opúsculo mediante la sigla Ps.-Thomas AQu. I) conoció una primera edición, a saber: S. Tommaso D’Aquino, Ars musice, Trattato inedito, illustrato e trascritto da Mario di Martino, Napoli, Eugenio de Simone - Libraio Editore, 1933, págs. 24-29. Al texto de la edición de Di Martino se puede acceder también on-line dentro de la colección electrónica de textos musicales conocida como Thesaurus Musicarum Latinarum (=ThML); concretamente, el texto de la edición del Ars musyce de Di Martino se encuentra en el fichero denominado "AQUARS TEXT". Igualmente, también se puede consultar on-line la edición de Di Martino en Corpus Thomisticum (=CTh), siguiendo esta secuencia de enlaces: "Corpus Thomisticum, S. Thomae de Aquino Opera omnia, Opera aliqua false adscripta, Opuscula philosophica, Ignoti Auctoris Ars musyce, Textum a M. di Martino Neapoli 1933 editum ac automato translatum a Roberto Busa sj in taenias magneticas, denuo recognovit Enrique Alarcón atque instruxit”.

La edición de Di Martino, más que una edición en el exacto y preciso sentido del término, es una simple traslación o transcripción del contenido textual del manuscrito $V=$ Roma, Vat. lat. 4357 fol. 58 $-60^{\text {v }}$ (saec. XIII ex. / saec. XIV in.). Lecturas puntuales demuestran, sin embargo, que el manuscrito $V$ es una mera copia del manuscrito $B=$ Basilea, Universitätsbibl. F IX 54 fol. $2^{\text {ra }}-4^{\text {v }}$ (saec. XIII ex. / saec. XIV in.), que obviamente no fue tomado en consideración por Di Martino. Al contenido del manuscrito de Basilea también tenemos acceso on-line en ThML; concretamente, en el fichero denominado "WFANON2B MBUFIX54".

Por otra parte, el texto del Ars musyce está conformado en su mayor parte por extractos literales procedentes de una amplia gama de tratadistas, cuya cronología se extiende desde finales de la Antigüedad Tardía (casos, por ejemplo, de Macrobio, Boecio e Isidoro) hasta finales del siglo XI o principios del siglo XII (casos, por ejemplo, de Berno Augiensis, Hermannus Contractus, Aribo, Willehelmus Hirsaugensis y Iohannes dictus Cotto sive Affigemensis). Por consiguiente, la consulta de los textos de los referidos autores resulta exigencia 
inexcusable para comprender en su más precisa dimensión el contenido testimoniado por los mencionados manuscritos. Pondremos únicamente un par de ejemplos para que se entienda con mayor exactitud tanto la necesidad de la consideración del manuscrito $B$, como la conveniencia de consultar los textos técnicos de teoría musical que inserta nuestro anónimo tratado musical.

Así, Di Martino, op. cit., pág. 25, edita: "sicut in musyca. Brunonis (?) dicitur”. Es posible que Di Martino no comprendiera o no leyera correctamente el texto testimoniado por el manuscrito $V 58^{\text {v }}$; en todo caso, si hubiera consultado el manuscrito $B$ fol. $2^{\text {va }}$, seguramente hubiese escrito: "sicut in musyca Bernonis dicitur". Entonces le hubiera quedado claro al editor italiano y, seguramente también al lector, que se está reproduciendo un pasaje literal del Prologus in tonarium (post 1021) de Bern de Reichenau (ca.978-1048)2.

Y, un poco más abajo, Di Martino, op. cit., pág. 25, escribe: "Is inquam talis magis lascivie que ultimo anni tempore". En este caso, sin embargo, poca ayuda le hubiese proporcionado el manuscrito $B$ fol. $2^{\text {va }}$, que también dice: "Is inquam tale magis lasciuie que ultimo anni tempore". Tan sólo la consulta del texto de Bern de Reichenau ${ }^{3}$ nos hubiera aclarado el exacto sentido de la frase, pues allí se puede efectivamente leer: "is inquam talis magis lusciniae, quae verno anni tempore". Y es esta lectura la que incorpora la edición en la que nosotros nos hemos apoyado: "is, inquam, talis magis luscinie, que verno anni tempore" 4

Así, pues, la versión española, que seguidamente presentamos, toma como base de referencia la reciente edición de Michael Bernhard, Die Thomas von Aquin zugeschriebenen Musiktraktate, Bayerische Akademie der Wissenschaften, Veröffentlichungen der Musikhistorischen Kommission, Band 18, München, Verlag der Bayerischen Akademie der Wissenschaften, in Kommision bei dem Verlag C. H. Beck, 2006, espec. págs. 66-68 (="3. Ars musyce"), págs. 76-84 (=“Edition”) y págs. 85-88 (="Kommentar").

Entre las principales convenciones tipográficas que hemos utilizado en la versión española del citado texto latino mencionemos las siguientes. En primer lugar, los epígrafes encerrados entre corchetes rectos no forman parte del texto transmitido del Ps.-Thomas AQu. I: o bien están directamente trasladados de la edición de Bernhard ${ }^{5}$; o bien se encuentran reflejados en la traducción con mínimas variaciones de detalle. Por su parte, las cifras incluidas entre rayas y encerradas entre corchetes hacen referencia al número de página de la edición de Bernhard; en cambio, las encerradas entre paréntesis reproducen el número de párrafo o parágrafo de la mencionada edición. Y, en fin, al igual que hace Bernhard en su edición del texto latino, también nosotros observamos la convención tipográfica de que él hace uso, empleando la letra cursiva para advertir al lector sobre la existencia de un paralelo textual documentable, que el pasaje en cuestión del Ps.-Thomas AQU. I incorpora y reproduce literalmente; 
pero, utilizando, en cambio, la letra redonda, cuando no es posible documentar positiva y textualmente el modelo que inserta el anónimo tratado que lleva por título Ars musyce.

\section{Traducción}

Comienza el ARTE de la música

[1-2: Definición de música]

[-77-] (1) Para tratar sobre la música hay que definir qué es la música 6 . (2) Y la música es el movimiento armónico de los sonidos ${ }^{7}$ y la ciencia de sonar bien ${ }^{8}$.

\section{[3-12: Etimología de la palabra música]}

(3) De donde se dice música a partir de 'moys' en griego', que en latín se dice 'aqua' (="agua") $)^{10}$, porque en tiempos remotos fue descubierta por vez primera en los bidraulos, esto es, en los instrumentos de agua ${ }^{11}$, y en los martillos de una herrería por Pitágoras ${ }^{12}$; de ahí que también antiguamente se tocaba con instrumentos de agua ${ }^{13}$. (4) O bien ${ }^{14}$, música se dice a partir de 'musa' ${ }^{15}$, que, como quieren algunos, es un determinado instrumento musical que suena bastante armoniosa $y$ agradablemente, superando a todos los instrumentos musicales, por el hecho de que contiene en si la potencia y la afinación de todos los demás, sea que se insufle aire humano como la tibia ${ }^{16}$, sea que se toque con la mano como la viella ${ }^{17}$, sea que se accione con un fuelle como el órgano. (5) Dícese a partir del griego $\mathrm{MH} \Sigma \mathrm{A}^{18}$, esto es, 'media' (="intermedia") porque, al igual que trayectorias divergentes convergen en un punto intermedio, asi también en la musa convergen la mayoria de los instrumentos. (6) De ahi que, no sin motivo, la música haya sacado su denominación de su principal componente. (7) Dicen también algunos que la música ha recibido su denominación a partir de las Musas, por el hecho de que entre los antiguos se las tenia por perfectas en este arte y porque de ellas se alcanzaba la maestria en el arte de modular ${ }^{19}$. (8) De abi que de 'muso 20 , esto es, 'quaerere' (="buscar"), se piense que se dice Musas. (9) Otros piensan que música se dice como si se dijera 'mundica', esto es, del sonido del 'mundus'(=“mundo"), o sea, del cielo.

(10) Dice Cicerón ${ }^{21}$ : "¿Qué es eso que llena completamente mis oídos, ese sonido tan intenso y tan maravilloso?" (11) "Es, contestó él, el que se produce por el impulso y movimiento de las propias esferas y que, combinando los agudos con los graves, produce variadas concertaciones armónicas".

(12) Basten estas breves observaciones sobre la denominación de la música.

$$
\text { [13-15: Necesidad de la gamma como nota más grave] }
$$

(13) Los antiguos músicos no incluían la gamma en los monocordios. (14) Sin embargo, en Guido ${ }^{22}$, debido a la gravedad del segundo tono ${ }^{23}$, aparece consignada; sin ella no puede interpretarse el canto de éste, como en el Ofertorio 'In omnem terram' (="En toda la tierra”) ${ }^{24}$ y en otros más. (15) Donde nosotros 
decimos 'A', ahí los griegos dicen 'proslambanomenos' (=lat. 'adquisitus', esp. "añadida”) 25 ; y donde nosotros ·B', ahí los griegos 'ypathehypaton' (=lat. "principalis principalium', esp. "principal de las principales") ${ }^{26}$.

\section{[16-20: Consonancias e intervalos]}

[-78-] (16) Es de notar que estas seis consonancias se llaman consonancias precisamente cuando la nota precedente del uno y la subsiguiente del otro entran en contacto. (17) Pero cuando uno entona un diapente, un diatesarón o un diapasón y, así sucesivamente, se llaman intervalos. (18) Y entre las consonancias simples la diatesarón es agradable, la diapente más agradable y la más agradable la diapasón ${ }^{27}$. (19) Entre las compuestas ${ }^{28}$, la primera es agradable, la segunda más agradable y la tercera la más agradable ${ }^{29}$. (20) Esto se comprueba en el órgano ${ }^{30}$, en la cítara y en el discanto ${ }^{31}$.

\section{[21-37: La música y las artes liberales]}

(21) Es de notar, como se dice en la "Música" de BERN ${ }^{32}$, que todo aquel que se figura que canta bien sin conocimiento de este arte, cuando, al preguntársele por los ritmos <o por $>$ los intervalos entre los sonidos agudos y graves ${ }^{33}$, no es capaz de responder y pretende dar crédito ${ }^{34}$ al sentido del oído, y no a la guía de la razón, aun cuando necesariamente hay que recurrir al juicio de ambos, si bien en mayor medida al de la razón $n^{35}$, que meridianamente capta la verdad y la esencia en la naturaleza de las cosas, en la medida en que ello es posible, por un don del Creador Todopoderoso: este tal, digo, más bien debiera comparársele con el ruiseñor ${ }^{36}$, que en la estación de la primavera tan encantadora y armoniosamente canta ${ }^{37}$, que ser tenido por un cantor consumado.

(22) Pues $^{38}$, en efecto, en la música tanto más aplicado se vuelve uno, cuanto por más útil reconoce este arte. (23) La música es la única de las sietes artes, que se llaman liberales, connatural, como efectivamente lo son también las otras ${ }^{39}$. (24) De ahi que a juglares y actores, que son absolutamente analfabetos, los veamos en ocasiones componer preciosas canciones ${ }^{40}$. (25) A propósito de esto va el célebre pasaje de Boecio en el capítulo primero de su "Música": (26) Nada ${ }^{41}$, dice, tan connatural y tan característico del ser humano como relajarse con melodiosos sones y exasperarse con los contrarios. (27) A tenor de ello ${ }^{42}$ puede también entenderse 10 que no en vano dijo PLATóN ${ }^{43}$ : que el alma del mundo se halla ensamblada según un ajuste musical ${ }^{44}$.

(28) Pues, cuando en lo que dentro de nosotros se balla acoplado y convenientemente ensamblado percibimos aquello que en los sonidos se balla armoniosa y convenientemente ajustado, y con ello nos deleitamos, caemos en la cuenta de que también nosotros mismos estamos conformados con análoga semejanza. (29) Pues la semejanza le es odiosa a la desemejanza ${ }^{45}$.

[-79-] (30) Pero ${ }^{46}$ ¿̇a qué viene todo esto? Pues a que no puede ponerse en 
duda que el estado de nuestra alma y nuestro cuerpo parece en cierto modo estar configurado seguin unas proporciones musicales ${ }^{47}$. (31) De abi que una canción melodiosa embelese a los chiquillos; en cambio, algo áspero y desabrido les quite las ganas de seguir escuchando. (32) Esta misma sensación la experimenta toda edad y todo sexo; estos grupos, si bien se diferencian por sus comportamientos respectivos, todos ellos, sin embargo, coinciden en idéntica afición a la música. (33) Esto <dijo> Boecio.

(34) Pero" igual que la gramática, la dialéctica y las restantes artes ${ }^{49}$, si no se las redactase por escrito y se las presentase mediante normas, resultan ${ }^{50}$ vagas y caóticas, asi también ésta ${ }^{51}$. (35) Y hay que saber que esta arte no debe ser considerada como la más insignificante entre las demás artes, sobre todo porque es especialmente necesaria para los clérigos, y resulta útil y entretenida para cualquier persona que la practique. (36) Pues todo aquel que le dedique incesantemente su esfuerzo y persevere incansablemente sin interrupción, podrá obtener de ella un provecho tal que sobre la calidad de una composición musical será capaz de valorar si es refinada o corriente, buena o mala, y de rectificar una defectuosa y componer una nueva. (37) No es, por lo tanto, un modesto elogio, una utilidad escasa y un trabajo baldio el dominio de la música, que gracias a su conocimiento ${ }^{52}$ lo convierte a uno en juez de una pieza ya compuesta, en corrector de una defectuosa y en creador de una nueva $a^{53}$.

[38-43: Diferencia entre musicus (="músico") y cantor (="intérprete")] $]^{54}$

(38) Es de notar, empero ${ }^{55}$, que el músico y el intérprete de oficio ${ }^{56}$ no poco se diferencian entre si. (39) Pues mientras el músico siempre avanza derecho gracias al arte, el intérprete de oficio sólo en contadas ocasiones mantiene la senda recta gracias a la práctica. (40) ¿Con quién mejor compararía yo al intérprete de oficio que con el borrachin, que se va a su casa, pero no tiene ni idea de por qué calle tirar? (41) Pero también la piedra de un molino produce de vez en cuando un chirrido perceptible, si bien sin tener ella misma ${ }^{57}$ conciencia de lo que está haciendo, como un ser inanimado que es. (42) De ahi que GuIDo diga en el "Micrólogo" (='Breve tratado') 58.

(43) Entre músicos e intérpretes de oficio gran diferencia bay ${ }^{59}$.

Pues quien hace algo que no sabe qué es, por animal se le tiene, etc.

[44-49: Sílabas de solmisación]

(44) Asi es que ${ }^{60}$ lo primero que le recomendamos al que quiera prepararse para el aprendizaje de la música es esto: que procure afianzar el conocimiento de las letras ${ }^{61}$ junto con las sílabas consignadas en la figura adjunta ${ }^{62}$, y que no ceje en su empeño hasta no grabarlas firmemente en la memoria ${ }^{63}$. (45) Seis son las sílabas que empleamos en el ámbito de la música, diferentes ciertamente entre las diferentes nacionalidades; si bien, los ingleses, los franceses y los alemanes emplean éstas: [-80-] ut, re, mi, fa sol, la ${ }^{64}$, importadas, según se dice, del conocido bimno, cuyo comienzo es ${ }^{65}$ : (46) "Ut queant laxis", aqui tenemos ut; "resonare fi<bris>", aqui 
re; "mira gestorum", ahi mi; "famuli tuorum", ahifa; "solve pol<luti>", aqui sol; "labii reatum”, aqui la. (47) Asi es que, mediante estas silabas, quien aspire a saber música, que aprenda a cantar unas cuantas canciones hasta que domine perfecta y claramente sus subidas, sus bajadas y sus numerosas variaciones ${ }^{66}$. (48) Hasta con los dedos de la mano ${ }^{67}$ acostúmbrese incansablemente a modular ${ }^{68}$ la melodia ${ }^{69}$ y con ella valore, rectifique y cree una composición musical. (49) Que si esto lo hiciere unas cuantas veces y lo depositare firmemente en la memoria ${ }^{70}$, sin lugar a dudas tendrá un camino más expedito hacia la música.

\section{[50: Tipos de músicos]}

(50) Tres son ${ }^{71}$, pues, los tipos de músicos: uno, el del que compone piezas musicales ${ }^{72}$; el segundo, el del que toca los instrumentos ${ }^{73}$; el tercero, el del que valora la ejecución instrumental y la composición musical.

\section{[51: Definición de músico]}

(51) Es, pues, uno músico ${ }^{74}$ cuando tiene asimilada la ciencia del canto, no bajo la esclavitud de la ejecución, sino con la soberanía de la especulación, como más arriba dice Boecio.

[52-61: Significado y efectos de la música]

(52) Ninguna disciplina ${ }^{75}$, como él mismo dice, sin la música puede ser perfecta, porque sin ella nada queda ${ }^{76}$. (53) El mismo Universo está conformado según una determinada armonia de sonidos y el propio cielo gira según una modulación armónica77. (54) Y entre los pitagóricos, los estoicos, los platónicos, la †física $\dagger^{78}$, más vergonzoso $0^{79}$ resultaba ignorar la música que las letras $^{80}$.

(55) Pero tampoco ${ }^{81}$ conviene pasar en silencio la enorme capacidad de conmover los sentimientos de la gente que posee el sonido de la música ${ }^{82}$. (56) Si, como en efecto, halaga el oído, eleva el espiritu, incita a los combatientes a la lucha, reanima a los abatidos y desesperados, conforta a los caminantes, desarma a los bandidos, apacigua a los airados, alegra a los tristes y afligidos, reconcilia a los enfrentados, arranca de raiz los malos pensamientos y calma la furia de los locos. (57) Como se lee en el "Libro de los Reyes" a propósito de Saúl en el pasaje sobre la cítara de David". (58) Igualmente también un loco fue curado ${ }^{84}$ por el médico Asclepiades ${ }^{85}$ tocando la citara, según cuenta Boecio ${ }^{86}$. (59) Pero también él mismo refiere de Pitágoras ${ }^{87}$ que a un joven calavera lo apartó de su descontrolada pasión al son de la música ${ }^{88}$. (60) Pues, en efecto, mediante una clase de música podrás incitar a uno a la lujuria y mediante otra distinta podrás reconducir inmediatamente a esta misma persona impulsada por el arrepentimiento. (61) Como prueba de ello nos refiere GUIDO ${ }^{89}$ el caso de cierto joven. 
[62: Particiones de la música]

[-81-] LAS TRES MÚSICAS ${ }^{90}$.

(62) Sobre las tres músicas ${ }^{91}$, esto es, la mundana ${ }^{92}$, la humana y la instrumenta ${ }^{93}$ y sobre los tres géneros ${ }^{94}$ de la melodía ${ }^{95}$ musical, a saber, el diatónico ${ }^{96}$, el enarmónico ${ }^{97}$ y el cromático ${ }^{98}$, consulta la "Música" de Boecio, de Cicerón, de Filolao y de Macrobio ${ }^{99}$ y los tratados de los modernos FILÓSOFOS ${ }^{100}$.

EL UNísono ${ }^{101}$.

\section{[63-77: Intervalos musicales]}

(63) Unisono (='unisonus'), dicese como si tuviera una sola nota (=lat. 'unus sonus', esp. "una sola nota"), y se produce cuando una sola nota se repite ininterrumpidamente.

$\mathrm{EL}_{\mathrm{L}} \mathrm{TONO}^{102}$.

(64) Tono (='tonus') dicese a partir de 'tonare' (="atronar"). Y 'tonare' (="atronar") es sonar poderosamente, porque el tono tiene un sonido intenso en comparación con el semitono.

El Semitono ${ }^{103}$.

(65) Al semitono PLATÓN lo llama <'limma'> (="resto") $)^{104}$, esto es, tono no completo, sino incompleto, de donde Virgilio ${ }^{105}$ : "FFrigios, medio hombres?".

El SEMIDíTONO ${ }^{106}$.

(66) Semiditono ${ }^{107}$ dicese, porque no es un ditono completo. Hay de él dos clases: una, <que consta $>$ de tono y semitono; $y$ otra, de semitono $<y$ tono $>$.

Pone cosas notables ${ }^{108}$.

(67) Pero conviene saber ${ }^{109}$ que son nueve los intervalos ${ }^{110}$ con los que se compone toda melodía, a saber: unísono, semitono, tono ${ }^{111}$, semiditono, ditono ${ }^{112}$, < diatesarón $>^{113}$, diapente, semitono con diapente y tono con diapente. (68) A estos ${ }^{114}$ los MODERNOS añaden otros dos, a saber, el trítono y el diapasón ${ }^{115}$. (69) De ellos seis se dicen consonantes ${ }^{116}$ : tres, simples; y tres, compuestas ${ }^{117}$. (70) Simples son la diatesarón, la diapente y la diapasón; compuestas, la diatesarón con diapasón, la diapente con diapasón y la doble diapasón ${ }^{118}$. (71) Para esto vale la antífona: Ter terni sunt modi quibus omnis ${ }^{119}$ (= "Tres veces tres son los intervalos ${ }^{120}$ con los que"), etc.

[-82-] (72) Diapente ${ }^{121}$ en latín se dice a partir de 'quinque' (="cinco"), porque a partir de una nota inicial efectúa un salto de hasta una quinta, conteniendo en su interior una diatesarón y un tono. (73) $Y$ es $<$ de cuatro clases $>$ 122: La primera, entre $\cdot C \cdot y \cdot G \cdot ;$ la segunda, entre $\cdot D \cdot y \cdot a \cdot$; la tercera, entre $\cdot E \cdot y \cdot \cdot \cdot \cdot \cdot 123 ; y$ la cuarta, entre $\cdot F$. $y \cdot{ }^{124}$. (74) Los dos intervalos ${ }^{125}$ que quedan, a saber, semitono con diapente ${ }^{126}$ y tono con diapente $e^{127}$, se denominan “intervalos". (75) Juliano, apóstata y ${ }^{128}$ emperador, añadió el semitono con diapente ${ }^{129}$. (76) Y ten en cuenta ${ }^{130}$ que, cuando dices semitono con diapente, te estás refiriendo a un solo intervalo; pero, cuando semitono $y$ diapente, a dos. Lo mismo en el caso de tono y diapente. 
EL DIAPASÓN ${ }^{13}$.

(77) Diapasón 132 dícese a partir de 'omnes' (="todas"), porque contiene en su interior todas las consonancias, ya que la diatesarón y la diapente conforman la diapasón ${ }^{133}$.

[78-85: Los tonos eclesiásticos] $]^{134}$

Sigue < LA EXPOSICIÓN> DE LOS PLAGALES ${ }^{135}$.

(78) El primero de los plagales, esto es, el segundo tono ${ }^{136}$, consta de la primera especie de diatesarón inferior, que es desde $\cdot A \cdot$ hasta $\cdot D \cdot$, y de la primera especie de diapente, que es desde la misma $\cdot \mathrm{D} \cdot$ hasta $\cdot \mathrm{a} \cdot \mathrm{y}$ de la primera especie de diapasón, que es desde $\cdot \mathrm{A} \cdot$ hasta $\cdot \mathrm{a} \cdot$.

El SEGUNDO DE LOS PLAGALES.

(79) $\mathrm{El}$ segundo de los plagales, esto es, el cuarto tono, consta de la segunda especie de diatesarón inferior, que es desde $\cdot \mathrm{B} \cdot$ hasta $\cdot \mathrm{E} \cdot \mathrm{y}$ de la segunda especie de diapente, que es desde la misma $\cdot E \cdot$ hasta $\cdot \hbar \cdot$, y de la segunda especie de diapasón, que es desde $\cdot B \cdot$ hasta $\cdot \bullet \cdot$

El TERCERo DE LOS PLAGALES.

(80) El tercero de los plagales, esto es, el sexto tono, consta de la tercera especie de diatesarón inferior, que es desde $\cdot \mathrm{C} \cdot$ hasta $\cdot \mathrm{F} \cdot$, y de la tercera especie de diapente, que es desde la misma $\cdot \mathrm{F} \cdot$ hasta ${ }^{\circ} \mathrm{c}$, y de la tercera especie de diapasón, que es desde $\cdot \mathrm{C} \cdot$ hasta ${ }^{\circ} \mathrm{C} \cdot$.

El CuARTo de LOS PLAGALES ${ }^{137}$.

(81) El cuarto plagal, esto es, el octavo tono, consta de la cuarta ${ }^{138}$ especie de diatesarón inferior, que es desde $\cdot \mathrm{D} \cdot$ hasta $\cdot \mathrm{G}$, y de la cuarta especie de diapente, que es desde la misma $\cdot \mathrm{G} \cdot$ hasta $\cdot \mathrm{d} \cdot$, y de la cuarta especie de diapasón, que es desde $\cdot \mathrm{D} \cdot$ hasta $\cdot \mathrm{d} \cdot$.

\section{[-83-] Sigue < LA EXPosición> DE LOS PRINCIPALEs ${ }^{139}$.}

(82) El primero de los principales ${ }^{140}$, esto es, el primer tono, consta de la primera especie de diapente, que es desde $\cdot \mathrm{D} \cdot$ hasta $\cdot \mathrm{a} \cdot \mathrm{y}$ de la primera especie de diatesarón superior, que es desde la misma $\cdot a \cdot$ hasta $\cdot d \cdot$, y de la primera especie de diapasón ${ }^{141}$, que es desde $\cdot \mathrm{D} \cdot$ hasta $\cdot \mathrm{d} \cdot$.

EL SEGUNDO PRINCIPAL.

(83) El segundo de los principales, esto es, el tercer tono, consta de la segunda especie de diapente que es desde $\cdot E \cdot$ hasta $\cdot \bullet \cdot$, y de la segunda especie de diatesarón superior, que es desde la misma $\bullet \bullet \cdot$ hasta $\cdot e \cdot$, y de la segunda especie de diapasón, que es desde $\cdot E \cdot$ hasta $\cdot e \cdot$.

EL TERCER PRINCIPAL.

(84) El tercero de los principales, esto es, el quinto tono, consta de la tercera especie de diapente, que es desde $\cdot F \cdot$ hasta $\cdot c \cdot$, y de la tercera especie de diatesarón superior, que es desde la misma ${ }^{\circ} \cdot{ }^{\cdot}$ hasta $\cdot f \cdot$, y de la cuarta especie de diapasón, que es desde $\cdot F \cdot$ hasta $\cdot f \cdot$ 
El CUARTO PRINCIPAL.

(85) $\mathrm{El}$ cuarto de los principales, esto es, el séptimo tono, consta de la cuarta especie de diapente, que es desde $\cdot \mathrm{G} \cdot$ hasta $\cdot \mathrm{d} \cdot$, y de la cuarta especie de diatesarón superior, que es desde $\cdot d \cdot$ hasta $\cdot g \cdot$, y de la cuarta especie de diapasón, que es desde $\cdot \mathrm{G} \cdot$ hasta $\cdot g \cdot$

[86-89]: Representación gráfica de los tonos eclesiásticos ${ }^{142}$

$(86)^{143}$

\section{Coro femenino Coro masculino}
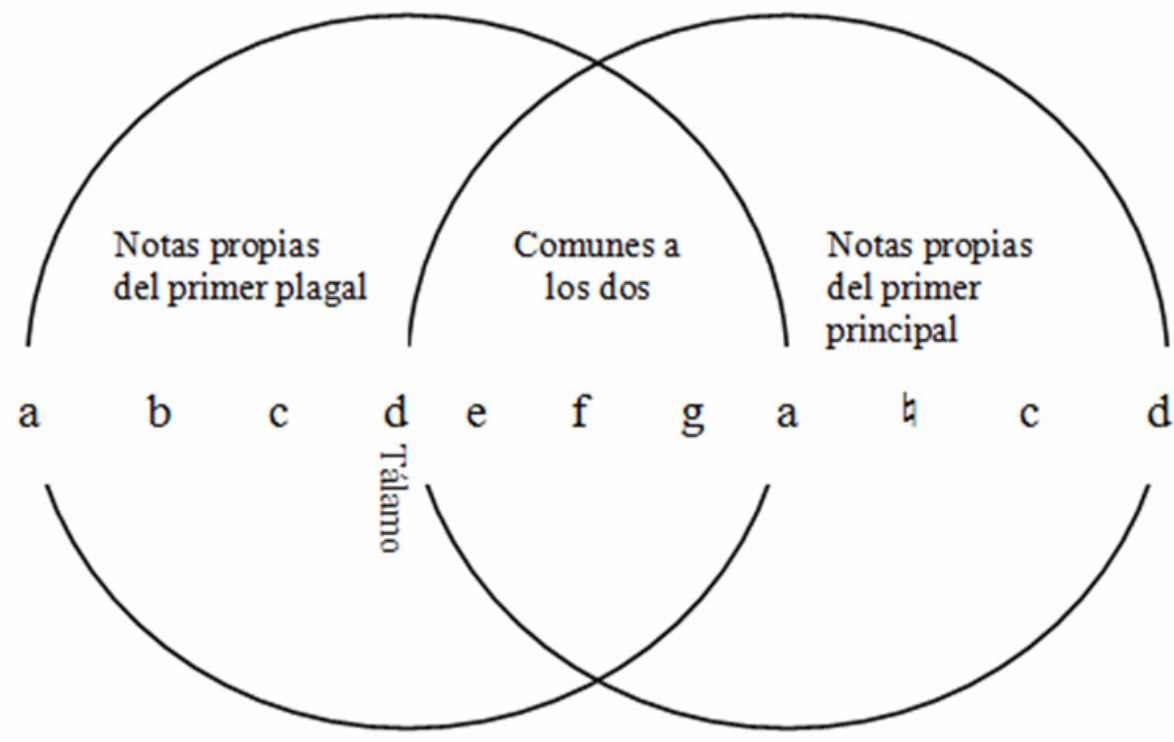

Representación del primer principal y de su subordinado 


\section{$<$ Coro femenino $>\quad$ Coro masculino}
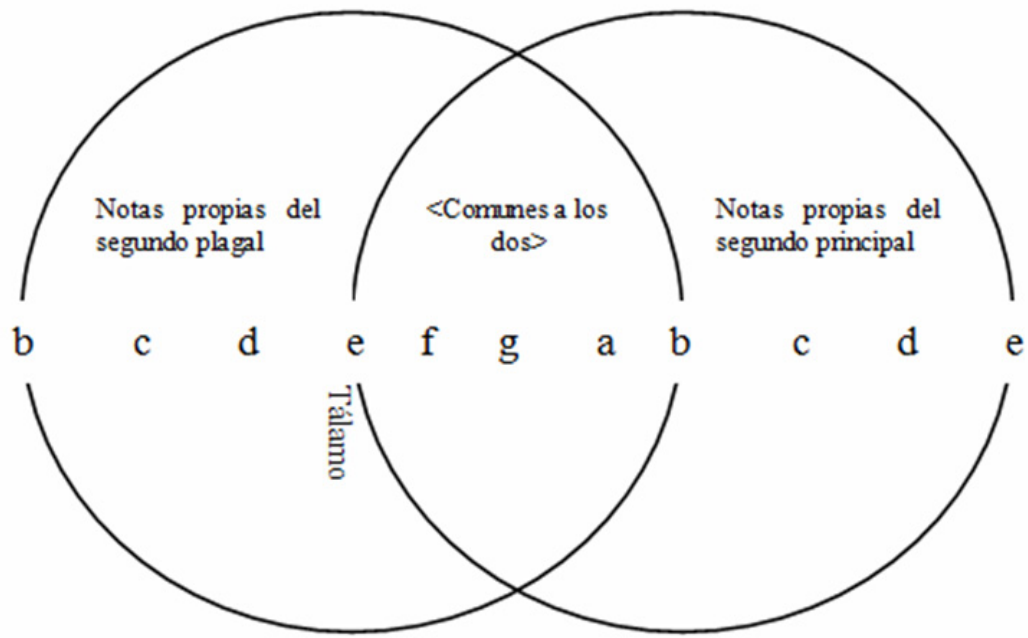

Representación del segundo principal y de su subordinado

$(88)^{145}$

\section{Coro femenino Coro masculino}
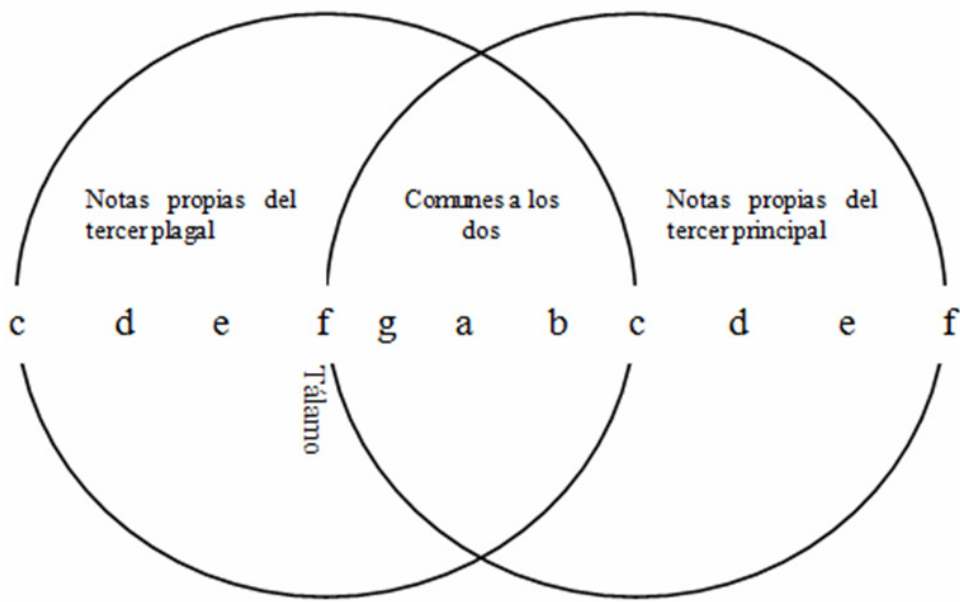

Representación del tercer principal y de su plagal 
$(89)^{146}$

\section{Coro femenino Coro masculino}

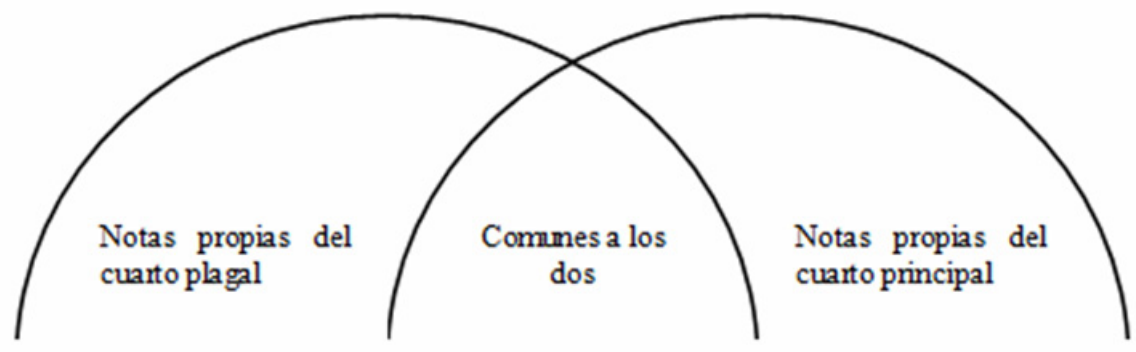

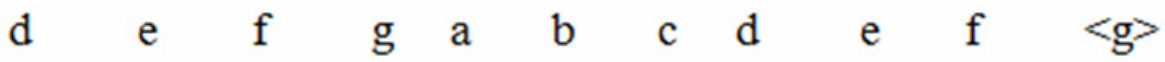

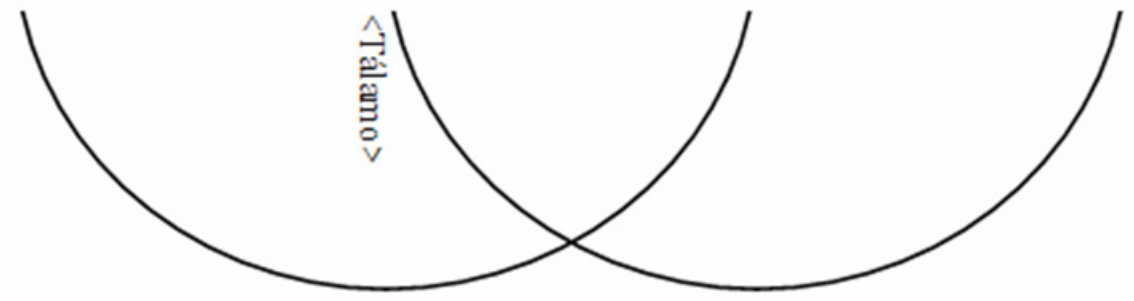

Representación del cuarto principal y de su subordinado 
${ }^{1}$ Este trabajo se inserta dentro del Proyecto de Investigación FFI 2008-05611/FILO que, bajo la dirección del Prof. Luque Moreno, se desarrolla en el Departamento de Filología Latina de la Universidad de Granada.

${ }^{2}$ Cf. Berno prol. 11, 14-16, págs. 64-65 [Edición del texto en Alexander Rausch, Die Musiktraktate des Abtes Bern von Reichenau. Edition und Interpretation, Musica Mediaevalis Europae Occidentalis, Publikationen zur älteren Musikgeschichte des Institutes für Musikwissenschaft der Universität Wien und des Institutum Musices Feldkirchense, Band 5, Tutzing, Verlegt bei Hans Schneider, 1999, págs. 31-68].

${ }^{3}$ Cf. Berno prol.11,16, pág. 64.

${ }^{4}$ Cf. Ps.-Thomas Aqu. I 21, pág. 78.

${ }^{5}$ Cf. Bernhard, op. cit., págs. 66-67.

${ }_{6}$ Tal como aparece editada en el texto de Ps.-Thomas Aqu. I 1, pág. 77, la expresión “Tractaturi de musyca videndum est, quid sit musyca”, resulta poco trabada sintácticamente; el texto de Di Martino, op. cit., pág. 24, sobre la base del códice $V 58^{\mathrm{r}}$, coincidiendo en esto con el manuscrito $B 2^{\text {ra }}$, propone solventar el anacoluto escribiendo: "Tractaturi de musyca. videndum est quid sit musyca”.

${ }^{7}$ Ps.-Thomas Aqu. I 2, pág. 77 = Іон. Сотт. (ca. 1053 - ca. 1121) mus. (ca. 1100) 4, 9, pág. 58 [Edición del texto en Johannis Affligemensis De musica cum Tonario, ed. J. Smits van Waesberghe, Corpus Scriptorum de Musica (=CSM), vol. 1, Rome, American Institute of Musicology, 1950]: "Est enim musica nihil aliud quam vocum motio congrua". Disponemos también de traducción de esta obra en lengua inglesa, a saber: Hucbald, Guido and John, On Music. Three Medieval Treatises, Translated by Warren Babb, Edited with Introductions by Claude V. Palisca, Index of Chants by Alejandro Enrique Planchart, New Haven and London, Yale University Press, 1978, págs. 84-100 (='Introduction'), págs. 101-187 (=‘Translation'), espec. pág. 107: "For music is nothing other than the fit progression of tones". La palabra latina vox (=gr. $\varphi \omega v \eta ́)$ no se refiere exclusivamente a la 'voz humana' sino al sonido propio y característico de la música en general, con independencia del medio de ejecución, sea éste la voz humana, o sea el sonido armonioso producido por cualquier instrumento musical; $c f$., sobre el particular, Boecio, Sobre el Fundamento de la Música. Cinco libros, Introducción, Traducción y Notas de Jesús Luque, Francisco Fuentes, Carlos López, Pedro R. Díaz y Mariano Madrid, Madrid, Editorial Gredos, Biblioteca Clásica Gredos, no 377, 2009, pág. 76, n. 58.

${ }^{8}$ Ps.-Thomas Aqu. I 2, pág. 77 = Ps.-Odo dial. (circa 1000) [Edición del texto en Ps.ODo, <Dialogus de musica>, ed. Martin Gerbert, Scriptores Ecclesiastici de Musica Sacra potissimum ex variis Italiae, Galliae E Germaniae codicibus manuscriptis collecti et nunc primum publica luce donati (=SEMS), St. Blaise, Typis San-Blasianis, 1784 (reprint ed. Hildesheim-Zürich-New York, Georg Olms Verlag, 1990)], vol. I, pág. 252a: "D. Quid est Musica? M. Veraciter canendi scientia...". Lo mismo que el ars grammatica, la primera de las artes liberales, se define como recte dicendi scientia (cf., por ejemplo, Qvint. inst. I 4, 2), la música, habitualmente la última de las siete artes liberales, también se puede definir como recte canendi scientia; vid., sin embargo, Avgrst. (354-430) mus. (387-389) I 2, 2 [Edición del texto en Avrelivs Avgrstinvs, De musica libri VI, ed. Guy Finaert \& F. J. Thonnard, La musique. De musica libri sex, Texte de l'édition bénedictine, Introduction, Traduction et Notes de Guy Finaert, A. A. (Livres I-V) et F.-J. Thonhard, A. A. (Livre VI), Oeuvres de Saint Augustin, $1^{\text {re }}$ série: Opuscules, VII. Dialogues philosophiques, VI, Paris, 1947; de esta obra disponemos también de traducción española, a saber, San Agustín, Sobre la Música. Seis Libros, Introducción, Traducción y Notas de Jesús Luque Moreno \& Antonio López Eisman, Madrid, Editorial Gredos, Biblioteca Clásica Gredos, no 359, 2007]: "Musica est scientia bene modulandi", expresión que parece, a primera vista, valorar mayormente la componente estética (='bene’) que la componente normativa (='recte’) de la música. La distinta calificación adverbial que vemos utilizada en las definiciones de música 'recte/bene' (es decir, el par "corrección/elegancia”) es la que sirve también para diferenciar, dentro de la primera serie de las artes liberales, a la gramática de la retórica ( $c f$., por ejemplo, Qvint. inst. II 14, 5). Ahora bien, en la definición agustiniana de música, el término latino 'bene’ puede 
entenderse como equiparable semánticamente a 'recte'. Por otra parte, como en nota precedente decíamos a propósito del término latino vox (=gr. $\varphi \omega v \eta ́)$, igualmente el verbo canere en latín no significa exclusivamente "cantar" (esto es, el sonido musical característico de la voz humana), sino "sonar" (o sea, el sonido musical que pueden emitir ya sea la voz humana ya sea cualquier instrumento musical): sobre el particular, $c f$. , por ejemplo, LuQue \& López Eisman, op. cit., pág. 90 y n. 9; y, también, LuQue \& Fuentes, op. cit., pág. 74, n. 54.

9 También aquí vertimos el texto editado por Bernhard, op. cit., pág. 77: "Unde dicitur musyca a 'moys' Greco”. Hay en este caso coincidencia con Di Martino, op. cit., pág. 24, que, como sabemos, prefiere las lecturas del manuscrito $V 58^{\text {r }}$; en cambio, la puntuación de $B 2^{\text {ra }}$ es: "Vnde dicitur musyca. A moys greco".

${ }^{10}$ BAB B, op. cit., pág. 106, n. 3, trae a colación la siguiente cita del Libro del Éxodo: "Moysica: Exod. 2: 10. See Noel Swedlow, "Musica dicitur a moys, quod est aqua", Journal of the American Musicological Society 20 (1967) :3-9”. E1 texto del Libro del “Éxodo”, esto es, Vulg. ex. 2, 10, pág. $77^{\mathrm{b}}$ [Edición del texto en Biblia Sacra iuxta Vulgatam versionem, ed. Robertus Weber, Stuttgart, Deutsche Bibelgesellschaft, 19944] dice: "quem [sc. Mosen] illa [sc. filia Pharaonis] adoptavit in locum filii vocavitque nomen eius Mosi dicens quia de aqua tuli eum”. Sobre el particular, cf. también Ps.-Thomas Aqu. II, 31-32, pág. 97 (a partir de las lecturas del manuscrito $D=$ Durham, University Library, Cosin V.V.4, fol. 200'): "Musica autem dicitur apotoymoys. Moys enim lingua Egipciaca aqua Latine dicitur, inde Moyses aquaticus"; vid. también Pedro RAfAeL Díaz DíAz, "El tratado Ars musice armonie indebidamente atribuido a Santo Tomás de Aquino (Traducción y Notas)”, Humanitas, 62 (2010), págs. 113-145, espec. pág. 123.

${ }^{11} \mathrm{Al}$ tenor literal de Ps.-Thomas Aqu. I 3, pág. 77, se aproxima muy de cerca Hier. Mor. (inter 1272-1307), mus. [Edición del texto en Hieronymus de Moravia O.P., Tractatus de musica, ed. Simon M. Cserba, Freiburger Studien zur Musikwissenschaft, vol. 2, Regensburg, Pustet, 1935], pág. 12, 6-8: "alii musicam quasi moysicam a moys, quod est aqua, quia olim primo inventa fuit in hydraulis, id est in aquaticis instrumentis"; en igual sentido también, GLoss. Boeth. mus. (ss. IX-XII) [Edición del texto en Glossa maior in institutionem musicam Boethii, edd. Michael Bernhard \& Calvin M. Bower, Bayerische Akademie der Wissenschaften, Veröffentlichungen der Musikhistorischen Kommission, Band 9, Editionsband I, München, Verlag der Bayerischen Akademie der Wissenschaften, In Kommission bei der Verlag C. H. Beck'schen Verlagsbuchhandlung, 1993], vol. 1, I 1, 6, pág. 1: "Moys est aqua, inde <...>; et hoc ideo, quia prius ibi <reper $>$ ta est in idrau<licis> i. aquaticis vasis"; $c f$. también, sobre el particular, Ps.-Thomas AQu. II, 33, págs. 97-98 (igualmente sobre las lecturas del manuscrito $D$ fol. 200r) y Díaz Díaz, op. cit., pág. 123. A la vista de todas estas coincidencias textuales, Bernhard, op. cit., "Kommentar", pág. $85, \S 3$, presupone la existencia de una compilación etimológicolexicográfica como fuente de doctrina común para todos estos pasajes.

${ }_{12}^{12}$ Sobre la anécdota en cuestión, $c f$., por ejemplo, LuQue \& Fuentes, op. cit., pág. 97, n. 131.

${ }^{13}$ Sobre la distinción terminológica y/o conceptual entre instrumentum y organum, vid., por ejemplo, LuQue \& López Eisman, op. cit., pág. 95 y n. 25.

${ }^{14}$ Ps.-Thomas Aqu. I 4-9, pág. 77 = Iон. Сотт. mus. 3, 1-10, págs. 54-55; cf. también Вавв, op. cit., págs. $105-106$.

${ }^{15}$ Cf., sobre el particular, ВАвв, op. cit., pág. 105: "It is called music... from musa [bagpipe]". Vid. también Ps.-Thomas Aqu. II 34, pág. 99 (según las lecturas del manuscrito D fol. 200v): "Vel musica dicitur a Musys, id est naturalibus instrumentis" y Díaz Díaz, op. cit., pág. 123 y n. 58.

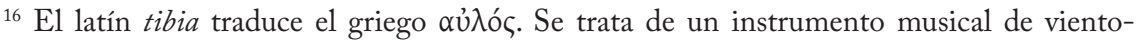
madera, provisto de lengüeta; por lo tanto, la tibia romana no es una flauta, ya que la flauta carece de lengüeta; $c f$., por ejemplo, sobre el particular, LuQue \& Fuentes, op. cit., pág. 71, n. 41.

${ }^{17}$ En Іон. Сотт. mus. 3, 4, pág. 54 se lee: "manu temperetur ut phiala”; cf. ВАвв, op. cit., pág 105, traduce: "For... it is regulated by the hand like the fiddle".Vid., sobre el particular, Michael Bernhard, Lexicon Musicum Latinum Medii Aevi (=LMLMA), Worterbuch der lateinischen Musikterminologie des Mittelalters bis zum Ausgang des 15. Jahrbunderts / Dictionary of Medieval Latin Musical Terminology to the End of the 15th Century, 9. Faszikel-Fascicle 9, Bayerische Akademie der Wissenschaften, Musikhistorische Kommission, München, Verlag 
der Bayerischen Akademie der Wissenschaften, In Kommission bei dem Verlag C. H. Beck, 2007, s. v. "figella", col. 63a: "v. phiala”. Sobre el grado de legitimidad y aceptación de la lectura figella, puede verse, no obstante, Bernhard, op. cit., "Kommentar”, pág. 85, § 4.

${ }^{18}$ Más propiamente, $\mu \epsilon ́ \sigma \eta ; ~ c f$. ВАВв, op. cit., pág. 105: «Hence musa derives from the Greek $-\mu \epsilon \in \sigma \eta$, that is, "central"».

${ }^{19}$ El verbo latino modulari no se emplea aquí en el sentido restringido de nuestro moderno tecnicismo "modular", sino que, antes bien, se refiere a la articulación estructural que entraña la música en sus diversos aspectos, melódico o rítmico, así como también a la medida de los versos o de los movimientos de la danza; $c f$. ., por ejemplo, Luque Moreno \& López Eisman, op. cit., pág. 90, n. 9; cf. también LuQue \& Fuentes, op. cit., pág. 73, n. 50.

${ }^{20} C f$., sin embargo, Вав в, op. cit., pág. 105, n. 1: aто $\theta v \mu v \sigma \omega$ of John's text is a corruption via Isidore's Etymologies 3.15.1, and Cassiodorus, Institutiones (GS1:15), of Plato's ảmò Toû $\mu \omega \hat{\sigma} \theta \theta$ al. Se atribuye, en efecto, a Platón la etimología que hace derivar $\mu$ ov $\sigma a$ de $\mu \omega \sigma \theta \theta a ;$ vid. Plat. Crat.

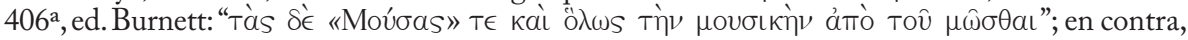
sin embargo, Platón, Diálogos, vol. II: Crátilo, trad. esp. J. L. Calvo Martínez, Madrid, Editorial Gredos, Biblioteca Básica Gredos, 2000, pág. 397, n. 82: "El verbo môsthai está, probablemente, emparentado con lat. mos y nada tiene que ver con Moûsa que procede de *Montja (cf. Schwyzer, Griechische Grammatik, pág. 473)". Vid. también Cassiod. (saec. VI in.) inst. (post 540) [Edición del texto en Cassiodori Senatoris Institutiones, Edited from the Manuscripts by R. A. B. Mynors, Oxford, Clarendon Press, $1963\left(=1937^{1}\right)$ ] II 5, 1, págs. 142-143: "nam Musae ipsae appellatae sunt “AПO TY MA $\mathrm{O}$ ”, id est a quaerendo, quod per ipsas, sicut antiqui voluerunt, vis carminum et vocis modulatio quaereretur"; $c f$., asimismo, Isid. (circa 570-636) etym. (circa 627-636) [Edición del texto en Isidori Hispalensis Episcopi Etymologiarum sive Originum libri XX, ed. W. M. Lindsay, Oxford, At the Clarendon Press, 1911ㄹ] III 15, 1, vol. I, pág. 139: "Et dicta Musica per derivationem a Musis. Musae autem appellatae ámò tov̂ $\mu a ́ \sigma a l$, id est a quaerendo, quod per ipsas, sicut antiqui voluerunt, vis carminum et vocis modulatio quaereretur"; $c f$., además, Isidoro Di Siviglia, Etimologie o Origini, a cura di Angelo Valastro Canale, Torino, Unione Tipografico-Editrice Torinese, 2004, vol. I (Libri I-XI), pág. 297, n. 26 :

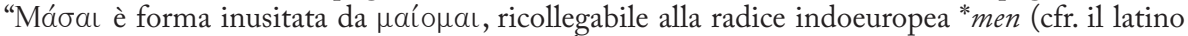
mens)"; cf., igualmente, Isidore de SÉville, Etymologies, Livre III: De mathematica, Texte établi par G. Gasparotto avec la collaboration de J.-Y. Guillaumin, traduit et commenté par J.-Y. Guillaumin, Paris, Les Belles Lettres, 2009, pág. 54, n. 116: "Il existe en grec un verbe raíouaı

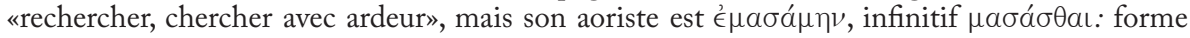
moyenne, non pas la forme active que donne ici Isidore"; $c f$., en fin, sobre el particular, GLoss. Boeth. mus. I 34, 43, 11-12, pág. 354: "Et musica dicta per derivationem a musis. Musae autem appellatae $\mathrm{A} \Pi \mathrm{T} \Upsilon \mathrm{M} \Omega \Sigma \Omega \mathrm{N}$, i. a querendo, quod per eas sicut antiqui voluerunt, vis carminum et vocis modulatio quereretur".

${ }^{21}$ Ps.-Thomas Aqu. I 10-11, pág. 77 = Macrob. (saec. V in.) som. (circa 400) II 1, 2 [Edición del texto en Ambrosir Theodosir Macrobir, Commentarii in Somnium Scipionis, ed. James Willis, Leipzig, BSB B. G. Teubner Verlagsgesellschaft, 1970², pág. 95]; $c f$. también Macrobe, Commentaire au Songe de Scipion, Tome II: Livre II, Texte établi, traduit et commenté par Mireille Armisen-Marchetti, Paris, Les Belles Lettres, 2003, pág. 2; cf., igualmente, Macrobio, Comentario al "Sueño de Escipión", Introducción, Traducción y Notas de Fernando Navarro Antolín, Madrid, Editorial Gredos, Biblioteca Clásica Gredos, no 351, 2006, pág. 321; cf., en fin, Macrobio, Commento al Sogno di Scipione, Testo latino a fronte, Saggio introduttivo di Ilaria Ramelli, Traduzione, Bibliografia, Note e Apparati di Moreno Neri, Milano, I Edizioni Bompiani, Il Pensiero Occidentale, 2007, pág. 435. Para el texto referido de Cicerón, cf. Cic. rep. VI 18 [Edición del texto en M. Tvllivs Cicero, Scripta quae manserunt omnia, fasc. 39: De re publica librorum sex quae manserunt, ed. K. Ziegler, Leipzig, BSB B.G. Teubner Verlagsgesellschaft, 1969, pág. 131].

${ }_{22}$ Guido de Arezzo (circa 990 - post 1033), en el Micrologus (1025/1026) [Edición del texto en Guidonis Aretini Micrologus, ed. Jos. Smits van Waesberghe, CSM, vol. 4, Rome, American Institute of Musicology, 1955], afirma que los modernos teóricos de la música, pero no precisamente él, añadieron la $\bullet \cdot \cdot$ griega a las quince notas que los antiguos tratadistas 
habían distinguido en el monocordio regular; $c f$. Gvido micr. 2, 3, pág. 93: "In primis ponitur . G. graecum a modernis adiunctum”; también, BABB, op. cit., pág. 59. La información aparece desarrollada con mayor precisión en John Cotton, quien atribuye a Guido la adición de las cuatro notas restantes del tetracordio de las superacutae; $c f$. Іон. Сотт. mus. 5, 2-8, págs. 59-60; cf., ВАВв, op. cit., págs. 107-108.

${ }^{23}$ Sobre el secundus tonus sive primus plagalium, cf., aquí mismo, Ps.-Thomas AQu. I 78, pág. 82; vid., también, Bernhard, op. cit., "Kommentar", pág. 85, § 14.

${ }^{24}$ Cf. Bernhard, op. cit., "Kommentar", pág. 85, § 14 y n. 40; cf. también Іон. Сотт. mus. 10,18 , pág. 78: "Nam cantus nunc in gravibus vagatur, ut in offertorio illo: In omnem terram"; $c f$., asimismo, ВАв В, op. cit., pág. 116.

${ }^{25} \mathrm{Vid}$. Boeth. (circa 480-524) mus. (ante 510) [Edición del texto en Anici Manli Torquati Severini Boeti De institutione musica libri quinque, ed. Godofredus Friedlein, Frankfurt am Main, Minerva G.M.B.H., 1966 (=Leipzig, 1867)] IV 3, pág. 309, lín. 22: "Proslambanomenos, qui adquisitus dici potest"; $c f$. también Anicio Manlio Torquato Severino Boecio, Tratado de Música, Prólogo, traducción, notas y apéndices de Salvador Villegas Guillén, Madrid, Ediciones Clásicas, 2005, pág. 146; $c f$. asimismo LuQue Moreno \& López Delgado, op. cit., pág. 282 y n. 28.

${ }^{26}$ Vid. Boeth. mus. IV 3, pág. 309, líns. 23-24: "hypate hypaton, quae est principalis principalium”; $c f$. Villegas Guillén, op. cit., pág. 146 y Luque Moreno \& López Delgado, op. cit., pág. 282.

${ }^{27}$ Bernhard, op. cit., "Kommentar", pág. 85, § 18, cita, con bastante verosimilitud, como muy próximo en cuanto al contenido, el testimonio de Anon. La Fage I (s. XII/2) [Edición del texto en Anonymous quem ed. La Fage (s. Martialis), "Quoniam de canendi scientia", ed. Albert Seay, «An Anoymous Treatise from St. Martial», Annales Musicologiques, 5 (1957), págs. 1342], pág. 17: "Tres vero sunt consonantiae ex coniunctionibus compositae, quibus in discantu et organo organizatores utuntur. Prima est diatesseron, secunda diapente, tertia diapason. Quare dicuntur consonantiae. Consonantiae autem ideo dicuntur, quia earum extremae voces primis vocibus consonare noscuntur. Diatesseron reddit dulcem melodiam, diapente dulciorem, diapason dulcissimam et quandam identitatem vocum”; $c f$. también, aquí mismo, Ps.-Thomas AQu. I 70, pág. 81: "Simplices sunt dyatesseron, dyapente, dyapason".

${ }^{28}$ Estas tres consonanciae compositae serían, respectivamente, la diapasón con diatesarón, la diapente con diapasón y la doble diapasón; cf., aquí mismo, Ps.-Thomas Aqu. I 70, pág. 81: "conposite (sc. consonancie) dyatesseron cum dyapason, dyapente cum dyapason, bis dyapason". Vid. también Willeh. Hirs. (†rogr), mus. (ante 1069) 22, pág. 55 [Edición del texto en Willehelmi Hirsaugensis Musica, ed. Denis Harbinson, CSM, vol. 23, Rome, American Institute of Musicology, 1975]: "Sex sunt consonantiae; tres simplices et tres compositae. Simplices sunt diatessaron, diapente, diapason; compositae diapason cum diatessaron, diapason cum diapente, bisdiapason".

${ }^{29}$ Respectivamente, diapason cum diatessaron, diapason cum diapente y disdiapason, según la terminología empleada por Bernhard, op. cit., "Kommentar", pág. 84, § 19; en contra, el testimonio de la transmisión manuscrita $\left(c f . B 3^{\mathrm{vb}}\right)$ y de la propia edición del texto ( $c f$. Ps.Thomas AQu. I 70, pág. 81), a saber, y también respectivamente, dyatesseron cum dyapason, dyapente cum dyapason y bis dyapason.

${ }^{30}$ Difícil decidirse entre el instrumento musical (lat. 'organum', esp. "órgano") y una de las dos variedades del canto polifónico, consistente en añadir a una melodía gregoriana llamada cantus firmus, una segunda voz, a distancia de cuarta o quinta, llamada vox organalis; sin embargo, Bernhard, op. cit., "Kommentar”, pág. 85, § 20, se inclina por la primera opción como la más probable: "Organum ist in diesem Falle wohl die Orgel".

${ }^{31} \mathrm{El}$ discantus es una variedad del canto polifónico medieval, según la cual dos voces seguían movimientos contrarios; $c f$. también Bernhard, op. cit., "Kommentar”, pág. 86, § 20.

${ }^{32}$ Ps.-Thomas Aqu. I 21, pág. 78 = Berno prol. 11, 14-16, págs. 64-65.

${ }^{33}$ En este caso, no traducimos literalmente el texto editado por Bernhard ( $c f$. Ps.-Thomas

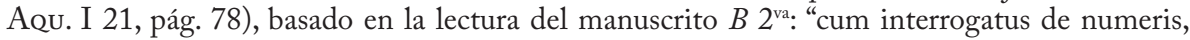
intervallis acutorum graviumque sonorum nescit respondere”; preferimos atenernos al texto- 
fuente que reproduce el Ars musyce, esto es, BERno, prol. 11, 14, pág. 64: "cum interrogatus de numero vel de intervallis acutorum graviumque sonorum nesciat respondere".

${ }^{34}$ Berno, prol. 11, 14, pág. 64: "solummodo" (="en exclusiva”).

${ }_{35}$ Con referencia a la prioridad de la ratio sobre el aurium sensus ya se había pronunciado inequívocamente Boєтн. mus. V 2, pág. 354, líns. 9-12: "Idcirco non est aurium sensui dandum omne iudicium, sed exhibenda est etiam ratio, quae errantem sensum regat ac temperet, qua labens sensus deficiensque veluti baculo innitatur"; $c f$., respectivamente, Villegas guillén, op. cit., págs. 192-193; y LuQue Moreno \& López Delgado, op. cit., pág. 348.

${ }^{36} \mathrm{La}$ referencia intertextual del tratado de Bern de Reichenau con respecto al De musica agustiniano (vid. nota subsiguiente), al igual que la bella imagen del ruiseñor, que armoniosamente canta sin tener conocimientos ni nociones musicales, sino por una especie de instinto natural, desaparece completamente del texto transmitido por el manuscrito $V 58^{\mathrm{v}}$ (al igual que también desaparece del texto testimoniado por el manuscrito $B 2^{\mathrm{va}}$ ) y, por ende, del texto editado por Di Martino, op. cit., pág. 25: "Is inquam talis magis lascivie que ultimo anni tempore ac sic suaviter et dignitose cantat est comparandum".

${ }^{37}$ Sobre la imagen del ruiseñor, que canta por instinto natural, sin conocimiento ni sujeción a ninguna norma o preceptiva artística, puede verse Avgvst. mus. I 4, 5, pág. 32: "M. Responde igitur, utrum tibi videatur bene modulari vocem luscinia verna parte anni: nam et numerosus est et suavissimus ille cantus, et, nisi fallor, tempori congruit... M. Dic mihi ergo, quaeso te; nonne tales tibi omnes videntur, qualis illa luscinia est, qui sensu quodam ducti bene canunt, hoc est numerose id faciunt ac suaviter, quamvis interrogati de ipsis numeris, vel de intervallis acutarum graviumque vocum, respondere non possint?"; $c f$. también Luque Moreno \& López Eisman, op. cit., págs. 97-98 y n. 21.

${ }^{38}$ Ps.-Thomas Aqu. I 22-24, pág. 78 = Іон. Сотт. mus. 2, 2-4, pág. 51; $c f$. también BAвв, op. cit., pág. 104.

${ }^{39}$ Se entiende, claro está, "las otras artes, que no pertenecen al conjunto de las siete artes liberales".

${ }^{40}$ Sobre la variedad de significados que recubre el término latino cantilena (a saber, 'canción', 'cancioncilla', 'canto', 'articulación tonal del sonido'), vid. LuQue \& Fuentes, op. cit., pág. 62, n. 9.

${ }^{41}$ Ps.-Thomas Aqu. I 26, pág. 78 = Boeth. mus. I 1, pág. 179, líns. 23-25; cf. Villegas Guillén, op. cit., págs. 23-24 y LuQue \& Fuentes, op. cit., pág. 61 y, también, pág. 60, n. 4 sobre el significado de modus; $c f$., asimismo, DRAE, s.v. "son" espec. no 4: "Tenor, modo o manera".

${ }_{22}$ Ps.-Thomas Aqu. I 27-29, pág. 78 = Boeth. mus. I 1, pág. 180, líns. 3-10; cf. Villegas Guillén, op. cit., pág. 24 y LuQue-Fuentes, op. cit., pág. 62.

${ }^{43}$ Plat. Tim. 35 ${ }^{\mathrm{b}}$, ed. Burnett.

${ }^{44}$ Ps.-Thomas Aqu. I 27, pág. 78: "musyca continencia"; tal es la lectura que avalan tanto el manuscrito $B 2^{\mathrm{vb}}$ como el manuscrito $V 58^{\mathrm{v}}$ y la edición de Di MARTino, op. cit., 25 ; sin embargo, en Boетн. mus. I 1, pág. 180, lín. 5: "musica convenientia". A propósito del significado del término latino "convenientia", cf. LuQue \& Fuentes, op. cit., pág. 62, n. 10.

${ }^{45}$ En Ps.-Thomas Aqu. I 29, pág. 78 se lee: "Est enim similitudo dissimilitudini odiosa”; sin embargo, en Boетн. mus. I 1, pág. 180, líns. 9-10: "Amica est enim similitudo, dissimilitudo odiosa atque contraria”; $c f$. Villegas Guillén, op. cit., pág. 24; $c f$. también LuQue \& Fuentes, op. cit., pág. 62.

${ }^{46}$ Ps.-Thomas Aqu. I 30-32, pág. 79 = Boeth. mus. I 1, pág. 186, líns. 8-17; cf. Villegas Guillén, op. cit., pág. 28; cf. también LuQue \& Fuentes, op. cit., pág. 73.

${ }^{47}$ Ps.-Thomas AQu. I 30, pág. 79: “... musicis proporcionibus quodammodo videatur esse compositus”; Вовтн. mus. I 1, pág. 186, líns. 10-13: “... eisdem quodammodo proportionibus videatur esse compositus, quibus armonicas modulationes posterior disputatio coniungi copularique monstrabit”. Para el significado del término latino proportio, $c f$. Anicius Manlius Severinus Boethius, Fundamentals of Music, Translated, with Introduction and Notes, by Calvin M. Bower, Edited by Claude V. Palisca, New Haven \& London, Yale University Press, 1989, pág. 7, n. 30: "Ratio' is a translation of the Latin proportio, which Boethius translated

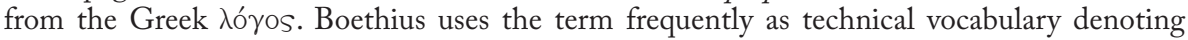
a mathematical ratio... In the present context, Boethius is speaking in analogical terms; but 
ultimately, the text is Pythagorean, and Pythagoreans would argue that the reality of the relation between body and soul is a ratio of numbers".

${ }^{48}$ Ps.-Thomas Aqu. I 34-43, pág. 79 = Іон. Сотт. mus. 2, 4-13, págs. 51-52; cf. también ВАв В, op. cit., págs. 104-105.

${ }^{49}$ Se entiende, naturalmente, "las restantes artes que pertenecen al conjunto de las siete artes liberales".

${ }^{50}$ Іон. Сотт. mus. 2, 4, pág. 51: “baberentur”; cf. también ВАв в, op. cit., pág. 104. En cambio, Ps.-Thomas Aqu. I 34, pág. 79: "babentur"; $c f . B 2^{\mathrm{vb}}$ y $V 58^{\mathrm{v}}$, sobre cuya lectura Di Martino, op. cit., pág. 25.

${ }^{51}$ Se entiende, evidentemente, "la música".

${ }^{52}$ Іон. Сотт. mus. 2, 7, pág. 52: “quae sui cognitorem”; cf. también BAв в, op. cit., pág. 104. En cambio, Ps.-Thomas AQu. I 37, pág. 79: "qui sui cognicione”; cf. B $3^{\text {ra }}$ y $V 59^{\mathrm{r}}$, sobre cuya lectura Di Martino, op. cit., pág. 26.

${ }^{53}$ No podemos dejar de resaltar la construcción paralelística rematada por efectos rimados, probablemente buscada con intención por John Cotton, que contribuye sin duda a facilitar el aprendizaje y la fijación memorística, tal como podemos observar en esta última frase: "compositi cantus efficit iudicem, / falsi emendatorem, / novi inventorem".

${ }^{54} \mathrm{La}$ superioridad del conocimiento teórico de la música, cualidad distintiva del auténtico musicus, frente a la ejecución vocal o instrumental, característica del cantor, es un tópico abundantemente documentado en numerosos tratados musicales desde la Antigüedad Tardía: así, por ejemplo, Boетн. mus. I 34, pág. 224, líns. 6-7: "Quanto igitur praeclarior est scientia musicae in cognitione rationis quam in opere efficiendi atque actu!"; $c f$. LuQue \& Fuentes, op. cit., pág. 148, n. 278, y Villegas Guillén, op. cit., pág. 62; cf., asimismo, sobre el particular Avgvst. mus. I 4, 5-6, 12 y Luque Moreno \& López Eisman, op. cit., págs. 97-111.

${ }^{55}$ Іон. Сотт. mus. 2, 8, pág. 52: "Nec praetereundum videtur"; $c f$. BAвв, op. cit., pág. 105. En cambio, Ps.-Thomas AQu. I 38, pág. 79: "Notandum autem”; así, el códice $B 3^{\text {ra }}$ y $V 59^{\text {r }}$, sobre cuya lectura, Di Martino, op. cit., pág. 26.

${ }^{56} \mathrm{El}$ adjetivo usualis (="de oficio", conseguido, claro está, por la práctica asidua, esto es, el 'usus', del canto), repetidamente aplicado por Ps.-Thomas AQu. I (cf. §§ 38, 39, 40 y 43) a cantor (="intérprete"), no figura en la actual edición del texto del De musica de Іон. Сотт. En su "Kommentar", pág. 86, §§ 38-43, Bernhard nos informa que el adjetivo usualis aplicado a cantor aparece en la Compil. Lips. (s. XIV) pág. 132 [Edición del texto en Anonymus, Tractatulus de musica, ed. Peter WAgner, «Aus dem St. Thomas-Archiv zu Leipzig», Zeitschrift für Musikwissenschaft, 12 (1929), págs. 129-137], y ya en el siglo XV el sintagma cantor usualis aparece con relativa frecuencia en los tratados y compilaciones musicales de esta época.

${ }^{57}$ Ps.-Thomas Aqu. I 41, pág. 79: “ipse”. Misma lectura en $B 3^{\text {ra }}$ y $V 59^{\text {r }}$, sobre cuya lectura Di Martino, op. cit., pág. 26; por contra, Іон. Сотт. mus. 2, 11, pág. 52: “ipsa”.

${ }^{58}$ Estas palabras de Guido de Arezzo no se hallan en el texto actualmente editado del Micrologus, pero sí se documentan en el opúsculo que lleva por título Regulae rhythmicae (1025/1026) [Edición del texto en Guido D’Arezzo's Regule ritmice, Prologus in antiphonarium and Epistola ad Michaelem, A Critical Text and Translation with an Introduction, Annotations, Indices and New Manuscript Inventories, by Dolores Pesce, Ottawa, The Institute of Mediaeval Music, Wissenschaftliche Abhandlungen, Band LXXIII / Musicological Studies, Vol. LXXIII, 1999, II 8 y 10, págs. 330 n. 4 y 332; cf. también Gvidonis Aretini “Regulae rhythmicae”, ed. Joseph Smits van Waesberghe \& Eduard Vetter, Divitiae musicae artis, A/IV, Buren, Frits Knuf, 1985, pág. 95, líns. 1 y 3 ].

${ }_{59}$ En Ps.-Thomas Aqu. I 43, pág. 79 no figura el siguiente verso, que sí leemos en IoH. Сотт. mus. 2, 13, pág. 53: "Illi dicunt, isti sciunt, quae componit musica"; cf. ВАвв, op. cit., pág. 105.

${ }^{60}$ Ps.-Thomas Aqu. I 44-49, págs. 79-80 = Іон. Сотт. mus. 1, 1-10, págs. 49-50; cf. también ВАВ В, op. cit., págs. 103-104.

${ }^{61}$ La edición de Bernhard, op. cit. 44, pág. 79: "litteras cum sillabis ascriptis"; el códice $B$ $3^{\text {ra: }}$ "litteras cum sillabis ascriptis"; el códice $V$ 59": "licteras cum sillabis ascriptis", sobre cuya lectura Di Martino, op. cit., pág. 26. Sin embargo, Іон. Сотт. mus. 1, 1, pág. 49: "litteras 
monochordi cum sillabis suprascriptis”; $c f$. BAвB, op. cit., pág. 103.

${ }^{62}$ Ps.-Thomas Aqu. I 4, pág. 79: "figure subiecte”, que no figura en el texto de John Cotton, porque nuestro anónimo tratado ha prescindido del término monochordi y ahora se ve obligado a rellenar con este sintagma para intentar aclarar el sentido de la frase. Sorprendentemente, no encontramos ninguna referencia o mención al hecho en el, por otra parte, preciso y ajustado "Kommentar" de Bernhard.

${ }^{63}$ En el tratado de Iон. Сотт. mus. 1, 2, pág. 49, se puede leer: "Sed de litteris nunc dicere differimus, ut post hoc commodius atque uberius de eis tractemus. Nunc autem de syllabis aliquid dicamus"; en concreto, sobre el particular, $c f$. Іон. Сотт. mus. 5, 1-21, págs. 59-62: "De numero litterarum et de discretione earum"; $c f$. ВАвв, op. cit., pág. 103.

${ }^{64}$ En el tratado de Іон. Сотт. mus. 1, 3-4, pág. 49, se puede leer: "Itali autem alias habent, quas qui nosse desiderant, stipulentur ab ipsis. Eas vero, quibus nos utimur syllabas". Todo este fragmento falta en Ps.-Thomas AQu. I. Sobre el peculiar sistema de solmisación utilizado por los italianos, $c f$. ВАBB, op. cit., pág. 104, n. 1 .

${ }^{65}$ Himno, en estrofas sáficas, dedicado a San Juan Bautista, y de autoría atribuida a Paulus Warnefridus "Diaconus" (720/40-789/801); cf. M. A. Marcos Casquero \& J. Oroz Reta, Lírica latina medieval, vol. II: Poesía religiosa, Madrid, Biblioteca de Autores Cristianos, no 580, 1997, págs. 282-285, espec. pág. 282, nota: "Ut queant laxis resonare fibris / Mira gestorum famuli tuorum, / Solve polluti labii reatum, / Sancte Iohannes”, o sea: 'Para que puedan hacer sonar en las livianas cuerdas / tus siervos las maravillas de tus actos / desata el pecado de nuestros labios impuros, / joh, San Juan!'. En negrita aparecen resaltadas las sílabas de solmisación. La nota /sil no formaba parte, en principio, de este sistema hexacordal, pero fue agregada posteriormente, tomando pie en el adonio que cierra la estrofa sáfica del referido himno. También después, /ut/ fue cambiada por /do/, tal como seguimos haciendo actualmente.

${ }^{66}$ Iон. Сотт. mus. 1, 8, pág. 50: "multimodasque earum varietates plene ac lucide pernoscat"; cf. Вавв, op. cit., pág. 104. Sin embargo, Ps.-Thomas Aqu. I 47, pág. 80: "multasque earum varietates plene ac lucide pernoscat".

${ }^{67} C f$., sobre el particular, ВАвв, op. cit., pág. 104, n. 3: "I.e. according to the so-called "Guidonian" hand".

${ }^{68}$ Sobre “modulari”, cf. Bower, op. cit., pág. 7, n. 31; también, ВАВв, op. cit., pág. 105 y n. 2.

${ }^{69}$ Іон. Сотт. mus. 1, 9, pág. 50: "ut eas postmodum quotiens voluerit pro monochordo potiatur”; $c f$. ВАВ В, op. cit., pág. 104. Estas palabras faltan en nuestro anónimo tratado musical.

${ }^{70}$ Іон. Сотт. mus. 1, 10, pág. 50: "Haec ubi aliquamdiu iuxta quod diximus frequentaverit"; cf. ВАвв, op. cit., pág. 104. El sintagma "iuxta quod diximus" falta en nuestro anónimo tratado musical.

${ }^{71}$ Ps.-Thomas Aqu. I 50, pág. 80 = Boeth. mus. I 34, pág. 224, líns. 25-28; cf. Villegas Guillén, op. cit., pág. 62, LuQue \& Fuentes, op. cit., pág. 149, n. 283, y Gloss. Boeth. mus. I 34, 43, 1-9, pág. 354.

${ }^{72}$ Cf. Luque \& Fuentes, op. cit., pág. 149, n. 282: "el que modela las composiciones musicales"; Bower, op. cit., pág. 51: "who compose songs"; Marzi [Edición del texto en AN. M. T. Severini Boethit, De institutione musica, a cura di Giovanni Marzi, Roma, Istituto Italiano per la Storia della Musica, Roma, 1990] pág. 324: “l'altra dei compositori”; MeYer [Edición del texto en BoÈce, Traité de la musique, Introduction, Traduction et Notes par Christian Meyer, Turnhout, Brepols Publishers n.v., 2004], pág. 95: "on compose de chants"; Paul [Edición del texto en Anicius Manlius Severinus Boethius, Fünf Bücher über Musik, Aus der lateinischen in die deutsche Sprache übertragen und mit besonderer Berücksichtigung der griechischen Harmonik, sachlich erklärt von Oscar Paul, Hildesheim-Zürich-New York, Georg Olms Verlag, 1985 (=Leipzig, Verlag von F. E. C. Leuckart (Constantin Sander), 1872] pág. 37: "die andere componirt Lieder". No nos parece, en cambio, muy lograda la versión de Villegas Guillén, op. cit., pág. 62: “el que modela los versos”; traduciendo así, parece que nos fijamos más en la letra que en la música de la composición poética.

${ }^{73} C f$. Villegas Guillén, op. cit., pág. 62: "uno es el que trata de los instrumentos". Pero Boeтн. mus. I 34, pág. 224, líns. 26-27, dice: "Unus genus est, quod instrumentis agitur”; no dice: "quod de instrumentis agitur". Traduciendo así, se pierde la idea de la ejecución o interpretación 
del instrumentista, que es a lo que se refiere Boecio; $c f$. Luque \& Fuentes, op. cit., págs. 148-149, n. 278: "La diferencia entre ciencia y artesanía se pone más que de manifiesto en el caso de la música, donde el conocimiento de la teoría queda muy por encima tanto de la puesta en práctica [opus efficiendi] de dicha teoría, es decir, de la composición musical, como de la actualización [actus] o ejecución de una pieza”.

${ }^{74}$ Ps.-Thomas Aqu. I 51, pág. 80 = Boeth. mus. I 34, pág. 224, líns. 18-20; cf. Villegas Guillén, op. cit., pág. 62 y LuQue \& Fuentes, op. cit., pág. 149 y n. 281.

${ }^{75}$ Ps.-Thomas AQu. I 52-53, pág. 80 = Isid. etym. III 17, 1, vol. I, pág. 140. Mismo texto reproducido también por Hraban. (circa 810), De origine rerum, pág. 366 [Edición del texto en Adrien de la FAge, Essais de diphthérographie musicale ou Notices, descriptions, analyses, extraits et reproductions de manuscrits relatifs à la pratique, à la théorie et à l'histoire de la musique, Paris, $\mathrm{O}$. Legouix, 1864 (=reprint ed. Elibron, Adamant Media Corporation, 2006)]: "Itaque sine musica nulla disciplina potest esse perfecta; nihil enim sine illa: nam et ipse mundus quadam harmonia sonorum fertur esse positus et coelum ipsum sub harmoniae modulationem revolvitur".

${ }^{76}$ Cf. Guillaumin, op. cit., pág. 58, n. 128: "D’autre part, la première partie de la phrase rappelle un passage de Quintilien dont elle est sans doute inspirée: sine omnium talium scientia, non potest esse perfecta eloquentia (inst. or. I 10,11, où omnium talium renvoie à la musique théorique et à la musique pratique)".

${ }^{77}$ Cf. Valastro Canale, op. cit., vol. I, pág. 298, n. 29: "La dottrina pitagorica della «musica delle sfere», ripresa da Platone e dagli Stoici, giunse al medioevo cristiano attraverso l'influsso esercitato dall'esegesi biblica giudaico-ellenizante sul pensiero dei Padri”. Por otra parte, Guillaumin, op. cit., pág. 58, n. 129: "Ceci est copié sur Cassiodore, pág. 143, lín. 17 Mynors"; cf. CAssiod. inst. II 5, 2, pág. 143: "caelum quoque et terra, vel omnia quae in eis dispensatione superna peraguntur, non sunt sine musica disciplina; nam Pythagoras hunc mundum per musicam conditum et gubernari posse testatur".

${ }^{78}$ En Ps.-Thomas Aqu. I 54, pág. 80, nos encontramos con un locus desperatus: "†physicam†”; el manuscrito $B 3^{\text {vaa }}$ "philosophicam"; el manuscrito $V 59^{\text {r: }}$ "phy(si)cam", sobre cuya lectura, Di Martino, op. cit., pág. 26: "phy(si)cam".

${ }^{79}$ Cf. Isid. etym. III 16, 2, vol. I, pág. 140: “eratque tam turpe”; Ps.-Thomas Aqu. I 54, pág. 80: "turpius erat". Mismo texto, reproducido también por Hraban., De origine rerum, pág. 366: "eratque tam turpe musicam nescire quam litteras".

${ }^{80}$ Ps.-Thomas Aqu. I 54, pág. 80 = Isid. etym. III 16, 2, vol. I, pág. 140; cf. SAn Isidoro de Sevilla, Etimologías. Edición bilingüe, Texto latino, Versión española y Notas por José Oroz Reta y Manuel-A. Marcos Casquero, Introducción general por Manuel C. Díaz y Díaz, Madrid, Biblioteca de Autores Cristianos, n 647, 2009 (=2004¹), pág. 435, n. 33: "La extensión y atención que dedica Isidoro a la música es muy similar a las que dedica a la aritmética, aunque principalmente se limita a la descripción de términos musicales de viento y de cuerda. Por lo que nos dice, no parece que poseyera un conocimiento serio de la música en sentido técnico. Lo que nos dice se reduce a unas, no siempre acertadas, paráfrasis de lo que habían escrito Casiodoro, Agustín y otros. A la vista de lo que nos conservan las Etimologías, podemos descubrir la ignorancia completa de la época en lo que se refiere a la música”.

${ }^{81}$ Ps.-Thomas Aqu. I 55-61, pág. 80 = Іон. Сотт. mus. 17, 1-5, pág. 114; cf. Вавв, op. cit., pág. 136.

${ }^{82}$ Tópico muy extendido en todas las épocas de la literatura universal; $c f$, por ejemplo, Cervantes, Quijote, Primera parte, cap. 28: "porque la experiencia me mostraba que la música compone los ánimos descompuestos y alivia los trabajos que nacen del espíritu”.

${ }^{83}$ I Sam. 16, 16-23, espec. 23: "igitur quandocumque spiritus Dei arripiebat Saul, tollebat David citharam et percutiebat manu sua et refocilabatur Saul et levius habebat, recedebat enim ab eo spiritus malus". La anécdota aparece recogida en Іон. Сотт. mus. 17, 2, pág. 114: "Unde et de Rege Saul in libro Regum legitur, quod a daemonio correptus David in cithara canente mitigabatur, cessante vero nihilominus vexabatur”. Figura también, aunque redactada en otros términos y colocada en otra posición (a saber, después de la anécdota relativa al médico Asclepíades), en Gvido micr. 14, 16-17, pág. 161: "Item et David Saul daemonium cithara mitigabat et daemoniacam feritatem huius artis potenti vi ac suavitate frangebat". Se puede 
leer también en IsıD. etym. III 17, 3, vol. I, pág. 140 y IV 13, 3, vol. I, pág. 179: "sicut de David legitur, qui ab spiritu inmundo Saulem arte modulationis eripuit". Y también la hallamos, si bien formulada en otros términos, en CAssiod. inst. II 5 9, pág. 148: "Quid de David dicimus, qui ab spiritibus immundis Saulem disciplina saluberrimae modulationis eripuit, novoque modo per auditum sanitatem contulit regi, quam medici non poterant herbarum potestatibus operari”.

${ }^{84}$ Iон. Сотт. mus. 17, 3, pág. 114: “ab insania”. Esta expresión no figura en el texto de Ps. Santo Tomás de Aquino.

${ }^{85}$ Sobre la identidad del médico Asclepíades de Prusa o de Quíos (s. I a.C.), cf. Ramelli, op. cit., pág. 616, n. 259: "Molto probabilmente, Asclepiade di Prusa (130-40 a.C.), medico e filosofo atomista che fu amico di Cicerone. Ma c’è anche un Asclepiade di Eretria (IV-III sec. a. C.), membro della scuola platonica, oppure un altro Asclepiade egiziano, profondo conoscitore della teologia egizia, citato da Svetonio (Augusto, 94)"; también, Martiani Capellae (ante 439) De nuptiis Philologiae et Mercurii Liber LX, Introduzione, Traduzione e Commento di Lucio Cristante, Medioevo e Umanesimo, no 64, Padova, Editrice Antenore, 1987, pág. 272 del "Commento"; en fin, Marziano Capela, Le nozze di Filologia e Mercurio, Introduzione, Traduzione, Commentario e Appendici di Ilaria Ramelli, Testo latino a fronte, Milano, I Edizioni Bompiani, Il Pensiero Occidentale, 2004 (=2001), pág. 995, n. 43: "Asclepiade in effetti, oltre ad essere il nome di un poeta dell'Antologia Palatina, è anche il nome di un medico e di un filosofo, attestato di Cicerone". La anécdota relativa a los métodos terapéuticos del médico Asclepíades se puede leer en Іон. Сотт. mus. 17, 3, pág. 114: "Item phreneticus quidam Asclepiade medico canente ab insania fertur fuisse liberatus”. Aparece también en Gvido micr. 14, 12, pág. 160: "Ita quondam legitur quidam phreneticus canente Asclepiade medico ab insania revocatur". Pero figura también en Isıd. etym. IV 13, 3, vol. I, pág. 179: "Asclepiades quoque medicus phreneticum quendam per symphoniam pristinae sanitati restituit". Seguramente aquí el obispo Hispalense refleja la doctrina y la formulación de CAssiod. inst. II 5, 9, pág. 149: "Asclepiades quoque, medicus maiorum attestatione doctissimus, freneticum quendam per symphoniam pristinae sanitati, reddidisse memoratur". Este texto, en fin, recuerda a CENs. nat. (238) [Edición del texto en Censorini De die natali liber ad Q. Caerellium. Accedit Anonymi cuiusdam epitoma disciplinarum (Fragmentum Censorini), edidit Nicolaus Sallmann, Leipzig, BSB B. G. Teubner, Verlagsgesellschaft, $1983^{1}$ ] 12, 4, pág. 22: "et Asclepiades medicus phreneticorum mentes morbo turbatas saepe per symphoniam suae naturae reddidit".

${ }^{86}$ Pero la fuente no es aquí Boecio, sino Іон. Сотт. mus. 17, 3, pág. 114; cf. también BAвв, op. cit., pág. 136.

${ }^{87}$ Іон. Сотт. mus. 17, 4, pág. 114: "Sed et de Pytagora memoratur, quod luxuriosum quendam iuvenem ab immoderata libidine musica modulatione revocaverit". La anécdota aparece más desarrollada en BoEth. mus. I 1, pág. 185, líns. 3-9 y 9-17; en cambio, de forma mucho más breve y sin mencionar a Pitágoras, en Gvido micr. 14, 13-15, pág. 160.

${ }^{88}$ Cf. Вавв, op. cit., pág. 136, n. 3. En Ps. Sto. Tomás de Aquino falta el siguiente texto de Іон. Сотт. mus. 17, 5, pág. 114: "Habet autem musica secundum diversos modos diversas potentias".

${ }^{89}$ Gvido micr. 14, 13-15, pág. 160: "Et item alius quidam sonitu citharae in tantam libidinem incitatus, ut cubiculum puellae quaereret effringere dementatus, moxque citharoedo mutante modum voluptatis poenitentia ductum recessisse confusum”; $c f$. ВАВ B, op. cit., pág. 70.

${ }^{90}$ Cf. Boeth. mus. I 2, pág. 187, lín. 17: "Tres esse musicas"; Luque \& Fuentes, op. cit., pág. 76; Villegas Guillén, op. cit., pág. 29; Gloss. Boeth. mus. I 2, 2, pág. 82 y I 2, 9a-9c págs. 83-84.

${ }^{91}$ Cf. Boeth. mus. I 2, pág. 187, líns. 20-23: "Sunt autem tria (sc. musicae genera). Et prima quidem mundana est, secunda vero humana, tertia, quae in quibusdam constituta est instrumentis"; Luque \& Fuentes, op. cit., pág. 76 y Villegas Guillén, op. cit., pág. 29.

92 Cf. Boeth. mus. I 2, pág. 187, líns. 23-26: "Et primum ea, quae est mundana, in his maxime perspicienda est, quae in ipso caelo vel compage elementorum vel temporum varietate visuntur”; LuQue \& Fuentes, op. cit., pág. 77, espec. n. 59 y Villegas Guillén, op. cit., pág. 29, espec. n. 36; GLoss. Boeth. mus. I 2, 17-31, págs. 86-88.

${ }^{3}$ Cf. Luque \& Fuentes, op. cit., pág. 77, espec. n. 60: "Así, pues, la música «mundana» (es decir, la que se expresa en el orden del mundo, en el cosmos), la música «humana» (la que se 
refleja en la estructura psicosomática del ser humano) y la música «instrumental» (la real, la que se realiza en nuestra vida a base de los instrumentos sonoros) de Boecio no son otra cosa que las

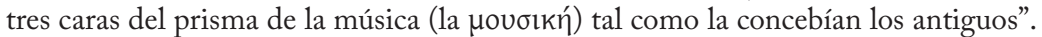

${ }^{94}$ Cf. Boeth. mus. I 21, pág. 212, lín. 25: "Sunt autem tria (sc. genera melorum): diatonum, chroma, enarmonium”; $c f$. LuQue \& Fuentes, op. cit., pág. 130, espec. n. 241, a propósito de "melorum": "es decir, los géneros o tipos de articulación melódica del sonido musical, tal como se reconocen en la célula básica de la misma, el tetracordo o intervalo de cuarta”. Tal vez este texto boeciano pueda estar en la base y dar razón, siquiera por aproximación, de la lectura "melodye", testimoniada, con ligeras variantes, por la transmisión textual.

${ }_{95} B 3^{\text {vb: }}$ "meledye"; V 59r: "melodie"; Di Martino, op. cit., pág. 27: "melodie".

${ }^{96} B 3^{\text {vb: }}$ "dytriamyca"; V59: "dytriamica”; Di Martino, op. cit., pág. 27: "dytriamica”.

${ }_{77}$ Cf. Ps.-Thomas Aqu. I 62, pág. 81: "enormonico"; igual lectura en $B 3^{\text {vb }}, V 59^{\mathrm{r}}$ y Di Martino, op. cit., pág. 27.

${ }_{98}$ Sobre las características generales de esta división tripartita, $c f$. Bовтн. mus. I 21, pág. 212, lín. 25 - pág. 213, lín. 2: "Et diatonum quidem aliquanto durius et naturalius, chroma vero iam quasi ab illa naturali intentione discedens et in mollius decidens, enarmonium vero optime atque apte coniunctum"; vid. también LuQue \& Fuentes, op. cit., págs. 130-131 y Villegas Guillén, op. cit., pág. 52; y, en fin, Gloss. Boeth. mus. I 21, 1-14, págs. 285-286.

${ }^{99}$ Cf. BERn hard, op. cit., "Kommentar", pág. 86, §62. Allíse hace referencia al Somnium Scipionis, una sección transmitida independientemente del tratado filosófico de Cicerón que lleva por título De republica, así como a los Commentarii in somnium Scipionis de Macrobio. Para el texto de los fragmentos del filósofo y médico pitagórico Filolao, $c f$. Hermann Diels \& Walther Kranz, Die Fragmente der Vorsokratiker, Greichisch und Deutsch, Berlin, Weidmansche Verlagsbuchhandlung, 1960, vol. I, págs. 398-406 (=A. Leben, Apophthegma, Schriften und Lehre) y 406-419 (=B. Fragmente), espec. pág. 404, fr. 23 (Mасrob. somn. Scip. I 14, 19: "Pythagoras et Philolaus harmoniam [sc. animam esse dixerunt]”) y pág. 405, fr. 26 (BоEтн. mus. III 5, pág. 276, lín. 14: "Quemadmodum Philolaus tonum dividat" y pág. 278, líns. 11-17: "De minoribus semitonio intervallis"); $c f$. también, M. Timpanaro Cardini, Pitagorici, Testimonianze e Frammenti, Firenze, La Nuova Italia, 1962, vol. II, págs. 262-385; C. A. Huffman, Philolaos of Croton: Pytagorean and Presocratic, Cambridge, University Press, 1993. Sobre las doctrinas filosóficas y musicales de Filolao, W. K. C. Guthrie, Historia de la Filosofía Griega, trad. esp. Alberto Medina González, Madrid, RBA Coleccionables, Grandes Obras de la Cultura, 2005, vol. I, págs. 312-319; también, C. A. Huffman, ap. Standford Encyclopedia of Philosophy, s. v. "Philolaus". Breve nota biográfica sobre Filolao, en LuQue \& Fuentes, op. cit., pág. 237, n. 34.

${ }^{100}$ Entre ellos, como mínimo, puesto que se incorporan literalmente pasajes de obras de estos autores al texto de Ps.-Thomas Aqu. I, Berno Avgiensis (circa 978-1048) y su Prologus in tonarium (post 1021), Hermannvs Contractrs (1013-1054) y el poema didáctico a él atribuido Ter terni sunt modi (ante 1054), Aribo y su De musica (inter 1068-1078), Willehelmvs Hirsavgensis ( $†$ 1091) y su Musica (ante 1069) y Iohannes dictvs Cotto sive Affligemensis y su De musica (circa 1100).

${ }^{101}$ Ps.-Thomas Aqu. I 63, pág. 81 = Іон. Сотт. mus. 8, 5, pág. 68; cf. Вавв, op. cit., pág. 111. Boecio, en su tratado musical, habla de voces unisonae (=gr. íótovos); $c f$. , sobre el particular, Boeth. mus. V 5, pág. 356, líns. 7-8: "Unisonae (sc. voces) sunt, quarum sonus unus est vel in gravi vel in acuto”; Villegas Guillén, op. cit., pág. 194; LuQue \& Fuentes, op. cit., pág. 351 y n. 27. Sobre el intervalo denominado unisonus, cf. Ps.-THomas AQu. II 109-111, pág. 126; también DíAz Díaz, op. cit., pág. 136 y n. 172. Ejemplo de intervalo unisonus puede ser [·ut•-ut*]; cf. Ioн. Сотт. mus. 8, 18, pág. 70 у ВАвв, op. cit., pág. 112.

102 Ps.-Thomas Aqu. I 64, pág. 81 = Іон. Сотт. mus. 8, 5-6, pág. 68: "Vel certe a Graecis sumptum est hoc nomen (sc. tonus)”; cf. ВАВB, op. cit., pág. 111; ahora bien, nuestro anónimo tratado musical ha prescindido de la segunda explicación de la palabra tonus, como préstamo del griego. Sobre la consonancia denominada tonus, cf. Ps.-Thомas AQU. II 111-113, pág. 126; también Díaz Díaz, op. cit., pág. 136. Ejemplo de la consonancia tonus puede ser [·ut--·re ]; $c f$. Іон. Сотт. mus. 8, 18, pág. 70 у ВАвв, op. cit., pág. 112 .

${ }^{103}$ Ps.-Thomas Aqu. I 65, pág. 81 = Іон. Сотт. mus. 8, 8, págs. 68-69; cf. ВАвв, op. cit., 
pág. 111. Sobre la consonancia denominada semitonium, cf. Ps.-Thomas AQU. II 114-117, pág. 128; también Díaz Díaz, op. cit., pág. 137. Ejemplo de la consonancia semitonium puede ser $[\cdot m i \cdot-\cdot f a \cdot] ; c f$. Іон. Сотт. mus. 8, 18, pág. 70 у Вавв, op. cit., pág. 112.

${ }^{104}$ Sin embargo, como dice ВАв B, op. cit., pág. 111, n. 1: "Plato does not use the word leimma $(\lambda \in \hat{\imath} \mu \mu a$, "remainder, John's limma) for these"; $c f$. Plat. Tim. 36b. Sobre la denominación y el concepto del "semitonium" (="leimma” vel "limma”), cf. Bовтн. mus. II 28, pág. 260, líns. 21-28: "huiusque spatii, quod nunc quidem semitonium nuncupamus, apud antiquiores autem limma vel diesis vocabatur"; vid. también CRistante, op. cit., págs. 278-279, s.v. "hemitonium”; Bower,

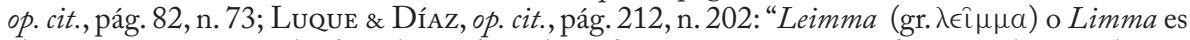
el término técnico empleado, sobre todo en la tradición pitagórica, para designar el intervalo que queda de uno de cuarta, cuando se le restan dos tonos; el propio término denota esta concepción del semitono («lo que resta»...) y responde a la conciencia técnica de que el intervalo restante no era propiamente un «semitono», como en un plano coloquial o menos técnico se lo llamaba".

105 Verg. Aen. XII 99: "semiviri Phrygis"; $c f$., a propósito del término "semiviri”, Cervantes, Quijote, Primera parte, cap. 43: "a este agujero pusiéronse las dos semidoncellas [sc. la hija del ventero y Maritornes, la criada]”.

106 Antes del tratamiento del semidytonus, en Іон. Сотт. mus. 8, 10, pág. 69, leemos la siguiente definición etimológica del dytonus, que falta en nuestro anónimo tratado musical: "Ditonus graece appellatur, quod duos in se tonos habet"; $c f$. ВАвв, op. cit., pág. 111. Sobre la consonancia denominada dytonus, cf. Ps.-Thomas AQU. II 118-120, págs. 128-130; también Díaz Díaz, op. cit., pág. 137. Ejemplo de la consonancia dytonus puede ser [·ut--mi $\cdot$; $c f$. IoH. Сотт. mus. 8, 18, pág. 70 у ВАвв, op. cit., pág. 112.

${ }^{107}$ Ps.-Thомas Aqu. I 66, pág. 81 = Іон. Сотт. mus. 8, 10-11, pág. 69; cf. Вавв, op. cit., pág. 111. Sobre la consonancia denominada semidytonus, cf. Ps.-THomas AQU. II 121-123, pág. 130; también DíAz DíAz, op. cit., pág. 137. Ejemplo de consonancia semidytonus puede ser [-re--·fa$\cdot$; cf. Іон. Сотт. mus. 8, 18, pág. 70 у ВАвв, op. cit., pág. 112.

108 Ponit notabilia. Así, en $B 3^{\mathrm{vb}}$, en $V 5^{\mathrm{r}}$ y en Di Martino, op. cit., pág. 27. No hay más explicaciones al respecto en el "Kommentar" de Bernhard.

${ }^{109}$ Ps.-Thоmas Aqu. I 67, pág. 81 = Іон. Сотт. mus. 8, 1, pág. 67; cf. Вавв, op. cit., pág. 110.

110 Sobre modus, cf. LuQue \& Fuentes, op. cit., pág. 60: "El término modus... se usa también como tecnicismo, con el sentido de «medida» o «unidad de medida», $y$, entonces, tratándose del lenguaje o de la música, es decir, de un sistema de comunicación mediante el sonido, designa cualquier unidad en que se articula dicho sonido (que por esencia ha de ser «discontinuo») en cualquiera de sus facetas, tonal, intensiva o durativa". En este caso concreto, hemos escogido la versión "intervalo" para designar estas unidades de medida; $c f$. también BAвB, op. cit., pág. 110.

${ }^{111}$ Tal la enumeración (a saber, primero, semitonium; luego, tonus) tanto en Іон. Сотт. como en Ps.-Thomas Aqu. I; y tanto en un caso como en otro, alterando, de manera inconsecuente, el orden en la definición de ambos intervalos musicales (a saber, primero tonus; luego, semitonium).

${ }^{112}$ Tal la ordenación en Ps.-Thomas AQu. I (a saber, primero semidytonus; luego, dytonus); si bien, en la exposición doctrinal se prescinde directamente del intervalo dytonus. Por contra, en la enumeración y en la exposición doctrinal de Іон. Сотт. mus. 8, 1, pág. 67, tenemos la siguiente ordenación: primero, ditonus; luego, semiditonus.

${ }^{113}$ Reconstruido, naturalmente, a partir del texto de Іон. Сотт. mus. 8, 1, pág. 67. A la consonancia dyatesseron, sorprendentemente tampoco se hace referencia, un poco más adelante, en nuestro anónimo tratado musical, aunque sí se describe, y en los mismos términos en que lo hace John Cotton, la consonancia dyapente.

${ }^{114}$ Se entiende, naturalmente, modi = "intervalos".

115 Bernhard, op. cit., “Kommentar”, pág. 86, § 68: "Die Diskussion um den Tritonus wird in der süddeutschen Musiktheorie um 1100 sichtbar". Ambos intervalos (esto es, el trítono y el diapasón) también figuran enumerados en Ps.-Thomas AQu. II 105, pág. 122 (según los manuscritos $B V$ ): "Hee autem species in XI dividuntur, prima quarum est unisonus, secunda tonus, tercia semitonus, quarta dytonus, quinta semidytonus, $\mathrm{VI}^{\text {ta }}$ dyatesseron, $\mathrm{VII}^{\mathrm{a}}$ tritonus, VIII ${ }^{a}$ dyapente, <IX tonus cum dyapente>, X semitonium cum dyapente, XI dyapason"; $c f$. también Díaz Díaz, op. cit., pág. 135 . Ejemplo de intervalo tritonus puede ser $[\cdot F \cdot$ fa ut grave 
per propriam notam - • • fa mi acutum per $\sqsubset$ quadratum ]; cf. Ps.-THomas AQU. II 136, pág. 134; también Díaz Díaz, op. cit., pág. 139 y n. 197.

${ }^{116}$ Ps.-Thomas Aqu. I 69, pág. 81: "Ex hiis dicuntur VI consonantes"; $c f$. ., sin embargo, Ioн. Сотт. mus. 8, 2, pág. 67: "Ex hiis sex consonantiae dicuntur"y, también, Willeh. Hirs. mus. 22, 1, pág. 55: "Sex sunt consonantiae". La lectura “consonantes" está testimoniada, claramente, por $B$ $3^{\text {vb }}, V 59^{\mathrm{r}}$ y Di Martino, op. cit., pág. 27.

${ }_{117}$ Ps.-Thomas Aqu. I 69-70, pág. 81 = Willeh. Hirs. mus. 22, 1-2, pág. 55.

${ }^{118}$ Cf., nuevamente, Ps.-Thomas Aqu. I 18-19, pág. 78, a propósito de las "VI consonancie”.

119 Hermann. (1013-1054), mod. (1054) [Edición del texto en Martin Gerbert, SEMS, vol. II, pág. 150]: “Ter terni sunt modi, quibus omnis cantilena contexitur: scilicet unisonus, semitonium, tonus, semiditonus, ditonus, diatessaron, diapente, semitonium cum diapente, tonus cum diapente, ad haec sonus, diapason...". E1 verso inicial aparece también reproducido en Іон. Сотт. mus. 8, 19, pág. 70: "Ter terni sunt modi quibus omnis cantilena contexitur et cetera". Babb recoge el parecer de Oesch, que atribuye la autoría de los versos no a Hermannus Contractus, sino a otro autor indeterminado; $c f$. ВАвв, op. cit., pág. 112, espec. n. 6: "The didactic song for teaching intervals... is attributed to Hermannus; but H. Oesch has suggested, in Berno und Hermann, pág. 139, that this song may have been modeled by someone else on Hermann's Ter tria iunctorum”. En concreto, Bernhard defiende la autoría de Wilhelm de Hirsau; cf. Bernhard, op. cit., "Kommentar", pág. 86, § 68: "Nach der Aufzählung der neun, im Gregorianischen Choral verwendbaren Intervalle nach der wahrscheinlich von Wilhelm von Hirsau stammenden Merkmelodie Ter terni sunt modi,..."

${ }^{120}$ No compartimos la versión de Babb para el término de John Cotton modi (="ways"); $c f$. BАB , op. cit., pág. 112, n. 6: "Thrice three are the ways in wich all song is composed".

121 Ps.-Thomas Aqu. I 72-74, pág. 82 = Іон. Сотт. mus. 8, 13-14, pág. 69; cf. Вавв, op. cit., págs. 111-112. Sin embargo, en Іон. Сотт. mus. 8, 12-13, pág. 69, se expone previamente la consonancia diatessaron, que en el texto de nuestro anónimo tratado musical, de forma sorprendente, no figura: "Diatessaron interpretatur de quattuor; ab una enim voce incipiens ad quartam transilit, constans ditono et semitonio, ut a $\Gamma \cdot$ ad.$C$. Est autem diatessaron trimodum verbi gratia ut fa, re sol, mi la"; cf. también ВАBB, op. cit., pág. 111. Sobre la consonancia denominada dyatesseron, $c f$. Ps.-Thomas AQu. II 124-130, págs. 130-132; también DíAz DíAz, op. cit., págs. 137-138. Ejemplo de consonancia dyatesseron puede ser [· ut•-·fa $]$; $c f$. Іон. Сотт. mus. 8, 18, pág. 70 у ВАВв, op. cit., pág. 112.

${ }_{122}$ Ps.-Thomas Aqu. I 73, pág. 82: “quemadmodum”. Es ésta también la lectura que documentan el manuscrito $B 4^{\text {ra }}$, el manuscrito $V 59^{\mathrm{r}}$ y la edición de Di Martino, op. cit., pág. 28. Se trata de una lectura errónea, como se demuestra por comparación con Ioн. Сотт. mus. 8, 14, pág. 69: “quadrimodum”, analógico con Іон. Сотт. mus. 8, 13, pág. 69: “trimodum”. Sobre la consonancia denominada dyapente, cf. Ps.-Thomas Aqu. II 137-148, págs. 134-136; también DíAz DíAz, op. cit., págs. 139-141. Ejemplo de consonancia dyapente puede ser [·ut·-sol·]; $f$. Іон. Сотт. mus. 8, 18, pág. 70 у ВАвв, op. cit., pág. 112.

${ }^{123}$ Cf. Іон. Сотт. mus. 8, 14, pág. 69: "tertium inter ·E· et · $\cdot$ · quadratum”; vid. BAвв, op. cit., pág. 112: "the third between E and b-natural".

${ }^{124}$ Cf. Іон. Сотт. mus. 8, 14, pág. 69: "quartum in inferioribus syllabis inter · $\mathrm{F} \cdot$ et ' $\mathrm{c}$; vid. ВАвв, op. cit., pág. 112, n. 3: "the 'inferior'-i.e. less preferable- syllables are fa sol re mi fa (i.e. mutating from the natural to the hard haxachord), which give b-natural and put the semitone on top, whereas ut re mi fa sol give b-flat and thus equal the species C-G".

${ }_{125}$ Ps.-Thomas Aqu. I 74, pág. 82 = Іон. Сотт. mus. 8, 15, pág. 69; cf. también Вавв, op. cit., pág. 112, espec. n. 4: " Intervals» (intervalla), both to emphasize their greater size and to distinguish them from the preceding «six consonances», which are those of Guido's Micrologus, chap. 4 (CSM 4: 105)". El texto al que se refiere Babb es Gvido micr. 4, 12, pág. 105: "Habes itaque sex vocum consonantias, id est tonum, semitonium, ditonum, semiditonum, diatessaron et diapente"; $c f$. ВАвв, op. cit., pág. 61.

${ }_{126}$ Sobre el intervalo denominado semitonium cum dyapente, $c f$. Ps.-Thomas AQu. II 153155, pág. 138; también Díaz Díaz, op. cit., pág. 141. Ejemplo de intervalo semitonium cum dyapente puede ser, según Іон. Сотт. mus. 8, 18, pág. 70 у ВАв в, op. cit., pág. 112 [·mi - - ut· $]$; sin 
embargo, en Ps.-Thomas Aqu. II 155, pág. 138 se enumeran los intervalos [· $m i \cdot-\cdot f a \cdot]$ (en $B V, L$, $C$ y $D$ ), ['re'-·fa'] (sólo en $L$ ) y [· $m i \cdot-\cdot$ sol $\cdot]$ (sólo en $B V, C$ y $D$ ).

${ }^{127}$ Sobre el intervalo denominado tonus cum dyapente, cf. Ps.-Thомas AQu. II 149-152, págs. 136-138; también DíAz DíAz, op. cit., pág. 141. Ejemplo de intervalo semitonium cum dyapente puede ser, según Іон. Сотт. mus. 8, 18, pág. 70 у ВАв в, op. cit., pág. 112 [·ut•-la·].

${ }^{128}$ Ps.-Thomas Aqu. I 75, pág. 82: "Iulianus apostata et imperator"; tal la lectura de $B 4^{\text {ra }}$, de $V 59^{\mathrm{r}}$ y de Di Martino, op. cit., pág. 28.

${ }^{129}$ Cf. Bernhard, op. cit., "Kommentar", pág. 87, § 75: "Die Quelle für die ungewöhnliche Behauptung, daß der römische Kaiser Julianus Apostata die kleine Sexte eingeführt hätte, is nicht bekannt".

${ }^{130}$ Ps.-Thomas Aqu. I 76, pág. 82 = Іон. Сотт. mus. 8, 16, págs. 69-70; $c f$. , tambiénn, Вавв, op. cit., pág. 112.

131 Sobre la consonancia denominada dyapason, cf. Ps.-Thomas AQu. II 156-160, págs. 138-140; también DíAz DíAz, op. cit., pág. 142. Ejemplos de consonancia dyapason pueden ser $[\cdot \mathrm{C} \cdot-\cdot \cdot],[\cdot \mathrm{D} \cdot-\cdot \mathrm{d} \cdot]$ y $[\cdot \mathrm{E} \cdot-\cdot \mathrm{e} \cdot] ;$; $f$. Іон. Сотт. mus. 9, 13, pág. 74 у ВАв в, op. cit., pág. 114; también Gvido micr. 8, 32, pág. 129 y BABB, op. cit., pág. 65.

132 Ps.-Thomas Aqu. I 77, pág. 82 = Іон. Сотт. mus. 9, 9, pág. 73: “et hoc nomen (sc. diapason) habet, sive quod omnes consonantias in se concludit, sive quod ab una voce inchoans ad octavum saltum facit sicque omnes vocum discrepantias, quae sunt septem, in se continet"; cf. ВАвв, op. cit., pág. 114.

${ }^{133}$ La frase de Ps.-Thomas AQu. I 77, pág. 82: "quia dyatesseron dyapente constituunt dyapason", aparece en el texto editado por Bernhard en letra redonda y no en letra cursiva; probablemente se trata de un mero descuido tipográfico, porque también esta frase se puede documentar en el texto de Іон. Сотт. mus. 9, 13, pág. 74: "Siquidem diatessaron et diapente constituunt diapason"; $c f$. también BABв, op. cit., pág. 114.

134 Sobre la denominación "tonus", vid. Іон. Сотт. mus. 10, pág. 76: "De modis, quos abusive tonos appellamus” у ВАВB, op. cit., pág. 115; también, Gvido micr. 10, 2, pág. 133 y Вавв, op. cit., pág. 66. Sobre la fuente de la doctrina de los toni ecclesiastici, cf. BERnHARD, op. cit., "Kommentar", pág. 87, §§ 78-85: "Die als Zitat nicht verifizierte Darstellung der Kirchentonarten...”; también sobre el particular, Pedro Rafael Díaz Díaz, "La doctrina de los toni ecclesiastici en el tratado de música indebidamente atribuido a Santo Tomás de Aquino”, ap. Jesús Luque, Ma Dolores Rincón, Is abel Velázquez (eds.), Dulces Camenae. Poética y Poesía latinas, Jaén-Granada, Editorial Universidad de Granada, 2010, págs.377-387.

${ }^{135}$ Sobre el término en cuestión, $c f$., por ejemplo, Іон. Сотт. mus. 10, 34, pág. 81: "Plagis vel plagalis id est collateralis seu subiugalis diceretur"; también, aquí mismo, 10, 37, pág. 81: "Plagis (sc. vel plagalis) autem quasi partialis vel collateralis exponi potest; dicimus enim: in illa plaga, id est in illo latere sive in illa parte"; $c f$. ВАBв, op. cit., pág. 117. Sobre el método de presentación de los tonos eclesiásticos, $c f$. Díaz Díaz, op. cit., pág. 386: "Este método de presentación (sc. enumerar y describir, en primer lugar, los cuatro toni plagales y, a continuación, hacer lo propio con los cuatro toni autenti restantes) de la doctrina compendiada de los toni seguramente tenía la ventaja añadida de la facilidad mnemotécnica que proporciona el orden alfabético. En efecto, empezando por los toni plagales, los toni ecclesiastici seguirían una ordenación alfabética ascendente desde la vox $\cdot \mathrm{A} \cdot$ hasta la $v o x \cdot \mathrm{G}$; en cambio, empezando por los toni autenti, habría que partir de la vox $\cdot \mathrm{D} \cdot \mathrm{y}$ si, además, se utiliza el criterio de las parejas opuestas, las rupturas del orden alfabético serían más que evidentes (primero ·D· y, luego, $\cdot A \cdot$ )".

${ }^{136}$ Ps.-Thomas Aqu. I 78, pág. 82: "Primus plagalium, id est secundus tonus, constat ex prima specie dyatesseron inferius, quae est $\mathrm{ab} \cdot \mathrm{A} \cdot \mathrm{in} \cdot \mathrm{D} \cdot$, et ex prima specie dyapente, que est $\mathrm{ab}$ eadem $\cdot \mathrm{D} \cdot$ in $\cdot \mathrm{a} \cdot$, et ex prima specie dyapason, que est $\mathrm{ab} \cdot \mathrm{A} \cdot$ in $\cdot \mathrm{a} \cdot{ }^{\prime}$ vid. Hermann. mus. (ante 1054) [Edición del texto en Musica Hermanni Contracti, Presented from an unedited source and collated with the Vienna MS. No 51 and the editions of Gerbert and Brambach, with parallel English translation, Expanded from a thesis presented for the degree of Music by LEONARD Ellinwood, Eastman School of Music Studies, No 2, University of Rochester, 1952], pág. 66 : "utpote protus... et ex prima specie diatesseron quae est $a b \cdot A \cdot$ in $\cdot D \cdot$, et ex prima specie diapente, quae est $a \cdot D \cdot$ in $\cdot a$, et ex prima specie diapason, quae est ab $\cdot A \cdot$ in $\cdot a \cdot " ; c f$. también Willeh. Hirs. 
mus. 13, ex. 2, pág. 35: "utpote protus... \& exprima specie diatessaron, quae est ab $A \cdot$ in $\cdot D$, $\Xi^{\circ}$ ex prima specie diapente, quae est $a \cdot D \cdot$ in $\cdot a \cdot E$ ex prima specie... diapason, quae est $a b \cdot A \cdot$ in $\cdot a \cdot ; c f$. DíAz Díaz, op. cit., pág. 385: "Ahora bien, solamente en los tratados musicales de Hermann y de Wilhelm, podemos leer un pasaje de carácter recapitulativo, que bien pudo servir de plantilla o guión para la exposición de los toni ecclesiastici de Ps.-Thomas AQU. I... Precisamente, en esta frase se empieza por la descripción del primus plagalium, id est secundus tonus, como hace el anónimo tratado Ars musyce, y en unos términos francamente muy similares".

${ }^{137}$ El quartus plagalium es idéntico, en cuanto al resultado final, al primus autentorum, pues en ambos casos aparece una consonantia dyapason $(\cdot \mathrm{D} \cdot-\cdot \mathrm{d} \cdot)$, pero no en cuanto a la distribución de sus elementos integrantes: así, en el quartus plagalium la distribución es quarta species dyatesseron inferius $(\cdot \mathrm{D} \cdot-\cdot \mathrm{G} \cdot)$ + quarta species dyapente $(\cdot \mathrm{G} \cdot-\cdot \mathrm{d} \cdot)$; en cambio, en el primus autentorum la distribución es prima species dyapente $(\cdot \mathrm{D} \cdot-\cdot \mathrm{a} \cdot)+$ prima species dyatesseron superius $(\cdot \mathrm{a} \cdot-\cdot \mathrm{d} \cdot)$.

${ }^{138} \mathrm{La}$ admisión de una quarta species dyatesseron es doctrina que se documenta en Hermannus Contractus. Así, entre el quadrichordum grave sive principale y el quadrichordum finale se registran las siguientes cuatro modalidades de consonantia diatesseron ( $c f$. Hermann. mus. 5, pág. 27a): "Est igitur necessario prima species diatesseron $\cdot A \cdot-\cdot D \cdot$, constans tono, semitonio, tono... Secunda $\cdot \mathrm{B} \cdot-\mathrm{E} \cdot$, constans semitonio, tono, tono... Tercia $\cdot \mathrm{C} \cdot-\cdot \mathrm{F}$, constans tono, tono, semitonio... Quarta $\cdot \mathrm{D} \cdot-\cdot \mathrm{G} \cdot$.'. Ahora bien, entre el quadrichordum superius y el quadrichordum excellens se contabilizan estas otras cuatro modalidades de consonantia diatesseron ( $c f$. Hermann. mus. 5, pág. 29a): "et quod in gravibus vel principalibus factum est, in superioribus qui eiusdem naturae sunt efficere valebit. Sicque colligitur quatuor esse primas $\cdot A \cdot-\cdot D \cdot-\cdot a \cdot-\cdot d \cdot$, quatuor secundas

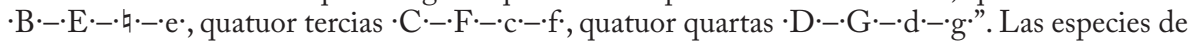
cuarta se construyen, así, de forma simétrica a las especies de quinta y de octava; $c f$. Harold $\mathrm{S}$. Powers/Frans Wiering, s.v. "Mode § II: Medieval modal theory", ap. Stanley Sadie (ed.), The New Grove Dictionary of Music and Musicians, London, Macmillan Publishers Limited, 2001², vol. 16, págs. 777ª-796 , espec. pág. 787a [también disponible en Harold S. Powers/Frans Wiering, Grove Music Online, s.v. "Mode § II: Medieval modal theory", Oxford University Press, 2007-2009]: "Hermannus's new theory began from a more elegant systematization of the modal species of $4^{\text {th }}, 5^{\text {th }}$ and octave, which were generated from the four fixed tone-semitonetone tetrachords of Hucbald's Boethian double octave”. Sobre el carácter simétrico del sistema teórico hermanniano, $c f$. Hermann. mus. 7, pág. 31ª: "Quid quaeso iocundius quid certius erit, quam omnis praedictas species diapason, diapente, diatesseron a suo ordine non deviare; sed omnis primas in primis literis quadrichordorum, in secundis secundas, in terciis tercias, in quartis quartas contineri?”

${ }^{139} C f$. Ps.-Thomas Aqu. I 82, pág. 83: "Sequitur de autentis": así, $B$ 4º ; así $V$ 60ª y así, Di Martino, op. cit., pág. 28. Sobre el término en cuestión, $c f$. Іон. Сотт. mus. 10, 34, pág. 81: “... autentus id est auctoralis sive principalis vocaretur”; y también, aquí mismo, 10, 36, pág.

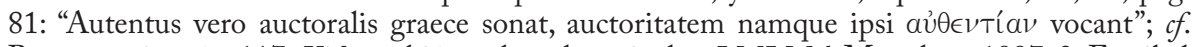
ВАв в, op. cit., pág. 117. Vid. también, sobre el particular, LMLMA, München, 1997, 3. Faszikel - Fascicle 3, s.v. "authentus", cols. $171^{\mathrm{a}}-184^{\mathrm{b}}$, espec. col. 171' "authentische Kirchentonart, Haupttonart... - authentic mode, principle mode...".

${ }^{140}$ Sobre las cuatro especies de tropi duplicados (esto es, quattuor tropi plagales y quattuor tropi autenti), $c f$. Hermann. mus. 8, pág. 31a: "Tropi autem sunt quatuor in natura; sed sicut praedictum est propter specialitatem acuminis et gravitatis subdividuntur in quatuor. Sunt ergo simil octo. Quorum quatuor autentici, id est auctorales, quatuor plagae, id est laterales vel subiugales sunt".

${ }^{141}$ Sobre las cuatro especies de octava duplicadas, $c f$. Hermann. mus. 7, pág. 31a: "Erit igitur prima (sc. diapason species) $\cdot A \cdot-\cdot a \cdot$, ex prima gravi et ex prima superiori; secunda $\cdot B \cdot-\cdot \cdot \cdot$, ex secunda gravi et ex secunda superiori; tercia $\cdot C^{\cdot} \cdot{ }^{\cdot} \cdot{ }^{\cdot}$, ex tercia gravi et ex tercia superiori; quarta $\cdot \mathrm{D} \cdot-\cdot \mathrm{d} \cdot$, ex quarta gravi et ex quarta superiori. Item prima propter praedictam communionis causam $\cdot \mathrm{D} \cdot-\cdot \mathrm{d} \cdot$, ex prima finali et ex prima excellenti; secunda $\cdot E \cdot-\cdot e \cdot$, ex secunda finali et ex secunda excellenti; tercia $\cdot F \cdot-\cdot f \cdot$, ex tercia finali et ex tercia excellenti; quarta $\cdot G \cdot-\cdot g \cdot$, ex quarta finali et ex quarta excellenti”.

${ }^{142}$ Cf. Bernhard, op. cit., pág. 67: "Unklar ist, ob fol. 4v der Basler Handschrift noch zum 
Bestand des Textes gerechnet werden kann”. Puede verse también, aquí mismo, las razones a favor y en contra de la inclusión en el texto de Ps.-Thomas AQu. I de las cuatro parejas de círculos entrelazados, que representan gráfica y simbólicamente los ocho tonos eclesiásticos.

${ }^{143}$ Ps.-Thomas Aqu.I 86, pág. 83 = Aribo (inter 1068-1078) [Edición del texto en Aribonis De musica, ed. Jos. Smits van Waesberghe, CSM, vol. 2, Rome, Institute of Musicology, 1951], pág. 18; $c f$., sobre el particular, Gabriela Ilnitchi, The Play of Meanings. Aribo's De Musica and the Hermeneutics of Musical Thought, The Scarecrow Press Inc., Lanham, Maryland-TorontoOxford,2005, espec. págs. 195-202: “Figura circularis”. Por lo que respecta propiamente al gráfico, la primera serie de caracteres alfabéticos, contando de izquierda a derecha, representa la octava grave; por lo tanto, debiera haber sido consignada en letras mayúsculas, para diferenciarla de la segunda octava, que normalmente se representa con letras minúsculas; tal es el procedimiento empleado en la edición del texto de Aribo. Sin embargo, la edición de Bernhard, seguramente por escrupulosa fidelidad al testimonio del manuscrito $B$, no distingue entre letras mayúsculas y minúsculas. Además, sólo en este primer gráfico de círculos entrelazados, pero no en los tres siguientes, se distingue la notación de la vox $\cdot \mathrm{b} \cdot$ quadratum, con un signo especial, que nosotros representamos por $\cdot \bullet \cdot$.

${ }^{144}$ Ps.-Thomas Aqu. I 87, pág. 84 = Aribo, pág. 19.

145 Ps.-Thomas Aqu. I 88, pág. 84 = Aribo, pág. 20.

${ }_{146}$ Ps.-Thomas Aqu. I 89, pág. 84 = Aribo, pág. 20. 


\title{
La presencia de Fedra e Hipólito en la lírica alemana
}

\author{
Birgit Linda Embeger \\ Universidad de Granada
}

\begin{abstract}
En recuerdo de María Luisa Picklesimer y como sentido homenaje a quien supo despertar en mí el interés y la fascinación por la mitología grecorromana.
\end{abstract}

En este trabajo quiero presentar siete poemas líricos alemanes en los que podemos encontrar el mito de Fedra e Hipólito. Éste es recreado en muy diverso grado, desde la simple mención de sus protagonistas hasta la relación de sus motivos más importantes. Sumamente dispar es también su función dentro de los poemas, pues mientras que unas veces constituye el argumento principal, otras, no es sino un eficaz adorno estilístico ${ }^{1}$. Por todo ello, el conocimiento de las versiones consagradas en las que sin duda se inspiraron los poetas es indispensable para el pleno disfrute y la correcta interpretación de estas obras².

\section{DANIEL CASPER VON LOHENSTEIN: VENUS (s. XVII)}

En 1695 se publicó el himno Venus del jurista, diplomático, dramaturgo y lírico barroco Daniel Casper von Lohenstein (1635-1683)³. Este "encomio erótico en tono ligeramente irónico, según las reglas de la Retórica antigua," ${ }^{4}$ consta de 1888 versos alejandrinos con rima pareada y contiene nada menos que 436 nombres propios mitológicos (dioses, humanos y lugares) y numerosas alusiones a Homero, Virgilio, Ovidio y Catulo, entre otros ${ }^{5}$. Venus es presentada bajo sus acepciones típicas como caprichosa y omnipotente dominadora de flora y fauna y de dioses y humanos ${ }^{6}$. En la oda, Lohenstein pasa revista a los diferentes tipos de amor y afirma que el más violento de todos ellos es el amor no correspondido, ya que no puede ser calmado ni siquiera por la muerte. Véanse, si no, estas mujeres mitológicas que aún en el reino de ultratumba conservan sus pasiones:

Alli aún más doloroso que aqui: el deseo no domado

Todavia arde en el pecho de Pasifae.

Dido aún conserva el puñal clavado en su pecho

Y Fedra sigue enamorada de su bijastro;

Deyanira maldice el manto ensangrentado de Neso;

El espiritu de Laodamía endulza su desgracia

A la sombra de su marido y muere sin morir;

El amor de Evadne no puede ser consumido por ninguna pira, 
Quema a la fría muchacha, pero no se extingue;

Helena conserva aún los signos del fuego de su amor. (Venus, vv. 1807-1816)

El pasaje muestra una acusada dependencia del canto 6 de la Eneida de Virgilio. En Aen. 6, 440, Eneas llega a "las Llanuras del Llanto" donde "a los que duro amor de cruel consunción devoró ocultan senderos escondidos y un bosque de mirto los envuelve; ni en la muerte les dejan sus cuitas" (vv. 442-444). Virgilio nombra aquí a siete mujeres míticas que protagonizaron amores particularmente dramáticos (Fedra, Procris, Erifile, Evadne, Pasífae, Laodamía y Céneo, vv. 445-449), para centrarse a continuación en el personaje de Dido, que acaba de quitarse la vida tras ser abandonada por Eneas (vv. 450-476). Lohenstein recoge a cinco de estas heroínas virgilianas, no sin una breve alusión a sus desgracias: Pasífae, Fedra, Dido, Laodamía y Evadne ${ }^{10}$. Añade a Deyanira, que comparte con Fedra y Dido el hecho de haberse quitado la vida cuando comprendieron la imposibilidad de sus amores ${ }^{11}$ y a Helena, sinónimo de la eterna y universalmente amada y enamorada. Así pues, aunque Lohenstein dedica solo un verso al mito de Fedra, consigue mencionar o insinuar varios de sus motivos principales: el amor de Fedra por su hijastro, la negativa del joven (por la temática del pasaje) ${ }^{12}$, el suicidio de Fedra (por cercanía con Dido y Deyanira) y su papel en la muerte del amado (por cercanía con Deyanira).

\section{FRANZ SCHUBERT/ F. VON GERSTENBERGK: HIPPOLITS $\operatorname{LIED~(1826)}$}

Siglo y medio más tarde, vio la luz una canción ( Lied) del compositor austriaco Franz Schubert (1797-1828), cuyo texto es del jurista y escritor Friedrich (Müller) von Gerstenbergk (1780-1838)13: Hippolits Lied $(1826)^{14}$.

La brevedad de la vida de Schubert contrasta con la cantidad y calidad de sus composiciones musicales ${ }^{15}$, entre las cuales ocupan un lugar destacado los más de seiscientos Lieder o Kunstlieder (canciones artísticas), unas breves piezas para voz y piano en las que el texto y la música se hallan en estrecha relación y perfecto equilibrio ${ }^{16}$. La gran novedad de esta pieza, radica en que nos encontramos con un Hipólito que canta las cuitas de su amor:

\section{HIPPOLITS LIED ${ }^{17}$}

Lasst mich, ob ich auch still verglüh',

Lasst mich nur stille geb'n;

Sie seh' ich spät, sie seh' ich früh'

Und ewig vor mir steh'n. 
Was ladet ibr zur Rub' mich ein?

Sie nabm die Rub' mir fort;

Und wo sie ist, da muss ich sein,

Hier sei es, oder dort.

Zürnt diesem armen Herzen nicht,

Es hat nur einen Fehl;

Treu muß es schlagen, bis es bricht,

Und hat dess nimmer Hehl.

Lasst mich, ich denke doch nur sie;

In ibr nur denke ich;

Ja! obne sie wär' ich einst nie

Bei Engeln ewiglich.

Im Leben denn und auch im Tod, Im Himmel, so wie hier,

Im Glück und in der Trennung Noth

Gehör' ich einzig ibr.

\section{LA CANCIÓN DE HIPÓLITO}

Dejadme, aunque en silencio me vaya quemando,

Dejad que en silencio me vaya;

La veo por la tarde, la veo por la mañana

$Y$ siempre delante de mí.

¿Por qué me invitáis a descansar?

Ella me robó el descanso;

$Y$ donde ella esté, alli debo estar yo,

Dondequiera que sea.

No le guardéis rencor a este pobre corazón,

Un solo error comete;

Fiel tiene que latir hasta que se rompa,

$Y$ no bace un secreto de ello.

Dejadme, si yo solo pienso en ella;

En ella solo pienso yo;

¡Ay, sí! sin ella no llegaría jamás

A la eternidad de los ángeles.

En la vida y en la muerte,

en el cielo como en la tierra, 
en las alegrías y en las penas de la separación

Solo suyo soy.

La música de este "desesperado canto de un corazón solitario y desgraciado" ${ }^{18}$, escrita en la menor, refleja e incrementa el desconsuelo expresado por la letra ${ }^{19}$. La forma del poema sigue los cánones clásicos ${ }^{20}$, con gran aprovechamiento de los recursos estilísticos, entre los cuales destacan la repetición ${ }^{21}$, la variación ${ }^{22}$, la antítesis ${ }^{23}$ y las alusiones a la liturgia cristiana (última estrofa). El amor es descrito mediante los tópicos románticos del amor eterno y único, el amor como fuego abrasador y fuente de inquietud, el amor más allá de la muerte.

Vemos que la única alusión directa al mito de Fedra se halla en el título. Es Hipólito quien canta, dirigiéndose a unos interlocutores desconocidos. Tampoco llegamos a conocer la identidad de la mujer sobre la que canta, la cual podría ser o bien Aricia (según Racine, recientemente traducido por Schiller $)^{24}$ o bien Fedra, inaugurando de este modo la línea de los Hipólitos alemanes decimonónicos que tímidamente correspondieron a los sentimientos de su madrastra ${ }^{25}$.

\section{WILHELM LEHMANN: ARTEMIS UND HIPPOLYT(1952)}

Wilhelm Lehmann (1882-1968), filólogo y filósofo, escritor y profesor de secundaria ${ }^{26}$, compuso el 8 de julio de 1952 un poema sobre Ártemis e Hipólito, que fue publicado pocos días después (26 de julio) en el diario Frankfurter Allgemeine Zeitung:

ARTEMIS UND HIPPOLYT ${ }^{27}$

Erstes Heu ist gerwonnen;

Die Birnen schrwellen, grüne Vasen.

Zirruswolken, kraus gedrehte,

Schafe über blauen Rasen.

Der Kümmel reift. Das Kleid gescbürzt,

Zieht Artemis durch die Bauernwälder.

Aus gefüllten Schalen würzt

Kräftiger ibr die Luft Kamille.

Artemis rubt, ibr Köcher rubt.

Aus dem Nest gestürzter Zeisig,

Ziege, länglicher Pupille,

Weiß sich in ibrer Hut. 
Wind hat die Zirren ausgewischt.

Arkturus glüht.

Elfenbeinen sommert der Holunder.

Engelwurz kühlt mit glasig runder

Scheide, als biete ibre Hand die Göttin mir

Und ich sei Hippolyt.

ARTEMIS E HIPÓLITO

El primer heno se ha recogido;

Las peras engordan, verdosos jarrones.

Nubes de cirro, enroscadas, rizadas,

Ovejas en un prado azul.

El comino madura. Con el vestido levantado,

Atraviesa Ártemis los bosques campestres.

Cogiendo de fuentes rebosantes, endulza

Para ella la manzanilla el aire con intenso perfume.

Artemis descansa, su carcaj descansa.

Caido de su nido el chamariz,

La cabra, de pupila alargada,

Está segura de su protección.

El viento ha borrado los cirros.

Arturo arde.

Cual marfil estivalea el saúco.

La angélica refresca con vidriosa, redonda

Vaina, como si su mano la diosa me ofreciese

Y como si yo fuera Hipólito.

Lehmann es considerado como uno de los principales representantes de la Naturlyrik (lírica de la naturaleza) alemana, una de las corrientes más características de la poesía almena de la postguerra ${ }^{28}$. En sus composiciones suele combinar su amor por la naturaleza con su fascinación por las lenguas y literaturas clásicas y alemanas ${ }^{29}$. Así también en este poema, en el que dibuja un cuadro veraniego, caracterizado por la vegetación exuberante, el buen tiempo y el calor. La protagonista es la diosa Ártemis, que es presentada siguiendo los modelos clásicos, esto es, viviendo en estrecha relación con la naturaleza, como cazadora y protectora a la vez.

La forma sigue los modelos clásicos alemanes y los recursos estilísticos más destacados son la comparación ${ }^{30}$, la metáfora ${ }^{31}$, la antítesis ${ }^{32}$, la repetición ${ }^{33}$ y la aliteración ${ }^{34}$. Obsérvense también el uso de los colores (verde, azul) y la creación de palabras nuevas ${ }^{35}$. 
Hipólito, anunciado por el título, no aparece hasta el final del poema, donde recibe particular énfasis tanto por la posición última y por rimar con "glübt" como por la identificación con el poeta. Éste compara el poder refrescante de los tallos de la angélica con la ayuda vital que Ártemis le prestó a Hipólito, esto es, la resucitación del joven por el dios-médico Asclepio ${ }^{36}$. Lehmann alude, así pues, a un episodio que tiene lugar con posterioridad al mito de Fedra propiamente dicho. Ahora bien, aunque Fedra no aparece en este poema ni se habla de su amor por Hipólito, bien es cierto que la historia de éste no se entiende sin la intervención de su madrastra. De hecho, en las explicaciones con las que Lehmann acompaña la pieza leemos: "Hipólito, consagrado por completo al servicio de la virginal Ártemis, es amado y calumniado por su madrastra y es matado por Poseidón a petición de su padre. Es resucitado por Ártemis" ${ }^{37}$.

De particular importancia para el mito de Fedra en la literatura alemana de la segunda mitad del s. XX es el llamado "Sarcófago de Fedra" que se guarda en la Iglesia de San Nicola en Agrigento (Sicilia). Datado en el siglo III d. C. se trata de uno de los más valiosos sarcófagos que representan este mito ${ }^{38}$ que ya a Goethe le causó honda impresión ${ }^{39}$. En él se inspiran al menos tres obras literarias alemanas, entre ellas, dos poemas líricos ${ }^{40}$.

\section{MARIE LUISE KASCHNITZ: AGRIGENT(1957)}

Marie Luise Kaschnitz (1901-1974), que es sin duda una de las autoras alemanas más prolíferas del siglo $\mathrm{XX}^{41}$, se inspiró de forma constante $\mathrm{y}$ recurrente en la tradición clásica para sus propias creaciones literarias. En los años 30 escribió una colección de mitos griegos que se caracteriza por su enfoque personal, tanto en lo que respecta a la selección de las historias como al desarrollo de las mismas ${ }^{42}$. De especial interés para nuestro estudio es su recreación de la primera nekya de la Odisea (Od.11), titulada "Die Begegnung" (El encuentro ${ }^{43}$. Fedra, siguiendo el modelo euripídeo, acaba de ahorcarse, pero ahora parece arrepentirse de su acto, pues "con pavor indecible sujeta entre ambas manos la soga"44.

En su autobiografía Orte (Lugares, 1973), Kaschnitz describe su visita a Agrigento. Su recorrido la llevó "de un templo a otro", donde ella dio rienda suelta a su fantasía mientras su marido, el arqueólogo Guido Kaschnitz von Weinberg, le hizo interesantes observaciones acerca de la arquitectura y las costumbres religiosas del lugar ${ }^{45}$. Por la noche, visitaron la iglesia de San Nicola y contemplaron las dramáticas escenas del bajorrelieve del sarcófago de Fedra $^{46}$. Algún tiempo después, Kaschnitz recordó aquellos momentos en el poema Agrigent que forma parte del ciclo Sizilianischer Herbst, publicado en la colección Neue Gedichte (1957): 


\section{AGRIGENT ${ }^{47}$}

Der Sturm hat die Kabel zerrissen. Kein Licht

Im Dom von Agrigent.

Nur Kerzen um den starren Katafalk

Und die grauen Gebete der Schatten.

Erloschen im Fenster die Stadt und achtlos

Hingeworfen über die breiten Hügel.

Scheinwerferstrabl verloren in den Schluchten

Taucht auf, verschwindet.

Eine Stimme, wann in der Nacht, rief Empedokles!

Und einer am erloschnen Lagerfeuer

Erwachte, sab den Angerufenen

In einem Glanz von Fackeln bergwärts und

Dann niemals wieder.

Phädra im Kerzenlicht, die Klagende

Tritt aus dem Sarkophag und Hippolyt.

Die Hufe stampfen und die heilige Kammer

Hallt wider vom wahnwitzigen Liebesschrei.

Stehen die Wächter wartend nicht am Tor

Und wandert fernher nicht in Regengüssen

Über Felsspalten springend, blutend vom Hagel

Der dem Tode Versprochene?

Der Sturm hat die Kabel zerrissen in der Stadt Agrigent.

Glühend leben die Toten.

\section{AGRIGENTO}

La tormenta ha roto los cables. Sin luz

En la catedral de Agrigento.

Solo velas en torno al pétreo catafalco

$Y$ las oraciones grisáceas de las sombras.

Apagada en la ventana la ciudad y sin cuidado

Diseminada sobre las anchas colinas.

Los faros de un coche perdidos en los barrancos

Aparecen, desaparecen. 
Una voz, cuando de noche, gritó: ;Empédocles!

$Y$ junto al fuego apagado, uno

Se despertó, vio al que habia sido llamado,

En el resplandor de las antorchas, colina arriba y

Después nunca más.

Fedra a la luz de la vela, la quejumbrosa,

Sale del sarcófago e Hipólito.

Los cascos piafan y la sagrada cámara

Resuena del enloquecido grito de amor.

${ }_{\dot{\zeta}}$ No están los guardias esperando en la puerta

Y no camina a lo lejos, bajo la lluvia,

Saltando sobre rocosas grietas, herido por el granizo

El a la muerte prometido?

La tormenta ha roto los cables en la ciudad de Agrigento.

Candentes viven los muertos.

Los trabajos de la colección Neue Gedichte son "nuevos" no solo por su fecha de composición, sino también por su forma y contenido. Librándose de la influencia de Eliot y Rilke, Kaschnitz empezó a componer poemas más breves, en los que abandonó definitivamente la rima y modificó intencionadamente el ritmo del texto ${ }^{48}$. Con respecto al contenido, los argumentos más frecuentes son, por un lado, la combinación de historias y personajes mitológicos con el tiempo presente $y$, por otro, los encontrados sentimientos de la autora frente a la naturaleza salvaje e indomable ${ }^{49}$.

Ambos temas se entremezclan en Agrigent, en el que, con el trasfondo de una fuerte tormenta y una misa de réquiem (estrofa 1 ), se evocan el mito de Fedra (estrofa 4) y dos leyendas locales: la muerte de Empédocles, célebre político, sacerdote, médico, poeta y filósofo del s.V a.C. (estrofa 3) ${ }^{50}$, y la amistad de Mero y Selinuntio (estrofa 5) ${ }^{51}$. Mediante el solapamiento de escenarios y perspectivas, entre ellas, la suya propia, Kaschnitz logra recrear los momentos más sobrecogedores de estas historias con gran plasticidad y fuerza expresiva. Para esbozar el mito de Fedra se sirve de una serie de sonidos estridentes, con clara función premonitora de las desgracias por suceder ${ }^{52}$. Opino que su modelo más inmediato fue la Phaedra de Séneca, con la que comparte el furor del amor de Fedra (enloquecido grito de amor) y la simultaneidad de sus lamentos con la partida del joven.

Este poema se caracteriza además por el elevado aprovechamiento de la alternancia entre luz y oscuridad ${ }^{53}$, espacio interior y paisaje exterior, $y$ entre experiencia real y mito. La conexión entre el presente y el pasado es posible gracias a la eliminación de los avances de la civilización: Agrigento 
se ha quedado sin suministro eléctrico y, rodeados de oscuridad y tormenta, "candentes viven los muertos".

\section{ERICH ARENDT: DER SARKOPHAG (AGRIGENT) (1973/74)}

También el poema Der Sarkophag (Agrigent) de Erich Arendt (19031984) surge a raíz de la contemplación del sarcófago siciliano, combinando experiencia real y relato mitológico. Asimismo, la pieza comparte con la anterior la alternancia entre luz y oscuridad, ruido y silencio y paisaje exterior y espacio interior:

DER SARKOPHAG (AGRIGENT) ${ }^{54}$

\section{Lichtzerrissen}

der Fels im

$$
\text { dehnenden }
$$

Feld des

Lichts: all-

glühender Morgen, und

aus dem Schierlingsmeer

beller das

durchsichtge Geripp,

der Tempel.

(Hand des Karthagers, sie

ließ $\beta$ es bewenden

hier mit des Ölbaums

Tod).

Jede Stunde erfährt das

Nie-war-es-anders.

Der Berg dort der

Dom.

In seinem Gewölb,

(draußen

Staubwolkendicht,

Lärm)

dem Kathedralendämmer allein

Jahrhundert-

Stille:

Weiß

wie eine

innre Geburt

der Sarkophag:

$$
\text { Phaidra! - }
$$


Birgit Linda Emberger

$$
\begin{aligned}
& \text { vom lachenden Auge } \\
& \text { umtanzt, } \\
& \text { lorbeerblattschmal, } \\
& \text { eines Kindes, }
\end{aligned}
$$

die Tote drin

neckend, als

spür die

über den Säulentrommeln

am Hang

$$
\begin{aligned}
& \text { schattenlos oben } \\
& \text { die Schwinge, die } \\
& \text { eigene Zeit, }
\end{aligned}
$$

blut-

schänderisch

zitternde Hand:

verschmäht! - die

Blätter der Myrthe

durchstechend,

zornblendender

Mittag und übers Marmorweiß

schleifen,

vom Stierbaupt der Woge

erschreckt,

die ungeliebte Liebe

Rosse

zutod.

Komm,

kleine Francesca, über dir

bängen wird auch

die Schlinge,

$$
\begin{aligned}
& \text { blindlings; } \\
& \text { meeresgenarbt }
\end{aligned}
$$

in den Lüsten, im Wind

die Myrthe.

\section{EL SARCÓFAGO (AGRIGENTO)}

Rasgado por la luz

La roca en medio del

extendido

campo de la

luz: omni- 
candente mañana, $y$

en el mar de las cicutas

más luminoso el

transparente esqueleto,

el templo.

(Mano del cartaginés, ella

Se conformó

Aqui con la muertedel

olivo).

Cada hora experimenta el

Nunca-ba-sido-de-otra-manera.

La montaña allí la

catedral.

Bajo su bóveda,

(fuera

espesas nubes de polvo,

ruido)

para la penumbra de la catedral solamente

de los siglos

el silencio:

Blanco

como un

nacimiento interior

el sarcófago:

¡Fedra! -

por el ojo sonriente

rodeada,

fino como la hoja de laurel, de un niño,

a la difunta en su interior

fastidiando, como si

sintiera la

por encima de los tambores de columna

en la ladera

sin sombra arriba

el ala, el

propio tiempo,

in-

cestuosamente

temblorosa mano:

¡desdeñada! - las

hojas del mirto

agujereando, 
deslumbrante de ira

el mediodía

y sobre la blancura marmórea

arrastran,

por la cabeza de toro de la

espantados,

caballos

el amor no amado

a la muerte.

Ven,

pequeña Francesca, por encima de ti

también colgará

la $\operatorname{sog} a$,

a ciegas;

herido por el mar

en los placeres, en el viento

el mirto.

La biografía de Arendt, quien se da a sí mismo el apelativo de "vagante", se articula en una sucesión de mudanzas y viajes que le llevaron a través de Europa y Sudamérica $(\text { Colombia })^{55}$. Fruto de su vida errante fueron el conocimiento de los paisajes y pueblos más diversos, así como un excelente dominio de, al menos, cuatro lenguas modernas (alemán, español, francés, inglés). A ello debemos añadir unas nociones básicas de latín y griego y una gran pasión por las culturas mediterráneas, especialmente la grecorromana ${ }^{56}$. De particular importancia para su producción lírica es la tradición de la Wortkunst (arte de la palabra), una línea secundaria dentro de la corriente expresionista, que busca potenciar la palabra aislada ${ }^{57}$. Los efectos formales surgidos de la combinación de palabras (verso, estrofa, metro, etc.) pierden importancia, a la vez que se altera el sentido original (racional) de las frases, para conseguir una comunicación más inmediata y concisa en la que cada vocablo se carga de valor y significado. Con respecto al contenido, Arendt entremezcla en sus poemas temas universales como el amor, la vejez y la muerte con las impresiones que le evocan la naturaleza o alguna obra de arte ${ }^{58}$.

La primera parte de este poema tiene un aspecto marcadamente estático y contemplativo, reforzado por los elementos pétreos Fels y Berg. Bajo la intensa luz de la mañana, Arendt visita los templos ${ }^{59}$, recordando algún episodio de la agitada historia del lugar ${ }^{60}$. Dirige entonces su mirada hacia la ciudad, donde divisa la Iglesia de San Nicola, en cuyo interior sabe que se encuentra el sarcófago de Fedra. Tras adentrarse en el templo, el texto se vuelve más dinámico, convirtiéndose en un místico teatro de mimos. Al igual que en el poema anterior, Fedra e Hipólito salen de la oscuridad y cobran vida para representar su historia. En comparación con Kaschnitz, se detecta mayor detalle 
en la recreación del mito, que incluye motivos como el incesto, la negativa del joven, la ola con apariencia de toro, la muerte de Fedra (die Schlinge) y las hojas de mirto. Vemos que Arendt recrea el mito según Euripides (muerte por ahorcamiento) y Séneca (Fedra aún sigue con vida cuando Hipólito sufre el accidente), añadiendo el motivo del mirto, acaso inventado por Pausanias para explicar la presencia de una planta particular junto al templo trecenio de Afrodita Catascopia ${ }^{61}$.

La apelación directa a un interlocutor concreto es un recurso altamente aprovechado por el autor, particularmente en sus poemas más tardíos. Aunque sin duda se refiere a personajes reales, su identidad queda oculta sin que se ofrezca ningún indicio para su identificación. De este modo, a salvo de la censura de su país (la República Democrática Alemana) y a salvo también de miradas y comentarios impertinentes, el poeta establece un diálogo íntimo con amigos y desconocidos, con vivos, muertos o desaparecidos ${ }^{62}$. En este poema, así pues, se dirige a la "pequeña Francesca" para advertirle de la fragilidad y brevedad de la vida y los sentimientos humanos frente a la eternidad de la luz, la naturaleza, el amor y la muerte (el Nie-war-es-anders del poema).

\section{KARL KROLOW: GUTE NACHT (1975) ${ }^{63}$}

Karl Krolow (1915-1999), al igual que Lehmann, aprovechó el mito de Fedra para un poema amoroso, ambientado en una agradable noche de mayo:

\section{GUTE NACHT}

Dieser endgültige Frühling nachts.

Nur weiße Zäbne leuchten.

Das läßt sich in keiner Sprache

sagen. Die Logik der Körper

ist stärker. Eine Musik in jedem

Augenblick, wie eine Hand,

die unter eine Acbsel faßt,

ein anderes Leben in jedem Fall,

vielleicht eine notwendige

Vorbereitung auf den Tod,

ohne Angst das alles, eine Girlande,

weil Mai ist und es überall

knistert vor Glück.

Was ist Liebe?

La douce pensée.

Werther ist weit. Wieviel Schlaflosigkeit!

Die Osrambirnen glühen

für Phädra. Gute Nacht, gute Nacht. 


\section{BUENAS NOCHES}

Esa primavera definitiva por la noche.

Solo brillan unos dientes blancos.

Eso, en ninguna lengua puede

decirse. La lógica de los cuerpos

es más fuerte. Una música en cada

instante, como una mano,

que se introduce debajo de la axila,

otra vida, en todo caso,

tal vez una indispensable

preparación para la muerte,

sin miedo todo ello, una guirnalda,

porque estamos en mayo y por doquier

chisporrotea la felicidad.

¿Qué es el amor?

La douce pensée.

Werther queda lejos. ; Cuánto insomnio!

Las bombillas de Osram se encienden

para Fedra. Buenas noches, buenas noches.

Krolow, poeta, traductor, crítico literario y profesor universitario, es considerado como una de las figuras más importantes de la literatura alemana después de 1945, particularmente en el campo de la lírica. Disfrutó de la aprobación y admiración de sus contemporáneos, y la concesión del premio Büchner (1956), considerado el máximo galardón de la literatura alemana, da fe de la extraordinaria calidad de su obra ${ }^{64}$.

En sus poemas, que presentan acusadas influencias de la Naturlyrik, el Expresionismo y el Surrealismo ${ }^{65}$, Krolow busca siempre una comunicación lo más concisa y precisa posible con un mínimo de palabras y recursos (laconismo). Esta aparente sencillez lingüística se opone a la profundidad del mensaje expresado, creando un interesante efecto de contraste y sorpresa, pues el poeta gusta de llamar nuestra atención sobre cuestiones de la vida diaria, en las que ya no reparamos debido al ritmo acelerado de nuestra vida o porque pensamos conocerlas ya suficientemente ${ }^{66}$.

Gute Nacht está concebido a modo de monólogo en el que el autor, que no está solo, se plantea la eterna pregunta “¿qué es el amor?”. No disimula sus dificultades para describirlo (vv. $3 \mathrm{~s}$.), por lo que se limita a enumerar una serie de pensamientos y sentimientos personales (vv. 4-15).

Nuestro análisis mitológico debe centrarse en los tres últimos versos del poema, en los que se alude a los amores de Werther y Fedra ${ }^{67}$. Según el autor, la historia de Werther pertenece al pasado (Werther ist weit), mientras que la de Fedra disfruta de plena actualidad (es iluminada por las bombillas Osram, 
símbolo del mundo moderno).Desde un punto de vista programático o metaliterario, podríamos ver aquí la renuncia del escritor a los clásicos alemanes y su intento de conectar con la literatura universal. En cambio, más difícil es saber si Krolow quiere establecer una oposición entre los dos amores que menciona (en el sentido de que el amor de Werther causa insomnio mientras que el de Fedra pertenece a una buena noche $)^{68} \mathrm{o}$ si, en cambio, los presenta como dos versiones de un mismo dilema (al igual que antaño el amor de Werther, ahora el de Fedra sigue causando insomnio) ${ }^{69}$. No hay respuesta definitiva y universalmente válida a esta cuestión, pues advierte el propio Krolow que "el lector no tiene que reconstruir con minuciosa exactitud lo que el autor habría querido expresar, sino que [debe] integrar sus propias experiencias en la discusión de las cuestiones planteadas de modo general y construir su propia comprensión"70.

\section{OSKAR PASTIOR: VOLTAIRE VON DER AUGENSCHEIDE (CA. 1986) $)^{71}$}

Oskar Pastior (1927-2006) ${ }^{72}$ incluyó el nombre de Fedra en su poema voltaire von der augenscheide, escrito durante la segunda mitad de los años 80 del siglo pasado ${ }^{73}$.

En sus creaciones líricas, Pastior emplea las técnicas de la "escritura limitada”, identificada con el grupo poético OULIPE (Ouvroir de littérature potentielle - Taller de literatura potencial $)^{74}$, que consiste en usar la lengua según determinados criterios de selección o restricción ${ }^{75}$. De este modo se consigue potenciar un aspecto lingüístico determinado, para tantear el verdadero alcance de la palabra y revelar sus significados ocultos y originarios ${ }^{76}$.

El poema que aquí nos ocupa pertenece a una colección de piezas con "aspecto de lista"77. Se trata de largas enumeraciones que constituyen una especie de "Suchbilder"78, en los que el lector debe detectar o averiguar los criterios de selección y ordenación. Voltaire von der augenscheide se compone de veintidós estrofas de cuatro versos cada una. Cada verso consta de cuatro palabras, escritas en letra minúscula ${ }^{79}$ y con total ausencia de signos de puntuación. Entre los efectos sonoros sobresalen las rimas internas y finales y la sucesión de palabras fonéticamente afines ${ }^{80}$. Con respecto al contenido, el poema combina vocablos reales con otros imaginarios ${ }^{81}$, todos ellos con un marcado aspecto nominal. Se perfilan diferentes campos semánticos (nombres de flora ${ }^{82}$ y fauna ${ }^{83}$, términos y denominaciones geográficos ${ }^{84}$, vocablos con fuertes connotaciones erótico-sexuales ${ }^{85}$ ), a la vez que encontramos una serie de voces extranjeras ${ }^{86}$, también griegas y latinas ${ }^{87}$, y varios nombres propios: pindar, alfons, triton, brutus, leda, phädra, luther. 


\section{CONCLUSIONES}

Todos los poemas analizados tienen en común el hecho de pertenecer a escritores de primera categoría y de corresponder a un momento relativamente tardío en su biografía. Como poemas líricos que son, contienen una gran carga subjetiva, concebidos para dar salida a los pensamientos y sentimientos más íntimos de su autor. A ello se debe también la inclusión del poeta o de elementos autobiográficos en el poema (especialmente en el caso de Lehmann, Kaschnitz, Arendt y Krolow). Es propio de la lírica que los mitos y argumentos no se narren de forma completa y detallada, sino parcial y alusiva, seleccionando las imágenes y motivos con mayor fuerza simbólica y expresiva.

Con respecto a la función que desempeña el mito de Fedra en estos poemas, podemos distinguir tres tipos distintos: constituye el argumento principal de los poemas de Schubert/Gerstenbergk y Arendt. Kaschnitz lo narra junto a otros dos mitos clásicos. Lohenstein, Lehmann, Krolow, y probablemente también Pastior, lo emplean como símbolo o metáfora de unos sentimientos determinados. Detectamos también significativas diferencias en el enfoque y la amplitud con los que el mito es abordado: Mientras que Lohenstein, Krolow y Pastior se centran en Fedra, Schubert/Gerstenbergk y Lehmann adoptan la perspectiva de Hipólito, cuyos amores han sido siempre inusuales y controvertidos. Kaschnitz y Arendt, quienes recrean el mito con mayor detalle, lo evocan en el contexto de sus encuentros personales con la Antigüedad clásica. 
${ }^{1}$ Para el uso del mito clásico en la poesía lírica moderna, cf. J. S. LASSO DE LA VEGA, Helenismo y literatura contemporánea, Madrid, Prensa Española, 1967, pp. 21-42: "El mito clásico en la poesía lírica”; C. GARCÍA GUAL, "Los mitos griegos en la literatura”, en Dulce Estefanía et al. (eds.), Cuadernos de literatura griega y latina IV: Proyección de la mitología greco-latina en las literaturas europeas, Alcalá de Henares, Universidad, 2007, pp. 9-25.

${ }^{2}$ Son cuatro los modelos clásicos grecolatinos: las tragedias Hippolytos de Eurípides (428 a. C.) y Phaedra de Séneca (s. I d. C.) y los poemas Heroida 4 y Metamorfosis (15, 492-546) de Ovidio (s. I a. C.). A ello debemos añadir la tragedia francesa Phèdre de Jean Racine (1677). Para el mito de Fedra en la literatura clásica y moderna a nivel internacional, cf. A. POCIÑA - A. LÓPEZ (eds.), Fedras de ayer y de hoy. Teatro, poesía, narrativa y cine ante un mito clásico, Granada, Universidad, 2008.

${ }^{3}$ Para la vida y obra de Casper (con el título nobiliario “von Lohenstein” a partir de 1670), cf. W. A. PASSOW, Daniel Casper von Lohenstein, seine Trauerspiele und seine Sprache, Meiningen, Brückner \& Kenner, 1852; B. ASMUTH, Daniel Casper von Lohenstein, Stuttgart, Metzler, 1971.

4 "Ein leicht ironisch gehaltenes erotisches Enkomion nach den Vorschriften der antiken Rhetorik" (V. RIEDEL, Antikerezeption in der deutschen Literatur vom Renaissance-Humanismus bis zur Gegenwart, Stuttgart, Metzler, 2000, p. 99).

${ }^{5}$ RIEDEL, op. cit., p. 100.

${ }^{6}$ Cf. EUR. Hipp. 1-10, 525-564 y 1268-1282; OVID. her. 4, 11 s.; SEN. Phaedr. 274-359, entre muchos otros.

${ }^{7}$ A no ser que se indique lo contrario, todas las traducciones están hechas por mí misma. La traducción se hace en prosa suelta y atendiendo principalmente al contenido semántico.

8 "Dort schmertzlicher/ als hier: die ungezähmte lust// Brennt der Pasiphae noch immer in der brust.// Der Dido steckt das schwerdt noch immer in den brüsten// Und Phädra lässet sich des stieff-sohns noch gelüsten;// Die Dejanire fluch't auff Nessus blutig kleid;// Laodamiens geist bezuckert ihr das leid// Im schatten ihres manns/ und stirbet ohne sterben;// Evadnens liebe kan kein holtz-stoß nicht verderben// Sie brennt das kalte kind/ wiewohl sie nicht verbrennt;// Das feuer wird noch itzt an Helenen erkennt". El texto sigue B. NEUKIRCH, Anthologie. Herrn von Hoffmannswaldau und anderer Deutschen auserlesener und bißher ungedruckter Gedichte erster Teil, Tubinga, de Gruyter, 1961 (sobre una edición de 1697), pp. 290-346.

${ }^{9}$ lugentes campi, cf. Venus, v. 1800: “das geheime thal der trauer-felder". El texto de la Eneida sigue la traducción de R. FONTÁN BARREIRO: Virgilio. Eneida, Introducción y traducción de Rafael Fontán Barreiro, Madrid, Alianza, 2001.

10 "El deseo no domado" alude a la unión de Pasífae con el toro blanco, fruto de la cual nació el Minotauro (APOLLOD. bibl. III, 1, 3 s.; HYG. fab. 40). Tras perder a Eneas, Dido se apuñaló sobre una gran pira (VERG. Aen. 1 y 4; OVID. her. 7). Laodamía, se suicidó para seguirle a su esposo Protesilao al Hades (OVID. her. 13; HYG. fab. 103; 104; 243, 3; APOLLOD. epit. III, 30). Evadne se arrojó a las llamas de la pira de su esposo Capaneo (APOLLOD. bibl. III, 7, 1; HYG. fab. 243, 2).

${ }^{11}$ Deyanira mató accidentalmente a su esposo Heracles cuando trató de recuperar su amor. Después se quitó la vida (APOLLOD. bibl. II, 7, 5 s.; HYG. fab. 34; 36; 243, 3; OVID. her. 9).

${ }_{12}$ Vemos que la dependencia de Lohenstein de su modelo es tal que no se limita a las mujeres víctimas de amores no correspondidos (como había anunciado), sino que enumera una serie de mujeres cuya muerte está en estrecha relación con sus amoríos.

${ }^{13}$ Para la vida y obra de Georg Friedrich Konrad Ludwig (Müller) von Gerstenbergk, cf. E. WEGE et al., Das Stammbuch Friedrich von Matthissons: Transkription und Kommentar zum Faksimile, Gotinga, Wallstein, 2007, pp. 282 s.

${ }^{14} \mathrm{El}$ texto fue falsamente atribuido a Johanna Schopenhauer, madre del filósofo Arthur Schopenhauer y amante de Gerstenbergk, quien incluyó el poema en su novela Gabriela (Leipzig, Brockhaus, 1821). Cf. B. MASSIN, Franz Schubert. II. Obra, Madrid, Turner, 1991, p. 1218. Ibidem se indica "julio de 1826" como fecha de composición de este lied. 
${ }^{15}$ Para la vida y obra de Schubert, cf. A. EINSTEIN, Schubert. Retrato musical, Madrid, Taurus, 1981 (traducción de B. Moreno Carrillo); B. PAUMGARTNER, Frank Schubert, Madrid, Alianza, 1992 (traducción de B. Bas Álvarez).

${ }^{16}$ Para los lieder de Schubert, cf. D. FISCHER-DIESKAU, Los lieder de Schubert. Creación - Esencia - Efecto, Madrid, Alianza, 1989 (traducción de A. Hochleitner de Vigil). Un listado completo de los lieder y los autores de sus textos (célebres poetas clásicos y románticos nacionales e internacionales) puede encontrarse en EINSTEIN, op. cit., pp. 359-373.

${ }^{17}$ Hippolits Lied (1826) fue publicado por primera vez en 1830. La edición consultada es: FRANZ SCHUBERT, Gesänge für eine Singstimme mit Klavierbegleitung (edición de M. Friedländer), Leipzig, Peters, 1885, vol. V, pp. 5 s.

${ }^{18}$ MASSIN, op. cit., p. 1218.

${ }^{19}$ Cf. A. REVERTER, Schubert. Lieder completos, Barcelona, Ediciones Península, 1999, p. 336: "se deriva una infinita tristeza propiciada por el obsesivo acompañamiento de la mano derecha, que traza un motivo simbólico de la implacabilidad del tiempo desarticulada por el intervalo de la primera parte del compás y por el mordente que se coloca sobre la segunda en una escritura en corcheas. A la vez un sombrío motivo, que enlaza con el de la línea vocal, circula por los bajos del teclado".

${ }^{20}$ El poema se articula en cinco estrofas, de cuatro versos cada una, escritos en tetrámetros y trímetros yámbicos y con rima cruzada.

${ }^{21}$ Lasst mich - Lasst mich - Lasst mich; still-stille; Sie seh'ich - sie seh 'ich; Ruh' - Ruh'.

${ }^{22}$ Ich denke doch nur sie - In ihr nur denke ich.

${ }^{23}$ Spät-früb; Was ladet ibr zur Rub' mich ein? - Sie nabm die Rub' mir fort.

${ }^{24}$ Es ésta la interpretación de R. ABENSTEIN, "Eine tödliche Liebe", en Damals 1/2008, 2008, pp. 21-27. La tragedia de Racine fue traducida al alemán por Friedrich von Schiller en diciembre de 1804 y fue estrenada en el Hoftheater de Weimar el 30 de enero de 1805. En ella, Hippolyte está enamorado de Aricie, princesa ateniense de una familia enemiga de Thésée.

${ }^{25}$ El motivo del amor correspondido aparece por primera vez en la tragedia Hypolite ou Le garçon insensible (1646) de Gabriel Gilbert (H. J. TSCHIEDEL, Phaedra und Hippolytus. Variationen eines tragischen Konfliktes, Erlangen, 1969, pp. 77 s.). Fue retomado por todos los autores alemanes decimonónicos posteriores que trataron el mito de Fedra (O. MARBACH, Hippolyt, 1846; G. CONRAD, Phädra. Trauerspiel, 1864 y Phädra. Melodrama, 1866; M. v. MEYSENBUG, Phädra, 1885; S. LIPINER, Hippolytos, 1899). Opino que Hippolits Lied no se refiere al amor del joven por la diosa Ártemis, debido a la vehemencia de los sentimientos expresados (más allá de la veneración por una diosa) y las alusiones a la presencia física de la amada.

${ }^{26}$ Para la vida y obra de Lehmann, cf. H. BRUNS, Wilhelm Lehmann. Sein Leben und Dichten, Kiel, Mühlau, 1962; U. DOSTER - J. MEYER (eds.), Wilhelm Lehmann, Marbach, Deutsche Schillergesellschaft, 1982.

${ }^{27}$ WILHELM LEHMANN, Artemis und Hippolyt (1952) en id. (1982), Gesammelte Werke I. Sämtliche Gedichte, Stuttgart, Klett-Cotta, 1982, p. 224. Como variante textual más llamativa frente a las ediciones anteriores se observa la corrección en la trascripción del nombre del joven: "Hippolyth" ha pasado a "Hippolyt", cf. H. D. SCHÄFER, "Anhang” en W. LEHMANN, Gesammelte Werke I., Stuttgart, Klett-Cotta, 1982, pp. 465 s.

${ }^{28}$ Cf. K. KROLOW, Aspekte zeitgenössischer deutscher Lyrik, Gütersloh, Gerd Mohn, 1961, pp. 29-53: "Möglichkeiten und Grenzen der neuen deutschen Naturlyrik". Para Lehmann como poeta de la Naturlyrik, cf. DOSTER - MEYER, op. cit., pp. 3 s.

${ }^{29}$ BRUNS, op. cit., pp. 10, 70, 98; DOSTER - MEYER, op. cit., p. 68.

${ }^{30}$ Birnen - grüne Vasen; Zirruswolken - Schafe.

${ }^{31}$ Gefüllte Schalen (por flores); Arkturus (por verano).

${ }^{32}$ Aus dem Nest gestürzter - in ihrer Hut; glüht/sommert - küblt.

${ }^{33}$ Rubt-rubt.

${ }^{34}$ Kümmel - Kleid - Kräftiger - Kamille; Zeisig - Ziege; Elfenbeinen - Engelwurz.

35 "Elfenbeinen" es un adverbio denominativo de Elfenbein (marfil). "Sommert" es un verbo 
denominativo de Sommer (verano). He intentado mantener y reflejar el carácter particular de estos neologismos en mi traducción: "cual marfil", "estivalea".

${ }^{36}$ Para la resurrección del joven por Asclepio a petición de Ártemis, cf. VERG. Aen. VII 761-782; OVID. met. XV 531-546; OVID. fast. VI 737-762; PAUS. II, 27, 4; II 32, 4, entre otros. Hipólito es trasladado al bosque sagrado de Aricia y recibe el nuevo nombre de Virbio. Cf. F. MOYA DEL BAÑO, Estudio mitográfico de las Heroidas de Ovidio, Murcia, Universidad, 1969 , pp. 32-36. Para el santuario y bosque sagrado de Diana en Nemi y las dos divinidades menores que allí se encuentran (la ninfa Egeria y Virbio), cf. J. G. FRAZER, La rama dorada, Méjico, Fondo de Cultura Económica, 2001 (traducción de E. y T. I. Campuzano), pp. 23-28. Para su relación con el mito de Hipólito, cf. ibidem, pp. 28-31.

37 "Hippolyt, einzig dem Dienste der unberührten Artemis geweiht, wird von seiner Stiefmutter geliebt und verdächtigt und auf Verlangen seines Vaters von Poseidon getötet. Artemis bringt ihn wieder ins Leben”. (Cita en SCHÄFER, art. cit., p. 466).

38 Cf. F. WOTKE, "Phaidra", RE XIX 2 (1938), col. 1543-1552: "Die künstlerisch wertvollsten Hippolytos-Sarkophage befinden sich in Agrigento (Robert Nr. 152) und in Petersburg" (col. 1551).

${ }^{39}$ Goethe, quien vio el sarcófago en abril de 1787, escribió en su Italienische Reise: "Dann führte er uns [...] zum Kunstgenuß in die Hauptkirche. Diese enthält einen wohlerhaltenen Sarkophag, [...] Mich dünkt von halberhabener Arbeit nichts herrlicheres gesehen zu haben" (JOHANN WOLFGANG VON GOETHE, Gedenkausgabe der Werke, Briefe und Gespräche: Die Italienische Reise, Die Annalen. Zúrich, Artemis-Verlag, 1950, p. 299).

${ }^{40}$ La tercera versión es un relato de Wolfgang Koeppen, del cual se publicaron dos versiones muy distintas: W. KOEPPEN, Der Sarkophag der Phädra. Erzählung (erste Fassung, ?), en id., Auf dem Phantasieross. Prosa aus dem Nachlass, Fráncfort/Meno, Suhrkamp, 2000, pp. 350-363 y Der Sarkophag der Phädra. Erzählung (zweite Fassung, 1950), en id., Gesammelte Werke in sechs Bänden. 3: Erzählende Prosa, Fráncfort/Meno, Suhrkamp, 1986, pp. 173-187.

${ }^{41}$ Para la vida y obra de Kaschnitz, cf. U. SCHWEIKERT (ed.), Marie Luise Kaschnitz, Fráncfort/Meno, Suhrkamp, 1984; E. PULVER, Marie Luise Kaschnitz, Múnich, C. H. Beck, 1984.

${ }^{42}$ La obra se publicó en 1946. En su "Vorwort" explica la autora: "Die Auswahl der von mir in diesem Buche behandelten mythologischen Gestalten ist auf eine durchaus persönliche Weise erfolgt. Was immer mich beim Lesen der griechischen Sagen und ihrer späteren Umdichtungen am unmittelbarsten berührte, habe ich neu aufzuzeichnen und auf meine Art zu deuten versucht" (M. L. KASCHNITZ, Griechische Mythen, Hamburgo, Claassen, 1975, p. 7).

${ }^{43}$ Griechische Mythen, op. cit., pp. 104-110.

${ }^{44}$ Cf. Griechische Mythen, op. cit., p. 105: "Phaidra, über dem Abgrund aufgehängt, griff mit beiden Händen in namenloser Angst nach dem Strick".

${ }^{45}$ M. L. KASCHNITZ, Orte, Fráncfort/Meno, Insel Verlag, 1973. También en español en traducción de Fruela Fernández: Lugares, Valencia, Pre-textos, 2007. Cf. ibídem, p. 219: "Íbamos de un templo a otro y yo imaginaba cómo habría sido todo entonces, en el tiempo de los templos” [Traducción de F. Fernández].

${ }^{46}$ Cf. ibídem, p. 219: "Cuando regresábamos a la ciudad, hacia el atardecer, había en la catedral un oficio funeral ante un catafalco. En el pequeño cuarto vecino, donde se guarda el sarcófago de Fedra, ya había oscurecido, y el sacristán encendía un hachón. En la hermosa, cálida luz vimos a Hipólito junto a su atelaje y a la muchacha que, tan severa y aplicada, le acerca su lanza. En una de las partes angostas, Fedra con Ana y, en la otra, de nuevo el atelaje y la cabeza del mostro marittimo que tan mortalmente lo aterra" [Traducción de F. Fernández].

${ }^{47}$ MARIE LUISE KASCHNITZ, Agrigent (1957) en id. (1985), Gesammelte Werke V. Die Gedichte, Fráncfort/Meno, Insel, 1985, pp. 266 s.

${ }^{48}$ Para la colección Neue Gedichte, cf. PULVER, op. cit., pp. 66-73.

${ }^{49}$ Cf. PULVER, op. cit., p. 48: "Die Natur enthält für sie Bezauberndes und Beruhigendes so gut wie Gewalttätiges und Bedrohliches; das Erschrecken gehört zu ihrem Naturerleben wie die Freude. [...] Verbindung von lustvollem Erschrecken und beängstigtem Entzücken”.

${ }^{50}$ Para la vida y obra de Empédocles, cf. DIOG. LAERT. VIII, 2, 51-77. De la leyenda de 
que Empédocles se suicidara arrojándose al volcán Etna, se hacen eco la tragedia Der Tod des Empedokles (1800) de Friedrich Hölderlin y el poema Der Schuh des Empedokles (1936) de Bert Brecht. Para las diferentes versiones acerca de su muerte, cf. DIOG. LAERT. VIII, 2, 74 s.

${ }^{51}$ Cf. Lugares, op. cit., pp. 219 s.: "Por la ventana se veía la zona montañosa cruzada por las luces del ferrocarril y de los lugares lejanos. Pensamos en aquel muchacho de la balada de Schiller, que, justo allí, a través de tales aguaceros y riadas, seguía imperturbable su sendero" [Traducción de F. Fernández]. Se refiere a la balada Die Bürgschaft (El aval, 1799), que adapta libremente la leyenda de Mero y Selinuntio, según fue contada por HYG. fab. 257,3-8.

${ }^{52}$ También la estrofa 3 mezcla efectos acústicos (la voz que trata de retener a Empédocles) con otros visuales (aparición de los protagonistas a la luz de antorchas y velas). En la estrofa 5, en cambio, predominan las imágenes visuales. Todo ello mientras suenan las "grisáceas oraciones de las sombras" (obsérvese la hipálage).

${ }^{53}$ En medio de la oscuridad (kein Licht, graue Gebete, Schatten, erloschen im Fenster die Stadt, erloschnen Lagerfeuer), son escasas y temblorosas las luces que iluminan el escenario: velas, antorchas y los faros de algún que otro coche en la distancia.

${ }^{54}$ ERICH ARENDT, Der Sarkophag (Agrigent) (1973/4) en id. (1977), Memento und Bild. Gedichte, Darmstadt, Agora, 1977, pp. 32-34.

${ }^{55}$ Para la vida y obra de Arendt, cf. G. LASCHEN - M. SCHLÖSSER (eds.), Der zerstückte Traum. Für Erich Arendt zum 75. Geburtstag, Berlín/Darmstadt, Agora, 1978; H. RÖDER (ed.), Vagant, der ich bin. Erich Arendt zum 90. Geburtstag, Berlín, G. Wolf janus press, 1993.

${ }^{56}$ LASCHEN - SCHLÖSSER, op. cit., p. 23.

57 Para la lengua de Arendt, cf. G. WOLF, "Ein Wort voraus"; A. F. KELLETAT, "Schelmgewoge und Lendenmäulchen”; S. H. KASZYNSKI, "Die Schlüsselworte im Spätwerk Erich Arendts”, en RÖDER, op. cit., pp. 14-24; 30-50; 55-67 (respectivamente).

${ }^{58}$ Cf. F. J. RADDATZ, "Erich Arendt - Mahner zum Traum", en LASCHEN SCHLÖSSER, op. cit., pp. 11-20, sobre todo, pp. 16 s.

${ }^{59}$ Arendt se encuentra en la valle dei templi de Agrigento, que alberga una hilera de templos griegos datados en los siglos VI y $\mathrm{V}$ a. C.

${ }^{60}$ Es frecuente en los poemas de Arendt que parte del texto aparezca entre paréntesis; habitualmente se trata de comentarios del autor, digresiones temáticas, etc. Aquí alude a algún ataque cartaginés, probablemente en el transcurso de las guerras púnicas (264-146 a. C.).

${ }^{61}$ Cf. PAUS. I, 22, 2 y II, 32, 3. Según el autor griego, Fedra agujereó con el alfiler de sus cabellos las hojas de un mirto que crecía junto al templo de Afrodita en Trecén mientras contemplaba, loca de pasión, los ejercicios deportivos de Hipólito quien todavía no sabía nada. Arendt, en cambio, parece ambientar esta actitud después de la declaración de amor. Como sea, ambos momentos se caracterizan por la gran agitación emocional de la mujer, que trata de dar salida a su nerviosismo arremetiendo contra la planta.

${ }^{62}$ Cf. A. ENDLER, “Der sterbende Dichter”, en RÖDER, op. cit., pp. 162-177, sobre todo, pp. 174 s.

${ }^{63}$ KARL KROLOW, Gute Nacht (1975) en id. (1985), Gesammelte Gedichte III, Fráncfort/ Meno, Suhrkamp, 1985, p. 26.

${ }^{64}$ Para la vida y obra de Krolow: R. PAULUS - G. KOLTER, Der Lyriker Karl Krolow. Biographie, Werkentwicklung, Gedichtinterpretation, Bibliographie, Bonn, Bouvier, 1983; H. L. ARNOLD (ed.), Karl Krolow, Text+Kritik 77, Múnich, 1983.

${ }^{65}$ Entre los recursos estilísticos destaca particularmente la sinestesia (combinación de efectos ópticos, táctiles, olfáticos y psicológicos), que no hace sino reforzar la inmediatez y universalidad de las sensaciones a la vez que añade un matiz surrealista de desconcierto y confusión. El poema comparte con los de Kaschnitz y Arendt la oposición entre luz (Nur weiße Zähne leuchten, Osrambirnen glühen) y oscuridad (nachts).

${ }^{66}$ Cf. P. RÜHMKOPF, texto de portada de KROLOW, Gesammelte Gedichte 2, op. cit.

${ }^{67}$ Mediante los nombres propios, Krolow se refiere metafóricamente a los desgraciados y mortíferos amores de Fedra y Werther. Éste es el protagonista de la novela Die Leiden des jungen Werther de J. W. v. GOETHE (1773; Los padecimientos del joven Werther, traducción de E. J. González García, Madrid, Akal, 2008). Werther es el símbolo de un corazón sensible y 
apasionado que ama sin esperanza (su amada Lotte está prometida con otro), y de un espíritu impulsivo, rebelde y orgulloso que no logra adaptarse a la sociedad en la que vive (la burguesía ilustrada de finales del s.XVIII).

${ }^{68}$ Observaré que se trataría de una interpretación poco habitual del mito de Fedra.

${ }^{69}$ Según esta interpretación, el deseo "buenas noches" adquiere un acusado tono irónico, que es un recurso frecuente en los poemas de Krolow.

70 "Der Leser soll also nicht peinlich genau rekonstruieren, was der Autor einbrachte, sondern in der Auseinandersetzung mit den allgemein vorstrukturierten Elementen die eigene Erfahrung einbauen und eigene Erkenntnis aufbauen" (cita en PAULUS - KOLTER, op. cit., p. 53).

${ }^{71}$ OSKAR PASTIOR, voltaire von der augenscheide (ca. 1986) en id. (1991), Feiggehege. Listen, Schnüre, Häufungen, Berlín, Literarisches Colloquium, 1991, pp. 27-30.

${ }^{72}$ Para la vida y obra de Pastior, cf. H. L. ARNOLD (ed.), Oskar Pastior, Text+Kritik 186, Gotinga, 2010.

${ }^{73}$ Cf. O. PASTIOR, “Nachwort”, en id., Feiggehege. Listen, Schnüre, Häufungen, op. cit., pp. 99-104: "Die hier gesammelten Texte sind [...] am Rande der letzten vier, fünf Jahre ins Kraut geschossen” (p. 103).

${ }^{74}$ Para el grupo de OULIPO y la relación de Pastior con el mismo (es miembro a partir de 1994), cf. H. MATHEWS, "Oskar oulipotisch"; T. STRÄSSLE, "Werkstatt für potenzielle Übersetzung. Pastior intoniert Baudelaire”, en ARNOLD 2010, op. cit., pp. 47-49 y 83-93, respectivamente.

${ }^{75}$ En este sentido nos encontramos con poemas en los que el aspecto sonoro predomina sobre el semántico (clara influencia del Dadaísmo), y otros, en los que sucede al contrario (cercanos al Surrealismo). Hay también criterios de restricción ajenos al ámbito filológico (cantidad de letras fija, esquemas basados en cálculos matemáticos, etc.).

${ }^{76}$ Cf. L. HARIG, texto de portada en O. PASTIOR, Ein Tangopoem und andere Texte, Berlín, Literarisches Colloquium, 1978: "Ein jahrelanger unbedachter übertragener Gebrauch hat uns die Wörter der Sprachen nur noch als Metaphern erscheinen lassen. Dieser verhüllte, dieser verhüllende Gebrauch hat uns vom ursprünglichen Wortsinn entfernt. [...] Pastior führt uns wieder zur Ursprünglichkeit von Sprache zurück".

77 "Listenartigen Charakter" (PASTIOR, "Nachwort", art. cit., p. 103).

${ }^{78}$ PASTIOR, "Nachwort”, art. cit., p. 103. Al género del "Suchbild” pertenecen, por ejemplo, las famosas imágenes de la colección ¿¿Dónde está Wally?

${ }^{79} \mathrm{La}$ ortografía alemana exige mayúscula para la primera letra de los sustantivos y de todo término sustantivado.

${ }^{80}$ kalter - psalter - haber - kuble - kalber; rodel-nudel-ruder - rudel; etc.

${ }^{81}$ Las palabras ficticias presentan habitualmente alguna base conocida y reconocible: kalber (de Kalb-ternera); foreller (de Forelle - trucha); walden (de Wald-bosque); etc.

${ }^{82}$ bonsai, kiefer, ahorn, staude, eibe, wirsing, flieder, aster, bambus, dattel.

${ }^{83}$ assel, rabe, kondor, flunder, keiler, zander, panda, pudel, meise, falter, zeisig, panther, hamster, rüde, zobel, rudel, flosse, pansen, motte, köter, euter.

${ }^{84}$ kongo, london, wannsee, büsum, lindau, fulda, donau, lima, torgau, spandau, hügel, heide.

${ }^{85}$ geiler, steifer, spanner, sado, dildo, vulva.

${ }^{86}$ voodoo, zombi, turban, walker, reader, halwa, funghi, double, wigrwam, high-fi, stalker. Acerca de la inclusión de términos extranjeros en la obra de Pastior, cf. A. GILBERT, "Ich lobe mir das Gemenge'. Polyglotte Auf- und Ausbrüche in Oskar Pastiors Dichtung”, en ARNOLD 2010, op. cit., pp. 72-82. Resume la autora: "Der experimentelle Sprachkünstler war immer auch polyglotter Sprachenkünstler" (p. 72).

${ }^{87}$ rheuma, phono, thorax y quantum, pudor, tandem, tangens, limes, tibia. 


\title{
BREVITAS, LONGITUDO, ETC., COMO TECNICISMOS PROSÓDICOS ${ }^{1}$
}

\author{
Francisco Fuentes Moreno \\ Universidad de Granada
}

1. El sustantivo brevitas, derivado de brevis, se halla documentado en latín desde $\mathrm{Accio}^{2}$. Es utilizado ampliamente en época clásica con el significado de "brevedad", referido tanto al espacio como al tiempo:

Caes., civ. 1, 82, 3 spatii brevitas etiam in fugam coniectis adversariis non multum ad summam victoriae iuvare poterat, Cic., Verr. 6, 26 diei brevitas conviviis, noctis longitudo stupris ... continebatur.

Como tecnicismo prosódico es frecuente en gramáticos y rétores, con el sentido de "brevedad, carácter breve de una vocal o sílaba". Tiene su correlato griego en $\beta \rho \alpha \chi u ́ \tau \eta \varsigma^{3}$ Con este sentido puede verse ya en la Rhetorica ad Herennium en el siguiente pasaje, en el que aparece opuesto a productio:

4, 21, 29 Adnominatio est, cum ad idem uerbum et nomen acceditur commutatione uocum aut litterarum, ... Productione eiusdem litterae < hoc modo : binc auium dulcedo ducit ad auium'. Breuitate eiusdem litterae >: 'bic, tametsi uidetur esse honoris cupidus, tantum tamen curiam diligit, quantum Curiam?

Frecuentemente aparece también en oposición a longitudo en el mismo contexto, como veremos más adelante al hablar de este término.

2. Correptio, formado a partir del verbo corripio 4 , tiene el significado general de "acción de coger", y con ese sentido puede leerse, por ejemplo, en Gelio (20, 10). El término está documentado en latín desde Vitrubio, donde aparece con el significado de "disminución":

Arch. 9, 8, 7 sin autem cuneorum adiectionibus et detractionibus correptiones dierum aut crescentiae + ex cuneis non probabuntur fieri, quod cunei saepissime vitia faciunt, sic erit explicandum.

De ahí deriva el significado de "abreviamiento", "acción de pronunciar breve una vocal o sílaba", con que habitualmente suele ser empleado en los textos gramaticales. Con este sentido aparece en la obra de Quintiliano. En los dos ejemplos que siguen correptio se halla en contraposición a productio:

Inst. 7, 9, 13 productio quoque in scripto et correptio in dubio relicta causa est ambiguitatis, ut in hoc 'cato'. alium enim ostendit brevis secunda syllaba casu 
nominativo, <alium eadem syllaba producta casu dativo aut ablativo.>

9, 3, 69-70 aliter quoque voces aut eaedem diversa in significatione ponuntur aut productione tantum vel correptione mutatae: quod etiam in iocis frigidum equidem tradi inter praecepta miror, eorumque exempla vitandi potius quam imitandi gratia pono: 'amari iocundum est, si curetur ne quid insit amari.' 'avium dulcedo ad avium ducit', et apud Ovidium ludentem: cur ego non dicam, Furia, te furiam?

Correptio es el término que utilizan normalmente los gramáticos para definir el metaplasmo denominado systole ${ }^{5}$ así, Diomedes:

GLK I 442, 5 Systole est correptio contraria ectasi;

Elio Donato:

GLK IV 396, 16 Systole est correptio contraria ectasi, ut 'aquosus Orion', cum Orion producte dici debeat;

Julián de Toledo:

p. 193, 54 (ed. Maestre Yenes) Systole est correptio, contraria ectasi, ut "aquosus Orion", cum Orion producte dici debeat,

Isidoro de Sevilla:

Etym. 1, 35, 4 (ed. Lindsay) Systole correptio contra naturam, ut: [urbemque Fidenam", cum prima syllaba produci debet];

Aparece igualmente en los comentarios a Donato del siglo IX: así, en Sedulio Escoto:

In Donati artem maiorem, p. 357, 22 (ed. Löfstedt) systole est correptio syllabae contra naturam uerbi contraria ectasi ut aquosus Orion cum Orion producte dici debeat;

en el Ars Laureshamensis, Expositio in Donatum maiorem:

p. 215, 10 (ed. Löfstedt) SISTOLE ESTCORREPTIO CONTRA NATVRAM VERBI CONTRARIA ECTASI, VT AQVOSVS ORION, CVM ORION PRODVCTE DICI DEBEAT;

o en Murethach:

In Donati artem maiorem, p. 226, 55 (ed. Holtz) SISTOLE ESTCORREPTIO CONTRA NATVRAM VERBI CONTRARIA ECTASI, VT AQVOSVS 


\section{ORION, CVM ORION PRODVCI DEBEAT;}

O incluso más adelante, como en Hugo de San Víctor (s. XI-XII):

De grammatica, p. 145, 2083 Systole est correptio contra naturam uerbi contraria ectasi ut cum subito assurgens fluctu nimbosus Orion cum Orion primo producte dici debeat ${ }^{6}$.

Como sinónimo de correptio es utilizada también por los gramáticos la expresión detractio temporis.

Detractio, formado a partir de detrahere, significa "acción de detraer, restar, sustraer, suprimir”. Este término técnico de la gramática y de la retórica, documentado a partir de Cicerón ${ }^{7}$, es frecuente en los textos gramaticales tardíos:

Audax, GLK VII 362, 11 Quot modis fit barbarismus? [...] detractione temporis, ut si dicamus correpta media syllaba emerunt, cum producta emerunt dici debeat.

Charis., gramm., p. 350, 6 (ed. Barwick-Kühnert) barbarismus fit modis quattuor [...]detractione temporis, ut $(A .8,677)$ 'fervere Leucaten' pro fervere producta e littera;

Diom., GLK I 452, 14 detractionis species sunt aeque quattuor, detractione temporis litterae syllabae adspirationis: temporis, ut siquis dicat fervere correpte, cum produci debeat media syllaba, ut 'fervere Leucaten';

Donat., GLK IV 392, 10 [...] funt barbarismi, [...] per detractionem ... temporis, ut 'unius ob noxam' pro unius:

Mar. Victor., soloec., p. 36, 16 (ed. Niedermann) quid detractione temporis? ut si dicamus "emerunt" correpta media syllaba, cum "emerunt" producta dici debeat.

Ps.Aug., Ars breuiata 11, 2 (ed. Weber) Aut si dicat pone et primam syllabam corripiat detractione temporis,

Consent., barbar., p. 5, 17 (ed. Niedermann) ex his duo primi sunt (metaplasmi), unus qui temporis adiectione, alius qui detractione consistit.

Consent., barbar., p. 11, 13 (ed. Niedermann) per detractionem funt barbarismi sic: [...] temporis, ut siquis dicat orator correpta priore syllaba, quod ipsum vitium Afrorum speciale est;

Iul. Tol., gramm. p. 180, 39 (ed. Maestre Yenes) Per detractionem temporis, ut: "Unius ob noxam" pro unius; 'ni' enim syllaba naturaliter longa est, et loco breuis est posita.

3. El término adbreviatio, creado sobre el verbo adbreuiare ${ }^{8}$, no parece documentarse antes del siglo IV. Con el sentido de "resumen" puede verse en la obra del luciferiano Faustino:

Trinit. 48, 2 quia non ut librum, sicut praedixi, scribere coeperam, sed ut quasi cuiusdam adbreuiationis de fide quaedam taxatio signaretur, ne ad hoc me de tua mira beneuolentia prouocatum infidelem crederes, si tacerem. 
Varias veces aparece en la Biblia Vulgata con el significado de "disminución”; así, por ejemplo, en:

Is.10, 23 consummationem enim et adbreviationem Dominus Deus exercituum faciet in medio omnis terrae.

Estos son los dos sentidos con que abbreviatio es recogido en el ThlL9 .

Como tecnicismo prosódico se encuentra en un pasaje del Commentum Einsidlense in Donati barbarismum (s. X):

GLKVIII 267, 4 (ed. Hagen) Systole est correptio i(dest) adbreuiatio. Contraria ectasi, ut aquosus Orion, cum Orion antepaenultima producte dici debeat.

Aquí, como puede observarse, correptio, que sirve para definir la systole, es glosado por el término adbreviatio ${ }^{10}$.

4. Contractio, sustantivo formado a partir de contrahere, se documenta en latín desde Cicerón. Tiene el sentido general de "acción de contraer", frecuentemente referido a los miembros del cuerpo ${ }^{11}$ :

Cic., Sest., 19 tanta erat gravitas in oculo, tanta contractio frontis, ut illo supercilio annus ille niti tamquam <vade> videretur.

Con el sentido de "acción de unir, aglutinar" puede verse, por ejemplo, en Diomedes:

GLK I 442, 20 Episynaliphe est conglutinatio seu contractio duarum syllabarum in unam syllabam facta contraria synaliphe, ut fixerit aeripedem cervam licet, cum aeripedem quinque syllabas dicere debeamus.

Como tecnicismo prosódico aparece en algunos casos con el sentido de "acción de abreviar" una vocal o una sílaba; equivalente, por tanto, a correptio, y en oposición a productio:

Cic., de Or. 3,196 at in iis si paulum modo offensum est, ut aut contractione brevius fieret aut productione longius, theatra tota reclamant.

Consent., nom., GLK V 347,1 non dissimili ratione est etiam productio aut contractio syllabae in eadem dictione, quae sub uno genere diversa significat, ut 'pressos propaginis arcus': si proprie loquaris, producas necesse est; si translative, corripias, ut est 'Itala virtute propago'. 
5. Longitudo (correspondiente al gr. $\mu \tilde{\eta} \kappa o \varsigma$ у $\mu \alpha \kappa \rho o ́ \tau \eta \varsigma^{12}$, está formado sobre el adjetivo longus y tiene el sentido de "longitud, largura, extensión", E1 término, documentado desde Plauto, se utiliza tanto en un sentido local como temporal ${ }^{13}$. En los gramáticos hace referencia al "carácter largo", "pronunciación como larga”, de una vocal o sílaba.

Con este sentido se opone frecuentemente a brevitas. Ejemplo de ello tenemos en Cicerón:

Or. 173: in versu quidem theatra tota exclamant, si fuit una syllaba aut brevior aut longior; nec vero multitudo pedes novit nec ullos numeros tenet nec illud quod offendit aut cur aut in quo offendat intellegit; et tamen omnium longitudinum et brevitatum in sonis sicut acutarum graviumque vocum iudicium ipsa natura in auribus nostris collocavit ${ }^{4}$;

a menudo en los gramáticos:

Scaur., De orth., GLK VII 18,12 Primum igitur per adiectionem illa videntur esse vitiosa, quod Accius geminatis vocalibus scribi natura longas syllabas voluit, cum alioqui adiecto vel sublato apice longitudinis et brevitatis nota posset ostendi.

Mar. Victorin. - Aphtonio, GLK VI 39,7 nam musici non omnes inter se longas aut breves pari mensura consistere, siquidem et brevi breviorem et longa longiorem dicant posse syllabam fieri; metrici autem, prout cuiusque syllabae longitudo ac brevitas fuerit, ita temporum spatia definiri neque [brevi] breviorem aut [longa] longiorem, quam natura in syllabarum enuntiatione protulit, posse aliquam reperiri. Mall. Theod., De metris, GLKVI 588,5-6 ex his enim pedibus, qui ex brevibus aut ex longis syllabis ita conficiuntur, ut in his brevitatis et longitudinis varietas nulla sit, nisi ex longis et brevibus syllabis temperati adiungantur pedes, metrum omnino effici non potest.

Eutyches, Ars de uerbo, GLK V 478,18 in quibus notantur demo demis, promo promis, quia ab eo quod est emo secundum quosdam composita longitudinem praepositionis servaverunt, sicut perimo perimis brevitatem: quibusdam non ab eo videntur composita.

Aug., De ordine, 2,14,40 recognouit binc esse illa semina, quae in grammatica, cum syllabas diligenti consideratione uersaret, pedes et accentus uocauerat, et quia in ipsis uerbis breuitates et longitudines syllabarum prope aequali multitudine sparsas in oratione attendere facile fuit, temptauit pedes illos in ordine certos disponere atque coniungere, et in eo primo sensum ipsum secuta moderatos inpressit articulos, quae caesa et membra nominant.

Posteriormente se documenta también en textos técnicos de época carolingia; así, en el capítulo De pedibus del Ars Laureshamensis, Expositio in Donatum maiorem (s. IX): 
Pars 1, p. 170, 14 (ed. Löfstedt) Quo nomine appellatur iste pes (trocheus), eo quod a longitudine incipiens ut tractus rotae in breuitatem terminetur ceu rota.

El mismo texto aparece en el comentario a Donato de Murethach (s. IX), In Donati artem maiorem:

Pars 1, p. 30, 20 ss. (ed. Holtz) Quo nomine appellatur iste pes (trocheus), eo quod a longitudine incipiens ut tractus rotae in breuitatem terminetur ceu rota. [...] Huic (tribracho) contrarius est molossus. Contrarius dicitur illi, quia sicut ille ex breuitate ita e contrario iste ex longitudine consistat;

también en el Ars grammatica de Donato Ortígrafo (s. IX?):

De littera, 1.623 (ed. Chitenden) DISCIPULUS. Vtrum suum sonum obseruant proprium uocales apud Latinos quando breues sunt et quando longae? MAGISTER. Tres de ipsis suum sonum obseruant in longitudine et in breuitate: $A$ IV;

De syllaba, 1.38 DISCIPULUS. Quot modis possumus intellegere regulam partium orationis in longitudine et breuitate?; 1.153 Quae enim nascuntur ab aliis regulam primae positionis obseruant in longitudine et breuitate.

6. Productio, formado sobre producere, está documentado en latín desde la Rhetorica ad Herennium, Cicerón o Varrón ${ }^{15}$; tiene el sentido de "alargamiento, prolongación". Es un término usado habitualmente por los gramáticos para referirse al "alargamiento" o "pronunciación como larga" de una vocal o sílaba; así, por ejemplo:

Rhet. Her. 4, 21, 29 Productione eiusdem litterae < hoc modo: hinc auium dulcedo ducit ad auium'

Gell., Att., 2, 17, 9 Praeterea 'coligatus' et 'conexus' producte dicitur. Sed tamen videri potest in his, quae posui, ob eam causam particula haec produci, quoniam eliditur ex ea $n$ littera: nam detrimentum litterae productione syllabae compensatur.

Ejemplos como éstos se repiten en los textos gramaticales. En muchos de ellos productio se halla en oposición a correptio dentro del mismo contexto: así, en Quintiliano:

Inst., 7, 9, 13 productio quoque in scripto et correptio in dubio relicta causa est ambiguitatis, ut in hoc 'cato'. alium enim ostendit brevis secunda syllaba casu nominativo, <alium eadem syllaba producta casu dativo aut ablativo.> plurimae praeterea sunt aliae species, quas persequi nibil necesse est.

9, 3, 69 aliter quoque voces aut eaedem diversa in significatione ponuntur aut 
productione tantum vel correptione mutatae: quod etiam in iocis frigidum equidem tradi inter praecepta miror, eorumque exempla vitandi potius quam imitandi gratia pono: 'amari iocundum est, si curetur ne quid insit amari.' 'avium dulcedo ad avium ducit', et apud Ovidium ludentem: cur ego non dicam, Furia, te furiam?

\section{Velio Longo:}

Orth., GLK VII 47, 18 ac primum eadem est nostrarum potestas vocalium, quae fuit Graecorum apud antiquos circa correptionem productionemque, siquidem apud illos quinque tantum fuere vocales, $\alpha \varepsilon 10 v$, atque hae similiter producebantur corripiebanturque, sicut hodieque $\alpha 1 v$, quae appellantur apud illos kolvaí;

\section{Terenciano Mauro:}

GLKVI 329, 121 O Graiugenum longior altera est figura, alter sonus est et nota temporum minori, compendia nostri meliora crediderunt, vocalibus ut non nisi quinque fungeremur; productio longis daret ut tempora bina, correptio plus tempore non valeret uno;

\section{Sacerdote:}

GLK VI 451, 4 Barbarismus est vitiosa dictio unius verbi, qui fit modis octo: per productionem, ac si dicas pernix <et> per producas, quae correpta est: per correptionem, steterunt te correpta, quae longa est....;

Y, al igual que en éstos, en Ps.Valerio Probo (GLKIV 259, 3), Diomedes (GLKI 308, 13; 308, 14; 309, 5; 434, 6) o Pompeyo Mauro (GLKV 296, 26).

En alguna ocasión productio se opone a brevitas en el mismo contexto; es el caso del siguiente pasaje de la Rhetorica ad Herennium ${ }^{16}$, con el que ejemplificábamos antes el sentido prosódico del término brevitas:

4, 21, 29 Adnominatio est, cum ad idem uerbum et nomen acceditur commutatione uocum aut litterarum, ... Productione eiusdem litterae < hoc modo : hinc auium dulcedo ducit ad auium'. Breuitate eiusdem litterae >: 'bic, tametsi uidetur esse honoris cupidus, tantum tamen curiam diligit, quantum Curiam?

Por último, y como ya hemos señalado, también se halla productio en oposición a contractio. 
Productio es usado también por algunos gramáticos para traducir o definir el metaplasmo ectasis: ${ }^{17}$ así, por ejemplo, Pompeyo Mauro:

GLKV 297, 17 ectasis est in illa syllaba, 'Italiam fato profugus': i naturaliter brevis est, sed ubique producitur, et fit ectasis, id est productio;

San Isidoro de Sevilla:

Etym. 1, 35, 4 Ectasis, productio contra naturam, ut: ["exercet Diana choros"];

o Hugo de San Víctor:

De grammatica, 18, p. 145, 2079 (ed. Baron) Ectasis est productio syllabe contra naturam uerbi ut 'Italiam fato profugus Lauinaque uenit littora' cum Italia primo correpte dici debeat.

Sin embargo, la mayoría de los gramáticos describen el fenómeno utilizando no el sustantivo productio, sino el verbo producere:

Sacerd., GLK VI 452, 17 Ectasis est, cum corripienda syllaba producitur metri causa, ut 'religione patrum multos servata per annos', ut re producatur, quae semper correpta pronuntiatur, et 'reliquias Danaum'.

Ps.Prob., GLK IV 263, 17 Ectasis est, cum per licentiam brevis producitur, ut 'exercet Diana choros'.

Charis., gramm., p. 367, 8 (ed. Barwick-Kühnert) Ectasis est cum correpta syllaba contra rationem producitur, ut $(A .1,499)$ 'exercet Diana choros', et $(A .1,478)$ 'versa pulvis inscribitur hasta';

Remigius Autissiodorensis, Commentum Einsidlense in Donati barbarismum (= Comm. in Donati artem maiorem sec. cod. Einsidlensem 172, liber III) p. 267, 2 Sed Virgilius ectasin faciens contra naturam produxit.

o formas similares:

Consent., barbar. p. 5, 19 (ed. Niedermann) ectasis est, | cum correpta syllaba poeta sic auctoritate sua utitur, tamquam sit temporis longioris, ut est Italiam fato profugus'...

Pomp., GLKV 297, 14 ectasis dicitur, quotiens naturaliter brevis syllaba est, et nos illam longam facimus.

Como sinónimo de productio es utilizada también la expresión adiectio temporis. Adiectio, formado a partir de adicere, tiene el sentido general de "acción de añadir"18. Los gramáticos usan la expresión adiectio temporis de forma 
habitual en el capítulo De barbarismis. Es en especial ilustrativo el primero de los pasajes que siguen, en el que el gramático Diomedes glosa dicha expresión precisamente con el término productio:

Diom., GLK I 451, 33 ss. || barbarismus fit modis principalibus quattuor, adiectione detractione mutatione transmutatione. adiectionis species sunt quattuor, [aut] per adiectionem temporis sive productionem, per adiectionem litterae, per adiectionem syllabae, per adiectionem adspirationis. adiectione temporis sive productione fit hoc modo, ut "Italiam fato profugus"; i enim prima syllaba cum corripi debeat, producta est, id est, cum habere debeat tempus unum, habet duo:

Son parecidos los ejemplos que pueden rastrearse en los textos gramaticales de la latinidad tardía y altomedieval:

Audax, GLK VII 362, 9 adiectione temporis, ut 'exercet Diana chorum': producta enim di geminatur tempus syllabae, cum correpte Diana dici debeat.

Charis., p. 350, 6 (ed. Barwick-Kühnert) barbarismus fit modis quattuor, adiectione detractione transmutatione inmutatione: adiectione temporis, ut (A. 1 , 2) 'Italiam fato profugus', cum Italia corripi debeat,

Donat., GLK IV 392, 10 per adiectionem ... funt barbarismi, ... temporis, ut 'Italiam fato profugus', cum Italiam correpta prima littera dicere debeamus:

Mar. Victor., soloec., p. 36, 8 (ed. Niedermann) quomodo adiectione temporis? ut "exercet Diana choros"; producta enim "di" geminabitur tempus syllabae, cum correpte "Diana" dici debeat.

Ps.Aug., Ars breuiata, 11, 2 (ed. Weber) Aut si dicat pone et primam syllabam corripiat detractione temporis, barbarismus est, aut si dicat bonus et primam syllabam producat adiectione temporis, uitium est, aut si enuntiet nomen et nullam in eo acuat syllabam, acuminis detractione peccat.

Consent., barbar., p. 11, 3ss. (ed. Niedermann) per adiectionem litterae sic fit (barbarismus), ut...; temporis, ut quidam dicunt piper producta priore syllaba, cum sit brevis, quod vitium Afrorum familiare est;

Iul. Tolet., p. 180, 33 (ed. Maestre Yenes) Per adiectionem temporis, ut: "Italiam fato profugus Lauinia", cum Italiam correpta prima littera dicere debeamus.

Ars Lauresh., barbar., p. 192, 55 (ed. Löfstedt) Adiectio temporis est hic, quia in eo nomine quod est Italia i naturaliter breuis est, sed adicitur illi unum tempus causa necessitatis in metro.

Murethach, In Don., p. 194, 1 (ed. Holtz) Per adiectionem TEMPORIS VT ITALIAM FATO PROFVGVS, CVM ITALIAM CORREPTA PRIMA LITTERA DICERE DEBEAMVS, ne aliquis arbitraretur, quod Aeneas fugiendo pergeret ad Italiam.

Murethach, In Don., p. 195, 5 Adiectio temporis est ibi, quia i correpta est naturaliter, sed adicitur illi unum tempus causa necessitatis in metro.

Sedul. Scott., In Don., p. 327, 70 (ed. Löfstedt) per adiectionem quoque temporis funt barbarismi ut Italiam fato profugus cum correpta prima littera Italiam dicere 
debeamus. [...] adiectio temporis est hic quia in eo nomine quod est Italia i naturaliter breuis est sed adicitur illi unum tempus causa necessitatis in metro.

7. Extensio ${ }^{19}$, tiene el sentido de "acción de extender, alargar", "extensión". Con un sentido temporal, aludiendo al "alargamiento" de una vocal o sílaba, y, en consecuencia, con un significado próximo a productio, aparece en los textos latinos tardíos de gramática y métrica. Así, lo vemos en San Jerónimo, en el que aparece en oposición a brevitas: ${ }^{20}$

Hier., Comm. in IV epistulas Paulinas, Ad Titum, PL 26, col. 594D et si forte errauerimus in accentu, in extensione et breuitate syllabae, uel breuia producentes, uel producta breuiantes, solent irridere nos imperitiae, maxime in aspirationibus in quibusdam cum rasura gulae litteris proferendis.

El mismo texto aparece en el comentario de Sedulio Escoto (s. IX) a las epístolas paulinas:

Sedul. Scot., Collectaneum in Apostolum, In epist. ad Titum, PL 103, 248, 55 et si forte errauimus in accentu extensione et breuitate syllabae uel breuia producentes uel producta breuiantes solent irridere nos imperitiae maxime in spirationibus et quibusdam rasura gulae litteris proferendis.

El término tensio, "tensión", derivado de tendo, parece haber sido creado en época imperial por la lengua de la medicina para traducir el griego tá $\sigma \varsigma^{21}$ (de $\tau \varepsilon i ́ v \omega)$. Del mismo modo extensio, derivado de extendo, es utilizado por los

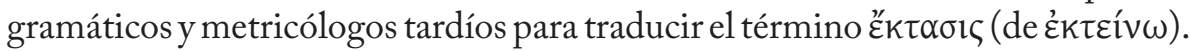
Con este nombre se designa un tipo de metaplasmo, consistente en convertir en larga una sílaba que es breve por naturaleza. Los gramáticos latinos suelen traducir el término normalmente por extensio, y a veces también por productio, como hemos visto anteriormente, y es descrito como un alargamiento contra naturam:

En Diomedes:

GLK I 442,1 Ectasis est extensio, quae fit cum correpta syllaba contra rationem per licentiam producitur, ut exercet Diana choros.

o en Donato:

GLKIV 396,14 Ectasis est extensio syllabae contra naturam verbi, ut 'Italiam fato profugus', cum Italia correpte dici debeat; 
Otros gramáticos se limitan a describir el fenómeno de la ectasis, sin hacer mención de la palabra extensio; es el caso de Sacerdote:

GLK VI 452,17 Ectasis est, cum corripienda syllaba producitur metri causa, ut 'religione patrum multos servata per annos', / ut re producatur, quae semper correpta pronuntiatur, et 'reliquias Danaum';

Servio:

Aen. 1, 343 (p. 121, 5 ed. Thilo-Hagen) sane Sychaeus Sy brevis est per naturam; sed hoc loco ectasin fecit ea licentia quae est in propriis nominibus;

\section{Máximo Victorino:}

gramm., GLKVI 221, 19 interdum in nominibus appellativis prima syllaba contra naturam producitur, quia aliter in versu poni non potest, ut 'Italiam contra' [Verg. Aen. 1, 13 $]^{22}$

Ps.Probo, De ultimis syllabis:

GLK IV 263, 17 Ectasis est, cum per licentiam brevis producitur, ut 'exercet Diana choros'.

Carisio:

p. 367,8 (edd. Barwick-Kühnert 1997 [1964]) Ectasis est cum correpta syllaba contra rationem producitur, ut $(A .1,499)$ 'exercet Diana choros', / et $(A .1,478)$ 'versa pulvis inscribitur hasta'.

\section{Consencio:}

barbar., p. 5, 19 ectasis est, | cum correpta syllaba poeta sic auctoritate sua utitur, tamquam sit temporis longioris, ut est 'Italiam fato profugus' et 'conubia nostra repulit', cum $i$ et $u$ aperte breves sint, ...

o Pompeyo Mauro:

GLK V 297,14 Sunt alii duo inter se contrarii, ectasis et systole. ectasis dicitur, quotiens naturaliter brevis syllaba est, et nos illam longam facimus. ectasis est in illa syllaba, 'Italiam fato profugus': i naturaliter brevis est, sed ubique producitur, et fit ectasis, id est productio. 
Posteriormente el texto de Donato es recogido en distintos comentaristas del gramático: en Julián de Toledo (s. VII):

Gramm., p. 193, 50 (ed. Maestre Yenes) Ectasis est extensio syllabae contra naturam uerbi, ut: "Italiam fato profugus", cum Italia correpta prima littera dicere debeamus;

y en textos ya de plena Edad Media, como son los siguientes comentarios del siglo IX al Ars maior de Donato:

Ars Laur., in Don., pars: 3, p. 215, 4ss. (ed. Löfstedt) Ectasis est extensio syllabae contra naturam verbi, ut Italiam fato profugus, cum "Italia" correpta prima littera dici debeat. Extensio syllabae dicitur ectasis, eo quod breuitas extenditur in longitudinem, sicut bic $i$, cum breue sit naturaliter, extenditur contra naturam, quia saepe erat poeta nominaturus Italiam.

Murethach, In Don. pars 3, p. 225, 42ss. (ed. Holtz) ECTASIS ESTEXTENSIO SYLLABAE CONTRA NATVRAM VERBI, VT ITALLAM FATO PROFVGVS, CVM 'TTALIA' CORREPTE DICI DEBEAT. Extensio syllabae dicitur ectasis, eo quod breuitas extendatur in longitudinem, sicut hic: i, cum breue sit naturaliter, extenditur contra naturam, quia saepe erat poeta nominaturus Italiam.

Sedul. Scott., In Donati artem maiorem, pars: 3, p. 354, 31 (ed. Löfstedt) ectasis extensio.

p. 357, 14 (ed. Löfstedt) ectasis est extensio syllabae contra naturam uerbi ut Italiam fato profugus cum Italia correpte dici debeat.

Remig. Autiss., Commentum Einsidlense in Donati barbarismum (= Comm. in Donati artem maiorem sec. cod. Einsidlensem 172, liber III) p. 267, 2 Sed Virgilius ectasin faciens contra naturam produxit.

8. El término extentio se considera doblete o variante de extensio, sin poder distinguirse claramente cuál es la forma genuina ${ }^{23}$. Escasamente documentado en latín, lo vemos usado como tecnicismo prosódico, equivalente a productio ${ }^{24}$, en la gramática de Mario Victorino - Aptonio en contraposición a brevitas:

GLKVI 45, 12 hi (tribrachys et molossus) temporum inter se brevitate et extentione discrepant; nam prior trium, sequens sex temporum spatio prolatatur, quod in disyllabis in pyrrichio et spondeo docuimus.

9. El sustantivo proceritas "alargamiento, elevada estatura", está formado sobre procerus ${ }^{25}$ "alargado, largo, alto, grande". Es un término usado desde época clásica ${ }^{26}$. Ya Cicerón lo utiliza como tecnicismo prosódico, en oposición a brevitas en un pasaje del orator: 
Cic., or. 212 fluit omnino numerus a primo tum incitatius brevitate pedum tum proceritate tardius. ${ }^{27}$

Este texto es recogido por Rufino de Antioquía (s. V-VI) en su Commentarium de numeris oratorum:

Ruf., GLK VI 570,29 In alio loco sic dicit, "Fluit omnino | numerus a primo tum incitatius brevitate pedum, tum proceritate tardius".

Algunos ejemplos pueden verse en Mario Victorino - Aptonio:

GLK VI 37, 6 nam <aut> brevis syllaba est loco <longae> posita, <aut> positione longa vim | suae proceritatis loci condicione non obtinet;

37, 20 neque enim bic finalem syllabam causatus sis: nam nulla ibi proceritas sonat, ubi vere finalis non est, velut 'arma virumque cano'. quamvis enim ma syllaba partem orationis compleat, tamen, \| quia loco longae posita non est, vim proceritatis capere non potest;

93, 30 igitur secundae coniugationis prima syllaba, quae debet esse brevis, mutatur ea condicione, ut vim suae proceritatis quartae syllabae brevi, quae est ultima primae coniugationis, impertiat; et ipsa quidem brevis remanet facta unius temporis, superiorem autem a se syllabam, quae fuerat brevis, commercio suae proceritatis extendit.

\section{Bibliografía}

Achard, G., 1989: Rhétorique à Herennius, texte établi et traduit, Paris.

Baron, R., 1966: Hugonis de Sancto Victore opera propaedeutica, Public. in Mediaev. Studies, Univ. of Nôtre Dame, XX (Practica geometriae, De grammatica, Epitome Dindimi in philosophiam).

Barwick, C. - Kühnert, F., 1964: Flavii Sosipatri Charisii artis grammaticae libri $V$, edidit Carolus Barwick, editio stereotypa correctior editionis prioris, addenda et corrigenda collegit et adiecit F. Kühnert, Lipsiae.

Bornecque, H. - Courbaud, E., 1971 (1930): Cicéron. De l'orateur, Livre troisième, texte établi par $\mathrm{H}$. Bornecque et traduit par E. Courbaud et $\mathrm{H}$. Bornecque, quatrième tirage, Paris.

Chantraine, P., 1968: Dictionnaire étymologique de la langue grecque. Histoire des mots, Paris.

Chitenden,J.,1982: Donatus ortigraphus, Ars Grammatica, CChr, CM, Turnhout.

D’Arbela, E. V., 1958: M. Tullio Cicerone. L'oratore, edizione critica con 
traduzione e note italiane, Milano.

Fuentes Moreno, F., 2008: “Brevio / corripio: tecnicismos prosódicos en los gramáticos latinos”, Florentia Iliberritana, 19, pp.127-141.

GLK: Grammatici Latini, ed. H. Keil, Leipzig 1855-1880.

Holtz, L., 1977: Murethach (Muridac). In Donati artem maiorem, CChr CM, Turnhout.

Iso,J.J., 2002: Cicerón. Sobre el orador, introducción, traducción y notas, Madrid. Lausberg, H., 1984 (1960): Manual de Retórica Literaria, versión española de José Pérez Riesco, 3 vols., 2a reimpr., Madrid.

Lindsay, W.M., 1911: Isidorus Hispalensis. Etymologiarum siue Originum libri $X X$, Oxford.

Löfstedt, B., 1977: Sedulius Scottus. In Donati artem maiorem, CChr CM, Turnhout.

Löfstedt, B, 1977: Ars Laureshamensis. Expositio in Donatum maiorem, CChr CM, Turnhout.

Maestre Yenes, María A.H., 1973: Ars Iuliani Toletani Episcopi. Una gramática latina de la España visigoda, estudio y edición crítica, Toledo.

Mariotti, I., 1967: Marii Victorini, Ars Grammatica, introduzione, testo critico e commento, Firenze.

Niedermann, M., 1937: Consentii Ars de barbarismis et metaplasmis; Victorini Fragmentum de soloecismo et barbarismo, Neuchâtel.

Núñez, S., 1997: Retórica a Herenio, introducción, traducción y notas, Madrid.

Sánchez Salor, E., 1991: Cicerón. El orador, traducción, introducción y notas, Madrid.

Tovar, A. - Bujaldón, A.R., 1992: Marco Tulio Cicerón. El orador, texto revisado y traducido, $2^{\mathrm{a}}$ ed., Madrid.

Yon, A., 1964: Cicéron. L'orateur, Du meilleur genre d'orateurs, texte établi et traduit, Paris.

Weber, C.F., 1861: Pseudo Augustinus, Ars breviata, Marburg. 
${ }^{1}$ Este trabajo se ha realizado dentro del Proyecto de Investigación FFI2008-05611/FILO, titulado Métrica, música y gramática romanas: estudio del léxico y las doctrinas, ediciones, traducciones y comentarios, financiado por el Ministerio de Ciencia e Innovación.

${ }^{2}$ En él aparece una sola vez: ut dum velint brevitatem consequi verborum, / aliter ac sit relatum redhostiant responsum. (frg. 10,1 Blänsdorf 1995). Cf. ThlL II 2187, 56 ss.

${ }^{3}$ Cf. Chantraine 1968, s.v.; Arist., Poet. $1456^{\text {b }} 32$ (opuesto a $\mu \tilde{\eta}$ ko $)$ ).

${ }^{4}$ Sobre este término, cf. Ernout-Meillet 1967, s.v. rapio; Forcellini, s.v. correptio; ThlL IV 1030, 50 ss.; Fuentes 2008, pp. 127 s.

${ }^{5}$ Sobre este término cf. Lausberg 1984 (1960), § 491.

${ }^{6}$ En otros gramáticos no aparece el término correptio, sino que es utilizado el verbo corripere: Sacerd., GLKVI 452, 15 Systole est, cum producta syllaba contra rationem metri causa corripitur, ut 'steteruntque comae' pro steterunt; Ps.Prob., GLK IV 263, 19 Systole est e contrario, quando syllaba longa corripitur, ut 'aquosus Orion': cum prima produci debeat, corripitur; Charis., p. 367, 13 (edd. Barwick / Kühnert) Systole est cum producta syllaba contra rationem corripitur, ut (A. 6, 773) 'urbemque Fidenam', cum prima syllaba debeat produci; Serv., Aen.1, 73, (p. 41, 11 Thilo-Hagen) sed est tropus systole, qui fit quotienscumque longa corripitur syllaba propter metri necessitatem. Hay, en cambio, otros autores que usan en estos contextos expresiones como longam syllabam castigare o facere brevem: así, por ejemplo, Consent., barbar., p. 6, 5-9 (ed. Niedermann) systole contrarius est superiori metaplasmus, cum poeta longiorem syllabam metri necessitate castiget, ut est 'aquosus Orion', cum prima Orionis syllaba utique longa sit, ut alibi et 'ircumspicit Oriona'; o Pomp., Commentum artis Donati, GLKV 297, 15 e contrario systole est, quotiens naturaliter longa syllaba est, et nos eam brevem facimus.

${ }^{7}$ Cf. ThLL V 1, 820, 71 ss.

${ }^{8}$ Sobre el uso de adbrevio como término prosódico, $c f$. Fuentes Moreno 2008, p. 136.

${ }^{9}$ I 51,3 ss.

${ }^{10} \mathrm{El}$ término breviatio, no documentado, al parecer, antes del siglo IV, no es usado por los gramáticos como tecnicismo prosódico; escasamente documentado, en estos autores sólo tiene el sentido de "sumario, resumen": así, en Ps.Baso (GLKVI 307, 1 breviatio pedum). Cf. ThLL II 2170,18-29.

${ }^{11}$ Cf. ThLL IV 752, 12-69 s.v.

${ }^{12}$ Cf. Forcellini, s. v. longitudo; ThLL VII.2, 1630, 20 ss.; Ernout-Meillet, s. v. longus.

${ }^{13}$ Así, por ejemplo, Cic., In Verr. II 5, 26 ita diei brevitas conviviis, noctis longitudo stupris et flagitiis continebatur.

${ }^{14}$ Ese sentido es recogido en las traducciones; en la de Tovar - Bujaldón : "Tratándose del verso el teatro entero prorrumpe en griterío si ha sido demasiado breve o demasiado largo en una sílaba; y por cierto que la multitud no sabe de pies ni domina ritmos de ninguna clase ni entiende lo que le choca ni por qué ni en qué le choca, y sin embargo de todas las cantidades largas y breves de los sonidos, como de los tonos agudos y graves, la naturaleza misma ha puesto el juicio en nuestros oídos."; en la de Yon: "Dans un vers des théâtres entiers s'exclament s'il est trop long ou trop court d'une syllabe. Ce n'est pas que la foule connaisse les pieds, ait aucune notion des nombres et comprenne ce qui la choque, ou pourquoi, ou en quoi: mais l'appréciation de toutes les longues et brèves dans les sons, comme de l'aigu et du grave dans les tons, c'est la nature elle-même qui l'a mise dans nos oreilles."; en la de D'Arbela: "Interi teatri protestano per un verso, se è di una sillaba più breve o più lungo del necessario, eppure la folla non si intende di piedi e non ha nozioni di metrica, e non si rende conto di quello che le offende l'orecchio $o$ perchè $o$ in che cosa; e tuttavia il senso della quantità lunga o breve di tutti i suoni, come quello dei toni gravi e acuti ci è stato posto nell'orecchio dalla natura stessa"; en la de Sánchez Salor: "En el caso de los versos, el teatro entero grita si una sílaba es excesivamente breve o excesivamente larga; $y$, sin embargo, la gente no conoce los pies, ni tiene noción del ritmo, ni sabe 
por qué ni en qué le choca lo que le choca; y, no obstante, la naturaleza misma puso en nuestros oídos la apreciación de todas las largas y las breves en los sonidos, como puso la apreciación de los tonos agudos y graves."

${ }^{15}$ Cf. ThlL X.2, 1643, 36 ss.

${ }^{16}$ Achard (1989, p. 164) traduce por 'allongement' / 'abrègement'. Núñez (1997, p. 257), traduce como 'alargamiento' / 'abreviamiento'; adelante.

${ }^{17}$ Para definir este metaplasmo se usa también el término extensio, como veremos más

${ }^{18} \mathrm{Cf}$. ThLL I 674, 80 ss.

${ }^{19}$ ThlL V 2, 1980, 54 ss.; 1982, 38 ss.

${ }^{20}$ Cf. Fuentes 2008, pp. 138-139.

${ }^{21} \mathrm{Cf}$. Ernout-Meillet, s.v. tendo.

${ }^{22}$ Cf. ThlL V 2, 59, 38 ss.

${ }^{23}$ Cf. ThlL V 2, 1982, 70-75.

${ }^{24}$ Cf. ThlL V 2, 1983, 20-22.

${ }^{25} \mathrm{El}$ adjetivo es usado también como tecnicismo prosódico: Diom., gramm., GLK I 428, $22-25$.

${ }^{26}$ Cf. ThlL X 2, 1517,49 ss., especialmente 1519, 5 ss. sobre su uso en textos gramaticales y retóricos.

27 "Il ritmo si svolgi ad ogni modo fin dall'inizio ora più vivacemente per la brevità dei piedi ora più lentamente per la loro lunghezza" (trad. de D'Ârbela 1958). "En règle générale, le nombre se déroule dès le début de la phrase tantôt rapide par la brièveté des pieds, tantôt lent par leur longueur" (trad. Yon, Paris, 1964). "Por regla general, el ritmo fluye desde el comienzo de las frases unas veces más rápido por la brevedad de los pies, y otras veces lento por el carácter largo de los mismos". (trad. de Sánchez Salor 1991). "El ritmo fluye generalmente desde el principio, ora más acelerado por la brevedad de los pies, ora más lento por su cantidad larga" (trad. de Tovar - Bujaldón, Madrid 1992). 


\title{
Mito y religión en el $D E$ die NATALI de Censorino".
}

\author{
María del Carmen Hoces Sánchez \\ Universidad de Granada
}

0 . Pensando qué contribución podría yo aportar a este merecido recuerdo de nuestra tristemente desaparecida compañera, la Dra. Ma Luisa Picklesimer Pardo, y hallándome dedicada a otras cuestiones, no me parecía suficiente homenaje a su memoria por mi parte el presentar un trabajo de un tema cualquiera y sí en cambio que debía acercarme a la que, podría decirse, era su pasión en los estudios clásicos: sin olvidar su debilidad por Tito Livio, que siempre procuró explicar a los alumnos de tercero de filología clásica, su labor investigadora (de la que sin duda bebió también su labor docente) estuvo siempre centrada en la mitología.

Hace años realicé una traducción de Censorino, junto con el Dr. Jesús Luque Moreno, que, por avatares del destino, aún no ha visto la luz. El librito en cuestión es una obra de contenido variopinto, centrada en cuestiones que atañen de más cerca o más lejos al día del nacimiento, incluyendo en ello todo lo anterior al nacimiento (origen del hombre, concepción, desarrollo del feto y maduración del mismo, tema en el que ocupa un lugar primordial un capítulo dedicado a la doctrina harmónica ${ }^{2}$ y al cómputo del tiempo (desde el tiempo universal al establecimiento del saeculum y su duración, el año grande, el año cíclico o natural, la división de este en meses, los nombres de los mismos, la división del día en horas, etc.), presentado todo ello en forma de genethlíaco en honor de Quinto Cerelio, su protector, de ahí que en el tema científico se intercale en ocasiones la alabanza propia de las composiciones genthlíacas.

La obra ha sido objeto de traducciones a distintas lenguas y de estudios sobre cuestiones como el género de la misma o temas concretos que se tratan en ella.Pero ningún trabajo, que yo sepa, trata las numerosas alusiones a cuestiones mitológicas en la obra, en el sentido amplio del término, en el que mitología se refiere al conjunto de las leyendas, entendiendo leyenda como todo relato de sucesos inciertos y no comprobables, sobre los que existe una tradición que los presenta como reales ${ }^{3}$. Y dado que los dioses, personajes principales de la mitología, son también protagonistas de la vida religiosa de Roma, he incluido en este trabajo las cuestiones religiosas de las que habla Censorino.

Un breve repaso de todas esas cuestiones será el tema de este humilde homenaje a la mitóloga del departamento, que abordo con todos los reparos de quien es consciente de que muy poco puede aportar en el campo de la mitología y de que es incluso un atrevimiento hacerlo como homenaje a quien tanto sabía de ello. 


\section{1. ¿Qué cuestiones de mitología menciona Censorino?}

La gran variedad de temas que trata la obra justifica y propicia la aparición de numerosos temas, motivos y personajes mitológicos, de dioses, ritos y cultos, que son traídos a colación por Censorino en conexión con temas concretos y con distintas finalidades o funciones; lo mejor será ir glosándolos al hilo de la propia exposición de Censorino.

Ya en el capítulo primero Censorino habla de los dioses, en general: en estos primeros momentos de la obra en que Censorino presenta su librito y se dirige a su benefactor Cerelio, comienza un elogio de este, algo que no extraña en una obra que inicialmente parece un genetlíaco, refiriéndose a la verdadera riqueza, la del alma, que se acerca a la eternidad de los dioses inmortales (I. 4), y, siguiendo el ejemplo de los antepasados, que tenían todo lo existente por regalo de los dioses y de todo (de las cosechas, las primicias; de los terrenos, templos y santuarios; de sí mismos, incluso, por ejemplo dejaban crecer su pelo) consagraban algo a los dioses, en agradecimiento por sus dádivas, él, confiesa, paga los beneficios concedidos por Cerelio con la pequeña libación que supone la obrita que ha compuesto (I. 8-11).

Una vez introducida la obra, pasa a hablar del Genio (2-3), divinidad que no podía faltar en un libro que trata sobre el día del nacimiento: refiere, en primer lugar, la costumbre de verter vino puro al Genio en lugar de sacrificarle una víctima, y en esto, como en tantas otras cuestiones, acude a la autoridad de Varrón (en su Ático esta vez) para explicar que el rito obedece a la idea e intención de abstenerse de la matanza, para que, en el día en que uno ha recibido la vida, no se le quite a otro. Y haciendo gala de su erudición, concluye el tema de la ofrenda al Genio citando un correlato griego, y es que en Delos, dice, en el altar de Apolo Genitor ${ }^{4}$, nadie mata una víctima; y añade algún detalle más de la ceremonia de ofrenda al Genio.

Preocupado, como es su estilo, por dejar todo bien aclarado, y en atención a lo que alguien podría plantear, Censorino explica quién es el Genio o por qué lo venera cada cual en su propio natalicio: el Genio es el dios bajo cuya tutela cada cual, según ha nacido, vive; explica también Censorino la etimología de Genio $^{5}$, la identificación con otras divinidades, las fuentes que hablan sobre el Genio, como son los indigitamenta ${ }^{6}$ y el distinto culto de que es merecedor frente a otras divinidades que también intervienen en la vida de los hombres.

Pasa a continuación Censorino a hablar de las creencias sobre el origen del hombre, y en este contexto, tras exponer las diferentes teorías de los filósofos al respecto, entre las cuales algunas apuntan a la intervención divina, se refiere (4.5-6) a las fabulosas historias de los poetas, que sostienen que los hombres primeros o fueron formados del blando lodo de Prometeo o nacieron de las duras piedras de Deucalión y Pirra. Finalmente, existe también la creencia, prosigue Censorino, entre los que estudian la genealogía, de que, de ciertos 
pueblos, existen unos primeros hombres engendrados de la tierra, como en Ática, Arcadia o Tesalia, y que se suelen llamar autóctonos; o de que, en Italia, Ninfas y Faunos indígenas dominaron ciertos bosques; o de que de la tierra surgieron hombres como Erictonio ${ }^{7}$, a partir del semen de Vulcano, o los "espartos", algunos de los cuales fundaron Tebas junto a Cadmo, o Tages, ya en territorio itálico, que enunció las fórmulas de la disciplina de la observación de las entrañas, escritas luego por los lucumones.

Tras exponer las teorías sobre el origen de la especie humana, donde no faltan las de tipo mítico, como acabamos de ver, la obra continúa con la concepción y la gestación, cuestiones en las que se detiene en el origen de la simiente, el desarrollo del embrión (formación, nutrición, diversidad de sexos, parecido de los hijos, nacimiento de gemelos), duración de la gestación (opiniones sobre la maduración del feto y sobre la duración del embarazo), y en el capítulo 8, dedicado al cálculo de los caldeos (principios generales del sistema, el zodíaco, doctrina de las perspectivas), volvemos a encontrar otra alusión a cuestiones mitológicas, esta vez en conexión con el zodíaco y el lugar de la concepción: a las particulae los griegos ${ }^{9}$ las denominaron moirai, porque a las diosas del destino las llaman Moiras, y esas partículas para nosotros son como los hados.

Quizá uno de los aspectos más llamativos, y valiosos, del De die natali sea el amplio excurso sobre la música que ocupa básicamente el capítulo 10 . En la exposición de las opiniones de los pitagóricos respecto a los tipos de gestación (cap. 9), pasa a hablar sobre las leyes de la música (cap. 10) como había anunciado en el capítulo 7, necesarias para el excurso, y tras explicar la duración de los dos tipos de gestación (una de siete y otra de diez meses), se centra en las relaciones entre la música y el nacimiento, y es aquí donde aclara que la música "retiene mucho de la divinidad y para conseguir una conmoción en los ánimos es la que más vale”. Y argumenta que si la música no fuese grata a los dioses inmortales, no se habrían instituido los juegos escénicos para aplacar a los dioses, ni se emplearía un tañedor de tibia en todos los ritos suplicatorios ni en el triunfo en honor de Marte; ni estarían atribuidas a Apolo la cítara ${ }^{10}$, ni a las Musas las tibias y demás instrumentos de ese tipo ${ }^{11}$; ni a los tañedores de tibia, por mediación de los cuales son aplacadas las divinidades ${ }^{12}$, les estaría permitido organizar juegos públicos o tomar alimentos en el Capitolio ${ }^{13}$ o en los Quincuatros menores, según Censorino, en las idus de Junio, ${ }^{14}$ se les permitiría vagabundear por toda la ciudad disfrazados y borrachos.

El tema de la armonía del universo, del que se ocupa en el capítulo 13, y, dentro de él, el de los intervalos musicales que las distancias entre ellos constituyen, da entrada en el texto a una serie de nombres de dioses a los que se liga cada uno de los planetas : así, aparecen Mercurio (cuya estrella es Stilbon ${ }^{15}$ ), 
Venus (cuya estrella es Phosphoros), Marte (cuya estrella es Pyrois), Júpiter (cuya estrella es Phaeton) y Saturno (cuya estrella es Phaenon).

El siguiente bloque temático de la obra (capítulos 14-15) se articula en torno a los períodos de la vida, los años climatéricos y la duración de la vida, con ejemplos de la longevidad de algunos hombres célebres. Aquí se sitúa la alabanza a Cerelio que era de esperar en una obra de tipo genetlíaco, si es que esta lo es ${ }^{16}$.

En este punto, al tratar las edades del hombre, y tras exponer las opiniones de distintos autores al respecto, alude a los libros proféticos etruscos, que, según informa Varrón - dice Censorino - dan como edad razonable que cabe esperar como alcanzable para el hombre los 63 años, prorrogable a los 70 con ayuda de los dioses, edad después de la cual no debe pedirse ni esperarse de los dioses que se vea prolongada, y que, después de los ochenta y cuatro años, los hombres se alejan de su propia mente y para ellos no se hacen prodigios. Y más adelante, al plantear la cuestión de si el número decisivo, sobre el que se articula la vida humana, es el siete o, como propone Platón, el nueve, añade (14.13) que la opinión más generalizada es que estos dos números alternan, considerando que el siete atañe al cuerpo y está atribuido a Apolo, y que el nueve atañe al espíritu y está atribuido a las Musas.

En la segunda parte, dedicada de forma global a la cronología, el concepto de tiempo (tempus y aevum) y el cómputo del mismo llenan los capítulos 16-24: el capítulo 17, dedicado al siglo natural, el siglo romano y los juegos Seculares, el siglo civil y los siglos asignados a Roma, contiene una nueva alusión a la duración de la vida humana, en conexión con el siglo, esta vez. Así, en 17.3, afirma que los poetas han escrito muchas cosas increíbles, y, lo que es peor, también los historiadores griegos, aunque no era propio de ellos el apartarse de la verdad, y pone como ejemplo a Heródoto, en el que podemos leer que Argantonio, rey de los tartesios, llegó a tener 150 años, o a Éforo, según el cual los arcadios sostenían que algunos de sus reyes antiguos vivieron hasta los 300 años.

Este capítulo es uno de los más densos de la obra; en él se discute ampliamente sobre la duración de los siglos, aduciendo opiniones y testimonios variados, entre los que destaca, por lo que respecta al tema de estudio que me he propuesto, de nuevo el de Varrón, quien en el libro primero De los orígenes de la escena dejó así escrito: "como se producían muchos portentos, y el muro y la torre que hay entre la puerta Colina y la Esquilina habían sido alcanzados por un rayo y por eso los quindecenviros acudieron a los libros Sibilinos, trajeron por respuesta que se hicieran en honor del padre Dite y de Prosérpina los juegos tarentinos ${ }^{17}$ en el campo de Marte durante tres noches, y que se inmolaran tres víctimas negras ${ }^{18}$, y que los juegos se hicieran cada cien años". 
En conexión con la duración del siglo, llega al tema de cuántos siglos han sido asignados a Roma (17.15), y de nuevo cita a Varrón ${ }^{19}$, en el que ha leído que hubo en Roma un Vecio, célebre en cuestión de augurios, de grandes dotes, al que había oído él decir que el pueblo romano iba a llegar a los mil doscientos años.

Avanzando en la explicación de las distintas magnitudes temporales, llega al año grande ${ }^{20}$ y a las distintas formas que los distintos pueblos han tenido de fijar la duración del mismo, intercalando algún mes con una periodicidad determinada para hacer cuadrar el año natural o cíclico con el civil, organizado por meses lunares: en Grecia fijando la trieteris, llamada así porque la intercalación se hacía cada tercer año ${ }^{21}$; por eso a los misterios ${ }^{22}$ que se hacen en honor de Líber en años alternos les dicen los poetas trieterica ${ }^{23}$. Después, duplicaron este tiempo e hicieron la tetraeteris, año grande compuesto por cuatro años que pareció más ajustado ya que era conocido que un año del Sol consta de 365 días y en torno a la cuarta parte de un día, parte que en un cuatrienio completaba un día, por eso se celebra una competición tanto en la Hélade en honor de Júpiter Olímpico como en Roma en honor del Capitolino a la vuelta de cada quinto año ${ }^{24}$.

Relatando los distintos años grandes, llega al tema de Egipto, donde por cierto el cuatrienio es en torno a un día menor que el cuatrienio natural y toma su inicio en el primer día del mes, al que llaman los egipcios Tot ${ }^{25}$. También informa de que en Acaya se dice que los arcadios tuvieron primero un año trimestral, y que por ello son denominados proseleno ${ }^{26}$, no, como algunos ${ }^{27}$ piensan, porque hayan nacido antes de que el astro de la Luna estuviese en el cielo, sino porque tuvieron año antes de que dicho año se constituyera en Grecia de acuerdo con el curso de la Luna. Hay quienes transmiten (20.6) que este año trimestral lo instituyó Horus ${ }^{28}$, y que por ello a la primavera, al verano, al otoño y al invierno se les dice horai y al año horos, y a los anales griegos horoi, y a los que los escriben horographi.

Toda esta cuestión de la organización del año en meses lo lleva, no podía ser de otra forma, a hablar de la reforma del calendario romano: tras nombrar la variedad de calendarios según las naciones (20.4), se adhiere a la opinión de que el año romano, en un principio, fue de diez meses y que fue Numa ${ }^{29}$ (aunque algunos señalen a Tarquinio) quien añadió dos meses, obteniendo así un año de 355 días.

Uno de estos reajustes del calendario consistió en añadir un mes intercalar de veintidós o veintitrés días en años alternos, de modo que el año civil se igualara al natural y la intercalación se hizo en el mes de febrero entre los Terminalia ${ }^{30}$ y el Regifugio.

El capítulo 21 es muy interesante para el tema de este trabajo: en él Censorino, una vez más siguiendo a Varrón, anuncia que va a tratar el tiempo 
que el Reatino llama historikon. Varrón, en efecto -continúa Censorinotransmite que hay tres tiempos: el primero desde el principio de los hombres hasta el primer cataclismo, que se llama "oculto"; el segundo, desde el primer cataclismo a la primera olimpiada, que recibe el nombre de "mítico"; el tercero desde la primera olimpiada hasta nosotros, al que se le dice "histórico". En un intento de datar los límites de los dos últimos períodos acude a explicaciones mitológicas, mejor dicho, propone como fechas de inicio o final hechos que caen dentro de la mitología, o la leyenda, si se quiere: el primer cataclismo, al que llaman también "de Ógigo", el reinado de Ínaco y la caída de Troya.

La explicación de los nombres de los meses (cap. 22) es sin duda un terreno propicio para la aparición de variadas cuestiones mitológicas, básicamente los dioses epónimos y los personajes que asignaron dichos nombres, pero también alusiones a algunas fiestas religiosas ubicadas en los distintos meses: (22.9) los nombres a los diez antiguos meses ${ }^{31}$ se los puso Rómulo, y a los dos primeros, marzo y abril, los nombró a partir de sus padres, Marte y Afrodita $^{32}$, esto es, Venus, de donde se decían originarios sus mayores. Una vez más cita Censorino la opinión de Varrón, quien, en cambio, considerando que los romanos tomaron de los latinos los nombres de los meses, cree que los promotores de éstos fueron más antiguos que Roma, y así, que el mes de marzo recibió el nombre de Marte, pero no porque fuera el padre de Rómulo, sino porque la gente latina es belicosa; que abril no recibe su nombre a partir de Afrodita, sino a partir de "abrir", porque entonces casi todo nace y la naturaleza abre los cerrojos del nacer; que mayo tomó el nombre no de los mayores, sino de Maya $^{33}$ porque en dicho mes tanto en Roma como antes en el Lacio se rinde culto a Maya; que junio toma su nombre de Juno más bien que de "los más jóvenes", porque en ese mes, sobre todo, se rinden honores a Juno ${ }^{34}$; (22.1315) que después añadieron enero y febrero y que ianuarius tomó el nombre de Jano, a quien está atribuido y februarius de februo: februum es "algo que purifica y purga", y februamenta "purgaciones", igualmente februare es "purgar y hacer puro. Februum, sin embargo, no se le dice a lo mismo en todas partes; pues en cada rito se hace el februum, esto es, la purgación, de una manera. En este mes, por lo demás, en las Lupercales ${ }^{35}$, cuando se purifica Roma, llevan sal caliente a la que llaman februum; por eso al día de las Lupercales se le llama februatus y a partir de él, al mes, februarius.

En este repaso por las cuestiones mitológicas y religiosas que aparecen en De die natali, al final ya de la obra nombra Censorino algunos de los templos de Roma junto a los que se piensa que fue colocado el primer reloj solar: hay quienes dicen que fue cerca del templo de Quirino ${ }^{36}$; otros, que en el Capitolio (imagino que se refiere al templo de Júpiter en el Capitolio); algunos, que junto al templo de Diana en el Aventino. 


\section{2. ¿Qué opina Censorino de los mitos?}

Como acabamos de ver, la información que Censorino ofrece sobre cuestiones mitológicas y religiosas es variada y abundante, pero el valor de la misma no es uniforme.

Junto a alusiones banales, sin relevancia ni interés mitológico, hay otras que sí lo tienen. Se puede decir que es una información más valiosa por lo que respecta a la religión que a la mitología, pues al menos en el caso de las alusiones religiosas sí que explica alguna cuestión de interés e informa sobre algunos cultos y ritos (como es el caso del Genio, cap. 2-3); no así en el caso de las alusiones mítico-legendarias, en las que por lo general se limita a citarlas como apoyo o breve explicación del tema tratado en ese momento. En general, pues, se puede decir que no aporta nada nuevo al respecto ni llega a explicar ningún mito. Así las cosas, lo que interesa es centrar la atención en su actitud ante las cuestiones religiosas y mitológicas que expone en su obra.

Haciendo un breve resumen de ellas, en cuanto a lo mítico-religioso Censorino nombra diversos dioses (Afrodita, Apolo, el Padre Dite, el Genio, Jano, Juno, Júpiter Capitolino y Olímpico, los Lares, Líber, Marte, Maya, Minerva, Orfeo, Prosérpina, Venus, Vulcano), ritos (sacra publica de Roma: Lupercalia, Parilia, Quinquatrus minusculae, Terminalia, Regifugium, el triunfo, las súplicas; y sobre todo juegos: ludi capitolini, saeculares, scaenici o tarentini), sacerdotes (pontífices, augures, harúspices, tibicines que intervienen en el culto), santuarios (aedes Quirini, sedes Dianae in Aventino, Capitolium) y obras especializadas de ciencia religiosa (indigitamenta, libros Sibilinos, libri rituales o fatales de los etruscos). Lo mítico-legendario hace presencia a través de alusiones a personajes como Argantonio, Deucalión, Erictonio, los Espartos, Evenor, los Faunos, Lino, las Musas, las Ninfas, Numa, Rómulo o Tages.

Este, precisamente, puede ser uno de los criterios de estudio de estos testimonios: lo mítico-religioso, por un lado, y, por otro, lo mítico-legendario; atendiendo, en cambio, al valor del testimonio, en una y otra clase, encontramos a su vez testimonios con y sin interés mitológico; $y$, al margen, teniendo en cuenta la actitud de Censorino ante aquello que narra, habría que distinguir entre cuestiones que Censorino asume con naturalidad y cuestiones hacia las que se muestra incrédulo o escéptico; por último, un testimonio de Censorino, quizá el más valioso, o al menos el más original, de todos, supone una propuesta cronológica para los hechos míticos, tanto en cuanto a la duración global del período dentro del cual se habrían desarrollado los hechos míticos, como en cuanto a una serie de subdivisiones marcadas por hechos míticos de gran relevancia; lo que queda fuera de ese período, tanto antes como después, no sería, pues, mítico.

La primera clasificación queda clara, creo, con la exposición del punto anterior, en que glosé los temas religiosos y míticos de que habla nuestro 
autor. A veces Censorino alude a cuestiones religiosas simplemente como nota erudita en su argumentación, así por ejemplo cuando cita, en relación con los períodos de cuatro años establecidos en Grecia para conciliar el año civil con el natural, las fiestas mistéricas que los poetas llaman trieterica, o explica el año grande de Egipto, que comienza en el primer día del mes dedicado al dios Tot y el año trimestral egipcio como instituido por el dios Horus. En este mismo sentido se deben tomar las alusiones a algunas fiestas entre las que se intercaló algún mes en el proceso de adaptación del calendario; o la mención de los dioses que han dado nombre a los distintos meses del calendario romano, que aparecen en el texto como explicación de los mismos, es decir, sin que se haga sobre ello ninguna reflexión de tipo mítico o religioso; o a los templos junto a los cuales se colocó en algún momento un reloj de sol.

Ahora bien, todas las demás alusiones a cuestiones religiosas, más abundantes, sí que encierran algún valor, ya sea testimonial, ya sea porque Censorino hace alguna reflexión sobre ellas. Ya desde el principio, la obrita se presenta como una libación a los dioses, es decir, como cumplimiento de un deber religioso, que además entronca con la tradición romana más antigua. Censorino y su auditorio están muy apegados a esto, y en ello se incluye el aporte griego (con la mención de Júpiter Capitolino, ligado al Zeus Olímpico, Venus llamada Afrodita, juegos de Delfos) como también el aporte etrusco, un elemento de pleno derecho de la tradición romana.

Los dioses se interesan por los hombres e intervienen en sus vidas: así el Genio protege a quien custodia; rogar a los dioses es útil (para prolongar la vida al menos hasta los setenta años, como, según Varrón, testimonian los libros etruscos); las fuerzas celestes señalan su voluntad mediante prodigios a cada uno o a todos en colectividad (así los presagios que anuncian el fin de un siglo); los juegos escénicos se instituyeron para aplacar a los dioses. Todas estas son creencias muy tradicionales en Roma. Es decir, en cuanto a las ideas religiosas y el apego afectivo al culto tradicional, Censorino está en total acuerdo con sus contemporáneos paganos y los movimientos de pensamiento de su época. De esta manera, el De die natali constituye para nosotros un testimonio valioso sobre la religiosidad pagana del s. III d.C.

Pero la obra tiene indicios de una evolución del paganismo: la vuelta a lo antiguo depende de un propósito deliberado y de una voluntad de permanecer fiel a la herencia legada por los maiores; las creencias exhibidas son en general las del paganismo tradicional, pero combinadas con una voluntad de depuración y con una clara inclinación hacia el platonismo y más aún hacia la astrología, dos movimientos de un gran éxito hasta el final del Imperio; finalmente, la concepción del universo expresada es sobre todo la del pitagorismo que, también, está y estará muy en boga ${ }^{37}$. 
Pero Censorino no da por bueno todo lo que aporta la tradición grecolatina o latino-etrusca: no parece creer en la mitología, y descarta con desdén mitos como el de Deucalión y Pirra o el de Tages ${ }^{38}$.

Claras son, en este sentido, las palabras con que casi se excusa, por así decir, de traer a colación dichas historias: por ejemplo, cuando, al tratar del origen del hombre, da paso a las diferentes opiniones de los filósofos al respecto, dice expresamente (4.6) omitiendo lo que las fabulosas historias de los poetas refieren de que los hombres primeros o fueron formados del blando lodo de Prometeo o nacieron de las duras piedras de Deucalión y Pirra, y que incluso algunos filósofos propagan en sus teorías opiniones no sé si más grotescas, pero ciertamente no menos increíbles; o que (4.11) la ruda credulidad de los antiguos aceptó sin dificultad que, en Italia, Ninfas y Faunos indígenas dominaron ciertos bosques; o, finalmente en este tema del origen primero del hombre, después de hablar de la creencia divulgada de hombres que nacen de la tierra, concluye que hasta tal grado de licencia ha avanzado la pasión poética que conciben ficciones apenas tolerables de oír ${ }^{39}$.

En la explicación de la duración del siglo ${ }^{40}$, que podía variar y estar señalado con distintos prodigios ${ }^{41}$, se expresa Censorino en los siguientes términos (17.34): "Los poetas, desde luego, han escrito muchas cosas increíbles, y no menos los historiadores griegos...”; ya me he referido al pasaje en el que habla de la legendaria longevidad de algunos personajes, como Argantonio ${ }^{42}$ o algunos reyes arcadios. Pero estas cosas, en cuanto que fabulosas, las paso por alto; ni siquiera la autoridad de historiadores griegos de la talla de Heródoto, que refiere la edad de Argantonio, impiden que Censorino se muestre crítico con las leyendas, pues como él mismo explica, los historiadores griegos se apartaron en esas cuestiones de la verdad y se acercaron así a la inverosimilitud de la poesía, lo cual no debía ser propio de ellos.

Más adelante, en cambio, en este mismo capítulo, cuando, todavía sobre de la duración de los siglos, llega a referirse a la institución de los juegos tarentinos y seculares, tratándose ahora de tema más religioso que mítico (los cambios de siglo están anunciados por prodigios divinos; los juegos seculares fueron instituidos para celebrar o conmemorar esos cambios de siglo, o los juegos tarentinos, una especie de antecedente de los juegos seculares, se celebraron en primer lugar como respuesta a los distintos prodigios observados), no se muestra nuestro autor, en cambio, tan crítico.

El capítulo 17, tan denso, da mucho juego para el tema mítico: así en el párrafo 15, tratando los siglos que están asignados a Roma ${ }^{43}$, la actitud de Censorino no es tan abiertamente escéptica, pero el tono así lo sugiere: aunque, dice, no es el tema que lo ocupa, el haberlo leído en su principal fuente, Varrón, parece obligarlo al menos a referir que Vecio afirmaba, lo había oído Varrón decir, que si era tal como transmitían los historiadores acerca de los augurios de 
Rómulo, el pueblo romano iba a llegar a los mil doscientos años. Aunque la duda parte del tal Vecio, es evidente que Censorino no ha querido dejar pasar la ocasión no solo de citar lo que cuenta Varrón acerca del personaje sino también de dejar patente el escepticismo con que esto debe ser tomado; y más que un escepticismo hacia los auspicios (y la ciencia augural en general, a la que, como parte de la tradición religiosa romana, ya he dicho que Censorino se siente cercano) creo que el escepticismo va más bien dirigido hacia el personaje de Rómulo y los prodigios que se le mostraron, por más que la leyenda fundacional hubiera sido absorbida y reelaborada desde hacía mucho tiempo por la historia ${ }^{44}$.

En numerosas ocasiones, Censorino intenta interpretar en un sentido más racional los ritos o las creencias tradicionales: por ejemplo, al principio del libro afirmaba hacer como los antiguos, que ofrecían de todo una parte a los dioses más para serles gratos que porque pensaran que carecían de ello; o en 19.4 explica que a los arcadios se los llamaba proseleno ${ }^{45}$, no, como algunos piensan, porque hayan nacido antes de que el astro de la Luna estuviese en el cielo, sino porque tuvieron año antes de que dicho año se constituyera en Grecia de acuerdo con el curso de la Luna.

En la misma línea se encuentra su explicación (cap.22), siguiendo de nuevo a Varrón, de alguno de los nombres de los meses: marzo fue así llamado a partir del dios Marte, pero no porque este fuera el padre de Rómulo sino porque los latinos son belicosos; es decir, se decanta más por la vertiente religiosa (Martedios de la guerra) y rechaza la legendaria (Marte-padre de Rómulo). Esta misma explicación de índole religiosa es la que adopta para los nombres de los meses de mayo, llamado así a partir de la diosa Maya, junio, a partir de la diosa Juno, ianuarius, que tomó el nombre de Jano, a quien está atribuido y februarius de februo, y aquí la explicación de tipo religioso es incluso más amplia, como ha quedado dicho más arriba. Aquí Censorino acepta sin cuestionarse la explicación mítico-religiosa para el nombre de los meses, pues ya en la Antigüedad había consenso en cuanto a la misma. En cambio, para el mes de abril rechaza la etimología procedente del nombre de la diosa Afrodita y propone la del verbo "abrir", porque entonces casi todo nace y la naturaleza abre "los cerrojos del nacer". Curiosamente, en este caso, en el que hay opción entre la explicación religiosa y la "racional", por así decir, Censorino opta por la segunda ${ }^{46}$.

Pero la explicación de tipo religioso se sigue imponiendo en otras cuestiones: en el capítulo 20 habla con cierta amplitud de la división del año en meses y del paso de los diez meses originarios del calendario romano (opinión que secunda Censorino frente a la de otros que pensaron que fue desde un inicio de doce meses), obra de Numa, según dice Fulvio, o, según Junio, obra de Tarquinio; en ese cambio, los días pasaron a ser 355, a pesar de que la Luna con sus 12 meses se veía que completaba 354 días, y el que sobrara un día, dice Censorino, o fue un accidente por descuido o, cosa que creo más, por 
aquella creencia religiosa ${ }^{47}$ en virtud de la cual el número impar se tenía por pleno y más fausto, y curiosamente, aunque no es extraño que Censorino cite sus fuentes, para la explicación legendaria (atribución a Numa o a Tarquinio de la reforma del calendario) cita fuentes concretas, como intentado justificar o excusar la mención de dichas cuestiones o para dejar claro que se apoya en alguna autoridad, mientras que para la explicación de tipo religioso se permite omitir el dato; en alguna ocasión, incluso, expresa su opinión sin acudir a autoridad alguna, como ocurre cuando habla de los proselenoi, proponiendo una explicación más racional (como ha quedado dicho más arriba) que la más simple y con más visos de leyenda que sugiere que eran así llamados por haber organizado su calendario en años antes de que la Luna estuviese en el cielo.

Pero quizá el pasaje, si no más interesante, sí, al menos, más original o peculiar de Censorino para el tema que me ocupa sea el que constituye el principio del capítulo 21 , y que vale la pena reproducir íntegro ${ }^{48}$ :

"Ahora, en cambio, voy a tratar ese intervalo de tiempo que Varrón llama "bistórico". Él, en efecto, transmite que las demarcaciones de los tiempos son tres: la primera desde el principio de los hombres hasta el primer cataclismo ${ }^{49}$, que por ser desconocida se llama oculta; la segunda, desde el primer cataclismo a la primera olimpiada ${ }^{50}$, que, porque en ella se relatan muchas cosas fabulosas, recibe el nombre de "mitica"; la tercera desde la primera olimpiada hasta nosotros, a la que se le dice "bistórica", porque las cosas en ella llevadas a cabo se hallan contenidas en las historias verídicas. (2) El primer tiempo, tanto si tuvo inicio como si siempre existió, no se puede aprehender de cuántos años es exactamente. El segundo no se sabe abiertamente desde luego, pero, sin embargo, se cree que es de alrededor de mil seiscientos años: a saber, desde el primer cataclismo, al que le dicen también "de Ógygo"s1, hasta el reinado de Inaco $0^{52}$ contaron alrededor de cuatrocientos años, de aqui a la caída de Troya ${ }^{53}$ ochocientos años, de aqui a la primera olimpiada poco más de cuatrocientos; éstos solos, aunque los últimos del tiempo mítico, sin embargo, por ser los que más cerca están de la memoria de los escritores, algunos han querido delimitarlos con mayor precisión. (3) En efecto, Sosibio escribió que fueron 395; Eratóstenes, por su parte, cuatrocientos siete; Timeo, 417; Aretes, 514; y muchos más en diversos sentidos, cuyo disentimiento por si mismo deja claro que es algo impreciso ${ }^{54}$ ".

La importancia del pasaje es grande. La fuente es una vez más Varrón; pero la fuente de Varrón es griega, desde luego, como se ve por los adjetivos ${ }^{55}$ usados para denominar los distintos tiempos y por la periodización, basada en datos griegos (están ausentes sucesos romanos como la fundación de Roma o la llegada de Evandro o Eneas a tierras itálicas). Hay que destacar la profunda originalidad de esta tripartición en cuanto que no hay ningún testimonio anterior griego sobre una periodización de este tipo ${ }^{56}$.

Los historiadores griegos no se remontan al diluvio y parece que hubieran tenido presente más una periodización bipartita que tripartita cuando 
distinguen entre tiempo de los dioses y tiempo de los hombres, situando un momento de ruptura ya en la guerra de Troya, ya en el retorno de los Heraclidas.

En el mundo romano, excepción hecha de Censorino (Varrón), parece que para ciertos autores la separación más importante se deba colocar en la fundación de Roma, o en los sucesos inmediatamente anteriores y que la prepararon. De los sucesos anteriores no fueron tomados en consideración por los analistas republicanos más que los más o menos cercanos a la guerra de Troya, pero ningún representante latino de la tradición histórica se remontaba al diluvio, como hacen, en cambio, poetas como Ovidio o Juvenal. En cualquier caso, sus escritos conservados no presentan ninguna periodización explícita.

Tanto Rocca ${ }^{57}$ como Poucet ${ }^{58}$ llaman la atención sobre los criterios de periodización de Censorino: por una parte, la presencia o ausencia de informaciones (ignorantia); por otra, la naturaleza misma de las informaciones de las que podemos disponer, es decir, su carácter fabuloso o verdadero. Pero hablar de ignorancia sobre los orígenes del género humano parece demasiado simplificador; y, por otra parte, hacer intervenir lo fabulosum como criterio de distinción no es efectivo pues lo fabulosum también está presente en el período histórico.

Según acabo de decir, salvo Varrón-Censorino, ningún autor latino, de la tradición histórica, como tampoco griego, remonta al diluvio, y sus escritos conservados no dan periodización explícita alguna. En la conciencia de los antiguos no existía una línea fronteriza neta entre las fábulas y los hechos, o incluso lo que llamamos tiempo mítico y tiempo histórico. Los escritores antiguos parecen permanecer más bien indiferentes frente a todo lo que ha ocurrido antes de la documentación épica. Solo Varrón muestra una sensibilidad nueva. Cabe cuestionarse si los autores latinos de obras históricas conocían la distinción entre tiempo prehistórico, quizá identificable con el mítico, y tiempo histórico, como la conocemos nosotros; y si así fuese, dónde colocaban la separación.

En primer lugar, la frontera es relativamente borrosa y, sobre todo, no separa las fabulae de los facta. Lo fabuloso está igualmente presente de este lado de la frontera; de igual forma, el período del otro lado, para los antiguos, no está vacío de facta; para ellos incluye incontestablemente lo histórico, pero un elemento histórico con el que se mezclan muchos elementos fabulosa.

Censorino (Varrón), en cambio, sí parece establecer tajantemente una separación clara, para la que incluso propone una fecha de inicio, señalada por el diluvio de Ógigo, que puede ajustarse desde el tiempo en que vive Censorino, y una fecha final, la primera Olimpíada (un hecho "histórico" pues es el que da inicio al período así llamado) entre las cuales se establecen etapas o subdivisiones, marcadas por hechos como la destrucción de Troya. 
¿Cuál ha sido, podemos preguntarnos, la actitud de los antiguos, y de Censorino en particular, respecto a estos fabulosa? La posición de los romanos no ha sido diferente de la de los griegos: en todo mito, en toda leyenda, hay, para los espíritus antiguos, un fondo de verdad. No se puede hablar de lo que no es. "Es imposible mentir radicalmente". Los griegos y a su vez los romanos "jamás admitieron que la fabulación podía mentir completamente". Nadie puede mentir desde el inicio o completamente. A partir de ahí, "en su fondo, los mitos son auténticas tradiciones históricas" ${ }^{59}$.

Los criterios adoptados por los antiguos eran tales que nunca se vieron llevados a poner fundamentalmente en cuestión la historicidad general de sus relatos tradicionales. Así, creían no solamente en la historicidad de los reyes romanos, sino incluso en la de Evandro o Eneas, e incluso en la de Hércules. Lo que, por el contrario, rechazaban como no históricos eran los episodios como la filiación divina de los gemelos fundadores, o la ascensión de Rómulo, o los encuentros de Numa con Egeria. Eran cosas para ellos maravillosas que debían ser excluidas de la historia, así como todo lo que parecía cronológicamente inverosímil: las relaciones de Numa con Pitágoras, o el motivo de Eneas como abuelo de Rómulo y Remo ${ }^{60}$.

La conquista de la noción de un pasado humano objetivo, mesurable en generaciones o en años, no ha abolido esa historia mitológica que los poetas habían organizado. La tendencia de la historiografía antigua fue, al contrario, reducir el pasado mítico al pasado de los hombres. Es como si, a medida que la mirada se desplazase hacia tiempos más lejanos, la memoria colectiva se difuminase y llegase un momento en que el pasado de los hombres se confundiera con el de los dioses y los héroes sin aparente solución de continuidad. Los tiempos heroicos son los que, a causa de su lejanía, no pueden ser conocidos más que a través de relatos y leyendas.

$\mathrm{E} 1$ problema, de todas formas, parece haber despertado poco interés entre los autores de historia, y la teoría del tiempo desconocido y del tiempo histórico nos ha dejado este solo texto de Varrón, del De gente populi Romani, conservado en Censorino ${ }^{61}$.

Lo realmente llamativo y original de esta tripartición no es, o no solo es, en mi opinión, la propuesta de unas fechas para los hechos míticos, sino el planteamiento de un tiempo aún más lejano y desconocido que el mítico, en el que Censorino sitúa el origen del hombre (hecho que da inicio al tiempo "oculto") a diferencia de los escritores latinos, que, en líneas generales, lo colocan en un tiempo mítico.

El texto va a la raíz misma de la cuestión, pues replantea el concepto de hecho mítico cronológicamente, situándolo entre coordenadas bien precisas (en lenguaje actual diríamos que para Censorino es mítico todo hecho acaecido entre el 2400 a.C. y el 776 a.C.), pero es que además, sus palabras, 
pensándolas detenidamente, nos hacen cuestionarnos si los hechos míticos lo son por su propia naturaleza (hechos extraordinarios, sobrenaturales, al margen de las leyes de la naturaleza...) o por la forma en que han llegado a nuestro conocimiento: la lejanía del tiempo mítico parece haber propiciado la proliferación de las fabulosas historias de los poetas, de opiniones grotescas e increíbles de algunos filósofos, todo ello favorecido por el grado de licencia que ha alcanzado la pasión poética y por la ruda credulidad de los antiguos. Todo parece apuntar a una tradición que se ha encargo de elaborar historias fabulosas, ¿quizá a partir de hechos que no lo fueron, o no tanto?

Finalmente, esta propuesta de una tercera (primera, cronológicamente) partición del tiempo tiene como consecuencia, a su vez, que el tiempo mítico quede más cercano al histórico y comparta con él ciertas características, como el hecho de que pueda ser computado en años, o el poder ser conocido, aunque sea por medio de fábulas y leyendas (a veces increíbles, según Censorino), y, paulatinamente, asimilado al histórico.

Pese a todo ello (el aparente acercamiento del tiempo mítico al histórico $\mathrm{y}$ el hecho de que los antiguos no establecieran ninguna diferencia de estatuto histórico entre las diferentes partes de sus relatos), Censorino parece contemplar las fábulas, leyendas o historias míticas, cuando están desligadas de su vertiente más religiosa, a través de un prisma de incredulidad. 


\section{Bibliografía citada}

Baudot, A. (1973), Musiciens romains de l'Antiquité. Paris.

Beaujeu, J., (1975), "Grammaire, censure et calendrier: quinto quoque anno", REL 53 330-360.

Doxey, D. M. (2003), “Tot” en D. B. Redford, ed., Hablan los dioses. Diccionario de la religión egipcia, trad. esp. J. Rabasseda-Gascón, Barcelona, 2003 283284.

Ernout-Meillet, ed., (1994), Dictionnaire etymologique de la langue latine. Paris.

Festugière, A. J. (1972), Études de religion grecque et hellenistique. Paris.

Freyburger, G. (1992), "Un païen du IIIe siècle: Censorinus, auteur du De die natali", REL 70 215-227.

(1999) “Censorinus”, en D. Briquel y Ch. Guittard, ed., La divination dans le monde étrusco-italique. 8, Des Sévères à Constantin: les écrivains du III siècle et l'"Etrusca disciplina". Tours 41-50.

Grimal, P. ('1979), Diccionario de mitología griega y romana. Trad. esp. F. Payarols, Barcelona.

Guittard, Ch. (2002), "Les limites imparties a la vie des hommes et des cités à Rome et en Etrurie: les siècles", en Fco. Díez de Velasco Abellán, coord., Milenio: miedo y religión. Madrid 147-153; publicado on-line: http:// www.ull.es/congresos/conmirel/guittard1.html.

Hoces Sánchez, Ma C. (2009), "Censorino, doctissimus artis rhetoricae?" en T. Arcos Pereira- J. Fernández López- F. Moya del Baño, ed., Pectora mulcet. Estudios de retórica y oratoria latinas. 1, Logroño 321-334.

Lehmann, Y. (1999), “Temps humain et temps cosmique chez Varron”, Les Études Classiques 67: 211-228.

Maltby, R. (1991), A lexicon of ancient latin etymologies. Leeds.

Ogilvie, R. M. (1995), Los romanos y sus dioses, trad. esp. Madrid.

Picklesimer Pardo, Ma L. (2006), “'Y yo estoy sacrificando' (a propósito de Numa, I)”, Florentia Iliberritana 17 225.258.

Pighi, G. B., (1959), “Quarto quoque anno”, Convivium 27 720-728.

Pokorny, J. (1969), Indogermanisches etymologisches Wörterbuch. Bern-München.

Poucet, J. (1987), “Temps mythique et temps historique. Les origines et les premiers siècles de Rome", Gerion 5 69-85.

Rocca, S. (1997), "Nisi qua ratio vestigia monstrat. Osservazioni sull'idea di tempo preistorico negli autori latini”, Maia 49, 2 219-229. 
- (2006), "L'origo animantium in Ovidio tra mito e letteratura", Silvae di Latina Didaxis 7 no 18 29-49; versión digital: http://www.ulisseweb.eu/ pdf/perugia_convention_2006/Silvana_Rocca.pdf.

Rocca-Serra, G. (1980), Censorinus, Le jour natal, trad. annotée, Histoire des doctrines de l'Antiquité Classique 5. Paris.

Ruiz de Elvira, A. (1969), reseña de Ovide, Tristes, text. y trad. J. André, Paris, 1968, Emerita 37, 419-422.

___ (1976), "Problemas del calendario romano", $C F C$ 11, 9-17.

- (21982), Mitología clásica. Madrid.

Schilling, R. (1978), “Genius”, Rivista di archeologia cristiana 10, 52-83.

(1979), "Genius et Ange”, en Rites, cultes, dieux de Rome. París, 415444.

Sordi, M. (2002), "I saecula degli etrusci e gli ostenta”, Rivista storica italiana 114 (3) 715-725.

Van der Waerden, B.L. (1952), "Das grosse Jahr und die ewige Wiederkehr”, Hermes 80 129-155.

Veyne, P. (1987), ¿Creyeron los griegos en sus mitos? : ensayo sobre la imaginación constituyente. Barcelona.

Wille, G. (1967), Musica Romana. Amsterdam. 
${ }^{1}$ Este trabajo se ha realizado dentro del proyecto "Métrica, música y gramática romanas: estudio del léxico y las doctrinas, ediciones, traducciones y comentarios" FFI2008-05611/FILO, financiado por la Dirección General de Investigación del M.E.C

${ }^{2}$ Así con h, como es del gusto del profesor Luque, que mantiene la escritura etimológica en el sustantivo harmonía y el adjetivo harmónico, $-\mathrm{a}$, cuando se refieren a la antigua disciplina musical.

${ }^{3}$ De estas cuestiones presenta una exposición breve pero muy clara y útil Ruiz de Elvira 19827 ss.

${ }^{4}$ Bajo la denominación de Genitor, Apolo tenía consagrado en su isla natal un altar (ara Apollinis genetivi) que por no admitir ofrendas cruentas parece que fue de las preferencias de los pitagóricos: cf. Macrobio Sat. 1.17. 42; 3.6.2 ss.

${ }^{5}$ Varrón, como es bien sabido, destacó por su insistencia en este tipo de explicaciones que, por otra parte, fueron en general muy del gusto del mundo antiguo. Puede consultarse a este respecto Maltby 1991 s. v. Genius.Sobre esta especie de divinización de la personalidad o entidad individual de cada uno, cf. Schilling 1978 y 1979.

${ }^{6}$ Libros religiosos que contenían los nombres de los dioses y prescribían el modo de adorarlos y las fórmulas de invocación para dirigirse a ellos; cf. Ogilvie 196923 y 38.

${ }^{7}$ En la mitología griega, Erictonio es hijo de Hefesto que, enamorado de Atenea, la persiguió y logró darle alcance, a pesar de ser cojo. La diosa se defendió y en el forcejeo, parte del semen del dios se le esparció por la pierna. Atenea se secó con lana, que arrojó al suelo. De la tierra así fecundada nació un niño al que la diosa recogió y llamó Erictonio, nombre cuyo primer elemento recuerda la "lana", erion, y el segundo el "suelo", chthon. Censorino identifica a Vulcano con Hefesto.

${ }^{8}$ Los spartoi, "hombres sembrados", son los que nacieron de los dientes del dragón muerto por Cadmo en el lugar de la futura Tebas, sembrados por el héroe por consejo de Atenea.

${ }^{9}$ Particula se fijó como término técnico dentro del lenguaje de la astrología para designar cada uno de los 360 grados de la órbita del Zodiaco y, por tanto, cada uno de los 30 que le correspondían a cada signo: cf. Le Boeuffle 1987 s. v.

${ }^{10}$ Como dios de la música, uno de los atributos más antiguos y más frecuentes de Apolo en representaciones literarias e iconográficas (cf. Wille 1967 515-520) es la cítara (de la que alguna tradición lo hace incluso creador), que alterna en igualdad con la lira (uno de los regalos que su padre le envió en su nacimiento).

${ }^{11}$ Las Musas son también las cantoras divinas. Son representadas ejecutando cantos acompañadas de instrumentos de viento, como las "tibias" o los auloi, o de instrumentos de cuerda (a los que se refiere aquí Censorino), como la cítara o la lira (cf. Wille 1967 520-524).

${ }^{12}$ En todos los tiempos los romanos utilizaron músicos en sus ceremonias religiosas. Se encuentran también músicos en los banquetes en honor a los dioses, como el epulum Iovis, ofrecido por los miembros del collegium tibicinum con ocasión de su fiesta anual, en la que interviene también la lira; cf. Wille 1967 27-29; 33-38 y Baudot 1973 36-46.

${ }^{13} \mathrm{Si}$ se refiere al epulum Iovis, Censorino parece considerarlo como una fiesta distinta, al menos no celebrada el mismo día que los Quincuatros, a diferencia de otros autores, como Livio 9.30.5 (según el cual el privilegio estaría reservado solo a los tibicines que intervienen en los sacrificios), o Valerio Máximo 2.5.4.

${ }^{14}$ Se llamaban "Quincuatros” dos fiestas celebradas en honor de Minerva: la primera tenía lugar el 19 de marzo y duraba cinco días; la segunda, que duraba sólo un día, o tres según algunos autores, tenía lugar el 13 de junio y era propia de los tibicines, que recorrían la ciudad disfrazados. Debe su nombre bien a que se celebraba el quinto día después de las Idus, en el caso de la primera (cf. Varrón Ling. 6.14; Paulo Festo 255; Carisio pág. 102, 16 B., Barwick), bien a que concluía con la purificación de los instrumentos musicales que se utilizaban en los sacrificios, pues, según el citado testimonio de Carisio, los antiguos latinos decían "quinquare" por "lustrare", 'purificar'.

${ }^{15}$ Para este nombre y los siguientes, préstamos todos del griego, cf. Le Boeuffle $1987252 \mathrm{~s}$. 
vข. y para los distintos tipos de nomenclaturas que han recibido los planetas en la Antigüedad, cf. Le Boeuffle 1977 237-264. Como reacción a la gran confusión onomástica planetaria producida por la multiplicidad de tutelas divinas ejercidas sobre los cuerpos celestes, en época alejandrina, los astrónomos helénicos buscaron para los cinco planetas (Mercurio, Venus, Marte, Júpiter y Saturno) nombres que pudieran constituir una terminología duradera y científica, que atendieran al aspecto físico de los mismos. Como se puede comprobar por los nombres que actualmente reciben los planetas, acabó triunfando la terminología antigua o mitológica. Censorino ofrece aquí las dos series de nombres, tanto la mitológica como la científica.

${ }^{16}$ Ya he dedicado un trabajo a esta cuestión: cf. Hoces Sánchez 2009.

17 Así llamados, más que por la ciudad de Tarento, por un lugar del Campo de Marte conocido por Tarentum, en donde un tal Valesio, según cuenta Valerio Máximo (2.4.5), habría encontrado curación para sus hijos afectados por una epidemia. Este altar de Tarentum tenía un papel particularmente importante en la celebración de los juegos seculares.

${ }^{18}$ Por ir consagradas a dioses subterráneos, del mundo de las tinieblas: la propia Prosérpina es a veces (Horacio Carm. 2.13.21) calificada como furva, "negra", "sombría".

${ }^{19}$ En el libro decimoctavo de las Antigüedades, que pertenecía a la sección dedicada a la cronología (libros 14-19) y el pasaje aquí mencionado constituye el frg. 4 de Mirsch.

${ }^{20}$ Los “años grandes" son ciclos de años con los que los astrónomos trataban de conciliar con el Sol el habitual calendario lunar: cf., por ejemplo, van der Waerden 1952.

${ }^{21}$ Parece haber en todo este pasaje de Censorino una confusión con el cómputo de los años; explican estas cuestiones Beaujeu 1975, Ruiz de Elvira 1969 y 1976, o Pighi 1959.

22 Cultos "mistéricos", es decir, de iniciados. El culto a Dionisos estaba desligado del organismo cívico y no representaba un elemento de orden y estabilidad. La religión oficial se oponía a tal culto, lo que dio lugar a dos resultados: por una parte, en Ática sobre todo, el culto a Dionisos se hace oficial y se humaniza (desemboca en el ditirambo, la tragedia, la comedia); por otra, los elementos de la ciudad que lo habían acogido preferentemente, es decir, aquéllos que menos favorecía la religión cívica (mujeres, pobres...) forman asociaciones cultuales, los thiasoi, dentro de los cuales se desarrollan los misterios báquicos. Cf. Festugière 197213 ss.

${ }^{23}$ Por ejemplo, Virgilio Aen. 4.302; Ovidio Met. 6.587; Estacio Theb. 2.661.

${ }^{24}$ Es decir, cada cuatro años, según el cómputo exclusivo. Se refiere, obviamente, a los juegos Olímpicos; unos juegos Capitolinos fueron instituidos por Domiciano el año $86 \mathrm{~d}$. C.

${ }_{25}^{25}$ Tot, como dios de la Luna, regulaba las estaciones y las fases lunares y contaba las estrellas (cf. Doxey 2003). A él estaba dedicado el primer mes del año egipcio. El primer día de dicho mes, y, por tanto, del año nuevo, coincidía con la salida matinal de Sirio, hecho que indicaba también la crecida del Nilo.

26 "Prelunares", o sea, “anteriores a la Luna", denominación que ponía de relieve su especial antigüedad.

${ }^{27} \mathrm{Cf}$., por ejemplo, Ovidio Fast. 2.289 ss.

${ }^{28} \mathrm{El}$ dios solar egipcio, equivalente al griego Apolo, del que algunos hacen derivar el nombre de las estaciones, del año e incluso de las horas (cf. Macrobio Sat.1.21.13).

${ }^{29}$ Fulvio -a quien nombra Censorino como garante de esta opinión- de creencias pitagóricas, explicaba (cf. Rocca-Serra 1980 65-66) el año de 355 días por la superioridad del número impar, basándose en que Numa habría sido discípulo de Pitágoras. La cuestión sobre el número de meses del año romano primitivo dividía a los eruditos romanos, y también a los estudiosos actuales, aunque la atribución a Tarquinio está menos extendida que la atribución a Numa.

${ }^{30}$ Fiestas en honor del dios Término, el día 23 de febrero, que era originariamente el último mes del año, según atestiguan Varrón Ling. 6.13, Ovidio Fast. 2.49 ss.; 2.639 ss., Macrobio Sat. 1.13.15, etc. Los cinco días restantes de febrero se añadían al final del mes intercalar, de modo que a febrero seguía sucediéndolo marzo. febrero).

${ }^{31}$ Los meses que contaba el año antes de que Numa, o Tarquinio, añadiera dos (enero y

${ }^{32}$ La etimología propuesta por Censorino y otros muchos autores antiguos (cf. Maltby 1991 s. v. aprilis) parece que es acertada: cf. Ernout-Meillet, s. v. aprilis.

${ }^{33}$ Etimología correcta (cf. Ernout-Meillet s. v. Maia). La diosa latina Maya fue pronto 
identificada con la homónima diosa griega de la maternidad, con la que Zeus había tenido a Hermes, identificado, a su vez, con el latino Mercurio.

${ }^{34}$ De nuevo Varrón da la etimología correcta (cf. Ernout-Meillet, s. v. Iuno); hay autores que lo hacen derivar de "iunctus" (Ovidio Fast. 6.6), de "Junio Bruto" (Macrobio Sat.1.12.31) o de la diosa "Iuventa" (Agroecio, Gramm. 7.124.9); cf. Maltby 1991 s. v. Iunius. Así como cada hombre tenía su Genius, toda mujer tenía su Iuno.

${ }^{35}$ El 15 de febrero se celebraba una procesión en honor de Fauno Luperco. Los sacerdotes que la llevaban a cabo (llamados lupercos) daban la vuelta al Palatino desnudos, provistos de correas hechas con la piel de una cabra recién inmolada y con ellas golpeaban a las mujeres que encontraban para así volverlas fecundas.

${ }^{36}$ En el Quirinal, la colina que queda más al Norte, en territorio sabino (en efecto, los testimonios antiguos son casi unánimes en presentarlo como un dios de origen sabino). Uno de los dioses romanos más antiguos, dios de la guerra o, según la teoría de Dumézil, protector de los campesinos (cf. Grimal ${ }^{6} 1979$ s. v. Quirino). El principal mito relacionado con este dios es el de la asimilación de Rómulo a él (cf. Grimal ${ }^{6} 1979$ s. v. Rómulo). Según Plinio Nat.7.213, Lucio Papirio Cursor dedicó el templo en calidad de cónsul e hizo colocar el primer reloj solar en 293 a. C.

${ }^{37}$ Cf. Freyburger 1992.

${ }^{38}$ Cf. Freyburger 1999.

${ }^{39}$ Como indica Rocca 2006, Censorino, plantea la cuestión del origen de la especie humana en términos de eternidad o principio. En la primera parte, especifica a qué filósofos se atribuye la opinión de que el género humano es eterno y que no tuvo un momento inicial (Pitágoras, Platón, Aristóteles) y después, cuando pasa a las opiniones de quienes han creído que algunos hombres primigenios fueron creados por voluntad divina o por causas naturales, Censorino no solo omite las fabulares historiae, como la relativa a Prometeo y Deucalión y Pirra, sino que expresa su escepticismo también sobre las doctrinas antropogónicas de los filósofos (de cuyas opiniones afirma nescio an monstruosas, certe non minus incredibiles) y sobre los relatos de los poetas. En la segunda creación del hombre (Deucalión y Pirra), el nacimiento de las razas humanas, consecuencia de la siembra de Cadmo de los dientes de la serpiente (Ov., Met. III 99-130), la aparición de guerreros tellure creati de una terra gravida por los dientes del dragón, Censorino interpretará esas semillas como debidas a la licentiae poeticae libido, apenas creíbles cuando ya se habían constituido los pueblos y habían sido fundadas las ciudades. Tal es también el nacimiento de Erictonio en Ática de la tierra fecundada del semen de Vulcano.

${ }^{40}$ Cf. Guittard 2002.

${ }^{41} \mathrm{E} 1$ texto es de especial interés para el conocimiento de la Etrusca disciplina; cf. Sordi 2002.

${ }^{42}$ Rey del pueblo que habitaba, hace unos tres mil años, el suroeste de la Península Ibérica y que llegó a un grado de riqueza y desarrollo admirado por los autores griegos. En realidad Heródoto le atribuye ochenta años de reinado y ciento veinte años de vida; es Anacreonte (frg. 4 Gentili= 361 Page) el que habla de ciento cincuenta años. Con Heródoto coinciden Cicerón Cato 69; Valerio Máximo 8.13, ext. 4; y Plinio Nat. 7.154 y 156, que cita a Anacreonte, pero se inclina por la edad de ciento veinte años; cf. igualmente Ps. Luciano Longaev. 9-10. Todos los testimonios identifican el territorio de los tartesios con Gades (Cádiz).

${ }^{43}$ Las naciones, como los hombres, tienen un tiempo finito (cf. Lehmann 1999 ), que a veces es anunciado por parte de los dioses por distintos medios.

${ }^{44}$ Cf. Picklesimer Pardo 2006227.

45 "Prelunares", o sea, "anteriores a la Luna", denominación que ponía de relieve su especial antigüedad.

${ }^{46}$ La etimología propuesta por Censorino y otros muchos autores antiguos (cf. Maltby 1991 s. v. aprilis) parece que es acertada; cf. Ernout-Meillet, s. v. aprilis.

${ }^{47}$ La de la aritmética pitagórica.

${ }^{48}$ Trad. Luque-Hoces, en prensa.

${ }^{49}$ El cataclismo, o diluvio, es el período más crudo del invierno del año al que Aristóteles llama "máximo". Este primer diluvio fue, como dice en el párrafo siguiente, el de Ógygo.

${ }^{50}$ Año 776 a. C.

${ }^{51} \mathrm{El}$ mítico fundador y rey de Tebas, durante cuyo reinado se produjo un primer diluvio 
que inundó toda Beocia. Calculando hacia atrás desde la primera olimpiada, puede situarse este primer diluvio hacia el 2400 a. C.

${ }^{52}$ Hijo de Océano y de Tetis, mítico primer rey de Argos, unos mil doscientos años antes de la primera olimpiada, es decir, hacia el 2000 a. C. según los datos que da Censorino.

${ }^{53}$ Según Censorino, la caída de Troya habría acaecido unos cuatrocientos años antes de la primera olimpiada, es decir, hacia el 1200 a. C.

${ }^{54}$ No es impensable que en toda esta enumeración de autores Censorino se haga eco de las fuentes helenísticas que encontraba en Varrón.

${ }^{55}$ adelon, mythikon, historikon.

${ }^{56}$ Cf. Rocca 1997.

${ }^{57} \mathrm{Op}$. cit. en nota anterior.

${ }^{58}$ Poucet 1987.

${ }^{59}$ Cf. Veyne 198761 ss.

${ }^{60}$ Cf. Poucet 1987

${ }^{61}$ Cf. Rocca 1997 222-223. 


\title{
Los doce trabajos de Hércules en la literatura MEDIEVAL ESPAÑOLA
}

\author{
LORENA JiMÉNEZ Justicia \\ Universidad de Granada
}

Uno de los personajes de la mitología clásica que más ha fascinado a literatos y artistas occidentales ha sido Heracles ${ }^{1}$. El sufrimiento al que se ve sometido por tener que realizar los conocidos Doce Trabajos al servicio de Euristeo ha convertido su figura en símbolo de distintos valores éticos a lo largo de la historia, a través del ensalzamiento de algunos rasgos de su carácter, presentes ya desde la Antigüedad. En la Edad Media representa el gran esfuerzo que conlleva como una vida virtuosa pero que se ve recompensado con la inmortalidad, en una lectura de sus hazañas claramente influenciada por la moral cristiana. El Renacimiento seguirá por el mismo camino si bien nuestro protagonista será además un espejo en el que se miren los monarcas y gobernantes de la época mientras que en el Barroco el tema preferido es el peligro que acarrean ciertas mujeres a un hombre de bien, como Ónfale, encarnación de la lujuria, o Deyanira cuyos irracionales celos provocan la muerte del héroe. Durante la Época Moderna el auge de los movimientos sociales y de las nuevas ideas acerca de la sociedad y del hombre harán que se cuestione el valor de las empresas de nuestro protagonista poniéndolas en relación con el debate acerca de la libertad, la utilidad del Estado y la lucha contra la opresión.

En la literatura griega, patria de origen del mito, nos topamos con datos dispersos acerca de la vida del Anfitriónida aquí y alláa , sin embargo, es en la época helenística cuando se configura una biografía ordenada y racional en la que se distinguen los ع̌ $p \gamma \alpha$, en un número cerrado de doce, llevados a cabo

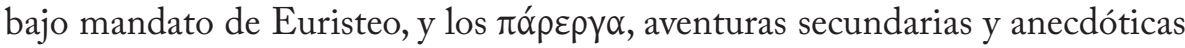
emanadas de la realización de éstos. El primer testimonio que poseemos con esta disposición es la Biblioteca, atribuida a Apolodoro³.

Sin embargo en el período que nos ocupa no hay distinción entre ع́pүa

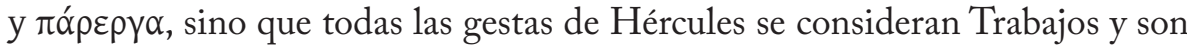
interpretadas combinando las tres corrientes exegéticas en boga: la evemerista, la astrológica o la alegórica ${ }^{4}$. Por otra parte, el desconocimiento de la literatura griega por aquel entonces hizo que los eruditos de este tiempo acudieran a autores tardíos y fuentes secundarias.

Así, la España medieval, fuertemente dominada por los dogmas de la Iglesia Católica encuentra en el hijo de Zeus un perfecto exponente de la victoria del Bien contra el pecado, que acecha por todas partes. Dos son los 
literatos que, en clave moral y evemerista se van a ocupar del do dekathlos: Alfonso X el Sabio en su General Estoria y Enrique de Villena en Los doce trabajos de Hércules. Entre ambos hay dos diferencias fundamentales: la primera, el uso de las fuentes, ya que a la publicación del compendio del rey Sabio no había aparecido todavía el Genalogiae deorum gentilium libri XV de Boccacio, tratado clave para el análisis de la mitología clásica desde su publicación hasta bien entrado el Renacimiento; la segunda afecta a la intencionalidad de los autores: el monarca trata con su obra de dar un augusto pasado a la monarquía castellana mientras que el Caballero Enrique de Villena usa su tratado para darse propaganda a sí mismo.

La General Estoria, redactada entre 1272 y 1284, con la ayuda de un grupo de compiladores al servicio del rey, es una historia universal en la que se narran los sucesos que aparecen en la Biblia junto con las leyendas de los "gentiles" basándose para el cómputo de las edades en las Crónicas de San Jerónimo (continuadas por Eusebio de Cesarea), que enfrentaba en líneas paralelas los sucesos de las diferentes civilizaciones año por año. La gran obra alfonsí empieza con la creación del mundo y pretendía llegar hasta la época en que se escribió pero quedó inacabada. En la Segunda Parte encontramos la Estoria de Ercules, desde su nacimiento hasta su muerte ${ }^{5}$. Nos centraremos aquí en los Doce Trabajos y en algunas aventuras secundarias que tuvieron gran peso en la tradición y que también trató Enrique de Villena. Las fuentes que se manejan principalmente, son las Metamorfosis de Ovidio, las Etimologías de Isidoro y el desconocido Libro de los linajes de los gentiles 6 .

Antes de ofrecernos la cuenta de los grandes fechos de Ercoles explica la razón por la que ha de llevarlos a cabo: la reina Juno, su madrastra, le odia y convence al rey Euristeo para que lo mande a afrontar estos peligros con la esperanza de que muera ${ }^{7}$. El primer gran "fecho" que lleva a cabo es "matar al puerco montés a manos". En este punto los eruditos castellanos cometen un error ya que confunden al jabalí de Erimanto con el de Calidón ${ }^{8}$ y es con la piel de éste con la que se viste el héroe.

A continuación se narra como el toro de Creta enviado a Minos, ya por Neptuno, ya por Júpiter, fue vencido in situ por el propio Hércules ${ }^{9}$ o, según otras versiones, lo llevó hasta Maratón, donde Teseo lo mató. Seguidamente se enfrentó a tres leones, el de Partemio (Partenio), hecho que dice haber leído en Ovidio ${ }^{10}$ y con cuya piel se hizo un traje, y otros dos en la selva de Nemea, a los que estranguló. Por estas empresas fue llamado «domador de leones e de las bestias fieras salvages».

La Hidra de Lerna no es más que una serpiente de agua, ya que ydros denomina este elemento en griego. Para vencerla "Ercoles" cogió todas sus cabezas y la estranguló o bien la mató con sus flechas, las cuales sumergió en su veneno y regaló a Filoctetes pero a éste, le cayó una en el pie y estuvo enfermo 
durante diez años; una vez recuperado, las usó en la Guerra de Troya ${ }^{11}$. Aquí se están mezclando dos episodios distintos: es cierto que el célebre arquero fue el depositario de las flechas pero, a quien le cayó una en el pie fue al Centauro Folo ${ }^{12}$. La enfermedad de Filoctetes, por la que sus compañeros de expedición lo abandonaron en Lemnos durante diez años, fue causada por la mordedura de una serpiente. Por último, acude a la explicación evemerista según la cual las siete cabezas de la Hidra representaban los siete brazos de una laguna que fue desecada ${ }^{13}$.

La captura de las estinfálides ${ }^{14}$ se confunde con el incidente de las Harpías y Fineo ${ }^{15}$, que esconde una alegoría moral: el nombre de estos pájaros viene de arpis que significa "robar", sentido que también se refleja en la etimología del nombre de cada uno: Aello: "querer lo ajeno"; Ocapite: "tomarlo forzado" y Seçeleno "esconder". Simbolizan, por tanto, la avaricia.

En cuanto a los antropófagos caballos de Diomedes encontramos una de las versiones antiguas, según la cual éste se convirtió en pasto de sus propios corceles ${ }^{16} \mathrm{y}$ una interpretación evemerista: dicho rey contaba con unos jinetes muy veloces que robaban por toda Grecia así que el semidiós lo encerró en su fortaleza y le obligó a comerse todo lo que allí había, por lo que, cuando los víveres se acabaron, murió de hambre.

Tras estos ingentes esfuerzos el héroe contrae matrimonio con Mera (Mégara), a la que conoció porque se demoró mucho tiempo en Tirrenia luchando contra los Centauros, que habían destrozado la boda de Periteo e Ypodame. De nuevo nos topamos con una mezcla de tradiciones, ya que si bien es verdad que Heracles tuvo que enfrentarse a estos hombres equinos cuando se dirigía a capturar al jabalí de Erimanto ${ }^{17}$, la Centauromaquia, que tuvo lugar durante la boda de Hipodamía, estuvo protagonizada por Teseo y Pirítoo. Sea como fuere la General Estoria ofrece una explicación acerca del linaje de estos seres: Exión era un Gigante, hijo de Saturno y consejero de la reina Juno. Quiso yacer con ella pero como ésta sabía de encantamientos le puso una nube delante y él estuvo en realidad con otra mujer, de la que nacieron estos monstruos, mitad hombres, mitad caballos ${ }^{18}$. Como los antiguos creyeron que habían sido engendrados en el aire los llamaron Centauros que viene de aura ("aire") y gignere ("engendrar"). Pero se recoge también otra explicación: antes no se usaban los animales para las labores agrícolas excepto en el reino de Ixión, que había conseguido domar a los caballos y aprovechó la pericia de sus jinetes para mandarlos a saquear Grecia. Cuando la gente los veía, a lo lejos, tenía la sensación de que volaban y de ahí viene su nombre que significa "cien en el aire".

Después se inserta el capítulo «De como conquirio e vençio Ercules las amazonas». Para luchar contra este pueblo guerrero se reunió a un contingente de hombres, que llegaron a la tierra de éstas por mar. Como no esperaban que hubiera una batalla próxima, estaban desarmadas por lo que las cogieron por 
sorpresa, mataron a algunas y raptaron a otras. Tenían las Amazonas dos reinas: Anthiopa y Oriçia ${ }^{19}$. El Anfitriónida tomó como cautivas a las dos hermanas de Antíope: Ypolita y Manolip; la primera se la entregó a Teseo que se casó con ella y con la que tuvo a su hijo Hipólito. La segunda la devolvió a su hermana, que le dio a cambio sus armas.

El héroe ha de dirigirse ahora hacia el jardín de las Hespérides. Éstas eran hijas del sabio astrólogo Atalante y se llamaban Experetusa, Eglan y Arechusa. Sin embargo, según El libro de los linajes de los gentiles, eran hijas de Espero, hijo de Jappeco, hijo, a su vez, de Titano. La razón de que haya dos genealogías es, para él, clara, estas Hespérides, hijas de Espero son otras que hubo antes y que tenían el mismo nombre. Fue de las hijas de Atlas de las que "Ercoles" aprendió todas las artes del quadrivium y del trivium por lo que los antiguos dijeron que había tomado las manzanas de oro de su jardín pues, para ellos, el saber era el bien más preciado. El dragón insomne que custodiaba las manzanas representa el afán de conocimiento por el cual uno no duerme. También aprendió astronomía con el padre de las muchachas, por ello los antiguos dijeron que sostuvo la bóveda celeste. Fabularon también que Atlas se convirtió en un monte ${ }^{20}$ porque el saber nos hace elevarnos como grandes montañas, cada vez más cerca de $\operatorname{Dios}^{21}$.

Alfonso X convierte la expedición en busca de los bueyes de Gerión en una empresa histórica por la que Heracles habría fundado varias ciudades en España $^{22}$. Desde África, llega a una isla en el extremo de Andalucía en la que levanta dos columnas por lo que el lugar recibió el nombre de Gades Ercules, que quiere decir "términos de Hércules". A Gerión lo hace, sorprendentemente, hijo de Euristeo y afirma que sus tres cabezas simbolizan el dominio sobre tres reinos ${ }^{23}$ : Galicia, la Lusitania y la Bética. Enterado de su mal gobierno Alcides ${ }^{24}$ lo derrota y conquista toda su tierra: Galicia fue llamada así porque la pobló con hombres de Galaçia; a la región del Guadiana la denominó Lusitania, de luso, "trabajo" y Ana, que es el nombre del río, lo que quiere decir «el canpo de los trebejos de Ercules fechos çerca de Guadiana». Tras obtener estas provincias, se quedó en Cádiz y empezó a recorrerla siguiendo el curso del Guadalquivir. Como traía consigo al pueblo de los "espalos", de cerca de Siçia, los asentó allí. En un principio hicieron sus casas con cañaveras y pajas sujetas por palos y como yper es en griego "sobre” y pilos en latín "palos", juntaron estas dos palabras y le dieron el nombre de "Yspalis", que ahora se llama Sevilla. También le atribuye los asentamientos de Tarragona, Urgel y Barcelona. Antes de proseguir con sus viajes y aventuras deja en esta tierra a su compañero Espan, por lo que el país, que antes se llamaba Esperia, por la estrella vespertina, fue llamado Espanna ${ }^{25}$.

A continuación se relatan las hazañas que tuvieron lugar en Italia, incluida la muerte de Cato (Caco), narrada en la Eneida para dar una explicación de los 
sacrificios anuales que se realizaban en el Ara Máxima: Caco, ser monstruoso que echaba fuego por la boca, robó a Hércules los ganados de Gerión cuando pasaba por allí y los metió en su cueva tirándoles de la cola para que entraran de espaldas y no pudieran ser encontrados por el rastro de las huellas, pero el hijo de Zeus logró dar con ellos y mató al ladrón. Los habitantes de la región, agradecidos por verse librados del bandido, erigieron el altar del Ara Máxima. ${ }^{26}$ Alfonso X lo cuenta tal cual aunque omite la dedicación del citado altar.

Llegamos así al último de los "Trabajos canónicos": sacar del Hades al can Cerbero. En este punto encontramos lo que podríamos llamar una declaración de intenciones: resulta que nuestro héroe fue tan famoso que todos trataron de él y «clerigos sabios de los gentiles contaronlo en latin e pusieronlo en libros que fizieron deso e de otras cosas; mas dixeronlo tan encubierta mente, e por tales razones e tan estrannas que semeja fablilla». La misión del Sabio es sacar a la luz su significado oculto. Tenemos, por tanto, la fablilla y su explicación. Euristeo y Juno, como le odiaban, lo mandan a por Cerbero, al que Alcides saca del infierno atándolo con una cadena. Una vez fuera, el perro, no acostumbrado a la luz, se agarró a una piedra porque quería volver al averno. Debido al forcejeo empezó a echar espuma por la boca que calló en la piedra y de la que se formó una hierba venenosa que se llama acónito ${ }^{27}$. Para una explicación histórica recurre a Filocoro, Eusebio y Sigiberto: había en el país de los molosos un rey llamado Orco, nombre que los latinos daban también al infierno. Estaba casado con una bella mujer a la que trataba muy mal. Ésta, no atreviéndose a pedirle al gran Hércules en persona que la rescatara, le dijo a Teseo que hablara con él, pero el ateniense pensó que era mejor tratar de raptarla con ayuda de Periteo, para que no se produjese una contienda. Este soberano tenía un gran perro que se comía a los hombres y en cuanto vio a Pirítoo lo devoró, después intentó acabar con Teseo, momento en que llegó Heracles, que se había enterado de todo, y lo salvó. La etimología que ofrece del nombre del animal coincide con la de las Etimologías de Isidoro ${ }^{28}$ : Cerbero vendría de крєoßópos : "que devora carne".

Los eruditos castellanos acuden a la leyenda hercúlea con fines políticos, para dar un augusto pasado a España, que habría sido así fundada por los griegos. En la Edad Media, cuando se empezaba a buscar la identidad nacional de los pueblos, eran normales estos tipos de asociaciones, todo reino quería contar con un gran antepasado mítico. El paso del Anfitriónida por Hispania, refrendado por los testimonios de los antiguos, daba la oportunidad de relacionarlo con las lejanas raíces de Castilla. No debe extrañarnos ésto, pues los literatos de la época augustea hicieron el mismo intento para retrotraer el linaje de la familia Julia y el del pueblo romano hasta el mismo dios Marte. Como es habitual en las obras que trataron temas mitológicos en este período, hay una gran influencia de la teoría evemerista según la cual los dioses de los 
antiguos fueron hombres y mujeres que hicieron un gran bien a la humanidad y, por ello, se les recordó como divinidades, pero frente a la exégesis histórica resalta la moral, en la que los monstruos se convierten en pecados con los que hay que acabar.

Pasemos ahora a analizar el tratamiento del tema por parte del escritor aragonés Enrique de Villena (ca.1382-1434). Este aristócrata destacó por ser el primero en traducir al castellano la Eneida de Virgilio y la Divina Comedia de Dante. Interesado por todas las ramas del saber, sus escritos abarcan tratados gastronómicos (Arte cistoria), sobre poesía (Arte de trovar), sobre medicina (Libro de la peste, Sobre la Alquimia) y estudios astrológicos, que fueron quemados a su muerte, ya que su fascinación por este tipo de cuestiones le crearon mala fama y le valieron el apodo de "el nigromante".

En 1417 escribió su primera obra Los dotze treballs de Hèrcules, a instancias del noble valenciano Mosén Pere Pardo. Poco después el conquense Juan Fernández de Valera le pide que la traduzca al castellano. En su traducción, Villena $^{29}$ añade nuevos matices y alguna que otra referencia. Contiene un prólogo y una carta a Mosén Pere en la que vemos su intención: este libro va dirigido a los caballeros para que sirva como «cresçimiento de virtudes e purgamiento de viçios». En el proemio explica como procede en cada capítulo (consta de doce): primero acude a la ficción tal como la narraron los antiguos o bistoria nuda, después explica la alegoría que se oculta tras ella o declaración, a continuación la realidad que está esconde, a la que llama verdad y por último la aplicación o enseñanza moral.

Esta estructura parece inspirarse en la que sigue Coluccio Salutati en su De laboribus Herculis ${ }^{30}$, donde hallamos la historia ad literam, que correspondería a la historia nuda de Villena, moraliter (declaración) y naturaliter, explicación de índole física o astral. En este último punto nuestro autor se aleja del italiano pero añade una novedad: las alegorías son un ejemplo para las distintas "clases sociales" del momento. Esta nueva forma de exégesis le da al escrito un aspecto nuevo e interesante y nos permite conocer la jerarquía social del medievo. Para Villena los estados en que está dividido el mundo son doce, de ahí la conveniencia de centrarse en este mito: el estado de príncipe, de prelado, de caballero, de religioso, de ciudadano, de mercader, de labrador, de ministral, de maestro, de discípulo, de solitario y de mujer. A su vez, cada uno de éstos contiene varios grados: el de príncipe representa a reyes, emperadores, duques, marqueses, etc. Por prelado se entiende Papa, cardenal, patriarca, obispo, arzobispo, vicario. En el estado religioso se incluye a capellanes y frailes así como las distintas órdenes, hermandades, cofradías o sociedades. Ciudadanos son burgueses, vagabundos y hombres que no viven de su trabajo. Los mercaderes son los comprantes y "vendientes", a los que no parece tener en mucha estima. En 
el nivel del labrador incluye también al pescador «e los otros que biven de su trabajo corporal, usando ofiçios o menesteres baxos e despreçiados». Entre los ministrales se encuentran herreros, tejedores, pintores, y todos aquéllos que, "por menester público», venden su labor para comer. Los maestros son los que saben un arte o ciencia y pueden enseñarla a sus discípulos o alumnos. Entre los solitarios están los ermitaños, los anacoretas y los presos. En fin, por el estado de mujer entiende «todos los grados femeniles»: doncella, moza y viuda.

Sus fuentes son el Metamorphoseos de Ovidio, la Mitología de Fulgencio, la Genealogía de Boccaccio, la Eneida de Virgilio, las Etimologías de Isidoro y la Consolación de la filosofía de Boecio, cuyo orden para la enumeración los Trabajos ${ }^{31}$, como él mismo dice en el Libro I, va a seguir.

Así pues, el primero es «domar a los centauros», pero en vez de tratar la anécdota de Folo, se va a basar en las Metamorfosis para contarnos la fábula de Uxio (Ixión) y Juno, como ya había hecho Alfonso $\mathrm{X}^{32}$. Su declaración procede de Fulgencio: Juno es la vida activa que se preocupa de las cosas temporales, pero es divina y diosa del aire $^{33}$ porque, aunque temporal, éste es necesario para la conservación de la vida. Hércules personifica la virtud, atacada por lo terrenal, su madrastra. Ixión es un hombre codicioso, que sólo da valor a las cosas efímeras, por ello se enamora de la vida activa. La nube simboliza el engaño de los que creen en este tipo de existencia, que engendra seres ambiguos y monstruosos. Los Centauros son el vicio contra el que el hombre virtuoso debe luchar. La verdad es que Ixión era un malvado rey de Grecia que aprendió a domar a los caballos para asustar a la gente. Al verlos de lejos se creyó que eran un sólo $\operatorname{ser}^{34}$. Su nombre significa «cien que corren como el viento». La moraleja es aplicable a los príncipes porque así ven qué tipo de vida les conviene. Por su parte, los súbditos aprenden que los malos han de ser castigados, como los Centauros, usando la justiçia comotativa, y los buenos, premiados, por medio de la justiçia destributiva. Espiritualmente también sirve al prelado, que ha de huir de los vicios.

La captura del león de Nemea le parece un hecho real, si bien alegóricamente alude a los soberbios, que se creen más virtuosos de lo que son. Deben tomar nota los prelados, ya que la selva de Nemea simboliza las tentaciones que les acechan y la maza, la justicia con la que deben atacarlas. Además el prelado debe oponerse al poder temporal, que quiere cambiar los dogmas de la Iglesia. Primero lo reprende con la maza y después con dureza, hasta quitarle la piel, que servirá de ejemplo público. Del mismo modo, los caballeros luchan contra los soberbios enemigos de la patria y traen sus despojos.

Siguiendo a Boecio, el tercer trabajo corresponde a cómo se enfrentó a las Harpías según el verso Fixit et certis volucres sagittis ${ }^{35}$, ( $\mathrm{Y}$ marcó a las aves con flechas certeras»). Villena, al igual que su predecesor, confunde el episodio de la captura de las Estinfálides con el de las Harpías, en el que, como hemos 
visto, Heracles no participó. Según su interpretación, Fineo encarna al hombre virtuoso que debe ser dueño de sus pasiones y al que conviene estar con aquélla mujer con la que ha engendrado hijos pero cae en la bigamia y se casa con la avaricia. Ésta es la madrastra de las buenas obras, que son los hijos de Fineo, a los que éste saca los ojos por tal de complacerla. Queda entonces cegado por los vicios, sin razonamiento. Las Harpías son la rapacidad y tienen cara humana ${ }^{36}$ porque hacen parecer razonable lo que no lo es. Las alas hacen referencia a la rapidez con la que el hombre vicioso se entrega al mal; las plumas, a los engaños con los que el avaro esconde lo que no ha ganado honestamente; las uñas afiladas, a la obstinación, que retiene lo ajeno sin voluntad de devolverlo. Este pecado ensucia el estado del hombre bueno, al que el sabio Heracles ayuda con el arco de su doctrina. La verdad es que Fineo era un rey de Grecia que repartió su hacienda entre sus descendientes cuando su primera esposa murió. Al casarse por segunda vez despojó a éstos de sus riquezas, que son la vista del estado temporal y quedó abocado a la ruina. Heracles llegó hasta él y le convenció de que la codicia no era buena y de que debía vivir en la abundancia como corresponde a un rey. Así, él recuperó su entendimiento y sus hijos los bienes que les pertenecían. Esta fábula se puede aplicar a cualquiera de los estados, pero sobre todo al de los monarcas y caballeros, que, a veces, tratan mal a sus vasallos e incluso a sus propios hijos a causa de la ambición y es entonces cuando se ven atacados por sus enemigos, las Harpías. Los caballeros tienen el deber de aconsejar y reprender a estos mandatarios. También los religiosos han de apartar de sí la codicia y mortificarla en los demás con santa doctrina, predicación y buen ejemplo.

La siguiente empresa consiste en ir a por las manzanas doradas del jardín de las Hespérides, que Villena relata como sigue: había un rey en Libia llamado Atlante que ordenó hacer un vergel cuyos frutos fueran de oro. En el centro de éste colocó el árbol más alto que contenía la más hermosa manzana por lo que era custodiado por un fiero dragón. La puerta estaba guardada por las "Espéridas", hijas de "Espero", hermano de Atalante. Su significado es el siguiente: Libia es nuestra condición humana, seca y arenosa, pero dispuesta para producir frutos maravillosos. Allí Atlas planta el jardín de las ciencias, siendo el árbol más alto la filosofía, guardada por la sutileza, que no puede dormir. Las Hespérides representan las tres cualidades necesarias para conocer todas las artes: inteligencia, memoria y elocuencia. Este singular huerto está cercado por un muro ${ }^{37}$, es decir, por las reglas y la ordenación de las distintas disciplinas y sólo se puede entrar por la puerta, que son los principios necesarios para adquirir el conocimiento. Heracles apacigua a las doncellas demostrándoles su inteligencia y se dirige directamente al mejor árbol, despreciando los saberes menores. Luego presenta la manzana ante Euristeo, que es su maestro, un rey amante del saber, que cultiva a su pueblo, antes rudo. 
Esta bella alegoría demuestra que Villena considera a la Filosofía la principal de las artes liberales y resulta casi pedagógica, pues nos habla de los instrumentos necesarios para el aprendizaje. Sorprende la buena consideración que tiene ante el rey Euristeo, frente a las fuentes clásicas. Está claro que se trata de una indirecta para los monarcas de su época: deben rodearse de gente instruida como hiciera el rey de Micenas. La aplicación va dirigida a los religiosos, que son los encargados de entregarse a la ciencia para exponer los secretos de las Sagradas Escrituras.

Como novedad, Hércules no baja al Hades para capturar a Cerbero sino que acompaña a Teseo y Pirítoo en su viaje para defenderlos del can. En cuanto a la realidad coincide con Alfonso $\mathrm{X}$ en narrarnos la historia del rey de los Molosos. Teseo y Pirítoo son la memoria y el entendimiento y Cerbero, el tiempo, que todo lo desgasta, mientras que Heracles es la constancia. El tiempo tiene tres cabezas: pasado, presente y futuro. Con el pasado muerde por olvido, con el presente por ignorancia, con el porvenir, por inadvertencia. Pirítoo es mordido por el olvido y Teseo hubiera sido mordido por la ignorancia si no hubiera estado con él la constancia. Otra interpretación hace de Cerbero la gula que atrae a los hombres de tres maneras: con viandas delicadas, con cantidad de las mismas o con ambas cosas a la vez. Esto enseña a los ciudadanos que deben ser generosos y ayudar a los que están en peligro, tanto si pertenecen a la clase baja (Pirítoo) como si son reyes (Teseo).

La exégesis del trabajo de las yeguas de Diomedes es social: el pueblo ha de rebelarse contra los mandatarios injustos por medio de la ley y el derecho natural. En cuanto a la aplicación han de tomar nota los mercaderes que no deben mantener lo que no puedanm, pues entonces incurrirán en el robo y la rapiña. Los labradores, por su parte, no han de negarse a pagar sus diezmos.

La Hidra de Lerna se convierte en los placeres de la carne; si uno es arrancado, surgen muchos más. Cada vez que se le cortaba una cabeza, le nacían tres: la pereza, la gula y la lujuria. Al hombre íntegro le acechan constantemente éstos peligros por lo que quiere acabar con ellos de raíz. Para ello, halla como remedio el fuego. El pantano donde vive esta serpiente constituye una alegoría de la ociosidad. Según Villena, para acabar con ella no basta con la represión, simbolizada en la espada de Heracles, ni con el freno de la razón, sino que es necesaria la aspereza de vida, la abstinencia y el trabajo continuado. La "historia verdadera" es que la Hidra era un pantano según Isidoro o un sofista según Platón ${ }^{38}$. E1 precepto moral va dirigido a los labradores, que no deben darse a la ociosidad, pues al ser hombres sin ciencia están más predispuestos a la lujuria.

El capítulo octavo trata de la lucha contra Atheleo (Aqueloo) que, como nos dice Villena, narra Ovidio en sus Metamorfosis. Cuando Hércules se llevaba a Deyanira, hija de Eneo, le salió al paso el gigante, que quiso quitarle a la mujer. 
En su lucha se sirvió de los encantamientos que sabía para transformarse en serpiente, pero, viendo que esto no le daba resultado, se metamorfoseó en toro, al que nuestro héroe le arrancó un cuerno y lo presentó «en el templo de la deessa Copia por recordança de acto tan cavalleril e señalado» ${ }^{39}$. Alegóricamente Alcides es el buen propósito del hombre virtuoso decidido a conservar dicha virtud, encarnada en Deyanira, la hija del rey, pues la buena vida se toma de los monarcas, ya que éstos la practican y la engendran, así, al igual que la esposa, esta vida no debe abandonarse. El "gigante" representa las tentaciones, que mudando de forma, intentan apartarnos del camino del bien. La Verdad es que Atheleo era un río difícil de atravesar, que el Anfitriónida dividió de manera que la forma del agua se asemejaba a dos cuernos $^{40}$. La enseñanza se aplica a los menestrales que, practicantes de la vida activa, deben ser virtuosos y esforzarse por seguir el camino de la rectitud no dejándose embaucar por aquellos de sus compañeros que le aconsejen viles acciones para enriquecerse. Por su parte, los maestros deben instruir demandando precios razonables y apartándose de toda codicia.

También es una aventura secundaria, como la anterior, la que se narra a continuación: el combate con Anteo, personificación de la lujuria según el aragonés. Hijo de Poseidón, que obligaba a los extranjeros a enfrentarse con él y siempre ganaba pues era invulnerable mientras estuviese en contacto con el suelo por lo que el hijo de Zeus lo venció sosteniéndolo en el aire mientras lo estrangulaba ${ }^{41}$.

Caco, de cuya historia ya hemos hablado, es aquí un Centauro, que encarna la disolución y el desorden. Roba el ganado de Gerión, los pensamientos carnales, que habían sido domados por Hércules. Cabe destacar que el rey de Hispania le regala sus bueyes, agradecido por haberlo llevado al camino del bien.

Como Boecio nombra sólo un jabalít2 sin indicar de cuál se trata Villena lo confunde con el de Calidón ${ }^{43}$. Este animal es el cuerpo que se deleita con el vicio, olvidando el espíritu y contra el que se han de usar todas nuestras fuerzas, por lo que se organiza una gran cacería en la que participan Hércules, la perseverancia, y Atalanta, la humildad, imprescindibles para vencer al "puerco". La humildad, no se deja impresionar por la fuerza de éste así que le saca la sangre de la soberbia y lo aplaca con la lanza de la paciencia, mas hasta que no es atacado con la perseverancia no muere. Conviene sobre todo como ejemplo para el solitario que pretende subyugar el cuerpo al alma para lo que necesita las dos condiciones aludidas. También se aplica a la mujer, pues, debido a su flaqueza, ha de temer a esta bestia, a la que deberá domar haciendo caso de los consejos de sus mayores y de su marido.

El último de los esfuerzos de Hércules, sostener la bóveda celeste, es contado en su forma mítica mezclando distintas tradiciones y haciendo de esta 
hazaña la que le sirvió para alcanzar la inmortalidad, tal como dice Boecio ${ }^{44}$. El rey de Libia, Atalante, se dispuso a sostener el cielo, pues estaba cayendo por su antigüedad, pero se cansa y pide ayuda al Anfitriónida. Júpiter, compadecido, lo convierte en un monte, en cuya cima se sube nuestro protagonista para seguir sosteniendo el firmamento. Los Gigantes quisieron echarlo abajo y como lo empujaron tendió una rodilla en tierra. El padre de los dioses lo convirtió en una constelación con esta misma postura ${ }^{45}$. Así, entre los astros, tuvo un descanso duradero de sus fatigas. El cielo son las obras espirituales, que estaban cayendo, pero Atlante, aunque no era un hombre de ciencia, quería seguir practicándolas y sosteniéndolas por lo que recurre a Alcides, persona docta y de entendimiento contemplativo. Atlas es convertido en una montaña porque las acciones del alma son vistas desde lejos. Sobre éste están los maestros defendiendo la verdad con disputas, razones, declaraciones e incluso con la muerte. Los Gigantes, pequeños en virtud, quieren destruir estas buenas obras, que estorban a sus vicios. Las dos piernas representan las partes del hombre: el cuerpo y el alma. La pierna del cuerpo se doblega y muere mientras que su alma es inmortal y la memoria de sus gestas queda marcada en los cuerpos celestes. Las aventuras de nuestro protagonista son un ejemplo de que para llegar a la vida contemplativa primero debe ser aprobada nuestra vida activa.

Atlas era en realidad un astrólogo que no pudo terminar su trabajo por lo que se lo encomendó a Hércules. Los Gigantes son los envidiosos que no entendían sus tratados, por ello, tuvo que bajar la rodilla, es decir, humillar su alto estilo. Toda composición literaria consta de dos partes: la materia y la forma, que, a juicio de Villena, ha de ser alta y retórica. Heracles tuvo que usar una forma sencilla pero la alteza de la materia permitió que su obra perviviera. Este trabajo nos enseña tres cosas: siendo ya anciano el hijo de Júpiter se dedicó a la sabiduría, debido a que había perdido su fuerza corporal; aun siendo un hombre de armas, no despreció el conocimiento y que la astrología es la soberana de todas las ciencias. La moraleja alude a las mujeres, cuyas principales cualidades espirituales han de ser la obediencia y la castidad, de las que los Gigantes quieren apartarlas, aunque, llegadas a una edad, hincan la rodilla, debido a su espíritu débil.

En fin, la obra de Villena ofrece el prototipo del héroe como exemplum virtutis, pero encontramos otros conceptos que deben ser destacados y que hacen referencia a la mentalidad de la época y del personaje. El primero de ellos es el de la necesidad de conjugar la vida activa y la vida contemplativa. Ésta última supone el culmen del conocimiento científico y espiritual, pero el hombre no puede despreciar la vida activa, ya que debe preocuparse de las tareas que le corresponden como ciudadano. Ahora bien, este tipo de existencia está rodeada de vicios y malos ejemplos, de ahí la necesidad de practicarla con integridad, que servirá de entrenamiento para que, una vez llegada la vejez, sea 
más fácil dedicarse por completo a la vida contemplativa. Esta tarea requiere gran esfuerzo y sacrificio por lo que es más apta para el ánimo masculino, sin embargo, hay que cuidar de que las mujeres procuren seguir una vida ejemplar, en la medida de las posibilidades del alma femenina. Mas esta dicotomía apunta también a una enseñanza social y es este punto el que cabe subrayar. Villena siempre tuvo dificultades para hacer valer sus derechos como heredero del marquesado que perteneció a su padre ${ }^{46} \mathrm{y}$ con sus Doce trabajos de Hércules parece estar lanzando un mensaje a los poderosos de la época: él es un hombre sabio y virtuoso, al igual que su protagonista, hecho que no le impide dedicarse a las armas. Heracles se convierte así en el ideal de caballero en el que el aragonés se ve reflejado. Además los reyes han de amar la ciencia y dejarse aconsejar por hombres de bien, ya que éstos tienen un gran sentido de la justicia.

Su teoría de los estados muestra la repugnancia de los nobles de este tiempo hacia los trabajos manuales. Labradores, mercaderes, pescadores, etc. llevan un tipo de vida más propensa al vicio, ya que, debido a sus menesteres, les cuesta más esquivar el pecado y, por esta razón, al igual que las mujeres, deben poner mucho cuidado frente a las tentaciones.

Como hemos podido comprobar hay grandes parecidos, pero también grandes diferencias entre la obra de nuestros autores: mientras que Alfonso $\mathrm{X}$ elige, ya una explicación evemerista o racionalista, ya una moral y considera como reales las luchas de Hércules contra el jabalí y los leones, Villena nos ofrece tres exégesis de cada uno de los Trabajos. Ambos los ven como un ejemplo a seguir para aquellos que quieran alcanzar la virtud y, en ocasiones, sus interpretaciones coinciden. Una razón de ello es que para algunos episodios echan mano de las Metamorfosis pero además podría ser una muestra de que el misterioso Libro del Linaje de los Gentiles, usado en la General Estoria y Boccaccio, una de las fuentes principales del escritor aragonés, bebieron de una fuente común. La intención de ambos, como hemos dicho al inicio de este estudio, es, sin embargo, muy distinta: dar legitimidad y gloria a la monarquía española en el caso del primero; ofrecer a los monarcas un ejemplo a seguir haciendo de Euristeo un rey de letras, que busca su apoyo en el Anfitriónida, convirtiéndose éste en una especie de Alter Ego de Villena. Aunque parece que nunca logró sus propósitos políticos su obra si fue bien estimada como lo demuestra su influencia sobre el poeta Juan de Mena ${ }^{47}$

Por otra parte, cabe señalar que el tratamiento que nos ofrecen de la vida del héroe no difiere del que se da en otras obras europeas que trataron el mismo tema y nos demuestra la gran importancia que tuvo Ovidio en la transmisión de la mitología griega a la cultura occidental. 
${ }^{1}$ Este estudio es un extracto de nuestra Memoria de Licenciatura: El dōdekáthlos en la tradición literaria y artística, desde Grecia a la época moderna, incluyendo la traducción y comentario de "Los doce trabajos de Heracles" de Juan Pediasimo, dirigida por la doctora Minerva Alganza Roldán y presentada en la Universidad de Granada el 30/06/2009.

${ }^{2}$ Cf. Il., VIII, 366 ss., XV, 639, XIX, 133-134; Od., XI, 639; Hes., Th., 287 ss., 309-318; Pi., O. III 20 ss., O. X, 20 ss.; B., Epigr. IX; Hdt., II, 43-45; S., Tr.passim; E., HF, passim.

${ }^{3}$ II, 4-8. Los trabajos se enumeran en un orden que se convertirá en "canónico": el león de Nemea, la Hidra de Lerna, la cierva cerinia, el jabalí de Erimanto, los establos de Augías, las aves estinfálides, el toro de Creta, las yeguas de Diomedes, el cinturón de Hipólita, los bueyes de Gerión, las manzanas de las Hespérides, el can Cerbero.

${ }^{4}$ Cf. Seznec, J., Los dioses de la Antigüedad en la Edad Media y el Renacimiento, Madrid, 1987, pp. 19-104. Uno de los primeros en adoptar la corriente evemerista fue Diodoro Sículo cuya interpretación de algunas de las hazañas de Heracles (IV.10-26) tuvo mucha influencia en la tradición posterior.

${ }^{5}$ Abarca desde el capítulo CCCXCIII al CDXXXV. Hemos usado la edición de Antonio G. Solalinde; Lloyd A. Kasten; Víctor R. B. Oelschläger, Alfonso El Sabio, General Estoria, Segunda Parte II, Madrid, 1961.

${ }^{6}$ Cf. Saquero Suárez-Somonte P; González Rolán, T., «Aproximación a la fuente latina del "Libro de las generaciones de los dioses de los gentiles" utilizada en la General Estoria de Alfonso X el Sabio» CFC (L) 4, 1993, 93-113

${ }^{7}$ Según Apolodoro, II, 4, 12, son una expiación por el asesinato de sus hijos.

${ }^{8}$ Este jabalí fue fruto de la furia de Ârtemis contra Eneo, padre de Meleagro, que se había olvidado de ofrecer a la diosa los sacrificios correspondientes. Meleagro monta entonces una gran cacería en la que participan los mejores héroes de Grecia. Entre ellos se encontraba Atalanta, que fue la primera en herir al jabalí mientras que el hijo del rey lo remató. El joven entregó los despojos del animal a la doncella, lo cual provocó una disputa con sus tíos, a los que dio muerte. Su madre Altea tiró entonces al fuego el tizón, que las Moiras le habían dado y del que dependía la vida de su hijo. Cf. D. S., IV, 34 ss. Otra versión del mito puede verse en Il., IX, 529 ss. Esta mezcla de leyendas era normal en las fuentes tardías y también la encontramos en el tratado medieval De deorum imaginibus libellus.

${ }^{9}$ La versión canónica es que se lo muestra a Euristeo y luego lo deja libre, $c f$. Apollod., II, 5, 7.

${ }^{10}$ Cf. met., IX, 188.

${ }^{11}$ El relato de la matanza de la Hidra, tal como nos ha sido transmitido por Apolodoro (II, 5, 2) cuenta que tenía nueve cabezas, siendo la del centro inmortal. Cada vez que Heracles golpeaba una con su maza surgían dos pero el héroe encontró la solución a este problema haciendo que su sobrino, Yolao, quemará con un tizón la raíz de las testas que él iba cercenando.

${ }^{12} C f$. Apollod. II, 86.

${ }^{13}$ Cf. XI, 3, 34-35.

14 Estos pájaros infestaban la ciudad de Estínfalo, en Arcadia. Para ahuyentarlos Atenea entregó al Anfitriónida unos crótalos de bronce, cuyo sonido provocó que las aves salieran huyendo. Cf. Apollod., II, 5, 6.

${ }^{15}$ Las Harpías eran pájaros con cabeza de mujer que atormentaban al rey tracio Fineo, quitándole la comida de la boca o defecando sobre ella. Le fueron enviadas por los dioses junto con la ceguera como castigo por haber abusado de sus dones proféticos revelando lo que no le estaba permitido. Los argonautas Zetes y Calais lo libraron de este suplicio. Cf. A.R., II, 285 ss. Según otra versión, más cara a los literatos medievales y renacentistas, Fineo se casó en segundas nupcias con Idea. Ésta tenía celos de los hijos tenidos con su mujer anterior, Cleopatra, por lo que los acusó ante su padre de haber intentado violarla. Fineo, creyéndola, cegó a sus hijos por lo que los dioses lo castigaron.

${ }^{16}$ Cf. D.S., IV, 14, 1. Apolodoro, II, 5, 8 describe el episodio como un enfrentamiento armado en el que muere Diomedes y las yeguas son llevadas ante Euristeo. 
${ }^{17}$ Cf. Apollod., II, 5, 4.

${ }^{18}$ Ixión, culpable de un delito de sangre, fue purificado por Zeus pero abusó de la confianza del dios y quiso tener relaciones con Hera. Ésta creo una nube con su aspecto con la que el hombre yació. De esta unión nacieron los Centauros. Ixión fue castigado por Zeus que lo ató a una rueda encendida que giraba sin cesar.

${ }^{19}$ Para Apolodoro (II, 5, 9) la reina de las Amazonas es Hipólita. Heracles debía presentar ante Euristeo su cinturón, regalo de Ares. Ésta accedió a dárselo de buen grado pero debido a las insidias de Hera, se entabló una batalla en la que el héroe la mató.

${ }^{20} \mathrm{Cf}$. Ov., met., IV, 657 ss.

${ }^{21}$ Se habla aquí de Atlas porque algunas fuentes dicen que, por consejo de Prometeo, Heracles pidió al gigante que fuera a por las manzanas mientras él sujetaba, en su lugar, la bóveda celeste, $c f$. Apollod. II, 5, 11. La tradición medieval consideró la hazaña de sujetar el cielo como otro de los Trabajos si bien en la Antigüedad era un "párergon".

${ }^{22}$ Ya los antiguos situaban a Gerión en Iberia, $c f$ D.S., IV, 17, 1, en concreto en Gadira (Cádiz), cf. Apollod. II, 5, 10.

${ }^{23}$ Para la versión canónica de la captura de los bueyes $c f$. Apollod., II, 5, 10.

${ }^{24}$ Este es el nombre con el que nuestro héroe fue bautizado, el cual, luego, la Pitia le cambiaría por el de Heracles. Cf. Apollod. II, 4, 12

${ }^{25}$ Florián de Ocampo en su Crónica de España, libro I, cap. X-XV, nos da otra versión acerca de las aventuras de Hércules en la Península. Sería Osiris, padre de Hércules, quien habría matado a Gerión. Los tres hijos de éste, para vengarse, sobornaron a Tifón para que asesinara a su hermano. Años más tarde, su hijo, al que los griegos llamaban "Iraclis", volvió para vengarse. No fundó Sevilla porque un astrólogo le dijo que estaba predestinado a otro la instauración de esta ciudad. Dejó como rey de España a su hijo Híspalo. Sobre el distinto tratamiento de nuestro héroe por parte de los cronistas españoles, $c f$. Tate, R.B., «Mitología en la historiografía española de la Edad Media y del Renacimiento», en Ensayos sobre la bistoriografía peninsular del siglo XV, Madrid, 1970, pp. 14-32.

${ }^{26}$ Cf. VERG., Aen., VIII, 184 ss.

${ }^{27}$ Cf. Ov., met., VII, 410-419.

${ }^{28}$ Orig., IX, 3, 33.

${ }^{29}$ Hemos usado la edición de P.M. Cátedra, «Los doce trabajos de Hércules», en Enrique de Villena, Obras Completas, vol. I, Madrid, 2000, pp.1-111. Puede verse un estudio sobre esta obra en M. Morreale, «Los doze trabajos de Hércules de E. de Villena. Un ensayo medieval de exégesis mitológica», Revista de Literatura 5 (1954), 21-34.

${ }^{30}$ Cf. la edición de B. L. Ullman, Coluccii Salutati De laboribus Herculis (2 vols.), Zürich, 1951. La obra consta de 4 libros en los que abundan las citas y está muy influenciada por el Genaelogiae deorum gentilium de Boccaccio.

${ }^{31}$ Cf. Boeth. cons., IV, 7, 1-35.

32 En realidad Ovidio no nos narra el encuentro entre Ixión y la nube sino que sólo describe la Centauromaquia, $c f$. met., XII, 210 ss. y parece dar por sentado que los Centauros son realmente hijos de Juno, $c f$. met., XII, 504-505.

${ }^{33}$ Coluccio Salutati también consideraba que Hera podía representar el aire, $c f$. II, 3, ed. cit.

${ }^{34} C f$. ISID. orig., XI, 3, 37 que nos dice que los Centauros eran unos jinetes tesalios que en la batalla corrían tanto que parecían un sólo ser.

${ }^{35}$ Boeth., cons., IV, 7, 16. La traducción es nuestra.

${ }^{36}$ Se basa en la descripción de Virgilio, cf. Aen., III, 216-218.

${ }^{37}$ Cf. Ov., met., IV, 646.

${ }^{38}$ Cf. P1., Euthd., 297 c 2.

${ }^{39} C f$. Ov., met., IX, 30-88. Aqueloo no es un gigante sino un dios-río, de ahí su capacidad metamórfica. Así mismo no es Hércules quien consagra el cuerno a la diosa de la Abundancia sino las Náyades.

${ }^{40}$ Esta explicación la encontramos ya entre los antiguos, $c f$. Str., X, 2, 19

${ }^{41}$ Cf. Apollod. II, 5, 11 y Ov., met., IX, 183.

${ }^{42}$ Cf. Boeth., cons. IV, 7, 28: Saetiger spumis umeros notavit («El jabalí llenó sus hombros 
de espumarajos»)

${ }^{43}$ Cf. n. 8.

${ }^{44}$ Cf. Boeth., cons., IV, 7, 29-31.

${ }^{45} \mathrm{La}$ fuente consultada por Villena debe basarse en Eratóstenes, Cat. 4, que describe la constelación del "Arrodillado" en que se ve a Hércules de rodillas sobre la serpiente guardiana del Jardín de las Hespérides.

${ }^{46}$ Sobre este aspecto vid. la "Introducción" de la edición citada.

${ }^{47}$ Cf. Pascual, J.A., «Los doce trabajos de Hércules, fuente de algunas glosas a la Coronación de Juan de Mena», Filología Moderna 47 (1972) 89-104; Carr, D.C., "Los doze trabajos de Hércules: fuente posible del Laberinto de Juan de Mena», Hispanic Review 41 (1973) 417-420 


\title{
Mario Vargas Llosa y el escándalo interminable de FEDRA*
}

\author{
Aurora López - Andrés Pociña \\ Universidad de Granada
}

\begin{abstract}
En recuerdo de María Luisa Picklesimer, que no creemos que gustara mucho del Elogio de la madrastra de Vargas Llosa, pero disfrutaría sin duda con la Phèdre de Racine y con El escándalo de nuestro Pedro Antonio
\end{abstract}

Granada, 1 de noviembre de 2010

\section{Un premio Nobel y una casualidad.}

Cuando el día 7 de octubre de 2010 irrumpió en todos los medios de comunicación la noticia de la concesión del premio Nobel de Literatura de este año al novelista de nacionalidad peruana y española Mario Vargas Llosa (Arequipa, Perú, 1936), teníamos en estado bastante avanzado de elaboración este trabajo, que respondía a un viejo proyecto de estudio, puesto de relieve en uno de nuestra autoría de entre los muchos contenidos en el libro Fedras de ayer $y$ de hoy, editado literariamente por ambos hace ahora dos años ${ }^{1}$. En efecto, después de ocuparnos de la "madrastra enamorada" que aparece en el libro X de la novela El asno de oro de Apuleyo, añadíamos este breve párrafo sobre un tratamiento del mismo tema en una obra cercana a nosotros en el tiempo: "Cuando, después de un número crecido de Fedras en el teatro, la poesía, la novelística, el cine, la escultura, la pintura, llegamos, en el año 1988, a la novela erótica de Mario Vargas Llosa, Elogio de la madrastra ${ }^{2}$, en la que doña Rigoberta, la madrastra, es quien resulta seducida por el perverso Fonchito, su hijastro, casi un niño, para luego eliminarla de su vida culpándola a ella ante su padre de lo ocurrido, llegamos a una revisión total, casi imposible de llevar más lejos, de las revisiones profundas iniciadas ya por el propio Eurípides en sus dos versiones de Hipólito"'.

Nos sorprende la casualidad de la concesión del universalmente reconocido premio a Vargas Llosa y nuestra aportación al estudio de su obra desde la perspectiva de sus fuentes clásicas. Somos concientes de que en la producción literaria del novelista ocupan un puesto de mayor relieve novelas más famosas, como por ejemplo La ciudad y los perros (1963), Conversación en La Catedral (1970), Pantaleón y las visitadoras (1973), La tía Julia y el escribidor (1977) o La fiesta del Chivo (2000), Travesuras de la niña mala (2006), entre otras muchas; sin embargo, la mucho menos conocida novela erótica Elogio de la madrastra, aúna en nuestra opinión el doble interés de ser, como decíamos, "una revisión total, casi imposible de llevar más lejos" del tema clásico de Fedra, y de ser una 
obra en que se manifiesta, en mayor grado que en ninguna otra de nuestro escritor, el influjo notable de un conocimiento profundo de la literatura y la cultura grecorromana.

\section{La pervivencia de Fedra}

Con el fin de colaborar en la medida de nuestras posibilidades al estudio del desarrollo y pervivencia del tema clásico de Fedra, desde cuanto es posible entrever y deducir a partir de los fragmentos de su tratamiento trágico por Sófocles y por la versión conservada del Hipólito de Eurípides, pasando después por Ovidio hasta la Phaedra de Séneca, y desde ellos a las múltiples relecturas a lo largo de los siglos, hasta el terrible drama Phaedra's love de Sarah Kane, organizamos en el mes de abril de 2005, en el seno de nuestra Universidad de Granada, el Simposio Internacional "Fedras de ayer y de hoy", cuyas aportaciones dieron lugar a los veintiocho trabajos contenidos en el volumen resultante, publicado con idéntico título ${ }^{4}$. Al final del mismo, un "Índice de versiones del tema de Fedra (e Hipólito)”, tenía la lógica finalidad de presentar todas las versiones objeto de estudio detallado o de cita, incluso simple alusión, en los diversos trabajos, cosa que, sin embargo, observamos con desagrado, cuando llegó el libro a nuestras manos, que no se había realizado debidamente. Nuestra pretensión era doble: por un lado, mostrar de forma inequívoca, por medio del prolongado listado, la gran abundancia de revisiones del tema de Fedra a lo largo de los siglos; por otro, remitir al lugar del volumen en que aparecían tratadas. Tan sólo apareció en la edición la lista de autores/autoras y títulos.

Hoy aprovechamos la ocasión que nos ofrece esta publicación para presentar una nueva lista, sensiblemente actualizada e incrementada gracias a sucesivos estudios nuestros y de otros autores y autoras ${ }^{5}$, para insistir en la pervivencia a lo largo de los tiempos y, de modo especial, en la actualidad, del tema de Fedra, que también ocupó al nuevo premio Nobel, Mario Vargas Llosa, en el teatro, la narrativa, la poesía y el cine ${ }^{6}$; las indicaciones bibliográficas que acompañan a algunos títulos, sin pretender en modo alguno acercarse a una exhaustividad que requeriría un estudio mucho más extenso, quieren simplemente servir de ayuda para el acercamiento a los mismos:

\section{Literatura griega:}

Eurípides, Hipólito (velado), (no conservado, 432?) teatro

Sófocles, Fedra (no conservada, ?) ${ }^{7} \quad$ teatro

Eurípides, Hipólito(portador de la corona) (428 a. C.) teatro

II. Literatura romana:

Ovidio, Phaedra Hippolyto (Heroida IV) (?) ${ }^{8} \quad$ poema 
Séneca, Fedra (s. I)

teatro

Apuleyo, Cuento de la madrastra (Apul., met. 10, 2-12) (s. II) $\quad$ relato

III. Literaturas posteriores:

Siglo XVI:

Bandello, Mateo, Il marchese Niccolò terzo da Este... (1554 ? $)^{10} \quad$ relato

Sachs, Hans, Theseus, ein könig in Athena $(1558)^{11}$ poema

Zara, Ottaviano, Ippolito (1558)

teatro

Sachs, Hans, Die zwölff argen künigin $(1562)^{12} \quad$ teatro

Garnier, Robert, Hippolyte (1573)

Bozza, Francesco, Fedra (1578) ${ }^{14}$ teatro

Siglo XVII:

Jacobilli, Vincenzo, Hippolito $(1601)^{15}$ teatro

Ortuso, Domenico, Fedra (1601) teatro

Bouistan, Pedro - Belleforest, Francisco de,

Historia de la marquesa de Ferrara (1603) $)^{16}$ relato

Parrot, Henry, "Nil violentum perpetuum" (a.1613) ${ }^{17} \quad$ poema (en inglés)

Freeman, Thomas, "Epigram. 65. In Phaedram” (a. 1614) ${ }^{18}$ poema (en inglés)

Santamaria, Andrea, Ippolito (1619) teatro

De'Monti, Gregorio, L'Ippolito $(1620)^{19}$ teatro

Parrot, Henry, "Vxor evertens" (a. 1626) ${ }^{20} \quad$ poema (en inglés)

Vega, Lope de, El castigo sin venganza (1631) ${ }^{21}$ teatro

La Pinélière, Guérin de, Hippolyte (1634) 22

teatro

Gilbert, Gabriel, Hippolyte, ou Le garçon insensible (1647) ${ }^{23} \quad$ teatro

Segrais, Jean Regnauld de, La mort d'Hippolyte (1648) teatro

Bontempo da Rimini, Leopardo, Ippolito redivivo (1659) teatro

Bissari, Pier Paolo, Fedra innamorata (1662) ${ }^{24}$ teatro

Bidar, Mathieu, Hippolyte (1674) ${ }^{25}$ teatro

Racine, Jean, Phèdre (1677) ${ }^{26}$ teatro

Pradon, Jacques, Phèdre et Hippolyte (1677) ${ }^{27}$ teatro

Stevenson, Matthew, "Phaedra to Hypolytus" (a. 1680)28 poema

La Fontaine, Jean de, "Les filles de Minée”(1683) ${ }^{29}$ poema

Cruz, Sor Juana Inés de la, Amor es más laberinto (1689)

Radcliffe, Alexander, "Phaedra to Hippolytus" (a. 1696) ${ }^{31} \quad$ poema

Siglo XVIII:

Smith, Edmund, Phaedra und Hippolitus (1707) $32 \quad$ teatro

Addison, Joseph, "Prologue to Phaedra and Hippolytus"(a. 1719) ${ }^{33}$ poema

Prior, Matthew, "Epilogue to Phaedra" (a.1721) 34 poema

Sheridan, Thoms, "Mr. Sheridan's Prologue” (a. 1721) 35 poema 
Siglo XIX:

Cubières Palmézeaux, Michel de, Hippolyte (1803) teatro

Olavide y Jáuregui, Pablo Antonio José de, Fedra $(1803)^{36} \quad$ teatro

Schiller, Friedrich von, Phädra (1805)

Della Valle, Cesare, Ippolito (1818)

Lauri, Giovanni di Macerata, Fedra (1820)

Baldamus, Karl (Max), Hippolyte (1822) ${ }^{37}$

teatro

teatro

teatro

novela

Schubert, Franz, "Hippolits Lied" $(1826)^{38}$

poema

Zàuli-Sajani, Tommaso, Fedra (1829) ${ }^{39}$

teatro

Marbach, Oswald, Hippolyt (1846) ${ }^{40}$

teatro

Howe, Julia Ward, Hippolytus (1858) ${ }^{41}$

teatro

Conrad, Georg, Phädra (en cinco actos) (1864) $)^{42}$

teatro

Conrad, Georg, Phädra (en un acto) (1866) ${ }^{43}$

Cory, William Johnson, "Phaedra'a Nurse" $(1866)^{44}$

melodrama

Love Peacock, Thomas, "Phaedra and the Nurse" $(1866)^{45}$

poema

poema

Swinburne, Algernon Charles, Phaedra (1866) ${ }^{46}$

Zola, Émile, La Curée (1872) ${ }^{47}$

Alarcón, Pedro Antonio de, El escándalo (1875) ${ }^{48}$

Zola, Émile, Renée $(1881)^{49}$

poema

novela

novela

Marthold, Jules de, Les Amants de Ferrara (1880)

teatro

teatro

Bang, H., Faedra (1883)

Meysenbug, Malwida von, Phädra $(1885)^{50}$

Weill, Alexandre. La nouvelle Phèdre (1889) ${ }^{51}$

novela

novela

Heredia, José María de, "L'égarement de Phèdre" (1894)

novela

Kucas, Hyppolite, Le Duc de Ferrara (1896)

poema

teatro

Lipiner, Siegfried, Hippolytos $(1899)^{52}$

teatro

\section{Siglo XX:}

Sturge Moore, T, Aphrodite against Astemis 1901) ${ }^{53} \quad$ teatro

Carman, Bliss, “At Phaedra's Tomb” (1904) ${ }^{54}$

Bois, Jules, Hippolyte couronné (a. 1904) ${ }^{55}$

Cather, Willa, The Marriage of Phaedra $(1905)^{56}$

Bozzini, Umberto, Fedra (1909) ${ }^{57}$

poema

teatro

relato

teatro

D’Annunzio, Gabrielle, Fedra (1909) $)^{58}$

teatro

Poletti, Cordula, Ippolito (1910)

teatro

Unamuno, Miguel de, Fedra (1910) ${ }^{59}$

teatro

Hewlett, Maurice, “The Death of Hippolytus" (1911) ${ }^{60}$

poema

Limbach, Hans, Phädra (1911) ${ }^{61}$

teatro

Sackville, Margaret, "The Coming of Hyppolitus" (1913) ${ }^{62}$ Hermann, Georg, Heinrich Schön jun. (1915) ${ }^{63}$

poema

novela 
Pape, Claire, Und sie rüttelte an der Kette (1915) $)^{64} \quad$ novela

Grau, Jacinto, El bijo pródigo (1918)

teatro

Lewis, C. S.,"Hippolytus", después “The Queen of Drum"(1919)

Doolittle, Hilda, "Phaedra" (1921) ${ }^{66}$

Doolittle, Hilda, "Hyppolitus Temporizes" (1921) ${ }^{67}$

poema

Doolittle, Hilda, "She Contrasts with Herself Hippolyta" (1921) ${ }^{68}$

Doolittle, Hilda, "She Rebukes Hippolyta" (1921) ${ }^{69}$

poema

poema

O'Neill, Eugene, Desire under the Elms (1924) $)^{70}$

poema

teatro

Deberly, Henri, Le supplice de Phèdre $(1926)^{71}$ novela

Cvetaeva, Marina I., Fedra (1928) ${ }^{72}$ teatro

Lacretelle, Jacques de, La mort d'Hippolyte (1928) ${ }^{73}$ relato

Angélico, Halma (pseud.), ver Clar Margarit, María Francisca

Clar Margarit, María Francisca, La nieta de Fedra (1929) ${ }^{74}$ teatro

Villalonga, Llorenç, Fedra (1932) $)^{75}$

Yourcenar, Marguerite, "Phèdre, ou Le désespoir" $(F e u x)(1936)^{76} \quad$ relato

Heider, Albert, Pbädra in Basel (1936) 77 teatro

Espriu, Salvador, Fedra $(1937)^{78} \quad$ relato

Brentano, Bernard von, Phädra (1939) $)^{79}$ teatro

Bianco, José, Las ratas (1943) novela

Yourcenar, Marguerite, Qui n' a pas son Minotaure? (1944) ${ }^{80} \quad$ teatro

Gide, André, Thésée (1946) ${ }^{81}$ relato

Bono, Elena, Ippolito (1951, ed. 1954) ${ }^{82}$ teatro

Gállego, Julián, Fedra (1951) ${ }^{83}$ teatro

Rexroth, Kenneth, Phaedra (1951) ${ }^{84}$ teatro

Koeppen, Wolfgang, Der Sarkophag der Phädra /1951) ${ }^{85}$ relato

Regás, María Luz, El mal amor $(1951)^{86}$ teatro

Ashbery, John, The Heroes (1952) ${ }^{87}$ teatro

Jeffers, Robinson, The Cretan Woman (1952) ${ }^{88}$ teatro

Lehmann, Wilhelm, "Artemis und Hippolyt" (1952) ${ }^{89}$ poema

Lundqvist, Ebba, Sangen um Fedra (esp. Elsueño de Fedra) (1952) poemas

Jeffers, Robinson, The Cretan Woman (1954) ${ }^{90}$ teatro

Mottura, Luis, El mal amor (1955) ${ }^{91}$ película

Mur Oti, Manuel, Fedra (1956) ${ }^{92}$ película

Schnabel, Erns, Der sechste Gesang $(1956)^{93} \quad$ novela

Wise, Robert, Tribute to a bad man (1956 $)^{94}$ película

Cukor, George, Wild is the wind (1957) ${ }^{95}$ película

Kaschnitz, Marie Luise, "Agrigent" (1957) ${ }^{96}$ poema

Terron, Carlo, Ippolito e la vendetta $(1957)^{97}$ teatro

Mann, Delbert, Desire under the Elms (1958) ${ }^{98}$ película

Schroeder, Juan Germán, Hipólito coronado (1959) teatro

Cela, Camilo José, El guerrero loco. Sinopsis para la 
tragedia del desamor (1961) ${ }^{99}$

Cesbron, Gilbert, Phèdre à Colombes (1961) ${ }^{100}$

Dassin, Jules, Phaedra (1962) $)^{101}$

Miró, César, Fedra entre los vascos (1962) ${ }^{102}$

Renault, Mary, The bull from the sea $(1962)^{103}$

Saslavsky, Luis, Las ratas (1962) $)^{104}$

Cárdenas Peña, José, “El poema a Fedra” (1964)

Moyà Gibert, Llorenç, Fedra (1964)

Gilroy, Frank, That Summer, that Fall (1967) ${ }^{105}$

Watkins, Vernon, "Phaedra" (a. 1967)

Jourdan, Pierre, Phèdre (1968)

Romero Marchent, Joaquín Luis, Fedra West (1968) ${ }^{108}$

Lourenzo, Manuel, Romería ás covas do demo (1969) ${ }^{109}$

Gunn, Thom, "Phaedra in the Farm House" (1971)110

Goodman, Paul, "The Other Man and I" (a. 1972)111

Lattimore, Richmond, "Hippolytus in Middle Life" (1972)112

Arendt, Erich, "Der Sarkophag (Agrigent)" (1973/1974)113

Miras, Domingo, Fedra (1973) $)^{114}$

Dourado, Autran, Os Sinos da Agonia (1974)

García Viñó, Manuel, Fedra (1975)

Harrison, Tony, Phaedra Britannica $(1975)^{115}$

Krolow, Karl, "Gute Nacht” (1975) 116

Espriu, Salvador, Una altra Fedra, si us plau (1978)

Ritsos, Yannis, Faidra (1978) ${ }^{117}$

Boggio, Marikla, Fedra (1979)

relato

teatro

película

novela

novela

película

poema

teatro

teatro

poema

película

película

teatro

poema

poema

poema

poema

teatro

novela

novela

teatro

poema

teatro

monólogo

teatro

Gil Novales, Ramón, El doble otoño de mamá bis.

Casi una Fedra (1979) ${ }^{118}$

teatro

Enquist, Per Olov, Till Fedra (esp. Para Fedra) (1980) $)^{119} \quad$ teatro

Martínez Mediero, Manuel, Fedra (1981) ${ }^{120}$

teatro

Uribe, Germán, Los secretos retozos de Fedra, la niña vieja (1981) relato

Lourenzo, Manuel, Fedra (1982) $)^{121}$

libreto para ópera

Ortiz, Lourdes, Fedra $(1984)^{122}$

teatro

Macaya, Emilia, La sombra en el espejo (1986) $)^{123}$

novela

Rodríguez, Armonía, Fedra, una tragedia española (1986)

teatro

Pastior, Oskar, "Voltaire von der augenscheide" (ca. 1986)124

Mendoza, Héctor, Fedra (1988)

poema

teatro

novela

Vargas Llosa, Mario, Elogio de la madrastra (1988)

Wertenbaker, Timberlake, The Love of the Nightingale (1988) ${ }^{125}$

Arredondo, Inés, Estio (1989) ${ }^{126}$

poema

Egloff, Elizabeth, Phaedra (1989)

novela teatro 
Fusini, Nadia, La luminosa. Genealogia di Fedra (1990) ${ }^{127}$ novela

Ragué, Ma José, Crits de gavina (1990) ${ }^{128}$ teatro

Ragué, Ma José, Lagartijas, gaviotas y mariposas (1991) ${ }^{129}$ teatro

Cardella, Lara, Fedra se ne va (1992) $)^{130} \quad$ novela

De Bernardi, Tonino, Chiamatemi Fedra (episodio de Piccoli orrori) (1994) película

Munch, Irmelin, Fedra, men Fedra (esp. Fedra, mi Fedra) (1994) novela

Valduga, Patrizia, Fedra (1994) $)^{131}$

Hernández, Raúl, Los restos: Fedra (1995, ed. 1999)

Kane, Sarah, Phaedra's Love (1996) ${ }^{133}$ teatro

Picchi, Arnaldo, Per Fedra (1996) teatro

Grieco, Agnese, Fedra (1998, ed. 2005) ${ }^{134} \quad$ teatro

Yankowitz, Susan, Phaedra in delirium (1998) teatro

Della Polla, Barbara, Stanotte vorrei parlare (1999) teatro

Escalante, Ximena, Fedra y otras griegas (2000) teatro

Gómez Arcos, Agustín, Fedra en el Sur (?) ? $^{135}$ teatro

Siglo XXI:

Paco, Diana de, Polifonía (2001) $)^{136}$

teatro

Ullúa, Alejandro, Hipólito y Fedra (la pasión desboicada) (2005) teatro

Cescutti, Fabio, Fedra, il colezionista e Piero Marussig (2006) novela

Lehnert, Christian, Phaedra (2007) ${ }^{137} \quad$ libreto para ópera

Lourenzo, Manuel, Despois do temporal Comedia en tres actos (2007) (138 $^{138}$ teatro

Folino, Lucía Angélica, "Fedra" (2008) poema (en español)

Roes, Michael, Ich weiss nicht mehr die Nacht (2008) ${ }^{139} \quad$ novela

Mayorga, Juan, Fedra (2009) $)^{140}$ teatro

Narros, Miguel, Fedra (2009, $1^{\text {a }}$ versión 1990) teatro

Espinosa Mendoza, Norge, Fedra/Phèdre/Phaídra (2010) teatro

Lourenzo, Manuel, Hipólito (2010) ${ }^{141} \quad$ teatro

Varios Autores/as, Fo la desesperación (2010) ${ }^{142} \quad$ teatro

\section{Los escándalos de Fedra.}

La primera versión teatral que conservamos completa del tema de Fedra e Hipólito se debe a un escándalo: se trata, es obvio, de la tragedia Hipólito de Eurípides, que obtuvo el primer premio en su estreno en el año 428 a. C., datos que leemos en el "argumento" de Aristófanes el Gramático que se edita antes de la obra, quien señala, además, que "el drama es de los mejores" del tragediógrafo; pero añade también: se trata del segundo Hipólito, en el que corregía "lo inconveniente y merecedor de censura" de una tragedia anterior. Los hechos son bien conocidos, y se repiten una y otra vez, hasta la saciedad, siempre que se habla sobre el Hipólito de Eurípides; tanto es así, que no resulta fácil poner una nota bibliográfica concerniente a este asunto. Para resumirlos de la 
forma más breve posible, diremos que Eurípides compuso una primera versión,

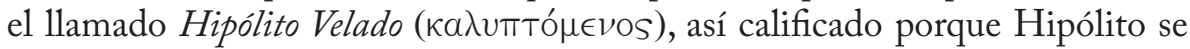
cubría la cabeza para ocultar la vergüenza que le producía la osada e impúdica declaración amorosa de su madrastra; cuando se representó, probablemente en 432 a. C., el público, escandalizado por el exceso inmoral de Fedra al declarar su pasión al hijo de su marido, rechazó la obra. Muy pocos años después ${ }^{143}$, Eurípides acusaba recibo de la crítica enviada por el público escandalizado, mandando a escena el Hipólito que conservamos, llamado Hipólito el de la

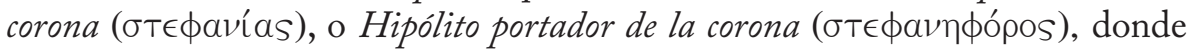
Fedra hacía gala de un comportamiento mucho más admisible desde el punto de vista moral, preocupada por ocultar su enamoramiento, que de ningún modo se atreve a declarar al hijastro; un enamoramiento que, por otra parte, se disculpa atribuyéndolo a la acción de la divinidad, la diosa Afrodita irritada contra Hipólito que se presenta en el Prólogo (vv. 1-57) ${ }^{144}$. La nueva versión, ya lo hemos recordado, ganó el concurso del año de su estreno.

El tema planteado por Eurípides, sin duda de manera menos osada en la versión segunda que en la primera, resultaba de todas formas escandaloso, en su tiempo, y aun en el nuestro, veinticinco siglos después. Se conjugaban en él la figura de una mujer apasionada e irrefrenablemente enamorada; una mujer enamorada, además, de un muchacho que se presupone de menor edad y falto de experiencia erótica; una mujer enamorada, sobre todo, de un joven que es su hijastro. Resulta, pues, un ejemplo perfecto y cabal del anti-prototipo de mujer, de esposa, de madre, siendo por el contrario perfecto ejemplo de madrastra, y dentro de la tipología de madrastra la que se conoce como "madrastra enamorada”. A Patricia A. Watson debemos un amplísimo estudio sobre la condición de las madrastras en el mundo greco-romano, analizándolas desde perspectivas literarias, históricas y sociológicas, explorando lo que es el retrato del estereotipo madrastra en el mito y la literatura, por comparación con la vida real ${ }^{145}$. Establece Watson tres variantes literarias: a) La madrastra asesina; b) La madrastra persecutora de su hijastra; c) La madrastra enamorada ${ }^{146}$. E1 tipo más frecuente en la literatura griega y latina es el primero, aunque aquí nos enfrentamos a un caso que corresponde al tercero. En palabras de la misma investigadora, "El tratamiento de la madrastra "enamorada" ostenta no sólo una disposición en favor de la generación más joven, sino también un prejuicio misógino contra la madrastra, que proviene de actitudes masculinas griegas con relación a la sexualidad de las mujeres" ${ }^{147}$.

El escándalo del estreno del Hipólito I debió de tener una gran repercusión en Atenas; sus ecos han llegado hasta nuestro tiempo a través de las comedias de Aristófanes, según ha estudiado con enorme detalle y acierto Maria de Fátima Silva ${ }^{148}$; sin repetir aquí el detalle del asunto, un párrafo del análisis de Silva puede poner bien de relieve las causas provocadoras del escándalo: 
“QQué era, pues, lo que vinculaba, desde la perspectiva de la comedia, las Fedras con las Estenebeas y Melanipas, transformándolas en modelo de libertinaje? Todas ellas violan el código moral normalmente aceptado para la condición femenina. Sometidas a una pasión devoradora, ponen en peligro su honra y sus deberes familiares, cuando se determinan a adentrarse por caminos osados buscando conquistar al hombre que aman. Decepcionadas o traicionadas, son capaces de todo, hasta el punto de dejar sembrada a su alrededor incluso la muerte a la que ellas mismas se habían condenado. En este aspecto, Fedra y Estenebea comparten un destino semejante; casadas, ambas han concebido por un joven un amor adúltero y al no verse correspondidas, denuncian, ante sus maridos, al amante renitente, atribuyéndole un intento de violación ${ }^{149 ”}$ (p. 107).

En el caso de la Fedra de Séneca, tan diferente del Hipólito de Eurípides que se conserva, hay razones de peso, en las que no podemos entrar aquí, para pensar que coincidía en más de un aspecto con la perdida tragedia del griego que originó el escándalo. No podemos en este caso hablar de nuevo escándalo, porque sabido es que no poseemos en absoluto datos sobre posibles representaciones de las Tragedias de Séneca en la Antigüedad, ni tampoco sobre su recepción en fechas cercanas a su redacción ${ }^{150}$. Ahora bien, la ruptura escandalosa del comportamiento moralmente admisible en una mujer de que hacía gala la Fedra de Séneca en su apasionada declaración amorosa a su hijastro Hipólito está fuera de duda, según estudiamos ya hace años y no vamos a repetir aquí ahora ${ }^{151}$.

Dando un salto de algo más de dieciséis siglos, estalla de nuevo un "escándalo Fedra", esta vez en el París de tiempos de Luis XIV: el escándalo consiste en el estreno, con sólo dos días de diferencia, de dos tragedias sobre Fedra, escritas por dos dramaturgos que se mueven en ámbitos social y literariamente enfrentados, Jean Racine y Jacques Pradon. Este escándalo, que conjuga en realidad dos escándalos, el inherente al tema -siempre la madrastra ciegamente enamorada del hijastro, con declaración incluida, al modo de la Fedra de Séneca- y el hecho de estrenarse dos reescrituras en la misma ciudad y al mismo tiempo, ha sido estudiado con detalle por Aurora López ${ }^{152}$; de allí tomamos este resumen de los hechos: "Todos estos enfrentamientos están en la base de la querella de las dos Fedras que se estrenan con sólo dos días de diferencia. Phèdre et Hippolyte de Racine se lleva a las tablas un viernes, el día 1 de enero de 1677, en el Hôtel de Bourgogne ${ }^{153}$. Dos días después, Pradon estrena Phèdre et Hippolyte en el Hôtel Génégaud. La rivalidad se declara manifiesta en el hecho mismo de tan seguidos estrenos" (p. 325).

A un escándalo distinto nos referimos al recordar, sólo muy de pasada, en la lista interminable de nuevas versiones literarias del enamoramiento de Fedra y el rechazo de Hipólito, una obra fundamental en la narrativa del siglo XIX español, curiosa y casualmente titulada El escándalo, publicada en 
1875 por el polifacético escritor guadijeño Pedro Antonio de Alarcón (18331891 $)^{154}$. Al calificar el título de la novela de Alarcón como curioso y casual nos referimos a la coincidencia con el de este trabajo nuestro, dado que el término escándalo no se refiere en este caso al provocado por la osadía de Fedra, ni tampoco a la historia de Lázaro y su madrastra (cuyo nombre no nos indica Alarcón), sino al que va a provocar el descubrimiento falseado de la complicada historia de Fabián Conde, el personaje principal de la novela. Dado que al estudio del tema de Fedra e Hipólito en la novela del guadijeño vamos a dedicar en breve plazo un largo trabajo, recordaremos aquí que, tal como lo plantea con indudable acierto Mariano Baquero Goyanes ${ }^{155}$, en la muy complicada estructura y entramado argumental de El escándalo, pueden aislarse tres novelas "entreveradas", la historia del padre de Fabián, la historia de Fabián Conde -la principal de las tres- y la historia de Lázaro, que es la que mueve nuestro interés en esta ocasión. En efecto, la versión peculiar y sumamente interesante del tema de Hipólito (pues así debería llamarse la reescritura alarconiana, infinitamente más centrada en el personaje de LázaroHipólito que en el de su anónima madrastra), centra uno de los ocho libros en que se divide la novela, precisamente el séptimo y penúltimo, que se titula "El secreto de Lázaro" (pp. 177-231). Es decir, casi a la altura del desenlace de la más complicada de las historias, la de Fabián Conde, llegamos por fin a saber, contada con pelos y señales, cuál es la verdadera historia de Lázaro, un personaje del que se nos comienza a hablar en el libro tercero, presentándolo ornado por las más encantadoras cualidades físicas imaginables ("notable hermosura y distinguidísimo porte", p. 68); "rostro de ángel", "puras y correctas facciones", "se parecía a un ángel, era un ángel fuerte”, p. 69), unidas, por si fuera poco, a un comportamiento moral irreprochable. Este personaje, al que rodea un misterio que no acertamos a descifrar, va a seguir apareciendo una y otra vez, con una frecuencia inusitada, a lo largo de los libros cuarto, quinto y sexto, con lo cual Pedro Antonio de Alarcón consigue despertar nuestra curiosidad por tan hermoso, tan ejemplar, pero tan misterioso, individuo. Al fin, en el libro séptimo, llegamos a saber que, por obra y gracia de nuestro escritor granadino, nos encontramos ante uno de los más curiosos Hipólitos de entre los innumerables de las literaturas de veintiséis siglos que hemos enumerado en nuestro apartado anterior.

Un siglo más tarde, esta vez en la España de los momentos más agobiantes de la Dictadura franquista, será muy probable motivo de escándalo nuestra historia, ahora convertida en película, volviendo esencialmente a la Phaedra de Séneca: nos referimos a la película Fedra del director Manuel Mur Oti, estrenada en 1956, con Emma Penella en el papel de Estrella (Fedra),Vicente Parra en el de Fernando (Hipólito), Enrique Diosdado en el de D. Juan (Teseo). El filme ha sido objeto de un excelente trabajo de Francisco Salvador 
Ventura ${ }^{156}$, quien pone de relieve el carácter trasgresor de la obra en el tiempo en que fue representada, con una Fedra de aspecto, comportamiento y palabra absolutamente fuera de lo admisible en el cine de aquellos años, cosa que sorprende igualmente en la presentación de Hipólito, en que el actor muy popular Vicente Parra aparece con un llamativo teñido rubio de cabellos y una indumentaria alusiva a una clara concepción como homosexual, en un momento político en el que la homosexualidad se consideraba un delito grave, castigado no sólo con la condena pública, sino con la pena de cárcel, en esa línea de conducta represora a la que todavía se aferra la derecha española en nuestros días. A pesar de todo, y para sorpresa nuestra, la obra consiguió estrenarse; eso sí, previamente la censura obligó al director a cambiar el final, en el que Fedra se suicidaba, hundiéndose en el mar después de besar en la boca a Hipólito, ya muerto. Seguimos preguntándonos cómo fue posible que semejante película no sucumbiese al rigor inquisitorial del franquismo, pues el hecho de que se trataba de una obra de inspiración clásica, basada en la Fedra de Séneca, no parece argumento exculpatorio suficiente.

\section{El escándalo de Elogio de la madrastra de MarioVargas Llosa.}

No nos consta que la novela Elogio de la madrastra de Mario Vargas Llosa haya causado un escándalo público importante, aunque tampoco nos extrañaría que hubiese podido hacerlo. Pero si nos escandaliza, de manera positiva, el hecho de que el recién estrenado premio Nobel haya escrito una novela tan diferente del resto de su producción narrativa, una novela erótica en el sentido más amplio de la palabra, partiendo de un tema clásico, el enamoramiento enloquecido de Fedra por su hijastro Hipólito, pero reconvirtiéndolo de una forma absoluta, sin precedentes; es ahí precisamente donde descubrimos el escándalo, digamos ahora que sorprendente, como sorprendente es la profunda cultura clásica grecolatina que se desliza con sutileza y elegancia por las páginas del libro.

Elogio de la madrasta apareció en 1988 en La Sonrisa Vertical, colección de literatura erótica dirigida por el emblemático cineasta, recientemente fallecido, Luis García Berlanga (1921-noviembre 2010), a quien dedica la novela Vargas Llosa "con cariño y admiración". El relato se articula en catorce capítulos y un epílogo, incluyéndose además seis reproducciones a todo color de cuadros, más o menos conocidos, indispensables por ir incluida su descripción en el desarrollo del conjunto; en ello reside una de las novedades interesantes de la obra, que llama la atención por su indudable originalidad narrativa.

El asunto consiste en una reescritura profunda del tema clásico de Fedra e Hipólito, en nuestra opinión basado esencialmente en la Fedra de Séneca, pero posiblemente también en importantes elaboraciones posteriores, con bastante 
probabilidad la Phèdre de Racine o la Fedra de Unamuno, sin olvidar los filmes de Manuel Mur Oti y de Jules Dassin, que es casi seguro que conocería Vargas Llosa, sobre todo el segundo de ellos, cuando escribió esta obra. Recordaremos sus líneas argumentales, partiendo de los personajes en su relación con los de las dos tragedias clásicas.

Comenzamos por don Rigoberto, el marido de la madrastra, reencarnación del Teseo antiguo, y lo hacemos así porque en la novela este personaje ocupa un puesto realmente importante, a diferencia de lo que ocurría en las dos tragedias clásicas, en las que aparecía en un momento ya muy avanzado del desarrollo, en el Hipólito de Eurípides en el tercer episodio, verso 790, donde se presentaba regresando del oráculo, en la Fedra de Séneca al comienzo del acto III, verso 835, donde anunciaba su regreso de los infiernos. Don Rigoberto, en cambio, está siempre presente en la novela, si bien hace algunos viajes cortos, de dos o tres días, que también interesan al desarrollo argumental; es un agente de seguros, divorciado, con un hijo pequeño; lleva una vida económicamente muy acomodada, con una elegante casa, de dos plantas y jardín, en Lima, donde habitan su hijo Alfonsito, más comúnmente llamado por el diminutivo afectuoso Fonchito, su nueva esposa, doña Lucrecia, y un nutrido servicio doméstico, con cocinera, jardinero y, sobre todo, una doncella, Justiniana, a la que Fonchito llama Justita, que desempeña un papel también importante, como veremos. Todo muy a punto, todo muy burgués, pero todo nada normal, porque don Rigoberto es, a su manera, émulo del siempre agitado Teseo de la mitología ${ }^{157}$ : buena parte del relato nos narra, con toda calma y con insinuante lascivia, el cuidado que don Rigoberto, auténtico Narciso, dedica todos los días indefectiblemente a su cuerpo, antes de ir a acostarse con su nueva esposa. Testigo un pequeño párrafo: "Hoy era martes, día de pies. Tenía la semana distribuida en órganos y miembros: lunes, manos; miércoles, orejas; jueves, nariz; viernes cabellos; sábado ojos y, domingo, piel. Era el elemento variable del nocturno ritual, lo que le confería un aire cambiante y reformista" (p. 86). De este modo, don Rigoberto, en apariencia un acomodado agente de seguros, esta poseído por una infatigable fijación erótica, concentrada en todos los órganos de su cuerpo, que Vargas Llosa nos hace conocer a lo largo de capítulos enteros, como el tercero, titulado "Las orejas del miércoles", o el sexto, "Las abluciones de don Rigoberto", en que nos vemos condenados a conocer con todo detalle el placer diario de los alivios intestinales del personaje. En suma, un individuo un tanto perturbado sexualmente, en el que actúan simultáneamente un onanismo-narcisismo en la adoración de su propio cuerpo, un indudable voyeurismo que manifiesta al comparar a su mujer con la esposa del rey Candaules, un ansia de animalismo cuando quiere compararse a un monstruo reflejo obvio del Minotauro. Este Teseo limeño, de erotismo insaciable, está 
locamente enamorado de doña Lucrecia, con la que mantiene todas las tardes unas relaciones sin duda satisfactorias.

Doña Lucrecia es una espléndida mujer de cuarenta años, nueva Fedra, menos en el desenlace de la novela, que se debate continuamente entre la inmoralidad y la inconveniencia del acoso sin duda sexual, por más que intente ignorarlo, a que la somete un niño, para colmo su hijastro, y el indudable placer que va experimentando progresivamente a medida que esa relación pedófila se desarrolla, hasta llegar a su plenitud. En apariencia, y a diferencia de lo que ocurría en las tragedias griega y romana de Fedra, doña Lucrecia es víctima del acoso de Fonchito, es decir, se subvierten los comportamientos de Fedra e Hipólito; pero en la realidad las cosas transcurren de otro modo, pues doña Lucrecia se engaña desde el comienzo, trata de interpretar los halagos, las caricias, los besos, los tocamientos a que la somete Fonchito como trastadas de un inocente niño, cosa que evidentemente no es así. Por más que reflexione intentando ocultarse la verdad de la relación, con un sentimiento de culpa que, libre de la seriedad trágica, nos recuerda el que asola a la cristiana Fedra de Unamuno ${ }^{158}$, sus sentidos le traicionan: al comienzo del relato, su doncella Justiniana le advierte de que, cuando se baña, su hijastro Fonchito la contempla encaramándose en el tejado de cristal; sin embargo, en una ocasión en que sabe que el niño está viéndola, reacciona de este modo: "La cólera la hacía temblar de pies a cabeza y sus dientes chocaban, como si tuviera mucho frío. Súbitamente se incorporó. Sin cubrirse con la toalla, sin encogerse para que aquellos ojitos invisibles tuvieran sólo una visión incompleta y fugaz de su cuerpo. No, al revés. Se incorporó empinándose, abriéndose, y, antes de salir de la bañera, se desperezó, mostrándose con largueza y obscenidad, mientras se sacaba el gorro de plástico y se sacudía los cabellos. Y, al salir de la bañera, en vez de ponerse de inmediato la bata, permaneció desnuda, el cuerpo brillando con gotitas de agua, tirante, audaz, colérico" (p. 63) ${ }^{159}$. Más adelante, cuando ya la relación con el niño sea plena, doña Lucrecia sigue jugando con la idea de que se trata de un niño, lo cual no exculpa la perversidad de su relación, en la consideración social y moral un caso obvio de pedofilia y adulterio, no de incesto.

Alfonsito, alias Fonchito, presenta grandes diferencias en comparación con el Hipólito trágico. En primer lugar no es un joven, ni siquiera un efebo, cualquiera que sea la edad o el modo de representarnos al hijastro de Fedra, sino claramente un niño, cuya edad no se precisa, pero que colocaríamos en torno a los diez años, incluso alguno menos. Un niño, pues, que como tal se comporta en todos los aspectos de su existir, si no es en el sexual, donde resulta verdaderamente precoz, y si no es en el psíquico, donde resulta un auténtico monstruo de maldad ${ }^{160}$. Frente a esto que acabamos de afirmar, Fonchito, pequeño, hermoso, de facciones bondadosas, se presenta a cada instante como 
un verdadero ángel: de este modo se nos describe al comienzo del relato, cuando la madrastra va a despedirlo antes de dormirse: "Doña Lucrecia tocó con los nudillos y entró: “¡Alfonsito!”. En el cono amarillento que irradiaba la lamparilla del velador, de detrás de un libro de Alejandro Dumas, asomó, asustada, una carita de Niño Jesús. Los bucles dorados revueltos, la boca entreabierta por la sorpresa mostrando la doble hilera de blanquísimos dientes, los grandes ojos azules desorbitados tratando de rescatarla de la sombra del umbral. Doña Lucrecia permanecía inmóvil, observándolo con ternura. ¡Qué bonito niño! Un ángel de nacimiento, uno de los pajes de los grabados galantes que su marido escondía bajo cuatro llaves”(p. 16 s.). Un Niño Jesús, un angelito de un Belén..., que, con sus halagos, caricias y besos, hace que la madrastra, cuando abandona el dormitorio, después de arroparlo tiernamente, se confiese que está sexualmente encendida ${ }^{161}$. El papel que desempeñará en el entramado argumental no debe ser objeto de nuestra exposición: Fonchito se ganará el favor, el apasionado y ardiente favor podríamos decir, de la madrastra, a lo largo del relato, hasta que, al final, pone en práctica su proyecto inicial, que consiste en deshacerse por completo de ella. La "inocente" maquinación que pone en marcha consiste en preguntarle a su padre, a la vuelta de un corto viaje (nueva coincidencia con las dos tragedias clásicas), qué significa la palabra "orgasmo", que le ha escuchado a doña Lucrecia. Don Rigoberto, atónito en su sospecha increíble, pide al niño que le deje leer una composición de tema libre que debe llevar a la escuela, y queda alucinado con la historia erótica que cuenta el angelical niño en su redacción "Elogio de la madrastra", que no se nos transmite en el texto, pero que nos damos cuenta de hace culpable a doña Lucrecia de todo lo ocurrido. El recurso de la redacción de Fonchito, así como su visión particular del asunto, corresponden perfectamente a los de la tablilla que deja escrita Fedra al suicidarse, en el Hipólito de Eurípides, por medio de la cual conoce Teseo su versión particular de sus relaciones con Hipólito (v. 856 ss.).

Tampoco resulta desdeñable el papel que desempeña en la novela el personaje de Justiniana, que evidentemente evoca el de la Nodriza en las tragedias clásicas, y de modo señalado el de la Nodriza de Fedra en el drama de Séneca ${ }^{162}$, en su función de consejera de doña Lucrecia, aunque no siempre buena consejera. Cuando revela a su ama las sesiones de voyeurismo a que la somete Fonchito mientras se baña, se nos presenta de este modo: "Era joven y, bajo el mandil azul del uniforme, las formas de su cuerpecillo se insinuaban frescas y elásticas. ¿Qué cara pondría cuando su marido le hacía el amor? Estaba casada con el portero de un restaurante, un negro alto y fornido como un atleta que venía a dejarla todas las mañanas. Doña Lucrecia le había aconsejado que no se complicara la vida con hijos siendo tan joven y la había llevado personalmente a su médico para que le recetara la píldora" (p. 56). En 
el Epílogo de la novela, las últimas palabras de Fonchito, entre caricias y besos a la doncella, que le ha recriminado su mal comportamiento con la madrastra, nos advierten de un nuevo giro en la vida de esta peculiar familia, en la que nadie se salva de una terrible servidumbre erótica: "-Lo hice por ti, Justita -lo oyó susurrar, con aterciopelada ternura-, no por mi mamá. Para que se fuera de esta casa y nos quedáramos solitos mi papá, yo y tú. Porque yo a ti... / La muchacha sintió que, sorpresivamente, la boca del niño se aplastaba contra la suya" (p. 197).

Parece obvio que Mario Vargas Llosa, en su reescritura del tema clásico de la madrastra enamorada, ha subvertido por completo los papeles, hasta un grado que no hemos observado en el casi centenar de versiones del tema de Fedra e Hipólito que conocemos directamente. No vamos a entrar en una crítica del resultado, pues no nos parece lógica ni necesaria, ni creemos admisible dar cabida a comentarios personales que no deben ser objeto de un estudio literario riguroso. Sin embargo, queremos subrayar, como ya anticipamos, de qué manera la cultura clásica grecolatina impregna con sutileza las páginas de la novela del escritor peruano-español. Veámoslo a través de tres pasajes de Elogio de la madrastra que lo demuestran de forma fehaciente.

El primero es el capítulo 9, "Semblanza de humano". Precedido por el óleo "Cabeza I" (1948) de Francis Bacon, una cabeza monstruosa, su semblanza sirve de respuesta a la fantasía erótica con que acaba don Rigoberto el capítulo anterior, en el que sugiere a su mujer que acaba de hacer el amor con un monstruo. A una persona no avezada en la lectura de los clásicos le parecería que, entre las varias perturbaciones sexuales de don Rigoberto, se encontraría esta repugnante escena de animalismo. Sin embargo, no hay duda de que Vargas Llosa, en una profunda lectura de los clásicos, sin duda ha reparado en la obsesión que preocupa a la Fedra, sobre todo a la de Séneca, de que su amor es monstruoso, como otros amores que han acontecido a miembros de su familia, como el amor monstruoso del Minotauro. El tema de esta obsesión de Fedra, precisamente la de Séneca, ha sido estudiado con enorme acierto y detalle por Gianna Petrone, como esencial en la configuración de la personalidad de la protagonista en el drama del filósofo cordobés ${ }^{163}$; es un aspecto en el que coincidimos con la latinista de Palermo cuando afirmamos lo siguiente: "En contra de ese ambiente vital propio de una mujer prototípica, Fedra evoca una existencia en espacios libres, montes, selvas (v. 122 ss.), que traen a su mente la imagen de su madre, Pasífae, y su amor monstruoso con el toro. Sus antecedentes familiares no hacen más que reforzar la culpa de su amor, un amor fatal, heredado de su madre y por decreto divino: "ninguna hija de Minos ha gozado / de un amor sencillo, siempre se le une una monstruosidad", dice Fedra (v. 127 s.). Un poco antes, Fedra interpela a su madre, a propósito de su relación con el toro: audax amasti (v. 117), unas palabras que hubiera 
podido aplicarse a sí misma cuando llega a la osadía de declararse a Hipólito. Madre e hija resultan audaces como consecuencia de sus amores irregulares y se despreocupan de comportarse en consonancia con la pudicitia que la sociedad les impone. En ese sentido el amor de Fedra lleva implícito un nefas" ${ }^{164}$. Parece claro que el capítulo sobre el monstruo que mantiene una relación con un humano le fue sugerido a Vargas Llosa por esa presencia constante del Minotauro en la mente agobiada de la protagonista de la Fedra de Séneca; a ello se suma sin duda la intervención fatal de Teseo, el antecedente mítico de don Rigoberto, en el desenlace de la historia del Minotauro ${ }^{165}$.

El segundo pasaje que queremos comentar por su influjo clásico es el segundo capítulo de la novela, encabezado por la reproducción del cuadro de Jacob Jordaens, "Candaules, rey de Lidia, muestra su mujer al primer ministro Giges”, un óleo de 1648, conservado en el Museo Nacional de Estocolmo. E1 relato de Candaules y Giges, pieza destacada de la literatura erótica y esencial en el tema del voyeurismo, aparece muy bien colocado en la novela, después de una de las primeras fantasías de don Rigoberto, que imagina que su mujer podría ser la hermosa esposa del rey de Lidia, y antes de que asistamos a las repetidas escenas de voyeurismo que protagonizará Fonchito al contemplar desde el tejado de cristal a su madrastra bañándose desnuda. Ahora bien, sabido es que el más antiguo relato de la historia de Candaules, rey de Lidia, y del desgraciado final al que le condujo su loco enamoramiento de su mujer, que a toda costa se empeña en que sea vista desnuda por Giges, se encuentra, magistral y deliciosamente narrado, como es habitual en él, al comienzo del libro I de las Historias de Heródoto (caps. 6-14) ${ }^{166}$. Vargas Llosa, que sigue a Heródoto hasta el punto de reproducir con exactitud el nombre del padre de Giges, Dascilo, rescribe el cuento a su gusto, incrementando mucho su erotismo, en especial en el momento en que el rey Candaules goza de su mujer sabiendo que Giges los está observando. Y después, de acuerdo con la conveniencia de la novela, corta el relato en el momento en que Giges ha contemplado a la reina desnuda, sin llegar al desenlace narrado por Heródoto, consistente en la venganza de ésta, que se alía con Giges para dar muerte a Candaules. Merece la pena una lectura comparada del relato elegante de Heródoto con el tremendamente obsceno de Vargas Llosa ${ }^{167}$.

En fin, el tercer pasaje que queríamos comentar: llegados ya al cap. 11 de la novela, cuando ya la madrastra tiene relaciones sexuales completas con Fonchito, asistimos a un momento en que doña Lucrecia se ha quedado a solas con él, que está completamente desnudo, después de realizar el acto sexual. Contemplándolo, piensa doña Lucrecia: "Así debían de ser los dioses griegos. [...] Los amorcillos de los cuadros, los pajes de las princesas, los geniecillos de Las mil y una noches, los spintria del libro de Suetonio" (p. 142). El pasaje del biógrafo latino es fácil de encontrar, pues este escritor sólo emplea este término 
una vez ${ }^{168}$ : se trata, nos dice Suetonio, del nombre, obviamente griego, que daba Tiberio a los participantes en sus bacanales. Merece la pena recordar el texto de Suetonio, tan semejante a muchos del Elogio de la madastra: lo haremos en la versión española de Mariano Bassols de Climent: "En su retiro de Capri ideó incluso una sala provista de divanes, escenario de sus pasiones secretas, a fin de que en ella pandillas de muchachas y de mozos de placer, reclutados de todas partes, así como inventores de monstruosos ayuntamientos, a los que llamaba spintrias, enlazados de tres en tres, se prostituyeran recíprocamente en su presencia para reanimar, con este espectáculo, su líbido que languidecía”169.

Nibil nouum sub sole, habría exclamado Terencio, sin duda con un deje no oculto de reprobación. 
${ }^{1}$ En concreto en el trabajo de A. Pociña, "De la tragedia al cuento: la madrastra enamorada en El asno de oro (Apul., met. 10, 2-12)”, en A. Pociña - A. López (2008), Fedras de ayer y de hoy. Teatro, poesía, narrativa y cine ante un mito clásico, Granada, Universidad, 269-285.

${ }^{2}$ M. Vargas Llosa (1988), Elogio de la madrastra, Barcelona, Tusquets Eds.: ${ }^{5} 2002$. Un acercamiento a esta novela desde la perspectiva de la tradición clásica puede verse en M. E. Assis de Rojo - N. M. Flawiá de Fernández (1998), "Fedra y Narciso en Elogio de la madrastra de Mario Vargas Llosa”, en Textos clásicos, reescrituras contemporáneas, San Miguel de Tucumán, Universidad, 87-99. Dada la novedad del asunto, reproduzco la interesante nota que a propósito de esta novela introducen G. Fiorencis y G. F. Gianotti, "Fedra e Ippolito in provincia", cit., 107, n. 100: "Cenno a parte meriterebbe, per raffinata e originale miscela di erotismo e mitologia, la recente 'riabilitazione' della matrigna tentata da Mario Vargas Llosa nell'Elogio de la madrastra (1988; tr. it., Rizzoli 1990): riabilitazione solo parziale negli esiti della storia, perché anche nel lontano Perù Fedra/Lucrecia finisce per essere cacciata, dopo aver assaporato una singolare sovranità su padre e figlio; riabilitazione vera, tuttavia, rispetto al palinsesto mitico, perché l'iniziativa del traingolo spetta, poco convenzionalmente, all'inquietante e non proprio innocente espansività fisica del figliastro adolescente (incarnazione di un Cupido luciferino, piuttosto che di un casto Ippolito)".

${ }^{3}$ A. Pociña, "De la tragedia al cuento...”, cit., 284-285. La nota precedente se encuentra en el original del texto citado; hemos considerado oportuno repetirla, dado que en ella citábamos los únicos dos trabajos conocidos por nosotros que se ocupaban de la obra de Vargas Llosa que estudiamos.

${ }^{4}$ A. Pociña - A. López, Fedras de ayer y de hoy. Teatro, poesía, narrativa y cine ante un mito clásico, Granada, Universidad, 2008

${ }^{5}$ Además de los estudios que recordábamos como fundamentales en este sentido en Fedras de ayer y de hoy, como los siguientes: W. S. Barrett (ed.), Euripides. Hippolytos, Oxford, Clarendon Press, 1964, pp. 1-45; H. J. Tschiedel, Phaedra und Hippolytus. Variationen eines tragischen Konfliktes, Diss. Erlangen-Nürnberg, 1969 (mecanografiado), esp. Teil II, “Das Nachleben”, pp. 58-99; G. Fiorencis - G. F. Gianotti, "Fedra e Ippolito in provincia”, MD 25 (1990) 71-114; J. M. Lucas, "El motivo de Putifar en la tragedia griega", Epos 8 (1992) 37-56; L. A. de Cuenca, "El motivo literario de Putifar", Revista de Occidente 148 (1993) 53-73; Zimmerman (2000), pp. 419-426; etc., queremos añadir ahora algunos otros trabajos que han enriquecido los datos de que disponíamos, como son los siguientes: A. G. Wood, Le mythe de Phèdre: les Hippolyte français du dix-septième siècle: textes des éditions originales de La Pinélière, de Gilbert et de Bidar, Paris, H. Champion, 1996; R. Ma Mariño Sánchez-Elvira, "Teseo, Fedra e Hipólito en el cine", Est.Clás.39 (1997) 111-125; Ch. Mougoyanni Hennessy, El mito disidente. Ulises y Fedra en el teatro español contemporáneo, Vilagarcía de Arousa, Mirabel, 2006; M. Rubino, Fedra Per mano femminile, Genova, Il nuovo melangolo, 2008. La exhaustiva información sobre la presencia del tema de Fedra e Hipólito en el teatro, narrativa y poesía alemanas nos ha sido generosamente facilitada por Birgit Linda Emberger (Univ. de Granada), con datos procedentes de su tesis doctoral, "El mito de Fedra e Hipólito en la literatura alemana" (en trámite de finalización, dirigida por A. López y A. Pociña), y de otros inéditos suyos, como el excelente trabajo "La presencia de Fedra e Hipólito en la lírica alemana”, que se publica en este volumen.

${ }^{6}$ Por razones de diversa índole no hemos incluido la pervivencia del mito de Fedra e Hipólito en la ópera, en creaciones musicales de tipos variados, ni en el ballet, ni en artes plásticas como la pintura y la escultura. Una útil y amplia lista de recreaciones del mito en estas artes, alcanzando hasta el año 1990, puede encontrarse en J. Davidson, The Oxford guide to classical mythology in the arts, 1300-19990, New York, Oxford University Press, 1993, pp. 803-888; cf. también Ch. Harrauer - H. Hunger, Diccionario de mitología griega y romana, trad. de J. A. Molina Gómez, Barcelona, Herder, 2008, pp. 338-339.

7 A. Kiso, "Sophocles' Phaedra and the Phaedra of the first Hippolytus", BICS 20 (1973) 22-36; J. V. Bañuls - P. Crespo, "La Fedra de Sófocles", en A. Pociña - A. López, Fedras de ayer $y$ de hoy..., cit., pp. 15-83.

${ }^{8}$ F. Moya del Baño, Estudio mitográfico de las Heroidas de Ovidio, Murcia, 1969, pp. 16-36; 
G. Rosati, "Forma elegiaca di un simbolo letterario. La Fedra di Ovidio”, en R. Uglione (ed.), Atti delle giornate si studio su Fedra, Torino 7-8-9 maggio 1984, Torino, 1985, pp. 113-131; M. C. Álvarez - R. M. Iglesias, "La Fedra de Ovidio", en A. Pociña - A. López, Fedras de ayer y de hoy..., cit., pp. 172-193; etc.

${ }^{9}$ A. Pociña, "De la tragedia al cuento: la madrastra enamorada en El asno de oro (Apul., met. 10, 2-12)”, en A. Pociña - A. López, Fedras de ayer y de hoy..., cit., pp. 269-285.

${ }^{10} \mathrm{M}$. Bandello, Il marchese Niccolò terzoi da Este trovato il figliuolo coin la matrigna in adulterio, a tutti dui in un medesimo giorno fa agliar il capo in Ferrara, novella XLIV; eds.: M. Bandello, La Prima Parte de le Novelle, 1554; La Prima Parte de le Novelle del Bandello. Tomo Terzo, London, Riccardo Bancker, 1971, pp. 170-185.

${ }^{11}$ Ed.: en H. Sachs, Werke, Tübingen, 1870-1908, vol. 8 (1874), pp. 495-500, Se trata de un poema épico-biográfico que narra la vida de Teseo, siguiendo a Plutarco; aproximadamente un tercio del poema relata la historia de Fedra e Hipólito (información proporcionada por Linda Emberger).

12 Ed.: H. Sachs, Werke, Tübingen, 1870-1908, vol. 16 (1886), pp. 3-21, Se trata de una tragedia en la que doce reinas desgraciadas (entre ellas Fedra) piden perdón por sus actos (información proporcionada por Linda Emberger).

${ }^{13}$ Ed.: R. Garnier, Tragédies, Paris, Patisson, 1580.

${ }^{14}$ Ed.: F. Bozza, Fedra, Venezia, De’Ferrari, 1578; Roma, Vecchiarelli, 1996; M. Arriaga Flórez, "Fedra y la literatura italiana", en A. Pociña - A. López, Fedras de ayer y de hoy..., cit., pp. 620-628.

15 Ed.: V. Jacobilli, Hippolito, Roma, Appresso Guglielmo Facciotto, 1601; L. Casella, "Hippolito" di Vincenzo Jacobilli, "Tesi di laurea" inédita, Univ. de Génova, 2008 (agradecemos a nuestra querida amiga Letizia Casella la información sobre esta larga (8148 versos) tragedia italiana de 1601, así como el habernos generosamente proporcionado el texto, todavía inédito, de su magnífico estudio de la misma).

${ }^{16}$ Ed. P. Bouistan - F. de Belleforest, Historias trágicas exemplares, Valladolid, 1603; C. F. A. van Dam, Lope de Vega. El castigo sin venganza, Salamanca, Ediciones Anaya, 1968, p. 14 ss.

${ }^{17}$ Ed.: H. Parrot, Laquei ridiculosi, o Springs for Woodcocks, 1613.

${ }^{18}$ Ed.: Th. Freeman, Rubbe and A great Cast, 1614.

${ }^{19}$ Ed.: G. De'Monti, L'Ippolito,Venezia, Baba, 1620.

${ }^{20}$ Ed.: H. Parrot, Cures for the itch, 1626.

${ }^{21}$ Manuscrito autógrafo en la Ticknor Library, de Boston, fechado el 1 de agosto de 1631; licencia de representación : 9 de mayo de 1632; estreno, unos días después de la licencia; primera edición: Barcelona, Pedro Lacabellería, 1634 (cf. L. de Vega, El castigo sin venganza. Edición, introducción y notas de C. F. A. van Dam, Salamanca, Ediciones Anaya, 1968); C. Morenilla Talens - P. Crespo Alcalá, "Fedra en Lope y Unamuno", en M. C. Álvarez Morán - R. M. Iglesias Montiel (eds.), Contemporaneidad de los clásicos en el umbral del tercer milenio, Murcia, Universidad, 1999, pp. 297-306. .

${ }^{22}$ Ed.: G. de la Pinelière, Hippolyte, Paris, De Sommaville, 1635; estreno, 1634, en Hôtel de Bourgogne, de París; A. G. Wood, Le mythe de Phèdre: les Hippolyte français du dix-septième siècle: textes des éditions originales de La Pinélière, de Gilbert et de Bidar, Paris, H. Champion, 1996

${ }^{23}$ Ed.: G. Gilbert, Hippolyte, ou Le garçon insensible, Paris, Courbé, 1647; estreno, 1646; A. G. Wood, Le mythe de Phèdre: les Hippolyte français..., cit.; H. J. Tschiedel, Phaedra und Hippolytus. Variationen eines tragischen Konfliktes, Erlangen, 1969, p. 77 ss.

${ }^{24}$ Ed.: P. P. Bissari, Fedra innamorata, Müncehn, Ieklino, 1662.

${ }^{25}$ Ed.: M. Bidar, Hippolyte, Lille, Le Francq, 1675; estreno, 1674; A. G. Wood, Le mythe de Phèdre: les Hippolyte français..., cit.

${ }^{26}$ Ed.: Oeuvres de Racine (con el título Phèdre et Hippolyte), Paris, C. Barbin - J. Ribou, 1676 ("achevé d'imprimer", marzo de 1677); Oeuvres de Racine (con el título Phèdre), Paris, C. Barbin - D. Thierry, 1687; trads. esps.: de R. Chacel, Madrid, Alfaguare, 1983; de M. D. Fernández Lladó, Madrid, Cátedra, 1999; Estreno: 1 de enero de 1677, Hôtel de Bourgone, París; A. W. Schlegel, Comparaison entre la Phèdre de Racine et celle d'Euripide, Paris, 1807; L. Goldmann, Jean Racine dramaturge, Paris, Paris, L'Arche, 1956; A. Niederst, Racine et la tragedie classique, 
Paris, P.U.F., 1978; A. López, “Amor y culpa en Fedra: Eurípides, Séneca, Racine”, en A. Pociña - A. López, Fedras de ayer y de hoy..., cit., pp. 147-169; A. López, "Nuevo escándalo de Fedra en el París de 1677: el estreno de Phèdre et Hippolyte de Jean Racine et de Jacques Pradon", en A. Pociña - A. López, Fedras de ayer y de hoy..., cit., pp. 323-335.

${ }^{27}$ Estreno: 3 de enero de 1677, Théâtre Guénégaud, Paris; A. López, "Nuevo escándalo de Fedra en el París de 1677...", cit.

${ }^{28}$ Ed.: M. Stevenson, The wits paraphras'd, 1680.

${ }^{29}$ Ed.: en Ouvrages de prose et de poésie des sieurs de Maucroix et de La Fontaine, Paris, Barbin, 1685.

${ }^{30}$ E. Marqués López, "El teatro de tradición clásica de Sor Juana Inés de la Cruz: Amor es más laberinto y Divino Narciso", en J. V. Bañuls Oller et al. (eds.), Literatura Iberoamericana y Tradición Clásica, Valencia, Univ. Autònoma de Barcelona y Univ. de València, 1999, pp. 281286.

${ }^{31}$ Ed.: A. Radcliffe, The Works, 1969.

${ }^{32}$ Ed.: E. Smith, Phaedra and Hippolytus, London, Lintott, 1707; estreno: 21 de abril de 1707, en Queen's Theatre, Haymarket, Londres.

${ }^{33}$ Ed.: J. Addison (1672-1719), The Miscellaneous Works of Joseph Addison, Edited by A. C. Guthkelch, 1914.

${ }^{34}$ Ed.: M. Prior (1664-1721), Poems on Several Occasions, 1905.

35 "Mr. Sheridan's Prologue, to the Greek Play of Phaedra and Hyppolitus; design'd to have been Spoke by a Boy of Six Years Old); ed.: Th. Sheridan, The Blunderful Blunder of Blunders, 1721.

${ }^{36}$ Ed. (moderna): P. A. J. de Olavide y Jáuregui, Obras dramáticas desconocidas, Lima, Biblioteca Nacional del Perú, 1971.

${ }^{37}$ Según Linda Emberger, debe considerarse perdida; aparece mencionada en "Baldamus, Karl”, en Allgemeine Deutsche Biographie, vol. I, Leipzig, Duncker \& Humblot, p. 780 s.

38 Publicado en 1830; ed. posterior, F. Schubert, Gesänge für eine Singstimme mit Klavierbegleitung, ed. de M. Friedländer, Leipzig, Peters, 1885, vol. V, p. 5 ss.;. B. L. Emberger, "La presencia de Fedra e Hipólito en la lírica alemana", en este mismo volumen (con el texto original del poema y traducción española).

${ }^{39}$ Ed.: T. Zàuli-Sajani, Fedra, Forli, Bordanini, 1829.

${ }^{40}$ Ed.: O. Marbach, Hippolyt, Leipzig, Carl B. Lorck, 1858.

${ }^{41}$ Ed.: J. W. Howe, Hippolytus, Princeton, University Press, 1941.

${ }^{42}$ Ed.: Phädra. Trauerspiel in fünf Aufzügen, en G. Conrad, Dramatische Werke I, Bremen, H. Stradt, 1870; B. L. Emberger, "Tradición e innovación en la Phädra de G. Conrad (Príncipe Georg v. Preuben) 1864”, en A. Pociña - A. López, Fedras de ayer y de hoy..., cit., pp. 337-358.

${ }^{43}$ Ed.: Phädra. Melodrama in einem Aufzuge, en G. Conrad, Dramatische Werke IV, Bremen, H. Stradt, 1870; B. L. Emberger, “Tradición e innovación en la Phädra de G. Conrad...”, cit.

${ }^{44}$ Ed.: W. J. Cory, Ionica, 1891.

${ }^{45}$ Ed.: Th. Love Peacock, Works, London, Constable, 1924-1934.

${ }^{46}$ Ed.: A. Ch. Swinburne, Poems and Ballads, London, Moxon, 1855; L. Monrós Gaspar, "La 'Phaedra' de Swinburne: construcciones de la feminidad en la literatura victoriana”, en A. Pociña - A. López, Fedras de ayer y de hoy..., cit., pp. 359-380.

${ }^{47}$ Segundo volumen de la famosa serie Les Rougon-Macquart; eds. É. Zola, La Curée, Paris, Bibliothèque Charpentier, 1906; É. Zola, Les Rougon-Macquart, Paris, Éds. du Seuil, 1969.

${ }^{48}$ Ed.: P. A. de Alarcón, El escándalo, Madrid, Medina y Navarro editores, 1875; P. A. de Alarcón, El escándalo. Edición, introducción y notas de M. Baquero Goyanes, Madrid, Espasa Calpe, 1973 (2 vols.).

${ }^{49}$ Ed.: É. Zola, Renée. Pièce en cinq actes, Paris, G. Charpentier, 1887.

50 Ed.: M. von Meisenbug, Phädra. Ein Roman, 3 vols. Leipzig, Verlag von Carl Reissner, 1885; B. L. Emberger, "Die Romantrilogie Pbädra von Malwida von Meysenbuch. Antikerezeption gegen Ende des 19. Jahrhunderts", en prensa en Jahrbuch der Malwida von Meysenbuch Gesellschaft, núm. 9. 
${ }^{51}$ Ed.: A. Weill, La nouvelle Phèdre, Paris, Sauvaitre, 1889.

${ }^{52}$ Ed.: S. Lipiner, Hippolytos, Stuttgart, Spemann, 1913.

${ }^{53}$ Ed.: T. Sturge Moore, Aphrodite ageinst Artemis, London, At the Sign of the Unicorn, 1901; estreno, 1 de abril de q906, en Londres.

${ }^{54}$ Ed.: B. Carman, Pipes of Pan, Boston, Page, 1904.

${ }^{55}$ Ed.: J. Bois, Hippolyte couronné, Paris, Charpentier \& Fasquelle, 1904; estreno, 30 de julio de 1904 en el Teatro Romano de Orange.

${ }^{56}$ Ed.: W. Cather, The Troll Garden, New York, McClure, Phillips, 1905.

${ }^{57}$ A. Jàcono, "Fedra di Umberto Bozzini", Dioniso 7 (1939) 247-250; F. De Martino, "Il bacio della pantera. La Fedra di D’Annunzio (e quella di Bozzini, 1909)”, en A. Pociña - A. López, Fedras de ayer y de hoy..., cit., pp. 383-419; M. Arriaga Flórez, "Fedra y la literatura italiana", cit.

${ }^{58}$ Ed.: G, D’Annunzio, Fedra, Milano, Treves, 1909; estreno, 10 de abril de 1909, Teatro Lirico de Milán; M. Guglielminetti, "La Fedra di D’Annunzio, e altre Fedre”, en R. Uglione (ed.), Atti delle giornate di studio su Fedra, Torino, C:E.L.I.D.,1985, pp. 33-54; I. Caliaro, “D'Annunzio lettore-scrittore: Le fonti della 'Fedra', Annali di Italianistica 5 (1987) 207-221; S. Abate, "Las dos caras de la Fedra dannunziana", Rev. de Literaturas Modernas 36 (1997) 8-22; M. Arriaga Flórez, "Fedra y la literatura italiana", cit.; F. De Martino, "Il bacio della pantera. La Fedra di d'Annunzio...", cit.

${ }^{59}$ Ed.: En la Rev.La Pluma (Madrid),1921, núms. 8, 9 y 10; M. de Unamuno, Teatro completo. Prólogo, ed. y notas bibliográficas de M. García Blanco, Madrid, Aguilar, 1959; estreno, 25 de marzo de 1918, Teatro Ateneo de Madrid; F. Lázaro Carreter, "El teatro de Unamuno", Cuads. de la Cátedra Miguel de Unamuno 7 (1956) 5-29; J. S. Lasso de la Vega, "Fedra' de Unamuno", en De Sócles a Brecht, Barcelona, Editorial Planeta, 1974, pp. 205-248; A. Pociña, "Seneca e le sue opere nel teatro spagnolo del XX secolo", en I. Dionigi (ed.), Seneca nella coscienza dell'Europa, Milano, Mondadori, 1999, pp. 299-325; C. Morenilla, "La obsesión por Fedra de Unamuno (1912), Villalonga (1932) y Espriu (1978)”, en A. Pociña - A. López, Fedras de ayer y de hoy..., cit., pp. 435-480.

${ }^{60}$ Ed.: M. Hewlett, The Agonists: A Trilogy of God and Man, New York, Scribner, 1911.

${ }^{61}$ Ed.: H. Limbach, Phädra. Ein Schiksal, Bern, Verlag von A. Francke, 1911.

${ }^{62}$ Ed.: M. Sackville, Songs of Aphrodite and Other Poems, London, Mathews, 1913.

${ }^{63}$ Ed. (última): G. Hermann, Heinrich Schön jun., Berlin, Verlag Das Neuue Berlin, 1998.

${ }^{64}$ Ed.: C. Pape, Und sie rüttelte an der Kette, Berlin, Verlag E. Hofmann, 1915.

${ }^{65}$ Ed.: C. S. Lewis, Narrative Poemas, New York, Harcourt, Brace, Jovanovich, 1969.

${ }^{66}$ Ed.: H. Doolittle, Collected Poems, New York, Boni \& Liveright, 1925; Collected Poems 1912-1944, Edited by L. L. Martz, 1983..

${ }^{67} \mathrm{Cf}$. nota anterior.

${ }^{68}$ Cf. nota anteúltima.

${ }^{69} \mathrm{Cf}$. poema anterior.

${ }^{70}$ Esteno, 11 de noviembre de 1924, Greenwich Village Theater de Nueva York; I. del Árbol - J. L. Vázquez, “La savia clkásica en Desire under the Elms (1924) de Eugene O’Neill”, en A. Pociña - A. López, Fedras de ayer y de hoy..., cit., pp. 421-433.

${ }^{71}$ Ed.: H. Deberly, Le supplice de Phèdre, Paris, Gallimard, 1926.

${ }^{72}$ M. Rubino, "Una 'Fedra' classica en el teatro ruso moderno", en A. Pociña - A. López, Fedras de ayer y de hoy..., cit., pp. 481-485; M. Rubino, "Martina Cvetaeva", en Fedra Per mano femminile, cit., pp. 35-56.

${ }^{73}$ J. de Lacretelle, L'âme cachée, Paris, Gallimard, 1928.

${ }^{74}$ Ed.: H. Angélico, La nieta de Fedra, Prólogo de Alejandro Bher, Madrid, Talleres Tipográficos Velasco, 1929.

75 S. Almazora, "Drama i tragèdia dins il cicle de Fedra de Llorenç Villalonga i Salvador Espriu”, en P. Rosselló (ed.), Actes del Col.loqui Llorenç Villalonga, Barcelona, Abadía de Montserrat, 1999, pp. 85-99; C. Morenilla, "La obsesión por Fedra de Unamuno (1912), Villalonga (1932) y Espriu (1978)", cit. 
${ }^{76}$ Ed.: M. Yourcenar, Feux, Paris, Grasset, 1936; Paris, Gallimard, 1974; trad. esp. de E. Calatayud, Madrid, Santillana, 2009; M. Rubino, "Marguerite Yourcenar", en Fedra Per mano femminile, cit., pp. 57-66.

${ }^{77}$ Ed.: A. Heider, Phädra in Basel, Basel, Brodbeck-Frehner, 1936.

${ }^{78}$ C. Morenilla, "La obsesión por Fedra de Unamuno (1912), Villalonga (1932) y Espriu (1978)", cit.

${ }^{79}$ Ed.: B. von Brentano, Phädra, Zurich, Oprecht, 1939; Wiesbaden, Limes-Verlag, 1948.

${ }^{80}$ M. Rubino, "Marguerite Yourcenar", en Fedra Per mano femminile, cit.

${ }^{81}$ A. Gide, Thesée, Paris, Gallimard, 1946.

${ }^{82}$ Ed.: E. Bono, Ippolito, Milano, Garzanti, 1954. Representado en 1951 por el "Teatro dell'Università di Padova”, y en 1957 en Roma por la "Compagnia di Emma Grammatica”.

${ }^{83}$ Ed.: J. Gállego, Fedra, Zaragoza, Heraldo de Aragón, 1951; E. Calderón Dorda, "Fedra: un personaje en busca de su época (cuatro Fedras contemporáneas)", en J. V. Bañuls - F. De Martino - C. Morenilla (eds.), El teatro greco-latino y su recepción en la tradición occidental, Bari, Levante Editori, 2006, pp. 113-139.

${ }^{84}$ Ed.: K. Rexroth, Phaedra (1 ${ }^{\text {a }}$ parte tetralogía Beyond the Mountains), New York, New Directions / London, Routledge, 1951; estreno, 1951 en Nueva York.

${ }^{85}$ Ed.: en W. Koeppen, Morgenrot, Frankfurt/Main, Suhrkamp, 1987, pp. 67-91.

${ }^{86}$ Cf. L. Mottura, El mal amor, 1955.5 de agosto de 1952, Living Theater, Nueva York.

${ }^{87}$ Ed.: J. Ashbery, Three Plays, Calais, Vt., Z Press, 1978; estreno, 5 de agosto de 1952, Living Theater, Nueva York.

${ }^{88}$ M. Bieber, Tha History of the Greek and Roman Theater, Princeton, University Press, 1961, p.260.

${ }^{89}$ Ed.: en W.Lehmann, Gesammelte Werke I. Sämtliche Gedichte, Stuttgart, Klett-Cotta, 1982, p. 224; B. L. Emberger, "La presencia de Fedra e Hipólito en la lírica alemana", en este mismo volumen, con el texto alemán y versión española.

${ }^{90}$ Ed.: R. Jeffers, Hungerfield and Other Poems, New York, Random House, 1954; estreno, 1954, Nueva York.

${ }^{91}$ El mal amor, 1955, dirección de Luis Mottura, intérpretes Pedro Hurtado, Mecha Ortiz, Ricardo Passano; guión de María Luz Regás y Juan Albornoz según la obra teatral El mal amor (1951) de Regás.

${ }_{92}$ Fedra, 1956, dirección de M. Mur Oti, intérpretes Emma Penella, Vicente Parra, Enrique Diosdado; S. Salvador Ventura, "Filmando Fedra en España (Manuel Mur Oti, 1956) y Francia (Jules Dassin, 1962)”, en A. Pociña - A. López, Fedras de ayer y de hoy..., cit., pp. 503-524; cf. también R. Ma. Mariño Sánchez-Elvira, "Teseo, Fedra e Hipólito en el cine”, cit.; Id., "Fedra (M. Mur Oti, 1956)", Metakinema www. metakinema.es/metakineman0s1a1.html

${ }^{93}$ Ed.: E. Schnabel, Der sechste Gesang, Frankfurt am Main, Deutsacher Bücherbund, 1956. Esta novela, reescritura de la Odisea de Homero, contiene (pp. 87-111) tres piezas de teatro de títeres que tratan muy de cerca el personaje de Fedra (información proporcionada por Linda Emberger).

${ }_{94}$ Tribute to a bad man, 1956, dirección de Robert Wise, intérpretes James Cagney, Vic Morrow, Lee Van Cleef.

${ }^{95}$ Wild is the wind, 1957, dirección de George Cukor, intérpretes Anna Magnani, Anthony Quinn, Anthony Franciosa; guión de Arnold Schulman.

${ }^{96}$ Publicado en 1957 dentro del ciclo Sizilianischer Herbst, en la colección Neue Gedichte; ed.:

M. L. Kaschnitz, Gesammelte Werke V. Die Gedichte, Frankfurt am Main, Insel, 1985, p. 266 s.; B. L. Emberger, "La presencia de Fedra e Hipólito en la lírica alemana", en este mismo volumen, con el texto alemán del poema y versión española.

${ }^{97}$ Ed.: C. Terron, Teatro, Bologna, Cappelli, 1961.

${ }^{98}$ M. McDonald, L'arte vivente della tragedia greca, Firenze, 2004, pp. 173-180.

${ }^{99}$ Ed.: C. J. Cela, Gavilla de fábulas sin amor, 1962.

100 Ed.: G. Cesbron, L’homme seul. Phèdre à Colombes. Dernier Acte, Paris, Robert Laffont, 1961; Paris, Éditions J’ai lu, 1972. 
${ }^{101}$ Phaedra, 1962, dirección de Jules Dassin, intérpretes Melina Mercouri, Anthony Perkins; R. Lavagnini, "Fedra al cinema", Dioniso (2003) 242-245; S. Salvador Ventura, "Filmando Fedra en España (Manuel Mur Oti, 1956) y Francia (Jules Dassin, 1962)”, cit.; M. Rubino, "Margarita Liberaki”, en M. Rubino, Fedra Per mano femminile, cit., pp. 67-73.

102 Ed.: C. Miró, Fedra entre los vascos, Buenos Aires, Editorial Losada, 1962; A. López, "De la tragedia clásica a la novela moderna: Fedra entre los vascos de César Miró (1962)”, en A. Pociña - A. López, Fedras de ayer y de hoy..., cit., pp. 487-501.

${ }^{103}$ M. Rubino, Fedra Per mano femminile, cit., pp. 76-79.

${ }^{104}$ Las ratas, 1962 (estreno: 22-8-1963), dirección de Luis Saslavsky; guión de Emilio Villalba Welsh y Simón Fourcade según la novela Las ratas (1943) de José Bianco; intérpretes Aurora Bautista, Alfredo Alcón, Bárbara Mujica, Juan José Míguez, etc.

105 Estreno, 1967, Nueva York.

${ }^{106}$ Ed.: V. Watkins, Fidelities, London, Faber \& Faber, 1968.

107 Phèdre, 1968, dirección P. Jourdan; intérpretes Marie Bell, Jacques Dacgnune, Jean Chevalier; según la Phèdre de Jean Racine.

${ }^{108}$ Fedra West, 1968, dirección J. Romero Marchent; intérpretes Norma Bengell, James Philbroock, Simón Andreu.

${ }^{109}$ Ed.: M. Lourenzo, Romería ás covas do demo, Santiago de Compostela, Pico Sacro, 1975; estreno, 1969, Teatro Circo, en A Coruña; J. A. Fernández Delgado, "La tradición griega en el teatro gallego", EstClás 38 (1996) 59-89, esp. pp 74-83; A. Pociña - A. López, "El tema de Fedra en el teatro gallego de Manuel Lourenzo", en A. Pociña - A. López, Fedras de ayer y de boy..., cit., pp. 525-544; A. Pociña - A. López, Medea e Fedra, dúas paixóns de Manuel Lourenzo (monografía, en prensa, Universidad de A Coruña).

${ }^{110}$ Ed.: Th. Gunn, Moly, London, Faber \& Faber, 1971.

${ }^{111}$ Ed.: P. Goodman (1911-1972), Collected Poems, New York, Random House, 1973.

${ }^{112}$ Ed.: R. Lattimore, Poems from Three Decades, Newwq York, Scribner, 1972.

${ }^{113}$ Ed.: en E. Arendt, Memento und Bild. Gedichte, Darmstadt, Agora, 1977, pp. 32-34; B. L. Emberger, "La presencia de Fedra e Hipólito en la lírica alemana", en este mismo volumen, con el texto alemán completo y versión española.

${ }^{114}$ Ed.: D. Miras, Teatro mitológico, Edición de V. Serrano, Ciudad Real, Diputación, 1955; V. Serrano, El Teatro de Domingo Miras, Murcia, Universidad, 1991; D. de Paco, "Clitemnestra, Penélope y Fedra: Heroínas clásicas en el teatro de Domingo Miras”, Estreno 28 (2002) 31-37; E. Calderón Dorda, "Fedra: un personaje en busca de su época ...", cit.

${ }^{115}$ Ed.: T. Harrison, Phaedra Britannica, London, Collings, 1975; estreno, 9 de septiembre de 1975, Old Vic Theatre de Londres.

${ }^{116}$ Ed.: en K. Krolow, Gesammelte Gedichte III, Frankfurt am Main, Suhrkamp., 1985, p. 26; B. L. Emberger, "La presencia de Fedra e Hipólito en la lírica alemana”, en este mismo volumen, con el texto original y versión española.

${ }^{117}$ Ed.: G. Ritsos, Phaídra, Atenas, Ed. Kedros, 1978 (1 $1^{\text {a }}$ ed.); trad. esp.: Y. Ritsos, Florilegio de obras poéticas, Selección,, trad. y notas de A. Pociña, Granada, Centro de Estudios Bizantinos, Neogriegos y Chipriotas, 2009, pp. 145-176; R. Trombino, "La Fedra di Ghiannis Ritsos. Note di lettura", Dioniso 60 (1990)75-81; M. Bravo, "Fedra", Más cerca de Grecia 7 (1991) 157-163; M. Morfakidis - A. Pociña, "La Fedra de Yannis Ritsos (1978)", en A. Pociña - A. López, Fedras de ayer y de hoy..., cit., pp. 545-561; E. Pozzi, "Interpretare Fedra", en M. Rubino, Fedra Per mano femminile, cit., pp. 119-121.

${ }^{118}$ E. Calderón Dorda, "Fedra: un personaje en busca de su época ...”, cit.

119 P. O. Enquist, Till Fedra, Stockholm, Norstedts Förlag, 1980.,

${ }^{120}$ Ed.: M. Martínez Mediero, Fedra, en Primer Acto 197 (1983), pp. 76-100; estreno, 1981 Teatro Romano de Mérida.

${ }^{121}$ Ed.: M. Lourenzo, Fedra, A Coruña, Cadernos da escola dramática galega,no 28, 1982; M.-J. Ragué Arias, Los personajes y temas de la tragedia griega en el teatro gallego contemporáneo, Sada - A Coruña, Ediciós do Castro, 1991, pp. 88-91; A. Pociña - A. López, "E1 tema de Fedra en el teatro gallego de Manuel Lourenzo", cit. 
${ }^{122}$ Inédita; estrenada en el Teatro Lope de Vega, Sevilla, y en la Sala Pol, Madrid; M. J. Ragué Arias, Lo que fue Troya. Los mitos griegos en el teatro español actual, Madrid, Asociación de Autores de Teatro, 1992, pp. 129-134.

${ }^{123}$ J. V. Bañuls - P. Crespo, "La sombra de Fedra en El espejo de Emilia Macaya (1986)", en A. Pociña - A. López, Fedras de ayer y de hoy..., cit., pp. 563-589.

${ }^{124}$ Ed.: O. Pastior, Feiggehege. Listen, Schnüre, Häufungen, Berlin, Literarisches Colloquium, 1991, pp. 27-30; B. L. Emberger, "La presencia de Fedra e Hipólito en la lírica alemana”, en este mismo volumen.

${ }^{125}$ L. Monrós Gaspar, "El amor de Fedra en The Love of the Nightingale (1988>) de Timberlake Wertenbaker”, en A. Pociña - A. López, Fedras de ayer y de hoy..., cit., pp. 591-612.

${ }^{126}$ M.A.Garza,"La(s) representación(es) de la subjetividad femenina a través del palimpsesto en La sunamita y Estio de Inés Arredondo", RMMLA, en http://rmmla.wsu.edu/ereview/55.1/ articles/garza.asp.

127 Ed.: N. Fusini, La luminosa. Genealogia di Fedra, Milano, Feltrinelli, 1990; M. Arriaga Flórez, "Fedra y la literatura italiana", cit.; M. Rubino, Fedra Per mano femminile, cit., pp. 81-83.

${ }_{128}$ A. López, "Una reescritura feminista de Fedra: Lagartijas, gaviotas y mariposas de MaríaJosé Ragué”, en A. López - A. Pociña (eds.), En recuerdo de Beatriz Rabaza. Comedias, tragedias y leyendas grecorromanas en el teatro del siglo XX, Granada, Editorial Universidad de Granada, 2009, pp. 311-321.

${ }^{129}$ Ed.: M.-J. Ragué Arias, Lagartijas, gaviotas y mariposas (Lectura moderna del mito de Fedra), Introd. J. G. Schroeder, Murcia, Universidad, 1991; E. Calderón Dorda, "Fedra: un personaje en busca de su época ...", cit.; A. López, "Una reescritura feminista de Fedra: Lagartijas...", cit.

${ }^{130}$ Ed.: L. Cardella, Fedra se ne va, Milano, Rizzoli, 1992; M. Rubino, Fedra Per mano femminile, cit., pp. 83-87.

${ }^{131}$ M. Rubino, Fedra Per mano femminile, cit., pp. 87-92.

${ }^{132}$ Ed.: junto con Los restos: Agamenón vuelve a casa, Madrid, Fundación Autor (SGAE), 1999; M.-J. Ragué Arias, "Clitemnestra, Medea, Fedra. Contemporaneidad de su transgresión mítica”, en F. De Martino - C. Morenilla (eds.), El fil d'Ariadna, Bari, Levante Editori, 2001, pp. 367-378.

${ }^{133}$ Ed.: S. Kane, Blasted E' Phaedra's Love, London. Methuen, 1996; G. Saunders, "Love me or Kill me". Sarah Kane and the theatre of extremes, Manchester - New York, 2002; J. V. Martínez Luciano, "Sarah Kane y El Amor de Fedra", en F. de Martino - C. Morenilla (eds.), El caliu de l'oikos, Bari, Levante Editori, 2004, pp. 373-383; M. Matteuzzi, "Phaedra's love di Sarah Kane (1996): una cruda riscrittura tra Euripide e Seneca”, en A. Pociña - A. López, Fedras de ayer y de hoy..., cit., pp. 613-617; M. Rubino, Fedra Per mano femminile, cit., pp. 93-108.

${ }^{134}$ Ed. A. Grieco, Per amore, Il Saggiatore, 2005.

135 Obra teatral citada, sin fecha ni otras precisiones, en M. Gómez García, Diccionario del Teatro, Tres Cantos, Ediciones Akal, 1997, p.367.

${ }^{136}$ Ed.: D. de Paco, Polifonía, Introducción de D. Miras, Primer Acto 291 (2001) 103-123; V. Serrano, "Nuevas voces de mujer para las heroínas clásicas", en A. Pociña - A. López, Fedras de ayer $y$ de boy..., cit., pp. 619-628.

${ }^{137}$ Ed.: Ch. Lehnert, Phaedra. Ein Werkbuch, Berlin, Klaus Wagenbach, 2007. Música de la ópera: Hans Werner Henze.

${ }^{138}$ Ed.: M. Lourenzo, Medea dos fuxidos e outras pezas, A Coruña, Biblos clube de lectores, 2009, pp. 179-128. De esta obra, la más reciente de las varias reescrituras del tema de Fedra e Hipólito escritas por el dramaturgo gallego Manuel Lourenzo, nos ocupamos en nuestro libro: A. Pociña - A. López, Medea e Fedra, dúas paixóns de Manuel Lourenzo, de próxima publicación en la Universidad de A Coruña.

${ }^{139}$ Ed.: M. Roes, Ich weiss nicht mehr die Nacht, Berlin, Matthes \& Seitz, 2008.

${ }^{140}$ Ed. J. Mayorga, Fedra, Oviedo, Ediciones KRK, 2010.

${ }^{141}$ Ed.: en C. Lourenço Módia, Teatro Circo. Tres textos, A Coruña, Deputación Provincial da Coruña, 2010, pp. 173-197. 
${ }^{142}$ Representación teatral, a partir de Eurípides, Racine, Mayorga, Yannis Ritsos, Ximena Escalante, y especialmente Marguerite Yourcenar, dirigida por Esther André; estreno, 27 de junio de 2010 en el I Festival de Teatro Intrauniversitario, Universidad Autónoma de Nuevo León.

${ }^{143}$ No olvidemos que, entre las dos composiciones del Hipólito de Eurípides, es casi seguro que hayamos de colocar el estreno de la Fedra de Sófocles (aunque no toda la crítica está de acuerdo con esta colocación de esta tragedia perdida). Cf. a este propósito, de forma especial,J.V. Bañuls - P. Crespo, "La Fedra de Sófocles", en A. Pociña - A. López, Fedras de ayer y de hoy..., cit., pp. 15-83; y, en particular, "En Sófocles al componer su Fedra -y dejamos por ahora a un lado la cuestión de la datación-, debió influir el ambiente generado en Atenas por la Fedra euripidea, pero lejos de verse mediatizado por él, debió contribuir a enriquecer a su personaje, a su Fedra, a esto hay que añadir la expectación que debió provocar entre los atenienses el que Sófocles fuese a llevar al teatro una tragedia sobre Fedra e Hipólito" (p. 31).

${ }^{144} \mathrm{La}$ diferencia esencial que existe entre la intervención de la divinidad, reflejada por la presencia en concreto de las diosas Afrodita en el Prólogo y Ártemis en el Éxodo, en el Hipólito de Eurípides, y su ausencia en la Fedra de Séneca, ha sido estudiada con todo acierto por G. Petrone, "Eccessi di eros e parentella nella Fedra di Seneca", en A. Pociña - A. López, Fedras de ayer y de hoy..., cit., pp. 239-250.

${ }^{145}$ Patricia A. Watson, Ancient Stepmothers. Myth, Misogyny and Reality, Leiden - New York - Köln, 1995.

${ }^{146}$ Op. cit., p. 208: "The literary stereotype of the stepmother takes three main forms: (1) the stepmother as murderess, her motivation being to obtain the inheritance for her own son (2) the stepmother as persecutor of a stepdaughter (3) the 'amorous' stepmother".

${ }^{147}$ Op. cit., p. 216.

${ }^{148}$ M. de F. Silva, "La Fedra de Eurípides. Ecos de un escándalo", en A. Pociña - A. López, Fedras de ayer y de hoy..., cit., pp. 105-123.

${ }^{149} \mathrm{El}$ tema de la mujer que se enamora de un hombre más joven vuelve a aparecer, dentro de la obra de Eurípides, en Los Cretenses, Fénix y probablemente en Peleo. Por su parte, Estenebea, la mujer de Preto, rey de Tirinto, al verse rechazada por Belerofonte, joven huésped de la corte de su marido, acaba por denunciarlo como su seductor. Cf. la reconstrucción de la pieza llevada a cabo por T. B. L. Webster, The tragedies of Euripides, London, 1967, pp. 80-84.

${ }^{150}$ Cf. A. Pociña, "Una vez más sobre la representación de las tragedias de Séneca", Emerita 41 (1973) 297-308; A. Pociña - A. López, "Las Tragedias de Séneca desde nuevas perspectivas de estudio”, Ponencia en el XXI Simposio Nacional de Estudios Clásicos, Santa Fe, Argentina, septiembre de 1910 (en prensa).

${ }^{151}$ Cf. A. López, "Ruptura del prototipo de mujer: Fedra se declara a Hipólito (Ov. Her. 4 y Sen.Phaedr.)”, en M. Rodríguez-Pantoja (ed.), Séneca, dos mil años después, Córdoba, Universidad, 1997, pp. 281-289; Ead., "La Fedra de Séneca: una ruptura del prototipo", en A. Pociña - A. López, Fedras de ayer y de hoy..., cit., pp. 251-267.

${ }^{152}$ En A. López, "Nuevo escándalo de Fedra en el París de 1677: el estreno de Phèdre et Hippolyte Jean Racine et de Jacques Pradon”, en A. Pociña - A. López, Fedras de ayer y de hoy..., cit., pp. 323-335.

${ }^{153}$ Poco tiempo después, en 1687 aparece ya con el título reducido sólo a Phèdre, que es con el que la conocerá y editará la posteridad.

154 P. Antonio de Alarcón, El escándalo, Madrid, Medina y Navarro editores, 1875; seguimos en nuestro trabajo la edición de la benemérita y desafortunadamente extinguida colección "Clásicos Castellanos", P. A. de Alarcón, El escándalo. Edición, introducción y notas de M. Baquero Goyanes, Madrid, Espasa Calpe, 1973 (2 vols.), con una excelente y ejemplar introducción que nos ha sido de gran utilidad, y de modo especial su "Bibliografía" (pp. cxxxvicxxxix), que comienza precisando que "El escándalo ha sido una de las novelas españolas que más ediciones ha alcanzado".

${ }^{155}$ Cf. la Introducción a la edición citada en la nota anterior, especialmente el apartado "XV. Estructura de El escándalo", pp. cxviii-cxxix).

${ }^{156}$ S. Salvador Ventura, "Filmando Fedra en España (Manuel Mur Oti, 1956) y Francia 
(Jules Dassin, 1962)”, en A. Pociña - A. López, Fedras de ayer y de hoy..., cit., pp. 503-524; cf. también R. Ma Mariño Sánchez-Elvira, “Teseo, Fedra e Hipólito en el cine”, cit., esp. pp. 113115 .

${ }^{157}$ Una presentación de las múltiples peripecias y aventuras de este personaje mitológico puede verse en el dilatado tratamiento que le tributa P. Grimal, Diccionario de la mitologías griega y romana, trad. de F. Payarols, Barcelona, Editorial Labor, 1965, pp. 505-510.

${ }^{158}$ Cf. A. Pociña, "Seneca e le sue opere nel teatro spagnolo del XX secolo", en I. Dionigi (ed.), Seneca nella coscienza dell'Europa, Milano, Mondadori, 1999, pp. 299-325.

${ }^{159}$ Esta escena del baño es seguida por la reproducción del famoso cuadro de François Boucher, "Diana después de su baño" (Museo del Louvre, París), que se glosa en el capítulo 5 de la novela, donde Diana y su acompañante se transforman en doña Lucrecia y su doncella Justiniana, que sin ambages muestran que conocen muy bien la naturaleza erótica de las relaciones entre la madrastra y Fonchito.

${ }^{160}$ El tema de las edades de Fedra e Hipólito tiene un notable interés por su peculiar interpretación en muchas de las reescrituras de la leyenda, según esperamos mostrar en la ponencia de A. Pociña, "Retrato físico de Fedra e Hipólito en diez reescrituras desde la Grecia clásica al siglo XXI", que estamos preparando para el Congreso Nacional de Literatura Comparada que se celebrará en la Universidad de La Plata en el mes de agosto de 2011.

${ }^{161} \mathrm{El}$ niño muy pequeño que representa a Eros / Amor en el cuadro de Tiziano "Venus con el Amor y la Música” del Museo del Prado, que se glosará en el capítulo 7, en el momento en que don Rigoberto acaba los cuidados corporales que le sirven de preámbulo y estímulo para sus relaciones con doña Lucrecia ("Hoy no será Lucrecia sino Venus y hoy pasarás de peruana a italiana y de terrestre a diosa y símbolo", p. 103), no corresponde a la edad de Fonchito, que por fuerza ha de ser un niño de más años, ya más desarrollado, pero en modo alguno un adolescente, pues se nos dice que "acaba de hacer su primera comunión" (p. 53).

${ }^{162}$ Cf. A. López, "La Fedra de Séneca: una ruptura del prototipo", en A. Pociña - A. López, Fedras de ayer y de hoy..., cit.

${ }^{163}$ G. Petrone, "Eccessi di eros e parentella nella Fedra di Seneca", cit. Véase, por ejemplo, este acertado y preciso párrafo: "Lungamente evocato a più riprese, il fratello animale di Fedra testimonia la perversione erotica della madre e della parentela femminile, rivelando nel suo stesso essere le conseguenze terribili della violazione delle leggi regolatrici dell'universo. Questa ossessiva presenza del Minotauro, il cui ricordo perseguita Fedra come un orrore 'familiare' ed è usato come deterrente dalla nutrice, ad un certo punto si trasforma da fantasma della mente in una sorta di doppio reale. Infatti il mostro marino, mezzo toro e mezzo pesce, che sollevandosi dal mare, in seguito alla maledizione di Teseo, causa la morte di Ippolito, non può non ricollegarsi al Minotauro, la cui spaventosa ambiguità riproduce. L'incubo della creatura indefinibile partorita da Pasifae in qualche modo si rinnova in un nuovo mostro, evocato da Teseo, ma generato in ultima analisi dall'amore fuori dalle regole di Fedra. Dietro Fedra, c’è infatti costantemente, secondo l'interpretazione senecana, la madre Pasifae, il cui modo abominevole d'amare segna la figlia come una condanna e una coazione a ripetere. La protagonista assomiglia troppo alla propria madre e lo sa" (p. 240).

${ }^{164}$ A. López, "La Fedra de Séneca: una ruptura del prototipo", en A. Pociña - A. López, Fedras de ayer y de hoy..., cit., p. 259 s.

165 Por otra parte, no nos parece nada raro que, al incluir este capítulo, Vargas Llosa haya tenido presente la personalísima reescritura del mito Minotauro en el no menos curioso drama Los Reyes $\left(1947,1^{\mathrm{a}}\right.$ ed. Buenos Aires, 1949) de Julio Cortázar, que pone en escena a Teseo, el Minotauro, Minos y Ariana (sic); raro sería que Vargas Llosa no conociese esta obrita al escribir el Elogio de la madrastra (sobre Los Reyes: M. Taylor, "Los Reyes de Julio Cortázar. E1 Minotauro redimido", Revista Iberoamericana 39 (1973) 542; M. del C. Cabrero, "E1 mito del Minotauro y su proyección en Los Reyes de Julio Cortázar", en AA. VV., Tradición clásica y literaturas contemporáneas, Bahía Blanca, Editorial de la Univ. Nal. del Sur, 1996, pp. 83-102; R. López Gregoris, "El personaje del Minotauro en J. L. Borges y J. Cortázar. Tradición clásica y originalidad", en J. V. Bañuls Oller et al. (eds.), Literatura Iberoamericana y Tradición Clásica, cit., pp. 267-271; S. Boldy, "Prólogo" de Julio Cortázar, Obras completas II, Ed. de S. Yurkievich, 
Barcelona, Galaxia Gutember, 2004, pp. 9-39; A. M. González de Tobia, "Los Reyes en su laberinto", en A. López - A. Pociña (eds.), En recuerdo de Beatriz Rabaza. Comedias, tragedias y leyendas grecorromanas en el teatro del siglo XX, cit., pp. 265-275; etc.

${ }^{166} \mathrm{Cf}$. Heródoto, Historias Libro I, Texro revisado y traducido por J. Berenguer Amenós, Barcelona, Ediciones Alma Mater, 1960.

${ }^{167}$ Un tratamiento también original del tema de Candaules había sido llevada a cabo por André Gide en Le roi Candaule. El gran maestro y pionero en los estudios sobre tradición clásica Gilbert Highet, que hace gala de una profunda antipatía por Gide y sus reinterpretaciones “repulsivas" (en opinión de Highet) de los mitos clásicos, escribe: "La historia de Candaules y Giges, según la cuenta Heródoto (y según la vuelve a contar Gautier), es ya bastante picante: el rey está tan pagado de la hermosura de su mujer, que esconde en el aposento a Giges, su visir, para que la vea desnudarse. Pero Gide hace que el rey, en un fenomenal acceso de generosidad, salga de la habitación y diga a Giges que lo sustituya esa noche" (G. Highet, La tradición clásica. Influencias griegas y romanas en la literatura occidental, Trad. de A. Alatorre, México, Fondo de Cultura Económica, 1978 (= 1954), vol. II, pp. 353-354). Esta innovación de Gide es diferente de la de Vargas Llosa; no podemos saber si el escritor peruano conocía la versión del francés cuando escribió la suya propia.

${ }^{168}$ Vargas Llosa, en cambio, lo repetirá de nuevo poco después, en la página 146.

${ }^{169}$ Suet., Tib. 43: Secessu uero Caprensi etiam sellaria excogitauit, sedem arcanarum libidinum, in quam undique conquisiti puellarum et exoletorum greges monstrosique concubitus repertores, quos spintrias appellabat, triplici serie conexi, in uicem incestarent coram ipso, ut aspectu deficientis libidines excitaret (C. Suetonio Tranquilo, Vida de los doce Césares, texto revisado y traducido por Mariano Bassols de Climent, vol. II, Barcelona, Alma Mater, 1968). 


\section{Ecos DE LOS CLÁSICOS EN EL TEATRO RIOPLATENSE ${ }^{I}$ (Siglo XIX)}

Concepción López Rodríguez ${ }^{2}$

Universidad de Granada

Globalmente considerada, la literatura hispanoamericana del siglo XIX, de la que no se sustrae el territorio del río de la Plata (es decir, Argentina y Uruguay), recorre una trayectoria que puede esquematizarse de la siguiente forma:

Primera etapa: restos de Neoclasicismo (hasta los años veinte)

Segunda etapa: inicios del Romanticismo (desde 1825-1860)

Tercera etapa: Romanticismo (1860-1890)

Cuarta etapa: Realismo y Naturalismo (1890-primeros años del 1900)

Obviamente esta es una simplificación metodológica que tiende más bien a facilitar unas coordenadas generales que enmarquen el desarrollo de la temática aquí propuesta.

Todos los movimientos literarios arriba citados abarcan el cultivo de diferentes géneros: novela, ensayo, poesía y teatro, en mayor o menor medida; pero, para este último caso, el drama, hago mías y comunes a casi todas las etapas literarias citadas, las palabras que Cedomil $\mathrm{Goic}^{3}$, en su Historia y crítica de la literatura hispanoamericana, dedica al período romántico: "Género menos feliz (que la poesía) fue el teatro, dominantemente costumbrista y próximo a los modelos de Moratín y Gorostiza y, más tarde, de Bretón de los Herreros, tuvo, sin embargo un momento de excepcional originalidad que lamentablemente no llegó a desarrollarse: el teatro gauchesco, representación mímica, animada con atrevimiento en una carpa de circo, y al cual el diálogo ulteriormente agregado no llegó a salvar".

Nos encontramos pues ante un panorama pobre tanto en la época predominantemente neoclásica como en el romanticismo, tanto por el número de las obras teatrales como por la calidad de las mismas. Este hecho, la escasez relativa de las obras, no es el único rasgo que singulariza la producción del siglo XIX en el aspecto dramático. Otro rasgo que involucra a otros géneros literarios define la producción literaria hispanoamericana y que supone para ella la dolorosa carga de falta de identidad propia. Es una cuestión muy debatida la originalidad de sus obras, hecho no atribuible solamente a estos años; en realidad ha sido un tópico y se ha destacado el carácter de literatura secundaria, aplicado al siglo XVIII, por ejemplo. Sin entrar ahora en una batalla teórica, es cierto que su historia determina en una primera instancia una dependencia cultural de los países colonizadores. No cabe duda que las letras francesas, las españolas, las italianas... desplegaron en estas tierras todo su amplio bagaje 
cultural $^{4}$. Argentina y Uruguay llegan al siglo XIX habiendo conocido el teatro religioso español, adaptaciones de obras francesas e italianas.... Con todo ello quiero dar a entender que en la mayoría de los casos los elementos de la tradición greco-latina están mediatizados por un intermediario europeo o son productos, en una escasa minoría, de autores cultos que conocen al menos las fuentes latinas de manera directa. Pero, al abarcar esta perspectiva nuestra una etapa tan amplia (siglo XIX), se ha de señalar y plantear esa otra corriente interesantísima desde el punto de vista de la historia literaria por su carácter más genuino y original, de menor influencia clásica conscientemente asumida, pero que al unísono con el cambio histórico-social irrumpió en las escenas de los territorios que baña el río de la Plata durante el siglo XIX; se trata del teatro "gauchesco", donde son perceptibles lazos de unión, a veces casi subterráneos, con el teatro greco-latino y cuyos rasgos generales ofrecen el carisma de lo auténticamente local o son consonancias de lo auténticamente local con elementos presentes en el drama clásico.

\section{Primera opción: presencia conscientemente asumida de la cultura clásica: El neoclasicismo de Juan Varela}

La opción primera, es decir, cuando constatamos o bien una lectura directa de los clásicos o bien conocemos claramente que la obra iberoamericana está inspirada en una fuente europea, aparece representada por las tragedias Dido, Argia y la inconclusa Idomeneo de Juan Cruz Varela, cuya vida transcurrió entre los años 1794-1839, época de Rivadavia; fue cantor de los grandes triunfos de Maipú (1818). También cantó la guerra contra Brasil y los comienzos de lo que habría de ser una época de trágica violencia con la llegada de Juan Manuel Rosas, que dominó la Argentina de 1829 a 1852. En los últimos años de su vida, según declara Bellini ${ }^{5}$, Juan Cruz Varela escribió desde su exilio en Montevideo una encendida invectiva contra el tirano. Este autor de poesías compuso también obras teatrales, tragedias, a las que se consideraba el prototipo de obra excelsa en el Neoclasicismo.

Se sabe que Juan Cruz Varela tuvo una gran formación cultural. Su padre era miembro de la burguesía bonaerense y gallego de origen, lo que en absoluto implica que su hijo defendiera la patria de su progenitor. Lo interesante, sin embargo, es señalar esa elevada educación y formación del poeta. Fue alumno de Victorio Acheaga en latín. De sus enseñanzas es producto la traducción que Varela hizo de algunos cantos de la Eneida (las dos primeros cantos) de Virgilio así como de algunas Odas de Horacio (I, XV y XXXIV del libro primero, y del libro tercero, las odas V y IX). Pero, no solo eso, el conocimiento de los versos de Virgilio lo impulsó para crear y readaptar en otro género literario como es el teatro, la leyenda de Dido y Eneas, aspirando a dotar a su patria, Argentina, de un producto cultural que sirviera de referente a los jóvenes y que iniciara el 
camino por donde, suponía, habrían de seguir las generaciones futuras.

Dido ${ }^{6}$ evoca y sigue muy de cerca el conocido episodio de la Eneida (Canto IV) donde Eneas acepta el destino que le imponen los dioses y se aleja del amor de la reina. La obra hispanoamericana supone una dramatización del conflicto poético virgiliano y cumple ejemplarmente con la preceptiva aristotélica; la unidad de acción, tiempo y lugar es observada con rigor. La acción transcurre en Cartago y a lo largo de tres actos vemos desarrollarse esa unidad de acción requerida por la poética neoclásica: los amores de Dido y Eneas en su etapa última, el dolor de ella, la renuncia de él y el trágico final de la reina. La obra está dedicada al Sr. D. Bernardino Rivadavia, ministro de Gobierno y de Relaciones Exteriores, cumpliendo con ello un protocolo común a muchos escritores neoclásicos, la de aspirar a ser protegidos por el poder. En su dedicatoria el autor destaca la función didáctica de su obra, guardando con ello también la preceptiva horaciana de enseñar. Así se expresa el autor:

Mi Dido seráfeliz si, en alguno de los ratos que dejen a V. S. libres sus vastas atenciones consiguen excitarle ese dulce placer que nace de saber sentirs. Por lo demás, yo quisiera que mi temeridad sirviera de estímulo a alguno de nuestros jóvenes privilegiados por la naturaleza, que ejercitarán sus talentos en el drama, y que algún día una musa argentina llegue a merecer que se diga de ella: SOLA SOPHOCLEO TUA CARMINA DIGNA COTHURNO.

Las palabras finales resumen muy bien la aspiración del autor, emular a Sófocles, al que considera el máximo exponente del teatro universal, hecho que también queda patente en Argia, donde siguiendo de cerca la obra de Alfieri, como bien puso ya de manifiesto Ricardo Rojas ${ }^{9}$, recrea un episodio de la historia de la saga tebana: Argia, viuda de Polinices reclama a Creonte los restos del muerto para darle sepultura, acompañada de Lisandro, su hijo. La ambiciosa aspiración de Juan Cruz Varela, crear una corriente ilustrada que consolidara su curso en el panorama cultural de la nueva Argentina, no halló la respuesta esperada. De ello ha dado fe Juan María Gutiérrez ${ }^{10}$, cuando dice: "La tragedia clásica nació y murió en las orillas argentinas con el señor don Juan Cruz Varela”.

Por esta singularidad de su figura merece el autor argentino un destacado interés. Tal interés se centra de manera especial en su Dido; la obra, que transcurre a través de amplios parlamentos versificados, no tiene la tensión propia del drama de Sófocles, ni su restricción y maestría expresivas, a pesar de la aspiración del autor; no obstante la obra de Varela se lee con agrado y nadie puede negarle la gran importancia de su empresa que no sólo es simplemente literaria sino también cultural, social e histórica. Es la labor de un hombre ilustrado que, emulando a los clásicos, de manera directa en el 
caso de Virgilio, indirecta, según se ha constatado ya, en el caso de los grandes trágicos griegos, Esquilo, Sófocles y Eurípides, compone esta Dido, además de las otras obras mencionadas. Las intervenciones de los personajes más bien parecen una alternada recitación lírica en endecasílabos que verdadero drama en acción y por ello se puede afirmar que en la trama de la historia Juan Cruz Varela se ha limitado a situar los hechos en otro momento de la leyenda pero que, en definitiva, la lectura de esta Dido sigue de cerca el texto virgiliano produciendo una ruptura en la intervenciones de los diversos personajes que hablan independientemente y no inmersos en el relato de una voz, la voz del poeta, es decir, cobrando vida autónoma, por lo tanto, convirtiendo la épica en drama. Comienza la obra de Varela con un diálogo entre los dos jefes troyanos Sergesto y Nesteo, quienes comentan la situación sin salida del amor entre Dido y Eneas y la disposición de las naves para partir. El autor argentino se sitúa precisamente en el punto final de la historia virgiliana:

SERGESTO
[...] Dido es hermosa, es reina; nuestras naves
en paz amiga recibió en sus puertos;
y desde aquella noche en que, pendiente
de los labios de Eneas, el suceso
oyó de Troya, y nuestros crudos males,
la flecha del amor hirió su pecho.
Todo es verdad; pero jamás podría
nuestro rey humillarse hasta el extremo
de olvidarse de sí mismo, porque Dido
no se acuerda de sí. Nunca, Nesteo,
me quise persuadir que el mismo Eneas
manchase así la historia de sus hechos.
En fin, ya tú lo ves: nuestros bajeles
las velas hoy ofrecerán al viento;

Comienza Virgilio"11 su canto IV de la inmortal Eneida, con el presentimiento por parte de la reina Dido del enorme poder y atractivo que ejerce sobre ella el extranjero recién llegado $^{12}$ :

Ahuyentada del cielo por la aurora

la húmeda sombra, el nuevo sol las tierras

empezaba a lustrar, cuando, transida, se abre a su hermana, que su afán comparte:

“Ay, Ana, hermana mía, horribles sueños

Sin consejo me tienen y aterrada!

¡qué distinto de todos este huésped

Que entró a nuestra mansión! ¡Qué aire tan noble, 
qué valor, qué figura tan gallarda!

Es en la escena segunda del drama de Juan Varela cuando interviene la reina dialogando con su hermana. Dido; expresa su desenfrenado amor por Eneas, haciendo una retrospectiva de su historia:

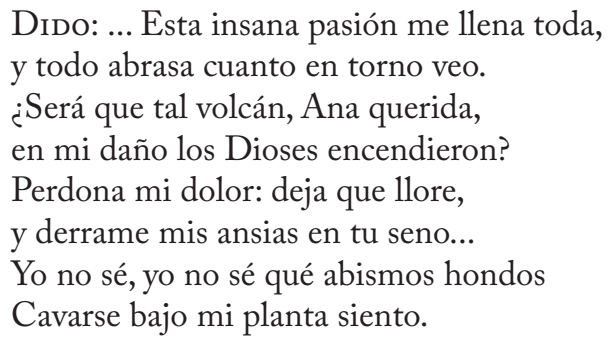

Varela ${ }^{13}$ construyó una obra que cumple en su estructuración y desarrollo con las recomendaciones que Aristóteles da en su Poética"14: "la función del poeta no es contar lo sucedido, sino lo que podría suceder y lo posible en virtud de la verosimilitud o de la necesidad” y “...la tragedia es la imitación de una acción acabada y completa que posee una cierta extensión: pues puede darse una cosa entera que carezca de extensión. Completo es lo que tiene principio, medio y fin". El autor argentino cumple muy bien con el precepto de la verosimilitud pues al leer sus versos se siente que la acción podría haber sucedido así y cumple con la disposición de principio, medio y fin al estructurar su obra en tres actos, no meramente yuxtapuestos sino en un progresivo descenso hasta el desenlace, que llega con la muerte de la reina y la partida hacia Italia del héroe troyano. En resumen, Dido ejemplifica el eco del mundo griego en su recorrido latino, desde el punto de vista de la temática, pues expone un episodio de un héroe de la guerra de Troya, Eneas, protagonista a su vez de la gran obra virgiliana y, al mismo tiempo, ejemplifica la adopción de la preceptiva clásica (Aristóteles, principalmente) en la estructuración de la misma.

\section{Segunda opción: romanticismo: teatro gauchesco}

La segunda perspectiva o línea trazada en el espacio escénico del siglo XIX rioplatense es la opción de lo más genuino: se trata del teatro gauchesco. Juan Alberto Godoy ${ }^{15}$, argentino, fue el iniciador del género. Hacia 1820 dio a conocer sus composiciones de tema y estilo populares, adoptando una posición tal vez polémica frente al castellano académico al recurrir precisamente al lenguaje criollo. Se suele afirmar que su mejor obra es Corro, diálogo de un gaucho sobre la batalla de Salta, pero el texto no llegó hasta nosotros. Se trataba de una reivindicación de presencias locales, legitimada por la reciente 
independencia y la consolidación de la nueva nacionalidad. Mayores fueron los ecos que despertó el uruguayo Bartolomé Hidalgo (1788-1822), considerado por muchos como el verdadero iniciador, con mucha más originalidad que Godoy, de una revalorización del ambiente rural rioplatense. La suya no es poesía popular sino de características populares elaborada artísticamente. En cualquier caso, estamos ante la revalorización de la parte menos tenida en cuenta por la literatura, de las cualidades positivas de la tierra y de sus habitantes, pasadas por alto durante tanto tiempo o negadas sin más. Puede entenderse como una tácita protesta contra la vida ciudadana y contra la civilización en su aspecto mecánico y así sucesivamente.

En las guerras de la Independencia hispanoamericana los gauchos habían representado en el sur del continente, sobre todo en la Argentina, una considerable ayuda; por consiguiente, su figura, que hasta ese momento había significado el símbolo del desorden de la rebelión, la expresión de la mala vida, quedó rehabilitada. En los "cielitos" y en "los diálogos" de Hidalgo la realidad política del momento está directamente vinculada a la sensibilidad del hombre de la pampa. Los grandes acontecimientos de la independencia se contemplan con evidente nostalgia, ante un presente sobre el que se ciernen violentas disputas civiles; nos referimos al periodo que va desde 1821 al 1822, en el que tantas esperanzas naufragaron.

Tras la estela de esta iniciativa poética y novelística, el teatro también se vio impregnado de esta tendencia, precisamente partiendo del relato en prosa Juan Moreira, personaje convertido en teatral pero en realidad procedente de la novela de Eduardo Gutiérrez (1880).

"Siguiendo, pues, la lógica de nuestro razonamiento, debemos decir que el teatro
nacional cuenta ya existencia entre nosotros, desde la primera noche en que
una producción nacional fue aceptada por una gran mayoría de público. Todos
conocen el hecho: la pantomima de Juan Moreira ha atraído tanta concurrencia
al circo Politeama, que la policía tiene que intervenir cuando se representa, para
impedir que se venda un mayor número de entradas del que pueda expenderse
sin peligro para la concurrencia ¿Cuándo ha sucedido semejante cosa en las
obras de teatro nacionales?"16 (C. Olivera, En la brecha, 1887).

Estamos, pues, ante otra alternativa de la configuración del teatro o a una reiniciación del hecho teatral. De la culta y regularizada obra neoclásica pasamos al libre e intuitivo drama de la pampa. Son estos en realidad dos polos entre los que se mueven otra serie de obras, de carácter menor, de rasgos costumbristas, cercana a los entremeses, pasos o sainetes. Estas piezas de extensión breve tienen su tradición en el teatro español y como herencia de los clásicos guardan también una coherencia estructural y un seguimiento normativo en su composición, más próximo a la comedia. Pero el auténtico teatro gauchesco es más libre o más 
romántico, si se quiere. Así, Juan Moreira ${ }^{17}$ aparece configurado como drama en dos actos. El escenario del Acto Primero en su Escena I representa un juzgado de paz; la escena II en cambio representa una pulpería donde aparecen varios gauchos jugando a los naipes y milongueando:

Gaucho I: Cante, Don Mariano, una milonga;

déjese de tanto estar acordiando

las pajas las lleva el viento

pues cantemos un momento,

déjense de barajar,

$\mathrm{y}$ formando la milonga

como buenos compañeros

y el que dispone primero

las copas ha de pagar.

La escena III representa la casa de Moreira. La cuarta el campo... Parece, por tanto, una obra de escenas yuxtapuestas cuya unidad temática es el personaje Juan Moreira, victima inocente de la justicia oficial, que muere al término de la obra; no hay progreso en la acción ni vacilaciones en el personaje: es valiente y nunca se planteará al modo del Áyax sofocleo que pueda haberse equivocado. Nada o casi nada tiene este teatro en común con el drama griego clásico, sí guarda en cambio mayor similitud con el mimo helenístico y con la fábula atelana; por ello tal vez Ricardo Rojas ${ }^{18}$ tenga algo de razón al decir en su Historia de la literatura argentina que "la influencia de la cultura griega en la civilización argentina contemporánea subsiste de modo tan evidente que, para demostrarlo, bastaría probar cómo en arte, en filosofía, en política, continuamos pensando sobre los arquetipos de aquella cultura... En el caso del arte dramático esto es notorio, desde el nombre teatro con que lo designamos, hasta las categorías estéticas que llamamos tragedia y comedia en la arquitectura global del género; orquestra y escena en la arquitectura material; diálogo y coro en las partes de la composición; coturno y máscara en las de su representación; todo ello, en Esquilo tan solemne, en Sófocles tan glorioso, en Aristófanes tan complejo, fue rudimentario en los iniciales cantos del hirco, anteriores a Tespis, cuando el teatro griego era solo una representación mimada y cantada de la alegría o de la fe populares.

En Grecia el germen folklórico se desenvolvió normalmente hasta llegar a su plenitud estética y el coro dionisiaco se convirtió en tragedia. Una vez creada esta, su arquetipo influyó sobre los pueblos sucesores; y el teatro formado en estos fue mera aclimatación de la especie griega como en Roma, o imitación literaria de aquella como en Francia, o combinación del trasplante clásico y de gérmenes populares en cada nueva región. Entre nosotros, debemos el teatro al pueblo, pero no a este actual, -europeizado él mismo-, sino al pueblo antiguo 
de nuestras campiñas, al pastor de las pampas, el gaucho, cuyo genio plasmó el cuerpo de la patria en sus guerras y el espíritu de la patria en su canto".

La pregunta que se plantea tras las eruditas palabras de Rojas es: ¿El arquetipo?creado por los griegos en sus orígenes teatrales influyó conscientemente en el autor/escritor de obras gauchescas? o, más bien, ¿Los autores argentinos y el público implicado en las representaciones, no identificándose con la tragedia neoclásica, alejada del pueblo y cercana a círculos restringidos de índole políticointelectual, dejaron atrás el pasado con el que no se identificaban y, apoyados por las circunstancias históricas (guerras de independencia) así como por los nuevos aires románticos, quisieron crear "un verdadero teatro nacional", que afianzara el elemento propiamente argentino sobre corrientes literarias foráneas? La segunda opción parece, a mi juicio la más certera, no ignorando, sin embargo, que esta mímesis dramática del gaucho en escena participa también de la mímesis aristotélica y no sólo del mimo helenístico; pero la mímesis es un concepto consustancial al teatro, de forma que todo teatro no puede escapar a la influencia helénica porque fueron los griegos los que tuvieron la grandeza de objetivar en sus téchnai el hecho mismo de la producción dramática, tal vez abstrayendo una de las cualidades propias del ser humano: la capacidad de imitar.

Al margen de esta consideración fundamental y básica, el protagonista de la pampa, el gaucho, difiere mucho en su caracterización de un personaje trágico por excelencia; su destino resulta trágico en verdad porque ha de sucumbir ante el gringo pero la complejidad de matices en su tratamiento literario está ausente por lo general del teatro argentino, su conducta es impulsiva y su tratamiento en la escena demasiado lineal: no tiene dudas, no piensa: Moreira sabe que morirá , no se plantea el porqué ni le asusta la perspectiva; desde la primera línea de la obra así está trazado; no hay, en suma, peripecia porque se describe un cuadro tras otro en una taxonomía primaria, a excepción hecha de Don Zoilo, gaucho protagonista de la obra de Florencio Sánchez, Barranca abajo.

No obstante, éste es el más argentino o rioplatense de los teatros porque vincula sus raíces a su gente y a su tierra. Él será el protagonista de otra serie de obras como Calandria de Martiniano Legizamón ${ }^{19}$ (1858-1935), autor de Rosario de Tala (Entre Ríos); estudió en el colegio de Concepción de Uruguay. Tres años más tarde se traslada a Buenos Aires. Ejerció el periodismo y fue catedrático de Literatura e Historia en institutos de enseñanza secundaria. Fue "cantor del terruño y de sus tradiciones". Toda su obra "está condicionada por un sentimiento preponderante que la ennoblece y le pone límites al mismo tiempo: el amor a la tierra natal, a la llamada "patria chica", amor que en este autor suele manifestarse en acentos polémicos para condenar el cosmopolitismo que, ya a fines del siglo XIX, amenazaba la pureza del acervo hispano-criollo"20. Tal es el juicio de Martín Alberto Noel, autor de El regionalismo de Martiniano Leguizamón. El carácter de "égloga" que posee esta obra de teatro ha sido puesto 
de relieve por Julia Grifón quien titula su estudio Martiniano Leguizamón y su égloga "Calandria" 1

Calandria (1896), en efecto, tiene mucho de égloga; la misma dedicatoria del autor así lo deja entrever: "A la memoria de mi padre, el coronel Martiniano Leguizamón, que me enseñó a conocer el alma noble y sencilla de nuestros gauchos"22. El protagonista principal es el gaucho matrero Calandria; intervienen también, como si de un coro especial se tratara, otros gauchos, guitarreros, cantores, estudiantes uruguayos... ; la acción se configura como "costumbres campestres en diez escenas". El lenguaje resulta, en ocasiones, ininteligible, porque el ethos de los personajes está muy bien caracterizado y hablan con sus regionalismos y particularismos y algún salpicado cultismo, como cuando en la escena de "El bailecito" dice Lucía: “¿Y si me pierdo?... mira que no soy muy baquiana”. En la obra aparecen entremezclados diálogos y cantos de los gauchos:

\author{
A mi me llaman Calandria \\ porque burlo los pesares \\ cantando alegres cantares \\ en la rueda del fogón \\ porque cruso los senderos \\ sin temor a la partida \\ porque alegro mi guarida \\ bordoniando un pericón.
}

La tradición bucólica grecolatina de Teócrito y Virgilio puede ser referida aquí, incluso de manera consciente tal vez, dado que Leguizamón pertenecía al mundo de la cultura ${ }^{23}$ y los personajes de Calandria se puede decir que están artísticamente diseñados: su ruralismo es obra del arte, no de la pluma más espontánea del autor de Juan Moreira.

"Un lazo de unión de lo cómico español y su técnica teatral con lo genuinamente criollo" ${ }^{24}$ es la obra del bonaerense Nemesio Trejo (1862-1916). Definición que también comparten otros autores como Luis Ordaz ${ }^{25}$ "Se advierte la directa influencia del género chico hispano, sobre todo en los coros y duetos típicos, pero la temática de la pieza, sus personajes y su lenguaje poseen ya un sentido propio, característico, es decir, nacional. Interesa particularmente esta obra (Los politicos) porque en ella se descubre (a pesar de toda influencia) el temperamento dramático de los creadores de nuestro sainete”.

En efecto, la obra Los políticos es un sainete cómico-lírico en un acto y tres cuadros, en prosa y en verso; recuerda en el tratamiento de los personajes a las comedias de Menandro.

Finalmente citaré a otro autor destacado en la producción dramática del río de la Plata, Florencio Sánchez, y, dentro de la producción de este destacado 
autor, me referiré a su obra Barranca abajo, que puede ser definida como una tragedia rural. En realidad la obra se estrenó en 1905 pero la hemos integrado en este repertorio porque su autor vivió la mayor parte de su vida durante el siglo XIX (1875-1910) por lo que la obra puede ser considerada como producto de un autor decimonónico. Florencio Sánchez nació en Montevideo, cursó en Minas los grados de la escuela primaria, única enseñanza sistemática que recibió. De 1892 datan sus primeros intentos de escribir para el teatro; a mediados de año llega a Buenos Aires y consigue trabajo en la Plata. Dos años después ejerce el periodismo en Montevideo. Durante el 1900 reside en Buenos Aires.

El protagonista principal de Barranca abajo es D. Zoilo, un viejo gaucho arruinado, como declara el propio protagonista en la escena XXI del primer acto:

“... Usté sabe que esta casa y este campo fueron míos;

que los heredé de mi padre, y que habían sido de mis agüelos... ¿no? Que todas las vaquitas y ovejitas existentes en el campo, el pan de mis hijos, los crié yo a juerza de trabajo y de sudores, ¿no es eso? Bien saben todos que, con mi familia, fue creciendo mi haber, a pesar de que la mala suerte, como la sombra del árbol, siempre me acompañó. (pág.138)

Esta obra es una tragedia que guarda la unidad de acción en torno al personaje principal y expone su progresiva decadencia y soledad; con Zoilo mueren también los valores del mundo rural. Aunque Florencio Sánchez no fue un autor de gran cultura, según destaca la crítica sí leyó a Nietszche, por ejemplo; tuvo una intuición clara del hecho teatral y cuando uno lee Barranca abajo le viene a la memoria algún héroe de la tragedia griega: existe una cierta consonancia de tono y comparte también con muchas obras clásicas la denominación de los personajes por la cualidad que representan o de la que carecen, en antítesis a sus valores. Así, Robustiana es tratada por su familia como un animal, se encarga de todas las labores del hogar y de los caprichos de su madre y hermana, sin embargo, traicionando su propia identidad, es la única de ellas que muere, convirtiéndose en la más débil. Dolores se llama la afligida madre que llena el escenario con sus continuas quejas de "enferma". D. Zoilo es D. Solo, su nombre preanuncia su propia tragedia, pues pierde al único ser verdaderamente querido, Robustiana; es el último gaucho y se encamina "solo" a su muerte por él mismo procurada. El Áyax de Sófocles también expresa la coincidencia de su nombre con los propios males: ¡Ay, Ay! quién bubiera creido que mi nombre iba a coincidir tan sonoramente con mis males. Florencio Sánchez utiliza, por tanto, un recurso muy usado por Sófocles y le confiere al protagonista de su obra es aire de trágico presagio. Dice D. Zoilo: 
... Agarran a un hombre, sano, güeno, honrao, trabajador servicial, lo despojan de todo lo que tiene, de sus bienes amontonaos a juerza de sudor, del cariño de su familia, que es su mejor consuelo, de su honra... jcanejo!... y cuando ese desgraciao, cuando ese viejo Zoilo cansao, deshecho, inuitil pa todo, sin una esperanza, loco de vergüenza y de sufrimientos resuelve acabar de una vez con tanta inmundicia de vida, todos corren a atajarlo. ¡No se mate, que la vida es güena!'̇üena paqué?

¿Qué conclusión extraemos de este apresurado recorrido? Es evidente y destacada la presencia del mundo grecolatino, aunque no frecuente, en algunas obras del teatro neoclásico del Río de la Plata; el tema de Dido proviene por completo de Roma y Grecia, el autor no intenta actualizarlo pero nos lo presenta recreando el episodio del final de los amores de Dido y Eneas, siguiendo el criterio de verosimilitud aristotélica: las palabras que se dicen dramáticamente estos personajes pudieron muy bien ser dichas; por otra parte, la obra se ajusta a los cánones neoclásicos, al fin y al cabo clásicos, de mantenimiento de la unidad de acción, tiempo y lugar. Pero, otras corrientes literarias vinieron a llenar el agitado mundo decimonónico: el Romanticismo y la propia historia de Argentina y Uruguay auparon como héroe de los teatros al gaucho de la pampa, quien en algunas obras, Calandria, por ejemplo, es presentado en todo su esplendor y fuerza vital para aparecer en otras como hombre despojado de su antigua grandeza; así D. Zoilo, de Barranca Abajo, representa su ocaso y postrer declive. En algunas de estas obras existen consonancias con el mundo de la tragedia griega, a nivel de destino del héroe, de peripecia dramática, pero no una consciente imitación de los clásicos.

Hay en todo al panorama cultural del teatro rioplatense otro mundo aludido, el de la sátira, el de la risa, el del entretenimiento, el de la comedia en suma; encontramos ejemplos de este otro ámbito teatral en Los políticos, de Nemesio Trejo, cuyo tono y tratamiento de los personajes se acercan al teatro de Moratín o a los sainetes de D. Ramón de la Cruz. Se guardan en este género algunas pautas de composición enseñadas por la poética neoclásica. A veces se observan ecos de la comedia de Menandro o Terencio. 


\section{Bibliografía}

\section{I.-GENÉRICA}

-BELLINI, G., Nueva historia de la literatura hispanoamericana, Madrid, Castalia, 1997.

-BERENGUER CARISOMO, A., Las ideas estéticas en el teatro argentino, Buenos Aires, Instituto Nacional de Estudios de Teatro, 1947.

-CASTAGNINO, R. H., Esquema de la literatura dramática argentina, 1717/ 1949, Buenos Aires, Instituto de Historia del Teatro Americano, 1950.

- Teatro argentino premoreirista, 1860-1884, Buenos Aires, Plus Ultra (Colección clásicos hispanoamericanos, 18), 1969 (2a edición).

-Revalorización del género chico criollo, Buenos Aires, Universidad de Buenos Aires (serie Cuadernos), 1977.

-CRUZ, J., Teatro romántico argentino, Buenos Aires, Ediciones Culturales Argentinas, 1972.

-FOSTER, D. W., The Argentine Generation of 1880. Ideology and Cultural Texts, Columbia, University of Missouri Press, 1990.

-GÁLVEZ ACERO, M., El teatro hispanoamericano, Madrid, Taurus, 1988.

-GOIC, C., Historia y crítica de la literatura hispanoamericana. Vol. 2: Del romanticismo al modernismo, Barcelona, Crítica, 1990.

-GONZÁLEZ, B. et al. (Compiladores), Esplendores y miserias del siglo XIX. Cultura y Sociedad en la América Latina, Caracas, Monte Ávila Editores, Editorial de la Universidad Simón Bolivar, 1994.

-MAGGI, C., MARTÍNEZ MORENO, C. y REAL DE AZÚA, C., eds. Historia de la literatura uruguaya, 3 vols., Montevideo, CEAL, 1971.

-OVIEDO, J. M., Historia de la literatura hispanoamericana, Madrid, Alianza Editorial, 2003.

-ORDAZ, L., El teatro en el Rio de la Plata, desde sus orígenes hasta nuestros días, Buenos Aires, Leviatán, 1957 (2a edición).

-El teatro argentino, Buenos Aires, CEAL, 1972.

-RELA, W., Historia del teatro uruguayo, 1808-1968, Montevideo, Ediciones de la Banda Oriental, 1969.

-ROJAS, R., Historia de la literatura argentina, $4^{\mathrm{a}}$ ed., 9 vols., Buenos Aires, Kraft, 1957.

-SUÁREZ RADILLO, C. M., El teatro neoclásico y costumbrista bispanoamericano, Madrid, Cultura Hispánica, ICI, 1984, 2 vols. 


\section{II.-TEXTOS}

-CRUZ VARELA, J., Poesías y las tragedias de Dido y Argia, Buenos Aires, Imprenta de la Tribuna, 1879.

-LAFFORGUE, J., TEATRO RIOPLATENSE (1886-1930) (Selección de obras de E. Gutiérrez, M. Leguizamón, N. Trejo, F. Sánchez, C. M. Pacheco, G. de Laferrère, E. Herrera, A. Vacarezza, J. Sánchez Gardel, A. Discépolo y F. Defilippis Novoa, con prólogo de David Viñas), Caracas, Biblioteca Ayacucho, 1977.

-EDICIÓN DIGITAL de la obra Dido, de Juan Cruz Varela a partir de Teatro Hispanoamericano, Tomo II, S. XIX, Nueva York, Anaya Book, 1973, pp. 14-69, http://www.cervantesvirtual.com.

\section{III.- OBRAS CRÍTICAS SOBRE LOS PRINCIPALES AUTORES CONSIDERADOS}

1.-Sobre Juan Cruz Varela:

-BERENGUER CARISOMO, A., Juan Cruz Varela y el Neoclasicismo, Buenos Aires, Instituto Nacional de Estudios de Teatro-Cuadernos de Cultura Teatral, 1940.

-GARELLI, M., "La tragedia Dido de Juan Cruz Varela (su relación de intertextualidad con el canto IV de la Eneida), en Praesentia, Revista venezolana de Estudios Clásicos, Mérida I, 1, 1996.

-BARSOTTI, R., Una tragedia inédita de Juan Cruz Varela, Buenos Aires, E1 Ateneo, 1954.

-GUTIÉRREZ, J. M., "Estudio sobre las obras y la persona del literato y publicista argentino don Juan Cruz Varela”, en Revista del Rio de la Plata, 1871, tomo I.

-PAGÉS, G.H., "Virgilio en las letras argentinas", en Boletin de la Academia Argentina de las Letras, Buenos Aires, tomo XXVI, n. 99 enero-marzo y n. 100 abril-junio, 1967.

-VILANOVA, A., "Las heroínas del drama clásico grecolatino en el teatro iberoamericano: algunas observaciones sobre la tragedia de Argia de Juan Cruz Varela”, en I Encuentro de Investigadores de Literatura Venezolana y Latinoamericana, Instituto de Investigaciones Literarias "Gonzalo Picón Febres”.Accesible desde Internet: Heroínas. HTM.

2.-Sobre Martiniano Leguizamón

-GRIFONE, J., Matiniano Leguizamón y su égloga"Calandria", Buenos Aires, Instituto de Literatura Argentina, 1940. 
-NOEL, M. A., El regionalismo de Martiniano Leguizamón, Buenos Aires, Penser, 1945.

3.-Sobre Florencio Sánchez

-COSTA, R., "The Dramaturgy of Florencio Sánchez: An Analysis of Barranca abajo", Latin American Theatre Review, 7, 2 (1974), pp. 25-37.

-CRUZ, J., Genio y figura de Florencio Sánchez, Buenos Aires, EUDEBA, 1966.

-FREIRE, T. J., Ubicación de Florencio Sánchez en la literatura teatral, Montevideo, Comisión de teatros Municipales, 1961.

\section{IV.- FUENTES CLÁSICAS}

-ARISTÓTELES, Poética. Prólogo, Traducción y Notas de Antonio López Eire. Madrid, Istmo, 2002.

- VIRGILIO, Eneida. Traducción de Eugenio Ochoa. Barcelona, Círculo de Lectores, 1999.

-VIRGILIO, Eneida, en Publio Virgilio Marón: Obras Completas. Traducción de Aurelio Espinosa Pólit, Madrid, Cátedra, 2003. 
${ }^{1}$ El germen de este trabajo está en la ponencia, de diferente título y contenido no coincidente en su totalidad: "Ecos de la escena griega en el, teatro rioplatense" presentada al XVII COLOQUIO INTERNACIONAL DE FILOLOGÍA GRIEGA (Madrid, 1, 2, 3 de marzo de 2006): LA TRADICIÓN CLÁSICA EN LA LITERATURA ESPAÑNOLA E HISPANOAMERICANA DEL SIGLO XIX, organizado en el Área de Filología griega de la UNED bajo la dirección del catedrático J. Antonio López Férez, a quien corresponde en realidad la propuesta inicial del tema.

${ }^{2}$ Le dedico a la que fue mi compañera María Luisa Picklesimer Pardo estas reflexiones sobre la presencia del mundo grecolatino en el teatro rioplatense. También a sus brillantes aguas llegaron los ecos dramáticos de griegos y romanos. Al analizar algunos de los dramas, me ha venido a la memoria tu imagen y tus investigaciones; no una sola vez sino muchas, te oí hablar de Dido y Eneas; ahora yo, como un eco de la memoria, te contesto aquí en un diálogo que podría haber sido eterno.

${ }^{3}$ Vid. Cedomil Goic, Historia y crítica de la literatura hispanoamericana. Vol. 2: Del romanticismo al modernismo, Barcelona, Crítica, 1990. Vol. II, p. 29.

${ }^{4}$ A veces, no hay que dudarlo, esta cultura europea es sentida como auténtica tiranía por algunos. Léanse las palabras de Ricardo Rojas (Vid. Historia de la literatura argentina, "E1 clasicismo de Juan Valera", Vol. IV Buenos Aires, Kraft, 1957, p. 642): "El caso de Varela es concluyente, porque es representativo de toda esta última generación colonial. Capaz de sacudir como ciudadano el yugo politico, no era capaz de sacudir el yugo literario. No es que no lo pudiera; es que no lo sabia. Sólo a la generación siguiente, seríale dado denunciar esta segunda y más honda subordinación colonial." 208.

${ }^{5}$ Vid. G. Bellini, Nueva historia de la literatura hispanoamericana, Madrid, Castalia, 1997, p.

${ }^{6}$ Esta obra data del 1823 y con ella Juan Cruz Varela pretende no sólo dejar constancia de su cultura y conocimientos de la cultura clásica, en especial de Virgilio, sino también de servir a un propósito más ambicioso como es el de construir un referente de calidad para reconducir la producción literaria de su tierra e insertarla en un propósito literario ambicioso que corre paralelo al propósito puramente político de encumbramiento y glorificación de una nueva entidad nacional. Por ello, dice al comienzo de la dedicatoria: "En una época en que todo marcha en nuestro país rápidamente hacia la perfección, cada individuo particular se siente arrebatado del movimiento comun, y sus ideas insensiblemente se elevan Mi pobre musa también ha sido envuelta en esta revolución general". Vid. Juan Cruz Varela, Tragedias, Buenos Aires, Biblioteca Argentina, 1915.

${ }^{7}$ A. Vilanova, en una afirmación en el curso de su trabajo, nos revela el conocimiento de Virgilio por parte de Juan Cruz: "En honor a la verdad, y con sincera pena, tengo que confesar que hasta no hace mucho tiempo, Juan Cruz Varela habia sido sólo uno de los varios y en apariencia intrascendentes versificadores neoclásicos, a quienes uno leía casi exclusivamente por obligación, incluso pese a sus estrechas conexiones con Virgilio, tan cuidadosamente estudiadas por Gerardo Pagés." Más adelante, A. Vilanova expresa de manera más concreta la posible formación clásica de Juan Cruz Varela y dice: "No he encontrado testimonios que prueben, especificamente en el caso de Varela que es el que importa ahora, lecturas de los textos de Esquilo, Sófocles y Eurípides. Así como demuestra conocer muy bien a los más grandes poetas latinos, Virgilio, en particular (pero también Horacio y Lucrecia, cuya Eneida traduce en parte (lo que le ganó el elogio de Menéndez y Pelayo y Maria Rosa Lida) y escribe una tragedia, Dido, transdramatizando el libro IV, su relación con la tradición clásica griega, en cambio, reconoce la mediación de diversos autores, especialmente, sobre todo por lo que se refiere a Argia, de Vittorio Alfieri, el poeta y dramaturgo italiano (1749-1803), varias de cuyas tragedias vuelven sobre algunos clásicos temas griegos, sin que no obstante tampoco pueda comprobarse sin dudas entre autor y temas una relación más directa que mediada". Vid. A. Vilanova, "Las heroínas del drama clásico grecolatino en el teatro iberoamericano: algunas observaciones sobre la tragedia de Argia de Juan Cruz Varela”, en I Encuentro de Investigadores de Literatura Venezolana y Latinoamericana, Instituto de Investigaciones Literarias "Gonzalo Picón Febres". Accesible desde Internet: Heroínas. HTM, pp. 1 y 5. 
${ }^{8}$ Enuncia Juan Cruz Varela cuáles son los propósitos de su obra desde el punto de vista del oyente, respetando con ello las "leyes" aristotélicas de la teoría retórica, pues el filósofo griego establece sus genera discursivos teniendo en cuenta al receptor de los mismos como principal punto de articulación. Varela, ante todo, aspira a que su obra cause placer. Pero, añade otra aspiración más: docere, instruir a los jóvenes de su país. Delectare y docere, principios enraizados en las más clásicas de las retóricas cumplen aquí también su debida misión.

9 "En esa mina tantas veces explotada por los dramaturgos del clasicismo oficial, se contaba Alfieri con su Polinice y su Antigona. Estas dos tragedias italianas, especialmente la última, fueron las que inspiraron a Varela. Como se ve, nuestro dramaturgo osaba lanzar su navecilla por los mares solemnes de la antigüedad, pero la entregaba a expertos pilotos. No se lo reprochamos, porque tal era el avisado procedimiento de casi todos los "clásicos" de aquella época". Vid. Ricardo Rojas, Historia de la literatura argentina, cap. "El clasicismo de Juan Varela", Buenos Aires, Guillermo Kraft Limitada, 1957.

${ }^{10}$ Vid.J.M. Gutiérrez, "Estudio sobre las obras y la persona del literato y publicista argentino don Juan Cruz Varela", en Revista del Rio de la Plata, 1871, tomo I, p. 250.

${ }_{11}$ Así describe Virgilio las inquietudes, la admiración y preocupación de Dido ante la figura de Eneas: Posterea Phoebea Lustrabat lampade terras/umentemque Aurora polo dimouerat umbram/, cum sic unanimam adloquitur male sana sororem:/"Anna sopor, quae me suspensam insomnia terrent!' Quis nouns hic nostris successit sedibus hospes, /quem sese ore ferens, quam forti pectore et armis!

${ }^{12}$ Cito la traducción en verso llevada a cabo por Aurelio Espinosa Pólit. Vid. Publio Virgilio Marón. Obras Completas. Traducción de Bucólicas, Geórgicas y Eneida: Aurelio Espinosa Pólit, Madrid, Cátedra, 2003.

${ }^{13}$ Merecería, no cabe duda, la Dido de Varela un estudio más detenido, exhaustivo y pormenorizado que se centrara únicamente sobre este texto y su referente latino, donde podrían analizarse, por ejemplo, la caracterización y el papel desempeñado por los dioses/ Dioses . No lo descarto; sin embargo, determinados dioses/Dioses me imponen otro ritmo.

${ }^{14}$ Aristóteles, Poética, VII, 1451a y VII, 1450b.

${ }^{15}$ Vid. G. Bellini, Op. Cit., p. 208-209.

${ }^{16}$ Esta palabras aparecen como cita que antecede al capítulo "Juan Moreira" de David Viñas en el apartado IV.1 de su Prólogo a la obra Teatro Rioplatense (1886-1930), cuidada y muy útil selección y cronología llevada a cabo por Jorge Lafforgue, Caracas, Biblioteca Ayacucho, 1977, p. XXIII.

${ }^{17}$ Jorge Lafforgue (Teatro Rio..., Op. Cit.), en su nota preliminar a la obra de Juan Moreira, transmite la siguiente información: "A partir de su novela Juan Moreira [Eduardo Gutierrez] realizó por expreso pedido una pantomima en 1884, a la cual José J. Podestá le dio la forma dialogada en 1886, pero incluso ese texto "es apenas un esquema primario de lo que llegó a ser, luego de incesantes modificaciones y agregados" (A.Rama)... Acerca de la adaptación teatral de Juan Moreira, léase el ensayo de Ángel Rama: "Sobre la creación de un teatro nacional", en Los gauchipoliticos rioplatenses. Literatura y sociedad, Buenos Aires, Calicanto, 1976. El manuscrito del drama, donado por J.J. Podestá, fue publicado en 1935 por el Instituto de Literatura Argentina de la Universidad de Buenos Aires con noticia de Carlos Vega, en Orígenes del teatro nacional, Sección Documentos, Tomo VI, $N^{o}$ 1, págs. 1-58"

${ }^{18} \mathrm{Vid}$. Ricardo Rojas, Op. Cit., pág. 609.

${ }^{19}$ La obra de Martiniano Leguizamón, Calandria, aparece en la selección de teatro rioplatense realizada por Lafforgue para la editorial Ayacucho, Op. Cit., pp.23-59.

${ }^{20}$ Así escribe Martín Alberto Noel en su obra El regionalismo de Martiniano Leguizamón, Buenos Aires, Peuser, 1945. Estas palabras de Lafforgue están recogidas en la nota preliminar al texto de la obra Calandria, incluida en la selección de teatro para la editorial Ayacucho mencionada anteriormente.

${ }^{21}$ Julia Grifón, Martiniano Leguizamón y su égloga "Calandria", Buenos Aires, Instituto de Literatura Argentina, 1940.

${ }^{22}$ Estas palabras están recogidas de la selección de Lafforgue, Op. Cit. , p. 23.

${ }^{23}$ Cito algunas referencias sobre la vida y formación de este autor: "Nace en Rosario del Tala, villa de Entre Ríos, y muchos de su infancia y adolescencia transcurren en una estancia paterna de Gualeguay, al tiempo que estudia en una escuela rural y luego en el colegio de Concepción de 
Uruguay. En 1877 escribe para un grupo actoral improvisado, que integran algunos estudiantes, Los apuros del sábado, cuyos originales se han perdido. Tres años más tarde se traslada a Buenos Aires para cursar la carrera de abogado en la Facultad de Derecho, hasta graduarse. En esta ciudad se radica y de ella sólo se alejará en breves temporadas. El ejercicio del periodismo, la cátedra de literatura e historia en institutos de enseñanza secundaria y ocasionales puestos de funcionario público, a la par que su tarea de escritor e investigador del pasado argentino, conforman la trama de sus muchos años de actividad. En la finca de La Morita (González Catán, Provincia de Buenos Aires), cuyo paisaje pampeano era grato al espíritu de Martiniano Leguizamón transcurren los últimos años de este cantor del terruño y de sus tradiciones. Allí le sorprenderá la muerte.”Vid.J. Lafforgue, Op. Cit., p. 21.

${ }^{24}$ Según recoge J. Lafforge (Op. Cit., p. 61), esta opinión pertenece a Mariano G. Bosch.

${ }^{25}$ Vid. J. Lafforgue, Op. Cit.p. 61. 


\section{Sílabas LARGAS POR BREVES Y BREVES POR LARGAS: LOS NOMBRES PROPIOS ${ }^{1}$}

0. En el hexámetro, sobre todo, pero también en otro tipo de versos cuantitativos, latinos y griegos, se constatan a veces vacilaciones en la cantidad de ciertas sílabas; de ellas se hacían eco en buena medida los artígrafos ${ }^{2}$, tanto griegos como latinos, por ejemplo, en sus exposiciones sobre los "accidentes" ( $\pi \alpha \dot{\theta} \theta \eta)$ del hexámetro ${ }^{3}$ o sobre determinados vicios o licencias (barbarismos o metaplasmos) ${ }^{4}$ o cuando desarrollaban la doctrina de las "sílabas comunes"s. Se trata de vacilaciones o alteraciones que en general se achacan a la presión del metro y se interpretan muchas veces como "licencias" que se permitían los versificadores para encajar ciertas palabras en el esquema de un verso determinado:

Serv., Aen. I 343 quotiens poeta aspera invenit nomina vel in metro non stantia, aut mutat ea aut de his aliquid mutat.

En el De ultimis syllabis incluía, por ejemplo, el pseudo Probo entre los metaplasmos la ectasis y la systole, que definía en estos términos:

Ps. Prob., ult. syll. 263,17 Ectasis est cum per licentiam brevis producitur. ut exercet Diana choros (Verg., Aen. I 499). Systole est e contrario quando syllaba longa corripitur, ut aquosus Orion (Verg., Aen. IV 52): cum prima produci debeat, corripitur.

Justo en el apartado anterior, inmediatamente después de haber hablado de las syllabae communes, había pasado revista a una larga serie de casos de abreviación y alargamiento de sílabas (De productione et correptione syllabarum) por necesidades del metro (metri necessitas):

259,4 sunt aliquae sllabae apud Vergilium, quae necessitate metrica cum vitio barbarismi, qui apud poetas metaplasmus appellatur, contra rationem corripiuntur. sunt aliquae, quae, cum breves sint, necessario producuntur.

Se trata, a juicio del artígrafo, de libertades por imperativos métricos que a una autoridad como Virgilio se le pueden consentir, dada su talla como poeta o la envergadura de su obra; pero en la habitual práctica versificatoria lo suyo es evitarlas: 
259,27 ideo haec intellegenda esse arbitror, ut caveri possint. Vergilius enim propter operis magnitudinem et auctoritatem sui, qua multum valet, non sine necessitate metrica naturam syllabarum convertit diverso genere.

Así, pues, la cantidad vocálica o silábica, que se hace patente de manera especial (de manera exclusiva para nosotros y para los propios hablantes latinos a partir de determinada época) en los esquemas métricos de los versos, resulta a veces transgredida, y nada menos que en el hexámetro dactílico, que en nuestro caso es la principal fuente de que disponemos para reconocer dicha cantidad, sobre todo, cuando se trata de sílabas abiertas ${ }^{6}$.

Queda a veces la impresión de que la "forma métrica" de los versos tuviera la capacidad de abreviar o de alargar determinadas vocales o sílabas. Esto, propiamente hablando, no es lo que ocurría - no podía ocurrir- en la lengua latina; aun así, los artígrafos parecen entenderlo así, cuando hablan de alargamientos o abreviaciones de vocales metri causa, contra lo vigente en el sistema prosódico. Véanse al respecto, por ejemplo, estas frases de Quintiliano:

Plus exigunt subtilitatis quae accidunt in dicendo vitia, quia exempla eorum tradi scripto non possunt, nisi cum in versus inciderunt ... Praeterea quae fiunt spatio, sive cum syllaba correpta producitur, ut

'Italiam fato profugus' (Verg., Aen. I 2),

seu longa corripitur, <ut>

'unius ob noxam et furias' (Verg., Aen. I 41),

extra carmen non deprehendas, sed nec in carmine vitia dicenda sunt ${ }^{7}$.

E1 rétor, por cierto, no termina de decidirse por reconocer en tales casos una auténtica falta (vitium, barbarismus) contra el sistema lingüístico; tal vez por entenderlos más bien como licencias poéticas (metaplasmi). En cualquier caso, falta o licencia, era algo que chocaba fuertemente al oído de cualquiera, aunque no fuera un experto en música o en métrica; así lo había afirmado enfáticamente en dos ocasiones su modelo, Cicerón ${ }^{8}$.

Y era, sobre todo, en el verso donde se notaba tal peculiaridad; fuera de él no resultaba fácil de captar (extra carmen non deprehendas). Lo cual en modo alguno quiere decir que fuera del verso no se percibiera la cantidad vocálica o silábica; cualquier hablante con la normal competencia lingüística la percibía en el seno de cualquier palabra o frase; ¿cómo no, si era algo pertinente en el sistema de su lengua?

Por tanto, de lo que habla Quintiliano no es de que se alterara la cantidad de dichas sílabas, sino de que dicha cantidad chocaba con el esquema métrico, rompía la expectación de la "forma" métrica, que, en cuanto que componente del sistema versificatorio, también conocía cualquier latino-hablante. 
No se trata, pues, de "alargamientos" o "abreviaciones" sino de empleos anómalos de determinadas sílabas breves o largas, es decir, de la presencia de sílabas breves o largas en lugares indebidos según el esquema métrico. Dichas sílabas "alargadas" o "abreviadas" funcionaban en el verso, de manera más o menos ocasional, según los casos, como "largas" o como "breves". Lo cual ni suponía una irregularidad en la "forma" métrica ni, por supuesto, una vacilación en el sistema prosódico de la lengua; dicho sistema quedaba incólume, como incólume quedaba asimismo la "forma" métrica: en todo caso, era sencillamente una transgresión ocasional, impuesta por dicha "forma" métrica y fomentada por una "norma" versificatoria que hundía sus raíces nada menos que en Homero. Propiamente se trataba sólo de un vicio o una licencia en el nivel de la "composición" -según denota el pasaje de Quintiliano- o en el de la "ejecución" -a donde apuntan los pasajes de Cicerón a los que me he referido- ${ }^{9}$.

Voy a atender aquí a este fenómeno, reduciéndome al campo de los nombres propios, que, sin ser el único en que se da, parece haberse mostrado especialmente propicio para ello. Me ha parecido oportuno como tema de mi aportación a este recuerdo y homenaje a nuestra querida amiga y compañera, $\mathrm{M}^{\mathrm{a}}$ Luisa Picklesimer; con ella, a propósito de la que fue una de sus principales parcelas de estudio, tuve ocasión de comentar muchas de estas curiosidades y anomalías.

1. Muchas veces, como vamos a ir viendo enseguida, las vacilaciones a que me refiero aparecen en extranjerismos y, ante todo, en nombres propios griegos. En efecto, el alargamiento de una vocal para dar cabida en el esquema del hexámetro a determinadas palabras, especialmente nombres propios, era frecuente ya en el hexámetro homérico, sobre todo en los tiempos marcados

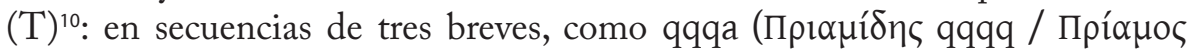

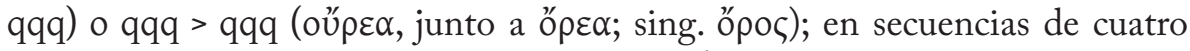

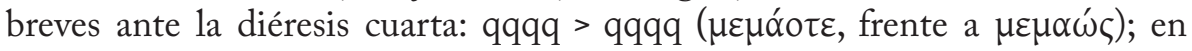
secuencias antispásticas al final del verso: qqq > qqq ('A $\pi$ $\lambda \lambda \omega \nu$ o frente a

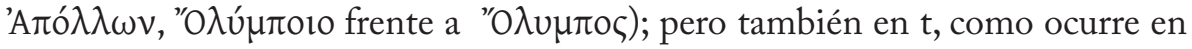
las secuencias créticas qqq > qqq ${ }^{11}$.

La lengua poética latina, en cambio, nunca parece haber aplicado de manera habitual este recurso del "alargamiento métrico"; Ennio, por ejemplo, que tanto debe a Homero, no se puede decir que siguiera en esto de cerca sus huellas: así, por ejemplo, ante el problema que al escribir en hexámetros entrañaba una palabra como capitibus (qqqq) no optó por un alargamiento del tipo qqqq, sino por ubicarla en la cabecera del hexámetro con resolución del primer T:

Ann. 490 Vahlen Capitibus nutantis pinos rectosque cupressos. 
Se diría que prefirió una anomalía en la forma métrica a una irregularidad prosódica. Y en el mismo sentido apunta la evidente tendencia a evitar todas aquellas formas que no encajaban en el esquema del hexámetro, sustituyéndolas por otras o por algún tipo de variante de estructura prosódica apropiada. Se recurría así, por ejemplo, a las posibilidades que ofrecían la "abreviación por énclisis"12, la "abreviación yámbica"13 o la eliminación de la $-s$ en la pronunciación ${ }^{14}$; se echaba mano asimismo de una serie de recursos de tipo fónico-prosódico ${ }^{15}$, sintáctico ${ }^{16}$ o léxico-morfológico ${ }^{17}$, que ya desde Ennio fueron contribuyendo a fijar una especie de "lengua especial o técnica" de la poesía ${ }^{18}$.

Con todo, no faltan, como he dicho, las vacilaciones y, en consecuencia, aparecen a veces medidas como largas sílabas que normalmente se miden breves o viceversa.

2. "Alargamiento de breves". La utilización como largas de sílabas que habitualmente son medidas breves se observa también en otro tipo de palabras, pero es, como digo, sobre todo, en nombres propios ${ }^{19}$ donde se la suele encontrar

El alargamiento de breves en nombres propios lo limitan los latinos, en principio, a formas en que sus predecesores helenos ya lo habían practicado. En casi todos los casos se trata palabras de cuatro sílabas, cuyas tres primeras, breves, pasan a qww en virtud del alargamiento de la inicial:

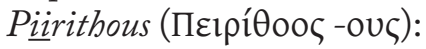

Verg., Aen. VI 393 accepisse lacu, nec Thesea Pirithoumque; 601 quid memorem Lapithas, Ixiona Pirithoumque?

Hor. ca. III 4,80 $<\mathrm{ALC} 10 \mathrm{~s}^{20}>$ Perithoum cobibent catenae;

Ov. met. VIII 303 et cum Pirithoo, felix concordia, Theseus; 403 Pirithous valida quatiens venabula dextra; XII 218 coniuge Pirithoum, quod paenefefellimus omen; 229 Pirithoum violesque duos ignarus in uno ${ }^{21}$;

aunque en este caso más que de un alargamiento de lo que se trata es de la

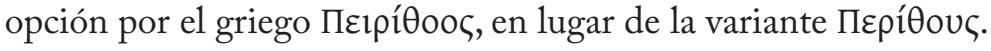

Priiamides [qwwq], frente a Priamus [wwu] o Priameia [wwqww]:

Virg., Aen. III 295 Priamidem Helenum Graias regnare per urbis;

Hor., serm. I 7,12 Hectora Priamiden, animosum atque inter Achillem

Ov., met. XIII 482 Priamidas et quid dederit domus una cruoris;

en cambio:

Virg., Aen. I 458 Atridas Priamumque et saevum ambobus Achillem;

Hor., ars 137 fortunam Priami cantabo et nobile bellum;

Ov., met. XIII 201 et moveo Priamum Priamoque Antenora iunctum;

Verg., Aen. II 403 ecce trahebatur passis Priameia virgo || crinibus

Ov., met. XIII 404 Troia simul Priamusque cadunt. Priameia coniunx. 


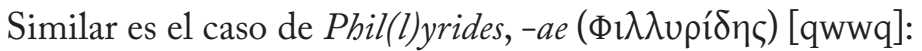

Virg., geo. III 550 Phillyrides Chiron Amythaoniusque Melampus;

Prop. II 1,60 (DApe) Phoenicis Chiron lumina Phillyrides;

Ov-.Ars I 11 Phillyrides puerum cithara perfecit Acbillem,

Ov., fast. V 383 Phillyrides tenuit; saxo stant antra vetusto;

Mart. II 14,6 (DApe) Si quid Phillyrides praestet et Aesonides.

frente a Philyra, -ae (Фı $\mathrm{u} \rho \alpha$, su madre) [wwu],

Germ., Arat. 634 at Philyra cum natus avitis surgit ab undis

philyra, -ae ( piel de tilo) [wwu]:

Hor., carm. I 38,2 (SAPH 11s) displicent nexae philyra coronae,

Ov., fast. V 337 ebrius incinctis philyra conviva capillis;

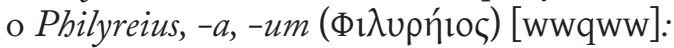

Ov., met. II 676 Flebat opemque tuam frustra Philyreius heros;

Ov., fast. V 391 excipit hospitio iuvenem Philyreius heros;

Ov., met. VII 352 Pelion umbrosum, Philyreia tecta, superque;

o el caso de Phyl(l)acides:

Prop. I 19,7 illic Phylacides iucundae coniugis heros;

Ov. am. II 6,41 tristia Phylacidae Thersites funera vidit; ars II 356 Phylacides aberat, Laodamia, tuus; ars III 17 Respice Phylaciden et quae comes isse marito.

De este mismo tipo son los alargamientos que se dan en secuencias de tres breves seguidas, en palabras como Iitalia $^{22}$ [qwwq]:

Ps. Prob., ult. syll. 259,18 deinde de brevibus dicam, quae pro longis sunt positae. Italiam fato profugus: primam syllabam, cum sit brevis, longam posuit, quamvis caput pedis faciat; alibi enim brevis est, ut antiqua e cedro Italusque paterque Sabinus (Verg., Aen. VII 178).

San Agustín se refiere en dos ocasiones (mus. VI 12.36; doct. Christ. II $38,56)$ a este alargamiento de la $i$ de Italia como indicio de la convencionalidad de las diferencias cuantitativas; si fueran, dice, algo natural, no convenido, no cambiarían los nuevos la práctica de los antiguos.

La originaria cantidad breve de esta $i$ se puede comprobar en Lucilio:

XXIX 825 Marx = 902 Krenkel [apud Non. 446,2] (IA6p) detru<s>sus tota vi deiect<us>que Italia;

Lucrecio distingue entre IItalia [qwwq] e Italus [wwu]; y lo mismo hace Virgilio:

Virg., Aen. I 2 Italiam fato profugus Laviniaque venit [ii-ta..],

frente a, por ejemplo,

Virg., Aen. I 252 prodimus atque Italis longe disiungimur oris [i-ta...] 
Virg., Aen. XII 827 sit Romana potens Itala virtute propago.

Virgilio mide siempre (44 veces) así la palabra Italia, mientras que Italus (en sus diferentes formas sustantivas o adjetivas) lo pronuncia normalmente (44 veces) con la $i$ breve. Similar al de Italia es el caso de Italides (las mujeres de Italia [qwwq]):

Verg., Aen. XI 657 Italides, quas ipsa decus sibi dia Camilla ${ }^{23}$.

También los griegos, desde Sófocles, habían recurrido al mismo alargamiento para encajar la palabra en versos de ritmo dactílico ${ }^{24:}$

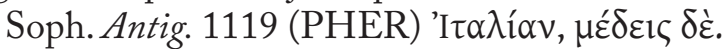

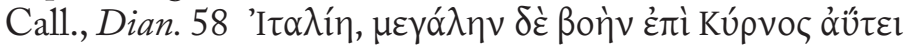

Pues bien, este "alargamiento métrico" de la $i$ de Italia parece haberse extendido a Italus [qww] en tres ocasiones ya en el propio Virgilio:

Verg., Aen. III 185 et saepe Hesperiam, saepe Itala regna vocare;

Verg., Aen.VII 643 complerint campos acies, quibus Itala iam tum \|floruerit terra...;

Verg., Aen. IX 698 coniecto sternit iaculo: volat Itala cornus;

otro tanto haría luego Estacio:

Stat., III 1,60 Itala terra focis Hecateidas excolit idus;

Stat., III 3,161 aequora curarum socius procul Itala rura.

Horacio, que mide siempre Italia con la inicial larga:

Hor., ca. I 37,16 (ALC10s) Caesar ab Italia volantem;

$[$ ii-ta-...]

Hor., ca. III 5,40 (ALC10s) altior Italiae ruinis!;

Hor., ca. IV 14,44 (ALC10s) Italiae dominaeque Romae;

Hor., serm. I 6,35 imperium fore et Italiam, delubra deorum;

Hor., epist. I 12,29 Italiae pleno defudit Copia cornu:

pronuncia Italus unas veces con $i$ breve:

Hor., ca. II 7,4 (ALC10s) dis patriis Italoque caelo;

Hor., serm. I 7,32 at Graecus, postquam est Italo perfusus aceto;

Hor., serm. II 6,56 praedia Caesar an est Itala tellure daturus?';

Hor., epist. I 18,57 nunc et, siquid abest, Italis adiudicat armis;

Hor., epist. II 1,2 res Italas armis tuteris, moribus ornes;

y otras con $i$ larga:

Hor., ca. II 13,18 (ALC11s) Parthi, catenas Parthus et Italum; [ii-ta-...]

Hor., ca. III 30,13 (ASCL12s) princeps Aeolium carmen ad Italos;

Hor., ca. IV 4,42 (ASCL12s) dirus per urbis Afer ut Italas;

Hor., ca. IV 15,13 (ALC11s) per quas Latinum nomen et Italae.

Larga se pronunciaba asimismo esta $i$ inicial en otras dos formas, que de este modo pasaban a ser coriámbicas [qwwq]: en el plural de Italis, -idis:

Verg., Aen. XI 657 Italides, quas ipsa decus sibi dia Camilla;

Ov., fast. II 441 'Italidas matres' inquit 'sacer hircus inito;

Stat., silv. I 2,274 at tu, pulcherrima forma \|Italidum, tandem merito 
possessa marito;

Mart. II 53,4 (DAPe) Romanam credere matres || Italides possunt, Atthides esse suam;

Sil. VII 429 Ad quae Cymodoce, Nympharum maxima natu || Italidum:

y en los diversos casos de Italicus [qwwq]:

Ov., met. XIV 17 litore in Italico, Messenia moenia contra,

Ov., met. XV 9 Graia quis Italicis auctor posuisset in oris

Stat., silv. IV 6,78 Hannibal. Italicae perfusum sanguine gentis ${ }^{25}$

Otro tanto ocurre con Siicelides [qwwq]:

Virg., Buc. IV 1: Sicelides Musae, paulo maiora canamus;

Ov., met. V 412 inter Sicelidas Cyane celeberrima nymphas;

frente a Siculus [wwu]:

Virg., Aen. I 34 vix e conspectu Siculae telluris in altum ${ }^{26}$;

o Siciliensis [wwwqu]:

Plaut., Rud. 451 (IA6p) meum erum lenonem Siciliensemque hospitem;

y con Sicanius [qwwq]:

Virg. Aen. VIII 416 insula Sicanium iuxta latus Aeoliamque ${ }^{27}$;

frente a Sicanus [wqu]:

Virg., Aen. V 293 undique conveniunt Teucri mixtique Sicani ${ }^{28}$,

aunque Silio Itálico, que así lo mide en final de hexámetro:

VIII 356 Faunigenae socio bella invasere Sicano;

XIV 34 vomere verterunt primum nova rura Sicano;

XIV 110 Tali Trinacriae motu rebusque Sicanis;

291 astus miscebant Tyrios levitate Sicana;

XV 356 sit praematurus felix labor. urbe Sicana;

pronuncia, en cambio, Sicanus [qww] en las tres ocasiones en que lo ubica en interior:

Sil. X 313 Sicana procumbit pubes, hic Hernica turma;

Sil.XIV 258 Cetera Elissaeis aderat gens Sicana votis;

Sil. XVI 216 Sicana nunc tellus, nunc litora Hibera cruorem.

En Ovidio aparece Sicanis, -idis [qww]:

Ov., Ibis 598 (DAPe) Plurima qua flammas Sicanis Aetna vomit.

Propercio mide Arabia y Arabius [qwwq]:

Prop. I 14,19 illa neque Arabium metuit transcendere limen;

Prop. II 3,15 ne si qua Arabio lucet bombyce puella;

Prop. II 19,16 (DApe) et domus intactae te tremit Arabiae;

frente a los habituales Arabia [wwwq]:

Plaut., Persa 522 (IA6p) furtivam, abductam ex Arabia penitissuma;

Plaut., Persa 541 (TRse) fieri doctos. To. Ne quis vero ex Arabia penitissuma II persequatur,

Plaut., Trin. 845 (TRse) advenio ex Seleucia, Macedonia, Asia atque Arabia; 
Plaut., Trin. 933 (TRse) omnium primum in Pontum advecti ad Arabiam terram sumus;

Plaut., Trin. 934 (TRse) CH. Eho an etiam Arabiast in Ponto? S. Est: non illa ubi tus gignitur;

Plaut., Persa 506 (IA6p) Chrysopolim Persae cepere urbem in Arabia; Arabs [wq], Arabis [wwu]:

Plaut., Curc. 443 (IA6p) Sinopes, Arabes, Cares, Cretanos, Syros;

Catull. 11,4 (SAPH11s) sive in Hyrcanos Arabasve molles;

Tibull. II 2,4 (DApe) Quos tener e terra divite mittit Arabs;

Tibull. III 2,24 (DApe) Eoique Arabes, dives et Assyria;

Tibull. III 3,18 (DApe) Cultor odoratae dives Arabs segetis,

Prop. II 29a 17 afflabunt tibi non Arabum de gramine odores;

Prop. III 13,18 (DApe) cinnamon et multi pistor odoris Arabs.

Virg., Geo. II 115: Eoasque domos Arabum pictosque Gelonos;

Verg-. Aen. VIII 706 omnis Arabs, omnes vertebant terga Sabaei;

Hor., carm. I 29,1 (ALC 11s.) Icci, beatis nunc Arabum invides || gazis;

Ov., Met. X 478 palmiferos Arabas Panchaeaque rura reliquit;

Arabus [wwu]:

Prop. II 3,15 nec si quando Arabo lucet bombyce puella;

Verg., Aen. VII 605 Hyrcanisve Arabisve parant, seu tendere ad Indos;

o Arabicus [wwwu]

Plaut., Miles 412 (IAse) gratesque agam eique ut Arabico fumificem odore amoene.

Una secuencia de cuatro breves la acomoda Ovidio al ritmo del hexámetro alargando la segunda: Lemuuria [wqww]:

Ov., Fast. V 421 ritus erit veteris, nocturna Lemuria, sacri;

la fiesta de los Lemures [wwq]:

Hor. Epist. II 2,209 nocturnos lemures portentaque Thessala rides;

Ov., Fast. V 483 mox etiam lemures animas dixere silentum;

Pers. 5,185 tum nigri lemures ovoque periculis rupto.

La primera $a$ de Asia, -ae es breve, como en el griego 'Aбía:

Lucil. 26, 671 (TRse) publicanus vero ut Asiae fiam, ut scripturarius;

Plaut., Stich. 152 (TR se) si quae forte ex Asia navis heri aut hodie venerit; 367 (TR se) ex Asia, negant venisse, conspicatus sum interim; Trin. 599 (IA 6p) latrocinatum, aut in Asiam aut in Ciliciam; 845 (TRse) advenio ex Seleucia, Macedonia, Asia atque Arabia;

Catull. 46,6 (PHAL) ad claras Asiae volemus urbes; 66,36 (DA pe) captam Asiam Aegypti finibus addiderat, 68,89 Troia (nefas) commune sepulcrum Asiae Europaeque;

Prop. I 6,14 (DApe) atque Asiae veteres cernere divitias; II 3,36 Europae 
atque Asiae causa puella fuit:

Verg., Georg. II 161 qui nunc extremis Asiae iam victor in oris; III 30 addam urbes Asiae domitas pulsumque Niphaten; Aen. I 385 Europa atque Asia pulsus.' nec plura querente, etc.

Hor., serm. I 7,19 ditem Asiam, Rupili et Persi par pugnat, uti non; serm. I 7,24 solem Asiae Brutum appellat stellasque salubris; 3,5 an pingues Asiae campi collesque morantur?

Ovid., am. II 12,18 (DApe) Tyndaris, Europae pax Asiaeque fore; epist. 16, 167 regna parens Asiae, qua nulla beatior ora est; etc.

Sen., Tro. 7 (IA 3m) pollentis Asiae, caelitum egregius labor; Ag. 205 (IA 3m) Asiae ferocis, ultor Europae, trahit; etc.

Lucan. II 674 Europamque Asiae Sestonque admovit Abydo; etc.;

Mart. V 74,1 Pompeios iuvenes Asia atque Europa, sed ipsum;

breve es también la $a$ inicial en los adjetivos Asiaticus (wwqwu) y Asianus (wwqu):

Colum. X 412 Frigoribus pigro veniunt Asiatica fetu;

Iuv. 3,218 haec Asianorum vetera ornamenta deorum; 7,14 quod non vidisti; faciant equites Asiani.

Dicha $a$, en cambio, es larga en el adjetivo Asius, - $a$, -um (qwu, como en el griego "Aøıs):

Catull 61,22 (GLYC) myrtus Asia ramulis;

Verg., georg. I 383 iam variae pelagi volucres et quae Asia circum|| dulcibus in stagnis rimantur prata Caystri; georg. IV 343 atque Ephyre atque Opis et Asia Deiopea; Aen. VII 701 dant per colla modos, sonat amnis et Asia longe || pulsa palus;

y en Asius, -ii, nombre de un héroe:

Verg., Aen. X 123 Asius Imbrasides Hicetaoniusque Thymoetes;

larga es también dicha $a$ en el adjetivo Asis, -idis ('Aøı)):

Ov., met. V 648 iam super Europen sublimis et Asida terram; IX 448 Aegaeas metiris aquas, et in Aside terra ${ }^{29}$.

Sobre Sidon, -onis (qq: $\Sigma 1 \delta \omega ́ v,-\tilde{\omega} v o \varsigma)$, palabra atestiguada a partir de Lucrecio:

Lucr. VI 585 in Syria Sidone quod accidit et fuit Aegi;

Verg., Aen. I 619 atque equidem Teucrum memini Sidona venire;

Ovid., met. IV 572 Cadmus ait 'fuerat, tum cum Sidone profectus;

Lucan. III 217 et Tyros in stabilis pretiosaque murice Sidon;

se forman los adjetivos Sidonius, -a,-um y Sidonis, -idis ( $\Sigma 1 \delta \omega v i ́ \varsigma)$, que, al igual que el griego $\Sigma 1 \delta \omega ́ v ı \iota \varsigma / \Sigma 1 \delta o ́ v ı \varsigma$, se pronuncian con la o tanto larga como breve: la pronunciación con larga (qqwu), que, en principio, sería la originaria, es menos frecuente; aparece siempre en versos dactílicos, ocupando la sílaba inicial $S i$ un tiempo no marcado; do, por tanto, realiza el tiempo 
marcado siguiente y las dos breves restantes el segundo tiempo, bisilábico, del dáctilo:

Sidoonius (qqww):

Prop. II 16,55 quare ne tibi sit tanti Sidonia vestis;

Verg., Aen. I 446 bic templum Iunoni ingens Sidonia Dido (= 613; IX 266; XI 74);

Ov., met. III 129 hos operis comites habuit Sidonius hospes,; Pont. I 3, 77 Liquit Agenorides Sidonia moenia Cadmus;

Sidoonida (qqww):

Ov., met. II 840 suspicit (indigenae Sidonida nomine dicunt),; X 267 conlocat hanc stratis concha Sidonide tinctis

Mucho más extendida es la pronunciación con 0 breve (qwwu), que se diría condicionada por el ritmo dactílico para permitir introducir la palabra -coriámbica o dactílica, según los casos- en un $\mathrm{T}$, formando las tres sílabas iniciales un dáctilo:

Sidonius (qwwq):

Prop. II 29a,15 quae cum Sidoniae nocturna ligamina mitrae; IV 9, 47 idem ego Sidonia feci servilia palla;

Tib. III 3,18 (DApe) Tinctaque Sidonio murice lana iuvat,

Verg., Aen. I 678 Sidoniam puer ire parat, mea maxima cura; IV 75 Sidoniasque ostentat opes urbemque paratam; IV 137 Sidoniam picto chlamydem circumdata limbo; 545 inferar et, quos Sidonia vix urbe revelli; 683 Sidonios urbemque tuam. date, uulnera lymphi; V 571 Sidonio est invectus equo, quem candida Dido;

Germ., Arat. 47 Sidoniamque ratem nunquam spectata fefellit,

Hor., epod. 16,59 non huc Sidonii torserunt cornua nautae; epist. I 10,26 non qui Sidonio contendere callidus ostro;

Ov., epist. 9, 101 Haec tu Sidonio potes insignitus amictu; trist. IV 2,27 hic, qui Sidonio fulget sublimis in ostro; Ib. 446 Sidonia iactis Graia per arva manu; met. IV 543 Sidoniae comites, quantum valuere secutae; trist. IV 3,2 (DA pe) altera Sidonias, utraque sicca, rates; fast. III 108 (DA pe) Sidoniis, Helicen Graia carina notet,

Lucan. X 411 candida Sidonio perlucent pectora filo;

Sidonis (qww):

Ov., met. XIV 89 Sidonis; inque pyra sacri sub imagine facta; fast. III 649 Sidonis interea magno clamore per agros; ars III 252 Perque fretum falso, Sidoni, vecta bove; fast. V 610 Sidoni, sic fueras aspicienda Iovi; 617 taurus init caelum: te, Sidoni, Iuppiter implet;

es ésta la pronunciación con que aparece Sidonius (qwwq) en las tragedias senecanas:

Sen., Herc. f. 467 (IA3m) fulsitque pictum veste Sidonia latus?; Med. 697 maior 
(Pelasgis apta, Sidoniis minor); Oed. 163 (AN 2m) miscuit undis Styga Sidoniis; Oed. 713 (ASCL 12s) umbram Sidonio praebuit hospiti; Herc. O. 663 (AN 2m) nec Sidonio mollis aeno;

Ps.Sen., Oct. 206 (AN 2m) modo Sidonii cornua tauri;

es éste el patrón fónico-prosódico del adjetivo Sidonicus (qwwu), que he encontrado sólo en Valerio Flaco:

Val. Fl. VI 95 ast ubi Sidonicas inter pedes aequat habenas.

Como alargamiento en T entendió Leumann ${ }^{30}$ el Vaatịicaanus [qqqu] de Marcial en estos pentámetros:

Mart. I 18,2 (DAPe) In Vaticanis condita musta cadis;

Mart. XII 48,14 (DAPe) Et Vaticani perfida vappa cadi,

frente, por ejemplo, al Vaaticaanus [qwqq] de Horacio:

Hor., carm. I 20,7 (SAPH11s) redderet laudes tibi Vaticani;

otro tanto se diría que ocurre en Juvenal:

Iuv. VI 344 et Vaticano fragiles de monte patellas.

Sin embargo, la presencia en el mismo Marcial de una Vaticanus con la ii larga ocupando la segunda sílaba de un falecio o el t1 de un hexámetro resta validez a tal explicación:

Mart. VI 92,3 (PHAL) Vaticana bibis: bibis venenum;

Mart. X 45,5 Vaticana bibas, si delectaris aceto.

Ovidio hace gala de libertad en la pronunciación de Tuuticaanus al enmarcarlo en el esquema métrico del dístico elegíaco:

Ov., Pont. IV 12, 10 s. (DAPe) artius adpellem Tuticanumque vocem [qwwq]

et potes in versum Tuticani more venire

[wwqq]

3. "Abreviación de largas".

Bastante menos frecuente que el "alargamiento" de breves es la "abreviación de largas”, o, mejor dicho, el empleo de largas en función de breves para acomodar una palabra al esquema rítmico-métrico del verso; aun así, no dejan de observarse algún que otro caso. Siguiendo, por ejemplo, los pasos de los griegos, los latinos pronunciaron con $e$ larga Cythera y Cytheriacus:

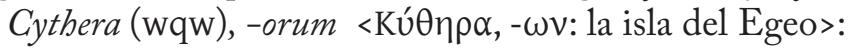

Verg., Aen. I 680 bunc ego sopitum somno super alta Cythera; X 51 est Amathus, est celsa mibi Paphus atque Cythera; 86 est Paphus Idaliumque tibi, sunt alta Cythera;

Ovid., am. II 17,4 (DApe) quae Paphon et fluctu pulsa Cythera tenet;

Lucan. IX 37 inde Cythera petit, Boreaque urguente carinas;

Val. Fl. VIII 229 Idalium furto subit aut dilecta Cythera;

Cytheriacus, -a,-um (wqwwu), "de Citera": 
Ovid., epist. 7,60 (DApe) nuda Cytheriacis edita fertur aquis; fast. IV 15 mota Cytheriaca leviter mea tempora myrto;

Nero, carm. frg. 2,1 Morel Colla Cytheriacae splendent agitata columbae;

Mart. II 47,2 (DApe) Levior o conchis, Galle, Cytheriacis; XIV 207,1 Sume Cytheriaco medicatum nectare ceston;

sin embargo, abreviaron dicha $e$ en otras formaciones de la misma familia que sin dicha abreviación entrañarían un moloso (wqqw), incompatible con determinados esquemas rítmicos, como el dactílico:

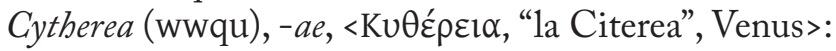

Tibull. III 13,3 Exorata meis illum Cytherea Camenis;

Prop. II 14,25 magna ego dona tua figam, Cytherea, columna;

Verg., Aen. I 257 parce metu, Cytherea, manent immota tuorum; 657 At Cytherea novas artis, nova pectore versat, IV 128 adnuit atque dolis risit $\mathrm{Cytherea}$ repertis; V 800; VIII 523; 615;

Ps. Verg., catal. XIV 11 adsis o Cytherea: tuus te Caesar Olympo;

Germ., Arat., frg. 4,76 incipit, exoriens haec te Cytherea monebit,

Hor., ca. I 4,5 (ARCH) iam Cytherea choros ducit Venus imminente luna; III 12,4 (IOMI) tibi qualum Cythereae puer ales, tibi telas;

Manil. II 439 Lanigerum Pallas, Taurum Cytherea tuetur, 922 asserit hanc Cytherea sibi per sidera sedem; IV 579 scilicet in piscem sese Cytherea novavit;

Ov., am. I 3,4 (DApe) audierit nostras tot Cytherea preces!; epist. 16,20 (DApe)pollicita est thalamo te Cytherea meo; 138; 17, 241; ars II 15; etc.

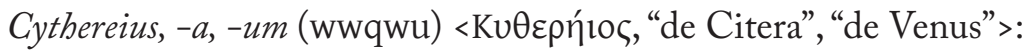

Germ., Arat., frg. 2,2 hac rapitur Phoebe, per idem Cythereius ignis || fertur iter; 4,69 cum sedem Aegoceri Cythereius attigit ignis;

Ovid., met. IV 190 Exigit indicii memorem Cythereia poenam; X 259 capta viri forma non iam Cythereia curat,

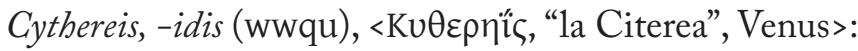

Manil. II 33 et morsu Cancrum, Pisces Cythereide versa;

Ov., met. IV 288 Mercurio puerum diva Cythereide natum; XIII 265 fert umeris, venerabile onus, Cythereius heros; XIV 584; fast. III 611; IV 195;

Una abreviación de este tipo se observa con cierta frecuencia en nombres propios con estructura de moloso (qqq: Orion, Sychaeus, Diana, Gradivus, Fidenae, Atinas), que aparecen escandidos wqq, como si la primera sílaba fuera de cantidad dudosa: esto, en prinicipio, se da, sobre todo, en final de hexámetro ${ }^{31}$ :

Orion ( $\Omega$ píov), por ejemplo, se pronuncia con la primera /o/ breve, en casos como éstos:

Virg., Aen. I 535 cum subito adsurgens fluctu nimbosus $\underline{\text { Orion }}$ [o-rii-oon] 
Virg., Aen. IV 52 dum pelago desaeuit biems et aquosus $\underline{\text { Orion, }}$

Virg., Aen. X 763 turbidus ingreditur campo. quam magnus $\underline{\text { Orion }}$

En cambio, otras veces dicha /o/ es larga:

Virg., Aen. VII 719 saeuus ubi Orion hibernis conditur undis, [oo-rii-oon]

Virg., Aen. III 517 armatumque auro circumspicit Oriona.

Para los antiguos artígrafos, esta 0 larga habría sido la originaria, que ocasionalmente se abreviaría por efecto de la systole:

Ps.Prob., ult. syll.263,17 Systole est e contrario quandosyllaba longa corripitur, ut aquosus Orion (Verg., Aen. IV 52): cum prima produci debeat, corripitur ... 259,13 item cun subito adsurgens fluctu nimbosus Orion (Verg., Aen. I 535): o syllabam corripuit quae alibi longa est, ut armatumque auro circumspicit Oriona (Verg., Aen. III 517)

Diana, en cambio, es entendido por los artígrafos como un caso en que la $i$ breve se alarga ocasionalmente por ectasis

Ps. Prob., ult. syll. 263,17 Ectasis est cum per licentiam brevis producitur. ut exercet Diana choros (Verg., Aen. I 499) ... 259,18 deinde de brevibus dicam quae pro longis sunt positae ... item exercet Diana choros (Verg., Aen. I 499): di syllabam produxit quia longa est; nam alibi eam brevem posuit, ut tergeminamque Hecaten, tria virginis ora Dianae (Verg., Aen. IV 511).

Diom. 442,1 ectasis est extensio, quae fit cum correpta syllaba contra rationem per licentiam producitur, ut exercet Diana choros (Aen. I 499), bic enim Dianae syllaba prima producta est, cum corripi debeat.

El genitivo Laviini (Laviinus, $-a$, - um) aparece en final de verso con la $a$ breve:

Virg., Aen. I 258 fata tibi; cernes urbem et promissa Lavini; 270 imperio explebit, regnumque ab sede Lavini; 84 (sed terrae graviora manent), in regna Lavini;

Tib. II 5,49 Ante oculos Laurens castrum murusque Lavini est; así parece también que pronunciaba Juvenal Lavinum, $-i$ :

Iuv. 12,71 atque novercali sedes praelata Lavino.

En cambio, otras veces encontramos dicha a pronunciada larga:

Prop. II 34,64 (DAPe) iactaque Laavinis moenia litoribus.

Ov., Met. XV 728 Laavini sedes Tiberinaque ad ostia venit

al igual que la de Lavinia -ae:

Virg., Aen. VI 764 quem tibi longaevo serum Laavinia coniunx;

la de Lavinius, $-a$, -um:

Virg., Aen. I 2 Italiam fato profugus Laaviniaque venit || litora

Prop. II 34a,64 (DApe) iactaque Laavinis moenia litoribus; 
o la de Lavinium, -ii:

Ov., met. XV 728 Laavini sedes Tiberinaque ad ostia venit

Encontramos asimismo Fideenae frente a Fïideenae ${ }^{32}$ :

Virg. Aen. VI 733 bi tibi Nomentum et Gabios urbemque Fidenam;

Ps. Prob. 259,13 item urbemque Fidenam (Verg., Aen. VI 773): fi syllaba cum sit longa, hoc loco brevis est;

frente a, por ejemplo:

Hor. Epist. I 11,8 Fidenis vicus; tamen illic uiuere uellem

Prop. IV 1a,36 (DApe) tunc ubi Fidenas longa erat isse via

Mart. IV 64,15 (PHAL) Fidenas veteres brevesque Rubras,

Iuv.X 100 an Fidenarum Gabiorumque esse potestas.

Y vemos también Gradiivuus en final de hexámetro:

Ov., Met. VI 427 et genus a magno ducentem forte Gradivo

[Gra-dii-voo]

frente a Graadiivous en interior de verso:

Ov., Met. XIV 820 inpavidus conscendit equos Gradivus et ictu [Graa-dii-v..]

Virg., Aen. X 542 lecta refert umeris tibi, rex Gradive, tropaeum.

Ov., Ars am. II 566 (DAPe) Rustica Gradivo difficilisque fuit. 


\section{Bibliografía mencionada}

Altheim, Fr., 1954: Geschichte der lateinischen Sprache von den Anfängen bis zum Beginn der Literatur, Frankfurt am Mein.

Bednara, E., 1905: De sermone dactylicorum Latinorum quaestiones: Catullus et Ovidius quibus rationibus linguam metro dactylico accommodaverint, I: Diss.Breslau, 1905, págs. 48.

Bednara, E., 1906, "De sermone dactylicorum latinorum quaestiones", $A L L 14$ (1906) 317-360; 532-604.

Bednara, E., 1909: “Aus der Werkstatt der daktylischen Dichter", ALL 15 (1909) 223-232.

Castillo,M. del,2002: "Los florilegios de las prosodias de Smetius y Ricciolius", en Maestre-Pascual-Charlo (eds.) 2002, págs. 761-778.

Castillo, M. del, 2005: "El genitivo de plural en -ntum. Recuperación literaria de una forma en desuso", en Conde -Velázquez (eds.), 2005, págs. 229254.

Conde, P.P.-Velázquez, I., 2005: La fllología latina, mil años más, Madrid.

Fedeli, P., 1994: Sexti Properti elegiarum libri IV ed. P.F., Stutgardiae-Lipsiae.

Housman, A.E., 1910: “On the Aetia of Callimachus”, Class. Quart. 4 (1910) 114-129.

Hosius, C., 1895: "Römische Dichter auf Inschriften”, RbM n.F. 50 (1895) 286-300.

Lachmann, K., 1850: Lucretius, De rerum natura, Berlin.

Leonhardt,J., 1985: Dimensio syllabarum. Studien zur lateinischen Prosodie- und Verslehre von der Spätantike bis zum frühen Renaissance, Göttingen.

Leumann, M., 1959: Kleine Schriften, Zürich-Stuttgart

Leumann, M., 1977: Lateinische Laut- und Formenlehre, München.

Lunelli, A., 1974: La lingua poetica latina, Bologna.

Luque Moreno, J., 2001: "Un sistema de signos para el análisis métrico de textos latinos en verso", Florentia Iliberritana 12 (2001) 267-294.

Luque Moreno, J., 2005: “Los versos de la Apocolocintosis”, Florentia Iliberritana 16 (2005) 135-221.

Luque Moreno, J., 2005b: “La síncopa como recurso versificatorio: Séneca”, en Conde-Velázquez (eds.) 2005, págs. 229-254.

Luque Moreno, J., 2005c: “Hexámetros especiales”, RELat 5 (2005) 117-145.

Luque Moreno,J., 2005d: “Scribere versus: la representación gráfica del lenguaje 
versificado", Emerita 73/2 (2005) 303-351.

Luque Moreno, J., 2009: "Los rétores y la cantidad silábica: Cicerón y Quintiliano", en T. Arcos-J. Fernández-F.Moya, Pectora mulcet. Estudios de Retórica y Oratoria latinas, Logroño, 2009, vol. I, pp. 203-216.

Luque, J.-Díaz, P.R. (eds.), 1999: Estudios de métrica latina, Granada.

Maestre, J.Ma.-Pascual, J.-Charlo, L. (eds.), 2002: Humanismo y pervivencia del mundo clásico. Homenaje al profesor Antonio Fontán, Alcañiz-Madrid.

Marx, F., 1922: Molossische und bakcheische Wortformen in der Verskunst der Griechen und Römer, Abh. Sachs. Ak. Leipzig, phil-bist. Kl. 37 (1922), 1-237.

Moya, F.-Carrasco, L., 1999: "La Prosodia Bononiensis de I.B.Ricciolius”, en Luque-Díaz 1999, págs. 719-736.

Müller, L., 1894: De re metrica poetarum latinorum praeter Plautum et Terentium libri septem, Leipzig (= 1967 Hildesheim).

Norden, E., 1903: “Stilistisch-metrische Anhänge”, en P. Vergilius Maro Aeneis Buch VI, Leipzig (Leipzig-Stuttgart 4a; cito por Darmstadt $1984=1916$ 2a), pp. 413-434.

Riccioli, J.B., 1746: Prosodia Bononiensis, Patavii.

Schulze, W., 1892: Quaestiones epicae, Gütersloh (= Hildesheim 1967).

Schulze, W., 1904: Zur Geschichte lateinischer Eigennamen, Göttingen.

Solta, G.R., 1974: Zur Stellung der lateinischen Sprache, Wien.

Sommer, F.-Pfister, R., 1977: Handbuch der lateinischen Laut- und Formenlehre. Band I: Einleitung und Lautlehre, Heidelberg.

Swanson, D.C., 1967: The Names in Roman Verse, Madison-MilwaukeeLondon.

Swanson, D.C., 1970: A Characterization of the Roman Poetic Onomasticon, Pennssylvania-London.

Viarre, S., 2005: Properce, Élégies, Texte établi, traduit et commenté par S.V., Paris.

Vollmer, F., 1923: Romische Metrik, Leipzig-Berlin (3a ed., 1927). 
${ }^{1}$ El presente trabajo ha sido realizado en el seno del proyecto de investigación FFI 200805611/FILO. El autor agradece a la Prof ${ }^{\text {a }}$. Carmen Hoces, de la Universidad de Granada, sus observaciones y correcciones.

2 Producto muchas veces de una deficiente transmisión de los textos en verso, tales vacilaciones fueron objeto de atención por parte de los estudiosos desde la antigüedad tardía y llegaron a merecer un apartado específico en los tratados de prosodia, tal como se puede ver, por ejemplo, en los índices de Riccioli (1746), en especial en el segundo, "Index syllabarum controversarum", págs. 614-670. Cf. al respecto, por ejemplo, Leonhardt 1985; Moya-Carrasco 1999; Del Castillo 2002. En la moderna filología no han dejado de ser objeto de atención, en especial por parte de los estudiosos de los versos dactílicos: véanse, por ejemplo, además de otros escritos anteriores citados por ellos, los de Lachmann 1850; Müller 1894, pp. 518 ss.; Hosius 1895; Norden 1903, pp. 413 ss.; Bednara 1905 (en especial, pp. 330 ss.); 1906; 1908; Vollmer 1923, pp. 17 ss.; Leumann 1977, § 130.

3 Las fuentes principales son las siguientes: Scholia B 17, págs. 288 ss. Consbruch; Appendix Dionysiaca 7, págs. 322 ss. Consbruch; 8, págs. 325 ss. Consbruch; Athen. XIV 632 c.d., págs. 347 s. Consbruch; Ps.Hephaest. § 11, págs. 348 s. Consbruch; Ps.Hephaest. § 17, págs. 349 s. Consbruch; Anonymus Parisinus (cod. Par. 2881 fol.76), págs. 349 ss. Consbruch; Anonymus Ambrosianus, en Anecdota varia, págs. 213 ss. Studemund; Cod. Venetus Marcianus CCCCLXXXIII, en A.V., pág. 190 Studemund; Diomedes GLKI 498,29 ss.; 500,5 ss.; Aphth. Ars Gramm. I, "De vitiis versuum" GLKVI 67,13 ss. A ellas se pueden añadir entre los latinos Terenciano Mauro, 1920 ss. o Sacerdote GLK VI 523,20 ss. Cf. Luque 2005c, especialmente págs. 126 ss.

${ }^{4}$ Quint. I 5,18; Sac. GLK VI 452,15; Char., ars IV 366,5 Barwick; Diom., GLK I 440,30; 442,1 ss.; Don., ars 661,11 Holtz; Ps. Probo, ult. syll. 259,3-262,17 etc.

${ }^{5}$ Los tres tipos (abreviación de vocal larga o diptongo seguidos de vocal; alargamiento de vocal breve seguida de muda más líquida; alargamiento -normalmente en T, aunque a veces también en $\mathrm{t}-$ de vocal breve seguida de una sola consonante o de ninguna) descritos por Hefestión (págs. 2,18 y 3,4 ss. Consbruch; cf. también Dionisio Tracio § 10, págs. 20,4-22,2 Uhlig; Aristides Quint., mus. I 21, págs. 42,22 ss. Winnington-Ingram), que luego concretarán y desarrollarán los escolios a Dionisio Tracio (Schol Vaticana, GG I, III, 208 ss.; Schol. Marciana, GG I, III, 349 ss.; Schol. Londinensia, GG I, III 511 ss.; Comm. Byzantinus, GG I, III 571 s.; Comm. Melampodis ( $G G \mathrm{I}, \mathrm{III}$, págs. 50 ss.), añadiendo nueve casos más, hasta contar un total de doce: dos en que una sílaba larga es tomada como breve y diez en que una breve es tomada como larga. Una doctrina que vemos extendida igualmente entre los gramáticos latinos: Carisio 10,18 ss. Barwick y Dosíteo GLKVII 387,10-388,15; Diomedes GLKI 428,21; Malio Teodoro, GLK VI 587,12 ss.; Aftonio, GLKVI 36,9-39,4 y Mario Victorino, GLKVI 27,10 ss. (5,11-15, pág. 91,16 Mariotti) y 30,7-31,16 (5,40-44, pág. 94,26 Mariotti); Donato (GLK IV 369,3) y los gramáticos de su grupo. Cf., por ejemplo, Müller 1894, págs. $13 \mathrm{~s}$.

${ }^{6}$ Leumann 1977, pág. 115.

${ }^{7}$ I 5,18 .

${ }^{8}$ Cic., or. 173; de or. III 196.

${ }^{9} \mathrm{Cf}$. Luque 2009.

${ }^{10} \mathrm{~T}$ = tiempo marcado $/ \mathrm{t}=$ tiempo no marcado.

${ }^{11}$ Cf., por ejemplo, Schulze 1892, pp. 137 ss: I. De vocabulis quae ob brevium syllabarum continuo sese excipientium numerum nisi mensura mutata versus epicus non admitttit: p. 140 II. De antispasticis versui heroico productione accommodatis: p. 257 III. De syllabis natura brevibus quae longis cinguntur numero dactylico aptatis: 275 de

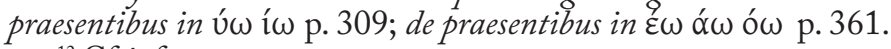

${ }^{12} \mathrm{Cf}$. infra.

${ }^{13}$ Cf., por ejemplo, Bednara 1906, pp. 332 s.; Leumann 1977, § 121.

${ }^{14}$ Cf., por ejemplo, Bednara 1906, p. 338; Leumann 1977, § 229.

${ }^{15}$ Explotación de las posibilidades de silabización del grupo muta cum liquida.

Contravenciones a la normal abreviación de las vocales delante de otra vocal (Bednara 1906, 
pp. 334 s.; Leumann 1977 § 118) o explotación de las posibilidades de silabización que ofrecía una secuencia de dos vocales: contracción o no de grupos de idéntico timbre (ee), synizesis (-eii, -eoo: Bednara 1906, pp. 335 s.), consonantización de $i, u$ antevocálicas (con el consiguiente alargamiento de la sílaba anterior): [abjete, genwa, tenwis]; viceversa, también se recurría a veces a vocalizar una w: [su-aa-det] en lugar de [swaa-det], [si-lu-a] en lugar de [sil-wa]. Recurso a pronunciaciones marginales -según el nomal proceso evolutivo- del sistema: por ejemplo las de ciertas vocales en final absoluto de palabra (-a, -0 , si y tu enclíticos: cf. Leumann 1977, § 122) o en sílabas finales cerradas por $-r,-t,-l$, o $-m$ (Leumann 1977, § 123). Las posibilidades de la síncopa (Bednara 1906, pp. 336 s.; Luque 2005).

${ }^{16}$ Recursos como la tmesis (Lucr. II 1104 praeterit examinatque indignos inque merentes; IV 832 cetera de genere hoc inter quaecumque pretantur; Verg., Aen. II 567 super unus eram; II 218 bis medium amplexi, bis collo squamea circum || terga dati) o la anástrofe (Virg., Aen. I 107 his unda dehiscens|| terram inter fluctus aperit, furit aestus harenis arma ... inter, hos super; 218 spemque metumque inter dubii, seu uiuere credant; VII 803 Hos super aduenit Volsca de gente Camilla) o el denominado "plural poético" (en neutros en -ium: silentia, gaudia; en un femenino como oblivio -oonis: obliuia) o tantos otros en el manejo de las categorías gramaticales: cf. Bednara 1906, pp. 532 ss.

${ }^{17}$ Variantes a base de síncopa (cf. Luque 2005) o de epéntesis (induperator, indugredi); -um por -ium en las formas participiales (Del Castillo 2005); recurso a diversos alomorfos en la flexión verbal: imperfectos en -iibam, perfectos en -erunt en lugar de -eerunt, pluscuamperfectos en -iee(ve)rant. Nuevas formaciones adjetivales en -eus (virgenus), neutros en -men (fragmina, libamina) en lugar de -mentum; formaciones en -itaas en lugar de las en -entia (differitas, pestilitas); iterativos en -itaare (increpitare, imperitare); nuevos compuestos verbales del tipo de omnipotens o a base de -fer, -ger o -ficus (leetifer, aaliger, horrificus). Cf. Bednara 1906, pp. 578 ss.; 1908.

${ }^{18}$ Cf. Lunelli 1974 (con los estudios al respecto de Kroll, Janssen y Leumann); Bednara 1905, 1906, 1909; Vollmer 1923, págs. 17 ss.; Leumann, 1959, págs. 137 y 143-155; 1977, § 130 C, pág. 116;

${ }^{19}$ Cf. Hosius 1895; Schulze 1904; Housman 1910; Swanson 1967; 1970.

${ }^{20}$ Indico la forma métrica cuando no se trata de hexámetros dactílicos. Para las siglas y otros signos, cf. Luque 2001.

${ }^{21}$ Otro tanto en 330, 332, 333.

${ }^{22}$ Sobre dicho nombre, cf., por ejemplo, Altheim 1954, p. 30; Solta 1974, pp. 43 s.

${ }^{23}$ Cf. Mart. XI 53,4 (DApe) Italides possunt, Atthides esse suam.

${ }^{24}$ Cf. Schulze 1892; Sommer-Pfister, loc. cit.; Leumann 1931, pág. 249; 1977, pág. 115.

${ }^{25}$ Imprecisable es la cantidd de la $i$ en Plaut., Men. 237 (IA6p) orasque Italicas omnis, qua adgreditur mare.

${ }^{26}$ Cf. asimismo Lucil. VI 253; Manil. II 40; Ov., met. VII 283; Iuv. 6 486; Stat., silv. I 5,7; II 1,10 ; etc. etc.

${ }^{27}$ Cf. asimismo Verg., Aen. I 557; III 629; Ov., met.V 464; 495; XIII 724; XV 279; Colum. X 170; 268; Lucan. II 548; III 59; 177; VI 66; Stat., silv. I 2,206; 3,33; II 4,36; V 3,41; Mart. II 46,2; VII 64,3; XI 8,8; Sil. I 35; II 334; III 243; IV 502; XIII 739; XIV 4; 237; 492.

${ }^{28}$ Otro tanto en Aen. VII 795; VIII 328

${ }^{29}$ Sobre los problemas textuales del Asis de Propercio IV 1, 125 (scandentisque Asis consurgit vertice murus), cf., ademas de Forcellini V, Onomasticon, s.v., Fedeli 1994, ad loc. y Viarre 2005, ad loc.

${ }^{30}$ Leumann 1977, pág. 115: alargamiento en "thesis".

${ }^{31}$ Abundante material en Marx 1922, p. 23, quien interpretó el fenómeno como abreviación pretónica, y Vollmer 1923, págs. 19 s.; contra la explicación de Marx cf. Leumann 1947, pág. 161.

${ }^{32}$ Sobre este nombre, así como sobre Atinas, cf. Schulze 1904, pág. 551. 


\title{
LA FUNCIÓN LITERARIA DE LA TRADICIÓN CLÁSICA EN LAS primeras novelas de Palacio Valdés
}

\author{
Carlos de Miguel Mora \\ Univesidad de Aveiro
}

Antes de iniciar nuestra exposición, conviene aclarar algunos de los conceptos que trataremos y que se exponen en el título de la misma. En primer lugar hay que decir que la expresión "tradición clásica" ha merecido últimamente en España una meditada reflexión que encuadrase adecuadamente la multiplicidad de trabajos que se están presentando bajo este epígrafe. Como ejemplo de la fertilidad de este ámbito en los estudios clásicos actuales podemos mencionar los sucesivos coloquios internacionales que anualmente organiza el área de Filología Griega de la UNED, bajo la dirección del Profesor López Férez, subordinados precisamente a la tradición clásica en la literatura española e hispano-americana.

El investigador español Laguna Mariscal ${ }^{1}$ demostró que la denominación "tradición clásica" se remontaba más allá de Gilbert Highet, a quien se atribuía su creación ${ }^{2}$ y apuntaba como acunador al filólogo italiano Domenico Comparetti en su libro Virgilio nel medioevo, publicado en Pisa en $1872^{3}$. Lo interesante de esta fecha no es quién ni dónde sino cuándo; como recuerda García Jurado ${ }^{4}$, poco antes, en torno a 1860, se puede fijar la creación del término "Renacimiento", con mayúscula, para referirse a determinada época donde comenzaba supuestamente la modernidad. Ambas acuñaciones se dan por lo tanto en el siglo XIX, en plena efervescencia del realismo y en la época de los autores que vamos a tratar aquí; ambas responden a la necesidad de dar cuenta de las relaciones del mundo y de las letras antiguas con el mundo y las letras modernas. Argumenta García Jurado que los motivos que llevan a estas creaciones se relacionan con la conciencia que se tiene entonces de que las lenguas y literaturas greco-latinas representan una realidad epistemológicamente diferente de las lenguas y literaturas modernas y que, a partir de esta diferenciación se puede estudiar cómo las primeras "renacen" (Renacimiento) o "perviven" (tradición clásica) en las segundas5.

El uso de la expresión tradición clásica, con este adjetivo y no el simple adjetivo tradición, supone entonces la conciencia de que hay tradiciones diferentes. Tenemos que tener en cuenta que al usar esta locución se realiza una diferenciación en tres niveles: tradición antigua por oposición a la moderna, tradición pagana por oposición a la cristiana y tradición culta por oposición a la vulgar. ${ }^{1}$ Solo así entenderemos qué entra en los límites de lo que se considera "tradición clásica". En las obras estudiadas encontraremos

${ }^{1}$ García Jurado, «¿Por qué nació... 187 
muchas expresiones latinas que no cabrían en esta definición, por venir del ámbito cristiano o vulgar.

Una vez justificada la expresión "tradición clásica" nos queda por explicar por qué hablamos de "función literaria" en nuestro título. Algunos trabajos actuales sobre tradición clásica en la literatura española han caído, infelizmente, en el mismo error en que cayeron los propios estudios clásicos en la época de la incesante búsqueda de las fuentes. La tarea de encontrar loci similes o "lugares comunes", pasajes en un autor que recuerdan los de otro, es la esencia de los tradicionales estudios literarios sobre la época clásica. La caza de las fuentes o "Quellenforschung" se convirtió en el pilar de cualquier estudio sobre un texto, calificando este fenómeno literario como "influencias" o "fuentes", pero no en términos de textos y estructura de los textos. El afán de detectar por detectar, sin un análisis literario, derivó en un comparatismo exacerbado sin un claro objetivo, y que parecía restar calidad a los textos en lugar de comentar su valor poético. Contra este desenfreno identificador de lo que parecen ser "préstamos literarios" se alzó toda una escuela de interpretación intertextual que nació en Italia con Conte y Barchiesi ${ }^{6}$ y pronto se extendió por el mundo anglófono ${ }^{7}$.

Del mismo modo, se puede caer en el error, al analizar la literatura en lenguas modernas, de la identificación como único objetivo, como si la referencia clásica fuera un elemento inerte que solo toma sentido inmerso en el nuevo texto, como si de repente asumiese una capacidad de significación de la que anteriormente estaba privado, en lugar de entenderlo como un elemento que de cierto modo ya estaba implícitamente dotado de una orientación. Nos interesa, así pues, no solo quedarnos en la localización de la referencia clásica, sino entender qué papel juega esa referencia en la estructura de la novela.

En este estudio nos centraremos en algunas de las primeras obras de Armando Palacio Valdés, escritas aún en el s.XIX. Los motivos para acotar nuestro estudio a este ámbito cronológico se centran en el cambio evidente que supuso en la trayectoria del autor la publicación de La aldea perdida en 1903, tanto en el tipo de novela que escribe ${ }^{8}$ como en la presencia de la antigüedad clásica?.

Los autores pueden realizar un aprovechamiento narrativo de la tradición clásica desde diferentes ámbitos o niveles. Uno de los más sencillos, que tiene que ver exclusivamente con la mayor o menor abundancia y complejidad de las referencias usadas, se deja ver en novelas con narrador autodiegético. Podemos ejemplificar este uso con dos novelas de Palacio Valdés, La hermana San Sulpicio y La alegría del capitán Ribot ${ }^{10}$. En las dos encontramos un protagonista narrador en primera persona, en ambas este protagonista se encuentra en un ambiente en el que se siente ligeramente desplazado, aunque se integre bastante bien. Ceferino Sanjurjo, el protagonista de la primera novela, es un joven gallego de familia acomodada, poeta que abandonó los estudios de medicina por su 
vocación, conferencista ocasional, que por amor a una novicia, la hermana San Sulpicio, pasa una larga temporada en Sevilla con el propósito de enamorarla y casarse con ella. El capitán Julián Ribot es un marino alicantino que se enamora platónicamente de una mujer casada, después de un episodio en que salva la vida a la madre de esta mujer. A pesar de los dictámenes de su conciencia, que le aconsejan que se aparte de la tentación, cede ante la invitación del marido de esta, agradecido por el salvamento de la suegra, y pasa largas temporadas en su casa. Pero el carácter honesto, abierto e ingenuo de este hombre lo enamoran más que la belleza de su mujer, de modo que se convierte en un íntimo y sincero amigo suyo y en protector de su honra, en lugar de amenazarla. Como dije, los dos personajes se encuentran ligeramente desplazados, uno geográfica, otro socialmente, pero se adaptan bastante bien a la situación.

En estos casos de narrador autodiegético el uso de la tradición clásica va a tener una función de caracterización del protagonista, evidentemente junto a otros elementos narrativos. De este modo, el narrador de La hermana San Sulpicio, el poeta y conferencista Sanjurjo, presenta de sí mismo una imagen positiva, de hombre culto, que el autor no contradice, pero matiza con diversos procedimientos situacionales y con el uso de la tradición clásica o quizá sería mejor decir con el poco uso. El narrador literato Sanjurjo introduce referencias vagas a Ulises, Homero, dos veces a Cupido, los Catones, la roca Tarpeya y el Capitolio, y de forma general a los héroes griegos y a las canciones báquicas. No solo es un pobre bagaje intelectual, sino que, además, si vemos algunos ejemplos comprenderemos la banalidad de algunas de estas referencias:

«Por varias reticencias que le escuché en sus discursos, entendí también que Cupido le había sido adverso, y que sólo después de una dolorosísima experiencia había llegado á adquirir un conocimiento exacto y completo de las tretas de este dios, lo cual la ponía ahora en situación de aleccionar á los neófitos como yo y prevenirles. Después de repetidas instancias por mi parte, me confesó que el dios alado se le había presentado hacía tres años en forma de aspirante á telégrafos.» ${ }^{11}$

«Pero como "la roca Tarpeya está muy cerca del Capitolio", como dice, un número sí y otro no, cierto periódico de mi pueblo titulado El Centinela del Bollo, estaba de Dios que no había de gozar muchas horas de la dicha con que amor y gloria me inundaban.» ${ }^{12}$

Todo lo contrario se puede decir del capitán Ribot, hombre humilde que repite y se lamenta de su falta de instrucción, pero al que el autor no solo muestra dotado de extraordinaria prudencia, sino, además, de una cultura mucho más profunda que lo que el narrador quiere reconocer. A través del velo de su modestia se adivina una formación sólida en cultura clásica. No 
sólo vemos las típicas citas superficiales a los héroes de Homero, a Esquilo, a los dioses del Olimpo en general y Júpiter en particular o a los gladiadores romanos, sino también a Urano, a Cornelia, la madre de los Gracos, a Pólux, Morfeo, César, Alejandro, o algunas referencias más precisas como puede ser la siguiente:

«Valencia despertaba y sonreía a su huerta de flores, a su mar y a su cielo incomparables. Aquella situación privilegiada me hizo pensar en la Grecia antigua, y al ver cruzar a mi lado los rostros alegres, serenos, inteligentes de sus habitantes, me apetecía repetirles las famosas palabras de Eurípides a sus compatriotas: “ $\mathrm{OH}$, hijos amados de los dioses bienhechores! Vosotros recogéis en vuestra patria sagrada y jamás conquistada la gloriosa sabiduría como fruto de vuestro suelo, y marcháis perpetuamente con dulce satisfacción en el éter radioso de vuestro cielo." ${ }^{13}$

La exactitud de una cita no demasiado evidente hace ver al lector que la cultura del capitán no es despreciable. Otro ejemplo ilustrativo podría ser:

«Doña Clara, en tanto que hablábamos, se había mantenido inmóvil y rígida mirando al espacio por encima de nuestras cabezas, en una actitud tan solemne y desdeñosa al mismo tiempo, que nada podría dar idea de su grandiosidad sino la Minerva de Fidias en lo alto del Acrópolis, si hubiéramos tenido la suerte de que esta obra maestra de la antigüedad pagana llegase intacta hasta nuestros días.» ${ }^{14}$

Así pues, en este tipo de novelas en primera persona el uso de la tradición clásica tiene, entre otras, una función de distanciamiento entre el autor y el narrador, permitiendo que el primero informe al lector real de unas características que el personaje narrador nunca diría al lector ideal, bien por orgullo bien por modestia.

En otras novelas de Palacio Valdés con narrador heterodiegético este parece ajustar su uso de la tradición clásica al medio social de los protagonistas. Si comparamos tres novelas muy próximas en el tiempo como José (1985), Riverita (1986) y Maximina (1987) podemos comprobar la disparidad de la presencia de referencias clásicas entre la primera y las dos segundas. Estas dos podemos tratarlas en conjunto porque, en puridad, la segunda es continuación de la primera ${ }^{15}$. El tema de José es, como dice el propio editor moderno de la obra, Jorge Campos, «una poco complicada intriga amorosa entre gentes sencillas: en unas normales relaciones amorosas se interponen obstáculos que acabarán por ser franqueados en un feliz desenlace» ${ }^{16}$. Las otras dos se centran en el recorrido vital de Miguel Rivera, una persona que vive toda su vida según ideales de nobleza (en sus múltiples significados, no solo de personas de ilustre 
linaje sino también en sus acepciones de inteligencia, generosidad, honra y estimación), y que va viendo poco a poco cómo el mundo moderno pertenece a otra clase, la de aquellos que saben mantenerse a flote en una sociedad materialista que recompensa a los más fuertes con la supervivencia.

Ajustándose al medio que está relatando, el narrador de José apenas si hace unas referencias a la tradición clásica que se pueden contar, literalmente, con los dedos de una mano. Solo cinco menciones vagas: a los dioses griegos y a las mujeres romanas en el prólogo de la novela ${ }^{17}$, la absolutamente banal expresión “AAllí fue Troya!” ${ }^{18}$ y otras dos que se justifican plenamente porque el narrador está hablando de personajes con mayor cultura. En una ocasión está realizando la descripción del marido de la tabernera, la señá Isabel, que es el maestro del pueblo donde transcurre la acción, Rodillero:

«Sentada detrás de la tabla de pino que servía de mostrador estaba la señá Isabel. Su esposo, don Claudio, maestro de primeras letras (y últimas también, porque no había otras) de Rodillero, se mantenía en pie a un lado cortando gravemente en pedazos una barra de jabón. La luenga levita que usaba, adornada a la sazón por un par de manguitos de percalina sujetos con cintas al brazo, y la rara erudición y florido lenguaje de que a menudo hacía gala, no eran parte a desviarle de esta ocupación grosera; diez años hacía que estaba casado con la viuda del difunto Vega, tendero y fabricante de escabeche, y en todo este tiempo había sabido compartir noblemente, y sin daño, las altas tareas del magisterio con las menos gloriosas del comercio, prestando igual atención a Minerva y a Mercurio.» ${ }^{19}$

Como es natural, el narrador deja escapar algo de "la rara erudición y florido lenguaje" del maestro, utilizando los dioses como antonomasia de la actividad que protegen. En la otra ocasión la tradición clásica se usa en combinación con otras tradiciones cultas al narrar la ayuda que a los humildes protagonistas presta el único aristócrata de Rodillero, el señor de Meira:

«En esta ocasión, como en tantas otras durante la Edad Media, fue necesario que el castillo viniese en socorro del estado llano. La casa de Meira, sin que ellos lo supiesen, ni menos persona alguna de Rodillero, trabajaba en favor suyo silenciosamente, con el misterio y sigilo diplomáticos que ha caracterizado siempre a los grandes linajes, a los Atridas, a los Médicis, a los Austrias. ${ }^{20}$

Se debe decir que es frecuente la unión de varias tradiciones cultas, como la de la antigüedad clásica, la historia medieval y del renacimiento, la bíblica, tanto en Palacio Valdés como en otros autores contemporáneos, como el padre Luis Coloma. Como vemos, en esta obra el uso de la tradición clásica es excepción, pero una excepción no arbitraria, pues se reserva para el momento en que aparecen actores de mayor cultura. En cambio, su uso es mucho mayor 
en Riverita y Maximina, obras, como dije, contemporáneas de la anterior. Ello se debe, parece claro, al carácter noble del protagonista, Miguel Rivera. Podemos escoger algún ejemplo aleatorio para mostrar este nivel cultural de la referencia clásica. Cuando se cuenta el abandono de una mujer por parte de su amante el narrador utiliza estos términos:

«Por este tiempo, el hijo del brigadier había cortado enteramente sus relaciones con la generala Bembo. No pocos esfuerzos caligráficos le costó aquel rompimiento. Las quejas de la nueva Ariadna venían diariamente por el correo, esparcidas en cinco o seis pliegos de letra menuda. Era necesario contestar a ella. Al fin, Teseo se cansó y las guardó filosóficamente en el bosillo. Entrado ya el inverno, Ariadna volvió a Madrid y no se pasaron quince días sin que la trompeta del escándalo pregonase sus amores con el secretario de la Embajada francesa. $»^{21}$

Se sirve así el narrador de una de las más famosas historias de abandono de la mitología griega. Para la descripción de la perfidia femenina, la que supuestamente realiza la mujer de un tío de Miguel, se recurre a la historia romana, específicamente a las mujeres del emperador Claudio:

«- Yo siempre pensé que era usted feliz en su matrimonio.

- ¡Lo era, Miguel! Lo era porque tenía una venda sobre los ojos. ¡Pluguiera a Dios que no se me hubiese caído...! Hubo un día en mi vida, tú lo sabes bien, en que, arrastrando el decoro de nuestra familia por el suelo, descendí hasta dar la mano a una mujer de muy diversa condición que la mía. Por este inmenso sacrificio, ¿no te parece que esa mujer debía besar el polvo que yo pisase...? Pues bien, esa mujer es una Mesalina.

- ¡Tío!

- Mejor dicho, una Agripina.» ${ }^{22}$

En esta misma novela, Maximina, se había servido el narrador de varias comparaciones mitológicas para describir la ira de un joven cadete despechado por las críticas burlonas de su profesor. Del largo fragmento podemos entresacar los trechos más interesantes que nos servirán para ilustrar uno de las funciones literarias más fructíferas de la tradición clásica en Palacio Valdés, la comparación ridícula. El cadete, un personaje insignificante que se da aires de una grandeza de la que carece, se equivoca por tres veces cuando el examinador de mecánica le pregunta la teoría del péndulo; tras los comentarios burlones del profesor de álgebra, uno de los miembros del tribunal examinador, se califica al cadete del modo siguiente:

«El hijo de Marte se retira tropezando con todos los objetos, porque no ve. El cuello más largo, la nuez más abultada, el corazón roído por el despecho y la cólera.» 
Su padre, no dispuesto a seguir pagando la carrera a un holgazán que poco provecho saca a los estudios, le informa que será a partir de entonces capataz en su fábrica de bujías, futuro que no parece digno al joven:

«-Si se ha de arrastrar mi dignidad hasta convertirme en un capataz de fábrica, valiera más que me sacasen ustedes al campo y me pegasen cuatro tiros.

- ¡Cuatro palos que te deslomen te voy a dar yo, haraganazo! ¡Aguarda, aguarda! Y el honrado fabricante giró en torno del despacho la irritada vista, y percibiendo un bastón de caña arrimado a una pared, se lanzó con furia a empuñarlo. Pero ya Aquiles, el de los pies ligeros, había salido de la habitación y en cuatro trancos se había retirado a su tienda.

Una vez en ella, después de haber dado vuelta a la llave con admirable escrupulosidad y haber escuchado atentamente un rato con el oído pegado a la cerradura, a fin de cerciorarse de que Peleo no había pasado del promedio del corredor, pudo entregarse libremente a la meditación.»

Rumiando su venganza prepara el borrador de una carta para citar a su examinador a duelo. Satisfecho de su misiva, el "heroico mancebo" se acuesta y se abandona en brazos de Morfeo. La mañana siguiente

«La Aurora divina, la del velo azafranado, escalaba ya las alturas del Guadarrama cuando el mancebo despertó en la misma fatídica disposición de ánimo. ¡Triste día, aquel que comenzaba, para una familia inocente (el profesor de Álgebra tenía seis hijos) si Júpiter no se hubiera apresurado a enviar a la cabecera del héroe a su hija Minerva en figura de ama de gobierno!»

La gobernanta intenta hacerlo entrar en razón con varios sensatos argumentos, entre ellos, que tal vez el profesor no hubiera tenido intención de burlarse de él, a lo que el joven cadete responde:

«-Aunque no haya tenido intención, el hecho es que se ha burlado, y yo no he tolerado hasta ahora, no tolero, no toleraré jamás que nadie se quede conmigo. Ya sabe usted que en este punto soy un hombre muy especial.

- Ya lo sé, Jacobito, ya lo sé. Tienes el genio lo mismo que tu abuelo (que en gloria esté). ¡Qué señor aquél! Era una pólvora. Figúrate que una vez, estando afeitándose, oyó un grito en el patio; volvió la cara tan deprisa, que se dió un tajo en las narices tremendo... Pero es necesario contenerse, hijo mío, reprimir un poco el genio para poder vivir en el mundo. Yo creo que si ese profesor se ha querido reír de ti, lo que debes hacer es reírte de él.

Tal fué, con leves variantes, el consejo que en los tiempos primitivos de la Grecia dió Minerva, la diosa de los ojos resplandecientes, al divino Aquiles en su famosa reyerta con el atrida Agamenón. Fuerza es reconocer que nuestro héroe no se mostró tan sumiso a las órdenes de la diosa como el hijo de Peleo. 
En vez de envainar, como éste, la espada inmediatamente, y someterse, se negó a incoar otro procedimiento que no fuese el de la fuerza. Lo único que doña Adelaida pudo conseguir, después de muchos ruegos, fué que aplazase para otro día la destrucción del profesor.» ${ }^{23}$

Después de este fragmento se habrá visto con bastante claridad lo que quise decir al denominar al procedimiento "comparación ridícula". En varias ocasiones utiliza Palacio Valdés este recurso, propio del realismo literario. Este movimiento, que tuvo su máxima expresión en la novelas, construye personajes de modo opuesto al romanticismo anterior. En el romanticismo se construyen personajes-tipo que permitan una identificación pasional del público con los protagonistas (Don Juan, el pirata de Espronceda, el enamorado que sufre.....). Esto era algo necesario para la comunión con el público, ya que personajes individualizados no lo consiguen -pues son esta o esta otra persona específica, identificable y única, y por lo tanto ajena a cada uno de los espectadores. Por el contrario, el realismo construye personajes que son individuos, sabemos su historia, sus orígenes, cada una de sus experiencias de vida que lo hacen ser como es, diferente a cualquier otro personaje y a cualquier persona real. E1 personaje realista es todo lo contrario a un universal, y los universales más paradigmáticos son los de la tradición clásica. Por ello, nada hay más opuesto al individuo específico y muchas veces ridículo de la novela realista que el universal representante del género humano que supone el mito o la referencia clásica. El choque es brutal. Por ese motivo hay muchas novelas de Palacio Valdés donde el mito solo surge cuando se intenta ridicularizar un individuo, como en el fragmento que vimos.

Una novela donde podemos ver con claridad este uso es La fe. En ella, un joven sacerdote pasa por una experiencia de dudas en la firmeza de su fe y sufre por ello. Es falsamente acusado de rapto e intento de violación por una beata que lo tienta y a la que desprecia, pero su parodia de juicio y su condena pública coincide con la recuperación de su fe perdida, por lo que al final de la novela se pone al descubierto la futilidad de las preocupaciones mundanas como ambición o incluso honra, al coincidir su máxima humillación social con su mayor alegría interior y espiritual. El tema de la novela se presta a las referencias católicas y bíblica y poco a las clásicas. Sin embargo, estas aparecen aquí y allí en contextos de comparación ridícula. Por ejemplo, en las rústicas celebraciones del pueblo para la inauguración de la nueva iglesia parroquial de Peñascosa. El tono irónico con que el autor cuenta toda la escena se ve aderezado con estas referencias clásicas. Después de entonar un himno, lamentable no solo porque fuera sombrío como un lamento y de pésima confección a juzgar por las dos estrofas con las que el narrador castiga al lector, se dice:

«Este himno de corte cásico, y que bien puede compararse, sin desmerecer, 
con los más inspirados de los sacerdotes salios, en el caso de que conociésemos alguno, despertó inmediatamente en los comensales y en el público mil ideas de progreso indefinido y perfectibilidad. Por un momento todos aquellos espíritus elevados vivieron dos siglos más adelante y vieron con los ojos del alma una Peñascosa ideal cuajada de fábricas y cervecerías. ¡Poder maravilloso de la poesía! Se aplaudió furiosamente con las manos y con las cucharillas. Y aunque algún personaje de espíritu ligero y afeminado manifestó por lo bajo que lo que él aplaudía eran los ojos negros y los dientes blancos de las peñascas, tenemos la certeza de que la mayoría supo apreciar perfectamente la intención pura y el clasicismo del himno del vate de Peñascosa»

Ante los aplausos, salió don Gaspar, el autor del himno, quien a su vez hizo salir a otro señor regordete, el director de la murga, que saludaron, se felicitaron mutuamente y se abrazaron sobre el escenario, provocando la gesticulación, el redoblar de los aplausos y hasta las lágrimas de la audiencia.

«Aquello fué un vértigo, un delirio; más de diez minutos duró el estrépito, mientras Euterpe y Talía permanecieron estrechamente abrazadas. Cuando empezó a sosegarse el tumulto se oyó una voz que dijo: “¿Que se besen!” Al parecer, quien lanzó este grito fué un periodista de Lancia. Si se trataba de una broma, la verdad es que tenía bien poca gracia. Burlarse, en aquel acto solemne donde se festejaba la regeneración moral y material de Peñascosa era una insolencia, y como decía muy bien don Juan Casanova, "no daba buena idea de la cultura de la prensa de Lancia". No se besaron, pues, aunque don Gaspar mostró ciertas tendencias a hacerlo, aproximando demasiadamente sus narices color violeta al rostro del aparecido; pero éste lo retiró, dando pruebas de prudencia, pues se hablaba en términos muy graves por Peñascosa de las narices de don Gaspar.»

A continuación hubo discursos y lectura de poemas, a cuál más pesado, y finalmente otra intervención de don Gaspar:

«En medio de un silencio religioso, el famoso vate de Peñascosa comenzó a leer con voz dramática una Oda a la religión. Los temas sagrados no eran su especialidad. Había preferido siempre poner la lira al servicio de la libertad y de las ideas democráticas. Su mejor composición era un soneto al pacto sinalagmático bilateral. Comprendiendo, sin embargo, con profunda intuición, el sublime destino que el cielo le había designado, cantaba, como los vates y semidioses de la antigüedad, todo lo que se ofrecía a su vista, la paz y la guerra, la democracia y los señoríos, la religión y el libre pensamiento.» ${ }^{24}$

No es necesario insistir en el ridículo de la comparación del himno con los cantos salios, de don Gaspar con Talía y el director de la murga con Euterpe, y del poeta local con Orfeo, que será probablemente el semidiós aludido. 
Esta función se ve del mismo modo realizada en otros autores contemporáneos, aunque con sutiles diferencias. El padre Luis Coloma tuvo bastante éxito con su novela Pequeñeces. Probablemente, más que su valor literario, aunque no es escaso, tuvo que ver la clara identificación de los personajes de su novela con personalidades reales de su tiempo. Pequeñeces, centrada en la sociedad aristocrática y en sus intrigas para apoyar a la monarquía alfonsina en la época de la Restauración, es una obra con intención satírica que se sirve en muchas ocasiones de la deformación hiperbólica y de la metáfora. En este contexto, el uso de las refencias clásicas se realiza de forma sistemática para la ridiculización, muchas veces de forma que el narrador atribuye un apodo a un personaje por su forma de actuar y lo mantiene durante gran parte de la obra, como por ejemplo:

«Con mesurado tono y severidad paterna contestó entonces el sabio Mentor al joven Telémaco, enterándole del regalo hecho por mademoiselle de Sirop a la kermesse, del justo enojo de Currita al recibir aquel ultraje, que revelaba la traición del amigo íntimo a quien tantos beneficios había prodigado, y de la ferocidad con que las lenguas murmuradoras se habían echado sobre la aventura, comentándola y riéndola a mandíbula batiente. El sesudo Mentor terminaba con protectora solicitud y paternal indulgencia: "Tu ligereza ha sido grande; pero inventa una disculpa, apresúrate a venir y trataremos de arreglarlo".

Jacobo no se hizo repetir el aviso, y cinco días después el joven Telémaco y el sabio Mentor se presentaban en el boudoir, es decir, abordaban a la playas de la isla de Ogigia, retiro encantador de la invulnerable Calipso...La escena debió de ser conmovedora; mas ninguna ninfa hizo traición a la diosa, revelando lo que oyó o pudo ver en la misteriosa gruta, e ignórase al presente cómo llegaron los tres personajes a la perfecta avenencia que todo Madrid pudo observar desde entonces entre ellos. $\aleph^{25}$

Todas las cursivas son del autor. Se debe notar, en efecto, que el padre Coloma llama la atención sobre los apodos que va atribuyendo a los personajes, y que en muchas ocasiones, como en esta, se repiten sin que se haga especialmente alusión a las características de los personajes que los convierten en sus trasuntos mitológicos.

Podemos ver, así pues, que en sus primeras novelas, antes del alarde de clasicismo que mostró en La aldea perdida, Armando Palacio Valdés utilizó la tradición clásica con mesura y con criterio, sirviéndose de ella en momentos específicos de la acción. En las novelas en primera persona consigue, gracias a su uso, transmitir una información al lector que se superpone a la información transmitida por el narrador. En las novelas en tercera persona su empleo es diversificado, pero donde realiza una función más interesante es en lo que 
La función literaria de la tradición clásica en las primeras novelas de Palacio Valdés

podemos llamar "comparación ridícula", donde se aprovecha de la disparidad entre el universal clásico y la intrascendente pequeñez del personaje para originar la comicidad. 
${ }^{1}$ En LAGUNA MARISCAL, G. (2004), «¿De dónde procede la denominación “Tradición Clásica”»", Cuadernos de Filología Clásica. Estudios Latinos, 24, pp. 83-93.

${ }^{2}$ En la obra HIGHET, G. (1949), The Classical Tradition. Greek and Roman Influences on Western Literature, Oxford, Clarendon Press.

${ }^{3}$ Este texto estaba accesible on-line, a 29 de junio de 2012, a partir de la edición de 1941 (Comparetti, D. (1941), Virgilio nel Medioevo, Firenze, La Nuova Italia): http://www. classicitaliani.it/index178.htm.

${ }^{4}$ En García Jurado, F. (2007), «¿Por qué nació la juntura «Tradición Clásica»? Razones historiográficas para un concepto moderno», Cuadernos de Filología Clásica. Estudios Latinos, 27, 161-192, maxime 165.

${ }^{5}$ García Jurado, «¿Por qué nació ....166-167.

${ }^{6}$ Cf. Conte, G. B. - Barchiesi, A. (I 993 $\left.{ }^{2}\right)$ ( I ${ }^{\text {a }}$ ED. I 989) «Imitazione e arte allusiva. Modi e funzioni dell'intertestualità», en G. Cavallo, P. Fedelli, A. Giardina (eds.), Lo spazio letterario di Roma Antica, Vol. I: La produzione del testo, Roma, Salerno Editrice, 8 I-I I 4 .

${ }^{7}$ Gracias, en gran parte, a la publicación en inglés del libro de Conte, G. B. (1986), The Rhetoric of Imitation. Genre and Poetic Memory in Virgil and Other Latin Poets, translated from de Italian, edited and with a foreword by Charles Segal, Ithaca and London, Cornell University Press.

${ }^{8}$ Por ejemplo, Leonardo Romero Tobar, «La aldea perdida en la trayectoria de la novela moderna. De la novela realista a la novela intelectual», en Elena DE Lorenzo ÁLvAREz y Álvaro Ruiz de la Peña (eds.), Palacio Valdés, un clásico olvidado (1853-2003). Actas del congreso celebrado en Entralgo - Laviana (24-26 de septiembre de 2003), Laviana, KRK, ediciones, 2005, pp. 303314 , la estudia en su contexto y demuestra que para el autor asturiano esta obra era diferente de las anteriores, como demuestra el hecho de haberla subtitulado Poema de costumbres campesinas, en lugar de Novela de costumbres... como había subtitulado las novelas anteriores (p. 309). En la obra es evidente, en efecto, los rasgos líricos y el abandono de muchas técnicas realistas.

${ }^{9}$ La presencia de la tradición clásica se yergue en esta obra como uno de sus ejes fundamentales, como ha sido reconocido por todos sus comentadores. Por ejemplo, Leonardo Romero Tobar, «La aldea perdida en la trayectoria...»; José Manuel Martín Morán, «El espacio en la novela regionalista. El caso de La aldea perdida, de Armando Palácio Valdés», Artifara, n. 4, (gennaio - giugno 2004), sezione Addenda, http://www.artifara.com/rivista4/ testi/aldea.asp, consultado a 21-enero-2011; Álvaro RUIz DE LA PEÑA, «Introducción» a la ed. de La aldea perdida, Madrid, Espasa-Calpe, 1993; Francisco Caudet, «La aldea perdida (1903) novela de tesis», en AA. VV., Estudios sobre Armando Palacio Valdés, B. Dendle \& S. Miller (eds.), Ottawa, Dovehouse, 1993, pp.85 -97.

${ }^{10}$ Las citas a estas dos obras se harán, respectivamente, según las siguientes ediciones: Palacio Valdés, A. (1949), La hermana San Sulpicio, Edimburgo, Ed. Nelson; Palacio Valdés, A. (1942), Obras escogidas. Con un prólogo de Luis Astrana Marín, Madrid, M. Aguilar Editor.

${ }^{11}$ La hermana..., 132-3.

${ }^{12}$ La hermana..., 448.

${ }^{13}$ La alegría..., 867. La cita de Eurípides pertenece a una intervención del coro en Medea (versos 824-830), pero no he podido averiguar qué traducción maneja Palácio Valdés.

${ }^{14}$ La alegría..., 906. Plinio da una buena descripción de la estatua en Nat. Hist., 36.5. Quizá sea la fuente de Palacio Valdés.

${ }^{15}$ Las citas a José se harán según la siguiente edición: Palacio Valdés, A. (1997), José. Edición de Jorge Campos, Madrid, Cátedra. Las que se realicen a las otras dos se harán según la edición citada de las Obras escogidas.
${ }^{16}$ José, 21.
${ }^{17}$ José, 60 y 61.
${ }^{18}$ José, 66.
${ }^{19}$ José, 75-76. 
La función literaria de la tradición clásica en las primeras novelas de Palacio Valdés

\author{
${ }^{20}$ José, $175-176$ \\ ${ }^{21}$ Riverita, 329. \\ ${ }^{22}$ Maximina, 389. Como es natural, la referencia a Mesalina quiere insinuar su promiscuidad \\ e infidelidad, y la mención a Agripina quiere insinuar que le causará la muerte. \\ ${ }^{23}$ Maximina, 361-4. \\ ${ }^{24}$ La fe, 1015-6. La cita se hace según la edición antes mencionada de las Obras escogidas. \\ ${ }^{25}$ Coloma. L. (1998), Pequeñeces. Edición de Enrique Miralles, Madrid, Editorial Espasa- \\ Calpe, S.A., pp. 452-3.
}




\title{
ÉRASE UNA VEZ UN POETA LAUREATUS
}

Manuel Molina SÁnchez
Universidad de Granada

\begin{abstract}
"Todos los hombres que aspiran a distinguirse del resto de los animales deben poner todo su empeño en no pasar la vida en silencio como las bestias, que la naturaleza forjó inclinadas a tierra y sumisas a su vientre".
\end{abstract}

(Salustio, Conjuración de Catilina, 1.1)

Lo que la historia nos ha legado de la vida del poeta Giacomo o Cosimo Baraballo $^{1}$ parece contradecir, sin embargo, el razonamiento del célebre historiador romano. Y no porque sus días transcurrieran "en silencio", sino porque, por una vez al menos, la fama de la bestia se impuso sobre la persona.

Los hechos que vamos a narrar a continuación son bien conocidos en el ámbito italiano y describen la relación existente entre un papa, un poeta y un elefante.

Corría el mes de marzo del año de 1514 cuando, en un alarde de generosidad destinado a fortalecer los vínculos de amistad con el Vaticano, el rey Manuel I de Portugal envió al papa León X, como regalo por su elevación al trono pontificio el año anterior, un preciado conjunto de enseres y animales, representativo de sus conquistas en la India y el Norte de África. Entre la multitud de aves orientales - papagayos, loros, gallinas indias- y especímenes raros -simios, un leopardo, un caballo persa-, se hallaba uno ciertamente exótico para la época: un elefante indio, cuya presencia causó gran impacto en la corte papal. Hacía mucho tiempo, desde la Antigüedad romana, que en Italia no se veía un animal semejante y, en consecuencia, la llegada a Roma del paquidermo fue festejada como todo un acontecimiento. ${ }^{2}$ Marino Sanuto, un cronista de la época, cuenta con detalle cómo fue la marcha a palacio del cortejo:

"Prima le famiglie del Papa e i cardinali, secondo il solito, poi le trombette, i pifferi di essi Oratori [del rey de Portugal], poi la loro famiglia con sajoni di velluto e cavalli bellissimi. Da po' l'elefante grande con una coperta di broccato d'oro, con un moro che gli sedeva sopra la testa ed un altro saracino a piedi che lo menava, e avanti l'elefante andava un moro a cavallo sopra un gianetto bianco, e sopra la groppa aveva in piedi una pantera che pare un leopardo. Da poi questo, venivano i gentiluomini di detti ambasciatori sopra mule bellissime, con finimenti di velluto, li passanti d'oro, che mai fu vista più ricca cosa. Vestivano chi di velluto, chi di raso, chi di damasco, chi di broccato, con molte gioie intorno e perle, con palafrenieri vestiti di seta. Da poi veniva un 
ambasciatore sopra un cavallo zanetto biondo bellissimo, coperto di broccato d'oro, la testiera a la moresca di smalto d'oro, con palafrenieri vestiti di seta, e lui vestito di velluto e raso nero a l'usanza del Portogallo; in testa una scuffia d'oro e sopra un cappello di velluto ricamato di perle e pendenti di perle, quale vien stimato ducati 6000 e più, e due altri ambasciatori vestiti benissimo con gran gioie attorno, sopra mule bellissime e ben in ordine, e tutti gli altri Oratori, che si trovano in Roma, dietro, e prelati”. ${ }^{3}$

El mismo Sanuto describe el elefante como un animal "bellísimo, de unos seis años de edad, grande como tres bueyes, que comprende dos lenguas, como criatura humana, la portuguesa y la india, llora como una mujer y finaliter, por hablar hacia fuera, hace todo esto como si fuese criatura humana" ${ }^{4}$

No faltan tampoco poemas que celebran la llegada de Annón, el nombre con que fue bautizado nuestro elefante (Annone en italiano) ${ }^{5}$. Entre ellos cabe destacar esta Elegia del aretino Giovanni Capitone:

Si te, Elephas, Lybico credas servire Leoni,

Falleris: e caelo decidit iste Leo.

Hic tuus est Dominus, terrarum gloria prima ${ }^{6}$,

Tergeminum decorat cui diadema caput.

Inter mortales plusquam mortalis habetur,

Claudere cui fas est et reserare polum ${ }^{7}$.

Si servire Deo vere est regnare, Leoni

Dum servis, regnas, nam Leo in orbe Deus.

Forsitan bic inter caeli te signa locabit,

Quando inter superos ille relatus erit.

Quid natale solum patriasque revisere silvas

Plus cupias? Sedes est sacra Roma Deum.

Non tu Parthorum regum male fida subibis

Tecta, sed heroum caelicolumque lares.

In Vaticano cum tu stabulabere colle,

Delicias orbis jure tenere putes.

Fertilitate locus pomorum et vere perenni

Hesperidumque hortos praestat et Alcinoi?

Quid memorem dulces auras caelumque salubre?

Elysia bic credas arva colenda piis.

Si te religio, Venus alma et gloria tangunt,

Religio hic regnat, gloria et alma Venus.

Bellandi studiis si flagres Martis et oestro,

Romuleam hanc urbem Martia turba colit.

Hac socia, invicti auspiciis ductuque Leonis, Ad Latios referes clara trophea Deos.

Laeta triumphalis ductabis fercula pompae,

Vel Capitolino plaustra superba Jovi. 
Vive diu hic laetus dans omina fausta Leoni,

Vescere cum Domino nectare et ambrosia.

Schoenobates ${ }^{9}$ fias, varios disce edere ludos,

Quis dominum curis mille levare queas.

Sic Latio poteris gratissimus esse Tonanti

Atque auram populi conciliare tibi.

Ne meditere fugam; quod si moriaris in urbe,

Non poteras fato nobiliore mori.

Pontificem in summum testabere Regis amorem,

Cum magna et sancta foedus amicitia.

O felix animal, fausto sub sydere ${ }^{10}$ natum,

Quod tam nobilitant Carmina, Roma, Leo. ${ }^{11}$

Incluso Pasquino, la famosa estatua portadora de anónimos mensajes provenientes, en su mayoría, de las malas lenguas, se hizo eco del hecho, como lo reflejan estos versos:

Roma mage simiolas, capreas, genus omne ferarum

Quo vix India, vix Aphrica tota tulit,

Immanemque elephantem, nam regnante leone,

Rege suo, debent in precio esse ferae. ${ }^{12}$

Lo cierto es que la embajada portuguesa y sus regalos al papa León X, especialmente el elefante, generaron toda una serie de noticias, recogidas en las crónicas y literatura de la época, que han llegado hasta nosotros y han sido objeto de un considerable número de estudios. ${ }^{13}$

También la pintura se sumó a este afán por inmortalizar la figura de Annón. Nada menos que el mismísimo Rafael Sanzio diseñó varios dibujos del animal, de los que uno se conserva en Berlín (Preussischer Kulturbesitz Kupferstichkabinett) y otro en Harvard (The Fogg Art Museum). Asimismo, a la muerte del elefante, y por deseo expreso del papa, Rafael se encargó de realizar personalmente en las paredes de acceso al Vaticano un fresco mural que representaba a Annón a tamaño natural. Del mural, hoy inexistente, y del epitafio que lo acompañaba se tienen noticias por un ejemplar, custodiado en la Biblioteca del Monasterio de El Escorial, perteneciente al libro de diseños del arquitecto portugués Francisco d'Ollanda (Roma, 1539) ${ }^{14}$, en cuyo fol 31v se reproduce un dibujo del elefante y la inscripción. ${ }^{15}$ Ésta reza como sigue:

$D$

$M^{16}$

MONTE SVB HOC ELEPHAS INGENTI CONTEGOR INGENS ${ }^{17}$

QVEM REX EMANVEL DEVICTO ORIENTE LEONI

CAPTIVVM MISIT DECIMO QVEM ROMVLA PVBES 


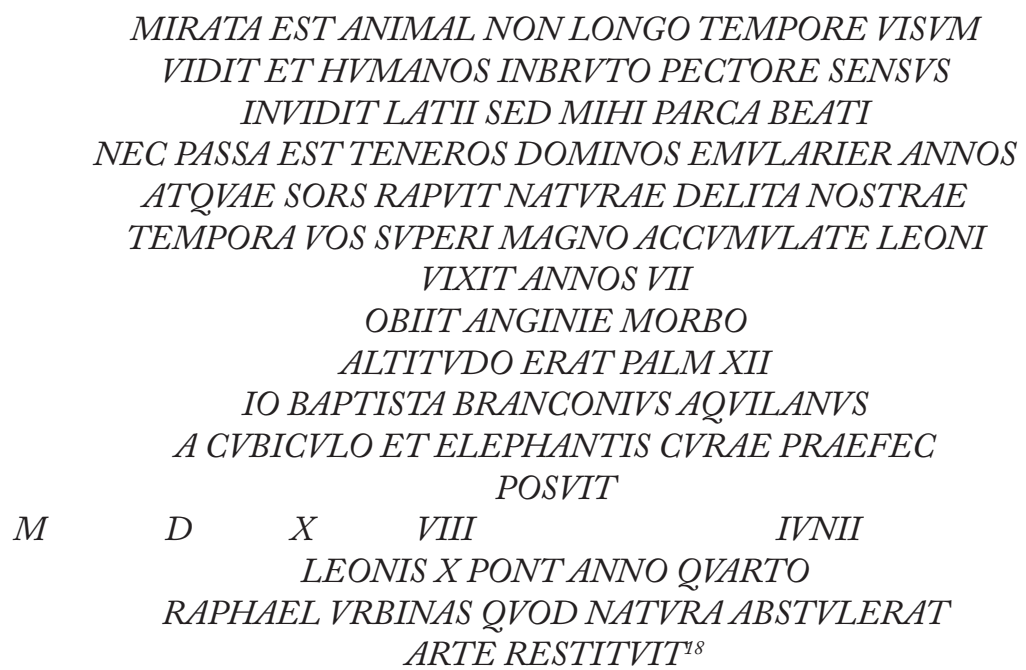

Pues bien, uno de los sucesos más sonados en relación a nuestro elefante fue la coronación del poeta Baraballo, abad de Gaeta. ${ }^{19}$ Conocida es la afición del papa León X por rodearse de artistas, literatos y pintores, así como, casi en igual medida, de bufones, poetastros y petimetres, con el fin de organizar espectáculos en los que mofarse a su costa. La coronación de Baraballo forma parte de estos últimos. Contaba también el Pontífice para tan honroso fin con la inestimable ayuda del cardenal Bibiena. Al respecto dice Pablo Giovio, biógrafo del papa:

Erat etiam Bibienna mirus artifex hominibus aetate vel professione gravibus ad insaniam impellendis, quo genere hominum pontifex adeo flagranter oblectabatur, ut laudando et mira eis persuadendo, donandoque plures ex stolidis stultissimos et maxime ridiculos efficere consuevisset. ${ }^{20}$

Los hechos ocurrieron del siguiente modo. Baraballo, un versificador irrisorio, que se consideraba alter Petrarca y se había otorgado a sí mismo el apelativo de "Archipoeta"21, pidió al papa el honor de ser laureado en el Capitolio. E1 Pontífice, con el beneplácito de Bibiena, vio en esta súplica una ocasión inmejorable de montar uno de sus espectáculos burlescos preferidos y accedió a la petición, fijando para el 27 de septiembre de aquel año (1514), festividad de los Santos Cosme y Damián, patronos de la casa de los Médici, el día de la coronación.

Llegó, pues, el esperado día y Baraballo, ansioso de gloria, acudió a palacio para mostrar sus inigualables dotes y recibir su premio, no sin antes haber hecho caso omiso a una delegación de ciudadanos y parientes de Gaeta que, conocedores de las frívolas intenciones del papa y deseosos de preservar el buen nombre de la familia Baraballo, habían intentado en los días previos disuadirle 
de su error. Para entonces la sede papal y los alrededores del Vaticano se habían engalanado con todo lujo de adornos y lustrosos preparativos. Los cardenales, la guardia pontificia y representantes de los diversos estamentos de la ciudad habían sido convocados por el papa para asistir a tan distinguida ceremonia. Poetas como Bernardo Accolti, Francesco Filomuso y Angelo Colocci leyeron sus composiciones ensalzando la figura del abad. Baraballo también leyó las suyas ante el pasmo de los presentes, que a duras penas podían contener la risa. Hasta se representó una comedia, hoy perdida, obra de Filippo Beroaldo el Joven. ${ }^{22}$

Concluida la ceremonia en el Vaticano, Baraballo, vestido a la antigua usanza, con toga y laticlavo de púrpura y oro, montó en Annón para dirigirse al Capitolio. La comitiva inició la marcha entre trompetas, tambores, personal de compañía y el gentío que se agolpaba a su paso entre gritos y aplausos. Lo cierto es que al llegar al puente de Sant'Angelo (entonces puente de Adriano), el tumulto debió ser tal que Annón, atemorizado, se negó a seguir y Baraballo se vio obligado a bajar del animal y a perderse por las calles de Roma entre el público asistente. Con ello puso fin a su anhelada coronación.

Giovio nos lo cuenta de esta guisa:

Baraballi quoque Caietani eximiae stoliditati, procacius quam sacrosanctum pontificem deceret, illusit, quum ille insulsissimos versus ab omni vocum ac numerorum enormitate ridendos facere et palam recitare soleret, seque alterum Petrarcham in Etruscis rythmis esse praedicaret. Eo enim perpetuis adulationibus inflammatum gloriae cupiditate perpulit, ut meritum gestandae laureae honorem postularit, ac subinde ut insigni pompa in Capitolium duceretur, quod in Capitolio Petrarcham coronatum quondam fuisse audivisset. Tanta vero vis singularis insaniae fuit, ut quum ad famam publici apparatus legatio amicorum et affinium Caietanorum propere in Vrbem convolasset, ut hominem a concepto furore deterrerent, acerbissimis verbis eos repulerit, tanquam maligne benignitatem pontificis interpretantes, ac rarissimi honoris immortali gloriae suae prorsus invidentes. Ergo quod vix credibile foret, nisi ea nos mira cum voluptate vidissemus, sexagenarius senex honesta ortus famiIia, proceritate, vultu et canicie venerabilis, toga palmata et lato clavo, auro purpuraque nitenti, caeterisque triumphi sumptuosis insignibus exornatus, in convivium praecinentibus tibiis deducitur, quum de more pontifex diem festum Cosmae et Damiano Mediceae familiae Divis tutelaribus dedicatum bilarius celebraret. Ibi quum diu ad ostentationem absolutae artis ineptissime multa carmina decantasset, omnibus iam in ipsa risus compressione defatigatis, ad extremum in area Vaticana despectante pontifice elephantem adscendit, aurato ephippio superstante triumphali sella instratum. Caeterum inter tympana, et tubas, et voces acclamantis populi, consternata bellua, ultra pontem Hadriani deduci pompa non potuit, cuius triumphi memoriam lignarii caelatores quum tessellato opere lascivirent, in interioris pontificii cubiculi foribus scitissime inscriptam reliquerunt. ${ }^{23}$ 
Como era de esperar, la fallida coronación de Baraballo, además de ser recogida por las crónicas, dio lugar a cierto número de manifestaciones literarias, algunas de las cuales han sido ya editadas y estudiadas. Es el caso de este soneto, transmitido como pasquinada anónima:

Il nostro archipoeta Baraballe, posto su l'archibestia di lontano pare, e da presso è, un sí bel capitano che de risa scoppiar fa le farfalle.

Ponli quattro saette su le spalle, parrà Alessandro; ponli un fiasco in mano, dirrai sia Bacco, il principe indiano; cávali un occhio e fia propio Aniballe.

Nominativo: hic poeta è'l matto, el Donato moderno cosí dice, che mutato ha l'antico senno affatto.

Non si chiami el Petrarca piú felice: s'egli d'alloro ornato fu quel tratto, questo or è insin di foglie di radice,

e poi che tutto lice io ho speranza ancor l'anno sequente teologo veder Giovan Manente. ${ }^{24}$

También Maquiavelo en su Asno de oro (cap. VI) alude a Baraballo:

Una figura, che pareva viva, Era di marmo scolpita davante Sopra il grand'arco, che l'uscio copriva.

E come Annibal sopra un elefante, Parea che trionfasse, e la sua vesta Era d'uom grave, famoso e prestante.

D'alloro una ghirlanda aveva in testa, La faccia aveva assai gioconda e lieta, D'intorno gente che li facean festa.

Colui è il grande abate di Gaeta, Disse la donna, come saper dei, Che fu già coronato per poeta.

Muy poco conocidos, sin embargo, son dos textos compuestos en fecha muy cercana al suceso de la coronación. El primero es un breve Diálogo 
anónimo de finales de 1514 o, a lo más tardar, de $1515,{ }^{25}$ del que hasta ahora no se tenía más noticia que la pura referencia, ${ }^{26}$ perteneciente al género literario del "pasquín", ${ }^{27}$ si bien no recogido en las colecciones canónicas del género. ${ }^{28}$ Su estudio y edición han sido objeto de una reciente publicación en la revista digital TeatrEsco ${ }^{29}$; sus características generales, por lo demás, han sido también perfiladas en un Congreso en Nueva Delhi. ${ }^{30}$

El segundo es el Prólogo que encabezaba la comedia de Beroaldo el Joven, representada el 27 de septiembre de 1514 . Como ya dijimos, no se conserva la comedia, pero sí su Prólogo. ${ }^{31} \mathrm{El}$ texto, citado aquí y allá por su título, ${ }^{32}$ no ha sido recogido íntegro ni estudiado en ningún lugar ${ }^{33}$. Lo presentamos aquí, pues, completo para su mejor conocimiento y comprensión.

PROLOGVS IN COMOEDIAM HABITAM

IN CORONATIONE BARABALLIS ${ }^{34}$

\section{GENIVS}

Heus, heus, tacete spectatores optumi $i^{35}$.

Iunet uocasse spectatores optumos,

Nam, ni tacetis, non spectatores optumos,

Sed uos uocabo nugatores pessumos.

Mibi loquendum est multibibo et merobibo ${ }^{36}$.

Nunc nostra conducta est lingua ${ }^{37}$, uestri oculi.

Vos, qui molesti estis Principis auribus

Atque ineptis susurrationibus,

Ambagibusque longis atque friuolis

Vobis fauorem aucupari creditis,

Cedite paululum, date otiosas mibi

Aures Leonis: alius erit garriendi locus.

Breuiloquum esse hominem seruum decet.

Stent medici procul, qui quasi aegroto assident,

Quos pol helleboro $0^{38}$ tam indigere arbitror

Quam me pecunia, aut Donatum memoria,

Lyppuтue uisu, aut Cynicum modestia. ${ }^{39}$

Domus Magister in domum rationes conferat,

Nec disputet hic quomodo diminuat,

Aut unciatim det Diaria familiae. ${ }^{40}$

Domi podagram (si sapit) curet suam,

Quamquam chiragram medici docti uocant. ${ }^{41}$

Sed seu podagra, siue chiragra est magis,

Aquam bibendo eam sobrie curet sobrius.

Porro Datarius cum Supplicationibus ${ }^{42}$

Hic disputare desinat an debeat dare

Duo triaue incompatibilia, 
An sub eodem tecto, an sub dio duit,

Gratis ubique omnibus danda omnia.

Quod uos mibi ni obtemperetis, protinus

Commilitones conuocabo buc buc meos, ut

Protum, Marianum, Catelacium,

Cecchonum, Cecchottum, Cecchettum, Cecchinum,

Ioannem Manentem, Romanellum, Christophorum, ${ }^{43}$

Archidoctorem dogmatis Mosaici, ${ }^{44}$

Ipsumque Baraballem Imperatorem meum,

In gratiam cuius haec agitur Comoedia,

Qui uos uelitis nolitis reddent tactos,

Fessosque pugnis abire cogent domum.

Tacetis? Ergo qui sim, cur huc uenerim

Mecum scietis pariter aeque simul.

Genium Latini me, Comum Graeci uocant.

Mania mater est mibi, Morus pater.

Festis diebus praesum et festiuis uiris,

Ideoque prodii Genius in hanc diem. ${ }^{45}$

Qui sim tenetis iam, cur buc uenerim

Atque argumentum accipite Comoediae.

Marphorius Graece scripsit Moridaphneam,

Pasquillus hanc mox uortit Stultilauream: ${ }^{46}$

Graues Poetae utrique atque alias Statarii,

Verum hoc loco ob materiam Motorii. ${ }^{47}$

Senex Baraballes condere coepit carmina, ${ }^{48}$

Furore bacchico percitus acerrime.

Qualis Poeta, talis est et Musicus,

Aeque Architectus, aeque uir politicus,

Amator aeque, aeque Saltator quoque,

Iuris peritus ${ }^{49}$ ut Medicae artis sciens.

Nam iura nouit optima Gallinacea,

Stomachoque sciens inutiles multum aquas,

Monet bibenda uina. Nouit Ficedulas

Salubriores Sturnis atque Gracculis.

Tantam ob scientiam ut premium ferat suum,

Omnes Dei et Deae coronam illi offerunt,

Appollo, Iuppiter, Pallas, Mercurius,

Mauors, Lycus atque Hercules ${ }^{50}$, et Venus,

Cui cum Mercurio conuitianti grauiter

Vulcanus inuocatus auxilio aduenit,

Qui uinculis alligat Deos omnes ferreis.

Mox et Cybele atque ipsa aeternitas

Sententiam ferunt dignumque iudicant

Omnibus coronis Baraballem maximum.

Ita septuplici ${ }^{51}$ corona fit coronatissimus, 
Archipoeta, Archiarchitectus, Archimusicus, Archipoliticus, Archiamator, Archisalius, Archigeometra, Archilyristes, Archiomnia. Mox Archibelluae insidens altissimae Turrigero Elephanto, quo Rex Callicuticus ${ }^{52}$ Aegit ${ }^{53}$ triumphum de Pigmeis Indicis, Geminisque curribus late praeeuntibus, Latoque Clauo conspicuus Romam petet, Vbi a Senatu, populoque, Equitibusque, Plausuque risuque ${ }^{54}$ excipietur hilarem in modum. Tantum est, ualete, uiuite, bibite ${ }^{55}$ memores mei. ${ }^{56}$

Con la presentación de este Prólogo damos por terminado nuestro trabajo. El episodio de Baraballo y el elefante Annón constituye un capítulo más en la larga serie de desmanes propiciados por el papa León X, de los que Giovio dio buena cuenta en su biografía del Pontífice. Ellos son responsables, en gran medida, de los profundos cambios iniciados por Lutero y la Reforma protestante, que transformarían radicalmente el mundo cristiano occidental. ${ }^{57}$ 


\section{Bibliografía}

Alonso Asenjo, J. 1998: «Panorámica del teatro estudiantil del Renacimiento español», en M. Chiabò - F. Doglio (eds.), Spettacoli Studenteschi nell'Europa Umanistica (XXI Convegno Internazionale del Centro di Studi sul Teatro Medioevale e Rinascimentale, Anagni, 20-22 Giugno 1997), Roma, pp. 151-191.

Alonso Asenjo, J. 2011: «¿Pasquín en las aulas? El Dialogus in donatione laureae Baraballis», en V. Maurya - M. Insúa (eds.), Actas del I Congreso Ibero-asiático de Hispanistas Siglo de Oro e Hispanismo general (Delhi, 9-12 noviembre 2010), Pamplona, Servicio de Publicaciones de la Universidad de Navarra, pp. 33-43 (Publicaciones digitales del Grupo de Investigación. Siglo de Oro, GRISO). http://hdl.handle. net/10171/20216AlonsoAsenjo.pdf.

Bedini, S. A. 1997: The Pope's elephant, Manchester.

Beroaldo, F. 1530: Philippi Beroaldi Bononiensis iunioris Carminum ad Augustum Triuultium libri III. Eiusdem Epigrammaton liber ad Liuium Podocatharum Cyprium, Romae.

Cesareo, G. A. 1938: Pasquino e pasquinate nella Roma di Leone X, Roma.

Ciutiis, S. De 1899: Une ambassade portugaise à Rome au XVTe siècle, Naples.

Colonna di Stigliano, F. 1923: «L'Elefante di Leone X e il Poeta Baraballo», Roma. Rivista di Studie di Vita Romana 1, no 5, pp. 169-175.

Cruciani, F. 1983: Teatro nel Rinascimento: Roma, 1450-1550, Roma.

Domínguez Sánchez, S. 2005: «Expedición del documento pontificio a partir de Sixto V», Actas de las III Jornadas de la Sociedad Española de Ciencias y Técnicas Historiográficas, Boletin de la Sociedad Española de Ciencias y Técnicas Historiográficas 3, pp. 127-175. (También en ed. electrónica: http://descargas.cervantesvirtual.com/servlet/ SirveObras/01715741982364028560035/024705.pdf).

Ferrajoli, A. 1984: «Il Ruolo della Corte di Leone X. Cap. XVIII», Archivio Storico della R. Società Romana di Storia Patria 39 (1916), pp. 537-576, incluido en A. Ferrajoli, Il Ruolo della Corte di Leone X (1514-1516), a cura di V. De Caprio, Roma, pp. 455-494.

Giovio, P. 1551a: Pauli Iovii De vita Leonis Decimi, Florentiae.

Giovio, P. 1551b: Pauli Iovii Elogia virorum bellica virtute illustrium, Florentiae.

Grimal, P. 1981: Diccionario de Mitología Griega y Romana, Barcelona.

Lach, D. F. 1994: Asia in the Making of Europe, vol. II: A Century of Wonder, Book 1: The Visual Arts, Chicago. 
Marucci, V. - Marzo, A. - Romano, A. (eds.) 1983: Pasquinate Romane del Cinquecento, Roma, 2 vols.

Matos, L. De 1960: «Natura, intelletto e costume dell'elefante», Boletim Internacional de Bibliografia Luso-Brasileira 1, pp. 44-55.

Molina Sánchez, M. - Alonso Asenjo, J. (eds.) 2011: «El Dialogus in donatione laureae Baraballis. Pasquillus et Marphorius. Estudio, edición y traducción», TeatrEsco 4, pp. 63-102, http://parnaseo.uv.es/Ars/ teatresco/Revista/Revista4/03_Molina-Alonso.pdf.

Onori, L. 1910: «L'Elefante Annone e il Poeta Baraballo», La Lettura 10, pp. 1143-1146.

Paquier, J. 1900: De Philippi Beroaldi Junioris vita et scriptis (1472-1518), Lutetiae Parisiorum.

Pellizzari, A. 1914: Portogallo e Italia nel secolo XVI. Studi e ricerche storiche e letterarie, Napoli.

Pozzo, G. Da 2007: Storia letteraria d'Italia. Il Cinquecento. T. I: La dinamica del rinnovamento (1494-1533), Padova.

Rahn, O. 1982: Cruzada contra el Grial. La tragedia del catarismo, Madrid.

Roca Barea, Ma. E. 1994: «El Genius latino en las comedias de Plauto», Fortunatae 6, pp. 307-314.

Romano, A. 1991: Periegesi Aretiniane. Testi, schede e note biografiche intorno a Pietro Aretino, Roma.

Romano, A. 2006: «La satira di Pasquino: formazione di un genere letterario», en C. Damianaki - P. Procaccioli - A. Romano (eds.), 'Ex marmore'. Pasquini, pasquinisti, pasquinate nell'Europa moderna, Roma, pp. 11-34.

Romano, P. 1936: Pasquino nel Cinquecento (Il Pontificato di Leone X), Roma.

Romei, D. 1992: «Aretino e Pasquino», Atti e Memorie della Accademia Petrarca di Lettere, Arti e Scienze 54, pp. 67-92. (También en ed. digital http:// www.nuovorinascimento.org/n-rinasc/saggi/pdf/romei/aretpasq.pdf).

Roscoe, W. 1805: The Life and Pontificate of Leo The Tenth, vol. II, Liverpool.

Rossi, V. 1890: «Un elefante famoso», Intermezzo 1, pp. 629-648.

Sanuto, M. 1969: I Diarii di Marino Sanuto (MCCCCXLVI-MDXXXIII), a cura di R. Fulin, F. Stefani, N. Barozzi, G. Berchet, M. Allegri, Bologna, rist. fotomeccanica dell'ediz. Venezia 1879-1902.

Serani, U. 2006: «Forma e natura e costumi de lo Rinocerote de Giovanni Giacomo Penni. Texto y Traducción», Etiópicas 2, pp. 146-171. (Ed. electrónica http://www.uhu.es/programa_calidad_literatura_amatoria/etiopicas/ num_2/serani.pdf). 


\title{
Tormo, E. (ed.) 1940: Os desenhos das antigualhas que vio Francisco D'Ollanda, pintor portugués (...1539-1540...), Madrid, facs. \\ Winner, M. 1964 : «Raffael malt einen Elefanten», Mitteilungen des kunsthistorischen Instituts in Florenz 11, pp. 71-109.
}

\begin{abstract}
${ }^{1}$ No existe acuerdo sobre el nombre de Baraballo: unas veces es llamado Cosimo (Cesareo 1938, p. 190; Marucci-Marzo-Romano 1983, vol. I, p. 80; Romano 1991, p. 98, n. 21), otras Giacomo (Bedini 1997, p. 90) o Iacopo (Ferrajoli 1984, p. 482, n. 5); incluso Leone puede hallarse en algún autor (Colonna di Stigliano 1923). Tampoco el apellido es unánime. La mayoría de estudiosos se inclina por su denominación italiana, Baraballo, presente en textos diversos de la época. Sin embargo, también sería lícito -y de hecho así se encuentra en más de una ocasión- el apelativo Barabal, de acuerdo con la flexión Baraballes, -is, rastreable también en la literatura contemporánea al poeta (Beroaldo 1530, Epigr. 43). Nosotros seguiremos la denominación más común.
\end{abstract}

${ }^{2}$ Neque mediocri cum voluptate munera ipsa aspeximus: Elephantum unum Indicum incredibili corporis magnitudine, et Pardum unum aliquanto specie ipsa venustiorem, virgato corpore et maculis distincto. Sed in Elephanto omnium admiratio major, vel propter memoriam antiquitatis, quod apud veteres haec bellua Romae frequens, tanto saeculorum intervallo visa non fuerit, postquam videlicet hujus maximae et nobilissimae civitatis veteres illae imperii et potentiae opes conciderunt, vel propter docilitatem belluae atque disciplinam, ita obtemperantis monitis et praeceptis rectoris sui, ut fides fieret non falso fuisse a gentilibus nostris litteris proditum, 'esse quandam illi belluae cum genere bumano societatem. ("Y con placer no menor hemos contemplado también los presentes: un elefante indio de enorme tamaño y un leopardo bastante más hermoso que los de su especie, con el cuerpo a rayas y moteado. Pero la mayor admiración de todos ha sido para el elefante, bien por el recuerdo de la Antigüedad, porque este animal, corriente en Roma en tiempos de nuestros antepasados, no se ha vuelto a ver después de tantos siglos, tras la caída sin duda del poder y la gloria de antaño de esta grandiosa y nobilísima ciudad; bien por la docilidad y disciplina del animal, tan obediente a las señales y mandatos de su guía, que podría creerse que no erraban nuestros paganos cuando escribían que "existe cierta afinidad entre esta bestia y el género humano"'. (De la Carta de León X al rey de Portugal, Roma, 11 de mayo de 1514: en Roscoe 1805, Appendix, no CII, pp. 111 s., trad. nuestra). La cita a que alude el Pontífice corresponde a Cic., Fam. 7.1.3.19.

${ }^{3}$ Sanuto 1969, vol. XVIII, col. 58.

${ }^{4}$ Ibid., col. 59.

${ }^{5}$ En cambio, en el mundo anglosajón y, por extensión, en la mayor parte de la literatura actual al respecto se le conoce como Hanno. Otro elefante famoso, Solimán (Salomón en la novela), regalo del rey de Portugal Juan III al archiduque Maximiliano de Austria en 1552 distinto, por tanto, a nuestro Annón-, será el protagonista de la novela de José Saramago El viaje del elefante (Lisboa, 2008).

${ }^{6}$ Mart., 4.75.2 Atque inter Latias gloria prima nurus.

${ }^{7}$ Sen., Her. fur. 963, Tro. 354.

${ }^{8}$ Plin., Nat. 19.49.3 Hesperidum hortos ac regum Adonidis et Alcinoi.

${ }^{9}$ Iuvenal., 3.77.

${ }^{10}$ Catul., 64.329 adveniet fausto cum sidere coniunx.

11 "Si crees, Elefante, que estás sirviendo a un León africano, te equivocas: del cielo ha caído este León. Él es tu Señor, gloria excelsa de la tierra, cuya cabeza adorna una triple corona. Entre los mortales se le considera más que mortal, pues tiene la potestad de abrir y cerrar el cielo. $\mathrm{Si}$ servir a Dios es en verdad reinar, mientras sirves a León, reinas, ya que León es Dios en la tierra. Tal vez te coloque entre las constelaciones del cielo, cuando sea elevado entre los dioses. ¿Por qué prefieres volver a tu suelo natal y a la selva patria? Roma es la sagrada sede de los dioses. 
No habitarás bajo el techo poco seguro de los reyes Partos, sino bajo la protección de héroes y seres celestiales. Cuando tú ocupes tu cubil en la colina Vaticana, pensarás que disfrutas con razón los placeres del orbe. Este lugar supera en la fertilidad de sus árboles frutales y en su eterna primavera a los huertos de las Hespérides y de Alcinoo. ¿Para qué recordar su agradable brisa y su saludable cielo? Creerás que los justos deben habitar aquí los Campos Elíseos. Si te conmueven la religión, la nutricia Venus y la gloria, aquí reinan la religión, la gloria y Venus nutricia. Si ardes en deseos y anhelos poéticos de combatir a Marte, una masa marcial habita esta ciudad de Rómulo. En compañía de ésta, bajo los auspicios y la égida de un invencible León, ofrecerás magníficos trofeos a los dioses del Lacio. Transportarás las gozosas angarillas de la pompa triunfal, o los majestuosos carros, a la morada de Júpiter Capitolino. Vive aquí feliz por mucho tiempo, otorgándole propicios augurios a León; gusta con tu señor del néctar y la ambrosía. Hazte funambulista, aprende a representar espectáculos diversos, con los que puedas aliviar a tu señor de mil preocupaciones. Así podrás ser muy grato al latino Tonante y ganarte el favor del pueblo. No pienses en huir; y si mueres en Roma, no podías morir con sino más noble. Hallarás en el Sumo Pontífice el amor de un rey, una alianza con una gran y santa amistad. ¡Oh feliz animal, nacido bajo una estrella propicia, a quien tanto dignifican la poesía, Roma y León”. (En Roscoe 1805, Appendix, n C, pp. 103 s., trad. nuestra).

12 "Roma produce más monitas, cabras salvajes y toda suerte de fieras, que casi la India y África enteras; y el enorme elefante, pues reinando el León, su rey, las fieras deben honrarle". (En Romano 1936, p. 40; trad. nuestra).

${ }^{13}$ Entre los que cabe destacar los de Rossi 1890; Ciutiis 1899; Pellizzari 1914, pp. 115-137; Matos 1960; Winner 1964; Romano 1991, pp. 89-145; Lach 1994, pp. 135-139; y Bedini 1997.

${ }^{14}$ Hay edición facsímil del ejemplar en Tormo 1940.

${ }^{15}$ Véase al respecto Winner 1964 y Bedini 1997, pp. 137-162.

16 Tormo (1940, p. 141) adopta una postura cristiana y traduce las siglas DM "Al Dios máximo". Nosotros creemos que la fórmula se adapta mejor al modelo clásico (DMS = Diis Manibus Sacrum) y, de este modo, participa de ese aroma renacentista de amor a lo clásico que se observa en toda la inscripción.

${ }^{17}$ El comienzo del epitafio reproduce el inicio de un conocido dístico, atribuido por Servio a Virgilio (Aen. 1, pr. 10): Monte sub hoc lapidum tegitur Ballista sepultus: / nocte die tutum carpe viator iter.

18 "A los Dioses Manes. Bajo este ingente monte estoy sepultado yo, ingente elefante, que el rey Manuel, vencido el Oriente, envió cautivo a León X. La juventud romana se maravilló de mí como de animal que en largo tiempo no había visto, y hasta sentimientos humanos vio en mi bruto pecho. Pero la Parca me privó del feliz Lacio y no permitió que mis tiernos años emulasen a sus dueños. Y así la suerte arrebató los deleites de nuestra naturaleza. Vosotros, Dioses, acumulad años para el gran León. Vivió siete años. Murió de anginas. Medía doce palmos de alto. Giovanni Battista Branconio d'Aquila, camarlengo del papa y encargado de la custodia del elefante, erigió esto el 8 de junio de 1516, cuarto año del pontificado de León X. Rafael de Urbino lo que la naturaleza se llevó con arte lo restituyó". (Trad. nuestra sobre la base de la realizada por Tormo 1940,p. 141). Las nueve primeras líneas corresponden a otros tantos hexámetros compuestos por Filippo Beroaldo el Joven, con ligeras pero importantes variantes: sedem por sed (1. 6), ternos domino famularier por teneros dominos emularier (1. 7), debita por delita (1. 8); cf. Beroaldo 1530, Epigr. 41, y Giovio 1551b, pp. 205 s. En cuanto a la fecha de defunción, se sabe que tuvo lugar en junio de 1516, si bien, como la misma indefinición de la inscripción muestra, es incierto el día: 8 para algunos (cf. Bedini 1997, p. 143), 16 para otros (cf. Winner 1964, p. 89).

${ }^{19}$ Sobre la cual puede verse Onori 1910 y Colonna di Stigliano 1923.

20 "Era también Bibiena un maestro prodigioso en provocar el desvarío en personas respetables por su edad o profesión, de las que el Pontífice se burlaba con tal ahínco que, mediante alabanzas, promesas de gloria y regalando a las más, solía convertirlas de tontas en tontísimas y especialmente ridículas”. (Giovio 1551a, p. 97, trad. nuestra).

${ }^{21}$ Cf. «I due archipoeti», en Cesareo 1938, pp. 187-205.

${ }^{22}$ Cf. Beroaldo 1530, Epigr. 43. 
23 “También se burló - más descaradamente de lo apropiado a un sacrosanto Pontífice- de la eximia necedad de Baraballo de Gaeta: solía éste componer versos tontísimos, dignos de risa por la completa exageración de sus voces y sus ritmos, y recitarlos en público, ufanándose de ser alter Petrarca en metros italianos. Así que, enardecido por las continuas muestras de adulación, se entusiasmó hasta tal punto con la avidez de gloria, que pidió el honor de llevar la merecida corona de laurel, y que después fuese conducido en solemne pompa al Capitolio, como en su día fue coronado Petrarca en el Capitolio, según había oído. Tan grande fue en verdad el impulso de su irrefrenable locura, que a una delegación de amigos y parientes de Gaeta que, ante la noticia del espectáculo público, se había desplazado rápidamente a Roma para disuadirlo del delirio concebido, la rechazó con durísimas palabras, como si hubiesen interpretado malamente la benignidad del Pontífice y sentido sólo envidia de la inmortal gloria conseguida con tan rarísimo honor. Lo cierto es que -sería difícil de creer, si no lo hubiese contemplado personalmente con perplejo placer- un anciano sexagenario, de familia honorable, venerable por su estatura, aspecto y canicie, ataviado con la toga palmata y el laticlavo refulgente de oro y púrpura, y demás insignias suntuosas de triunfo, es conducido al son de las flautas a los festejos del día de los Santos Cosme y Damián, patronos de la familia de los Médici, pues el Pontífice tenía por costumbre celebrar este día con gran jolgorio. Allí, después de haber recitado durante un buen rato, como ostentación de la perfección de su arte, bastantes poemas malísimos y cansados ya todos de contener la risa, finalmente en la plaza del Vaticano bajo la mirada del Pontífice sube a un elefante equipado con silla triunfal sobre aparejo de oro. Pero abrumado el animal por los atabales, las trompetas y los gritos de aclamación del pueblo, el cortejo no pudo proseguir más allá del puente de Adriano. En recuerdo de esta comitiva triunfal unos grabadores, como divertimento, dejaron una taracea, bellamente esculpida, en una puerta del interior del palacio pontificio". (Giovio 1551a, pp. 97 s., trad. nuestra). Sobre esta taracea, que aún se conserva, dice Romano: "Del fatto [la coronación de Baraballo], avvenuto il 27 settembre 1514, è rimasta memoria nell'intarsio interno, in alto a destra, della porta che divide la stanza della Segnatura da quella di Eliodoro, nelle sale di Raffaello dei Musei Vaticani: l'intarsio, che raffigura l'elefante che reca sul collo a cavalcioni il guardiano indiano e, poco piú in alto, issato sopra una specie di seggio trionfale, il Baraballo, è probabilmente opera di fra Giovanni da Verona (1457 ca.-1525)". (Romano 1991, p. 92). Y algo de jocoso tiene el comentario de Tormo al respecto: "En la puerta de las 'stanze', entre la 'stanza della Segnatura', al lado del fresco de la Escuela de Atenas, y la de la Misa de Bolsena, y al lado del fresco de Atila (al haz correspondiente al Atila), el conductor monta al propio elefante, y en trono encima del animal, un Papa de mentirijillas, con tiara sin trirregno y la diestra suya con rama de roble. Representa el triunfo de Baraballo". (Tormo 1940, p. 142).

${ }^{24}$ Marucci-Marzo-Romano 1983, vol. I, pp. 102 s. Cf. también Romei 1992. Para algunas variantes textuales del soneto véase Romano 1936, p. 46, y Cesareo 1938, p. 194.

25 Lleva por título Dialogus in donatione laureae Barabellis. Interlocutores Pasquillus et Marphorius. Se imprimió en Roma, muy probablemente en las prensas del editor Stefano Guillireti, y se conserva en dos ejemplares casi idénticos: el primero, en la Biblioteca Nacional de Madrid bajo el rótulo Francisci Decii Opera, sign. R/27032; el segundo, en la Biblioteca Capitular Colombina, sign. 4-2-4(4). Este último perteneció a Hernando Colón y en el colofón, escrito de su propia mano, se lee: "Este libro costo en roma vn quatrin por nouiēbre de.1515. Esta Registrado 2976".

${ }^{26}$ En Alonso Asenjo 1998, p. 171.

${ }^{27}$ Según el DRAE, "escrito anónimo que se fija en sitio público, con expresiones satíricas contra el Gobierno o contra una persona particular o corporación determinada”. Sobre la formación del "pasquín” como género literario, véase Romano 2006.

${ }^{28}$ Cf. Marucci-Marzo-Romano 1983.

${ }^{29}$ Cf. Molina Sánchez - Alonso Asenjo 2011.

${ }^{30}$ Cf. Alonso Asenjo 2011.

${ }^{31}$ Cf. Beroaldo 1530, Epigr. 43.

32 Por ejemplo en Romano 1936, p. 44, n. 33; Winner 1964, p. 87; Cruciani 1983, p. 474; Lach 1994, p. 138, n. 82; Bedini 1997, pp. 94 s.; Pozzo 2007, p. 210. Resulta por lo demás 
sorprendente que una Tesis doctoral, como la de Paquier 1900, dedicada al estudio de la vida y escritos de Beroaldo, no mencione ni una sola vez la comedia y haga caso omiso del Prologus, limitándose su autor a describir muy de pasada (jsiete líneas!) los metros usados en el conjunto de los 51 epigramas (cf. especialmente pp. 81 s.).

${ }^{33}$ La versión en italiano que hace Ferrajoli (1984, pp. 483-485) no es completa (faltan muchos versos), apenas incluye anotaciones (salvo las indicadas infra, notas 39 y 43 , a propósito de ciertos nombres propios), omite el texto latino e interpreta muy libremente el original. Es, en realidad, un resumen amplio del contenido.

${ }^{34}$ Para la correcta interpretación del Prólogo hay que tener en cuenta el público peculiar al que va dirigido. Nos hallamos en la curia romana ante un buen número de prelados, cuyos malos hábitos el poeta pretende censurar.

${ }_{35}^{35}$ Plaut., Cas. 1 Salvere iubeo spectatores optumos.

${ }^{36}$ meribibo cod. Cf. Plaut., Cur.77 nomen Leaenae est, multibiba atque merobiba. La vinculación del Genius con el vino se debe a que era este elemento una de las ofrendas que se le otorgaban como sacrificio en los días de fiesta (cf. Hor., Ars 210, Carm. 3.17.14, Epist. 2.1.144).

${ }^{37}$ Plaut., Aul. 455 Intro abite, opera huc conducta est vostra, non oratio.

${ }^{38}$ El eléboro es una planta medicinal cuya raíz se utiliza como cardiotónico y diurético.

${ }^{39}$ La comparación no es del todo clara. Según Ferrajoli (1984, p. 483, n. 3), el Donato aquí citado es Donato Poli, florentino, profesor de retórica en la Academia Romana. Cabe la posibilidad, no obstante, de que Donato sea el gramático del siglo IV Elio Donato y que la memoria mencionada aluda a lo poco que se conoce de su vida, a su "historia biográfica", más que a su "memoria" en sentido literal. Es posible también que con la expresión se haga referencia a la "corta vida" de su Commentum Terentii, descubierto en Maguncia por G. Aurispa en 1433 y editado por primera vez en Venecia en 1473. Llama la atención, por último, que en la pasquinada citada arriba (cf. nota 24) confluyan también Donato y Baraballo. En cuanto a Cynicum, puede referirse a Diógenes, el "cínico" por antonomasia, pero creemos que su objetivo es más general: los filósofos cínicos, contra los que Beroaldo parece sentir cierta aversión (véase Epigr. 44: $A d$ Hieronymum cynicum).

${ }^{40}$ El Magister domus que menciona el texto es el Mayordomo papal, a cuyo cargo estaba, entre otros asuntos, la economía de palacio. Tenía mucho poder, como refleja este comentario del cardenal Adriano a Enrique VII sobre el español Antonio de Savona: est et item dominus Antonius de Savona, quae civitas est patria papae, magister domus suae sanctitatis, qui plurimum potest. (Carta del cardenal Adriano a Enrique VII, 4 de enero de 1504, en http://www.thelatinlibrary.com/ henry1.html). Era un prelado, pues, de alto rango en la corte. El problema que plantean estos tres versos, en este sentido, es que Diaria puede entenderse tanto "comida" como "salario". Así se desprende del comentario del Pseudo-Acrón a Hor., Epist.1.14.40 (Pseudacronis Scholia in Horatium: Scholia in Epistulas): '<Diaria>] Aliter cibaria. Diaria sunt certa stipendia cottidiana, quae et salaria. Victus scilicet cottidianus, qui mensuratim seruis attribuitur, et est sensus: mauis, inquit, rodere in urbe stipendia [diaria] cum seruis, quam liber uiuere in rure'. Y lo mismo podría decirse de otros pasajes en los que se emplea el término (cf. Sen. Rhet., Contr. 9.4.20.10; Petron., Sat. 24.7.4, 136.4.3; Mart., Ep. 11.108.3). A este respecto, Ferrajoli (1984, p. 483) adopta una posición ambigua al traducir los versos, en forma sucinta, del siguiente modo: "Il maestro di casa non stia a discutere il modo di assottigliare il vitto ai famigliari". Nosotros creemos, sin embargo, que en este contexto es preferible la acepción de "salario". Y ello por dos razones. Parece impropio, primero, que un alto cargo de la corte se dedique a repartir comida entre los miembros de la curia (familia) en medio, además, de una representación. El sintagma rationes conferre, en segundo lugar, suele emplearse en sentido cuantitativo ("hacer cuentas": Sen., Ep. 118.1.1) y pecuniario (Cic., Att. 5.21.12.19, Phaedr., Fab. 4.5.17). Por último, unciatim es término más vinculado con pecunia que con victus.

${ }^{41}$ Aunque ambas dolencias están relacionadas, en cuanto que tienen que ver con la enfermedad de la gota, como sus propios nombres indican, la podagra es la gota del pie y la quiragra la de las manos.

${ }^{42}$ Otro prelado de la Sede Apostólica. Se trata del “datario”, registrador que anotaba la fecha de las súplicas dirigidas al papa: "Esta fecha la conservará la minuta y el posterior documento 
pontificio que se iba a expedir sobre el asunto. Por ello debía ocuparse de tal menester un personaje de confianza del Papa. Desde Martín V (1417-1431) ejercía este oficio un 'datario', denominándose la oficina donde éste trabajaba Dataría Apostólica o Datariatus, siendo desde entonces este organismo totalmente independiente de la Cancillería, que, además, asumió una función de consejo y de resolución de posibles cuestiones pendientes antes de promulgar las bulas. El cargo de datarius era en la Edad Moderna un munus praelatitium, tan importante que a veces fue confiado a cardenales, denominados entonces prodatarii. La Dataría apostólica preparaba la decisión del Papa y, entre sus competencias, cada vez mayores, estaba la concesión de dispensas, confirmación de indultos, exenciones y privilegios, ampliación o limitación de gracias ya concedidas, ocupación de beneficios reservados a la Santa Sede y otorgamiento de los benefitia affecta, aunque siempre siguiendo la máxima Papa, non datarius, concedit gratias". (Domínguez Sánchez 2005, pp. 145 s).

${ }^{43}$ Beroaldo cita aquí diversos nombres de escritores contemporáneos, valiéndose en algunos casos del juego de palabras (Cecchonum, Cecchottum, Cecchettum, Cecchinum). Su identificación nos la proporciona Ferrajoli (1984, pp. 484 ss.). Protum, así, es Nicolò Gabrielli, conocido como Proto da Lucca, célebre por su donaire, a quien Castiglione recoge en su Libro del Cortegiano (Venecia, 1565, libro II, p. 210). Marianum corresponde a Fray Mariano Fetti, famoso acólito del papa, sucesor de Bramante en el cargo de "Piombatore apostolico", esto es, estampador del sello de plomo en las bulas papales, y celebérrimo glotón (cf. Romano 1936, pp. 36 ss.). Catelacium, Catellaccio, otro glotón de renombre, aparece citado como tal en Pierio Valeriano (Hendecassillabi, Venecia, 1550, cap. 108) y P. Aretino (Cortigiana, Acto V, esc. 12). Los cuatro Cecchonum, Cecchottum, Cecchettum, Cecchinum citados corresponden a otros tantos Franciscos: Francesco Buglioni, Francesco de Castiglione-ligure, Francesco Tolomei da Pistoia y Francesco Freddi da Imola, respectivamente. Ioannem Manentem es el Giovanni Manente del último verso del soneto citado arriba (cf. nota 24), asistente personal de León X y "músico de pacotilla" (Romano 1936, p. 46, n. 39. No comparte esta opinión Ferrajoli 1984, p. 487). Romanellum es Abramo di Leone, llamado Romanello, judío, recogido también en la Cortigiana de Aretino (Acto IV, esc. 15). Christophorum, por último, es el sevillano Cristóbal de los Ríos. Todos ellos, a decir de Romano (ibid., pp. 35 s.), formaban parte de esa pléyade de poetas bufonescos de los que tan aficionado era a rodearse el Pontífice.

${ }^{44} \mathrm{El}$ principio del dogma mosaico del Génesis es que "Jahvé había creado primero a Adán andrógino para hacer de él el padre y madre de Eva”. (Rahn 1982, p. 63).

${ }^{45} \mathrm{La}$ asociación que Beroaldo hace aquí entre Genius, Comus, Mania y Morus es algo imprecisa. El Genio, en su origen, es el espíritu divino que habita en cada hombre desde su nacimiento, que lo protege y vela por su seguridad y felicidad. Su campo de acción se circunscribe, pues, al individuo y a la familia. Será posteriormente, a partir del siglo I d.C., cuando extienda su influencia a cualquier ámbito de la vida; de ahí la afirmación de Servio (Aen. 5.95): nullus locus sine genio. Su paralelo griego es el Daímon, no el Kömos: "El daimon era una divinidad de características muy parecidas a las del genio, y por eso fueron asociados desde muy pronto, con la consiguiente asimilación de los rasgos del uno por el otro". (Roca Barea, 1994, p. 313). "Como" es el dios griego de las fiestas y de la alegría, que presidía los placeres de la mesa. Cierto es que también el Genio participa de los días de fiesta, ya que, como dijimos (cf. nota 36), en esos días se le hacen sacrificios. En cuanto a Mania, es la personificación de la locura, forma parte de los genios populares y a veces se la considera "Madre de los manes" (Grimal 1981, p. 332). Morus, por su parte, que en Hesíodo (Theog. 211) designa al dios del destino (Móros), parece estar aquí representando al dios de la locura, personificación de mōrós.

${ }^{46}$ Sultilauream cod. Parece lógico que la traducción de Moridaphnea, "coronación laureada de un loco/tonto", sea Stultilaurea. Con estos títulos Beroaldo está pensando sin duda en el Elogio de la locura de Erasmo (Mōrías Enkōmion en griego, Stultitiae Laus en latín), una obra de 1509, que estaba en esta época en pleno florecimiento y que, pese a sus críticas a la Iglesia, no fue mal recibida por el papa León X (otra clara referencia erasmista es el final del Prólogo: cf. infra, nota 55). Todo ello nos da una idea de la vitalidad que a principios del XVI posee el concepto de "necedad/locura", cuyo precedente más inmediato es la magnífica obra de Sebastian Brant Das Narrenschiff (1494), traducida al latín por su discípulo Jacob Locher como Stultifera Navis 
(1497), “La nave de los necios”. A ella dedicará Foucault el primer capítulo de su Historia de la locura en la época clásica (Paris, 1964).

${ }^{47}$ Pasquino (Paschinus o Pasquillus en latín) y Marforio (Marphorius) son los dos personajes que integran las conocidas pasquinadas o pasquines literarios, diálogos humorísticos en los que se critican los hábitos o vicios de personajes públicos. Estos diálogos tienen su origen en los pasquines que se fijaban en la piedra de alguna de las seis estatuas parlantes de Roma (cf. nota 27). De ellas las más famosas son las estatuas de Pasquino y Marforio, la primera conservada en la Piazza Pasquino, a espaldas de la Piazza Navona; la segunda en el patio del Palazzo Nuovo, un ala de los Museos Capitolinos. Puesto que en los diálogos Pasquino y Marforio representan a las estatuas, son personajes estáticos (de ahí el statarii de Beroaldo). En la comedia que nos ocupa, en cambio, son personajes en movimiento, de donde motorii. En el empleo de estos términos puede intuirse también una alusión a la antigua división de comedias en fabulae statariae y fabulae motoriae (cf. Pseudacronis scholia in Horatium: De arte poetica, v. 288: Comoediarum genera sunt sex: stataria, motoria, praetextata, tabernaria, togata, palliata).

${ }^{48}$ Hor., Ars 436 si carmina condes.

${ }^{49}$ Por lo que va a contar a continuación, parece que Beroaldo juega aquí con la expresión iuris peritus, "experto en leyes", usual en el lenguaje forense, y "experto en caldos".

${ }^{50}$ Hércules mató a Lico, hijo de Neptuno, que pretendía asesinar a Mégara, su esposa, hija de Creonte, y a sus hijos Terímaco y Ofites, para apoderarse del reino. Así Hygin., Fab. 32.1-2: Hercules cum ad canem tricipitem esset missus ab Eurystheo rege et Lycus Neptuni filius putasset eum periisse, Megaram Creontis fliam uxorem eius et flios Ther $<i>$ machum et Ophiten interficere uoluit et regnum occupare. Hercules eo interuenit et Lycum interfecit.

${ }^{51}$ La utilización aquí del número siete es simbólica, como fácilmente se deduce de un simple recuento de las coronas otorgadas a Baraballo, y se inscribe en la estela de la tradición bíblica, que considera el siete número perfecto o infinito. Lo explica perfectamente San Lorenzo de Brindis en su exégesis al Génesis 4.15, dixitque ei Dominus nequaquam ita fiet sed omnis qui occiderit Cain septuplum punietur: "Mos est Sacrae Scripturae non raro determinato numero pro indeterminato uti, cuiusmodi est: Septies in die cadit iustus: idest multoties; et: Septies in die laudem dixi tibi: scilicet multis vicibus; et frequentissimum est in Sacra Scriptura praefixum terminis numerum pro indeterminato atque indefinito ponere... Quisquis itaque te occidere attentaverit, poenae septuplici, idest multiplici se obnoxium faciet". (Laurentius a Brundusio, Explanatio in Genesim, exegesis, cap. 4, p. 391).

${ }^{52}$ De Calicut, "hoy Kozikhode, en la costa occidental de Malabar", no de Calcuta (Serani 2006, p. 146).

53 Aegit $=$ egit .

${ }^{54}$ Petron., Sat. 11.2.4 risu itaque plausuque cellulam implevit.

${ }^{55}$ El final del Prólogo no podía ser más erasmista. Quare valete, plaudite, vivite, bibite, Moriae celeberrimi Mystae. Con estas palabras termina Erasmo su Laus stultitiae.

56 "PRÓLOGO A LA COMEDIA REPRESENTADA EN LA CORONACIÓN DE BARABALLO. EL GENIO. ¡Hola, hola! Guardad silencio, espectadores diligentes. Complaceos con que os haya llamado espectadores diligentes, pues si no guardáis silencio, no os llamaré espectadores diligentes, sino charlatanes imbéciles. Soy yo, gran bebedor y bebedor de buen vino, el que tengo que hablar. Es mi palabra la que aquí se ha contratado, y de vosotros, los ojos. Vosotros, que molestáis los oídos del Príncipe y creéis que con vuestras indecentes murmuraciones y circunloquios continuos y frívolos os ganáis su favor, parad un poco, dejadme libres los oídos de León: habrá otro lugar para la charla. Quien sirve debe ser persona de pocas palabras. Los médicos permanezcan de pie a lo lejos, que se sientan a su lado como si de enfermo se tratase; por Pólux que pienso que están tan necesitados de eléboro, como yo de dinero, Donato de historia, un cegarruto de visión o un cínico de moderación. El Mayordomo haga las cuentas en palacio y no regatee aquí cómo reducirlas, o bien entregue a los miembros de la curia el salario céntimo a céntimo. En palacio también se cure su podagra, si sabe, a la que, no obstante, los médicos doctos llaman quiragra. Pero ya sea podagra o quiragra más bien, la cure con sobriedad bebiendo sobrio agua. Además, el Registrador de las súplicas deje de debatir aquí si debe dar dos, o si tres son incompatibles, o si las da bajo el mismo techo o a plena luz del día: todas deben ser otorgadas gratis en cualquier parte a todos. Y si no me obedecéis, inmediatamente 
convocaré a mis colegas, como Proto, Mariano, Catellaccio, Ceccone, Ceccotto, Cecchetto, Cecchino, Giovanni Manente, Romanello, Cristóbal, archidoctor del dogma mosaico, y al propio Baraballo, mi general, en cuyo honor se representa esta comedia, quienes, queráis o no queráis, os harán callar y, después de agotaros a puñetazos, os obligarán a marcharos a casa. ¿Os calláis? Bien. Descubriréis conmigo quién soy y por qué he venido aquí. Los latinos me llaman Genio, Como los griegos. Mi madre es Manía, Moro mi padre. Presido los días de fiesta y a los hombres festivos, y por eso me he presentado aquí como Genio en este día. Ya sabéis quién soy y por qué he venido aquí; enteraos ahora del argumento de la comedia. Marforio escribió en griego una Moridáfnea, que Pasquillo vertió luego como Estultiláurea: poetas serios ambos y en otras obras estáticos, en ésta en cambio, por su asunto, móviles. El anciano Baraballo comenzó a componer poemas, enérgicamente inspirado por furor báquico. Cual poeta, así también es músico, arquitecto, político, amante y bailarín; experto en leyes, como conocedor del arte médica. En efecto, conoce los mejores caldos de pollo y, como sabe que el agua no sirve para nada en cuestiones de estómago, aconseja beber vino. También sabe que los papafigos son más sabrosos que los estorninos y los grajos. En recompensa por tan gran conocimiento, todos los dioses y diosas le ofrecen una corona: Apolo, Júpiter, Palas, Mercurio, Marte, Lico y Hércules; también Venus, quien, en fuerte discusión con Mercurio, invoca a Vulcano y recibe su ayuda. Éste encadena a todos los dioses con cadenas de hierro. Después Cibeles y la eternidad pronuncian su sentencia: consideran a Baraballo merecedor absoluto de todas las coronas. De este modo es coronado con las máximas distinciones: Archipoeta, Archiarquitecto, Archimúsico, Archipolítico, Archiamante, Archisaltarín, Archimatemático, Archilírico, Architodo. Se sentará después sobre una altísima Archibestia, un elefante con trono en forma de torre, con el que el rey de Calicut obtuvo un triunfo sobre los pigmeos indios, y, precedido de dos grandes carros, se dirigirá a Roma resplandeciente con su laticlavo. Allí será recibido de un modo festivo, con risas y aplausos, por el Senado, el pueblo y los Notables de la ciudad. Eso es todo, salud, vivid y bebed en conmemoración mía".

${ }^{57}$ Este trabajo se inscribe dentro del Proyecto de investigación "Teatro humanístico y escolar del Siglo XVI: el teatro de los Jesuitas Ávila, Rodríguez, Cigorondo y coetáneos de Ultramar” (Ref. FFI2009-08047). 


\section{ACTIVIDAD TEXTIL EN LA BÉTICA ${ }^{\mathrm{I}}$}

Eva María Morales Rodríguez

Universidad de Granada

\section{INTRODUCCIÓN}

Hispania era, en el conjunto del imperio romano, esencialmente una provincia proveedora de materias primas, que en su mayor parte eran exportadas hacia Italia. Las abundantes fuentes de riqueza: trigo, olivo, vid, lino, esparto, ovejas, cochinilla, oro, plata, plomo, etc. permitió su explotación al estado romano. La importancia que tiene en la economía hispana los productos agrícolas y ganaderos, determinó el carácter secundario de la producción de objetos manufacturados. No obstante, conviene subrayar el papel que desempeñaron las actividades artesanales.

El sur de la Península Ibérica ha sido siempre una zona de cría de ovejas, y las prendas de vestir tejidas de lana se usaban desde la prehistoria ${ }^{2}$. La lana es una fibra natural obtenida de las ovejas mediante la esquila y gracias a Marcial conocemos el proceso de lavado a orillas del fumen Betis ${ }^{3}$. Siguiendo el texto de Columela, las ovejas béticas tenían una magnifica consideración en el mundo antiguo por la alta calidad de su lana de color áureo ${ }^{4}$. También sabemos que la lana cordobesa era marrón oscura brillante y que contaba con un amplio mercado 5 . Juvenal reitera los colores oscuros y la gran calidad de la lana bética ${ }^{6}$. Estrabón, por su parte, reitera la hermosura de la lana y observa los elevados precios de la ganadería ovina en manos de los turdetanos ${ }^{7}$. Plinio indica que las lanas béticas eran muy cotizadas y los tejidos eran delicados ${ }^{8}$. Por su parte, el poeta Marcial sugiere que la lana bética es un regalo perfecto ${ }^{9}$ ya que tenía el color del oro ${ }^{10}$. Este índice de calidad y pureza de la lana bética debe tenerse en cuenta por los cruces de oveja de origen africano e itálico que se habían experimentado por parte del tío paterno de Columela ${ }^{11}$.

Esto, tal vez, implica que la producción de lana constituía un sector primordial en la provincia. Los trabajos en lana eran tarea para tejedores, pesadores de balas de lana, lavanderos, etc. Desde época temprana la Bética se muestra como punto de fabricación de textiles, para lo que era fundamental la materia prima de su cabaña ganadera lanar; lana que se manipula mediante el cardado, el hilado y finalmente se teje en pequeños talleres donde se confeccionan vestidos tipo toga o palla. Se exportan telas desde el siglo I a.C.y posteriormente lanas como lo expresan Estrabón y Marcial ${ }^{12}$.

La fibra textil más importante después de la lana es el lino; el tallo de esta planta herbácea es fundamental, ya que se emplea para 
confeccionar tela. El lino tiene zona de producción en el sur hispano, y en la ciudad de Gades se usaba hasta para hacer vendas para uso sanitario ${ }^{13}$. El lino era un material suave, ligero e ideal para la confección de túnicas. Conocemos el término con el cual estos artesanos textiles dedicados a la planta del lino son designados en el material epigráfico; concretamente, lintearius es el trabajador de la planta de lino y del hilo que se obtiene. E1 epitafio de L. Haterius procedente de Tucci, en la antigua Turdetania, revela la importancia de esta zona de cultivo. El valor de este cultivo hispano es fundamental, ya que se exportaba a Roma, donde los tejedores de lino alcanzaron un considerable auge y poder.

Los cambios urbanos que se producen en las ciudades, vinculadas al evergetismo ciudadano, exigen la presencia de los correspondientes técnicos; sin embargo, el material epigráfico nos los ha documentado de forma puntual. Sabemos que las ciudades contarían con un pequeño grupo de artesanos (curtidores, tejedores, tintoreros, sastres, zapateros, etc.) y un comercio local (vendedores de ropa, telas, etc.) ${ }^{14}$. Indirectamente conocemos la existencia de talleres que realizarían las demandas oficiales y particulares. En concreto, tan sólo algunos textos epigráficos revelan el desarrollo de la actividad textil en la Bética: se conservan alguno de estos oficios; así aparecen: infectores, lanificae, lintearii, purperii, sagarii, sarcinatrices o vestiarii.

Se trata de artesanos, agrupados en collegia, pertenecientes a la plebe urbana o libertos que se dedican a la comercialización de productos manufacturados, según se desprende del análisis onomástico.

\section{TABLA I}

\begin{tabular}{|c|c|c|c|}
\hline Procedencia & Nombre + actividad & Fuente & Comentario \\
\hline $\begin{array}{l}\text { Tucci. Necrópolis } \\
\text { rural. Ara de mármol. }\end{array}$ & Caesia L.f. Celsa, lanifica & $\begin{array}{l}\text { CIL, } \mathrm{II}^{2} / 5, \\
191\end{array}$ & $\begin{array}{l}\text { Trabaja la lana. Hija de } \\
\text { L. Caesius. Siglo I d.C. }\end{array}$ \\
\hline $\begin{array}{ll}\text { Tucci. } & \text { Necrópolis. } \\
\text { Lápida } & \text { de piedra } \\
\text { caliza. } & \end{array}$ & L. Haterius, lintearius & $\begin{array}{l}\text { CIL, } \mathrm{II}^{2} / 5, \\
112\end{array}$ & $\begin{array}{l}\text { Comerciante de telas. } \\
\text { Siglo I d.C. }\end{array}$ \\
\hline $\begin{array}{l}\text { Obulco. Necrópolis. } \\
\text { Estela de mármol. }\end{array}$ & Liberalis, infector. & $\begin{array}{l}\text { CIL, } \mathrm{II}^{2} / 7, \\
102\end{array}$ & $\begin{array}{l}\text { Tintorero de paño nuevo. } \\
\text { Servus. Siglo I d.C. }\end{array}$ \\
\hline $\begin{array}{l}\text { Sacili. Necrópolis. } \\
\text { Estela de arenisca. }\end{array}$ & Faustus, offector. & $\begin{array}{l}\text { CIL, } \mathrm{II}^{2} / 7, \\
198\end{array}$ & $\begin{array}{l}\text { Tintorero de prenda } \\
\text { a reciclar. Servus. } \\
\text { Mediados del siglo I d.C. }\end{array}$ \\
\hline $\begin{array}{l}\text { Corduba. } \\
\text { sepulcral. }\end{array}$ & $\begin{array}{l}\text { [---] } \\
\text { purpurarius. }\end{array}$ & $\begin{array}{l}\text { Ve n tura } \\
\text { y Marfil, } \\
1991, \text { n }^{\circ} 35\end{array}$ & $\begin{array}{l}\text { Purpurero. Tintorero } \\
\text { de tejidos purpúreos. } \\
\text { Liberto. Siglo I d.C. }\end{array}$ \\
\hline
\end{tabular}




\begin{tabular}{|c|c|c|c|}
\hline $\begin{array}{l}\text { Corduba. } \\
\text { sepulcral. }\end{array}$ & [---] Diocles, purpurarius. & $\begin{array}{l}\text { CIL, } \mathrm{II}^{2} / 7, \\
335\end{array}$ & $\begin{array}{ll}\text { Purpurero. } & \text { Tintorero } \\
\text { de tejidos purpúreos. } \\
\text { Liberto. Siglo I d.C. }\end{array}$ \\
\hline $\begin{array}{l}\text { Corduba. } \\
\text { sepulcral. }\end{array}$ & [Z]otimus, purpurarius. & $\begin{array}{l}\text { CIL, } \mathrm{II}^{2} / 7, \\
335\end{array}$ & $\begin{array}{ll}\text { Purpurero. } & \text { Tintorero } \\
\text { de tejidos purpúreos. } \\
\text { Liberto. Siglo I d.C. }\end{array}$ \\
\hline $\begin{array}{l}\text { Gades. Necrópolis. } \\
\text { Epígrafe funerario. }\end{array}$ & $\begin{array}{l}\text { Baebia } \\
\text { purpuraria }\end{array}$ & $\begin{array}{l}I L E R, \\
5746= \\
I R P C, 139\end{array}$ & $\begin{array}{l}\text { Purpurera. Tintorera } \\
\text { de tejidos purpúreos. } \\
\text { Aparece junto a su hijo } \\
\text { Baebius Venriosus. Siglo } \\
\text { II d.C. }\end{array}$ \\
\hline $\begin{array}{l}\text { Corduba.Necrópolis. } \\
\text { Estela de calcárea. }\end{array}$ & $\begin{array}{l}\text { Latinia M.l. Da[---], } \\
\text { sarcinatrix }\end{array}$ & $\begin{array}{l}\text { CIL, } \mathrm{II}^{2} / 7, \\
339\end{array}$ & $\begin{array}{l}\text { Modista. Liberta de } M \text {. } \\
\text { Latinius. Siglo I d.C. } \\
\text { Época de Augusto. }\end{array}$ \\
\hline $\begin{array}{l}\text { Corduba. Inscripción } \\
\text { honorífica de caliza. }\end{array}$ & {$[---F e] l i x$, sagarius } & $\begin{array}{l}\text { CIL, } \mathrm{II}^{2} / 7, \\
323\end{array}$ & $\begin{array}{l}\text { Fabricante de sayos. } \\
\text { Liberto, magister Larum } \\
\text { Augustorum. Siglo I d.C. }\end{array}$ \\
\hline $\begin{array}{l}\text { Corduba. Lápida } \\
\text { funeraria calcárea. }\end{array}$ & $\begin{array}{l}\text { Pomponius Pamphilus, } \\
\text { vestiarius }\end{array}$ & $\begin{array}{l}\text { CIL, } \mathrm{II}^{2} / 7, \\
343\end{array}$ & $\begin{array}{l}\text { Fabricante de ropa. } \\
\text { Liberto. Siglo I d.C. }\end{array}$ \\
\hline
\end{tabular}

\section{LOS PERSONAJES}

- Baebia Veneria ${ }^{15}$ : se señala en inscripción funeraria. Se trata de una purpuraria o artesana de la púrpura en una tinctoria de Gades fallecida a los veinticinco años, junto a su hijo Baebius Venerius de un año. Los Baebii se evidencian con cierta frecuencia en los epígrafes hispanos ${ }^{16}$. Veneria es un cognomen teofórico derivado de Venus ${ }^{17}$. Se fecha en la segunda mitad del siglo II d.C.

- Caesia Celsa ${ }^{18}$ : se presenta en una lápida procedente de Tucci (Martos, Jaén); hija de Lucio, fallecida a los 65 años. Se adscribe a la familia Caesia, un nomen con escasa representación en Hispania ${ }^{19}$; su epitafio la describe como "preclara en el trabajo de la lana", junto a otras cualidades positivas. Se data en el siglo I d.C.

- Diocles ${ }^{20}$ : se constata en título sepulcral de Corduba; purpurarius o tintorero, liberto con cognomen griego ${ }^{21}$, único en la onomástica hispana ${ }^{22}$. Se halla junto a otro liberto de la misma familia [Z]otimus. Esta lápida, de dos especialistas en el tinte de la púrpura, nos remite a una tintorería de carácter familiar, negocio próspero que les proporcionó la libertas y ascender socialmente ${ }^{23}$. Placa del s. I d.C.

- Faustus ${ }^{24}$ : se muestra en placa funeraria, de profesión offector o tintorero especializado en mezclar colores. De Sacili (Alcorrucén, Córdoba). E1 sobrenombre Faustus se relaciona con circunstancias afortunadas ${ }^{25}$. Por la paleografía se data en el siglo I d.C.

$-[--F e] l i x^{26}:$ se presenta en una inscripción funeraria procedente de 
Corduba. Se trata de un liberto con cognomen latino ${ }^{27}$, frecuente entre sectores serviles $^{28}$, es artesano o comerciante de sagas, profesión que le facilitó conseguir el cargo de Magister Larum Augustorum. Los recursos económicos de este antiguo servus son notables al vincular al acto evergético a su patrono. Se trata, pues de un liberto enriquecido con este oficio, lo que le facilitó el ascenso social y sufragar su promoción en la escala de cargos religiosos dedicados al culto imperial. Procede del s. I d.C.

- L. Haterius $^{29}$ : se documenta en inscripción funeraria, originario de Tucci (Martos, Jaén), donde este lintearius o comerciante de telas dedica el epitafio a Fadia. El gentilicio Haterius es poco frecuente en la epigrafía hispana. Se fecha en el siglo I d.C.

- Ignotus $^{30}$ : Testimoniado en una lápida muy fragmentada, hallada en Córdoba en 1991 en las obras de la estación del tren de alta velocidad. En la actualidad se conserva en el Servicio Arqueológico Provincial. A. Ventura y P.F. Marfil restituyen LIB(ertus), además de IN[(FECTOR] PU[RPURARIUS]. Liberto, si seguimos la lectura de A. Ventura y P.F. Marfili ${ }^{31}$, del que ignoramos su nombre debido al estado de fragmentación de la lápida. ¿Infector purpurarius?. A. Canto considera que es arriesgado proponer esta lectura ${ }^{32}$. Procede de fines del s. I d.C.

- Latinia M.l. Da[--- ${ }^{33}$ : se registra en título sepulcral de Corduba; liberta dedicada a tareas de costura. Es miembro de una familia de libertos, formada, al parecer, por el padre, $M$. Latinius, sus dos hijas, y probablemente el marido y el hijo de la primera. Una de ellas es costurera: sarcinatrix. Se data a fines del s. I o inicios del s. II d.C.

- Liberalis ${ }^{34}$ : aparece en cipo funerario de la necrópolis de Obulco (Porcuna, Jaén), de profesión infector o el que tiñe la lana de color extraño. El nombre Liberalis se relaciona con el calendario festivo ${ }^{35}$. Por la fórmula epigráfica procede del siglo I-II d.C.

- Pomponius Pamphilus ${ }^{36}$ : aparece en una losa procedente de Corduba. Se trata de un liberto que realiza su actividad profesional en el mundo de la confección, quizá un sastre o vestiarius. El gentilicio Pomponius también está representado en las inscripciones hispanas ${ }^{37}$. Pamphilus es un cognomen griego ${ }^{38}$, testimoniado en la onomástica hispana ${ }^{39}$ en Cartagena (Murcia) (CIL II 3461), Mérida (Badajoz) (CIL II 537), Osuna (Sevilla) ( $A E$ 1982, 533 S-339), Sevilla (CIL II 1198), y en Tarragona en dos ocasiones (CIL II 4185 y 4296). Procede del s. I d.C.

- [Z]otimus: Documentado en la lápida sepulcral hallada en el corral del Batanero en Córdoba. Libertus de origen griego ${ }^{40}$, al igual que su compañero Diocles es purpurarius. Datado a inicios del s. I d.C. 


\section{Consideraciones}

El fenómeno asociacionista, típico de la sociedad romana, queda constatado en la realidad urbana de estas civitates. Las formas de asociación que recoge la documentación epigráfica, se pueden estructurar en función los calificativos que acompañan a los collegiae. Básicamente se trata de corporaciones profesionales y de colegios religiosos ${ }^{41}$. La presencia de artesanos en las distintas civitates de la Baetica es evidente; lana y lino son productos que se emplean en la fabricación en tejidos; existe una clara especialización de los oficios, como hemos observado en la fabricación de púrpura. Las alusiones a los técnicos en tintado de prendas se concentran en el Conventus Cordubensis y Gades. Un infector está atestiguado en Obulco (Porcuna), un offector en Sacili (Alcorrucén). Cuatro inscripciones más, tres de Corduba, y otra de Gades, se refieren a purpurarii o tintoreros de púrpura. La extracción de la púrpura de los moluscos es esencial para el desarrollo de la industria textil; seguramente, desde las factorías de la costa gaditana, a través del Betis se subía río arriba; o bien desde las factorías malagueñas a través de la depresión antequerana llegaba hasta Corduba, donde tenemos constancia de este oficio y donde se habrían creado diversas tintorerías. Además, no sólo la capital provincial cuenta con este tipo de establecimientos, sino que en otras áreas del Conventus Cordubensis se destaca la presencia de varios especialistas en el teñido del paño asociados a estas instalaciones.

El tinte de paños o de otros tejidos de lana, así como el de la púrpura, no podría menos de florecer y prosperar en la región de los túrdulos, desde antiguo influida por la presencia feno-púnica. La existencia de talleres dedicados al lavado y teñido de ropa, fullonicae o tinctoriae, apenas si han sido identificados por las intervenciones arqueológicas en la Hispania meridional, aunque si en otros puntos de la geografía hispana ${ }^{42}$. Su funcionamiento está descrito en el texto pliniano ${ }^{43}$ y se conocen diversos ejemplos conservados en las ciudades itálicas y en otras zonas provinciales ${ }^{44}$. El infector Liberal y el offector Fausto representan las dos ramas de tan rica industria: el primero se dedica al teñido de la lana y al tintado de paños nuevos, mientras que el offector se emplea en la tinción de ropas usadas y desteñidas, utilizando colores propios y añadiendo otros nuevos ${ }^{45}$. Otra lápida de Córdoba da noticia de tres purpurarios, es decir, fabricantes ó expendedores de púrpura. El vocablo offector, aunque alguna vez se usó como sinónimo de infector, lo distinguió Cornelio Frontón, gramático del siglo II, y Pompeyo Festo del IV, diciendo que el infector mudaba con su tinte el color de la lana, o sea, añadía los pigmentos y que el offector avivaba el color en las piletas de teñido o lo preservaba de mudarse en otro. Asimismo, observamos como en las labores de tintado se emplean tanto a hombres como a mujeres, tal y como se deduce de las menciones epigráficas de Corduba y Gades. En esta industria, colaboran de manera conjunta; seguramente, se trata 
de grupos de libertos que continúan trabajando en el negocio de sus antiguos propietarios tras la manumisión.

Por otro lado, las menciones a confección de ropa también están presentes en el material epigráfico: un vestiarius o fabricante de ropa, aunque también puede designar al vendedor de vestidos; así como otros especialistas: un sagarius o sastre de sayos, una sarcinatrix o modista en Corduba y un lintearius o comerciante de tejidos en Tucci. Los vestiarii se han agrupado en Corduba, donde aparece Pomponius Pamphilus, vestiarius, seguramente un liberto; los sagarii formaron un collegium Larum Augustum, el carácter profesional de la corporación cordubense, no deja dudas; se trata de un colegio formado por individuos que tienen la misma profesión, fabricantes de ropa; aunque también es un colegio religioso de tipo privado que rinde culto a la casa divina y cuyo director es el magister de la cofradía, que dedica una estatua al emperador. Es destacable la actividad de este liberto, que por medio del desempeño de cargo religioso, alcanza un lugar relevante en su comunidad, protagonizando esta actividad evergética. La sarcinatrix, también forma parte de una familia de libertos, un grupo formado principalmente por razones profesionales y religiosas. Numerosas mujeres de origen servil, estaban empleadas en labores de costura y desarrollaban sus labores en pequeños establecimientos donde realizaban el cosido o zurcido de la ropa, para posteriormente ser distribuida y vendida. Precisamente, relacionado con el comercio de estos productos se conoce la estela de L. Haterius, un lintearius en Tucci, que a través de la venta de telas alcanzaría una posición económica desahogada que le permitió sufragar la estela de Fadia.

Existen escasos testimonios de trabajadores textiles en la provincia Bética. El epitafio de Caesia Celsa encontrado en Tucci, la describe como una lanifi praeclara; sin embargo, no es el hilado la profesión de Caesia, sino una cualidad de esta dama romana y respondía a los cánones doctrinales de lanam fecit et domun servavit. En esta línea, no podemos olvidar, las recomendaciones del emperador Augusto de elaborar la lana y vestirse con sus telas confeccionadas manualmente ${ }^{46}$.

La producción doméstica se registra arqueológicamente en la dispersión que tienen las pesas de telar de cerámica en los ámbitos privados; en el Sistema Integrado de Documentación y Gestión Museográfica denominado DOMUS, base de datos que recoge el catálogo de las colecciones de los museos andaluces hemos encontrado 20 pesas; que recogemos en la siguiente TABLA II:

\begin{tabular}{|c|c|c|c|c|}
\hline Procedencia & No Inventario & Dimensiones & Fuente & Comentario \\
\hline $\begin{array}{l}\text { Giribaile } \\
\text { (Jaén). }\end{array}$ & CE/DA03047 & $\begin{array}{l}\text { Altura }=1.8 \mathrm{~cm} \\
\text { Diámetro }=2 \mathrm{~cm} \\
\text { Peso }=10.64 \mathrm{gr}\end{array}$ & $\begin{array}{l}\text { Domus; } \\
\text { Servajean, } \\
\text { G., } \\
\text { Excavación }\end{array}$ & $\begin{array}{l}\text { Iberorromana. } \\
\text { Arcilla }\end{array}$ \\
\hline
\end{tabular}




\begin{tabular}{|c|c|c|c|c|}
\hline $\begin{array}{l}\text { Giribaile } \\
\text { (Jaén). }\end{array}$ & CE/DA03048 & $\begin{array}{l}\text { Altura }=2.5 \mathrm{~cm} \\
\text { Diámetro }=2.6 \mathrm{~cm} \\
\text { Peso }=13.95 \mathrm{gr}\end{array}$ & $\begin{array}{l}\text { Domus; } \\
\text { Servajean, } \\
\text { G., } \\
\text { Excavación }\end{array}$ & $\begin{array}{l}\text { Iberorromana. } \\
\text { Arcilla }\end{array}$ \\
\hline $\begin{array}{l}\text { Giribaile } \\
\text { (Jaén). }\end{array}$ & CE/DA03049 & $\begin{array}{l}\text { Altura }=2 \mathrm{~cm} \\
\text { Diámetro }=3.1 \mathrm{~cm} \\
\text { Peso }=16.80 \mathrm{gr}\end{array}$ & $\begin{array}{l}\text { Domus; } \\
\text { Servajean, } \\
\text { G., } \\
\text { Excavación }\end{array}$ & $\begin{array}{l}\text { Iberorromana. } \\
\text { Arcilla }\end{array}$ \\
\hline $\begin{array}{l}\text { Giribaile } \\
\text { (Jaén). }\end{array}$ & CE/DA03050 & $\begin{array}{l}\text { Altura }=2.8 \mathrm{~cm} \\
\text { Diámetro }=3.6 \mathrm{~cm} \\
\text { Peso }=23.22 \mathrm{gr}\end{array}$ & $\begin{array}{l}\text { Domus; } \\
\text { Servajean, } \\
\text { G., } \\
\text { Excavación }\end{array}$ & $\begin{array}{l}\text { Iberorromana. } \\
\text { Arcilla }\end{array}$ \\
\hline $\begin{array}{l}\text { Jaén. } \\
\text { Desconocida. }\end{array}$ & CE/DA01453 & $\begin{array}{l}\text { Longitud }=11.20 \mathrm{~cm} \\
\text { Anchura }=7.60 \mathrm{~cm} \\
\text { Grosor máx. }=3.82 \\
\mathrm{~cm}\end{array}$ & Domus & $\begin{array}{l}\text { Época } \\
\text { Romana. } \\
\text { Arcilla }\end{array}$ \\
\hline $\begin{array}{l}\text { Jaén. } \\
\text { Desconocida. }\end{array}$ & CE/DA01454 & $\begin{array}{l}\text { Longitud }=10.36 \mathrm{~cm} \\
\text { Anchura }=6.82 \mathrm{~cm} \\
\text { Grosor máx. }=3.30 \\
\mathrm{~cm}\end{array}$ & Domus & $\begin{array}{l}\text { Época } \\
\text { Romana. } \\
\text { Arcilla }\end{array}$ \\
\hline $\begin{array}{l}\text { Bruñel, } \\
\text { Quesada, } \\
\text { (Jaén). }\end{array}$ & CE/DA00560 & $\begin{array}{l}\text { Longitud }=5.22 \mathrm{~cm} \\
\text { Anchura }=2.01 \mathrm{~cm} \\
\text { Grosor máx. }=1.92 \\
\mathrm{~cm}\end{array}$ & Domus & $\begin{array}{l}\text { Bajo Imperio } \\
\text { Romano. } \\
\text { Plomo }\end{array}$ \\
\hline $\begin{array}{l}\text { Alfar de } \\
\text { Cartuja, } \\
\text { Granada. }\end{array}$ & CE09609 & $\begin{array}{l}\text { Altura }=8 \mathrm{~cm} \\
\text { Anchura }=7,4 \mathrm{~cm} \\
\text { Profundidad = 6,2 } \\
\mathrm{cm}\end{array}$ & $\begin{array}{l}\text { Domus; } \\
\text { Excavación } \\
\text { arqueológica, } \\
\text { 1964-1970, } \\
\text { Sotomayor } \\
\text { Muro, M. }\end{array}$ & $\begin{array}{l}\text { Alto Imperio } \\
\text { Romano. } \\
\text { Arcilla }\end{array}$ \\
\hline $\begin{array}{l}\text { Alfar de } \\
\text { Cartuja, } \\
\text { Granada. }\end{array}$ & CE09610 & $\begin{array}{l}\text { Altura }=7,8 \mathrm{~cm} \\
\text { Anchura }=5,8 \mathrm{~cm} \\
\text { Profundidad = 5,1 } \\
\mathrm{cm}\end{array}$ & $\begin{array}{l}\text { Domus; } \\
\text { Excavación } \\
\text { arqueológica, } \\
\text { 1964-1970, } \\
\text { Sotomayor } \\
\text { Muro, M. }\end{array}$ & $\begin{array}{l}\text { Alto Imperio } \\
\text { Romano. } \\
\text { Arcilla }\end{array}$ \\
\hline $\begin{array}{l}\text { Granada. } \\
\text { Desconocida. }\end{array}$ & CE04911 & $\begin{array}{l}\text { Altura }=11 \mathrm{~cm} \\
\text { Anchura }=7 \mathrm{~cm} \\
\text { Profundidad }=. \mathrm{cm}\end{array}$ & Domus & $\begin{array}{l}\text { Alto Imperio } \\
\text { Romano. } \\
\text { Arcilla }\end{array}$ \\
\hline $\begin{array}{l}\text { Termas } \\
\text { Torreblanca, } \\
\text { Fuengirola } \\
\text { (Málaga). }\end{array}$ & A/CE02825 & $\begin{array}{l}\text { Altura }=11 \mathrm{~cm} \\
\text { Longitud }=7.2 \mathrm{~cm} \\
\text { Anchura }=6.3 \mathrm{cc}\end{array}$ & $\begin{array}{l}\text { Domus; } \\
\text { Excavación } \\
\text { arqueológica, } \\
\text { Puertas } \\
\text { Tricas, R } \\
\end{array}$ & $\begin{array}{l}\text { Alto Imperio } \\
\text { Romano. } \\
\text { Arcilla. }\end{array}$ \\
\hline
\end{tabular}




\begin{tabular}{|c|c|c|c|c|}
\hline $\begin{array}{l}\text { Termas } \\
\text { Torreblanca, } \\
\text { Fuengirola } \\
\text { (Málaga). }\end{array}$ & A/CE02826 & $\begin{array}{l}\text { Altura }=6.6 \mathrm{~cm} \\
\text { Longitud }=16 \mathrm{~cm} \\
\text { Anchura }=3.5 \mathrm{cc}\end{array}$ & $\begin{array}{l}\text { Domus; } \\
\text { Excavación } \\
\text { arqueológica, } \\
\text { Puertas } \\
\text { Tricas, R }\end{array}$ & $\begin{array}{l}\text { Alto Imperio } \\
\text { Romano. } \\
\text { Arcilla. }\end{array}$ \\
\hline $\begin{array}{l}\text { Ctjo. } \\
\text { Santillán, } \\
\text { Mollina } \\
\text { (Málaga). }\end{array}$ & A/CE02875 & $\begin{array}{l}\text { Altura = } 10 \mathrm{~cm} \\
\text { Longitud }=8.2 \mathrm{~cm} \\
\text { Anchura }=4 \mathrm{~cm}\end{array}$ & $\begin{array}{l}\text { Domus; } \\
\text { Excavación } \\
\text { arqueológica, } \\
\text { 1982, Puertas } \\
\text { Tricas, R. }\end{array}$ & $\begin{array}{l}\text { Alto Imperio } \\
\text { Romano. } \\
\text { Arcilla }\end{array}$ \\
\hline $\begin{array}{l}\text { Málaga. } \\
\text { Desconocida. }\end{array}$ & A/CE04543/1 & $\begin{array}{l}\text { Anchura }=5.2 \mathrm{~cm} \\
\text { Diámetro }=10.2 \mathrm{~cm} \\
\text { Diámetro mín. }= \\
0.6 \mathrm{~cm}\end{array}$ & $\begin{array}{l}\text { Domus; } \\
\text { Puertas } \\
\text { Tricas, R. } \\
\text { (1982): } \\
\text { Excavaciones } \\
\text { arqueológicas } \\
\text { en Lacipo }\end{array}$ & $\begin{array}{l}\text { Alto Imperio } \\
\text { Romano. } \\
\text { Arcilla }\end{array}$ \\
\hline $\begin{array}{l}\text { Málaga. } \\
\text { Desconocida. }\end{array}$ & $\mathrm{A} / \mathrm{CE} 04543 / 2$ & $\begin{array}{l}\text { Anchura }=4.5 \mathrm{~cm} \\
\text { Diámetro ext. }=11.2 \\
\mathrm{~cm} \\
\text { Diámetro int. }=1.5 \\
\mathrm{~cm}\end{array}$ & $\begin{array}{l}\text { Domus; } \\
\text { Puertas } \\
\text { Tricas, R. } \\
\text { (1982): } \\
\text { Excavaciones } \\
\text { arqueológicas } \\
\text { en Lacipo }\end{array}$ & $\begin{array}{l}\text { Alto Imperio } \\
\text { Romano. } \\
\text { Arcilla }\end{array}$ \\
\hline $\begin{array}{l}\text { Salto de } \\
\text { la Mora, } \\
\text { Ubrique } \\
\text { (Cádiz). }\end{array}$ & DJ28988 & $\begin{array}{l}\text { Profundidad }=3 \mathrm{~cm} \\
\text { Anchura máxima }= \\
8.5 \mathrm{~cm} \\
\text { Anchura mínima = } \\
7 \mathrm{~cm} \\
\text { Altura máxima = } \\
13 \mathrm{~cm} \\
\text { Altura mínima }= \\
11.5 \mathrm{~cm}\end{array}$ & $\begin{array}{l}\text { Domus; } \\
\text { Vallejo } \\
\text { Sánchez, } \\
\text { Juan Ignacio } \\
\text { (2007): } \\
\text { "Ponderae } \\
\text { o pesas de } \\
\text { telar", La } \\
\text { mujer en } \\
\text { el mundo } \\
\text { antiguo, p. } \\
\text { 58; il.p. } 59\end{array}$ & $\begin{array}{l}\text { Época } \\
\text { Romana. } \\
\text { Arcilla. }\end{array}$ \\
\hline $\begin{array}{l}\text { El Coronil } \\
\text { (Sevilla) }\end{array}$ & REP17889 & $\begin{array}{l}\text { Altura }=9.1 \mathrm{~cm} \\
\text { Diámetro máx. }=14.5 \\
\mathrm{~cm} \\
\text { Diámetro mín. }=9 \\
\mathrm{~cm} \\
\text { Peso }=3170 \mathrm{gr}\end{array}$ & Domus & $\begin{array}{l}\text { Alto Imperio } \\
\text { Romano. } \\
\text { Arcilla }\end{array}$ \\
\hline
\end{tabular}




\begin{tabular}{|c|c|c|c|c|}
\hline $\begin{array}{l}\text { Cabezo de } \\
\text { S. Pedro } \\
\text { (Huelva) }\end{array}$ & A/CE4277/4 & $\begin{array}{l}\text { Altura = } 1 \mathrm{~cm} \\
\text { Diámetro máx. = } \\
2.1 \mathrm{~cm}\end{array}$ & $\begin{array}{l}\text { Domus; } \\
\text { Excavación, } \\
\text { 1968-1975, } \\
\text { Garrido } \\
\text { Roiz, / } \\
\text { Fernández } \\
\text { Miranda, } \\
\text { / Deamos } \\
\text { Belén, }\end{array}$ & $\begin{array}{l}\text { Época } \\
\text { Romana. } \\
\text { Arcilla }\end{array}$ \\
\hline $\begin{array}{l}\text { Niebla, Puerta } \\
\text { de Sevilla } \\
\text { (Huelva) }\end{array}$ & A/CE5800 & $\begin{array}{l}\text { Longitud }=7.3 \mathrm{~cm} \\
\text { Anchura }=4.3 \mathrm{~cm} \\
\text { Grosor }=2 \mathrm{~cm}\end{array}$ & $\begin{array}{l}\text { Domus; } \\
\text { Excavación, } \\
\text { 1981, Amo, } \\
\text { del / Belén } \\
\text { Deamos }\end{array}$ & $\begin{array}{l}\text { Época } \\
\text { Romana. } \\
\text { Arcilla }\end{array}$ \\
\hline
\end{tabular}

El descubrimiento de pesas de telar es generalmente puntual, se localizan en las estructuras domésticas; se trata de útiles de trabajo que forman parte del telar para tensar los hilos y facilitar de esta manera el proceso de elaboración de tejidos. A tenor del hallazgo de pesas de telar o ponderae en casi todos los ambientes domésticos, debemos pensar que la confección de tejidos era una actividad casera, cada unidad familiar proveía sus propias necesidades. E1 escritor gaditano Columela señala el papel que desarrolla la mujer en estos menesteres, al subrayar que la villica debe enseñar a las que trabajan en el telar de la villa ${ }^{47}$. En este sentido, debemos realizar la lectura del epitafio de Caesia Celsa procedente de Tucci, que la describe como lanifici praeclara.

Finalmente, es importante indicar dos aspectos sobresalientes. Uno relacionado con el número de profesionales aparecidos en la ciudad de Corduba, lo que está en consonancia con su status jurídico de colonia romana y capital de la provincia bética, que tras la reorganización de Augusto, se convierte en un centro económico, militar, cultural y una de las ciudades más florecientes hispanas, que beneficia a libertos; un gran número de inscripciones aluden a ellos; entre estas encontramos dedicatorias realizadas por los collegia, otras mencionan las ocupaciones de estos libertos privados, como la de magister larum; algunos desempeñaron el sevirato; gracias a las grandes fortunas que consiguen con la producción o tintado de tejidos, y por otra parte, otros están ocupados en negocios comerciales. Por otra parte, llama la atención la diversificación de oficios en relación a la tinción y a la confección. 


\section{BibLiografía:}

ABASCAL PALAZÓN, J.M., Los nombres personales en las inscripciones latinas de Hispania. Murcia, 1994.

ALFARO, C., Tejido y cestería en la Peninsula Ibérica. Historia de su técnica e industrias desde la prehistoria a la romanización. Madrid, 1984.

ALFARO, C., El tejido en época romana. Madrid, 1997.

ARLEGUI SÁNCHEZ, M. y BALLANO SORIANO, M., "Algunas cuestiones acerca de las llanadas pesas de telar: los "pondera" de Numancia, "Cuesta del Moro" y "Las Quintanas (Langa de Duero y "Castilterreño" (Izana)", Simposio sobre los celtíberos (3, 1991, Daroca): Poblamiento. Zaragoza, Institución Fernando el Católico, 1993, pp. 141-155.

BELTRÁN DE HEREDIA BERCERO, J., "Los restos arqueológicos de una fullonica y una tinctoria en la colonia romana de Barcino (Barcelona), Complutum 11 (2000), pp. 253-259.

BERNAL PASCUAL, F., GALLEGO GALLARDO, J. y LLINARES BENEYTO, J., "Aportación al estudio tipológico de pesas de Telar (E1 Macalón, Nerpio, Albacete)", Congreso de Historia de Albacete, Vol. I: Prehistoria y Arqueología. Albacete, 1984, pp. 167-176.

COARELLI, F., "Fregellae, Arpium, Aquinum: lana e fullonicae nel Lazio meridionale", Les élites municipales de l'Italie péninsulaire, des Gracques à Néron. Actes de la table Ronde de Clermont-Ferrand, Roma, 1996, pp. 199-205.

FEAR, A.T., "The Golden Sheep of Roman Andalusia”, Ag Hist Rev, 40, II, pp 151-155.

FITA COLOMÉ, F., Nuevas inscripciones romanas de Alcorrucén, Écija, Denia, Turis y Abia de las Torres. Noviembre de 1900. Biblioteca Virtual Miguel de Cervantes.

FLOHR, M., Organizing the Workshop. Water Management in Roman fullonicae. Cura Aquarum in Ephesus. vol.I. 2006, pp. 193-199.

GIMENO PASCUAL, H., Artesanos y técnicos en la epigrafía de Hispania. Barcelona, 1988.

GONZÁLEZ ROMÁN, C.; RODRÍGUEZ NEILA, J.F., MANGAS MANJARRÉS, J. y OREJAS, A., El trabajo en la Hispania romana. Madrid, Silex, 1999.

KAJANTO, I., The Latin cognomina. Roma, 1982.

LÓPEZ MIRA, J. A., "Actividad textil en el bajo Vinapolo desde la Prehistoria reciente hasta la romanización", Actas del XXIII Congreso Nacional de Arqueología. Volumen I. Elche, 1995, pp. 339-348.

MOELLER, O., "Infectores and offectores at Pompeii", Latomus XXXII (1973), pp. 368 y ss.

ROBERTIS, F.M. DE, Il fenomeno associativo nel mondo romano. Dai collegi della Repubblica alle corporazioni del Basso Impero. Roma, 1981. 
SÁEZ, P., "Los agrónomos latinos y la ganadería”, en J. GÓMEZ PANTOJA (coord.), Los rebaños de Gerión. Pastores y transhumancia en Iberia antigua y medieval. Madrid, 2001, pp. 159-171.

SANTERO SATURNINO, J.M., Asociaciones populares en la Hispania romana. Sevilla, 1978.

SOLIN, H., Die griechische Personenamen in Rom. Ein Namenbuch. BerlinNew York, 1982.

SPINAZOLA, V., Pompei alla luce degli scavi nuovi di via dell'Abbondanza (Anni 1910-1923), vol. 2. Roma, 1953, pp. 765-685.

USCATESCU, A., Fullonicae e tinctoriae en el mundo romano. Barcelona, 1994.

VICARI, F., Produzione e commercio dei tessuti nell'Occidente romano. Oxford, BAR International Series 916, 2001.

VENTURA VILLANUEVA, A. y MARFIL RUIZ, P.F., "Dos inscripciones inéditas halladas en las obras de la nueva estación de ferrocarril de Córdoba”, en AA.VV., Arqueología urbana. Catálogo de la exposición. Córdoba, 1991,pp. 41-47.

WALTZING, J.P., Étude historique sur les corporations professionnelles chez les Romains, depuis les origines jusqu'à la chute de l'empire d'Occident. (Bruxelles 1895-1900; reimpr. Lovaina 1970). 
${ }^{1} \mathrm{El}$ presente trabajo se inserta dentro de los proyectos del G.I. Arqueología e Historia en la Hispania Meridional en época romana y visigoda (HUM-215), Universidad de Granada.

${ }^{2}$ C. Alfaro, (1984), p. 19-45.

${ }^{3}$ Mart, VIII, 28, 5: An Tartesiaeus stabuli nutritor Hiberi/ Baetis in Hesperia te quoque lauit oue?..

${ }^{4}$ Colum., De r.r. VII,2: Quibusdam vero nationibus frumenti expertibus victum commodat, ex quo Nomadum Getarumque plurimi galaktopotai dicuntur. Igitur id pecus, quamvis mollissimum sit, ut ait prudentissime Celsus, valetudinis tutissimae est minimeque pestilentia laborat. Verum tamen eligendum est ad naturam loci, quod semper observari non solum in hoc, sed etiam in tota ruris disciplina Vergilius praecipit, cum ait: nec vero terrae ferre omnes omnia possunt.; VII, 3,13: Pinguis et campestris situs proceras ovis tolerat, gracilis et collinus quadratas, silvestris et montosus exiguas. Pratis planisque novalibus tectum pecus commodissime pascitur, idque non solum generibus, sed etiam coloribus plurimum refert. Generis eximii Calabras Apulasque et Milesias nostri existimabant earumque optimas Tarentinas. Nunc Gallicae pretiosiores habentur earumque praecipue Altinates, item quae circa Parmam et Mutinam macris stabulantur campis.; XII, 13: Caseo usibus domesticis praeparando hoc maxime idoneum tempus est, quod et caseus seri minimum remittit et ultimo tempore, cum iam exiguum lactis est, non tam expedit operas morari ad forum fructibus deferendis; et sane saepe deportati propter aestum acore vitiantur. Itaque praestat eos hoc ipso tempore in usum conficere. Id autem ut quam optime fiat, opilionis officium est, cui septimo libro praecepta dedimus, quae sequi debeat..

${ }^{5}$ Colum., De r.r., VII, 2,4: Sunt etiam suapte natura pretio commendabiles pullus atque fuscus, quos praebet in Italia Pollentia, in Baetica Corduba nec minus Asia rutilos, quos vocant erytbraious.

${ }^{6}$ Juvenal., XII, 41-42: "Fundite quae mea sunt" dicebat "cuncta"/ Catullus praecipitare uolens etiam pulcherrima, uestem/ purpuream teneris quoque Maecenatibus aptam/ atque alias quarum generosi graminis ipsum/ infecit natura pecus, sed et egregius fons/ uiribus occultis et Baeticus adiunat aer...

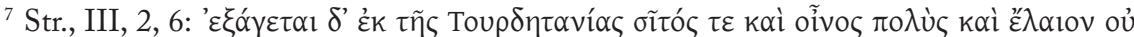

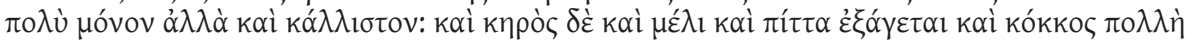

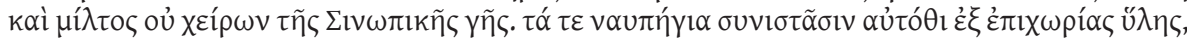

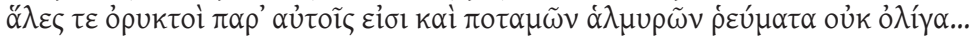

${ }^{8}$ Plin., NH., VIII, 75, 198-199 : In ipsa ove satis generositas ostenditur brevitate crurum, ventris vestitu. is quibus nudus esset, apicas vocabant damnabantque. Syriae cubitales ovium caudae plurimumque in ea parte lanicii. castrari agnos nisi quinquemenstres praematurum existimatur. Est in Hispania, sed maxime Corsica, non absimile pecori genus musmonum, caprino villo quam pecoris velleri propius, quorum e genere et ovibus natos prisci umbros vocaverunt. infirmissimum pecori caput, quam ob rem aversum a sole pasci cogendum, quoniam stultissima animalium lanata: qua timuere ingredit, unum cornu raptum sequuntur. vita longissima anni $X$, in Aethiopia XIII. capris eodem loco XI, in reliquo orbe plurimum octoni. utrumque genus intra quartum coitum inpletur.

${ }_{9}^{\mathrm{XII}}$, 65, 5: Gratis qui dare vos iubet, puellae,/Insulsissimus inprobissimusque est./Gratis ne date, basiate gratis./Hoc Aegle negat, hoc avara vendit./Sed vendat: bene basiare quantum est!

${ }^{10}$ Mart., IX, 61, 2: In Tartesiacis domus est notissima terris,/ qua dives placidum Corduba Baetin amat, / vellera nativo pallent ubi flava metallo/ et linit Hesperium brattea viva pecus.

${ }^{11}$ Colum., De r.r., VII, 2,4-5: sed et alias uaritates in hoc pecudis genere docuit usus exprimere. Nam cum in municipium Gaditanum ex uicino Africae miri coloris siluestres ac feri arietes sicut aliae bestiae munerariis deportarentur, Marcus Columella patruus meus, acris uir ingeni atque inlustris agricola, quosdam mercartus in agros transtulit et mansuefactos tectis ouibis admisit. Eae primum hirtos, sed paterni coloris agnos ediderunt, qui deinde et ipsi Taretinis ouibus inpositi tenuioris uelleris arietes progenerauerunt. Ex his rursus quicquid conceptum est, maternam mollitiem, paternum et auitum retullit colorem. Hoc modo Columella dicebat, qualemcumque speciem, quae fuerit in bestiis, per nepotum gradus mitigata feritate reddi.

${ }_{12}$ Strab. III, 2, 6: "Antes figuraba en primera linea su igualmente abundante paño, pero ahora lo hace la lana, de la que hay mas producción que de lanas coraxinas. Y en belleza es insuperable: los 
carneros para cría se compran al menos en un talento. Insuperables son también los tejidos ligeros, como los que fabrican los salacietas". Marcial XII, 65, 5: Formosa Phyllis nocte cum mibi tota/ Se praestitisset omnibus modis largam, / Et cogitarem mane quod darem munus, / Utrumne Cosmi, Nicerotis an libram,/An Baeticarum pondus acre lanarum,I An de moneta Caesaris decem favos:/ Amplexa collum basioque tam longo/Blandita, quam sunt nuptiae columbarum,/Rogare coepit Phyllis amphoram vini.

${ }^{13}$ Marc., De medic., VIII, 27.

${ }^{14}$ Cfr. H. Gimeno Pascual, (1988), p. 31.

${ }^{15}$ IRPC, $\mathrm{n}^{\circ}$. 139: D(is) M(anibus) S(acrum)/B[a]ebia Veneria/[pur]peraria/ [c(ara) s(uis)] avo dulcis ann(orum) XXV/B[a]ebius/Venriosus/ [a]nn(i) I m(ensium) III s(it) v(obis) t(erra) [l(evis)].

${ }^{16}$ Cfr. J.M. Abascal, (1994), pp. 93-96.

${ }^{17}$ Cfr. I. Kajanto (1982), pp. 53, 57.

${ }^{18}$ I CIL, II'2/5, 191: Caesia. [L(ucii)]. F(ilia). Celsa/ A N(norum). LXV. H(ic). S(ita). E(st)./ quod voto petiere suis plerumque parentes/ cuncta tibi dignae Caesia con[t]i[g]er[a]nt/ lanifici praeclara fides pietati alumnal priscae praecipve fama pudicitiae/ te rogo praeteriens dicas/s(it). t(ibi). t(erra). l(evis)./ Q(uo). Q(uo).V(orsum). L(ocus). P(edum). XII.

${ }^{19}$ Cfr. J. M. Abascal, (1994), p. 103.

${ }^{20} \mathrm{CIL}, \mathrm{II}^{2} / 7,335$ : ---]Diocles purpurarius pius/ [---] mater pia/ [---] ema ex test (amento) fratris $f$ (aciendum) c(uravit)/ [---]otimus purpur(arius) h(oc) m(onumentum) b(eredem) n(on) s(equetur)..

${ }^{21}$ Cfr. Solin, (1982), p. 40.

${ }^{22}$ Cfr. J.M. Abascal, (1994), p. 344.

${ }^{23}$ Cfr. H. Gimeno, (1988), p. 42.

${ }^{24}$ CIL, II'/7, 198: Faustus/ offector h(ic) s(itus) e(st)/s(it) t(ibi) t(erra) l(evis) in f(ronte) l(ocus) p(edum) XXV/ in ag(ro) p(edum) XXIIII.

${ }^{25}$ Cfr. I. Kajanto, (1982), pp. 29, 30, 41, 72, 73, 134, 272.

${ }^{26} \mathrm{CIL}, \mathrm{II}^{2} / 7,323$ : [---Fe]lix sagarius/ [mag(ister) Laru]m Aug(ustorum) c(olonorum) c(oloniae) $P$ (atriciae) sibi et/ [---a]phrae patronol [mag(istro) Lar]um Aug(ustorum) c(olonorum) c(oloniae) $P$ (atriciae) et/------.

${ }^{27}$ Cfr. Solin, (1982), p. 330

${ }^{28}$ Cfr. H. Gimeno, (1988), p. 44.

${ }^{29} \mathrm{CIL}, \mathrm{II}^{2} / 5,112:$ Fadiae [---]. / L(ucius). Hat[erius]/Lin[tearius].

${ }^{30}$ Cfr . A. Ventura Villanueva y P.F. Marfil Ruiz, (1991), n 35, p. 41; CIL II'2/7, 352: - - - $-{ }_{+++}[---] \backslash I N[---] \backslash B U[---] \backslash------$.

${ }^{31}$ A. Ventura y P.F. Marfil, (1991), no 35, p. 41.

${ }^{32}$ HEp 4, 1994, 290.

${ }^{33}$ CIL, II ${ }^{2} / 7,339: M$ (arcus) Latinius $M$ (arci) [l(ibertus)?---]/L(ucius) Afinius L(uci) l(ibertus) Ata[---]/Latinia M(arci) l(iberta) T+[---]/Demetrius fil[ius]/Latinia M(arci) l(iberta) Da+[---]/ sarcinatrix[---?].

${ }^{34} C I L, \mathrm{II}^{2} / 7,102$ : Liberalis/Infector. H(ic). S(itus). E(st)./ S(it). T(ibi). T(erra). L(evis)..

${ }^{35}$ Cfr. I. Kajanto, 1982, pp. 28, 62, 68, 220,256.

${ }_{36}$ CIL, II $2 / 7,343:$ [-] Pomponius [-l(ibertus)]/ Pamphilus vestia[rius]/ [Pomponi?]a T(iti) l(iberta) Anu[---]/ [Pomp]onia F[---]/ [---]A[---].

${ }^{37}$ Cfr. J.M. Abascal, (1994), p. 201.

${ }^{38}$ Cfr. Solin, (1982), pp. 128 y 179.

${ }^{39}$ Cfr. J.M. Abascal, (1994), p. 447.

${ }^{40}$ Cfr. Solin, (1982), p. 830.

${ }^{41}$ Seguimos la clasificación que el Prof. Santero ofrece en su obra J.M. Santero Saturnino, (1978), p. 14. Al respecto ver también J.P. Waltzing, (1970); F.M. De Robertis, (1981), pp. 21-29.

42 J. Beltrán de Heredia, (2000), pp. 253-260.

${ }^{43}$ Plin., NH., XXXV, 198: adeo omnia maioribus curae furere. ergo ordo bic est:primum abluitur vestis Sarda, dein sulpure suffitur, mox desquamatur Cimolia quae est coloris veri. fucatus enim deprehenditur nigrescitque et funditur sulpure, veros autem et pretiosos colores emollit Cimolia et quodam nitore exhilarat contristatos sulpure. candidis vestibus saxum utilius a sulpure, inimicum coloribus. Graecia pro Cimolia Tymphaico utitur gypso. 
${ }^{44}$ Pompeya: V. Spinazola, (1953), pp. 765-685; O. Moeller, (1973), p. 368 ss; Lazio: F. Coarelli, (1996), pp. 199-205; M. Florch, (2006), pp. 1993-199.

${ }^{45}$ A. Uscatescu, (1994).

${ }^{46}$ Suetonio, Augusto, LXXIII: Instrumenti eius et supellectilis parsimonia apparet etiam nunc residuis lectis atque mensis, quorum pleraquc vix privatae elegantiae sint. Ne toro quidem cubuisse aiunt nisi humili et modice instrato. Veste non temere alia quam domestica usus est, ab sorore et uxore et filia neptibusque confecta; togis neque restrictis neque fusis, clavo nec lato nec angusto, calciamentis altiusculis, ut procerior quam erat videretur. Et forensia autem et calceos numquam non intra cubiculum habuit ad subitos repentinosque casus parata.

${ }^{47}$ Colum., De r.r., XII, 5: Igitur haec nobis antiqui per $<$ I schomachi personam praecepta industriae ac diligentiae tradiderunt, quae nunc nos vilicae demonstramus.. XII, 8: Denique uno loco quam minime oportebit eam consistere: neque enim sedentaria eius opera est, sed modo ad telam debebit accedere ac, si quid melius sciat, docere, si minus, addiscere ab eo, qui plus intellegat; modo eos, qui cibum familiae conficiunt, invisere, tum etiam culinam et bubilia nec minus praesepia emundanda curare; valitudinaria quoque, vel si vacent ab inbecillis, identidem aperire et inmunditiis liberare, ut, cum res exegerit, bene ordinata [et ornata] et salubria languentibus praebeantur. 


\title{
El mito a la palestra. Los Juegos ANTIGUOS EN LA POÉTICA DE EsCALÍGERO Y EN LA mitología de Natale Conti ${ }^{\mathrm{I}}$.
}

\author{
María Nieves Muñoz Martín - José A. Sánchez Marín \\ Universidad de Granada
}

Hemos dejado constancia en otros lugares ${ }^{2}$ de la inesperada y singular presencia en la Poética de J. C. Escalígero de los capítulos sobre los juegos atléticos antiguos, que ocupan una sección central y extensa -casi un tercio- del libro primero (caps. 22-39). Examinábamos allí su contenido, tipo de análisis, la lógica interna y externa de su aparición en el tratado y los propósitos que el autor revela o parece revelar. Según Escalígero, los ludi son fábulas sin palabras, fabulae tacitae, y las fábulas teatrales son juegos que hablan, ludi loquentes ${ }^{3}$. Tanto los juegos como las fábulas resultan, pues, representaciones del mito, y en este trabajo pretendemos indagar las peculiaridades que el autor de la Poética manifiesta en el tratamiento del tema, frente a las que ofrece sobre el mismo uno de los tratados mitológicos más renombrados del Renacimiento, la Mythologia de Natale Conti, abundantemente editada y utilizada durante el siglo que siguió a su primera edición ${ }^{4}$. De esta confrontación pretendemos extraer rasgos caracterizadores del método y modo de actuación del teórico italo-francés sobre el que venimos trabajando. También queremos contribuir, aunque sea de modo tangencial, a la cuestión planteada por Stillers acerca de la relación entre el mundo de los dioses paganos y la reflexión teórico-poética del Renacimiento, cuestión insuficientemente atendida según el estudioso ${ }^{5}$.

Obviamente se trata de dos obras de muy distinto designio, estructura y ejecución. Sobre los juegos en el tratado de Escalígero, que vio la luz en 1561, recordemos aquí especialmente su presencia en el libro I, Historicus, donde el autor se ocupa del origen y desarrollo de las formas y especies poéticas, relacionándolas con los usos del lenguaje y con el devenir de la cultura y civilización humanas. En esta evolución se insertan naturalmente los géneros dramáticos, desde el pastoral como más antiguo, seguido del cómico, del que nació el trágico, finalizando con el mimo y la sátira dramática, todos ellos analizados en sus múltiples aspectos desde el capítulo 4 al 21. Para Escalígero, el nexo entre estos géneros y los ludi son la fabula y el apparatus, esto es, el mito y el espectáculo. El origen y desarrollo de los propios juegos se acomoda igualmente al proceso cultural. Del mismo modo que sucede con el nacimiento de los géneros literarios, partiendo de la vida natural y las diversiones de los pastores griegos, del movimiento simple y de lo meramente fortuito surgió el ejercicio más complejo y la competición. En razón de su naturaleza afín a los géneros dramáticos, puesto que incluyen mito y espectáculo, Escalígero dedica 
un espacio, aproximadamente un tercio del libro 1 -18 capítulos de un total de 57-, a una detallada exposición sobre los juegos atléticos, comenzando por los griegos (caps. 22-27) seguidos de los romanos (caps. 28-39), con una similar extensión del texto y con un análisis análogo dedicado a ambos grupos, cuyos rasgos principales ya hemos examinado. La última parte del Historicus (caps. 40-57) analiza el nacimiento y desarrollo de los géneros y especies poéticas no dramáticas.

El conocimiento y comprensión de los mitos y de las ficciones en general que contiene la poesía antigua es imprescindible tanto para quienes pretenden entender y disfrutar de ésta como para los que se disponen a escribirla en su propio tiempo a imitación de los antiguos. Investigaciones mitológicas en los autores antiguos, mayormente latinos, y creación poética son estrechamente solidarias en el padre de los tratados mitológicos renacentistas, Giovanni Boccaccio, junto con una apasionada defensa humanística de la poesía y de los poetas, a la que el autor de la Genealogia consagra el libro 14, mientras dedica el 15 y último a una autoapología y a la rehabilitación de las fábulas y ficciones de los antiguos. Es mérito especial de Boccaccio, según Stillers ${ }^{6}$, el intento de neutralizar ideológicamente el mundo pagano de los dioses, entendiéndolo como objeto literario ficticio y procedimiento afín y necesario a la obra poética. El particular objetivo de Boccaccio en su Genealogia no dejaba ciertamente lugar a un tratamiento específico de los juegos, a los que en muy rara ocasión alude, como es el caso de los Isthmia sacra?

También una comprometida defensa de la poesía y una detallada exposición sobre su naturaleza y el oficio del poeta contiene el primero de los cuatro libros de la obra de C. Salutati, De laboribus Herculis, que el autor dejó incompleta a su muerte en 1406. Sobre esta obra del canciller florentino como exponente del nuevo espíritu humanista hizo E. Garin esclarecedoras observaciones en un trabajo ${ }^{8}$ justamente recordado por Stillers ${ }^{9}$. Garin, como antes hizo B. Croce ${ }^{10}$, y después ha hecho Stillers, reacciona contra la tesis de J. Seznec ${ }^{11}$ sobre la inexistencia de cambios fundamentales entre las posiciones de la Edad Media y los temas renacentistas en cuanto a la mitología pagana. Garin repara en que Salutati, si bien parte de Boccaccio, celebra en el mito de las hazañas de Hércules, símbolo y protector de Florencia, al hombre heroico - vir fortis et gloriosus- transfigurado por el poder de la poesía ${ }^{12}$.

En los más destacados manuales mitológicos de pleno Renacimiento que, tras la huella de su predecesor, se plantean la materia bajo nuevas perspectivas ${ }^{13}$, tampoco surge nada similar a lo que encontraremos en la Mithologia de Natale Conti. La vasta obra de Lilio Gregorio Giraldi, De deis gentium varia et multiplex historia, originariamente publicada en $1548^{14}$, tiene muy aisladas y escasas referencias a los juegos, especialmente a los latinos. Según se menciona en el título completo, los intereses de este erudito tratado se dirigen a ilustrar la 
historia, imágenes, atributos, nombre y sobrenombres de los dioses paganos. $\mathrm{Si}$ a ello se añade su escasa aceptación de las interpretaciones alegóricas ${ }^{15}$, podría admitirse razonablemente la tesis de Stillers ${ }^{16}$, quien sostiene que el camino para la integración de la mitología en una comprensión literaria de la obra poética y la consiguiente revalorización estética de los mitos, que introduce como innovación el Humanismo renacentista, pasa por su reducción histórica, que sitúa los mitos en su propio tiempo asignándoles su trasfondo religioso.

El monumental tratado de Natale Conti lleva a cabo una revalorización sistemática de los mitos antiguos en los que destaca ante todo su valor simbólico y alegórico, ostensible ya en el título: Diez libros de mitología o de explicación de las fábulas, en las que se demuestra claramente que casi todos los dogmas de la filosofía natural y moral estaban contenidos en las fábulas de los antiguos ${ }^{17}$. Al final de su epístola nuncupatoria al Serenísimo y muy Cristiano rey Carlos IX de Francia, al comienzo de las ediciones de 1567 y $1568^{18}$, el autor se ufanó de haber mostrado, en una obra muy útil a todos los estudiosos, "que casi todas aquellas fábulas de los antiguos, que consideraron los ignorantes naderías de viejas, son muy sesudas opiniones de los sabios sobre la creación del mundo, de los elementos y de los animales; sobre las fuerzas de la naturaleza, sobre la providencia divina, la inmortalidad de las almas, los premios y los castigos que se imponen a cada uno después de la muerte, y sobre otras cosas semejantes ${ }^{19 "}$.

Al comenzar el libro primero (1.1.) el autor manifiesta, dirigiéndose de nuevo al rey Carlos IX, que estas fábulas relatadas por los poetas y autores sabios encubren realmente de modo obscuro y velado los preceptos universales de la filosofía, sin que nadie hasta él hubiera dado una explicación de conjunto

"que haya dejado al descubierto los más profundos y ocultos secretos de las fábulas, que haya sacado a la luz desde las obscuras tinieblas de las fábulas los dogmas de la filosofía que tienden o a poner de manifiesto las fuerzas y acciones de la naturaleza o a conformar las costumbres y regular la vida con rectitud o a entender las fuerzas y movimientos de los astros. Y por ello esto es más admirable, porque sin esta afanosa investigación de las fábulas no podemos comprender rectamente las opiniones de los poetas ni de los filósofos ni de escritor alguno..."

La sabiduría profunda de las fábulas se considera valiosa para los estudiosos en el ámbito de los conocimientos de la naturaleza y de la filosofía; de los autores antiguos, es decir, para la comprensión literaria; también es de gran utilidad para la vida humana. Conti asigna a su trabajo utilidad y placer, insistiendo de nuevo en sus objetivos y advirtiendo de que dejará a un lado toda 
"interpretación de hombres cambiados en árboles o en cuerpos que carecen de sentido o de razón, a no ser las que han podido ser transmitidas por utilidad; no tendremos ninguna explicación de aquellas fábulas que fueron pensadas tontamente por algunos... hemos de explicar solo esas fábulas que elevan a los hombres al conocimiento de las cosas celestes, que les dan reglas para las buenas costumbres, que los apartan de los placeres ilegítimos, que ponen de manifiesto los arcanos de la naturaleza, que los conducen o bien finalmente al conocimiento de las cosas necesarias para la vida bumana o las que los conducen a la honradez y las que... los preparan para conocer rectamente a cada uno de los mejores escritores" ${ }^{21}$.

Aunque el propósito de esclarecer los significados ocultos de las fábulas no es tan dominante ni sistemático en los demás mitógrafos del siglo XVI como lo es en Conti, en este aspecto y en el de proclamar su utilidad frente a los detractores, Boccacio es sin duda un precedente indiscutible. La Conclusión final de su obra Genealogia es bien explícita en ambos sentidos:

“... se ha llegado al fin de la larga obra, en la que he descrito con la habilidad que pude, según las antiguas tradiciones, el linaje de los dioses paganos y su descendencia..., en qué orden se dio y, según el mandato de tu serenidad ... he añadido después de las fábulas los significados de las ficciones, bien tomados de los antiguos, bien sacados de mi pequeña comprensión. Además he demostrado ... que los poetas ... no diré que son todos justos sino que ni son ridiculos ni simplemente fabulosos, por el contrario notables por su secular ciencia, ingenio y costumbres e incluso de insigne claridad... Asi también he apartado del marinero ${ }^{22}$ las saetas que consideré más perjudiciales... "23.

Una saeta que Boccaccio-marinero apartará, en su azaroso viaje en busca del linaje de los dioses antiguos, es la acusación de inmoralidad que contiene la poesía: pero solo algunos poetas, que dudosamente merecen este nombre, se dejaron persuadir por la placentera lascivia y cayeron en estas necedades -ineptiae-, que deben ser condenadas y rechazadas ${ }^{24}$. Adviértase que esta defensa de la poesía y de los poetas no se atribuye al mandato del monarca, sino que aparece como iniciativa del propio autor; a diferencia de esto, en el Proemio y en la Conclusión, Bocaccio manifiesta que se atiene a los deseos del monarca en cuanto a la descripción del linaje y descendencia de los dioses y a la explicación del significado de las ficciones.

Después de defender que la poesía es una actividad útil, no fútil,y explicar su origen y naturaleza, Boccacio destaca especialmente la utilidad de las fábulas en el capítulo 9 ("Componer fábulas parece más útil que perjudicial”) del libro 14, que tiene su correspondencia en el capítulo 2 del libro 1 de la Mythologia de Conti. Sinteticemos los argumentos de Boccaccio: los poetas son creadores de fábulas; fábula procede de hablar (for, faris); la naturaleza concedió a los hombres no solamente hablar sino "hablar unos con otros" 
(conloqui) y comunicarse con palabras, y esto es necio considerarlo malo; si bajo la cobertura de las fábulas se descubre algo juicioso no será superfluo haber contado fábulas. Boccaccio atribuye a la fábula, por tanto, la misma virtud (beneficiosa) que al lenguaje: provecho y deleite, y en concreto los efectos de aquella son ${ }^{25}$ : a) apaciguar los ánimos excitados por un loco furor; b) restituir placenteramente las fuerzas a los espíritus agotados en cosas más importantes; c) consolar a los fatigados por el peso de una adversa fortuna; d) reconducir a un mejor provecho los ánimos que tienden a la pereza; e) los ignorantes se divierten con la primera cobertura y los ingenios de los doctos se ejercitan en sus profundidades: con una misma lectura las fábulas aprovechan y deleitan.

Para Conti, la gran utilidad de las fábulas sólo se hace evidente a un preclaro ingenio que analice cuidadosamente a los escritores antiguos. De la misma forma que los médicos obtienen a partir de los venenos ponzoñosos los fármacos beneficiosos, así de las fábulas se puede obtener mucha utilidad, según atestigua además Platón $(R .377 \mathrm{c})$; Conti concluye poniendo de relieve sus efectos placenteros y didácticos-morales a un tiempo ${ }^{26}:$ a) lenitivo de la vida humana y consuelo de las fatigas; $b$ ) aprendizaje deleitoso de los preceptos que encaminan rectamente la vida.

Valorando lo dicho hasta aquí sobre los mitos antiguos en Boccaccio y en Conti, podríamos destacar en el padre del Humanismo una más elocuente defensa y un mayor énfasis y confianza en los efectos de la palabra persuasiva bien dirigida. Frente a esto se sitúa el conocimiento útil para la vida humana en sus diversas facetas, perceptible solo para los que atienden a los más profundos significados de las fábulas, que subraya Conti; en este conocimiento se incluye asimismo la comprensión de las fábulas dentro del fenómeno literario antiguo y también de la poética de los géneros ${ }^{27}$. El autor reivindica a Homero, "el llamado poeta por excelencia", que dotó de ocultos y edificantes sentidos a sus relatos y personajes.

Es precisamente a propósito de la utilidad de las fábulas cuando Boccaccio, y como él Conti, distingue las distintas clases de éstas. El primero, basándose en diferentes autores antiguos, de Cicerón a Isidoro de Sevilla ${ }^{28}$, y según el grado de verdad existente ya en la corteza o superficie, ya en el significado oculto, menciona cuatro clases de fábulas: la primera, carente por completo de verdad en su corteza, corresponde a las que escribió Esopo; de la segunda y tercera clase, que mezclan la verdad en su superficie, se valieron los poetas, expresamente los épicos y los dramáticos, entre ellos "los cómicos más honestos, como Plauto y Terencio..., queriendo describir con su arte las costumbres y palabras de distintos hombres y entre tanto enseñar a sus lectores y hacerlos cautos ${ }^{29}$ ". Porque también se usaron en la Sagradas Escrituras, Boccaccio justifica los tres primeros tipos, considerando el cuarto, que carece absolutamente de verdad, "una invención de las extravagantes 
viejecillas". Por su parte Conti se remite a Dionisio de Halicarnaso (2.20.1) sobre la diversidad de los mitos griegos según la utilidad que reportan al hombre, para después plantear una división de las fábulas según su valor simbólico de carácter natural o, sobre todo, moral. En el capítulo siguiente (1.3.) aborda también una clasificación según nombre del lugar, inventor y argumentos; dentro de esta última división incluye las fábulas Políticas, "aquellas que utilizaron los sabios para dulcificar los ánimos de los poderosos y para guiar a la muchedumbre a un modo más humano de vida”, (ad humaniorem vitae rationem), entre las cuales "han de ser enumerados los argumentos de las comedias y de las tragedias porque, si bien a través de éstas no son apartados los hombres de la vida agreste, sin embargo son llevados de los placeres ilegítimos y de todo tipo de intemperancia a la moderación de la vida" ${ }^{30}$. A continuación se extiende en la clasificación y en los distintos nombres que reciben las fábulas dramáticas. Seguidamente, en el capítulo 4 "Sobre la diferencia entre apólogos, fábulas y ainoi", identifica las fábulas llamadas mythoi, que "abarcan argumentos de tragedia y de comedia y, en último término, toda la esencia de la poesía que se da por imitación”, y se representan en escena para corregir y formar las costumbres de los hombres ${ }^{31}$.

Conti precisa que a ninguna de estas clases mencionadas se refieren en particular, puesto que son mezcla de todas, las fábulas que explicará en la obra. Es exactamente en el centro de su tratado, en los capítulos 1 a 4 del libro cinco de los diez de la Mythologia, donde el autor inserta el tratamiento sobre los juegos, y no hay otra referencia a ellos antes ni después. El libro se abre con un título general que, en este caso como en otros, conviene sólo a una parte de la materia tratada en él, "Por qué fueron instituidos los Olímpicos y las otras clases de certámenes”. Los estudiosos no han advertido, que sepamos, a qué lógica estructural responde su disposición en el tratado de Conti, lo que por otra parte es extensible en general al conjunto de la $M y$ thologia ${ }^{32}$. En nuestra opinión, esta ubicación del tratamiento de los juegos podría ser coherente con el capítulo que sigue inmediatamente después, el 5, dedicado al dios Mercurio, que a su vez es seguido por una serie de divinidades campestres menores que finalizan con Adonis, a quien sigue el Sol, que según algunos autores es identificado con el anterior, acabándose con otras divinidades campestres de los romanos. Mercurio, junto a sus otras atribuciones, es el dios de la palestra, como el propio Conti indica en su lugar ${ }^{33}$, ofreciendo el testimonio de Horacio (carm.1.10), que también incluye Boccaccio sobre Mercurio ${ }^{34}$; a esta atribución hace referencia alguno de sus sobrenombres indicados por el propio Conti (Enagonius).

En el proemio-dedicatoria que inicia el libro 5, encontramos de nuevo mencionadas las comedias y tragedias que fueron inventadas, junto con 
"muchas clases de juegos con los que los hombres no solo eran instruidos para enderezar las costumbres del espiritu, sino que también eran invitados a ejercitar las fuerzas del cuerpo con un cierto placer. Y asi se producía que el pueblo, que habia llegado para ver, se marchaba instruido con placer y después de haberse impregnado no sin satisfacción del equilibrio de la vida (vitae moderationem non sine delectatione imbibisset). $Y$, una vez que aquellos se realizaran para reanimar el espiritu, entonces se instituyeron muchos certámenes en honor de los dioses inmortales con los que los hombres se animaron al culto de los asuntos divinos y a ejercitar las fuerzas del cuerpo. Por tanto, llegaba desde toda Grecia una gran muchedumbre a los certámenes en parte por la esperanza de victoria, en parte por el deseo de ver ${ }^{35}$ ".

Se trata, como es evidente, del pueblo griego, porque Conti sólo hablará de los cuatro certámenes griegos más importantes. Ya que estos certámenes se hallan en estrecha relación con la religión de los dioses de los antiguos, el erudito renacentista se dispone a explicar "por qué motivos, dónde y cuándo fueron instituidos aquellos y cómo se hacían".

Los certámenes Olímpicos (5.1.) ocupan seis páginas a doble columna de las nueve páginas y media del texto latino dedicadas a los juegos. Se indica su origen y fundador -Hércules Dáctilo del Ida o el héroe Hércules hijo de Júpiter-, los tipos y modalidades de competiciones, con sus variables alternativas en el tiempo; sus organizadores, los premios concedidos, las diferentes versiones de su fundación, la institución de los jueces o árbitros y su cometido, el lugar de celebración; y, sobre todo, los vencedores en las distintas pruebas y ediciones de los juegos, hasta la Olimpiada 235: esta enumeración detallada y la inclusión de numerosos textos griegos citados y traducidos al latín motivan la dilatada extensión del capítulo.

A los certámenes Píticos (5.2.), al igual que a los restantes, se dedica una página a doble columna, indicándose al comienzo su creación posterior a los Juegos Olímpicos y anterioridad respecto a los otros, así como su institución en honor de Apolo. Se dan las distintas versiones sobre su fundación, nombre, diferentes pruebas y premios, intervalos de su convocatoria, y algunos vencedores hasta la Pitiada 67. El único texto incluido es uno de Ovidio (Metamorfosis 1.446 ss.), en cierto modo como último y definitivo testimonio de su fundador, motivo y recompensa. Muchos datos ofrecidos aquí aparecen también en 4,10, el capítulo "Sobre Apolo".

"Sobre los Nemeos" (5.3.) se indica lugar de celebración, su carácter fúnebre con distintas versiones sobre su origen, frecuentemente relacionado con Hipsípila y la muerte del niño Arquémoro-Ofeltes; los premios y posible refundación por Hércules, sin decirse nada sobre los vencedores.

En último lugar, "Sobre los Ístmicos (5.4.), también refiere Conti las diferentes versiones acerca del origen, especialmente su institución por Teseo en honor de Neptuno, o por Sísifo en honor de Melicertes, siendo en todo 
caso de origen fúnebre. El relato sobre la suerte de Melicertes y los honores y premios a los vencedores, sin citar nombres, ocupan casi todo el espacio; al final, citando la autoridad de Museo, admite la posibilidad de dos clases de certámenes en el Istmo, uno en honor de Neptuno y otro de Melicertes. Concluyendo el mismo capítulo 4, se refiere a otros juegos menos famosos entre los griegos (a los que Escalígero dedica el breve capítulo 27, Ludi alii minus nobiles) y que pocas veces mencionan los escritores. Entonces manifiesta el autor que va a continuar con "las restantes cosas que tienen que ver con la obra preestablecida ${ }^{36 "}$. ¿Esto podría significar que Conti ha considerado todo lo relativo a los juegos como un paréntesis introducido o añadido a su tratado, algo que en principio no pensó incluir? Desde luego el método de análisis a que somete toda la restante materia, buscando y tratando de clarificar el significado oculto de los personajes míticos y de las diversas ficciones, no lo aplica en absoluto en los capítulos aquí examinados. Y lo que es más significativo: en el libro 10 aborda exclusivamente la explicación de los principios filosóficos contenidos bajo las fábulas, recogiendo lo expuesto con tal propósito en los libros anteriores, y presentando sistemáticamente el relato sobre cada personaje o asunto desde el punto de vista histórico, físico y ético ${ }^{37}$; el autor procede con un estricto orden, siguiendo la materia examinada del libro 2 al libro 9, y sin embargo omite completamente los capítulos correspondientes a los juegos y ficciones que los originaron, que tan estrechamente había relacionado con la religión de los antiguos.

En los capítulos que Escalígero dedica a los juegos se halla también ausente, como era enteramente previsible, toda interpretación simbólica de los mitos antiguos desde cualquier punto de vista. En el tratamiento de los juegos griegos se distinguen bien dos apartados: a) el extenso capítulo inicial -22-, que trata sobre los juegos en general, aunque al hablar de su nacimiento es más aplicable a los griegos; considera aquí los aspectos histórico-culturales y técnicos, con la clasificación, análisis sistemático de las pruebas, terminología, técnicas propias, descripción física, e incluso algunos residuos coetáneos; b) los otros capítulos, cada uno dedicado separadamente a las cuatro grandes competiciones atléticas panhelénicas, se ocupan de los aspectos mitológicoliterarios, su relación con la fabulación, explicando detalladamente el origen, instauración y desarrollo histórico de los juegos.

Como ya dijimos, el autor atribuye el origen de los juegos a las reuniones que, convocadas o al azar, celebraban los pastores griegos, en las que al principio practicaban amistosamente y de modo natural saltos y carreras; después estos escarceos desembocaron en envidias y rivalidades, llegándose a la competición, por lo que se esforzaban en superarse los unos a los otros; más tarde a las competiciones se añade el arte, la técnica que definirá después cada prueba atlética y que permiten al autor caracterizar sistemáticamente los diferentes juegos: 
El mito a la palestra. Los juegos antiguos en la poética de Escalígero y en la mitología de Natale Conti

Multa ludorum genera ad summa duo reducuntur. Utrumque positum est in motu naturali addita postea arte. Verum alterum simplex est, alterum cum aemulatione. Nam per initia ubi coissent temere pastores, aliquid agebant saltu aut cursu. Tandem vero reddit res ad obtrectationem atque inde ad certamen, cum alius alii praestare videretur $^{38}$.

El origen de los juegos es semejante al nacimiento de los géneros poéticos, como el autor explica en el capítulo 4, Pastoralia, de este primer libro. Allí se identifica la poesía pastoril como "el género más antiguo de poesía que nació de la más antigua manera de vivir", surgiendo entonces dos clases de cancioncillas; una, cuando cualquiera, harto de comida, se cobijaba bajo la sombra estival y cantaba sus amores en un monólogo; otra al reunirse aquellos entre los que se había suscitado el amor u odio, o bien se había producido rivalidad o envidia. De aquí se generan dos tipos de canción, una natural y libre, sin ritmo fijo ni reglas, y otra en la que se intercambiaban a porfía versos semejantes:

Natae igitur duae species cantiuncularum: altera cum singuli sub aestivam reducti umbram saturi canerent amores (monoprosopos haec); altera cum aut forte aut consilio convenissent $i$, quos inter vel amor vel odium excitatum fuisset aut esset aemulatio obtrectatiove propter vel cantum vel gregem vel amicam. Huius cantus duo modi: unus cum sine numero certo, sine lege versus funderent, cui non est idcirco nomen impositum, quia vulgaris esset ac liber et naturalis neque tam quaesitus arte quam oblatus ultro; alter in quo sententias aemulas, versus et similes et pari numero reponerent... ${ }^{39}$

Fueron por tanto los pastores en Grecia quienes iniciaron no sólo la poesía ${ }^{40}$ sino también los juegos deportivos, en un proceso que transforma lo espontáneo y natural en competitivo y artístico. Este es el método que sigue Escalígero para presentar en el libro 1 todo el catálogo histórico de formas y géneros poéticos, desde lo más antiguo, simple y desmañado (Pastoralia) a lo más complejo, perfeccionado y artístico ${ }^{41}$. De acuerdo con su habitual modo de proceder, nuestro autor enumera y analiza sistemáticamente, en este caso basándose en el movimiento, las cinco pruebas originarias, carrera, lucha, salto, lanzamiento y boxeo, sopesando cuidadosamente su antigüedad relativa:

...Haudparva quaestio poterit oriri, quodnam primum inter pastores fuerit certamen. Quinque enim sunt: cursus, lucta, saltus, iactus, pugilatus... Ac pro motus quidem ratione statuendum est. Itaque luctam puto fuisse postremum omnium inventum. Est enim compositus quippe situs in duobus motus. Composita vero simplicibus posteriora. Cursum autem primum, mox saltum. Pedum initio iactum arbitror, mox lapidem crassum ac gravem. Qui motus fit quasi introrsum. Contrarius autem buic iactus extrorsum, quos in disco iaciendo exercebant. Nam ad iaculi aut pili missionem 
brachium pandimus, mox prorsum impellimus. Contra fit in disco manu ad pectus adducta atque extrorsum disclusa. Pugilatus ratio eadem quae in lucta; non enim sine antagonista fieri quit. Videtur autem subtilius contemplanti proportio quaedam inter haec quattuor. Nam cursus motus est aliquo modo continuus, saltus discretus; sic lucta motus quasi continuus (cohaerescunt enim), pugilatus autem discretus; sunt enim inter ictus ipsos intervalla. Uter igitur vestustior, lucta an pugilatus? Pugnis prius quam complexu certasse par est. Is enim primus congressus solutus. Mox lucta iunctis compositisque atque etiam insertis brachiis ac manibus mutuo. Ex temeraria aut hostili contentione res acta est ad exercitationem atque aemulationem. Sic ergo digerenda sunt ${ }^{42}$.

Los ejercicios que se exhiben en las pruebas atléticas no son los únicos. Escalígero acude a la autoridad de Galeno, escritor anotado y comentado por $\mathrm{e}^{43}$, quien en el libro segundo de su obra Sobre la conservación de la salud (De sanitate tuenda) menciona otros ejercicios privados realizados en los gimnasios y también citados por Aristóteles, Marcial y Juvenal.

En los capítulos posteriores al 22, hasta el 26 inclusive, el autor se ocupa de los grandes juegos panhelénicos en los que podían participar todos los ciudadanos griegos libres. Su tratamiento sobre ellos no se limita a situarlos en su época, recordar a los vencedores en cada una de las modalidades desde los tiempos míticos (especialmente en los Olímpicos) y los premios concedidos, señalar las adiciones o supresiones de ciertos deportes en algunas ediciones de los juegos. Insiste sobre todo en los orígenes, las causas, los dioses en cuyo honor se celebraron, los héroes o personajes por cuyas muertes se instauraron. Subraya que los juegos más célebres y famosos son todos ellos considerados de origen fúnebre por los antiguos: los Olímpicos se celebraron en honor de Júpiter por la muerte de Pélope, aunque no fue él quien murió; los Nemeos en honor de Neptuno por la muerte de Arquémoro; los Istmicos por la muerte de Melicertes, y los Píticos en honor de Apolo (¿por la muerte de la serpiente o dragón?). Como este dios era más antiguo que Hércules -fundador de los Olímpicos- y que Pélope, y los Nemeos e Ístmicos comenzaron a celebrarse mucho tiempo después, Escalígero comienza por los Píticos, los más antiguos según él.

En cuanto a los juegos romanos, que no incluye Conti, un capítulo inicial (28, Ludi Romani), simétrico al 22 para los griegos aunque menos extenso, informa de su diverso carácter, origen, denominaciones, institución, convocatoria y magistrados encargados. Seguidamente se dedican sendos capítulos, generalmente breves, del 29 al 39, a cada uno de los diferentes juegos, con una extensión total similar a la dedicada a los griegos. A diferencia de éstos, los aspectos mítico-religiosos apenas reciben atención aquí, mencionándose no obstante los dioses a los que están dedicados, cuando son de carácter sagrado. Se atiende en cambio más a cuestiones históricas, políticas, económicas, detalles curiosos y llamativos, celebraciones. 
Escalígero se interesa por los juegos en ciertos aspectos en los que coincide con Conti. De manera muy general, éste había expresado en 1,1 la utilidad del conocimiento de las fábulas para comprender las opiniones de los poetas y escritores. De modo implícito, aunque más concreto para Escalígero, el conocimiento de las fábulas como parte integrante de los juegos reporta indudable utilidad a la formación del poeta, del maestro y del crítico, tanto en relación con el conocimiento de los autores antiguos como inspiración para los eventos contemporáneos que el poeta renacentista tiene que celebrar. También coinciden ambos autores en el acercamiento de los juegos a los géneros dramáticos. Comedia, tragedia y juegos son para Conti invenciones de los antiguos a el fin de aliviar, con su visión, las pesadumbres, formar las costumbres y ejercitar las fuerzas del cuerpo con placer, e incitar al cultivo de la religión. Estos objetivos no son expresados en la Poética de Escalígero, aunque hay latente un valor social y educativo innegable para la colectividad, que se expone históricamente y progresa desde un nacimiento espontáneo entre los griegos hasta su conversión en actividad y espectáculo para los ciudadanos. En general predomina un aspecto cívico y celebrativo en relación con la comunidad, y sólo muy raramente se percibe una muestra de la brutalidad que conllevan algunas de estas manifestaciones, como por ejemplo la referencia al salvajismo de la lucha y el pancracio entre los griegos, las luchas de gladiadores en los Juegos Fúnebres romanos, o la crueldad de ciertos emperadores. Desinteresado por cualquier motivación religiosa, que sin embargo no ignora, Escalígero racionaliza los elementos técnicos ${ }^{44} \mathrm{y}$ míticos ${ }^{45}$ de los juegos, explica y discute su origen, da cuenta de su desarrollo y de sus diferentes versiones, a veces ironiza sobre algún aspecto de la tradición ${ }^{46}$. Pero nuestro autor siempre afirma su sentido físico, su connotación corporal y humana. En el capítulo introductorio de los juegos, al mencionar a los vencedores en el pentathlon, los quinquertiones romanos, relaciona el término ars, en su sentido primitivo "vigor" y "fortaleza", con Ares, arete, enaretos ${ }^{47}$. A continuación menciona la definición de la excelencia física asignada por Aristóteles a las distintas competiciones de los juegos, la cual consta de tamaño o porte, fortaleza y rapidez. La cita pertenece al libro 1 de la Retórica (1,5,1361 b 21ss.), lugar en que el filósofo griego incluye dicha excelencia física entre la partes constitutivas de la felicidad, que son examinadas dentro de la elocuencia deliberativa, de acuerdo con "las opiniones generalmente admitidas", y que Aristóteles hace consistir en la salud, la belleza, la fuerza, el porte y la capacidad para la competición: esta última a su vez está integrada por el porte (megethos), la fuerza y la velocidad, equivalentes de los tres elementos mencionados por Escalígero: magnitudo, robur, celeritas. De aquí resulta que la cultura atlética antigua, racional e históricamente expuesta por el autor, queda proyectada en un contexto persuasivo que la pone en valor y recomienda ante los lectores contemporáneos. 
Pero a ello no ha contribuido solamente el testimonio de Aristóteles y de otras autoridades, entre ellas Galeno. Intentemos ahora interpretar, a la luz de lo que la Poética permite inferir, la personal definición de los juegos que da Escalígero y el que podría ser el objetivo principal de su inclusión en esta obra. Frente a las fábulas teatrales, ludi loquentes, la expresión fabulae tacitae representa una síntesis paradójica, oximórica y chocante; un binomio que aúna dos conceptos contrapuestos, esenciales para los propósitos de Escalígero y que admiten ser disociados. La fábula, el mito, el lenguaje se relacionan sustancialmente con la poesía; narran y son capaces de producir persuasión y deleite. Ahora bien, en cuanto que silencio, el juego es acción, escenificación para ser contemplada, apparatus; impone una plástica en cuyo origen se sitúa el relato que la justifica. En cuanto mito, el juego es también mímesis, imita acontecimientos y acciones pasadas: imitación silenciosa, sin palabras, movimiento del cuerpo, acción y plástica.

$\mathrm{El}$ primer elemento integrante del juego, la fábula, relaciona a Escalígero con la poesía y la tradición mitológica. Los autores antiguos son fuente de los acontecimientos que se cuentan y que son razón de ser de los juegos, las historias míticas. El erudito renacentista no siente especial inclinación hacia estas historias míticas, que menciona con desdén en distintos lugares de la Poética y ni siquiera trata a propósito de los géneros dramáticos. Pero el mito no sólo acoge un soporte lingüístico, también admite una modalidad visual, ritual. En ambas modalidades, la lingüística y la visual, el mito, como ha enseñado el añorado profesor López Eire ${ }^{48}$, es pragmático (actúa sobre unos destinatarios), paradigmático (ejemplarizante) y metafórico (representa algo). Si el relato no es para Escalígero más que ficción engañadora con diferentes versiones ${ }^{49}$, el mito del juego se hace metafórico y paradigmático en el nivel visual, más allá del acontecimiento remoto al que se refiere. Representa algo y persuade de algo que actualiza para una comunidad. ¿Y qué es ello? Parece evidente: el valor del cultivo del cuerpo y la excelencia física, también para el mundo contemporáneo del autor, a imitación del mundo antiguo. El juego a nivel de mito funciona "como" lenguaje, opera pragmáticamente sobre la comunidad que lo recibe. El mito es el pretexto, el fin buscado es la persuasión de un modo de vida armónico a imitación de los antiguos. El mito transfiere al juego su esencial carácter social, que contacta con una determinada comunidad humana y se dirige a ella, proyectando y proponiendo ciertos valores a esa comunidad. Los juegos, como los mitos, actualizan elementos de cohesión en los pueblos que los originan y recrean. 
El mito a la palestra. Los juegos antiguos en la poética de Escalígero y en la mitología de Natale Conti

\section{Conclusiones}

Los juegos griegos, explicados por Conti en el conjunto de su Mythologia para ilustrar la religión de los antiguos, presentan rasgos coincidentes con los de Escalígero, posiblemente debidos a unas fuentes comunes antiguas y coetáneas ${ }^{50}$. Pero estimamos que en el caso de nuestro autor estos capítulos están perfectamente integrados, por medio de múltiples conexiones, en la lógica interna del tratado poético, mientras que en Conti los capítulos sobre los juegos, en contra de lo que cabría esperar, no guardan aparentemente relación con el tratado mitológico.

Valiéndose de la plástica ${ }^{51}$ evocada por el juego y de la plasticidad analítica del mito, utilizando la fábula como pretexto, Escalígero está planteando, con la mayor persuasión a su alcance, un modelo de civilización, una imagen del hombre y unos ideales cívicos que, a través de la cultura del ejercicio a imitación de los antiguos, contribuyan junto con la poesía a lograr una vida más armónica y ordenada. Así lo expresa en 3.1 (80,9 ss.), a propósito de la finalidad de la poesía y la imitación:

Atque in primo quidem libro poetices usum ostendimus atque eius originem simul et finem, quare imitaremur: ut scilicet humana vita compositior fiat...

De modo lapidario viene a manifestar en 1,2 (80,24 s.) la estrecha unión entre el encanto, el placer, la poesía y la salud física: ...Quod autem et Charites et laetitia et Musae et bona valetudo affines sint $t^{52}$...

En nuestra opinión, todo lo analizado aquí sobre los juegos pone de relieve la complejidad del libro 1, Historicus, y de la construcción entera del tratado de Poética de Escalígero. Este libro no es un compendio de material histórico ajeno a intereses teóricos, filosóficos y estéticos, sino que está fundamentado en la concepción teórica y ética de la poesía que profesa el autor.

Escalígero, como otros teóricos de pleno Renacimiento, ve en los mitos antiguos puras ficciones que sería absurdo examinar alegóricamente. Sin ignorarlo, tampoco se preocupa demasiado por su trasfondo religioso, como hace en cambio Conti, pero uno y otro lo relativizan y atribuyen a una etapa histórica determinada como fruto de las creencias de ese tiempo. Sin embargo, el efecto extraliterario de las fábulas no queda limitado a la Antigüedad y Edad Media, como sugiere en cambio Stillers ${ }^{53}$. Según se ha visto, tanto Conti como Escalígero admiten su capacidad de enseñanza para la vida, aunque de forma diferente. Para el primero, a través de la alegoría que ejerce su efecto extraliterario como sabiduría oculta e interpretada por los doctos, y así mismo necesaria para la comprensión intraliteraria. Para Escalígero, admitiendo sin duda esto último, el mito de los juegos recreado por medio de los textos antiguos, en virtud de su silencio -fabulae tacitae-, no lleva en sí el engaño 
fabuloso propio de los mitos antiguos, mientras que su valor paradigmático y la plástica del juego transmiten a la sociedad de su tiempo la persuasión de una vida más armónica, acorde sin duda con sus exigencias de médico y sus profundas aspiraciones humanísticas. 
El mito a la palestra. Los juegos antiguos en la poética de Escalígero y en la mitología de Natale Conti

\section{Referencias bibliográficas:}

G. Boccaccio (1951), Genealogie deorum gentilium libri. A cura di V. Romano, 2 vols. Bari, Laterza et Figli.

G.Boccaccio (2007), Los quince libros de la Genealogía de los dioses paganos. Introducción, traducción directa del Laurentius Plut. 52.9, notas e índices de M. ${ }^{a}$ C. Álvarez y R. M. ${ }^{a}$ Iglesias. Madrid, Centro de Lingüística Aplicada Atenea.

B. Carman Garner (1970), "Francis Bacon, Natalis Comes and the mythological tradition”, JWI 33 264-291.

N. Conti (1616), Natalis Comitis Mythologiae sive explicationis fabularum libri decem, in quibus omnia prope Naturalis et Moralis Philosophiae dogmata in veterum fabulis contenta fuisse perspicue demonstratur: Opus cuiusvis facultatis studiosis perutile ac prope necessarium... Patavii, apud Petrumpaulum Tozzium.

N. Conti (2006), Mitología. Traducción con introducción, notas e índices de R.M. ${ }^{a}$ Iglesias Montiel y M. ${ }^{a}$ C. Álvarez Morán, Murcia, Universidad.

B. Croce (1946), "Gli dei antichi nella tradizione mitologica del Medio Evo e del Rinascimento" PP 3 273-285.

L. Deitz-G. Vogt-Spira, eds. (1994-2003), Iulius Caesar Scaliger. Poetices libri septem. Sieben Bucher über die Dichtkunst... vide I.C.Scaliger.

E. Garin (1981), "Las fábulas antiguas", in Medioevo y Renacimiento. Madrid, Taurus Ed. (reimp. 1986) 52-68.

L.G. Giraldi (1560), De deis gentium uaria et multiplex Historia, Libris sive Syntagmatibus XVII comprehensa, in qua simul de eorum imaginibus et cognominibus agitur... Lilio Gregorio Gyraldo Ferrariensi auctore... Basileae, per Ioannem Oporinum.

R.M. ${ }^{a}$ Iglesias Montiel-M.a C. Álvarez Morán (1998), "Los manuales mitológicos del Renacimiento" Auster 3 83-99.

L. Lara Garrido (1998), "El mito clásico como lenguaje simbólico y alegórico. Notas hermenéuticas sobre la contemplación en la Epistola a Arias Montano de Francisco de Aldana", in Actas del Congreso Internacional sobre Humanismo y Renacimiento II, coords. J. Matas Caballero (et alii), León, Universidad, 39-70.

P.Lardet (1986), “Figure' dans la Poétique de Jules-César Scaliger: una plastique du discours" in La statue et l'empreinte. La Poétique de Scaliger. Études réunies et présentées par C. Balavoine et P. Laurens. Paris, Librairie Philosophique J. Vrin, 151-180.

A. López Eire (2002), Poéticas y Retóricas griegas. Madrid, Editorial Síntesis. 
A. López Eire (2002), "Mito, Retórica y Poética", Logo. Revista de Retórica y Teoría de la Comunicación 2 51-84.

A. López Eire (2004), “Mito y ritual: una aproximación”, Humanitas 56 329364.

A. López Eire (2005), La naturaleza retórica del lenguaje (Número monográfico de la revista Logo. Revista de Retórica y Teoría de la Comunicación 8-9).

M. Magnien (1982), "Un humaniste face aux problêmes d'édition, Jules-César Scaliger et les imprimeurs", Bibliothéque d'Humanisme et Renaissance. Travaux et documents 44,2 307-329.

M. a L. Picklesimer (1997), "Tradiciones míticas sobre el origen de la poesía en el De poetica de Viperano" in Humanismo y pervivencia del mundo clásico. Homenaje al Profesor Luis Gil, J.M. a Maestre Maestre, J. Pascual Varea, L. Charlo Brea, eds., Cádiz, Instituto de Estudios Turolenses, 349-356.

J.A. Sánchez Marín (2010), "Los juegos griegos y la Poética de J.C. Escalígero”, Calamus Renascens 11 173-188.

J.A. Sánchez Marín (2011) "Games in Julius Caesar Scaliger's Poetics" Humanitas 63 563-569.

J.C. Scaliger (1994-2003), Poetices libri septem. Sieben Bucher über die Dichtkunst. Unter Mitwirkung von M. Fubrmann herausgegeben von L. Detiz und G. Vogt-Spira. Stuttgart, frommann-holzboog, 5 vols.

R. Stillers (1994), “ZwischenLegitimation und systematischem Kontext. Zur Stellung der Mythologie in der italianischen Renaissancepoetik" in Renaissance-Poetik. Renaissance Poetics. Herausgegeben von... H. F. Plett. Berlin, Walter de Gruyter, 37-52 
${ }^{1}$ Este trabajo se incluye en el Proyecto de investigación Edición y estudio de los Poetices Libri Septem de Julio César Escalígero. Fuentes clásicas y pervivencia (FF2008-05882/FILO), desarrollado en el Departamento de Filología Latina de la Universidad de Granada.

2 Sánchez Marín 2010, Sánchez Marín 2011.

${ }^{3} 1.22$ (306,10 ss.): Hactenus fabularum ortus, genera, partes, apparatus. Ludi autem ipsi tametsi videntur ab illis separati, tamen ad apparatum ipsum maxime pertinent. Sane ludi sunt tacitae fabulae, fabulae vero ludi loquentes. Omnino ludorum pars fabula est, quare ipsi quoque actores ludiones dicti. De ludis igitur quam brevissime fieri poterit dicendum est. Utilizamos la siguiente edición: Iulius Caesar Scaliger. Poetices Libri Septem. Sieben Bücher über die Dichtkuns...herausgegeben von L. Deitz und G. Vogt-Spira, 5 vols., Stuttgart, Frommann-Holzboog, 1994-2003; solamente indicamos libro y capítulo, poniendo entre paréntesis página y línea.

${ }^{4}$ Aunque gran parte de los estudiosos de este tratado dan por supuesta la fecha de 1551 para su primera edición, no deberían desestimarse los argumentos de B. Carman Garner sobre la inexistencia de esta, y su consideración por tanto de la de 1567 como editio princeps; cf. Carman Garner 1970: 264.

${ }^{5}$ Stillers 1994: 37.

${ }^{6}$ Stillers 1994: $39 \mathrm{~s}$.

${ }^{7}$ Cf. libro 13.70 a propósito de Melicertes. Para las referencias al texto latino hemos utilizado la siguiente edición: Genealogie deorum gentilium libri, a cura di V. Romano, 2 v., Bari, Laterza, 1951. Para la traducción nos hemos valido de la siguiente obra: Los quince libros de la Genealogía de los dioses paganos. Introducción, traducción directa del Laurentianus Plut. 52.9, notas e índices de M. ${ }^{a}$ C. Álvarez Morán y R. M. a Iglesias Montiel, Madrid, Centro de Lingüística Aplicada Atenea 2007.

${ }^{8}$ Garin 1981: $61 \mathrm{~s}$.

${ }^{9}$ Stillers 1994: 38.

${ }^{10}$ Croce 1946: 273-285.

${ }^{11}$ Seznec 1983.

${ }^{12}$ A partir del Humanismo la figura de Hércules será abundantemente utilizada por los autores para expresar símbolos de diferente significado; cf. Lara Garrido 1998: 57 ss.

${ }^{13}$ Cf. Iglesias Montiel-Álvarez Morán1998: 83.

${ }^{14} \mathrm{Su}$ título completo es $\mathrm{De}$ deis gentium varia et multiplex Historia, in qua simul de eorum imaginibus et cognominibus agitur, ubi plurima etiam hactenus multis ignota explicantur, et pleraque clarius tractantur. Ad Herculem Estensem II Ferrariensem Ducem IV... Basileae 1548. En nuestra revisión hemos consultado la siguiente edición: Basileae, sumptibus Ioannis Oporini 1560. Giraldi fue educador y tutor del joven Hércules de Este II, futuro cardenal Rangone y protector suyo; en la edición de sus obras completas de Lugduni, 1696 se incluye en la Multiplex Historia los tratados Herculis vita y De musis, que el autor había publicado separadamente en 1539 y 1540. Interesado además por la historia literaria, escribió sobre poetas antiguos (Historiae poetarum tam Graecorum quam Latinorum dialogi decem, Basileae 1545) y contemporáneos (De Poetis nostrorum temporum dialogi duo, Basileae 1545), obra esta última que J. C. Escalígero solicitó que le enviasen a Agên sus amigos de Burdeos: cf. Magnien 1999: 155.

${ }^{15}$ Cf. Iglesias Montiel-Álvarez Morán 1998: 91.

${ }^{16}$ Stillers 1994: 48.

${ }_{17}$ Mythologiae sive explicationis fabularum libri decem, in quibus omnia prope Naturalis et Moralis philosophiae dogmata in veterum fabulis contenta fuisse perspicue demonstratur.

${ }^{18}$ Ambas en Venecia, exactamente iguales, son versión reducida de la obra; en 1581 aparecía, también en Venecia, la versión ampliada, con un dedicatario diferente, G. B. Campeggi, hasta 1560 obispo de Mallorca. Para el texto latino nos basamos en la edición de Padua de 1616, reedición de la versión ampliada de Venecia, 1581. La de 1616, que carece de epístola nuncupatoria al frente, es la ampliada que fundamentalmente manejaron las autoras de la traducción castellana que hemos utilizado: Natale Conti. Mitología. Traducción, con introducción, notas e índices de R. M. ${ }^{a}$ Iglesias Montiel y M. ${ }^{a}$ C. Álvarez Morán 2a ed., Murcia, Universidad, 2006. Esta traducción tiene también en cuenta las ediciones de 1567 y 1568 para la versión reducida, 
añadiendo entre corchetes el texto de la ampliada, ya que es deseo de las autoras ofrecer una visión unitaria del texto (p.33).

${ }^{19}$ Conti 2006: 45.

${ }^{20}$ Conti 2006: 48; Conti 1616 1.1: 1: ... Qui vero altissima et occultissima fabularum secreta denudaverit, qui philosophis dogmata ex obscuris fabularum tenebris in lucem eduxerit, aut ad vires actionesque naturae patefaciendas pertinentia, aut ad mores informandos, vitamque recte instituendam, aut ad vires motusque astrorum intelligendos... Hoc autem eo magis est mirabile, quod neque poetarum, neque philosophorum, neque ullorum scriptorum sententias sine hac diligenti fabularum investigatione percipere recte possumus...

${ }^{21}$ Conti 2006 ibidem; Conti 1616 1.1: 1, s.: ... nullas hominum in arbores mutatorum aut in corpora vel sensu vel ratione carentia, afferemus interpretationes, nisi quae utiliter afferri poterunt; nullamque habebimus fabularum illarum rationem, quae insulse fuerunt a nonnullis excogitatae... cum eas tantum fabulas simus explanaturi, quae homines ad rerum coelestium cognitionem erigunt, quae instituunt ad probitatem, quae deterrent ab illegitimis voluptatibus, quae pateficiunt arcana naturae, quae vel ad scientias denique rerum necesariarum humanae vitae, vel quae ad integritatem perducunt, et quae plurimum faciunt ad optimos quosque scriptores recte intelligendos.

${ }_{22}$ El símil del marinero y su frágil barquilla se inicia en el Proemio general a Hugo, rey de Jerusalén y Chipre por cuyo mandato supuestamente emprende el autor la elaboración de esta obra; también aparece en los proemios a cada libro y en la Conclusión final.

${ }^{23}$ Boccaccio 2007: 694. Boccaccio 1951: 784: ... in finem longi operis ventum est. In quo ea, qua potui, solertia iuxta veterum traditiones deorum gentilium genus et eorum posteritates... quo datum est ordine, descripsi, et iuxta mandatum tuae serenitatis... post fabulas fictionum sensus, seu ab antiquis sumptos, seu a tenui intellectum (sic) meo emunctos, apposui. Ostendi insuper.. poetas adversus opiniones talium non dicant iustos omnes, sed nec ridiculos aut simpliciter fabulosos esse, quin imo seculari scientia, ingenio, et moribus, ac etiam insigni claritate conspicuos...

${ }^{24}$ Boccaccio 1951: 699.

25 Boccaccio 1951: 708. Boccaccio 2007 14.9: 631.

${ }^{26}$ Conti 2006: 49 s. Conti 1616 1.2: 2 s.

${ }^{27} \mathrm{Cf}$. Conti 1616 1.3-4: 50-52.

${ }^{28}$ Boccaccio 2007: 629, n. 906, mencionándose los siguientes autores: CIC. inv. 1.27, Rhet. Her. 1.8, QVINT. inst. 2.4.2. MACR. somn. 1.2.7-11, MART. CAP. 193, ISID. orig. 1.44.5.

${ }^{29}$ Boccacio 2007: 630.

30 Conti 2006: 50. Conti 1616: 3 ... Inter politicas fabulas argumenta Comoediarum et Tragoediarum sunt connumeranda, quia etsi ab agresti vita homines per haec non evocantur, traducuntur tamen ab illegitimis voluptatibus et ab omni intemperantia ad vitae moderationem...

${ }^{31}$ Cf. nota 25.

${ }^{32}$ Conti 2006: 16.

${ }^{33}$ Conti 1616 5.5: 239:... Hic idem Mercurius Deorum inmortalium cultus et sacra prior instituit, hominesque ad humaniorem vitam revocavit; quare ita cecinit Horatius libro I Carminum: "Mercuri facunde nepos Atlantis / Qui feros cultus hominum recentum /Voce formasti, cautus et decorae / More palestrae". Hunc una cum Hercule palaestritis praefectum esse crediderunt; quia cum prudentissimus existeret, non mediocriter confere ad palaestram putabatur, quoniam cum viribus ubique coniuncta esse debet prudentia... Igualmente Giraldi (1560: 289) precisa que Mercurio junto con Hércules presiden la palestra, justificándolo en términos semejantes.

${ }^{34}$ Boccaccio 1951 2.7: 77.

${ }^{35}$ Conti 2006: 309.

${ }^{36}$ Conti 1616 5.4: 235... Quae, quoniam non erant valde illustria, raroque de bis mentio fit a scriptoribus, superioribus abunde ut arbitror explicatis, in praesenti omittemus, nunc reliqua ad institutum opus pertinentia persequamur.

${ }^{37}$ Ya Boccaccio había explicado variadamente el sentido oculto de las fábulas y ficciones desde el punto de vista historicus, moralis y naturalis, en ocasiones mezclados.

${ }^{38} 1.22$ (306), 17 ss.

${ }^{39} 1.4$ (94-96), 25 ss.

${ }^{40}$ En el capítulo 1.2 (Caput secundum prosequitur poetae nomen, poeseos originem, causas: 
efficientem, formam, materiam) el autor se ocupa de las tradiciones míticas sobre el origen de la poesía, valorándolas bajo el prisma de la vera philosophia, en especial con referencia a las Musas y a los elementos componentes de aquella; dedica también bastante atención a los relatos sobre el origen y a las clases de poetas, que distribuye en diferentes grupos: $(82,14$ ss.)... secundum spiritum, secundum aetatem (comenzando por el género vetus illud priscum, rude, incultum), secundum subiectum. Sobre A. Viperano como muestra del proceder renacentista en este aspecto, véase el detallado y clarificador trabajo de Picklesimer 1997: 349-356.

411.3 (94,11 ss.): ...Quod si tempora putemus ipsa, antiquissimum idem et mollissimum et simplicissimum et ineptissimum intellegemus. Praestat autem ab hoc auspicari naturam imitando, quae ex simplicioribus cetera componit.

$421.22(308,2-25)$

${ }^{43}$ En una carta datada en 1557 y dirigida a su amigo E. de La Boétie (Boethius), en la que Escalígero presenta el catálogo de casi toda su obra, menciona unas anotaciones y comentarios críticos originales que habría elaborado sobre las obras del célebre médico de Pérgamo; cf. Magnien 1982: 307.

${ }_{44}$ En cuanto a los elementos técnicos, ver nota 42; 1.1 (310,15 ss.); id. (312,13 ss.).

451.23 (316,9 ss.): Celeberrimi quattuor; veteres censuerunt eos omnes funebres. Sane Olympici in Iovis honorem ob mortem Pelopis. Nemei Neptuno propter Archemorum, eidem Isthmia in honorem Melicertae. Satis recte hactenus fortasse; non enim Pelops moritur, sed Oenomaus. Oenomaus vincitur; vincit Pelops, qui statuit ludos. Etiam miror hosce quoque Olympicos Iovi, non Neptuno a Pelope nuncupatos fuisse, quem victorem fecissent equi Neptuni, non Iovis. Praeterea Pythia Apollini dicata quis dicat in honorem caesi draconis? Profecto scelerato draconi cum eius interfectore eoque deo nobilissimo communem gloriam facere nefas arbitror... ibid. (324, 8 ss.): Neque vero iis assentior, qui coronae usum apud veteres nullum fuisse autumant, imbecilli sane argumento: propterea quod, inquiunt, eius nullam mentionem fecerit Homerus, cui ne stephanou quidem vox nota fuerit. At enimvero a Promethei usque temporibus coronae usum deducunt doctiores... Ego vero etiam ante Prometheum puto eos qui exstiterint mortales ad aestiva umbracula coronas excogitasse victoque in certaminibus ablatas atque impositas victori, ut ea ignominia caeli incommoda pateretur...

${ }^{46} 1.22$ (306,22 ss.): ... Vetustissimi ludi apud Romanos Consualia in honorem Neptuni, quem Consum vocabant sane minus considerate. Quis enim putet Neptunum esse numen consiliorum?... 1.23 (320,29 ss.): ... Quo tempore occiso Pythone tripodis custode oraculum suum fecit. Cuius corio obductus eiusdem opera tripos... Ex eo certamen septimo quoque die constitutum ille Pythicum appellavit. Mirum sane, cum rem sagittis confecisset, non et sagittandi certamen, sed cithara canendi posuisse.

$471.22(314,4$ ss.)... tamen quinque tantum illis constabat pentathlon, quod qui vicissent a Latinis sunt quinquertiones appellati, quoniam vox haec ars prima sua origine robur ac fortitudinem designavit. Graeca enim omnia: Ares, arete, enaretos. Sic virtus a viribus apud maiores nostros pro fortitudine tantum accipiebatur. Aristoteles in primo Rhetoricorum ita disponit. Quae corporis virtus attributa est certaminibus, constat magnitudine, robore, celeritate...

${ }^{48}$ Véanse sus trabajos mencionados en el apartado de la bibliografía.

${ }^{49} 1.23$ (320,19 ss.): Quoniam vero Graeca tractamus, hoc est mendacia et poetica, id est fabulas, festivitatis huius origo ex aliorum quoque auctorum fide narranda est... La crítica a las fábulas poéticas es especialmente áspera con respecto al ciclo troyano presente en Homero: cf. 1.5 $(126,18$ ss.)

${ }^{50}$ Principales fuentes comunes a ambos autores para los juegos son Pausanias (Descriptio Graeciae), Píndaro y sus escoliastas, Ateno de Naucratis (Dipnosophistae, que Conti tradujo por primera vez al latín -Lugduni, 1556-), Aristóteles, Plutarco (Quaestiones Convivales, Theseus), Estrabón. También escritores coetáneos como L. Gregorio Giraldi, y, especialmente utilizado por Escalígero para los juegos romanos, Alessandro Alessandri, autor de la extensa cornucopia Geniales Dies (Romae, 1522), que sin embargo también ilustra profusamente los juegos griegos y que es explícitamente mencionado por Giraldi: véase Seznec 1987: 194.

${ }^{51}$ Sobre la importancia crucial de la percepción plástica en esta obra (y en el De causis, la obra gramatical de Escalígero), en consonancia con la teoría estética renacentista, en la que Escalígero ocuparía un lugar propio, es fundamental el documentado y sugerente trabajo de Lardet 1986, del que no nos sustraemos a reproducir unas líneas (p. 169): “... dans la Poétic, les 
références aux arti del disegno se trouvent à coup sûr disposées de telle façon qu'elles-mêmes soulignent le dessin de l'oeuvre. Leur seule place dans son architecture très concertée donne déjà à voir ce qui s'enonce à leur propos. Leur site est déjà leur sens. Il fait dans une certaine mesure cela même qu'elles disent. Opération performative..." Con el trasfondo de los debates renacentistas sobre las artes, Lardet recuerda (p.159) cómo para Leonardo de Vinci la poesía se asemeja a una "pintura ciega".

521.2 (80, 13 ss.): ...[Musas] Gratiarum vero tum perpetuas socias tum affines propterea, quod elegantioris lautiorisque vitae auctores esse videantur non sine ea voluptate, quae in laetitiae temperatione sita est; hoc enim charis sonat quod et chairein, quae vox ad secundam valetudinem in epistolis atque salutationibus locum invenit communi loquendi usu... Est enim laetitia affectio animi in corpore sano... quod autem et charites et laetitia et Musae et bona valetudo affines sint, ex oraculi consilio colligi potest, quod Argivae Telesillae datum ait Plutarchus...

${ }^{53}$ Stillers 1994: 49. 


\title{
Memorial de don señor Pedro González de Mendoza al rey Felipe Tercero en razón de la eXPUlsión de loS MORISCOS CON EL OFICIO Y MISA
}

\author{
Lorenzo L. Padilla Mellado \\ Universidad de Granada
}

\section{1.- Introducción}

Tras la conquista de Granada en 1492, hay un breve período, en que se permite la religión musulmana y se respetan los acuerdos firmados en las Capitulaciones, la lengua, costumbres, vestidos, religión, etc. Aunque en este corto periodo que lleva al final del s. XV, hubo conversos, la mayoría de los vencidos se mantienen como mudéjares. Pero las Pragmáticas de cristianización forzosa decretadas a principios del s. XVI obligan a los mudéjares a su conversión forzosa o al exilio, por lo que se rompen los acuerdos expresados en las capitulaciones y hacen que la mayoría adquiera la condición de morisco, tras el bautismo obligatorio.

Con la revueltas de las Navidades de 1499, se inicia en Granada una nueva etapa para la población morisca o cristianos nuevos, llevándose a cabo conversiones masivas en la Diócesis de Granada, que continuaron con una mayor o menor intensidad hasta mediados de 1501, fecha en que los reyes admitían públicamente que en el reino granadino ya no quedaba infiel alguno.

El problema morisco, tanto la guerra de las Alpujarras como la decisión de su expulsión, ha sido y es uno de los temas más repetidos en la literatura y en la historiografía española. Los moriscos suponen un elevado contingente de población dentro de la realidad hispana del Siglo de Oro, lo que justifica ese interés. Esta minoría supone el último reducto de la dominación del Islam en la Península, pasando a engrosar el número de los marginados hispanos aproximadamente desde 1500, cuando se impone definitivamente la política intransigente puesta en marcha por el Cardenal Cisneros, frente a la política de tolerancia del primer arzobispo de Granada Fray Hernando de Talavera.

Si durante el reinado de los Reyes Católicos y el emperador Carlos V, la tolerancia es la base de esta convivencia entre estas dos culturas antagónicas, sin olvidar que en este periodo se dictan pragmáticas que prohíben los uso, costumbres s y formas de vida islámica de los moriscos, nunca llevadas a la práctica a cambio de fuertes sumas de dinero, el reinado de Felipe II estuvo marcado por la intolerancia y un fuerte control social y religioso. La situación internacional está impregnada de cambios, que coincide con la llegada al trono de Felipe II. Así en la segunda mitad del s. XVI, los turcos y los berberiscos amenazan el Mediterráneo Occidental, y se empieza a pensar en el morisco 
como una quinta columna que aliados al turco puede amenazar la Monarquía Hispana. En este un ambiente de más hostilidad hacia el morisco, se dictan sucesivas pragmáticas, como la de 1567 que prohíbe el uso de la ropa y la lengua árabe, y se convierte en uno de los principales desencadenantes de la Guerra de Granada (1568-1571). La convivencia entre cristianos nuevos y viejos se iría rompiendo paulatinamente, siendo de día en día más difícil la convivencia.

Este conflicto puede ser considerado como uno de los más crueles que ha visto la Historia de España, ya que además de ser una guerra civil, aparece impregnado de fanatismo religioso por los dos bandos. Es una lucha entre dos culturas: la cristiana, que desea imponer su sistema de vida en toda la extensión de la expresión y la hispano-musulmana que se defiende ante las limitaciones a sus costumbres y religión, pero sobretodo se defiende desesperadamente ante el peligro de la expulsión de sus tierras y acarreando su inminente extinción.

Acabada la guerra se producen traslados masivos desde el reino de Granada a los de Jaén, Córdoba y Sevilla y, después, desde éstos a Granada como repobladores de las tierras dejadas, a nuevos pobladores de cristianos viejos, que se instalaran en estos lugares, habitando sus casas y cultivando las tierras, aunque algunos no lo fueran o descendiesen de antiguos mudéjares asimilados.

A principios del s.XVII se llevara a cabo la total expulsión de esta minoría española que vivía en tierras hispanas conviviendo con castellanos, aragoneses, valencianos, catalanes y otros territorios de la Corona española, constituyendo uno de los temas más oscuros y turbios de nuestra historia. Quedaba atrás aquella tan idealizada tolerancia religiosa protagonizada por diferentes prácticas religiosas, culturas diversas, diferentes costumbres, etc., que fue sustituida con la modernidad por una tendencia de asimilación propugnada desde los Reyes Católicos y primeros monarcas Austrias.

El decreto firmado por el rey cuando se encontraba recluido en el Alcázar de Segovia el 4 de Abril de 1609 y que con su puesta en marcha se llevo a cabo la eliminación de la faz de España de millares de españoles dedicados en su mayoría al cultivo de las tierras, oficios artesanales, manufacturas y otros de gran valía, que requerían un especial conocimiento del oficio.

El decreto de expulsión estaba calcado del que llevaron a efecto los Reyes Católicos contra la expulsión de los judíos tras finalizar la Guerra de Granada en 1492, y como en esa ocasión lo que se perseguía era la religión y no la raza.

A Felipe III no le importó la incidencia económica ni política que con esta medida podía influir al buen desarrollo y estabilidad del país. Tampoco le alarmó el temor de una rebelión de los moriscos en los diferentes lugares de población, ya que la proporción de los cristianos viejos y los moriscos era bastante tranquilizante, pues por ejemplo en el reino de Valencia en el censo 
llevado a cabo en 1599 existían unas 28.000 familias moriscas por unas 74.000 cristianas.

Lo que sí llamaba la atención y era causa de envidias y recelos entre la población cristiana era su laboriosidad, sobriedad, frugalidad en el trabajo, su escasa ostentación, carencias de lujo en sus casas y vestimenta y sobretodo el afán en el que a pesar de la presión a que estaban sometidos en los impuestos que pagaban iban allegándose dinero y proporcionándose una situación mucho más ventajosa a la de muchos cristianos viejos. La rapidez en que crecía su población por no admitir el celibato entre ellos y el casarse muy jóvenes, el no contribuir a las filas del ejército, ya que estaban exentos del servicio de armas, sin perder gente en las múltiples y costosas guerras en que estaba implicada la monarquía española, y el tener prohibida la emigración en busca de riqueza al nuevo mundo, todo esto hacia que los moriscos crecieran con una extraordinaria rapidez.

Toda esta situación se hizo insostenible, siendo el día 23 de Septiembre de 1609 el día elegido para que en las calles y plazas de Valencia se pregonara la Pragmática de expulsión, en la que el rey tratando de herejes, apostatas y traidores, se ordenaba a la población morisca que fueren apresurados a ser embarcados en el término de tres días y dejasen para siempre las tierras de España. En este plazo tan corto los hombres y mujeres moriscos bajo pena de muerte si incumplían dicha orden, debían dirigirse a los puertos que a la sazón cada Comisario encargado para dicha misión les señalase.

No se les permitió sacar de sus casas más que los bienes que pudieran llevar sobre sus cuerpos. Se autorizaba a cualquiera que encontrase a un morisco desbandado fuera de su lugar pasados los tres días del edicto, para que pudiera apoderarse de lo que llevara, prenderle y darle muerte si ofreciera resistencia.

Es necesario imaginar la gran sorpresa y recelo que ocasionaría en la población morisca este terrible bando, por el que de la noche a la mañana y sin previo aviso se les obligaba a abandonar la tierra en la que habían nacido, sus recuerdos, las tumbas de sus parientes, el suelo en el que habían cultivado y regado con el sudor de su frente y que habían acrecentado con su esfuerzo y trabajo diario.

Aún quedaba lo peor y más peligroso y suponía el llegar a los puertos señalados para el embarque e iniciar el viaje que les llevara a sus destinos, pues los cristianos deseosos de venganza y atraídos por el amor al pillaje formaron cuadrillas en los caminos, asaltando y robando y en muchos casos asesinando a los infieles moriscos. En muchos de los casos algunos señores tuvieron que acompañar con numerosa escolta armada a sus moriscos hasta los puertos de embarque.

Muchas de las familias moriscas creyéndose más seguras fletaron para sí buques para su traslado, creyendo que estarían más seguros, cuan equivocados estaban, ya que perecieron en el camino víctimas de la codicia y brutalidad 
de patrones y marineros. Fueron robados y degollados durante la travesía y arrojados sus cuerpos al mar.

Para terminar y como reflexión de está nefasta medida, desde una perspectiva moral la expulsión supuso un acto de barbarie e intransigencia religiosa y política. Casi 112.000 personas fueron echadas de su país, por la sencilla razón de que eran diferentes: hablaban otra lengua, practicaban otras costumbres y adoraban al mismo Dios, con otro nombre y de una forma distinta. La perdida demográfica fue terrible. En el orden económico se vio privada la nación de la población más útil, productiva y contribuyente. Supuso un coste de 80.000 ducados el transporte de los moriscos a África, y por otra parte los moriscos pusieron en circulación una gran cantidad de moneda falsa que afecto negativamente al comercio y a la hacienda pública.

Los campos quedaron sin labrar, los señores territoriales perdieron muchas de sus rentas, la industria por falta de brazos se arruino, cerrándose fábricas y talleres. Fueron vendidos principalmente todos los bienes que no pudieron llevar consigo, lo que provocó una brusca caída de los precios por un exceso de oferta.

Los moriscos tras la expulsión produjeron otra clase de peligros para España, aún mas funestos que los que pretendían evitar con la expulsión, males que cubrieron las costas de luto y desolación durante largos años, pues los moriscos deseosos de venganza y animados del más profundo odio contra los españoles, muchos de ellos se dedicaron a ejercer la piratería sembrando el terror en las costas del Mediterráneo.

Esta era la situación en que quedó el suelo hispano tras la salida de los moriscos camino de allen de los mares. Y la Iglesia no era diferente a otras instituciones u organismos, ya que tras la expulsión los lugares quedaron vacios y no se recogían los suficientes tributos y rentas para llevar a cabo la reparación de las fábricas de Iglesias, devastadas y arruinadas y pagar las prebendas y salarios de curas y beneficiados, tras la guerra de la rebelión morisca de 1568 a 1570.

Sin embargo se daba gracias a Dios nuestro señor por la expulsión y erradicación de la etnia morisca de España. En un Memorial del Arzobispo de Granada, Señor Don Pedro González de Mendoza al rey Felipe III en razón de la expulsión de los moriscos se decía

"El Arzobispo de Granada dice a suplicado a Vuestra Majestad que fuera de las gracias que se han dado a Dios Nuestro Señor por la expulsión de los moriscos en estos reinos, haga instancia con Su Santidad para que señale día en que las Iglesias de España celebren fiesta y se las den rogándole por la larga vida de Su majestad $y$ aumentos de su Corona, dejándolos por ejemplo a los siglos venideros en que los sucesores de ella tengan que imitar, aumentándolo todo, como Vuestra majestad, lo ha hecho por la conservación de la Fe en ellos. 
Ahora vuelve de nuevo a representar a Vuestra Majestad que en los peligros y al salir de ellos, y en las victorias es costumbre de Vuestra majestad y de sus antecesores el dar gracias a la Divina Majestad por todo, y que ninguno ha habido más peligroso, ni victoria más digna de que se le den, que ésta.

El peligro de tener enemigos de las puertas adentro, y que las guerras civiles son las que más se demuestran y menos se satisfacen de la sangre que vierten, diciendo las historias y teniéndolas por las más crueles y que más se aúnan con el fuego arrasarlo y consumirlo todo. Ejemplo de esto las de los Marios, Silas, Césares y Pompeyos, que dentro de las de Roma se fraguaron sin que bastase la veneración que se debía al parentesco para que se dejase de arrojar el brazo con intento de mayor herida, de donde se podrá discurrir si se levantaran en España en gente pretensora, sentida, sujeta, deseosa de libertad apeteciendo venganza de diferente ley, y no emparentada, ni obligada a nadie, sí encaminaran de mayor gana la espada al pecho ajeno y creciera el peligro en mayor daño del enemigo extranjero. Con flacas fuerzas y buen amigo se consigue victoria y buenos sucesos y Vuestra Majestad lo ha alcanzado y los ha tenido muchas y diversas veces en su Monarquía. Flandes califica esta verdad con las que consigue y tiene cada día civitela fuerte, pequeños en el reino de Nápoles se defendió contra el ejército del Duque de Suisa que traía doce mil infantes y dos mil caballos, quinientos gastadores y doce piezas de artillería y otros que tenían pretensiones al Reino y Haciendas de Nápoles donde las mujeres tuvieron gran parte en la defensa, a quien el Duque de Alba dio plaza y privilegios de soldados a quien se casara con ellas, y a la Coruña poca gente y mujeres la defendieron del Duque y todo el poder de Inglaterra. Jerusalén cuando la cercaron Tito y Vespasiano tenía dentro trescientos y ochocientos y cuarenta y siete mil y quinientas personas que se habían juntado a la celebridad de la Pascua y ella tan pertrechada de muros y contramuros que por inexpugnable se juzgaba, hasta que las guerras civiles dieron paso y abrieron puerta al enemigo, que gustan más de matar al hermano y al vecino que al extranjero y extraños, y así a un mismo tiempo peleaban con los de fuera y con los de dentro con tan gran tesón que de los vecinos, amigos y parientes sacaron de la ciudad por una puerta sola cien mil personas muertas sin las que por otras echaron y quedaron en el campo sin vida a manos de los contrarios. Si a pique de este miserable estado se vio España, juzgue Vuestra Majestad si es justo se señale día en que se den gracias al cielo de la libertad del peligro.

En la perdida de España los que perdieron el miedo y la vergüenza dieron país al enemigo, y con ser tan pocos por ser de la tierra abrieron camino para que en ocho meses se conquistara toda con ser tan inexpugnable y cuatro turcos que ayudaron a los de este reino dieron en que entender largos años al Señor Don Juan de Austria con pérdida de lo mejor de Castilla, ¿que hicieron tantos tan repetidos y tan metidos en la 


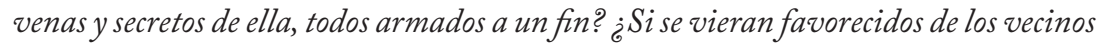
enemigos de ella? Si cuando se habia de ver Jerusalén en este estado que amenazo España, dicen los historiadores salieron ángeles diciendo que se fuesen, y San Gregorio en Italia cuenta sucedió lo mismo, antes de que fuese asolada por los bárbaros, cuya prevención celebraron los cristianos con hacimientos de gracias al cielo ¿̇uánto más corre la obligación a Vuestra Majestad que no le dijeron que fuese sin que los echase descubriéndole Dios la traición para que previniera el daño? No es nuevo lo que se intenta, pues la Iglesia Universal hace fiesta a la victoria del Emperador Heraclio contra Corroas. España por la victoria de las Navas de Tolosa del Rey Don Alonso el Noveno. Por el vencimiento de la batalla del Clavijo dejo el Rey Don Ramiro a España tributaria a la Iglesia de Santiago. Por la batalla naval que venció el señor Don Juan de Austria en Lepanto hace la Religión de Santo Domingo fiesta el primer Domingo de Octubre, y todas estas victorias aunque no se alcanzaran y se perdieran pusieran en recelo, pero si en peligro como lo quedara España si a una se levantaran contra ella los de dentro y los de fuera, y así más obligada en encomendar a Dios a Vuestra Majestad y dar gracias al cielo con sacrificios públicos y solemnes. ${ }^{1}$

También se solicita de su majestad el rey que se mantenga la gracia y limosna a la Iglesia del Arzobispado de Granada, de la mitad de la contribución de las pagas del subsidio y excusado, así por ser su Patrón como por la ruina que le sobrevino con la rebelión de los moriscos de este reino, de que resulto que los morales, olivares y otros árboles quedaron talados y destruidos y la mayor parte de los lugares despoblados. Ya que las rentas eclesiásticas vinieron en disminución de más de las dos partes y que las fábricas de las Iglesias no tienen de que acudir a sus obligaciones y que ahora es la necesidad mayor respecto del daño de la expulsión de los moriscos. Y en consideración de esto suplico a su majestad que le continúe la gracia y limosna que siempre se le ha hecho. Y aunque en cuarenta años que hace que pasó la rebelión de este reino, se han reparado las perdidas y daños que el estado eclesiástico del representa, y mediante esto se debía cesar la gracia y limosna que pide y que lo que montare se convierta en la continua e inexcusable guerra que se tiene contra los infieles enemigos de nuestra santa fe católica en que se ha gastado, gasta y consume tan gran suma como se deja considerar, y para este efecto, pues no le hay más propio ni necesario más urgente en que se deba emplear y no para otro ninguno.

Su majestad usando de su acostumbrada clemencia manda que Vuestra Señoría Ilustrísima con el recato y justificación que conviene, sepa y se informe y averigüe si las perdidas y daños que representa el estado eclesiástico están reparados y el estado que tiene esto y su pretensión. Y mande Vuestra Señoría Ilustrísima que se haga así con la inteligencia y advertencia que pide el negocio, de que se pueda tomar consecuencia y tan importante para todo. Y de la averiguación que se hiciere que se me enviara autorizada en forma y me mande avisar Vuestra Señoría Ilustrísima con su parecer para que yo dé cuenta de ello a su majestad. 
Memorial de don señor Pedro González de Mendoza al rey Felipe Tercero en razón de la expulsión de los moriscos con el oficio y misa

\section{Bibliografia}

BARRIOS AGUILERA, Manuel (2009): La suerte de los vencidos: Estudios y reflexiones sobre la cuestión morisca. Universidad de Granada. Granada.

BARRIOS AGUILERA, Manuel y SÁNCHEZ RAMOS, Valeriano (2001): Martirios y Mentalidad martirial en las Alpujarras (De la rebelión morisca a las Actas de Ugijar) Universidad. Granada.

DOMÍNGUEZ ORTIZ, Antonio (1997): Historia de los moriscos: Vida y tragedia de una minoría. Ed. Alianza. Madrid.

HITOS, Francisco A. (1993): Mártires de la Alpujarra en la rebelión de los moriscos (1568). Edición Facsimil. Ensayo introductorio de Manuel Barrios Aguilera. Universidad. Granada. PADILLA MELLADO, Lorenzo Luis (2010): Los Habices de las Iglesias del Valle de Lecrin. Historia y Arqueología. Tesis Doctoral Universidad de Granada. Granada.

PADILLA MELLADO, Lorenzo L. (2010): "Carta de los Comisarios de la Santa Cruzada al Arzobispo de Granada" Conversos i Expulsats. La minoría morisca entre l'asimilació $i$ el desterrament. Actas del Congreso de Historia sobre el 400 aniversario de la expulsión de los moriscos celebrado en Muro-Alcoy durante los días 16 al 18 de Octubre de 2009. Ajuntament de Muro. Alicante. pp. 397-414. 
Apéndice documental

$\mathrm{S} / \mathrm{F}$

Copia simple.- Memorial de Don Señor Pedro González de Mendoza al Rey Felipe Tercero en razón de la expulsión de los moriscos con el oficio y misa.

Archivo Histórico Diocesano del Arzobispado de Granada. (Leg. 1.601F) N. 42. Humanistica. Papel. 15 folios

\title{
Offitium
}

nocturnum atque diurnum.

\author{
Pro gratiarum actione de expul- \\ sione \\ et relegatione Tartareae sobolis \\ Sarracenorum \\ ab Ilustrissimo et Reverendisimo \\ D.D Fr. Petro \\ González á Mendoza Ar- \\ chiepiscopo Grannatensi, piae \\ devotioni Philippi Tertii \\ Hispaniarum et \\ Indiarum \\ Regis \\ Catholici
}

\section{Dicatum.}

\section{Pted Vesperas, Ptena}

Posuisti Domine inimicos nostros scabellum pedum nostrorum. Dixit Dominus Domino meo. Ps .109.

Ana. Pacificus fui cum iis, qui oderunt pacem, et cum loquebar illis impugnabant me gratis. Ad cum tribularer. Ps. 119.

Ana. Adjutorium nostrum in nomine Domini, qui fecit caelumet terram. Nisi quia Dominus erat in nobis. Ps. 123.

Ana. Prolongaverunt iniquitatem suam, etenim non potuerunt mihi. Saepe expugnaverunt me. Ps. 128.

Ana Neque dormitabit, neque dormiet, Dominus custodit te Dominus protectio tua. Levari oculos meos in montes. Ps. 129. 


\section{Capitulum}

\section{Charissimi: omnem solicitudinem faciens scribendi bobis de communi vestra salute necesse habui scribere vobis depresupercertari semel traditae sanctis fidei.}

Fol. 3r

\section{Himnus}

Christe lux vera, Patris alma proles,

Da nobis digne celebrare festum.

Quo confitemur liberatum gregem.

Duce Philippo,

Barbara turba, psudo christianorum,

Gregem signatum lacerare volens,

Dentes dum parat fortiter retundis

Dextera tua.

Nec ferus mortes Garramas, nec Indus

Horridus rediit, facinusvé majus,

Non secat saevius atrox ille Nero

Viscera Matris.

Quam truces Mauri rabidis sagittis

Perpetrant nostris domibus, cremantes

Templa, nec vitam pueris pepercit,

Ira cruenta.

Et sacerdotum resecant iniquis

Ensibus pectus crucis alma signa

Fronte cum ferro assimibat Magistri

Perfidus ultor.

Gloria Patri per inmensa saecla

Episque Tato, Sanctoque Spiritui

Quo diliguntur ambo in unitate

Almae subitantiae

Amen

Vers. Notam fecisti in gentibus virtutem tuam.

Resp. Liberasti in brachio tuo populum tuum.

$$
\text { Ad Magnificat. Ana. }
$$

Non relinquet Dominus virgam peccatorum super sortem justorum, ut non 
extendant justi ad iniquitates manus suas, Dominus concidit cervices peccatorum.

\section{Oratio.}

Deus cujus ventilabro area Sancta Ecclesia purgatur, et regitur, quique Philippo Tertio Regi Catholico profectori, et sancto fidei defensori potentiae tuae brachium ad expellendos illius perfidos inimicos praestitisti: concede propitiús ut illa tui sancti nominis gloria perseveret, et ad tui regni aeternam memoriam perducatur. Per Dominum nostrum. Pted Matutinum.

\section{Invitatorium}

Regem Regum christiani populi nutritium, Ecclesiae vissibilis tutorem et caelestis propitium glorificatorem. Venite adoremus. Ps. Venite.

Fol. 3v

Himnus

Ad Polorum Conditor,

Gementes praeces fundimus.

Ut plebem tutam serves

Faelicem sacro munere.

$\mathrm{Ne}$ nos scelestis, perfidis

Et criminossis caetibus,

Moristos trudas ad infima

Pena voracis guttura.

A lupis agnos separa

Quos nunc secludis fortiter.

Istos ad vitam revoca,

Illis gehemnae traditis.

Tu dimicantem protege,

Regem, juvaque et erige,

Ut gaudens tuus nomine

Claros triunphos pariat.

Venite cives plaudite.

Et vota votis addite,

Qui mortis post discrimina

Ad vitam vocati estis.

Honor, decus, imperium,

Sit Trinitati unicae

Patri, Nato, Paraclito,

Per infinita saecula. Amen. 
In primo nocturno. Ana.

Consilium impiorum, et cathedram pestilentiae projecisti Domine. Ps. $1^{\circ}$. Beatuor vir qui non abiit in consilio impiorum.

Ana. Fremebant Barbarae gentes, et meditabantur inania, sed tu Domine in caelis irridebas et subsanabas eos. Psal. $2^{\circ}$. Quare frenuarunt.

Ana. Multiplicabantur tribulantes nos, et insurgebant adversum nos, sed tu Domine susceptor noster, et gloria nostra. Psal. $3^{\circ}$. Domine quid multiplicati sunt.

Vers. Exurgat Deus, et dissipentur inimici ejus

Resp. Et fugiant qui oderunt cum a facie ejus.

Fol. $4 \mathrm{r}$

De Epistola secunda B. Pauli Apostoli ad Timotheum.

Lectio prima. cap. $2^{\circ}$

Charissime: in magna autem domo non solum sunt vasaaurea et argentea, sed et lignea et fictilia, et quaedam quidem in honorem, quodam autem in contundiam, si quis ergo enundaverit se ab istis, erit vas in honorem sanctificatum, et uti se domino ad omne opus bonum paratum juvenilia autem decidoria fuge, sectare vero justitiam, fidem, spem, charitatem et pacem cum iis, qui invocant Dominum de corde puro. Stultas autem, et serie disciplina quaestiones devita, sciens quia generant lotes,servum autem Domini non oportet litigare, sed mansuetum esse ad omnes, docibilem, paticutem, cum modestia corripientem eos, qui resistent veritati, nequando Deus (...) illis paenitentiam ad cognoscendam veritatem, et resipiscant a diaboli laqueis, á quo captivitenentur ad ipsius voluntatem.

Ps. Tu es Deus, qui facis mirabilia solus, ji notam fecisti in gentibus virtutem tuam.

Vers. Non veni pacem mittere, sed gladium ji notam fecisti in gentibus virtutem tuam.

\section{Lectio secunda.}

Hoc autem scito quod in novissimis diebus instabunt tempora periculosa, erunt homines seipsos amantes, cupidi, elati, superbi, blasphiemi, parentibus non obedientes, ingrati, scelesti, sine afectione, sine pace, criminatores, incontinentes, innutes, sine benignitate, preditores potervi, tunadi et voluptatum. Amatores magis quam Dei habentes speciem quidem pietatis, virtutem autem ejus abnegantes et hos devita, ex his enim sunt, qui penetrant 
domos, et captiva ducunt mulierculas oneratas peccatis, quo ducuntur variis desideriis, Semper discentes, et numquam ad scientiam veritatis pervenientes.

Ps. Populum humilem salvum facies, Domine, et oculos superborum humiliabis ji quoniam quis Deus praeter te Domine.

V. Viam pacis non cognoverunt, non est timor Dei ante oculos eorum. ji quoniam quis Deus praeter te Domine.

\section{Lectio tertia.}

Quemadmodum enim Jannes et Hambré restiterunt, Moisi ita et hi resistunt veritati, homines corrupti mente, reprobi circa fidem, sed ultra non proficient, insipientia enim eorum manifesta erit omnibus sicut et illorum fuit. Tu autem assequtus os meam doctrinam, institutionem; propositum, fidem, longanimitatem, dilectisnem, patientiam, persecutiones, passiones qualia mihi facta sunt Antiochiae, Icomis et Lutris, quales persecutiones sustinui, et ex omnibus eripuit me Dominus, et omnes qui pié volunt vivere in Christo Jesu persecutionem patientur. Hali autem homines et seductores proficient in pejús errantes, et sic onorem mittentes. Tu veró permane in his, quae /fol. $4 \mathrm{v} /$ didicisti, et credita sunt tibi serens á quae didisceris, et quia ab infantia sacras litteras (...), quae te posiunt instruere ad salutem per fidem, quae est in Christo Jesu.

Ps. Notus in Judea Deus in Israel magnum nomen ejus ji et factus est in pace locus ejus et habitatio ejus in Siom.

$\mathrm{V}$. Ipse enim est pax nostra que fecit utraque unum ji et factus est in pace locus ejus.

V. Gloria Patri ji et factus.

\section{In secundo nocturno. Ana}

Non rodebam retribuentibus nobis mala, et ideo comsumpta est nequitia pescatorum. Ps. $7^{\circ}$. Domine Deus meus in te speravi.

Ana. Intenderunt arcum suum paraverunt sagillas suas in pharetra, ut sagittent in obscuro rectos corde. Ps. 10 In Domino confido.

Ana. Labia dolora in corde, et corde locuti sunt; sed tu Domine servabis nos, et custodios nos. Ps. 11 Salvum me fac Deus quoniam defecit sanctus.

Vers Eripe me de inimicis meis Deus meus

Resp. Est ab insurgentibus in me libera me. Ex Historias.

\section{Lectio Quarta}

Philippus Tertius ab Austria, Hispaniarum et Indiarum Rex Catholicus, 
protector Ecclesiae, defensor fidei, Santae Sedis observantissimus filius. Dum hoc gloriossissima lenimata faelicissimé potiretur Catholicorum Regum Ferdinandi et Elisabeth vestigial sequtus, fidem imitatur, qui perfidos Judeos, illorum lucrum proventus, et faenda contemnentes ab Hispania expulerunt: praevia et matura cum Archiepiscopis et Praelatis et magno stans con silio consultatione praehabita flagrantissimo ardore tuende christianae religionis incensus, conmune, non solum laude, sed publica acclamatione, novos ex Sarracenis conversos non secús ac nocivam zizaniam a tritico ecclesiasticae arcae in longissimas terrarum plagas, non ut suorum criminum exigebat temeritas divinae, humanaeque laevae majestatis audatia, sed ut christiana suadebat clementia: evulsam et erradicatam aspicimus hilarescentes et securi.

Rs Rogate quae ad pacem sunt Hierusalem, et abundantia diligentibus te ji fiat pax in virtute tua, et abundantia in turribus tuis.

V Si gens illa fuerit digna pace, pax vestra erit super eam, si autem non fuerit digna pax vestra revertetur ad vos. ji fiat pax.

\section{Lectio Quinta}

Non profuerunt beneficia in hanc Tartaream sobolem collata, Philippi enim decundi munificentia numquam horum potuit lenire nativam duritiem et petulantiam. Quanta cura hujus Catholici Regis in providenda filiorum educatione, parentumque eruditione, et pro tam singulari patrocinio meritas volentez referre grates, funestissimarum conporationem textores /fol. $5 \mathrm{r} /$ fautores, auctores extiterunt, quibus miseram docentibus ruinam extremamque benefacientibus perniciem attulerunt. Nec in hoc conquerant audaces, sed praeterea ut gigantum illa infestissima monstra Deum ipsum furore perciti debellare intendunt. Simulata fronte se praestant religionis atque virtutis, exteriús amatores, superititioris faedissimisque flagitiis interiús innodati. Venerantur, et praedicant Christianorum nomina, sed intra domesticos parietes barbarorum notis nuncupantur. Intersunt Sacris, vel paena tímidi vel stipendio coacti, et mahometanos ritus observant, et celebrant in abscondite simulatores quasi Hoptrici, mímuli excordes extollidi: in ludibrium nostram habentes religionem.

Rs Ibi confregit potentias arcuum, scutum, gladium et bellum illuminans tu mirabiliter á montibus aeternis. ji turbati sunt omnes insipientes corde. V Qui non audient sermones vestres exentite pulverem de pedibus vestris ji turbati sunt.

\section{Lectio Sexta}

Ferina illorum pectorum crudelitas ¿quot cruentas strages in ultimo 
Regni Grannatensi invassione patravit? ¿ quot pudibundas virgines, honestas, ante maritos matronas, ut á vera Religione deflectarent ¡oh insana savitia! purpureum, purumque sanguinom gladiis, offuderunt mira illarum illaessa constantia.

Clamant jam templa frequenti verberatione conenssa, in quibus multis diebus inclussi christiani, praefamis magnitudine oculos in suos orbes conclussos habuerunt; et despina fere nudo pectora pendebant arida, efigies plane mortuorum et viventium mortalium cadavera. ¿ Qui tunc mulierum ullulatus? ¿ qui puerorum gemitus? quibus vita in paena, mors in lucro paenitur. Sed horum corda convalescente miserorum luctu silicis mores induunt ignem videlicet exduritie emitentes. Ipsosmet sacrosanctae fidei magistros acutissimis novaculis Sancta Crucis signa in ludibrium disciplina excudunt frontibus, et pectoribus aportis titillantia corda ferinis manibus extrahunt.

Cartusianae Religionis propositum, rerumque domesticanum curatorem arreptos in profundissimo puteo per multos dies claudunt: extractos postea venales in Africam mittunt. ¿A quibus attaribus, et imaginibus veneratis, sacrilegas et impias manus ista monstra continuerunt? \& quam indigne sacerdotum, et monachorum perpetrato caedes? ¿quae puerorum strages evitae? ¡oh generis humani pestes, faces patria, mahometis furia, ruina et labes Religionis! \& quae pectora tam mitissima erunt, quae tantae impudentiae et crudelitatis facinora in Divinam et humanam majestatem perpetrata sufferre poterunt? Pervenit ad culmen horum scelerata cupiditas, irrumpunt hostessacrorumque praedones. Quare ¡oh rerum Opifeo! pare jam quieta,/fol. $5 \mathrm{v} /$ somno plausibili Hispaniarum templa pro tanto beneficio grates rependunt, et praecantur, ut hujus Chatolici clarum Imperii in multos annos modereris, opibus firmes copiis locupletis, gratia augeaes, gloria amplificas, majestate defendas, clementia vegas: ut tuam sanctam Ecclesiam et illius vicarium protegas et defendas, et illum et nostrum Herculem Philippum pestilentes has feras detrudentem plenos meritis ad Regnum Caeleste hacendas.

Rs Renuniscere miserationum tuarum Domine, et misericordia tua, quae á saeculo sunt ne unquam dominentur nobis inimissi nostri ji libera nos Deus Israel V Deus pacis conterat sathanam sub pedibus (...) (...) ji Libera nos Deus. V Gloria Patri.

\section{In tertio nocturno. Ana.}

Corrupti sunt, et abominabiles facti sunt in studiis suis, et Dominus de caelo prospexit super filios nominum. Ps. 13 Dixit insipiens in corde suo.

Ana. Ad nihilum deducti sunt in conspectu opis maligni. Ps 14. Domine quis habitabit. 
Ana. Domine á paucis de terra dunde vos in vita eorum. Ps 16. Exaudi Domine justitiam meam.

V. Inimici Domini mentiti sunt ei.

Rs Et erit tempus eorum in saecula.

\section{Lectio Sancti Evangelii Secundum Lucam}

\section{Lectio Septima cap 14}

In illo tempore dicebat Jesus turbis judeorum: ¿ Quis iturus committere bellum adversus allium Regem non sedens prius cogitat si possit cum decem nullibus occurrere ei, qui cum viginti millibus venit ad se?: alioquinc illo longe agente, legationem mittens, rogat ea, quae pacis sunt. Et reliqua.

Homilia Sancti Augustini Episcopi. Lib. 2 q'qövang.q.31

Decem millia praelierturi cum Rege, qui habebat viginti millia ostendunt simplicitatem Christiani populi dimicaturi cum duplicitate diaboli, hoc est, cum dolis et fallaciis opis, in affectu constitute renuntiantis omnibus, quae sunt opis, ita enim concludit: si ergo omnis ex vobis, qui non renunciaverit omnibus, quae possidet non potest meus esse discipulus, inter quae omnia etiam ipsa temporalis vita intelligatur necesie est: quam oportet sic possidere ad tempus ut non impediat ad aeternia, qui eam fuerit minatus aufferre. Sicut autem de turri non perfecta per oprobium deterruit dicentium, quia hic homo caepit aedificare, et non potui consummare, sic in Rege, cum que dimicandum est, ipsam pacem accusavit cum (...) adhuc illo longe agente legationem milleus rogat ea, quae sunt pacis significans minar innominantium a diabolo tentationem, non sustinere homines qui non (...) /fol. 6r/ omnibus, quae possident, et pacem cum ex facere consentiendo, illi ad committenda peccata, et infra, salem infatuatum apostatam dixit.

Rs Deus virtutum convertere respice de caelo, vide et visita vincam

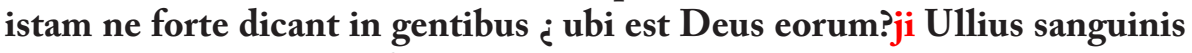
servorum tuerum qui effussus est intrat in conspectu tuus.

V Vincam meam locabus alliis agricolis qui dent fructum in tempore ji Ullius sanguinis.

\section{Lectio octava}

Manifestum est fratres: omnes, qui se dividiunt ab unitate pauci sunt, multi enim sunt, sed in unitate dum non sunt separantur ab unitate; cum enim caeperit ad eos non pertinere multitudo unitatis in haeresi, et in schismate pauci sunt, et pauci facti sunt et vexati sunt a tribulatione malorum, et dolore 
effussus est contemptus super principes. Reprobati enim sunt ab Ecclesia Dei, et magis quia principes esse voluerunt, ideo contempti sunt, et facti sunt sal infatuatum projectum feras, ideo conculcatus ab hominibus, effussus est contemptus super principes, et seducit eos in invio, et non in via. Illi superiús in via, illi ad civitatem directi. Denique illi deducti non seducti: isti autem in in via seducti: ¿ quid est seduxit eos? tradidit illos Deus in concupicentias cordis eorum; hoc est enim seduxit eos, donavit illos sibi nam si proprie quaeras ipsi se seducunt, qui enim putat se esse aliquod cum nihil sit se ipsum seducit ¿ quod est ergo seduxit eos? dimissit eos in invio, et non in via, utique tales ut minuantur ut pauci fiant hinc (...)

Rs Inimicus homo, Domine, in agro tuo super seminacit zizania, visimus et colligimus ea ji ne perdat simul et triticum.

$\mathrm{V}$ Colligite in fasciculos ad comburendum sed videte erradicantes zizaniam ji ne perdat simul et triticum. V Gloria Patri: ji ne perdat.

\section{Lectio nona}

A multitudine unitatis omnes exicrunt sicut paulo ante commemoravi dictum de illis: ex nobis exicrunt, sed non fuerunt ex nobis; si enim ex nobis fuissent permansissent utique nobiscum, sed si forté nostri sunt in occulta praestientia Dei, necessae est ut reddiant. ¡Quam multi non nostri adhúc quasi intús, et

quam multi nostri adhuc quasi foris! novit Dominus, qui sunt epis. Et illi non nostri, qui intús sunt quando occassiones invenerint redeunt. Illud ergo accipite quod novit Dominus, secundum hoc seduxit eos in invio, et non in via. ¿Et quid de illis fecit? Quod dicere experans, quod attenté andratis. Possuit illos parti intús semper, sed nos de illis non proficeremus. Cum autem separati sint, et per quaestiones malignas inquietent nos, perguentum est nobis ex illis, et inquisitionis extudium, et timoris exemplum. Et Deum laudamus.

Fol. 6v

Pted Laudes et per horas ana.

Indutus est Dominus ad protegendum nos et fortitudinem ad expellendos inimicos nostros.

Ps. 92. Dominus regnavit decorum.

Scitote quoniam Dominus ipse est Deus et nos populus ejus, et ovos pascuae ejus. Ps 99 Jubilate Deo omnis terra: servite.

Ipsi vero in vanum quaesierunt animam meam introibunt in inferiora terrae tradentur in manus gladii, Rex vero lactabitur in Deo

Ps 62 Deus Deus meus: ad te de luce. 
Memorial de don señor Pedro González de Mendoza al rey Felipe Tercero en razón de la expulsión de los moriscos con el oficio y misa

Tres pueri á Nabuchodonosor, et millia millium puerorum á barbara sita natione in fornaceru missi clamabant dicentes.

Cant. Benedicite omnia opera Domini Domino.

Beneplacitum fuit Domino in populo suo, et exaltavit mansuetos in salutem.

Ps 148 Laudate Dominum de caelis.

\section{Capitulum}

Charissimi: omnem. ut in vesperis.

Himnus. Christe, lux vera, et veris. Notam fecisti. ut in vesp.

\section{Ad Bnus ana.}

Fiant sicut faenum tectorum quod priusquam evellatur exaruit.

Oratio. Deus cujus ventilabrus ut supra.

\section{Ad tertiam.}

Ana. Scitote. Capit. Charissimi: omnem. Rs Exurgat Deus ji et dissipentur inimici ejus, $V$ et fugiant qui oderunt eum á facieejus. Gloria Patri. Exurgat Deus. V Eripe me de inimicis meis Deus meus Rs Et ab insurgentibus in me libera me.

\section{Ad sextam. ana}

Ipsi vero. Cap. Si autem quaecumque quidem ignorant blasphemant, quaecumque autem, tamquam multa animalia norunt, in his corrumpunt.

Rs Eripe me de inimicis meis ji Deus meus. V Et ab insurgentibus in me libera me. Deus meus. Gloria Patri. Eripe me. V Inimici Domini, mentiti sunt ei.

Rs Et erit tempus eorum in saecula.

\section{Ad nonam ana}

Beneplacitum. Capit. Nubes sinc aqua, quae á ventis circunferentur arbores autumnales, infructuonae, bis mortuae, erradicatae, fluctus feri maris dispumantes suas confussiones, sidera errantia, quibusque procella tenebrarum servata est in aeternum.

Rs Inimici Domini ji mentiti sunt ei. $V$ et erit tempus eorum in saecula, mentiti sunt ei. Gloria Patri. Inimici. V Notam fecisti in gentibus virtutem tuam. 
Rs Liberasti in brachiotuo populum tuum.

In secundis vesperis omnia ut in primio

Fol. 7r

\section{Ofitium Misae. \\ Introitus.}

PS. 68

PS. 78

Exurgat Deus,et dissipentur inimici ejus, et giant, qui oderunt eum á facie ejus. V Deus venerunt gentes in heriditatem tuam;; polluerunt templum sanctum tuum, posuerunt Hierusalem in pomorumcustodiam. V Gloria Patri et Filio.

\section{Oratio.}

Deus cujus ventilabro area Sanctae Ecclesiae purgatur et regitur quique Philippo Tertio Regi Catholico, illius protectori, et Sanctae fidei defensori potentiae tuae brachium ad expellendos illius perfidos inimicos prostitisti: concede propitiús ut illa in tui sancti nominis gloria perseveret, et ille ad tui regni aeternam memoriam perducatur. Per Dominum nostrum.

Lectio Epistola B. Judae Apostoli.

Judas Jesuchristi servus, frater autem Jacobi, his qui sunt in Deo Patre dilectis, et Christo Jesu conservatis et vocatis. Misericordia vobis et pax, et charitas adimpleatur. Charissimi: omnem solicitudinem faciens scribendi vobis de communi vestra salute, necessé habui scribere vobis; deprecans supercertari semel traditae sanctis fidei; subintroierunt enim quidam homines, (qui olim praeicripti sunt in hoc juditium), impiis Dei Nostri gratiam transferentes in luxuriam, et solum dominatorem, et Dominum Nostrum Jesum Christum negantes. Commonere autem vos volo, scientes semel omnia quoniam Jesus populum de terra Egipti salvans (..... 14) secundo eos, qui non crediderunt perdidit, angelos veró, qui non servaverunt suum principatum, sed dereliquerunt suum domicilium, in juditium magni diei, vinculis aeternis, sub caliginereservavit. Sicut Sodoma, Gomorrha, et finitimae civitates simili modo exfornicatae, et abeuntes post Canam alteram, factae sunt exemplum ignis aeterni penam sustinentes; similites, et hi carnem quidem maculant, dominationem ( ......3) autem spernunt, majestatem autem blasphemant cum Michael Archangelus cum diabolo disputans altercaretur de Moisi corpore non est ausus juditium 
inferre blasphemiae, sed dixit imporet tibi Dominus: hi autem quaecumque quidem ignorant blasphemant, quaecumque autem naturalites tanquam muta animalia norunt in his corrumpuntur $/$ fol. $7 \mathrm{v} /(.$. gen .....16 20 ...2). Vae illis qui in ira Cain abierunt et errore Balaam mercede Offussi sunt, et in contradicctione // Coré porierunt sanctipros pascentes, nubes sinc aqua, quae á ventis circunferentur, arbores autumnales, infructuriae, bis mortuae, erradicatae, fluctus feri maris dispumantes suas confussiones, sidera errantia quibus procella tenebrarum servata est in aeternum.

PS. 80

PS. 79

Gradualer. Inimici Domini mentiti sunt ei, et erit tempus, eorum in saecula.

V Deus meus ponc illos ut rotam et sicut stipulam ante faciem venti.

V. Ilta Alta Notam fecisti in gentibus virtutem tuam liberastiin brachio tuo populum tuum. Alla

\section{Sequentia Sancti Evangelii secundum Lucam \\ Lucae 14}

In illo tempore: dicebat Jesus turbis Judeorum: ¿ quis Rex iturus committere bellum adversus alium Regem non sedens cogitat si possit cum decem millibus occurrere ei, qui cum viginti millibus venit ad se? alioquim adhúc illus illus longi agente legationem mittens rogat ea, quae pacis sunt, sic ergo omnis ex vobis, qui non renuntiat omnibus, quae possidet non potest meus esse discipulus. Bonum est sal, si autem sal evanuerit ¿ in quo condietur? neque in terram, neque in sterquilinium utile est sed feras mittetur; qui habet aures audiendi audiat.

\section{Credo. Offrns}

( .... 42) Officio Haec dicit Dominus, si quiescentes mancritis in terra hac aedificabo vos et non destruam, plantabo et non evellam.

\section{Secreta}

Pacificum hoc sacrificium Regnorum dominates placatus assume, et qui Sanctae Ecclesiae inimicos et illorum sacrilegam feritatem expulisti: $a b$ omnibusque illam eruc bellorum nequitiis et in tuae protectionis securitate constitue, et apros hanc Sanctam vincam exterminare cupientes, gladius tuus devoret et consumat. Per Dominum. 
Eripe me de inimicis meis Deus meus, et ab insurgentibus in me libera me. Ego cantabo fortitudinem tuam et exaltabo mané misericordiam tuam.

\section{Post-Communionem}

Praetiosi corporis et sanguinis tui spirituali esca refectis,unionis et pacis gratiam clementis infunde, ut qui lupos rapaces in vestimentis ovium tuum gregem invadentes expulisti, oves, quae te Divinum Pastorem agnorunt ab inimicorum hostili perturbatione conserves. Per Dominum.

Fol. 8r

Estimó el Rey D. Felipe Tercero la expulsion de los moriscos por obra tan de la mano de la Divina Magestad, que encargó á todos los Prelados le diesen gracias, que como D. Fr. Pedro Gonzalez de Mendoza era Arzobispo de Granada, que tenía experiencia y noticia de lo que allí se había padecido con ellos, no solo dio las gracias, pero instó a Su Magestad se hiciese fiesta cada año, y rezo en que quedase el agradecimiento y memoria de este suceso en pie, como por el memorial que se sigue y forma del rezo que le envio se verá.

${ }^{1}$ Archivo Diocesano del Arzobispado de Granada. Signatura Legajo 1601-F. folios 1r-2v. Memorial del Señor Don Pedro González de Mendoza al Rey Felipe Tercero en razón de la expulsión de los moriscos, con el oficio y misa. 
Memorial de don señor Pedro González de Mendoza al rey Felipe Tercero en razón de la expulsión de los moriscos con el oficio y misa

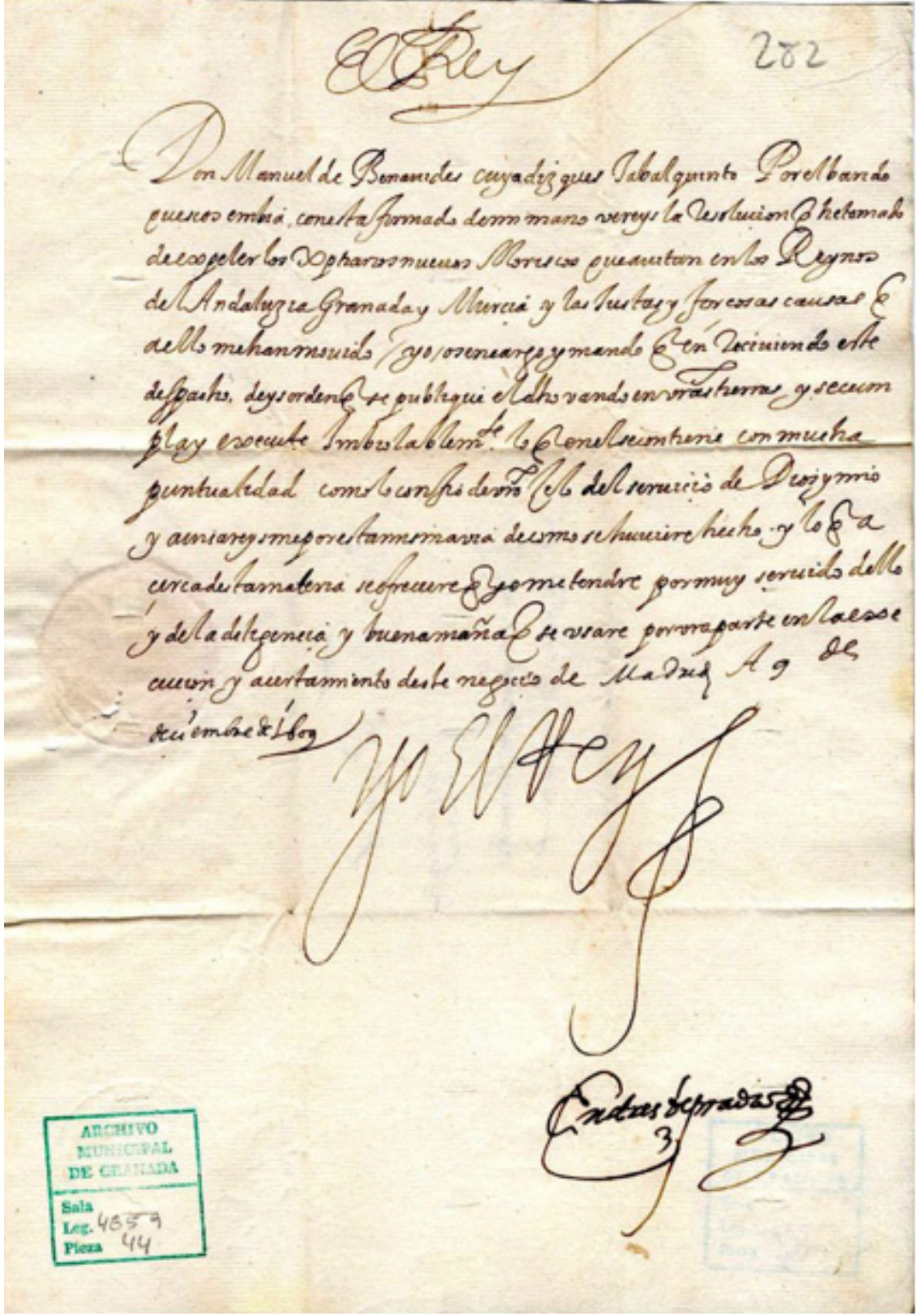

Decreto de expulsión 


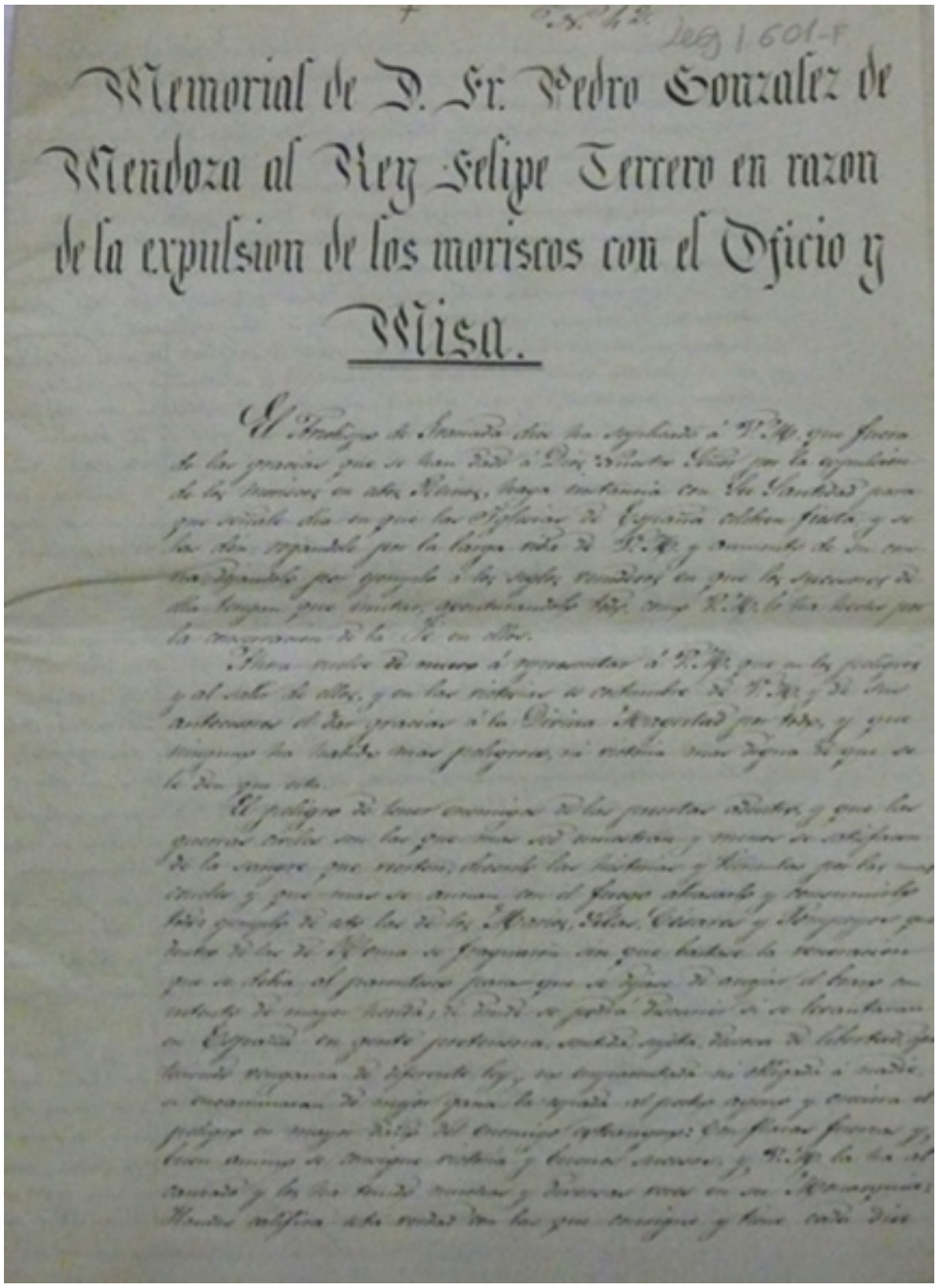

Memorial en razón de la expulsión 


\title{
El encomio a San Hieroteo de la Abadía del Sacromonte: TRANSCRIPCIÓN Y TRADUCCIÓN
}

\author{
Paraskevi Gatsioufa \\ Universidad de Granada

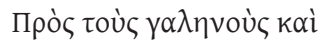

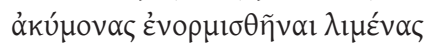

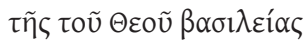

\section{Resumen}

El manuscrito número 160 de la Abadía del Sacromonte (Granada) contiene un texto griego poco conocido, el encomio a San Hieroteo. E1 problema de la autoría de este opúsculo todavía no está resuelto; según algunas fuentes es obra de Euthymios o de Euthymios Zigabenos, pero en nuestro trabajo se aporta documentación sobre otras fuentes que lo atribuyen a Symeon Metafrastes. En estas páginas se presenta la transcripción del texto griego y la primera traducción a una lengua moderna del mismo.

Palabras clave: Hierotheos, manuscrito 160 (Sacromonte), transcripción, traducción.

\section{Abstract}

The manuscript with the number 160 of the Abbey "Sacromonte" (Granada) contains a relatively unknown Greek text, the encomium for Saint Hierotheos. The mystery regarding the origin of the panegyric has not been yet resolved. According to some sources Euthymios or Euthymios Zigabenus is considered to be the author of this work. However, this article provides evidence supporting that it may be attributed to Symeon Metaphrastes. Moreover, we present the transcription of the Greek text and the first translation in a modern language.

Keywords: Hierotheos, manuscript 160 (Sacromonte), transcription, translation.

El manuscrito número 160 (olim $\mathrm{S}^{\mathrm{n}}$. $\mathrm{S}^{\mathrm{a}}$.- Oa.XLVI) de la Biblioteca de la Abadía del Sacromonte (Granada) contiene el Encomio a San Hieroteo, una obra poco conocida. Sobre su autoría no hay unanimidad, y en dicho manuscrito

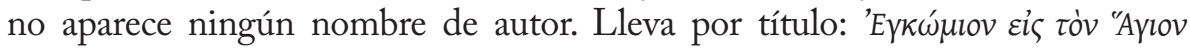
İpó $\theta \varepsilon$ cov. Los pocos detalles que se conocen sobre Hieroteo se han transmitido principalmente en las obras literarias de Pseudo-Dionisio, entre ellas en Пвpi $\theta \varepsilon i ́ \omega v$ óvoú́đ $\omega v$ (De divinis nominibus). En dicha obra Dionisio se refiere a Hieroteo 
como su profesor y le dedica frases de admiración y adoración. La tradición

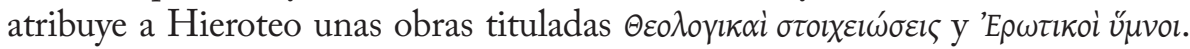
En ellas se mezclan teorías filosóficas neoplatónicas con las propias ideas de Dionisio Areopagita. Sin embargo, la opinión más extendida afirma que se trata de obras del propio Dionisio.

El manuscrito se compone en total de setenta y nueve folios. El texto del encomio ocupa desde el fol. 10v hasta el fol. 37v y aparece exclusivamente en los folios vueltos, porque los rectos estaban reservados para la correspondiente traducción latina. De hecho, en el fol. 11r comienza dicha traducción, pero ésta queda inconclusa, pues el traductor detiene su labor en el fol. 20r. Ambos textos, el griego y el latino, están escritos con la misma tinta, aunque no es seguro que sean de la misma mano.

La escritura griega del manuscrito es limpia y presenta una inclinación hacia la derecha. Hay ciertos errores, pero no son demasiados; los más frecuentes afectan a los espíritus o la ortografía, otros, no muy numerosos, son de mayor entidad. Como características de la escritura se pueden mencionar los siguientes hechos: Las consonantes $\mu, \nu, \rho, \varphi$ presentan siempre en su parte inferior una cola caligráfica acabada en curva. Se emplean las ligaturas usuales para el diptongo ou y para el conjunto consonántico $\sigma \tau$, así como para los vocablos $\tau \varepsilon$, үá́ $\rho$, koú; igualmente se emplean abreviaturas para las desinencias -ov de acusativo singular masculino, $-\eta \varsigma$ de genitivo singular femenino, $-\tau \alpha \iota$ de la tercera persona singular del presente de la voz medio-pasiva y $-\tau \omega v$ de genitivo plural. En ocasiones el copista escribe $\eta$ en un tamaño más grande que el resto de caracteres, y $\tau$ en un tamaño muy grande, de modo que destacan sobre el formato de la escritura, al estilo de la denominada "Fettaugenschrift". En otros momentos se salta letras u olvida poner acentos y espíritus. La puntuación, aunque consecuente en líneas generales, da lugar con frecuencia a confusión. Si el copista comprende que ha cometido un error, lo tacha y escribe al lado el término correcto, a pesar de que es costumbre poner puntos bajo el vocablo corregido. En todo el manuscrito sólo hay dos marginalia de la propia mano del copista; uno es una glosa, y el otro una correctura, aunque errónea.

En el texto se encuentran muchas citas de Pseudo-Dionysio, señaladas con marcas. El autor menciona además con palabras elogiosas las obras atribuidas a

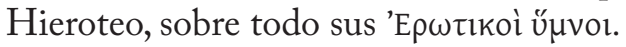

En los folios 38v-39r se ha transmitido otro texto de la misma mano. Tras él los demás folios están en blanco. Este segundo texto presenta el siguiente título:

"In fragmentis Hierothei, quae ex libro S. Dionysii de divinis nominibus desumta (sic) hic producit Autor huius encomii, nonnulla leguntur aliter, atque habentur in vulgaris codicibus. Ea visum hic annotare".

Sigue un listado con glosas. 
En lo que respecta a la persona del copista, con toda probabilidad se trata de un individuo no griego, porque la escritura es demasiado limpia y sin las complejidades propias de un nativo griego. Debe ser alguien que está estudiando o ha estudiado la lengua griega, e intenta copiar el modelo con la mayor fidelidad posible, con sumo cuidado y sin cometer errores, incluso reproduciendo ligaturas y abreviaturas como aparecen en el modelo, quizá sin entenderlas. Puede tratarse igualmente de un ejercicio de escuela, porque junto al texto griego aparece también una traducción latina. En conclusión, es muy probable que el texto haya sido escrito por un copista no profesional.

Sobre la datación y proveniencia del manuscrito hay que señalar que éste no presenta indicación alguna de fecha. Sin embargo, resulta obvio que el manuscrito es de factura reciente, con toda seguridad del siglo XVII. En efecto, es muy probable que fuese Diego Escolano, obispo de Segovia, ciudad que se gloriaba de haber tenido entre sus prelados a Hieroteo, y arzobispo de Granada desde 1668 a 1672, quien llevase el manuscrito a esta última ciudad. No hay que descartar que el propio Escolano hubiese conocido el original griego, del que el manuscrito sacromontano es copia, en la biblioteca del monasterio de El Escorial, donde estudió Humanidades y Filosofía en sus años de juventud. Se pueden barajar por tanto varias posibilidades: o bien lo copió el propio Escolano, o bien lo hizo copiar para él, o bien, ya en Granada, se sacó la copia conservada de otra copia intermedia, propiedad de dicho arzobispo.

La autoría del Encomio a San Hieroteo plantea una problemática de muy difícil resolución. Habiendo sido Dionisio Areopagita el supuesto discípulo de Hieroteo, no han faltado voces a lo largo de la historia que han atribuido el encomio al propio Dionisio, o a Pseudo-Dionisio. Sin embargo, entre los investigadores actuales se ha generalizado la atribución a Euthymios Zigabenos (Zigadena), partiendo de la consideración, iniciada quizá en Krumbacher, de que un testimonio manuscrito datado en el siglo XVIII lo atribuye precisamente a Zigabenos ${ }^{1}$. En este testimonio se basa la primera y hasta la fecha única edición del texto griego, la de Calogerás de 1887, quien añade el encomio tras editar el comentario de Zigabenos a las Epístolas de Pablo y a las Epístolas católicas, tomando el texto de otro manuscrito sin dar más indicaciones del mismo, sino que lo vio en el monasterio Zwүpá $\varphi$ ou de Athos ${ }^{2}$. Igualmente lo atribuye a Zigabenos otro manuscrito poco conocido y conservado en el Monasterio del Profeta Elías, en la isla de Hidra, y que se puede datar en el siglo XVIII ${ }^{3}$.

Pero existen otros testimonios manuscritos más antiguos que datan de

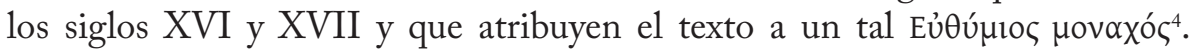
A este respecto Beck advierte de forma acertada que la equiparación entre este monje y el patriarca Euthymios Zigabenos no es segura ${ }^{5}$. De hecho, el autor del encomio, quienquiera que fuese, presenta rasgos de estilo que no se 
encuentran en Zigabenos, como es la utilización de citas de autores clásicos (Hesíodo, Homero, etc.) y la inclusión literal de párrafos extensos procedentes de las obras de Pseudo-Dionisio.

Sin embargo, en esta discusión no se ha tenido en cuenta toda la documentación relativa a la transmisión manuscrita e impresa, griega y latina, del encomio a Hieroteo. En efecto, una traducción latina de dicha obra, realizada por el padre Gabriel de San Jerónimo, monje del monasterio de E1 Escorial, y publicada por el mismo Diego Escolano en el Chronicon S. Hierothei ${ }^{6}$, atribuye el texto a Symeon Metaphrastes. Ciertamente el lenguaje y el estilo del texto presenta muchas similitudes con el de las vidas de otros santos escritas por Symeon. Además, esa misma tradución latina hace referencia a un manuscrito griego antiquísimo conservado en el monasterio de El Escorial que presenta a dicho hagiógrafo como autor del encomio. Desafortunadamente este manuscrito no se conserva hoy en día en la mencionada biblioteca. Puede que se haya perdido en algún incendio. En definitiva, la cuestión de la autoría de este opúsculo está todavía sin resolver.

En la transcripción del texto que se incluye en este trabajo se han corregido sin ninguna indicación al respecto los espíritus, acentos y errores ortográficos de menor importancia. La puntuación se ha modificado siguiendo criterios actuales. Ni que decir tiene que en muchos casos la puntuación del copista impide una correcta comprensión del texto. Las modificaciones de mayor importancia se realizan directamente sobre el texto transcrito y se señalan en nota al pie de página. En cambio, se respeta en el texto toda una serie de fenómenos textuales, sobre todo sintácticos, que difieren de la norma clásica; sólo se indica en nota a pie de página una posible corrección.

En lo que atañe a su contenido, el texto aúna elementos retóricos, teológicos y filosóficos en abigarrada simbiosis. Su finalidad era la de honrar a San Hieroteo en su festividad, el 4 de octubre.

La traducción al español incluida en este trabajo es la primera en una lengua moderna que se ha realizado hasta la fecha. En su elaboración, y para no caer en los excesos de una paráfrasis, se ha seguido un criterio de fidelidad al texto griego original, aunque ello suponga en alguna ocasión sacrificar la fluidez y la elegancia de la prosa española. 


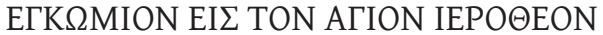

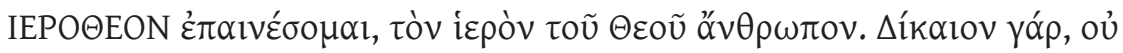

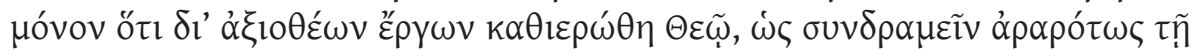

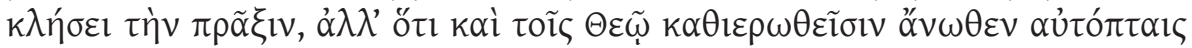

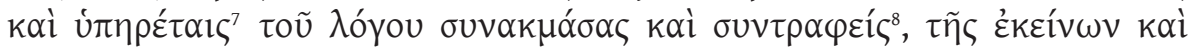

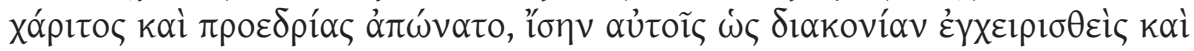

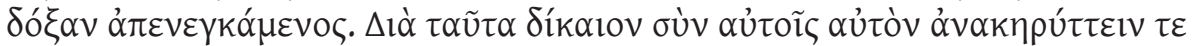

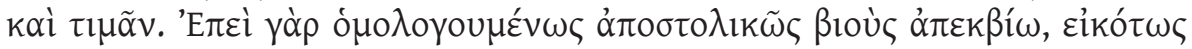

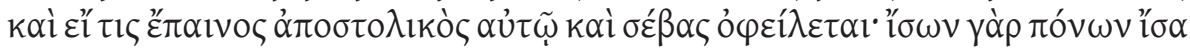

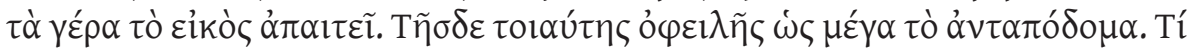

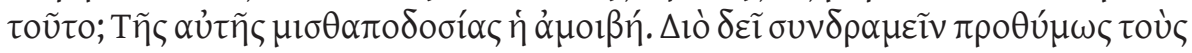

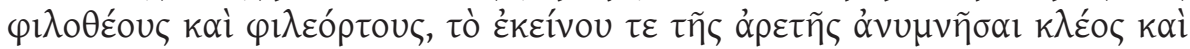

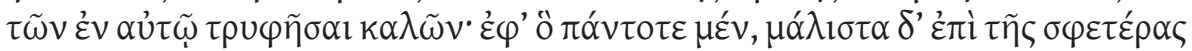

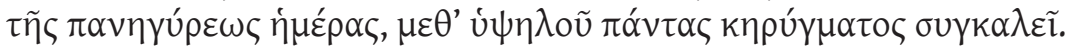

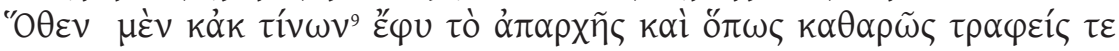

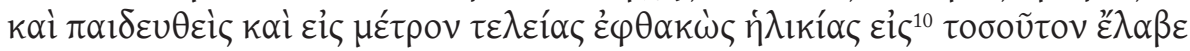

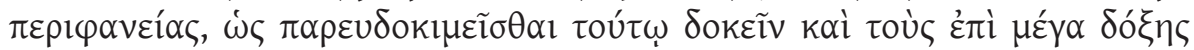

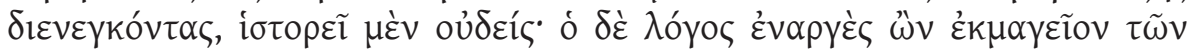

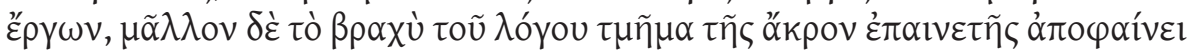

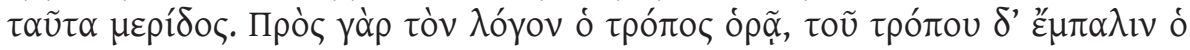

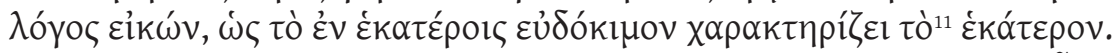

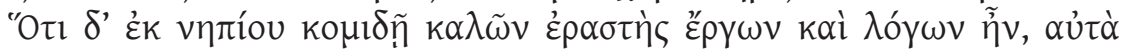

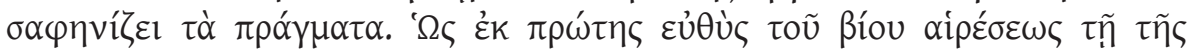

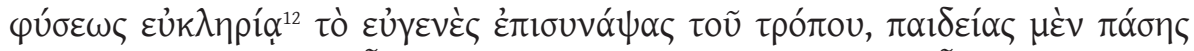

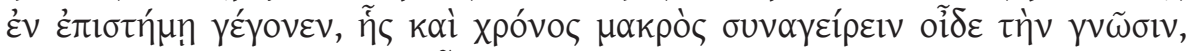

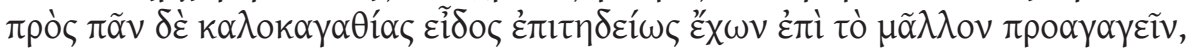

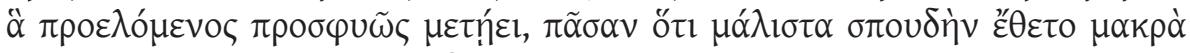

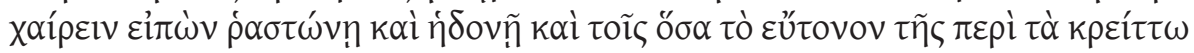

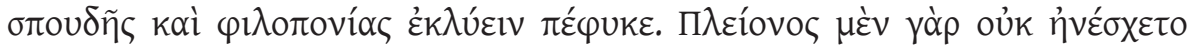

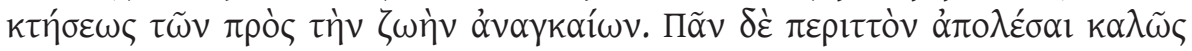

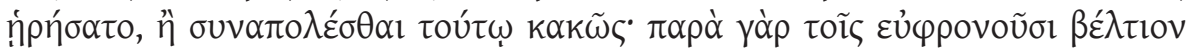

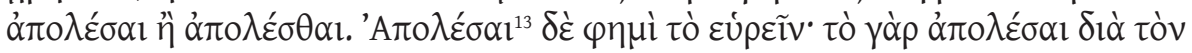

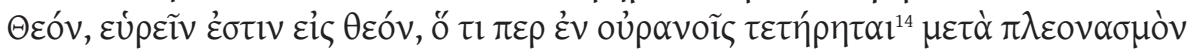

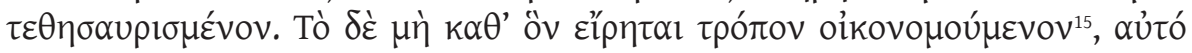

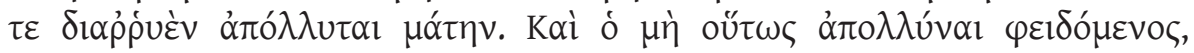

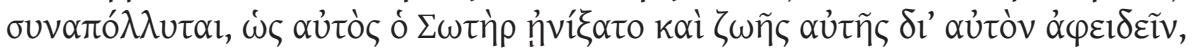

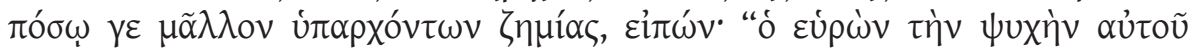

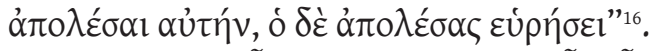

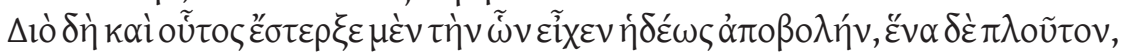

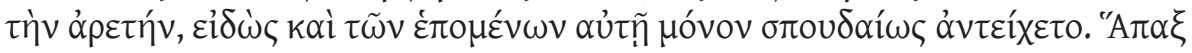

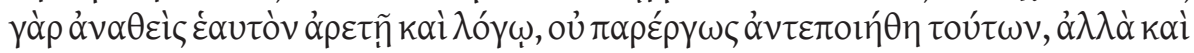




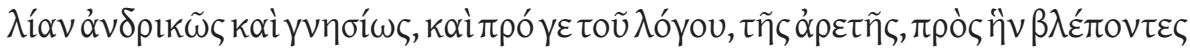

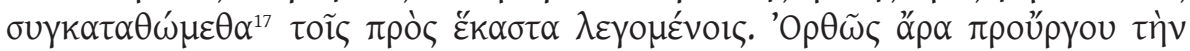

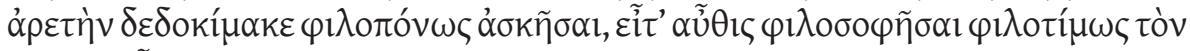

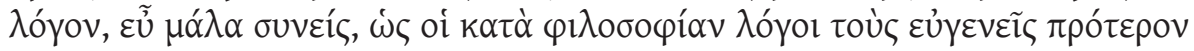

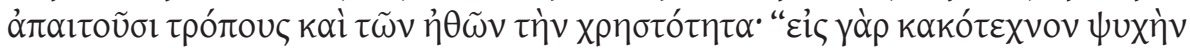

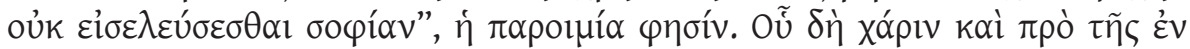

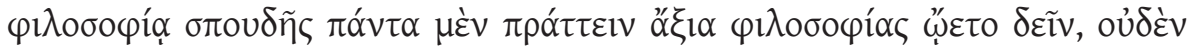

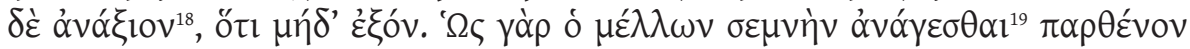

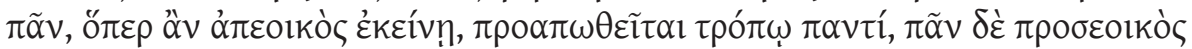

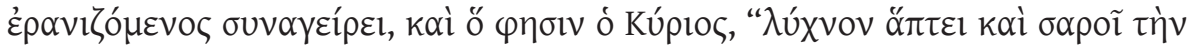

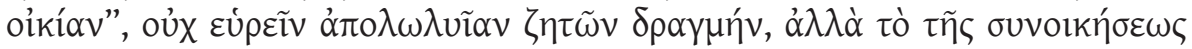

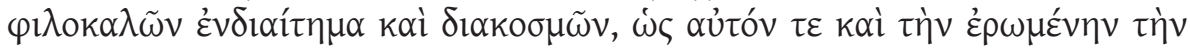

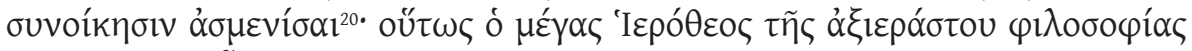

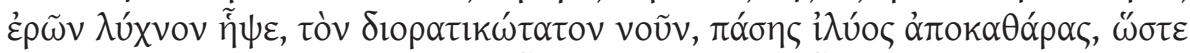

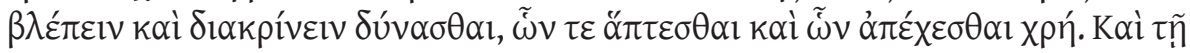

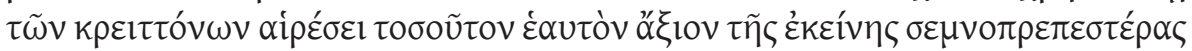

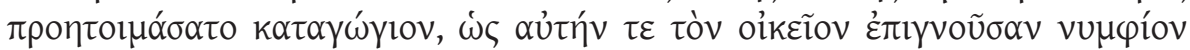

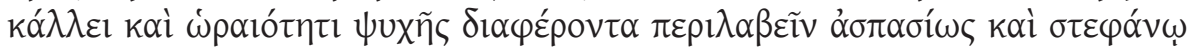

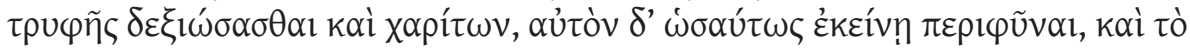

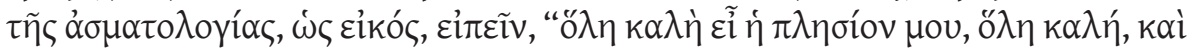

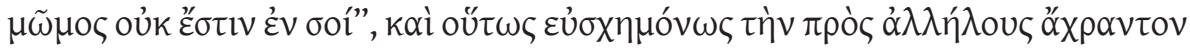

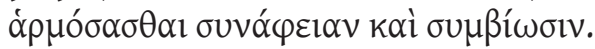

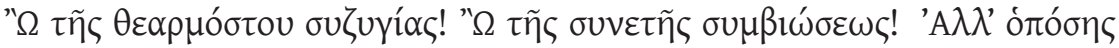

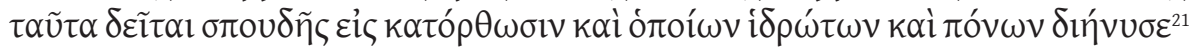

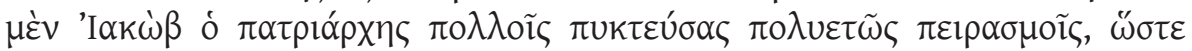

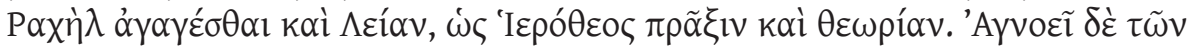

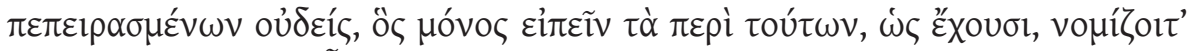

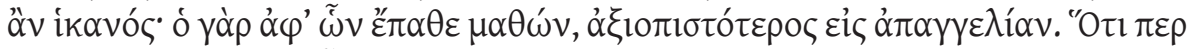

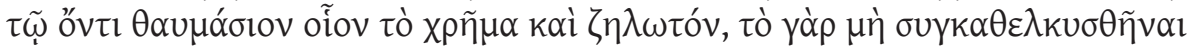

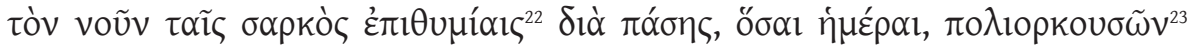

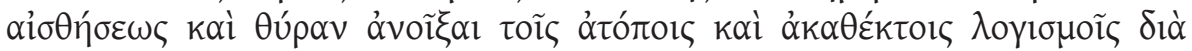

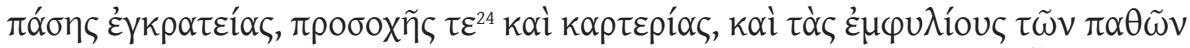

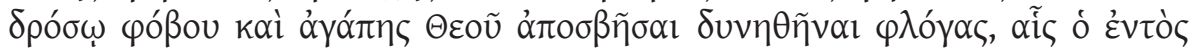

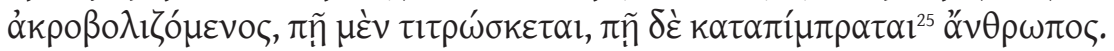

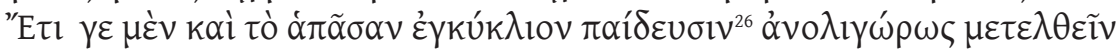

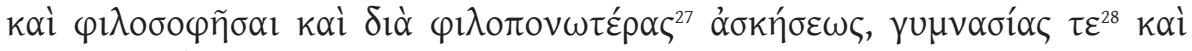

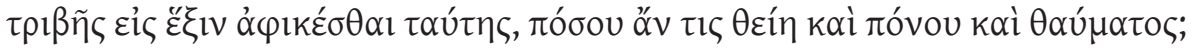

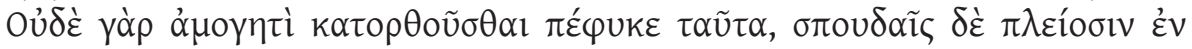

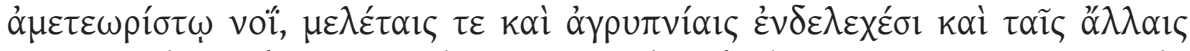

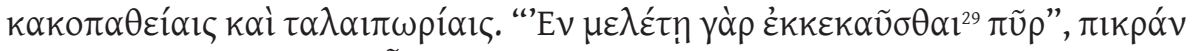

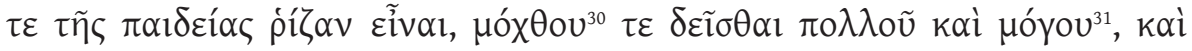




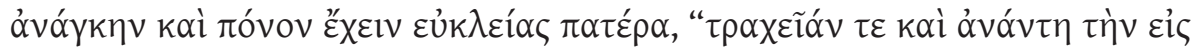

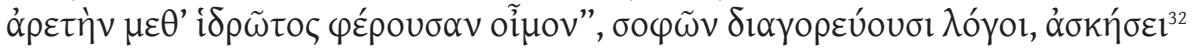

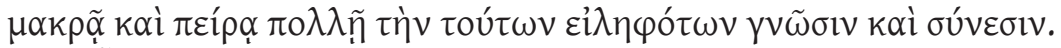

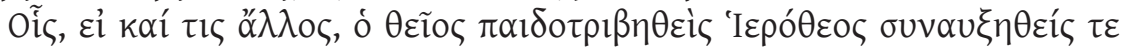

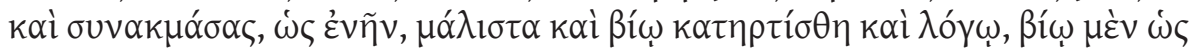

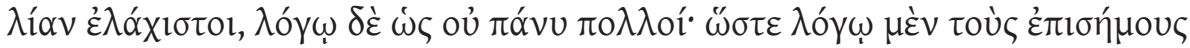

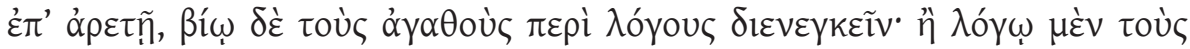

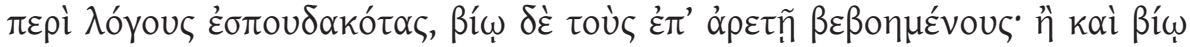

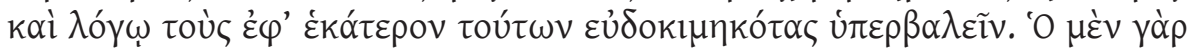

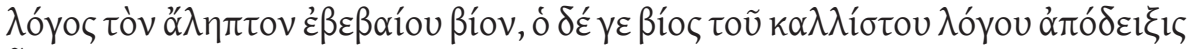

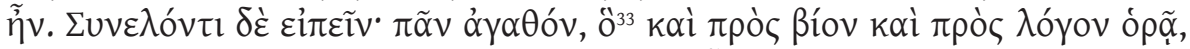

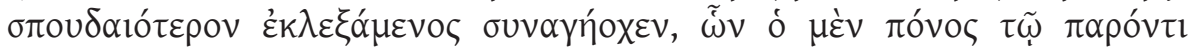

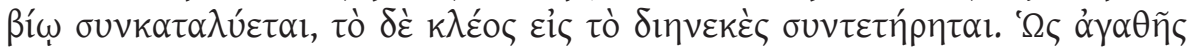

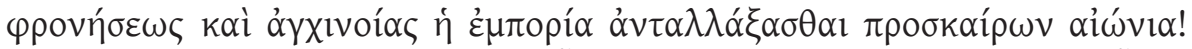

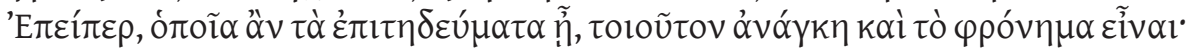

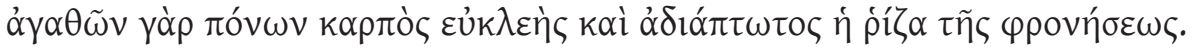

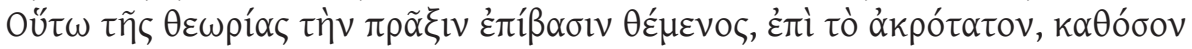

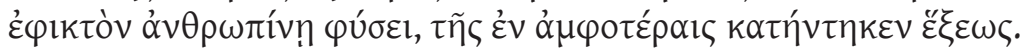

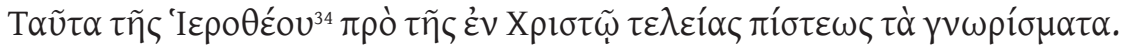

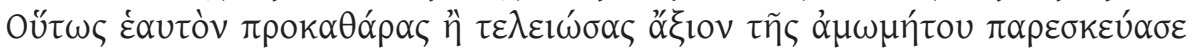

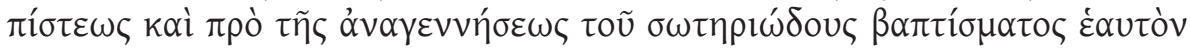

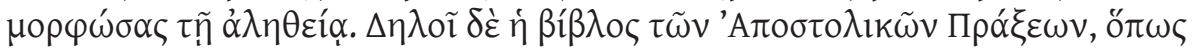

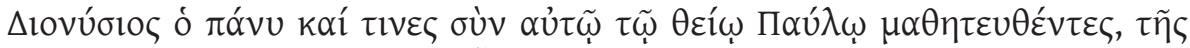

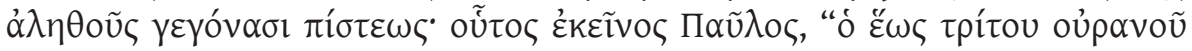

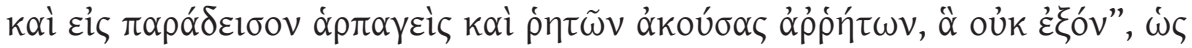

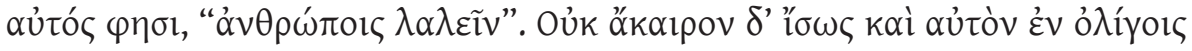

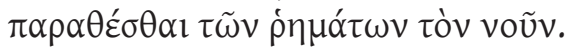

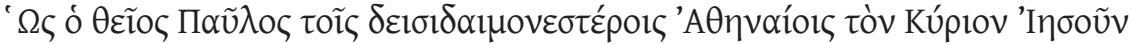

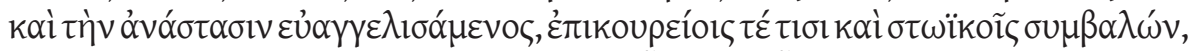

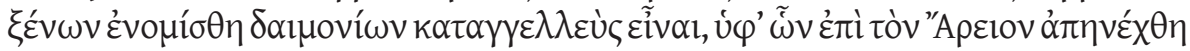

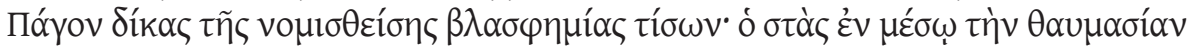

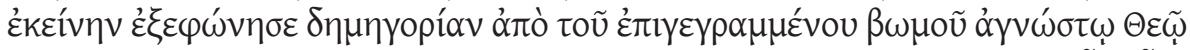

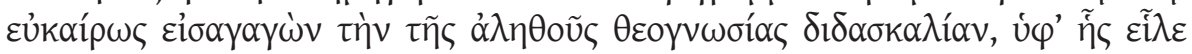

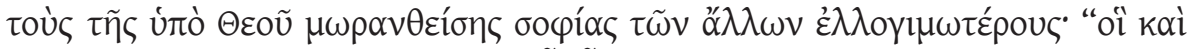

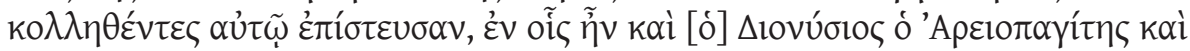

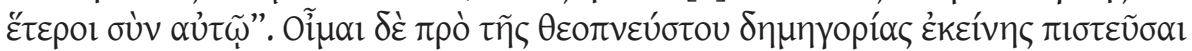

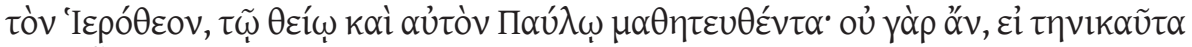

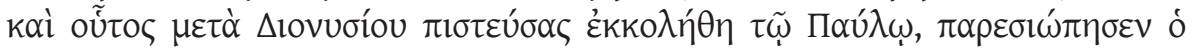

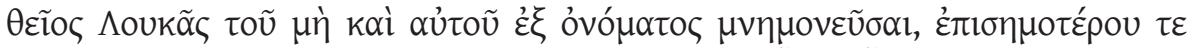

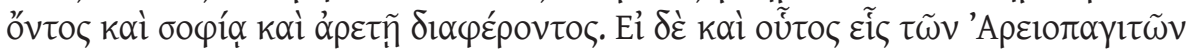

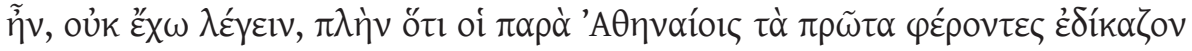




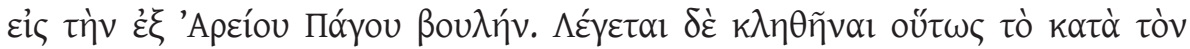

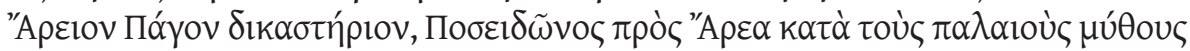

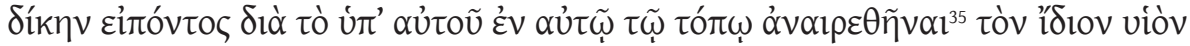

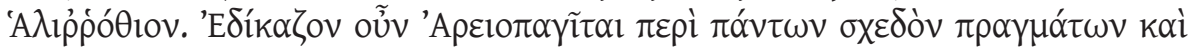

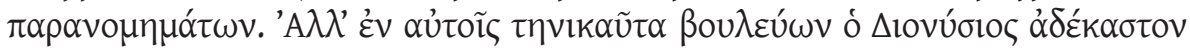

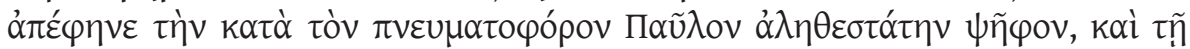

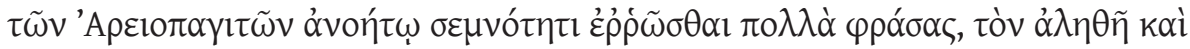

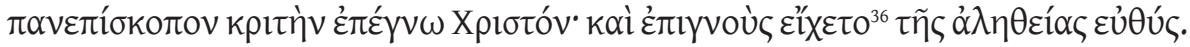

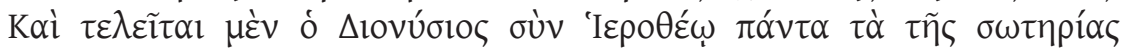

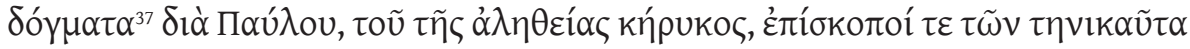

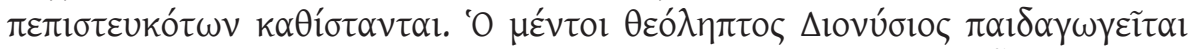

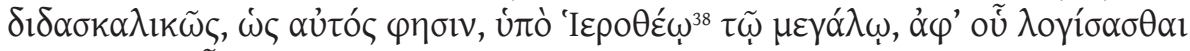

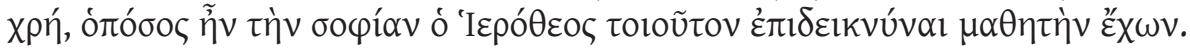

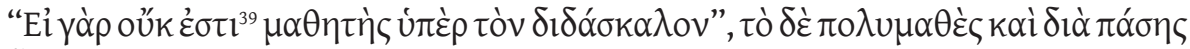

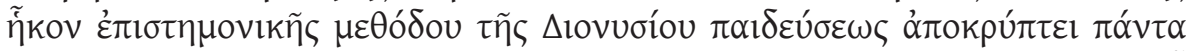

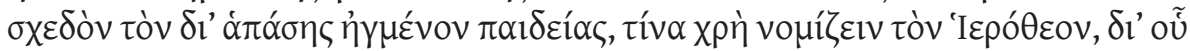

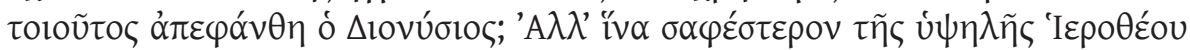

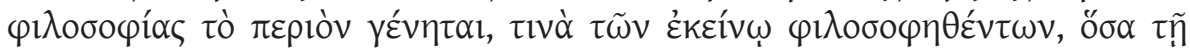

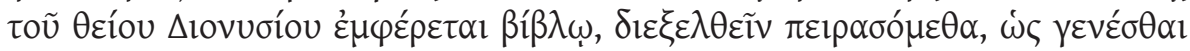

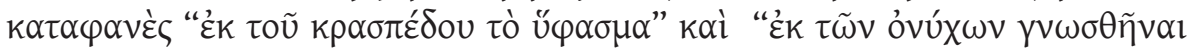

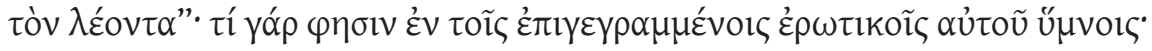

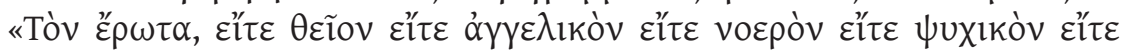

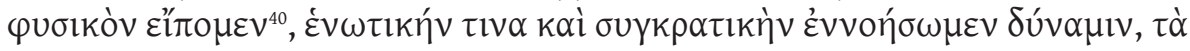

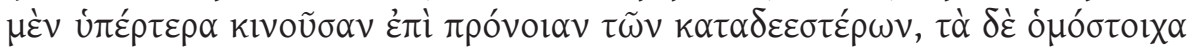

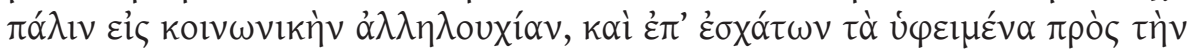

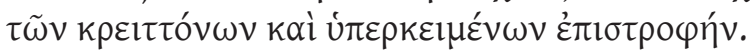

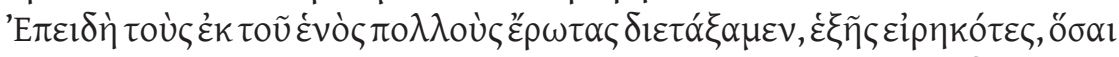

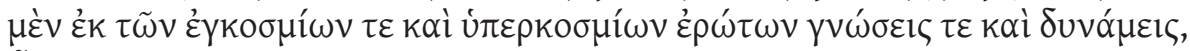

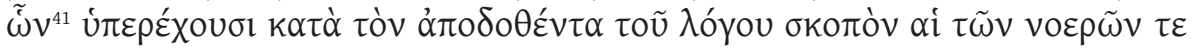

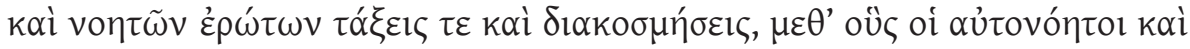

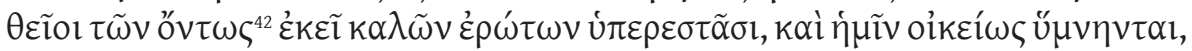

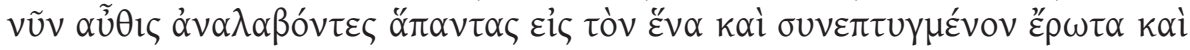

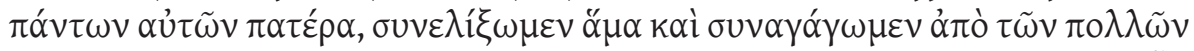

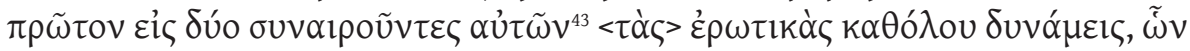

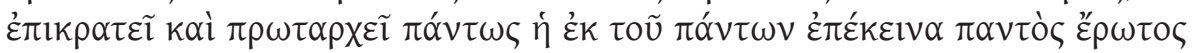

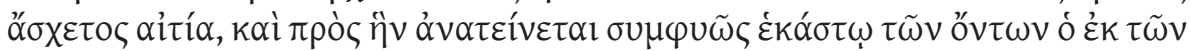

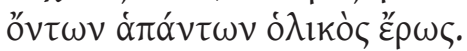

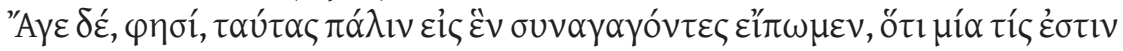

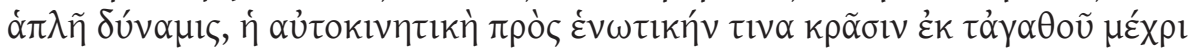

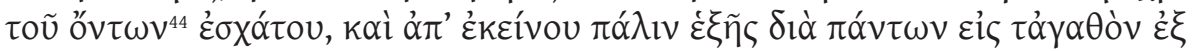

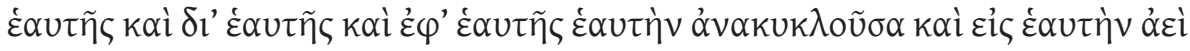




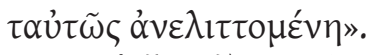

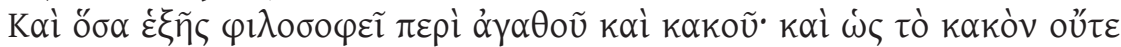

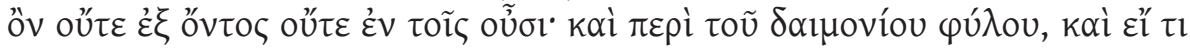

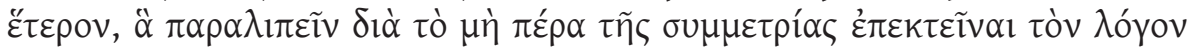

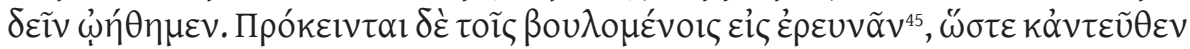

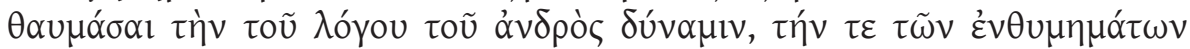

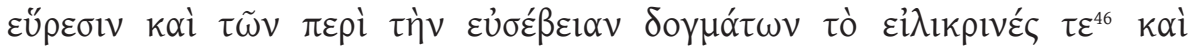

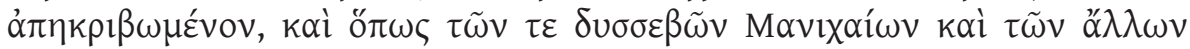

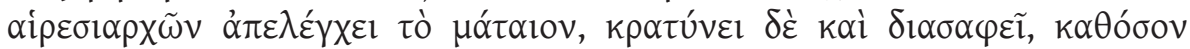

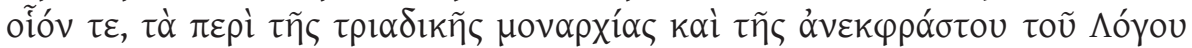

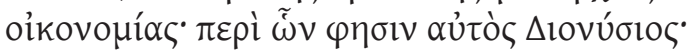

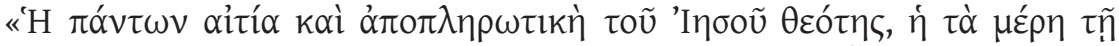

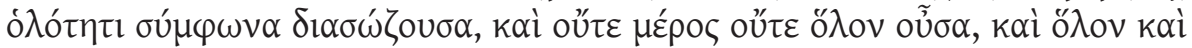

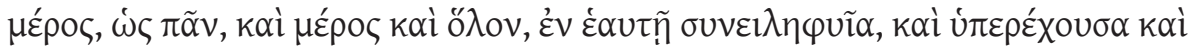

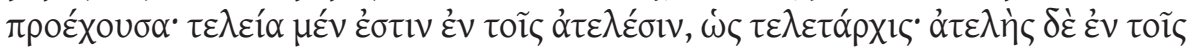

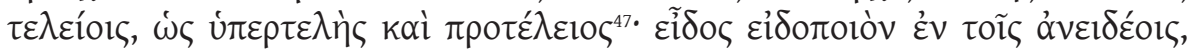

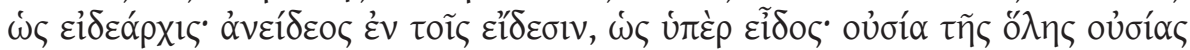

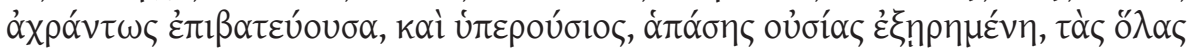

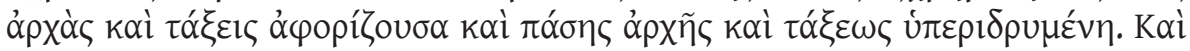

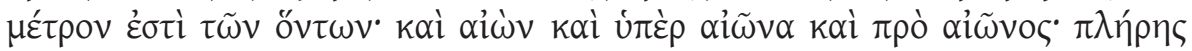

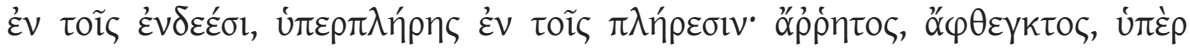

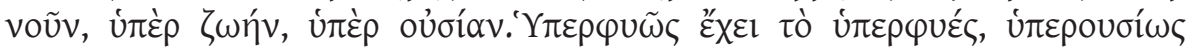

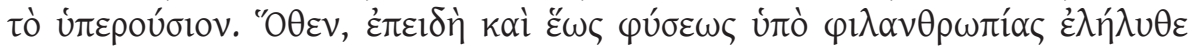

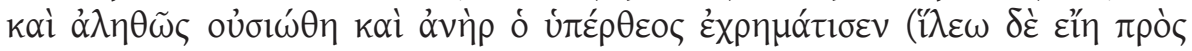

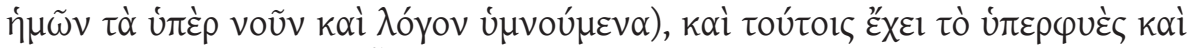

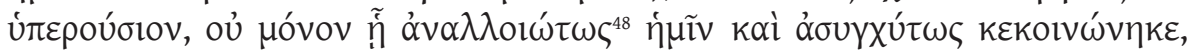

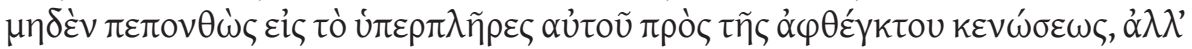

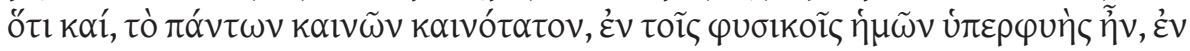

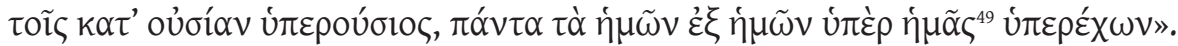

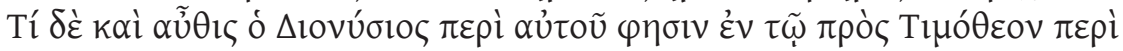

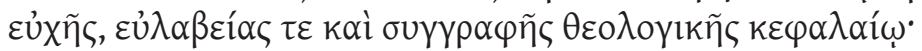

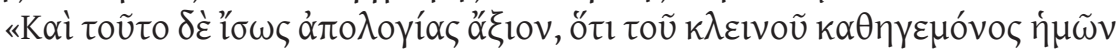

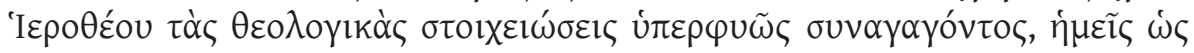

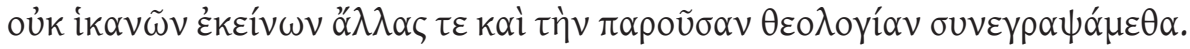

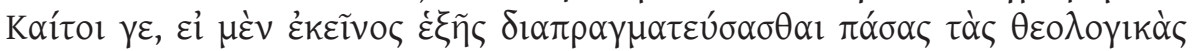

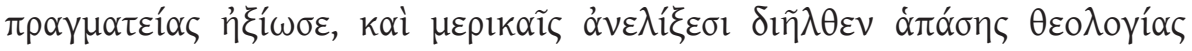

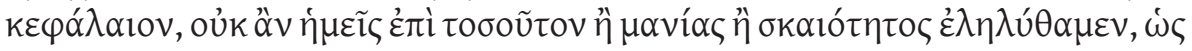

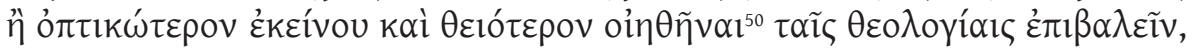

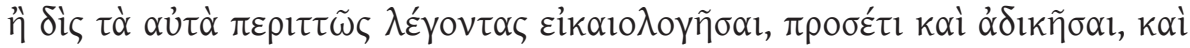

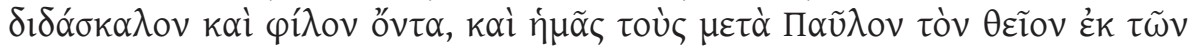

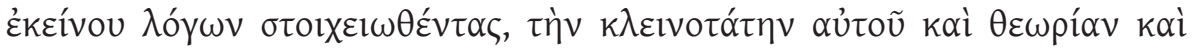




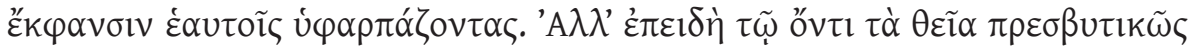

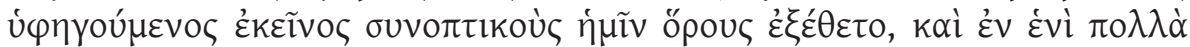

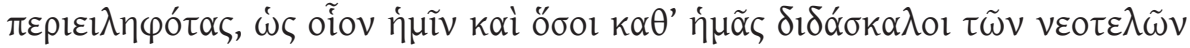

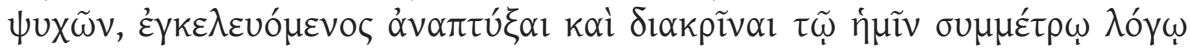

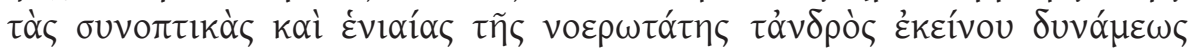

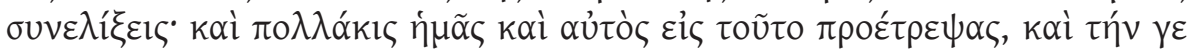

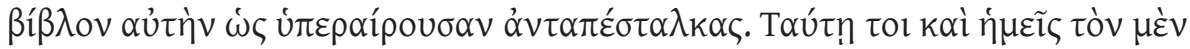

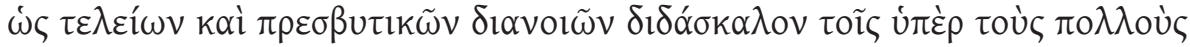

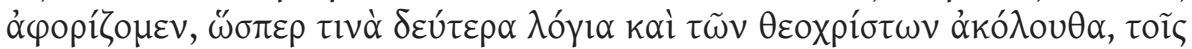

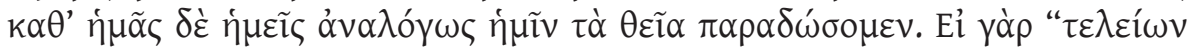

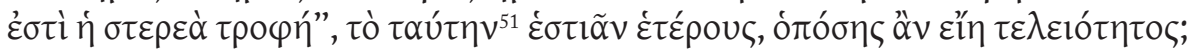

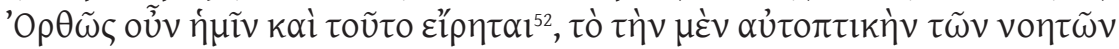

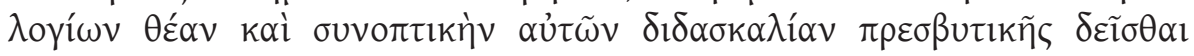

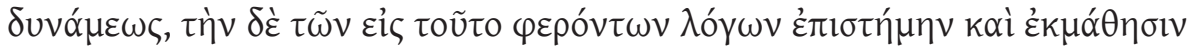

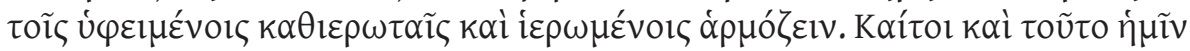

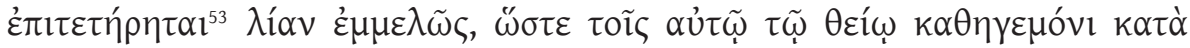

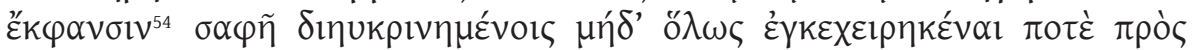

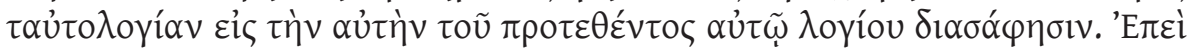

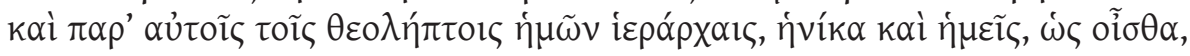

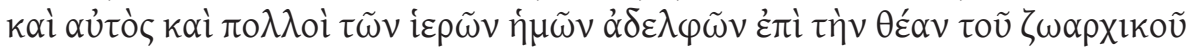

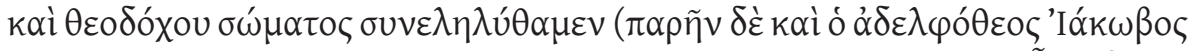

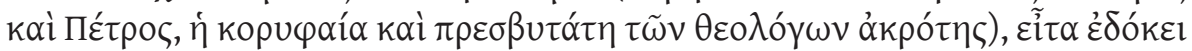

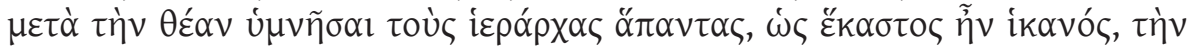

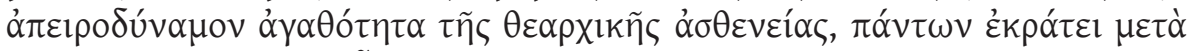

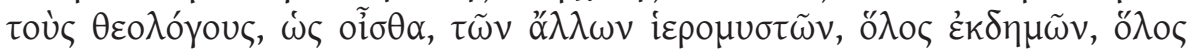

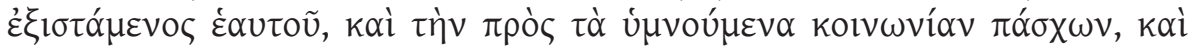

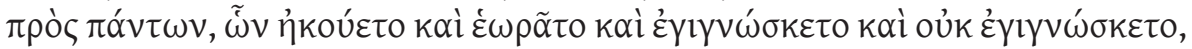

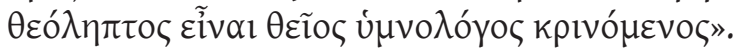

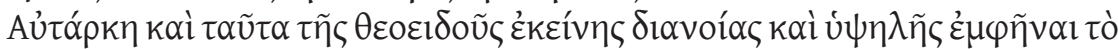

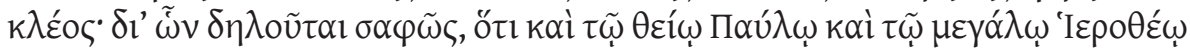

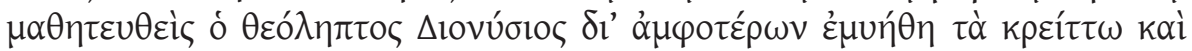

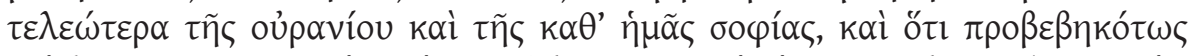

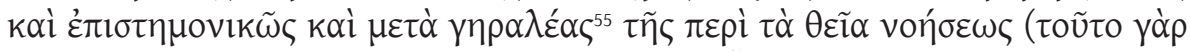

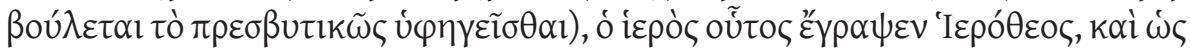

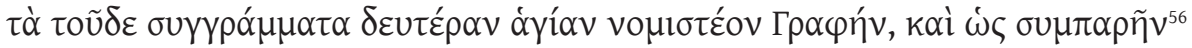

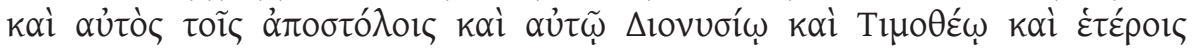

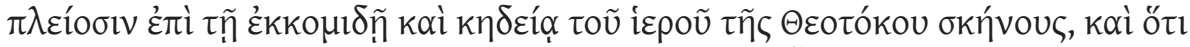

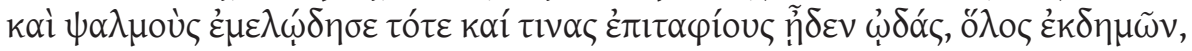

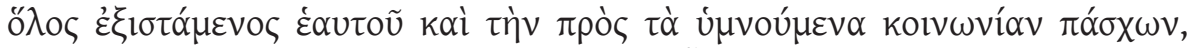

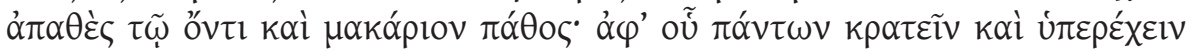

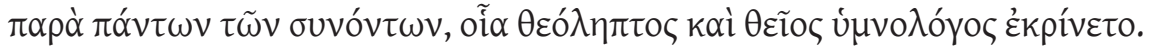




\section{Eĩ $\tau \alpha \dot{\varepsilon} \xi \tilde{\eta} \varsigma^{*}$}

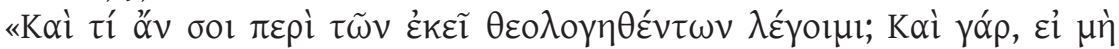

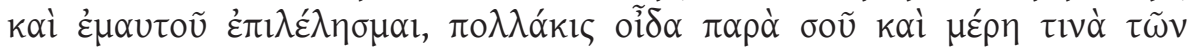

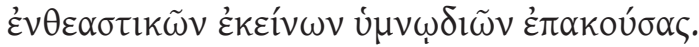

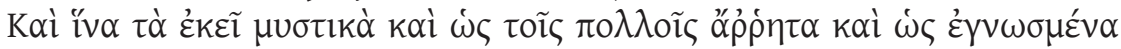

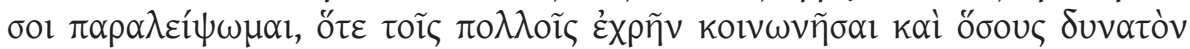

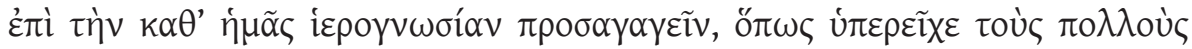

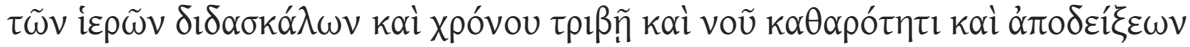

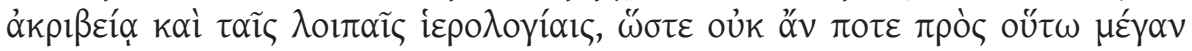

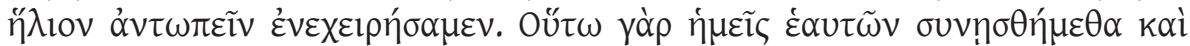
彳̌ $\sigma \mu v$,

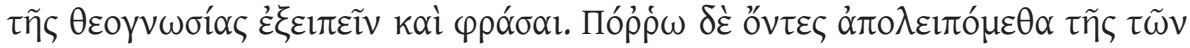

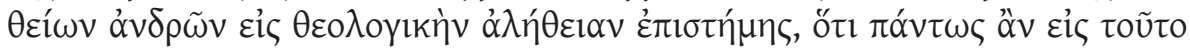

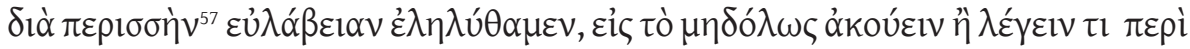

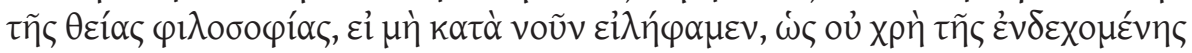

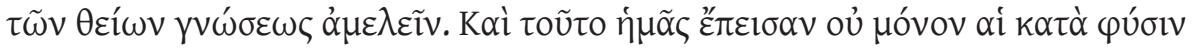

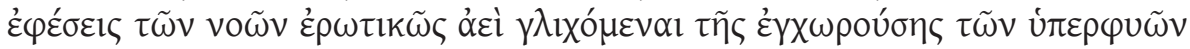

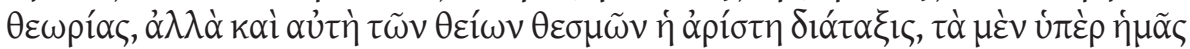

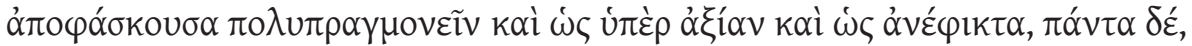

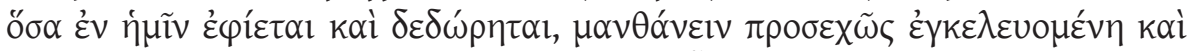

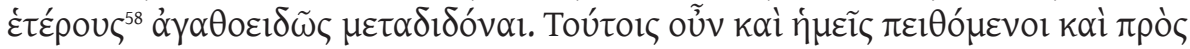

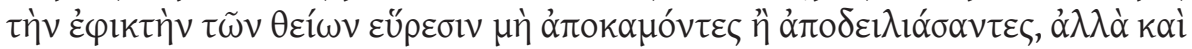

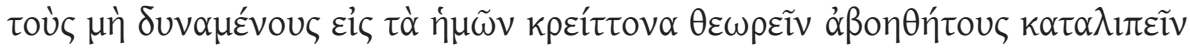

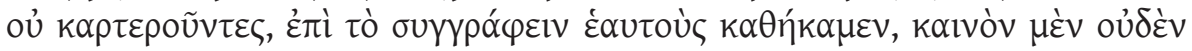

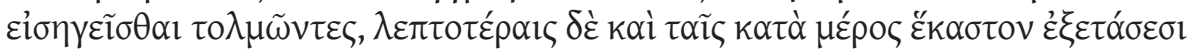

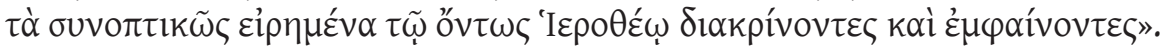

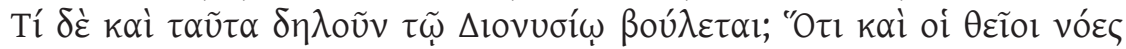

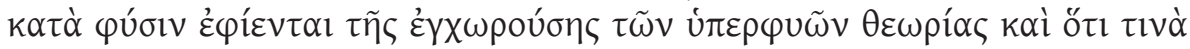

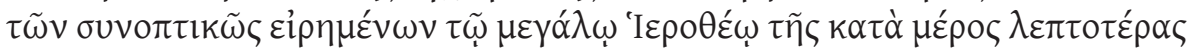

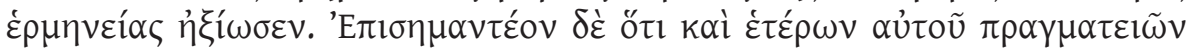

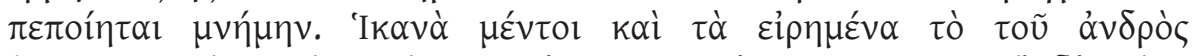

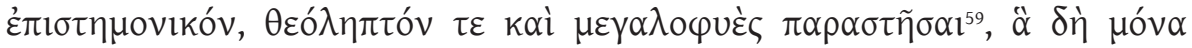

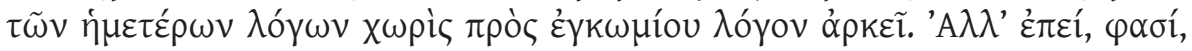

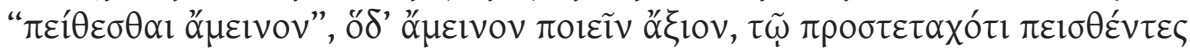

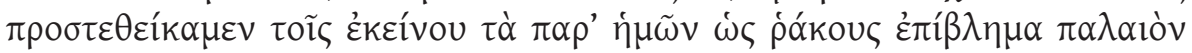

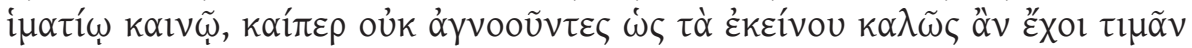

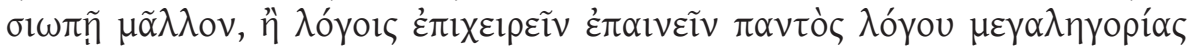

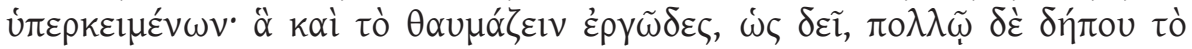

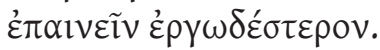

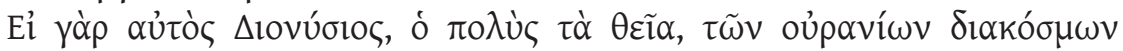

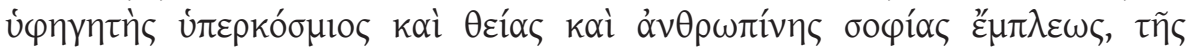




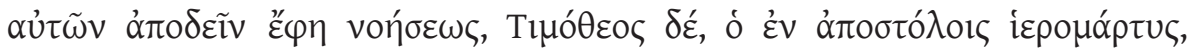

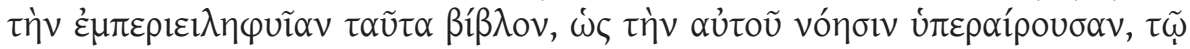

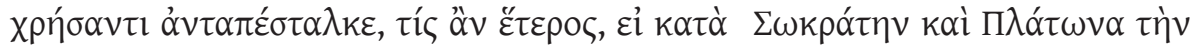

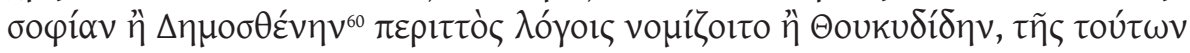

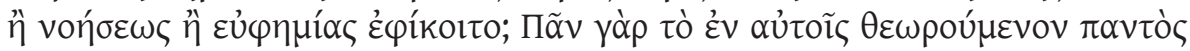

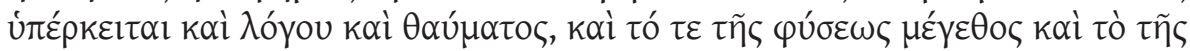

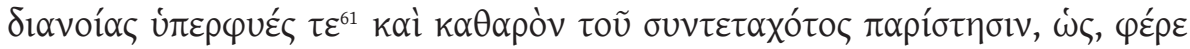

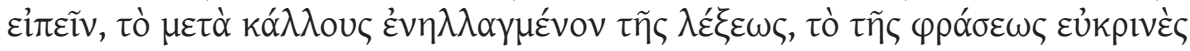

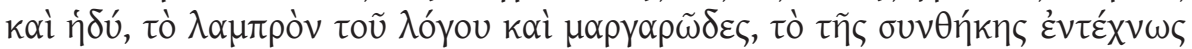

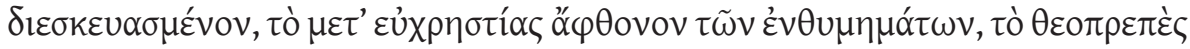

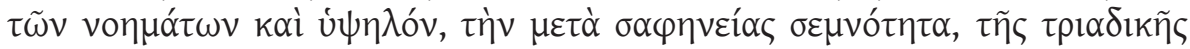

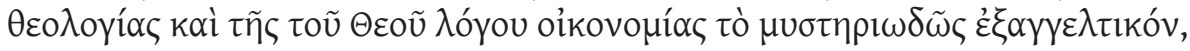

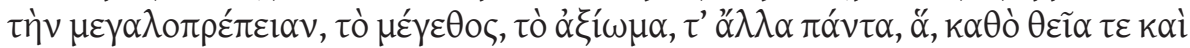

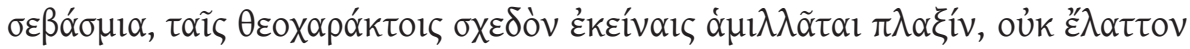

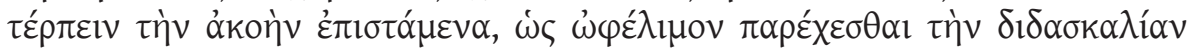

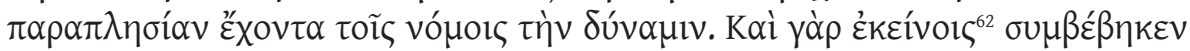

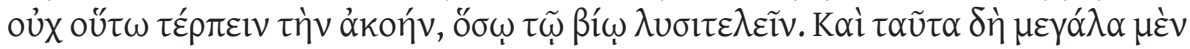

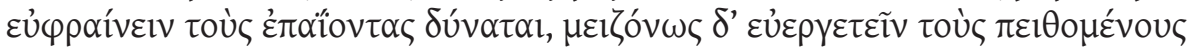

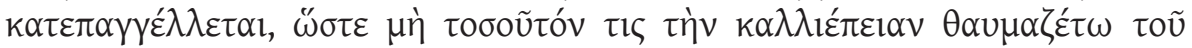

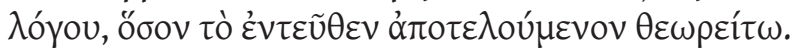

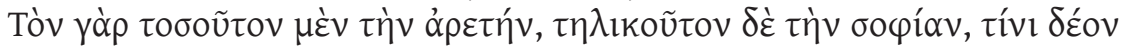

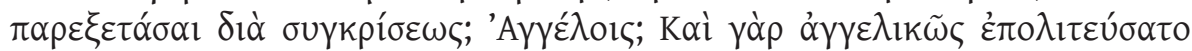

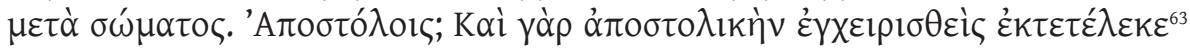

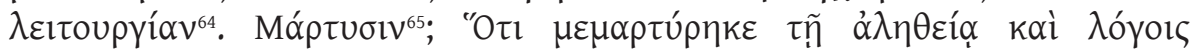

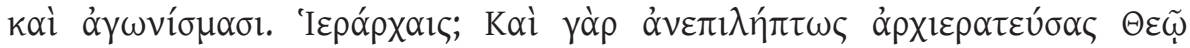

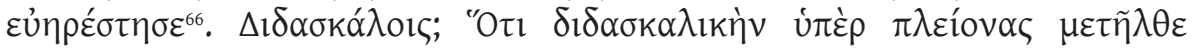

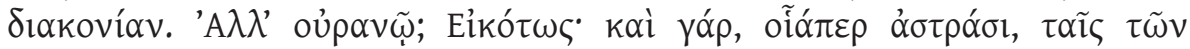

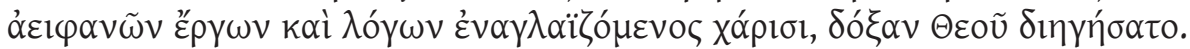

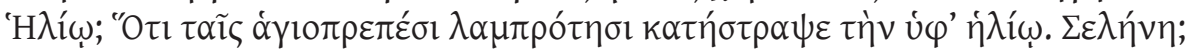

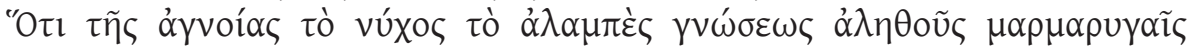

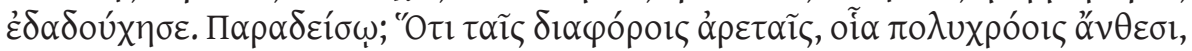

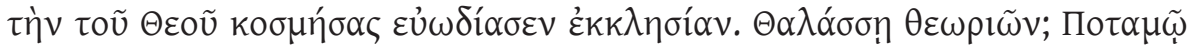

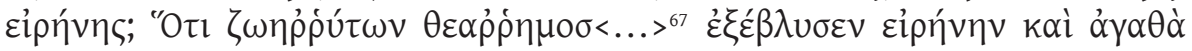

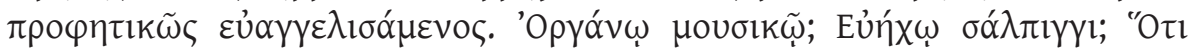

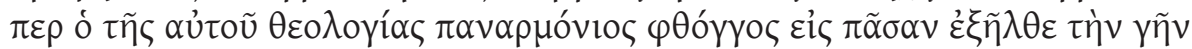

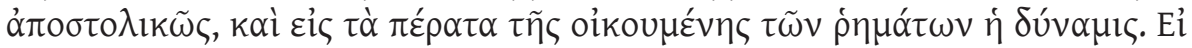

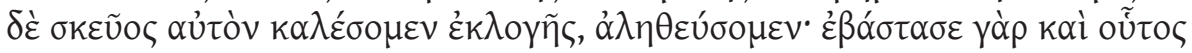

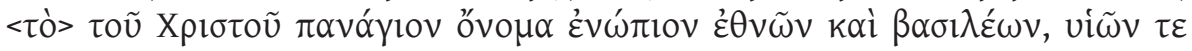

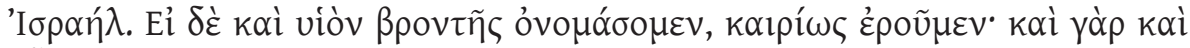

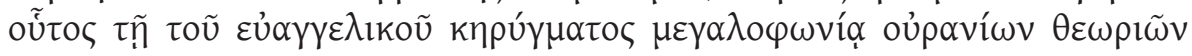

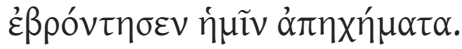




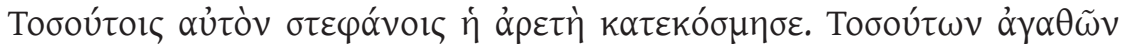

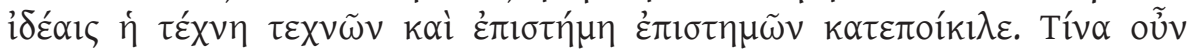

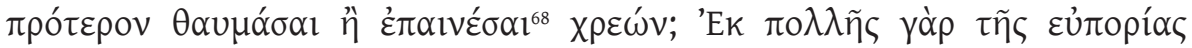

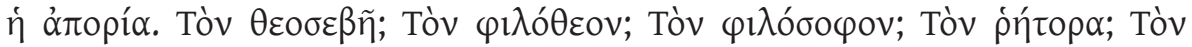

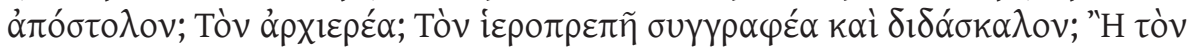

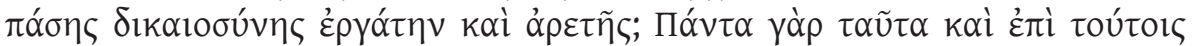

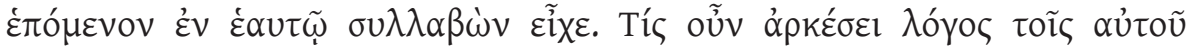

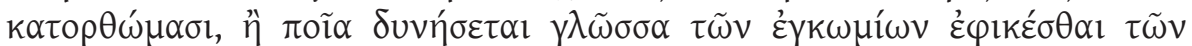

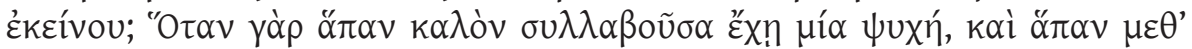

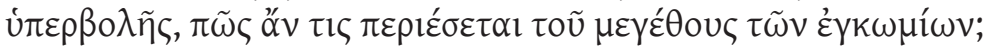

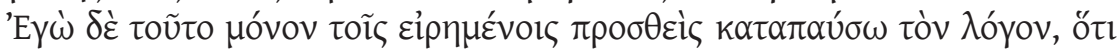

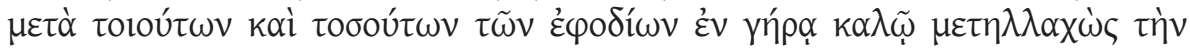

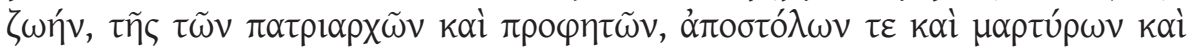

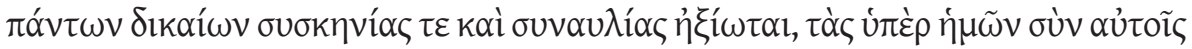

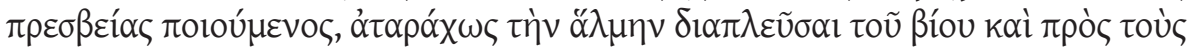

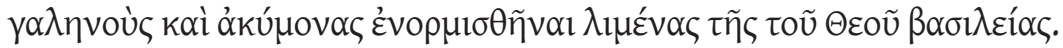

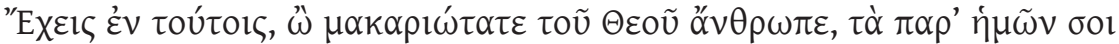

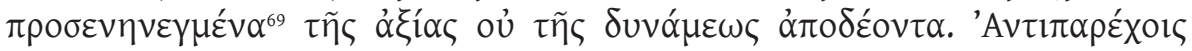

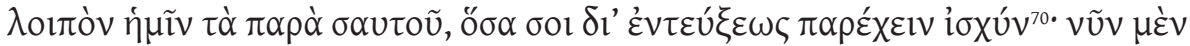

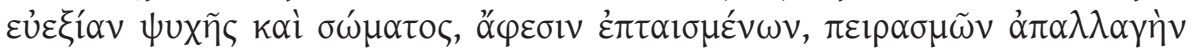

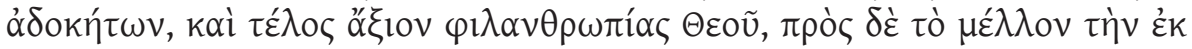

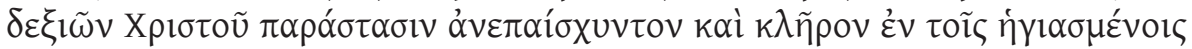

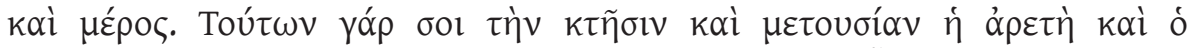

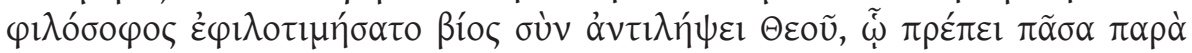

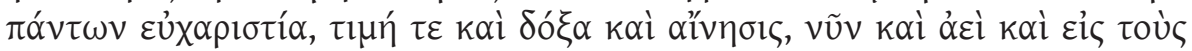

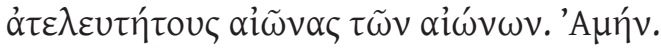




\section{Encomio a San Hieroteo}

Me dispongo a pronunciar un elogio en honor de Hieroteo, hombre sagrado de Dios. Ello es de justicia, no sólo porque él con sus obras devotas se consagró a Dios, hasta el punto de que sus acciones concuerdan sólidamente con su nombre, sino también porque, tras florecer y relacionarse en compañía de los testigos celestiales y servidores del Verbo consagrados a Dios, adquirió la gracia y la preeminencia de éstos, ya que asumió el mismo ministerio que ellos y obtuvo para sí la misma gloria. Por eso es justo que junto con ellos lo ensalcemos y lo honremos. Y puesto que dejó esta vida tras haber vivido en opinión de todos apostólicamente, es de derecho que se le tribute un elogio y una veneración apostólicos; pues es justo que por los mismos esfuerzos se exijan los mismos honores. ¡Por tal deuda qué gran retribución! ¿Por qué esto es así? Porque la recompensa deriva de esta misma merced. Por eso conviene que los amantes de Dios y de sus festividades se reúnan bien dispuestos, celebren la gloria de la virtud de Hieroteo y disfruten de lo bueno que él mismo ha aportado. A esto siempre, pero sobre todo en el día de su festividad, invita a todos con una predicación sublime.

Pues, de dónde y de quiénes provino en un principio, y cómo, tras haber sido criado y educado con pulcritud, y tras alcanzar en fin una edad madura, consiguió tal grado de celebridad que incluso parece adelantar a quienes sobresalen por la grandeza de su fama, esto nadie lo relata. Sin embargo, la palabra es imagen nítida de las obras; es más, la pequeña aportación de la palabra demuestra que éstas corresponden a una contribución sumamente elogiable. En efecto, el modo de vida mira a la palabra, y la palabra, por su parte, es imagen del modo de vida, de la misma manera que lo bien considerado en ambos caracteriza a cada uno por igual.

Que desde su niñez era amante de buenas obras y palabras, eso lo ponen en evidencia los mismos hechos: que inmediatamente desde el primer impulso de vida aunando la nobleza de su modo de vida con la gracia de la naturaleza resultó versado en la ciencia de todas las disciplinas, cuyo conocimiento se ha podido reunir en un tiempo prolongado; que, de otro lado, siendo idóneo para todo tipo de bondad y honestidad, con el fin de hacer avanzar sobre todo lo que ha elegido y perseguido con esfuerzo, puso todo su mayor empeño en ello, despidiéndose de la vida desocupada y del placer y de todo cuanto por naturaleza debilita la fuerza del empeño por acercarse a lo supremo y del amor al trabajo. Y es que no consintió mayor posesión que la de las cosas necesarias para la vida. Prefirió perder de buena manera todo lo superfluo antes que perderse de mala manera a sí mismo con ello; pues para los sensatos es mejor perder que perderse a sí mismo. En efecto, digo que perder es encontrar; pues perder por Dios es encontrar en Dios lo que precisamente está guardado en los cielos atesorado en abundancia; en cambio, lo que no está gobernado en 
el modo dicho, eso se filtra y se pierde en vano, pues quien se comporta con parquedad para así no perder nada, se pierde también él juntamente, como el mismo Salvador insinuó que no hay que ser parco en entregar la misma vida por él (cuánto más en la pérdida de bienes), diciendo: "Quien encontró su alma, la perderá, y quien la perdió, la encontrará”71.

Por eso, en verdad, él aceptó gustosamente la pérdida de lo que poseía y sabiendo que sólo existe una riqueza, la virtud, se aplicó afanosamente y en exclusividad a ella y también a todo lo que la acompaña; efectivamente, desde que de una vez y por siempre se entregó a la virtud y a la ciencia, no aspiró a ellas de forma descuidada, sino muy viril y sinceramente, y antes que a la ciencia a la virtud, mirando a la cual, asintamos en lo dicho sobre cada una de las partes. Por lo tanto, de forma acertada y con provecho ha experimentado el ejercicio incansable de la virtud, luego también la filosofía venerable de la ciencia, comprendiendo perfectamente que los estudios de filosofía exigen primero un modo de vida noble y la bondad de las costumbres; pues "en una alma fraudulenta no entrará la sabiduría”, dice el proverbio ${ }^{72}$. Por ello y antes del estudio de la filosofía pensaba que hay que hacer todo lo que es digno de la filosofía y nada indigno de ella, por no estar permitido. En efecto, del mismo modo que quien va a desposar una doncella decente, rechaza por todos los medios todo lo que es inapropiado a ella y busca y reúne todo lo adecuado, y lo que dice el Señor, "enciende una luz y limpia la casa"73, pero no buscando para encontrar la dracma que ha perdido ${ }^{74}$, sino embelleciendo y adornando la casa donde van a convivir, para que él y su amada disfruten de la vida en común, así el gran Hieroteo por amor a la filosofía digna de ser amada encendió una luz, el intelecto más perspicaz, limpiándolo de toda suciedad, para poder ver y distinguir qué es lo que hay que hacer y qué es lo que hay que evitar. Y según la elección de los mejores preparó un hogar tan digno de aquella honrada y seria mujer, que ella, reconociendo a su propio esposo como un hombre que se distingue por la belleza y hermosura de su alma, lo acogió con alegría y lo recibió con una corona de delicadeza y gracia, y él, por su parte, la abrazó igualmente, y dijo, como es lícito suponer, lo del Cantar de los Cantares: "Eres toda bella, compañera mía, toda bella, y no hay mancha en ti”75, y así con dignidad contrajeron entre ellos el enlace inmaculado y consumaron su unión.

¡Oh, enlace armonizado de Dios! ¡Oh, prudente unión! Pero, ¡cuánto empeño requieren estas cosas para su cumplimiento, y cuánto sudor y esfuerzo empleó el patriarca Jacob para luchar durante largos años contra muchas tentaciones, hasta el punto de casarse con Raquel y Lía, igual que Hieroteo con la acción y la contemplación! Esto no lo desconoce nadie de quienes han sufrido tentaciones, que se creyese él solo capaz de hablar de estas cosas como son; pues quien ha aprendido de lo que sufrió es más fiable para relatarlo. Porque en realidad es admirable y digno de imitación el hecho de que el intelecto no 
se vea arrastrado por los deseos de la carne, aunque ataquen a diario por todos los sentidos, no abra la puerta a pensamientos absurdos e irrefrenables gracias a su gran continencia, cuidado y paciencia, y pueda apagar las llamas interiores de las pasiones con el rocío del temor y del amor a Dios, porque el hombre que se ve arrojado a ellas o bien resulta herido o bien completamente quemado.

Además, perseguir no descuidadamente la formación en todos los saberes, filosofar, y llegar por medio de un ejercicio, un entrenamiento y una práctica más que incansables a la posesión de la ciencia, ¿cuánto esfuerzo y admiración debería colocar cualquiera en ello? En efecto, no es posible por naturaleza alcanzar estas cosas descuidadamente, sino con mucho esfuerzo dentro de una fortaleza mental constante, con afán, con vigilias continuas y otros sufrimientos y fatigas. Pues "con el roce prende el fuego"76; y por lo demás, la raíz de la educación es amarga y requiere mucho trabajo duro y privaciones, igualmente la necesidad y el esfuerzo contienen en sí mismos el origen de la gloria; y "el camino que conduce a la virtud con sudor es duro y empinado", declaran las palabras de los sabios ${ }^{77}$, que adquirieron el conocimiento y la sabiduría de estas cosas con ejercicio asiduo y mucha práctica.

Con todo ello el divino Hieroteo, como el que más, habiendo sido educado, habiendo crecido y llegado a su máximo esplendor, resultó ser el mejor preparado para la vida y la doctrina; en la vida ciertamente como muy pocos y en la doctrina como no muchos, hasta tal punto que en la doctrina destacaba sobre los distinguidos en virtud y en la vida sobre los sobresalientes en los saberes, o bien, en doctrina sobre los que han cultivado los saberes y en la vida sobre los más famosos por su virtud, o finalmente hasta el punto de que en la vida y en la doctrina superaba a los que han florecido en cada una de ellas. Efectivamente, de un lado la doctrina confirmaba la vida ininteligible y de otro la vida era la demostración de la más hermosa doctrina. En resumidas cuentas, reunió seleccionado con sumo celo todo lo bueno que afecta a la vida y a la doctrina, cuyo esfuerzo termina con la vida presente, pero cuya gloria persiste por siempre. ¡Qué gran prudencia e inteligencia requiere el negocio de cambiar lo temporal por lo eterno! Porque como es el modo de vida, así es necesario también que sea el pensamiento; pues de los buenos esfuerzos es glorioso el fruto e inmaculada la raíz de la sabiduría. Así, poniendo la acción como fundamento de la contemplación, ha llegado al más alto grado, que puede alcanzar la naturaleza humana, de la posesión de ambas.

Éstos son los rasgos característicos de Hieroteo antes de su fe perfecta en Cristo. Purificándose a sí mismo de este modo o alcanzando la perfección, se hizo digno de la fe irreprensible, y con la verdad tomó forma antes del renacimiento por medio del bautismo salvador. El libro de los Hechos de los Apóstoles declara cómo el gran Dionisio y junto con él algunos discípulos del divino Pablo llegaron a la verdadera $\mathrm{fe}^{78}$, el famoso Pablo, quien "arebatado al 
tercer cielo y al paraíso oyó palabras inefables que no es concedido al hombre hablar", como él mismo dice ${ }^{79}$. Quizá no sea inoportuno ahora exponer brevemente el mismo sentido de aquellas palabras:

Cómo el divino Pablo tras llevar la buena nueva del Señor Jesús y de la resurrección a los atenienses, supersticiosos en exceso, reuniéndose con algunos epicúreos y estoicos, fue considerado predicador de espíritus malignos extranjeros, por cuya causa se presentó como acusado ante el Areópago al objeto de pagar el castigo por la presunta blasfemia. Él, puesto en pie en el centro de todos, pronunció aquel maravilloso sermón desde el altar dedicado con la inscripción 'A Dios desconocido', introduciendo oportunamente la enseñanza del verdadero conocimiento de Dios, por la que convenció a los más destacados que los demás en la sabiduría entorpecida por Dios. "Los que estaban fijos en él creyeron, entre los cuales estaba también Dionisio, el Areopagita, y otros con él" ${ }^{80}$. Pero yo creo que, antes de aquel sermón inspirado por Dios, Hieroteo ya creía, habiendo sido él discípulo del divino Pablo; porque si hubiese sido entonces cuando él junto con Dionisio creyó y se adhirió a Pablo, el divino Lucas no lo habría pasado por alto sin mencionarlo también por su nombre, siendo él más ilustre y destacando en sabiduría y en virtud. Y es que si fue uno de los Areopagitas, eso yo no puedo decirlo, sino sólo que los más notables entre los atenienses eran quienes juzgaban en el Areópago. Se dice que el tribunal del Areópago fue llamado así porque Poseidón según las antiguas leyendas acusó a Ares por haber matado en el mismo lugar a su propio hijo, Halirrotio. En efecto, juzgaban los Areopagitas sobre casi todos los asuntos y delitos. Entonces Dionisio era entre ellos miembro de la asamblea y dictó de forma insobornable una sentencia certísima sobre Pablo, portador del Espíritu Santo, y tras despedirse de la absurda autoridad de los Areopagitas, conoció a Cristo, el verdadero juez que todo lo observa. Y tras conocerlo inmediatamente quedó infundido de la verdad.

Dionisio junto con Hieroteo se perfecciona en todos los dogmas de la salvación gracias a Pablo, el predicador de la verdad, y ambos se convierten en obispos de aquellos que entonces habían creído. Por lo tanto, Dionisio infundido de Dios recibe su formación metódicamente, como él mismo dice, del gran Hieroteo, por lo cual hay que pensar qué grande en sabiduría era Hieroteo pudiendo hacer ostentación de tal discípulo. En efecto, "si el discípulo nunca es superior al maestro" ${ }^{81}$, y si la amplia erudición de la formación de Dionisio que incluso ha recorrido todo el método científico oculta a casi todos los que han alcanzado toda la doctrina, ¿cómo habrá que considerar a Hieroteo, por cuyo magisterio Dionisio se mostró tal como fue? Pero para que quede más clara la superioridad de la sabiduría sublime de Hieroteo, intentaremos recorrer en nuestro discurso algunas de sus ideas filosóficas como se recogen en el libro del divino Dionisio, de modo que "por el borde se descubra el paño" ${ }^{22}$ y "por 
la garra se conozca al león”83; veamos qué dice, pues, en sus himnos titulados eróticos:

"El amor, ya lo denominemos divino, ya angélico,ya intelectual,ya psíquico, ya físico, deberemos entenderlo como una fuerza unitiva y cohesiva, que de un lado mueve a los entes superiores a ser providentes hacia los inferiores, de otro a los pertenecientes al mismo rango a una común compenetración, y finalmente a los subordinados a que se orienten hacia los mejores y superiores.

Tras haber clasificado los diversos amores provenientes de uno solo, mencionando en orden cuáles son los conocimientos y las facultades de los amores mundanos y ultramundanos, a los que anteceden según el objetivo señalado del discurso los órdenes y clasificaciones de los amores mentales e inteligibles, tras los cuales sobresalen los autointeligibles y divinos a los amores allí realmente hermosos, ya descritos por nosotros convenientemente, ahora de nuevo retomando todos ellos en el amor único y aglutinante y padre de todos, hagamos girar y juntamente reunamos a partir de las muchas que son, concentrándolas primero en dos tipos, todas sus facultades amorosas, sobre las que domina y antecede de qualquier modo la causa irresistible del amor entero más allá de todo, a la que tiende dependiendo de la naturaleza de cada uno de los seres el amor completo procedente de todos los seres.

Ea, pues, dice, reuniendo estas facultades de nuevo en una, expliquemos que existe sólo una simple facultad, la que se mueve espontáneamente hacia cierta mezcla unitiva desde el bien hasta el último de los seres y desde éste de nuevo en orden a través de todos los seres hasta el bien girando por ella y a través de ella y en ella y siempre del mismo modo rotando hacia sí misma" ${ }^{" 4}$.

Y cuanto filosofa ordenadamente sobre el bien y el mal; y que el mal no es el ser ni procede del ser ni está en los seres; y sobre la raza demoníaca y todo lo demás, que pensamos conviene omitir para no alargar el discurso más allá de la medida. Están a la disposición de los que quieran investigar para que así admiren la fuerza del verbo de este hombre, los hallazgos de sus razonamientos, lo claro y exacto de sus opiniones sobre la piedad, y cómo critica lo absurdo de los impíos Maniqueos y de los otros heresiarcas, y, por otra parte, afirma y aclara en la medida de lo posible lo relativo a la triádica monarquía y la inefable providencia del Verbo. Sobre esto dice el mismo Dionisio:

"La divinidad de Jesús, causa última de todo, que mantiene las partes en armonía con el todo, que no es ni parte ni todo, y sin embargo es todo y parte, porque engloba en sí misma el todo absoluto, la parte y el todo, y es superior y anterior, es perfecta en las cosas imperfectas en tanto que perfeccción originaria, e imperfecta en las perfectas en tanto que supera $\mathrm{y}$ antecede la perfección, es forma que da forma a las cosas informes en tanto que forma originaria, informe en las formas en tanto que está sobre la forma, es sustancia que penetra todas las sustancias de forma inmaculada, 
y sobresustancial, elevada sobre todas las sustancias, y que limita todos los principios y órdenes y se asienta sobre todo principio y orden. $Y$ es también medida de los seres y es tiempo y está más allá del tiempo y antes del tiempo. Es plena en las cosas incompletas, más que plena en las completas, es inefable e impronunciable, está por encima del intelecto, de la vida y de la esencia. Posee lo sobrenatural de forma sobrenatural, lo sobreesencial de forma sobreesencial. Por eso, ya que por amor al hombre tomó nuestra naturaleza y en verdad adquirió nuestra esencia y el Dios supremo se hizo hombre (ojalá nos sean propicios los misterios más allá del intelecto y el verbo cantados por nosotros), también en estas condiciones conserva lo sobrenatural y lo sobresustancial, no sólo en cuanto que él sin cambio y sin mezcla ha entrado en comumión con nosotros sin haber sufrido nada en su superplenitud por su impronunciable vaciamiento, sino también porque - lo más extraño de todo lo extraño - en nuestra naturaleza física seguía siendo sobrenatural, en lo que es relativo a nuestra sustancia, sobresustancial, poseyendo en abundancia todo lo nuestro desde nosotros más que nosotros" ${ }^{85}$.

Y qué dice otra vez Dionisio sobre él en el capítulo a Timoteo sobre la oración, la piedad y la escritura teológica:

"Y quizá merezca una disculpa el hecho de que, aunque nuestro famoso maestro Hieroteo compiló maravillosamente los elementos teológicos, nosotros, como si aquéllos no hubiesen sido suficientes, hemos escrito otros y el presente tratado teológico. Ciertamente, si él se hubiese decidido a tratar en orden todos los temas teológicos y hubiese repasado en detalle y en análisis pormenorizados el conjunto de la teología entera, nosotros no habríamos llegado hasta tal punto o de locura o de torpeza como para creer que podemos dedicarnos más clara y divinamente que él a los asuntos teológicos, o para esforzarnos en vano repitiendo las mismas cosas innecesariamente, y además para cometer una injusticia a un maestro y amigo, nosotros que, después de por el divino Pablo, hemos sido instruidos por sus palabras, apropiándonos de su espléndida teoría e interpretación. Pero puesto que él explicó realmente las cosas divinas con verdadera madurez y nos dejó indicadas unas definiciones sucintas que contienen muchas cosas en una, nos encomendó a nosotros, en la medida de lo posible, y a cuantos con nosotros son maestros de las almas neófitas, la tarea de desarrollar e interpretar con palabras apropiadas a nosotros las reflexiones sucintas y unitarias de su genio. $\mathrm{E}$ incluso muchas veces tú mismo nos animaste a ello, y nos has remitido a este libro por su excelencia. Por este motivo nosotros también lo distinguimos como maestro de reflexiones perfectas y maduras para quienes se sitúan por encima de la mayoría, considerándolo como unas segundas Escrituras apropiadas para los ungidos de Dios; en cambio, para quienes están a nuestro nivel nosotros transmitiremos las verdades divinas en la medida de nuestras posibilidades. Así 
pues, si "el alimento sólido es apropiado para los perfectos" ${ }^{86}$, alimentar a otros con éste ¿cuánta perfección revelaría?

En efecto, hemos dicho también con razón que, por una parte, para la visión presencial de las revelaciones intelectuales y para la enseñanza sucinta de las mismas es necesaria una fuerza madurada, y que, por otra, la ciencia y el aprendizaje de las palabras que llevan a ello son apropiados a los que están consagrados y dedicados a Dios en unos niveles inferiores. $Y$ también nos hemos precavido con mucho cuidado de no atrevernos nunca con las cosas que el mismo divino maestro puso de manifiesto en una explicación clara, para no repetirnos en la misma aclaración de la revelación ya expuesta por él. Puesto que entre nuestros mismos jerarcas inspirados por Dios, cuando éste y muchos de nuestros sagrados hermanos coincidieron con nosotros, como bien sabes, en la contemplación del cuerpo principio de vida y receptor de Dios (también estaban presentes Santiago, hermano del Señor, y Pedro, cumbre excelsa y la más venerable de los teólogos), en aquel instante pareció oportuno, tras ver el cuerpo, que todos los jerarcas cantasen un himno, como cada uno supiese, en honor de la bondad todopoderosa de la debilidad del principio divino, él aventajaba, tras los apóstoles, como bien sabes, a todos los otros depositarios de lo sagrado, completamente ausente, completamente fuera de sí, sintiéndose en comunión con lo cantado y considerado por todos los que lo escuchaban y veían y conocían y no conocían, un cantor de himnos divino y de divina inspiración” ${ }^{37}$.

Todo esto que hemos dicho es suficiente para manifestar la fama de este genio elevado y semejante a Dios. Con ello se demuestra claramente que Dionisio, el inspirado por Dios, habiendo sido discípulo del divino Pablo y del gran Hieroteo, se inició por ambos en los misterios de la mejor y más perfecta sabiduría celestial y humana, y también que este sagrado Hieroteo escribió sus obras con gran avance y científicamente y en la madurez de su inteligencia sobre las cosas divinas (pues esto es lo que quiere decir "enseñar con madurez"), que sus obras se han de considerar unas segundas Sagradas Escrituras, y que estaba presente junto a los apóstoles, junto al mismo Dionisio, junto a Timoteo y junto a muchos otros en el traslado y entierro del sagrado cadáver de la Madre de Dios, y que entonces entonó psalmos y cantó unos epitafios completamente ausente, completamente fuera de sí, sintiéndose en comunión con lo cantado, sintiendo una pasión realmente impasible y feliz. Por eso aventajaba a todos y superaba a todos los presentes en las cosas por las que era considerado un cantor de himnos divino y de divina inspiración.

Y continúa seguidamente:

“¿Qué podría decirte sobre las conversaciones teológicas que allí se mantuvieron? Porque, en efecto, si mal no recuerdo, sé que muchas veces he escuchado también de ti ciertas partes de aquellas himnodias de carácter divino.

Y para omitir aquellos misterios por ser inefables para la mayoría pero a 
ti conocidos, cuando convenía comunicar con muchos y atraer a cuantos fuese posible a nuestro conocimiento de lo sagrado, ¡cómo superaba a la mayoría de los sagrados maestros en la experiencia adquirida con el tiempo, en la claridad de su mente, en la exactitud de sus demostraciones y en lo restante de su lenguaje divino, por lo que nunca nos habríamos atrevido a mirar de frente a tan brillante sol! Así pues, somos perfectamente conscientes de nuestras limitaciones y sabemos que no somos capaces ni de comprender suficientemente lo comprensible de las verdades divinas ni de expresar ni pronunciar cuanto se ha dicho del conocimiento de las cosas divinas. Antes al contrario, estamos muy lejos de ello, y nos hemos quedado atrás en el conocimiento de la verdad teológica que poseen los varones divinos, porque de cualquier modo y debido a una excesiva reverencia habríamos llegado al punto de no oir en absoluto ni decir nada sobre la filosofía divina, si no hubiésemos comprendido que no debemos descuidar el conocimiento de lo divino que nosotros podemos conseguir. De ello nos convencieron no sólo las tendencias innatas del intelecto que aspiran siempre con impulso amoroso a la contemplación que le es permitida de lo sobrenatural, sino también esta misma perfectísima disposición de las leyes divinas, que de un lado nos disuade de ocuparnos en la investigación de las cosas que están por encima de nosotros dado que superan nuestra dignidad y porque son inalcanzables, y de otro lado nos insta a aprender inmediatamente todo lo que nos está permitido y se nos ha concedido, y a transmitirlo a los demás bondadosamente. Persuadidos, en efecto, de estas disposiciones, sin renunciar ni desanimarnos en la búsqueda factible de lo divino, pero tampoco consintiendo en dejar sin ayuda a los que no pueden contemplar las cosas que nos superan, nos hemos decidido por escribir, pero sin atrevernos a introducir nada nuevo, sino distinguiendo y explicando lo dicho sucintamente por el verdadero Hieroteo con análisis detallados y particulares para cada parte" 88 .

¿Qué quiere Dionisio mostrar con estas palabras? Que también el intelecto divino aspira a la contemplación que le es permitida de lo sobrenatural y que algunas cosas de las dichas sucintamente por el gran Hieroteo requieren una interpretación detallada por partes. También hay que señalar que ha mencionado otros tratados de Hieroteo. Sin embargo, lo dicho es suficiente para demostrar la capacidad intelectual, la inspiración divina y la genialidad de este hombre, y basta por sí solo sin nuestras palabras para construir un discurso encomiástico. Pero puesto que, según se dice, "lo mejor es obedecer" 89 (y merece la pena hacer lo que es mejor), obedeciendo pues al que ordena, hemos añadido a sus palabras las nuestras como un viejo remiendo de tela desgastada en ropa nueva, aunque no ignoramos que sería preferible honrar en silencio sus cualidades antes que intentar alabarlas con palabras, siendo aquéllas superiores a la magnificencia de cualquier palabra; así pues, admirarlas como conviene es laborioso, pero mucho más laborioso alabarlas. 
Por lo tanto, si el mismo Dionisio, tan poderoso en los conocimientos de Dios, guía transcendente de los órdenes celestes y rebosante de sabiduría divina y humana, reconoció que no alcanzaba a comprender estas cosas, y si por su parte Timoteo, santo mártir entre los apóstoles, devolvió a quien había hecho uso de él el libro que contenía todo ello, por ser superior a su capacidad de comprensión, ¿quién, aunque sea considerado en sabiduría igual a Sócrates y Platón o en elocuencia a Demóstenes o Tucídides, podría alcanzar o la intelección o la fama de sus obras? En efecto, todo lo examinado en ellas supera todo tipo de palabra y de admiración, y pone en evidencia la magnitud de su naturaleza, como lo sobrenatural de su pensamiento, como la pureza de lo escrito, como, por ejemplo, la hermosa alternancia del vocabulario, lo claro y dulce de la frase, el esplendor y los destellos perlados de su verbo, la ornamentación artística de la composición, la abundancia y utilidad de los razonamientos, la dignidad divina y la excelsitud de los pensamientos, la solemnidad con precisión, la divulgación mística de la teología de la Trinidad y de la providencia del Verbo de Dios, la majestuosidad, la grandeza, el valor, y todo lo demás, que, por ser divino y venerable, casi compite con aquellas tablas grabadas por Dios, no menos apto para acariciar el oído que para ofrecer una doctrina provechosa, conteniendo una fuerza semejante a las leyes. Pues con ellas siempre ha cuadrado no tanto acariciar el oído como ser útiles en la vida. Y ciertamente sus obras pueden agradar mucho a los oyentes, pero en mayor medida albergan la promesa de beneficiar a los creyentes; de modo que nadie se admire por la belleza de sus palabras tanto cuanto observe lo conseguido a partir de ellas.

En fin, un hombre tan grande en virtud y tan cumplido en sabiduría, ¿con quién se debe comparar? ¿Con los ángeles? Sí, porque vivió al modo de los ángeles en un cuerpo humano. ¿Con los apóstoles? Sí, porque tras emprender una labor apostólica la condujo a su fin. ¿Con los mártires? Sí, puesto que ha dado testimonio de la verdad con palabras y hechos excelentes. ¿Con los jerarcas? Sí, porque ejerciendo el sumo sacerdocio irreprochablemente complació a Dios. ¿Con los maestros? Sí, puesto que cumplió con el servicio de maestro por encima de la mayoría. ¿Acaso con el cielo? También, y con todo derecho, porque narró la gloria de Dios brillando como las estrellas por la gracia de sus obras y sus palabras, siempre lucientes. ¿Con el sol? Sí, puesto que con su esplendor propio de los santos iluminó la tierra. ¿Con la luna? Sí, puesto que alumbró la oscura noche de la ignorancia con los resplandores del verdadero conocimiento. ¿Con el paraíso? Sí, puesto que perfumó la iglesia de Dios adornándola con distintas virtudes como con flores de muchos colores. ¿Con el mar de la contemplación? ¿Con el río de la paz? Sí, puesto que brotó de la enseñanza divina que fluye en aguas vivificadoras divulgando paz y bienes como los profetas. ¿Con un instrumento musical? ¿Con una trompeta afinada? 
Sí, puesto que el sonido armonizado de su teología se esparció apostólicamente por toda la tierra y el poder de su verbo por los confines de la ecúmene. Por tanto, si lo nombramos objeto de elección, diremos la verdad; en efecto, levantó el santísimo nombre de Cristo ante los pueblos, los reyes y los hijos de Israel. Y si lo nombramos hijo del trueno, hablaremos con propiedad; porque él también con voz alta como en la predicación evangélica hizo tronar para nosotros las resonancias de la contemplación celestial.

Con tantas coronas lo adornó la virtud. Con la apariencia de tantos bienes lo embelleció el arte de las artes y la ciencia de las ciencias. En conclusión, ¿̇a quién habrá que admirar o elogiar primero? Pues de la mucha abundancia nace la perplejidad. ¿Al piadoso? ¿Al amante de Dios? ¿Al filósofo? ¿Al orador? ¿Al apóstol? ¿Al sumo sacerdote? ¿Al venerable escritor y maestro? ¿O al empleado de toda justicia y virtud? En efecto, todo esto y lo que se sigue de esto poseyó conteniéndolo en sí mismo. ¿Qué discurso, pues, será suficiente para sus logros o qué lengua podrá llegar a expresar sus elogios? En fin, cuando una alma posee todo el bien conteniéndolo en sí misma, y todo en abundancia, ¿cómo podría alguien superar la grandeza de los elogios?

Yo, por mi parte, pondré fin al discurso, cuando añada sólo lo siguiente a lo ya dicho, que con tales y tantas provisiones dejó esta vida en buena vejez y se hizo digno de la camaradería y convivencia con los patriarcas y profetas, con los apóstoles y mártires, y con todos los justos intercediendo junto con ellos por nosotros, para que naveguemos sin preocupación por el mar de la vida y arribemos a los puertos tranquilos y en calma del reino de Dios.

Tienes aquí, oh felicísimo hombre de Dios, nuestra ofrenda para ti, inferior a tus méritos pero no a nuestras posibilidades. Así pues, ofrécenos por tu parte todo lo que el poder divino ofrezca con tu intercesión, es decir, en el momento presente bienestar de cuerpo y alma, perdón de los pecados, liberación de tentaciones inesperadas y un fin digno del amor de Dios por los hombres; y en el futuro, un puesto irreprochable a la derecha de Cristo y lote y parte entre los santos. En efecto, con la posesión y comunión de todo esto te colmó generosamente la virtud y la vida filosófica con ayuda de Dios, a quien todos nosotros debemos toda acción de gracias, honor, gloria y alabanza, ahora y siempre y por los siglos infinitos de los siglos. Amén. 


\section{Bibliografía}

Th. Antonopoulou (1998), "Homiletic activity in Constantinople around 900" in M. B. Cunningham - P. Allen, eds, Preacher and audience: Studies in early Christian and Byzantine Homiletics. Leiden/Boston/Koeln, Brill.

H.-G. Beck (1959), Kirche und theologische Literatur im byzantinischen Reich, München.

A. Ehrhard (1937-1952), Überlieferung und Bestand der hagiographischen und homiletischen Literatur der griechischen Kirche von den Anfängen bis zum Ende des 16. Jabrbunderts, I-III, Texte und Untersuchungen zur Geschichte der altchristlichen Literatur 50-52. Leipzig.

D. Escolano (1667), Chronicon Sancti Hierothei, Athenarum primum, postea Secoviensis ecclesiae episcopi. Scriptum ab illmo. et rmo. domino d. Didaco Escolano, episcopo Secoviensi, electo archiepiscopo Granatensi (...), Matriti, in officina Dominici Garcia Moras, anno M. DC. LXVII.

P. P. Fuentes González (1999), "Andrés Darmario, copista en Granada de Alejandro de Afrodisiade”, Bibliothèque d' Humanisme et Renaissance 71 719-728.

F. Halkin, ed. ("31957), Bibliotheca Hagiographica Graeca, vol. I. Bruxelles.

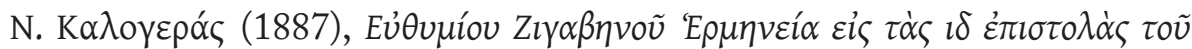

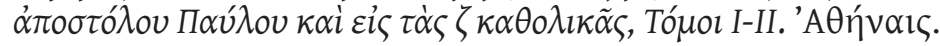

K. Krumbacher ( $\left.{ }^{2} 1897\right)$, Geschichte der byzantinischen Literatur von Justinian bis zum Ende des oströmischen Reiches, vol. I. München.

E. von Leutsch - F. W. Schneidewin, eds (1839), Corpus Paroemiographorum Graecorum, vol. I. Göttingen, Vandenhoeck \& Ruprecht (repr. 1965, Hildesheim, G. Olms).

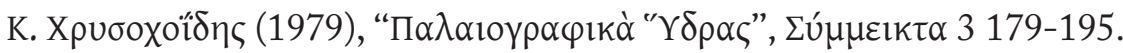


Quiero agradecer a Don Juan Sánchez Ocaña y a la Profesora Dña. María Luisa García Valverde por todas las facilidades que me han ofrecido para la realización de este trabajo.

${ }^{1}$ Krumbacher 1897 84. La opinión de Krumbacher se ha mantenido hasta nuestros días; cf., por ejemplo, Fuentes González 1999722.

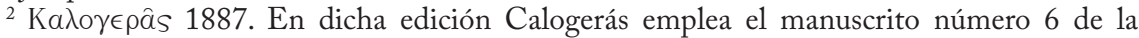
Biblioteca Casanatense, procedente del Monasterium fratrum praedicatorum Sanctae Mariae supra Minervam y datable en el siglo XIV. Pero para la edición del encomio ha usado un manuscrito perteneciente al monasterio Zografou de Athos sin facilitar más indicaciones sobre él. No obstante informa de que existe otro manuscrito del mismo texto en Russia (Mosq. 31). Según Antonopoulou (1998 326), el manuscrito del monasterio Zografou data del siglo XVIII.

${ }^{3}$ Xpuбoxoî́n 1979 179-195. El encomio en este manuscrito parece que está conservado

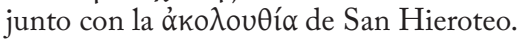

${ }^{4}$ Ehrhard 1952 481, 493: "Unter den vom Metaphrasten unabhängigen späten Panegyriken"

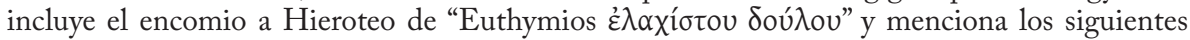

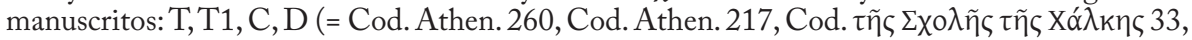
Cod. Athon. Dionys. 168 a); Halkin (1957 248) menciona una "laudatio a. Euthymio".

${ }^{5}$ Beck 1959 615: "Auch die Homilie über den hl. Hierotheos, den Lehrer des PseudoAreopagiten, wird erst in einer Hs. des 18. Jahrhunderts Zigabenos zugewiesen; alle früheren

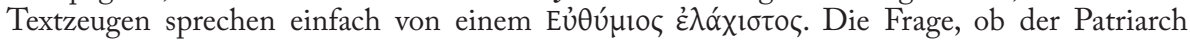
Zigabenos oder ein anderer Euthymios der Verfasser ist, steht offen".

${ }^{6}$ Escolano 1667346 y ss.

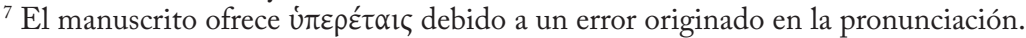

${ }^{8}$ En este lugar debería aparecer el participio $\sigma u v \alpha v \alpha \sigma \tau \rho \alpha \varphi \varepsilon i ́ \varsigma$, porque su significado es más adecuado al contexto.

${ }^{9} \mathrm{El}$ manuscrito ofrece $\tau \imath v \tilde{\omega} v$. Pero aquí se hace necesario el interrogativo.

${ }^{10}$ Es una correctura. En el manuscrito aparece escrito El y en el margen $\grave{\eta}$ manu ipsa.

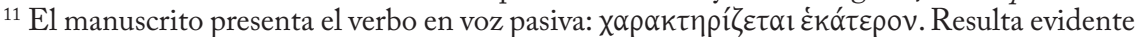

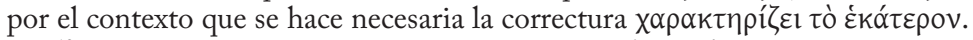

${ }^{12}$ Es una correctura. El manuscrito presenta $\varepsilon \cup ̉ \kappa \lambda \eta \rho i ́ \alpha \varsigma$ por influencia del genitivo anterior, aunque el artículo está correctamente en dativo.

${ }^{13}$ La desinencia $\alpha$ con apariencia de $\alpha \varsigma$ es caractarística del copista.

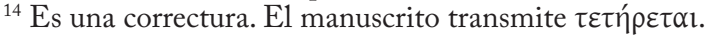

${ }^{15} \mathrm{El}$ manuscrito transmite erróneamente oíkovoúuદvov.

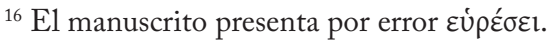

${ }^{17} \mathrm{E} 1$ manuscrito presenta una forma verbal inexistente, $\sigma u \gamma \kappa \alpha \tau \alpha o ́ \mu \varepsilon \theta \alpha$. Es evidente que en el texto del manuscrito uno o varios caracteres han sido borrados antes de la o. La forma más

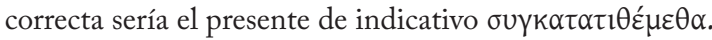

${ }^{18}$ En el margen aparece escrito ớ $\tau$ đó $\xi \omega v$ manu ipsa.

${ }^{19}$ Habitualmente con este sentido se emplea el verbo ớ $\gamma \omega$.

${ }^{20}$ Parece ớ$\sigma \varepsilon v i ́ \sigma \alpha \varsigma$, igual que el siguiente $\pi \varepsilon \rho \iota \varphi \tilde{v} v \alpha$. Cf. nota 13.

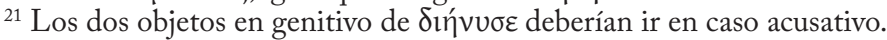

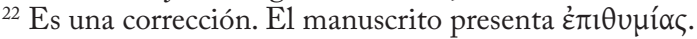

${ }^{23}$ Parece que es un rasgo del estilo del autor emplear el genitivo absoluto, a pesar de que el sujeto del participio está ya presente en el texto mediante otro caso gramatical.

${ }^{24}$ En el manuscrito aparece $\pi \rho \circ \sigma o x \eta \sigma \tau \varepsilon$.

${ }^{25} \mathrm{El}$ manuscrito transmite erróneamente $\kappa \alpha \tau \alpha \pi \rho i ́ \mu \pi \rho \alpha \tau \alpha 1$.

${ }^{26}$ Es corrección del propio copista. En un principio había escrito Ẻ $\gamma \kappa \lambda u ́ k ı$ (en lugar de

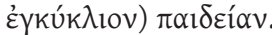

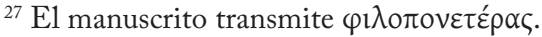

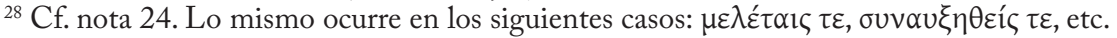

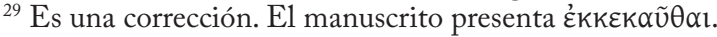

${ }^{30} \mathrm{El}$ manuscrito presenta por error $\mu$ xóxou. 
${ }^{31}$ El manuscrito presenta erróneamente $\mu$ óxov.

${ }^{32}$ Post correctionem. En un principio el copista escribió ả $\sigma \kappa \tilde{\eta} \sigma \alpha l$, y luego corrigió la desinencia sin cambiar el acento perispómeno, que permanece sobre la $\eta$ después de efectuar la corrección.

${ }^{33} \mathrm{El}$ manuscrito presenta ó, pero aquí es necesario el pronombre relativo.

${ }^{34}$ Falta un sustantivo en genitivo, como $\psi \cup x \tilde{n} \varsigma, \delta \iota \alpha v o$ ó $\alpha \zeta$ o algo parecido. En caso contrario, el artículo $\tau \tilde{\eta} \varsigma$ debe corregirse en $\tau o \tilde{v}$.

${ }^{35} \mathrm{El}$ manuscrito transmite erróneamente $\alpha \dot{v} \propto \iota \rho \eta \theta \tilde{\eta} v \alpha 1$.

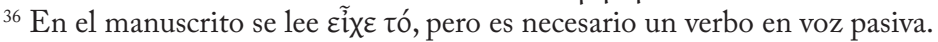

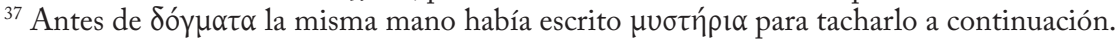

${ }^{38}$ Sería más conveniente el genitivo.

${ }^{39}$ Es una corrección. El manuscrito transmite हैं 1 .

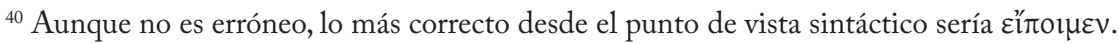

${ }^{41}$ Es una correctura necesaria. El manuscrito presenta erróneamente ǒv.

${ }^{42}$ En este lugar el manuscrito ofrece dos lecturas ő $v \tau \omega \nu$ y ő $v \tau \omega \varsigma$, sin que se pueda discernir cuál es la lectura primera y cuál la corrección del copista. En cualquier caso, parece que lo más acertado es öv $\tau \omega \varsigma$.

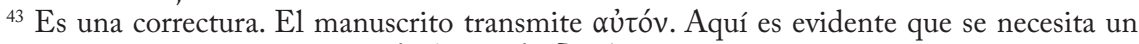

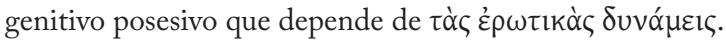

${ }^{44}$ Es una correctura. El manuscrito transmite őv $\tau \omega \varsigma$.

${ }^{45}$ Con esta preposición más adecuado sería emplear el sustantivo épquvov en lugar del infinitivo.

${ }^{46}$ Como es costumbre del copista, $\tau \varepsilon$ enclítico aparece unido en la escritura a la palabra que precede; en estos casos $\zeta$ final de palabra y $\tau$ inicial de la conjunción se escriben con la ligatura de $\sigma \tau$.

${ }^{47} \mathrm{El}$ manuscrito presenta $\pi \rho \omega \tau \varepsilon ́ \lambda \varepsilon l o \varsigma$, que es una formación errónea.

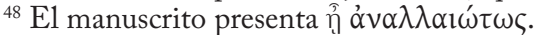

${ }^{49} \mathrm{El}$ manuscrito presenta úũ̃c. Es evidente por el contexto que la correctura se hace necesaria.

${ }^{50}$ Es una correctura. El manuscrito transmite $\mu \nu \eta \theta \tilde{\eta} v \alpha 1$ post correctionem. Con anterioridad a ésta había un espíritu, pues la palabra comenzaba por vocal. El cambio ol- $\mu$ v como error paleográfico es posible. En este caso, el segundo infinitivo es objeto del primero. El sentido y la sintaxis hacen necesaria esta intervención, muy justificada desde el punto de vista paleográfico.

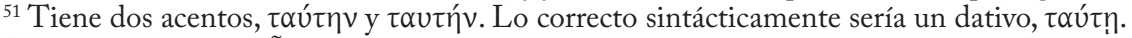

${ }^{52} \mathrm{El}$ copista escribe $\varepsilon \tilde{i} \rho \varepsilon \tau \alpha \mathrm{l}$. Al poner acento circunflejo en la antepenúltima sílaba denota su inexperiencia.

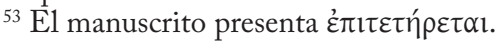

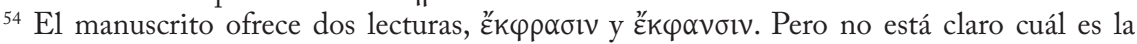
forma primigenia y cuál la corrección.

${ }^{55}$ Post correctionem.

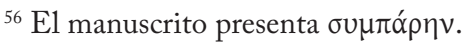

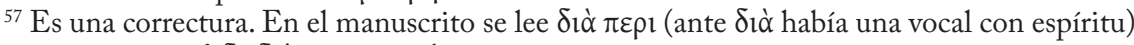

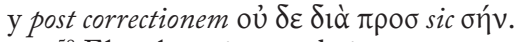

${ }^{58} \mathrm{El}$ verbo exige un dativo.

${ }^{59}$ Es una correctura. El manuscrito presenta una lectura absurda, $\pi \alpha \rho \alpha \gamma \tilde{\eta} \sigma \alpha 1$.

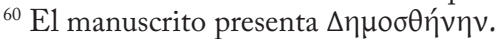

${ }^{61} \mathrm{Cf}$. nota 46.

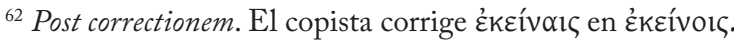

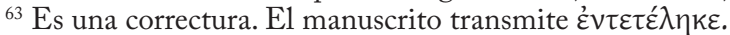

${ }^{64}$ Es una correctura. El manuscrito presenta $\lambda \varepsilon$ Eıouүíav.

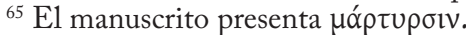

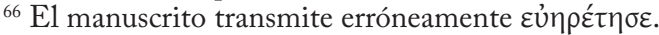

${ }^{67} \mathrm{La}$ laguna del texto se puede suplir con la terminación de genitivo $\theta \varepsilon o \rho \rho \eta \mu o \sigma u ́ v \eta \varsigma$, puesto que el verbo cuyo complemento es este sustantivo, exige genitivo; además hay que corregir $\alpha$ en $o$.

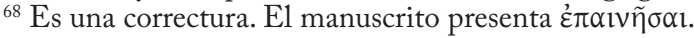


${ }^{69} \mathrm{El}$ manuscrito presenta por error $\pi \rho \circ \sigma \varepsilon v \eta \gamma \mu \varepsilon ́ v \alpha$.

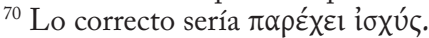

${ }^{71}$ Vulg. Matth. 10.39.

${ }^{72}$ Vulg. Sap. 1.4.

${ }^{73}$ Vulg. Luc. 15.8.

${ }^{74} \mathrm{El}$ texto del encomio, tras citar las palabras de Lucas, sigue haciendo referencia a ellas, pero cambiando el sentido original; por eso cita también la dracma perdida del texto bíblico.

${ }^{75}$ Vulg. Cant. 4.7.

${ }^{76}$ Vulg. Psalm. 39.4.

${ }^{77}$ Hes. Op. 290 y ss.

${ }^{78}$ Vulg. Act. 17.34.

${ }^{79}$ Vulg. II Cor. 12.4.

${ }^{80}$ Vulg. Act. 17.34.

${ }^{81}$ Vulg. Matth. 10.24; Luc. 6.40.

${ }^{82}$ Diogenian. 5.15.3 (Leutsch - Schneidewin 1839).

${ }^{83}$ Plutarch. Mor. 410c (De defectu oraculorum); Luc. Herm. 54.

${ }^{84}$ Dion. Ar. Div. nom. 4.14 y ss. (PG III 713).

${ }^{85}$ Dion. Ar. Div. nom. 2.10 (PG III 648-649).

${ }^{86}$ Vulg. Hebr. 5.14.

${ }^{87}$ Dion. Ar. Div. nom. 3.2 (PG III 681).

${ }^{88}$ Dion. Ar. Div. nom. 3.2-3 (PG III 684).

${ }^{89}$ Hom. Il. 1.274. 


\title{
REFLEXIONES SOBRE LAS SAGAS MÍTICAS EN LA TRAGEDIA GRIEGA
}

\author{
Héctor Felipe Pastor Andrés- Mauricio Pastor Muñoz \\ Universidad de Granada
}

El objetivo principal de este trabajo es analizar algunos aspectos de las sagas mitológicas griegas que aparecen representadas en las principales obras dramáticas del teatro griego ${ }^{1}$. Aproximarse a la Mitología griega supone acercarse a una verdad y a una realidad individual, social y psicológica de un pueblo concreto en un momento determinado de la Historia ${ }^{2}$. Más aún, la Mitología, esa estructura continente de una realidad velada por símbolos, supone para el teatro un humus sobre el que éste crece y del cual se nutre; un bumus rico y fértil que hace posible el crecimiento y la permanencia de un teatro grandioso, que perdura hasta nuestros días, y que sigue conteniendo referentes que son tan útiles hoy como ayer, y que lo seguirán siendo: los arquetipos dramáticos occidentales más primitivos, no marcados, extraídos directamente del sistema mítico de la Grecia Antigua. En este trabajo analizamos de forma narrada las sagas míticas de las principales tragedias e intentamos ver cómo se relacionan entre ellas, junto con el tratamiento que reciben por parte del tragodós ${ }^{3}$.

\section{Saga de los Átridas.-}

Llamamos "saga de los átridas" la que se refiere a los hechos que acaecieron antes y después de la guerra de Troya, es decir, al "ciclo troyano". Menelao y Agamenón eran los principales wanáktes ${ }^{4}$ de la expedición griega hacia la ciudad en la costa del Asia Menor y los hechos que las tragedias relatan son precisamente concernientes a ambos caudillos. Esta saga recibe el nombre de Átrida por ser descendiente de Atreo, aunque también podría recibir el nombre de Pelópida o Tantálida, como puede verse en el esquema genealógico simplificado que incluimos más abajo. Por otra parte, también tenemos la familia troyana cuyo aciago destino se une a la familia griega; a los descendientes de esta familia podríamos denominarlos Priámidas ${ }^{5}$, Laomedóntidas, Ílidas 6 , Trósidas ${ }^{7}$, Erictónidas y, su epónimo más antiguo y conocido, Dardánidas. Hemos desarrollado los abolorios de ambos pueblos para mostrar que, a pesar de sus enemistades y desavenencias, los dos comparten un origen común; el padre de los dioses, Zeus. 
Héctor Felipe Pastor Andrés- Mauricio Pastor Muñoz

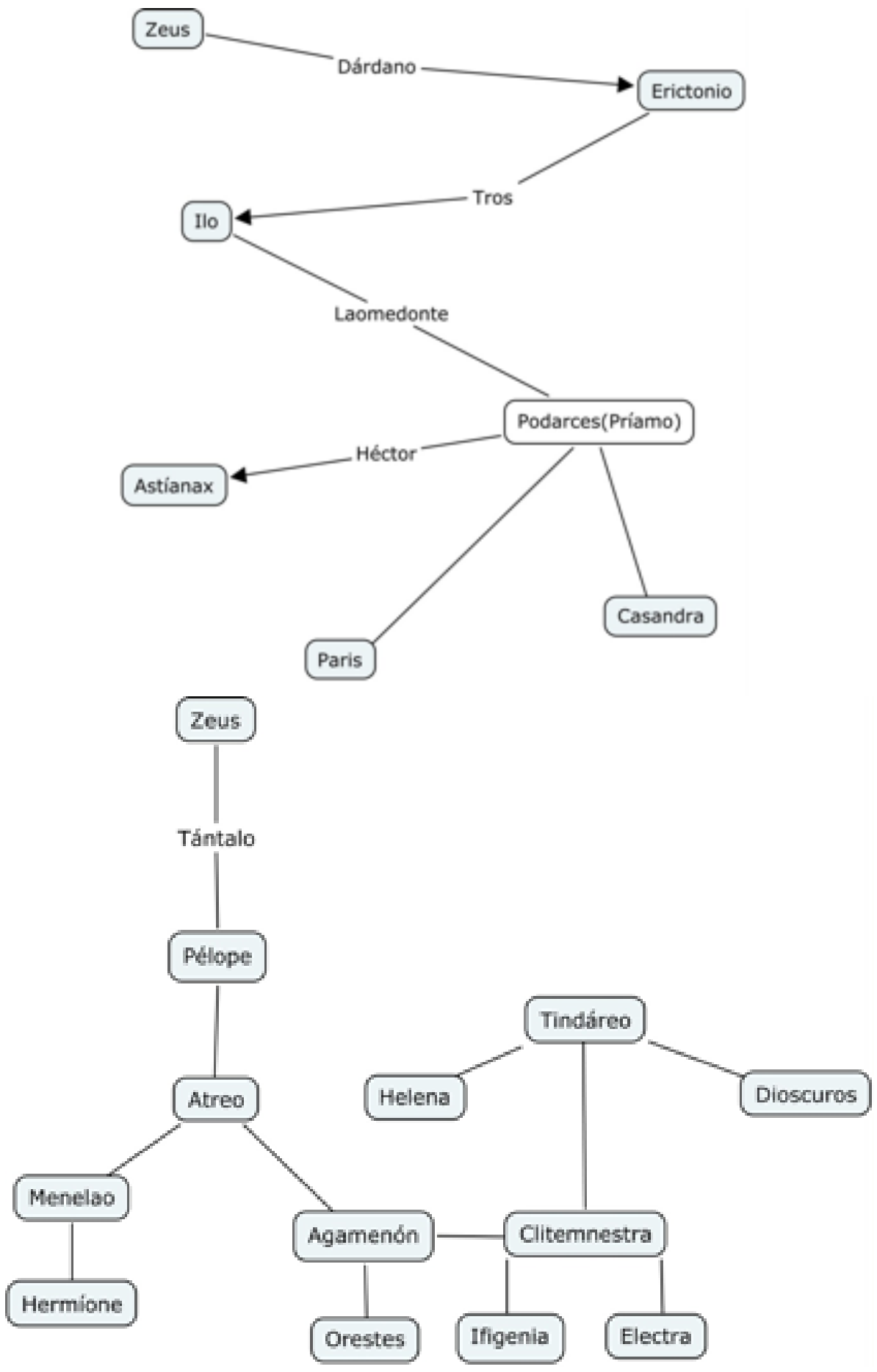


Pero vayamos ya, sin más preámbulos, al tratamiento que recibe esta saga en las tragedias de Esquilo, Sófocles y Eurípides ${ }^{8}$.

La saga comienza con el rapto de Helena ${ }^{9}$ por parte de Paris en la misma corte del rey Menelao, en Esparta.El hermano de Menelao, Agamenón persuade a muchos caudillos griegos para iniciar una expedición hacia Troya con el fin de vengarse del pueblo troyano por su ignominia. Así pues, convencidos cada uno por la razón que más le convenía, antes de zarpar, se concentran en la bahía de Áulide donde el adivino Calcante, hijo de Téstor, predice que hay que sacrificar a una hija de Agamenón, en concreto a Ifigenia, para que sople viento favorable y ningún obstáculo sobrenatural se oponga a la destrucción de Troya. Agamenón en primera instancia acepta este oráculo aunque con reticencia y manda buscar engañosamente a Ifigenia para que casara con Aquiles y, más tarde, se arrepiente y deshecha la idea del sacrificio. Después de una serie de discusiones entre Menelao, Agamenón y Clitemnestra ${ }^{10}$, Ifigenia decide que, voluntariamente, se sacrificará por el bien del ejército griego y su favorable trayectoria.

Tras el sacrificio, en el que, en última instancia, desapareció Ifigenia de las manos del verdugo apareciendo en su lugar una cierva degollada, comenzó la empresa hacia Ilión prolongándose durante diez años. El último año de la guerra es el que narra la Ilíada y, a su vez, es el que se trata someramente en las tragedias griegas.

Durante el transcurso de la guerra de Troya en su año postrero, justo antes de que Patroclo tomara las armas de Aquiles y embistiera contra los troyanos (la llamada Patroclea), los griegos enviaron a Odiseo y a Diomedes para que clandestinamente dieran muerte a Héctor Priámida. Mas los troyanos tramaron enviar un soldado para que espiara los movimientos de los griegos, Dolón, quien, al encontrarse con los dos héroes griegos, les describió la situación del rey tracio Reso y les aconsejó que éste se encontraba sin ningún guardia, totalmente indefenso él y su ejército. Una vez decapitado el delator por el acero del Tidida, acudieron ambos héroes al campamento de Reso asesinando a todos cuantos encontraron durmiendo y regresaron al campamento griego con una victoria sin bajas. Acontecimientos que se relatan en la tragedia Reso, de Eurípides.

Tras la muerte de Patroclo, vendría la de Héctor a manos de Aquiles, quien también moriría más tarde al ser herido en el talón ${ }^{11}$. Su madre Tetis decidió entregar las armas del mismo al guerrero más valiente y, pretendiéndolas Odiseo y Áyax, fueron concedidas al primero de ellos. Áyax decidió vengarse, pero Atenea lo enloqueció por lo que se lanzó con la espada contra un rebaño de ovejas creyendo que eran los griegos, causando un gran exterminio entre ellas. A dos de las que quedaban vivas las encadenó y azotó tomándolas por Agamenón y Odiseo. Cuando recobró el juicio, avergonzado por su deshonor, 
clavando en tierra su espada se arrojó sobre ella. Regaló su famoso escudo a su hijo Eurísaces, y dejó a Teucro el encargo de que lo enterrase y pide que lo venguen las Erinias y sea transportado a los campos de asfódelos ${ }^{12}$. Esta tragedia es contada por Sófocles en su Ayax.

También narra Sófocles el siguiente episodio acaecido antes de la conclusión de la guerra de Troya, y lo hace en su Filoctetes. Este héroe fue abandonado en la isla de Lemnos antes del inicio de la guerra, pues le había mordido una serpiente y su herida desprendía un fétido y nauseabundo olor. Tras diez años de guerra, cuando Odiseo capturó en una emboscada a Heleno y éste profetizó que Troya sería conquistada si los griegos contaban con Filoctetes y su arco y con Neoptólemo, Diomedes fue a buscar a Filoctetes a Lemnos. Éste regresó; fue curado por Macaón y mató en un duelo personal a Paris. Por su parte, Odiseo trajo a Neoptólemo de la isla de Esciros y le entregó las armas de Aquiles, su padre, que él había conseguido en el juicio de las armas frente a Áyax.

Los siguientes hechos que son contados en las tragedias son ya posteriores al culmen de la guerra troyana, y tienen relación con el reparto del botín por parte de los griegos. Dentro del botín se encuentran las esclavas y los griegos pretenden el siguiente reparto: Casandra quedaría asignada para Agamenón Atrida, Andrómaca, la mujer de Héctor, para el hijo de Aquiles, Neoptólemo, y Hécuba, la madre de Héctor y Paris, para el mismo Odiseo, suerte, según ella, la más desgraciada de todas. Odiseo decreta que es precisa la muerte de Astíanax Hectórida, asesinato que comete Taltibio junto con sus guardias, y Casandra predice la muerte funesta de Agamenón y de ella misma. Por su parte, Menelao acude furioso con virulentas intenciones a Helena que, defendiéndose, lo convence para que aplace sus vituperios hasta que se encuentren en Argos. Todo esto acontece durante el mismo incendio de la ciudad tal y como compuso Eurípides en Las Troyanas.

Mientras que la flota griega espera en la costa troyana un viento favorable para zarpar, Hécuba ${ }^{13}$ presencia la aparición de la sombra de su hijo Polidoro, al que supuestamente había puesto a salvo con el oro y el rey Poliméstor, pero quien, sin embargo, lo mató ${ }^{14}$, haciendo desgraciada a Hécuba. A su vez, la sombra de Aquiles exige el sacrificio de su otra hija, Políxena, que es conducida por Taltibio para ser sacrificada, cosa que hizo. Más tarde se encontró el cuerpo de Polidoro en el agua y Hécuba pide a Agamenón la venganza contra Poliméstor. Éste accede y Hécuba asesina a los dos hijos de Poliméstor y a él lo ciega, concluyendo así su venganza personal. Así lo cuenta Eurípides en su Hécuba.

El Cíclope es un drama satírico de Eurípides en el que se relata el encuentro del ciclope Polifemo con Odiseo y todos sus compañeros de viaje durante su regreso a Ítaca. La acción se desarrolla en Sicilia, en la cueva del ciclope Polifemo, 
quien intenta devorar a los navegantes pero que es engañado astutamente por Odiseo que lo emborracha y deja ciego, huyendo posteriormente enganchados bajo las patas de las ovejas. Este drama no entronca directamente con las demás historias que nos quedan de las tragedias, pero cronológicamente se debería situar en este punto ya que la acción se desarrolla en el viaje de vuelta de Troya.

El drama concerniente a Agamenón, cuya muerte ha sido profetizada en dos tragedias (Las Troyanas y Hécuba), comienza en la siguiente obra de Esquilo: Agamenón ${ }^{15}$. Esta obra nos muestra cómo Clitemnestra celebra el triunfo de los argivos sobre Troya y cómo, engañando a Agamenón, le hace entrar por el umbral de la puerta dirigido a su propia muerte. Mientras, Casandra está inmóvil conociendo su oscuro futuro y Agamenón grita por la herida que le ha infligido la propia Clitemnestra que asume la autoría del crimen y se retira a palacio con su amante Egisto, el hijo de Tiestes y de la propia hija de éste, Pelopia.

Esta familia ya tenía una mancha que venía arrastrando y trayéndole la desgracia. Desde que Tántalo matara a su hijo Pélope y lo sirviera como comida a los dioses condenó a todos sus descendientes. La tragedia no acaba con la muerte de Agamenón, sino que en Las Coéforas Esquilo otorga la venganza a los hijos de Agamenón, Orestes y Electra que, con la ayuda de Pílades, ejecutan, en primer lugar, a Egisto y, en segundo lugar, a Clitemnestra, ante la cual duda Orestes pero, con la exhortación de Pílades, la mata cumpliendo el mandato de Apolo. Luego será purificado por Apolo evitando así ser perseguido por las Erinias.

La misma situación se relata en la Electra ${ }^{16}$ de Sófocles, en la que, empero, existe la diferencia del personaje de Crisótemis, otra hija de Agamenón y Clitemnestra; además, el oráculo de Delfos en esta obra no sanciona el matricidio, Orestes no duda en acabar con Clitemnestra y con Egisto, matando primero a su madre, no como en Las Coéforas y en Electra de Eurípides y, por último, en Sófocles las Erinias, que deberían perseguir a Orestes por el matricidio, no juegan papel alguno en la obra.

Tal y como es de esperar, en la Electra de Eurípides también se cuenta la venganza de los hijos contra Egisto y Clitemnestra. Eurípides pretende racionalizar la situación e innovar un poco en el argumento. Coloca a la propia Electra en un campo de Argos, casada sólo formalmente con un labrador que respeta su virginidad. $\mathrm{El}$ anciano que había educado a Orestes lo reconoce y, mientras Egisto prepara una fiesta en honor de las Ninfas, fue asesinado por Orestes (con la colaboración de Pílades, que no participa con la palabra, sino que es un personaje mudo). Clitemnestra es engañada para que fuera a la casa de Electra y, allí mismo, la matan. Los Dioscuros, que aparecen sólo en la versión de Eurípides, designan que Electra se case con Pílades, que Orestes, perseguido por las Erinias, vaya a Atenas a que se le absuelva y que Egisto sea sepultado en Argos y Clitemnestra en Nauplio. 
Mientras estas cosas se daban en Argos, en Egipto se sitúa también la Helena de Eurípides. Helena se halla sola en la corte de Proteo que muere, dejando el reino a su hijo Teoclímeno. Éste ambiciona casarse con Helena quien se entera por boca de Teucro de la muerte de Menelao y de todos los jefes griegos, cosa que le impulsa a suicidarse hasta que decide ir a la profetisa Teónoe, hija de Proteo. La profetisa revela que Menelao sigue vivo y se encuentra muy cerca, además, Menelao creía que quien iba con él en su barco cuando naufragó era su esposa Helena, sin embargo, se trataba de un simulacro que había creado Hera. Tienen un inesperado y tierno reencuentro, pero deben evitar que Teoclímeno, por despecho, asesine a Menelao y celebre nupcias con Helena, así que celebran unas falsas honras fúnebres por los griegos muertos en el naufragio y se apoderan de un barco de Teoclímeno con el que logran escapar. Teoclímeno pretende arremeter contra su hermana Teónoe pero es persuadido a la calma por los Dioscuros que anuncian que la Tindárida será diosa cuando muera.

Continúan las cosas en la Grecia continental un tanto tensas tras la venganza de los hijos de Agamenón, pues la asamblea está planteándose la muerte de los matricidas. Sólo les queda la esperanza de la llegada de Menelao y Helena, que acuden allí para llevarse a su hija Hermíone. Orestes, perseguido por las Erinias, es el que suplica la salvación a Menealo, pero, a su vez, Tindáreo desea su castigo por haber asesinado a su hija. Menelao lo calma diciendo que aplacará la ira de Tindáreo pero, poco más tarde, un mensajero lleva consigo la noticia de la muerte de los culpables. Al recibir la noticia, Orestes se enfada y pretende vengarse de Menelao por lo que se dirigen ély Pílades a matar a Helena. Cuando Menelao va contra ellos lo amenazan con degollar a Hermíone, la hija de Menelao, pero ya, rodeados de argivos por todos lados, comienzan a prender fuego al palacio. Desciende Febo Apolo del cielo llevándose y divinizando a Helena, Orestes será absuelto por el Areópago y reinará Argos casado con Hermíone, mientras que Electra se casará con Pílades. Toda esta acción se narra con detalle en la tragedia Orestes, de Eurípides.

La absolución, que acabamos de comentar, se encuentra en Las Euménides de Esquilo, obra que comienza en el santuario de Apolo en Delfos, un dios que defiende siempre a Orestes y lo envía a Atenas para hacerlo inocente. En la obra aparece continuamente el espectro de Clitemnestra pidiendo venganza a las Erinias quienes rodean a Orestes. Aparece la ojizarca Atenea y deja a Orestes defenderse e indica que es peor romper el vínculo del matrimonio que el de la consanguinidad, por lo que, vengando a su padre, ha actuado píamente. Orestes es juzgado y absuelto gracias al voto de Atenea y convierten a las diosas de la venganza en benignas, Euménides, honrándolas de ahora en adelante en Atenas.

En su Ifigenia entre los Tauros, Eurípides cuenta en boca de Ifigenia que, 
cuando iba a ser sacrificada en Áulide, la diosa Artemisa la salvó y la llevó entre los tauros, haciéndola sacerdotisa de su propio culto que exige la muerte ritual de todo griego que llegue hasta allí. Orestes y Pílades son enviados por Apolo a dicho país para robar la estatua de Artemisa y llevarla a Atenas. Son descubiertos y junto con Ifigenia traman un ardid para escapar de la muerte que les estaba asignada solamente por provenir de Grecia. Por tanto, tal y como ocurre en Helena, que engañan al rey extranjero, en este caso engañan a Toante, huyendo con un barco los tres. Éste intenta alcanzar a los fugitivos hasta que Atenea desciende de las alturas celestiales y le arenga para que deponga su cólera.

La última tragedia que concierne a la saga de los Atridas y, más exactamente, al ciclo épico troyano, es la Andrómaca de Eurípides. En ésta, Andrómaca, la que fuera mujer de Héctor, es tomada como esposa por Neoptólemo ${ }^{17}$, el hijo de Aquiles. Tienen un hijo, pero éste, el priamicida ${ }^{18}$, toma como segunda esposa a Hermíone, hija de Menelao, que convence a su padre para que asesine a Andrómaca. Menelao ataca a Andrómaca y a su hijo y, en el momento en que iba a matarlos, llega Peleo y hace liberar a ambos, acusando a Menelao de pérfido y truculento. Hermíone, tras su fallido intento, pretende suicidarse pero Orestes la salva y se la lleva a Delfos donde barrunta la muerte de Neoptólemo. Mediante calumnias consigue su propósito y la diosa Tetis acude para consolar a Peleo. El Pelida Neoptólemo es enterrado en Delfos y Andrómaca es mandada a la tierra de los molosos donde se casa con Heleno.

Estas son las 16 tragedias que conforman el ciclo troyano, 10 de Eurípides, 3 de Esquilo y 3 de Sófocles. Cuatro de ellas transcurren en Troya (Reso, Ayante, Las Troyanas y Hécuba), 4 en Argos (Agamenón, Las Coéforas, Electra de Eurípides y Orestes), Filoctetes en Lemnos, El Cíclope en Sicilia, Electra de Sófocles en Micenas ${ }^{19}$, Helena en Egipto, Las Euménides primero en Delfos y luego en Atenas y Andrómaca primero en Ptía y luego en Delfos. Las Ifigenias cada una en donde menta el propio nombre de la tragedia, Áulide y Táuride.

\section{Saga de los Labdácidas.-}

Como observamos en el esquema, Zeus tuvo un hijo con Ío, éste se llamaba Épafo que, junto con Menfis, tuvieron a Libia. Poseidón mantuvo relaciones con esta Libia y dio a luz a Belo, Lálage y Agenor, considerado también el héroe epónimo del ciclo tebano, pues fue el padre de Cadmo, fundador de Tebas. Este Cadmo tuvo junto con Harmonía a Ágave de la que nació Penteo, protagonista de la primera tragedia, Las Bacantes. Sin embargo, no desciende Edipo de las entrañas de Ágave sino de su hermano Polidoro que, con Licteis, tuvieron a Lábdaco, padre de Layo y, éste a su vez, de Edipo. 


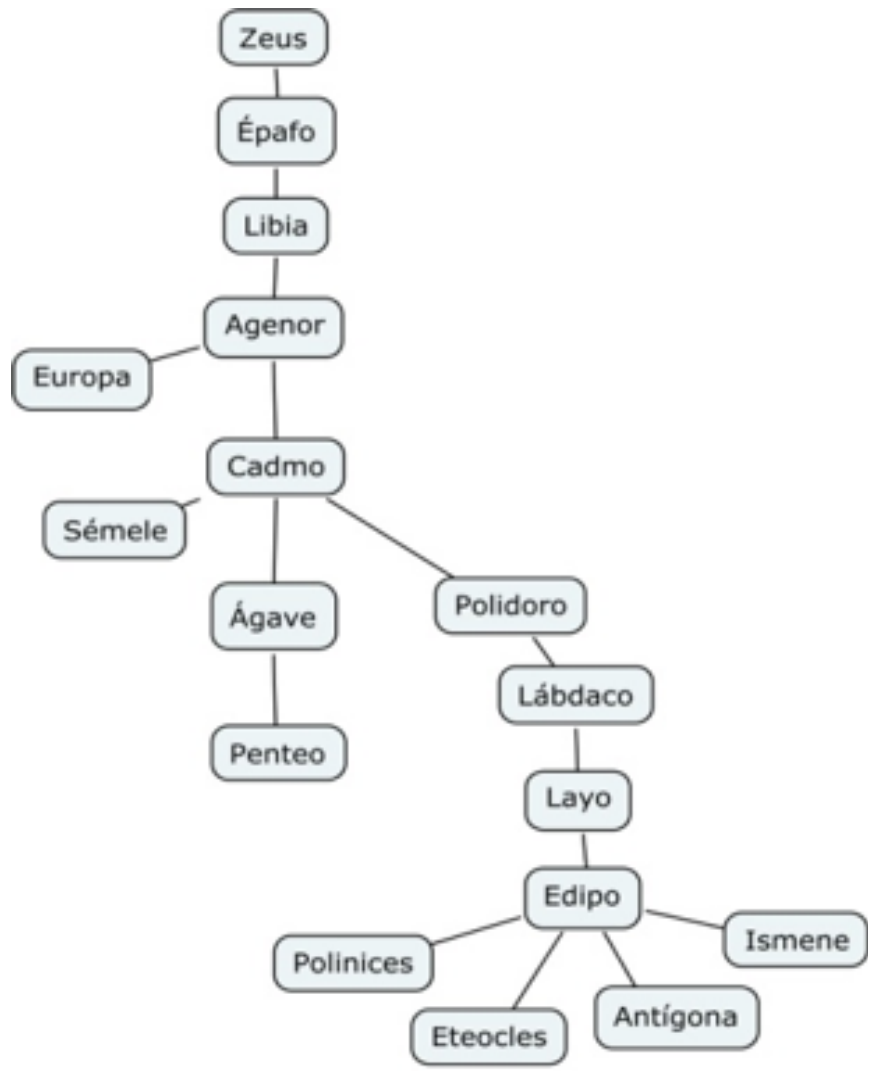

Las Bacantes de Eurípides es la primera tragedia que trata el ciclo tebano. Dioniso adopta figura humana y se dedica a trastornar a las mujeres en un delirio dionisíaco por no haberlo honrado como un dios. Cadmo y Tiresias se dan cuenta de la situación y comienzan a adorarlo como una divinidad mientras que Penteo, hijo de Ágave y rey de Tebas, se niega. Por lo tanto, manda arrestar a Dioniso y lo encarcela en una oscura cueva. Dioniso, con todo su poder, destroza la casa de Penteo, escapa y ofrece a Penteo que le acompañe al Citerón. Penteo se disfraza de mujer y marcha con el dios hacia el Citerón presa del furor báquico. Cuando están en medio de todas las Tíades, Dioniso lo desenmascara y, éstas, guiadas por su propia madre, Ágave, lo despedazan y clavan su cabeza en un tirso. Cuando ya ha desaparecido ese furor, Ágave reconoce que es la cabeza de su hijo la que está clavada en el tirso y se lamenta por la terrible acción cometida. Dioniso se aparece a Cadmo y se revela como dios diciendo que ha sido un castigo por negar el culto a su divinidad. A partir de ahora se ha de honrar a Dioniso como uno más entre los dioses olímpicos.

A Penteo sucede Lábdaco, hijo de Polidoro y Licteis, que tiene un hijo llamado Layo. Sin embargo, Lábdaco muere cuando Layo sólo tiene un año 
y ocupa el trono su tío Lico hasta que Layo esté preparado para regir. Un oráculo asegura a Layo que morirá a manos de su hijo por lo que, cuando le nació $\mathrm{Edipo}^{20}$, se lo entregó a un pastor, Melibeo, para que lo matara. Pero éste no hizo tal cosa sino que lo envió lejos a la corte de Corinto donde fue acogido por los reyes Pólibo y Mérope ${ }^{21}$. Cuando Edipo alcanzó la edad viril recibió un oráculo que le condenaba a matar a su propio padre y a mantener relaciones incestuosas con su propia madre, engendrando de ella varios hijos. Por culpa de este oráculo, Edipo se dirigió hacia su propio destino y, alejándose de la casa de sus supuestos padres, se puso en marcha hacia Tebas y, durante el camino, en una encrucijada, se encontró con una comitiva encabezada por el todavía desconocido rey de Tebas, su verdadero padre. Éstos tuvieron un rifirrafe y entraron en disputa, así que tras una dura pelea, Edipo mató a Layo y su comitiva para dirigirse a Tebas. Esta ciudad estaba siendo condenada por la Esfinge, hija de Tifón y Equidna ${ }^{22}$, pues realizaba una pregunta a los tebanos que ninguno era capaz de resolver por lo que los devoraba. Pero Edipo adivinó la respuesta y ésta saltó desde el monte Ficio y cayó por el valle. Los tebanos proclamaron nuevo rey a Edipo y éste casó con Yocasta, desconociendo que era su madre, teniendo con ella varios hijos: Eteocles, Polinices, Antígona e Ismene. Se cumplió así el oráculo que tanto trataba de evitar.

Aquí comienza el Edipo Rey de Sófocles, cuyo desenlace ahora sabemos. Comenzó a asolar una peste la ciudad de Tebas y Edipo trataba de averiguar a causa de qué llegó esa peste. Había que expulsar al asesino de Layo, pero nadie sabía que se trataba del mismo rey, ni siquiera él mismo. Tiresias terminó por confesarle a Edipo que era él la causa de la peste que invadía la ciudad y, por ende, había que desterrarlo a él. Tras una serie de investigaciones en las que intervinieron Creonte, Edipo y Yocasta, Edipo se convenció de su autoría y se atravesó los ojos con un alfiler que cogió del cadáver ahorcado de su madre y esposa Yocasta, quien se había dado cuenta de la desgracia antes que nadie.

Tras permanecer en Tebas un tiempo, decidió finalmente marchar al bosque de las Erinias, en Colono. Cuando llega allí, dispuesto a que llegue el fin de sus días, acompañado de su hija Antígona, unos ancianos intentan expulsarlo, sin embargo, deciden esperar la decisión de Teseo, el rey de Atenas. Ismene llega contando las disputas que hay entre sus dos hijos, Eteocles y Polinices, y que el rey tebano, Creonte, tenía en mente enterrar a Edipo en tierra tebana. Llega también Teseo que acoge hospitalariamente a Edipo pues un oráculo predijo que saldría vencedora la ciudad que tuviera enterrado en su territorio a Edipo. Creonte pide a Edipo que regrese pero ante su negativa, Creonte ordena a los soldados secuestrar a sus dos hijas. Teseo obliga a Creonte que le devuelva a Edipo a sus dos hijas. Al final de la obra aparece Polinices que afirma que no le queda más remedio que continuar la expedición contra Tebas y, después, Edipo se dispone a morir en terreno sagrado, eligiendo un lugar que sólo va a conocer 
Teseo, acto seguido, envía a sus hijas a Tebas. Este es el argumento del Edipo en Colono de Sófocles.

Una vez muerto Edipo, continúan las luchas entre los hermanos Eteocles y Polinices. Comenzaron las luchas porque los dos quisieron gobernar alternativamente pero Eteocles decidió gobernar por la fuerza y quedarse el reino. Polinices se fue exiliado a Argos donde el rey Adrasto lo ayudó para recuperar el reino tebano. A continuación ocurre lo que relata la obra de Esquilo, Los siete contra Tebas. Eteocles es advertido por un mensajero que los siete caudillos $\operatorname{argivos}^{23}$ se encuentran cada uno de ellos en una puerta de la ciudad. Eteocles decide colocar a sus siete mejores guerreros cada uno en una puerta de la ciudad y él mismo se colocará en la puerta en la que se halle su hermano Polinices. Tras la batalla regresa un mensajero anunciando que la ciudad se ha salvado pero que ambos hermanos se han dado muerte mutuamente, tal y como predijo el oráculo. Se manda enterrar en la ciudad a Eteocles pero dejar insepulto el cadáver de Polinices, acción que no está dispuesta a aceptar Antígona afirmando que dará unas honras fúnebres a sus dos hermanos por igual.

En Las Fenicias de Eurípides encontramos el mismo argumento, pero con algunas variantes. Por ejemplo, Tiresias vaticinó que la ciudad se salvaría si un príncipe de la casa real se ofrecía a ser sacrificado para Ares y el mismo Meneceo, hijo de Creonte se da muerte delante de las puertas de la ciudad. En la versión euripídea Yocasta aún no ha muerto y se suicida sobre los cadáveres de sus dos hijos, Creonte ordena que no se sepulte a Polinices y Antígona declara sus intenciones de sepultarlo, cueste lo que cueste, que es precisamente el tema que se trata en Antígona de Sófocles. Antígona ruega a Creonte que le permita enterrar honrosamente a su hermano Polinices, y éste continúa en sus trece. Un guardián del cuerpo de Polinices comunica a Creonte que alguien ha vertido tierra sobre el cadáver, entonces acusan a Antígona que se autoinculpa reconociendo haberlo hecho para respetar las leyes ágrafas. La discusión entre Creonte y la edípida inmiscuye también a otro hijo de Creonte, Hemón, que está prometido con Antígona. Creonte decide encerrar a Antígona hasta que muera y Tiresias replica al rey que son asolados por la contaminación del cadáver insepulto y que esto traerá graves consecuencias para la ciudad, pues la familia labdácida está manchada ya desde hace mucho. Cuando Creonte se arrepiente va en busca de Antígona pero la encuentra ahorcada y, a su lado, se da muerte Hemón. Eurídice es la esposa de Creonte y también ésta se suicida maldiciendo a su marido por su irreflexión.

Las Suplicantes de Eurípides es la última obra perteneciente al ciclo tebano, puesto que tiene relación todavía con la guerra de los siete caudillos contra Tebas, aunque ya no aparecen personajes labdácidas. Las madres de los jefes argivos caídos en Tebas se dirigen a Eleusis a solicitar ayuda a Teseo, rey de Atenas, guiadas por Adrasto, pues quieren conceder sepultura digna a sus 
hijos. Interviene la madre de Teseo, Etra, que se conmueve por las palabras de las mujeres y convence a su hijo para realizar tales honras fúnebres, a pesar de la oposición del heraldo que Creonte ha enviado. Teseo marcha contra Tebas y sale victorioso. Se dispone a tributar los honores a los caídos cuando Evadne, se tira a la pira con su marido muerto, Capaneo, ante la atónita mirada de su padre Ifis y de sus propios hijos. En última instancia Atenea interviene celebrando una amistad eterna entre Atenas y Argos.

Estas son las 7 tragedias que hemos tenido en cuenta y que hemos considerado como pertenecientes a la saga de los agenóridas o ciclo tebano: Tres de Eurípides, tres de Sófocles y tan sólo una de Esquilo. Como hemos podido ver, todas tienen una relación íntima y conforman un argumento no sólo ininterrumpido, sino también con variaciones e intromisiones entre ellas. Cinco se desarrollan en Tebas (Las Bacantes, Edipo Rey, Los siete contra Tebas, Las Fenicias y Antígona), Edipo en Colono tiene lugar en Colono y Las Suplicantes en Eleusis.

\section{La Saga de Heracles.-}

Es el más famoso de los héroes helénicos y el protagonista de un ciclo épico que desarrolla todas sus hazañas por todo el orbe conocido de los antiguos griegos. Las leyendas atribuidas por la tradición a este personaje eran tantas y, a veces, tan difíciles de relacionar entre sí, que se llegó a pensar en la Antigüedad que el nombre de Heracles había correspondido a varios héroes confundido en uno solo ${ }^{24}$. Sus hazañas se dividen en tres grupos: los áthloi, trabajos ordenados por Euristeo, las práxeis, tareas hechas por cuenta propia y los párerga, las pequeñas aventuras que le sucedieron durante los doce años que estuvo realizando los áthloi. Además, también hay que señalar los trabajos que realizó mientras estuvo sirviendo en el reino de Ónfale ${ }^{25}$, mientras estuvo casado con Deyanira, y también en su muerte y apoteosis final.

Hércules era hijo de Alcmena, que se casó con Anfitrión. Durante su matrimonio, Zeus se enamoró de ella y, tomando la apariencia de su marido, la tomó y de esta unión nació Heracles, un semidiós. De cualquier manera, sería imposible detenerse en todos los episodios concernientes a este héroe, por eso nos vamos a limitar a ver lo que muestran de él las tragedias griegas.

La primera cronológicamente es la Alcestis de Eurípides. Heracles llegó a la corte de Admeto ${ }^{26}$ en Feras, Tesalia. Este Admeto es un fiel servidor de Apolo quien consigue salvarlo de la muerte destinada a él siempre y cuando otra persona le sustituya. Pero nadie se ofreció, solamente su buena esposa Alcestis, que muere en sus brazos. Cuando Heracles está cenando en su corte, observa caras tristes y que la gente está de luto pero no le dan una respuesta clara. Entonces el padre de Admeto, Feres, reprocha a su hijo el dejar que muera su mujer por él, y su hijo hace lo propio con su padre, quien tenía menos tiempo 
de vida por disfrutar. Heracles, ebrio, deduce lo que está pasando gracias a la explicación de un esclavo, entonces se marcha trayendo consigo cuando vuelve a una mujer con el rostro velado. Pide a Admeto que la acoja como su mujer pero este se niega, hasta que vislumbra su rostro y reconoce en él a su mujer a quien Heracles había arrebatado del Hades.

Estando Heracles en Tebas con su esposa Mégara, hija de Creonte, tuvo que marchar y Lico, rey de Eubea, aprovechando la ausencia de Heracles usurpó el trono matando a Creonte y teniendo la intención de hacer lo propio con su mujer y sus hijos. Cuando ya estaba dispuesta la pira, Heracles, regresó victorioso liberando a los suyos y dando muerte a Lico. Pero la felicidad duró poco tiempo pues Hera, la eterna rival de $\mathrm{Heracles}^{27}$, lo inundó en tal locura que mató a sus hijos y mujer pensando que eran los hijos de Euristeo. Teseo le otorga hospitalidad en Atenas pues había sido ayudado por él en anteriores ocasiones, así lo relata Eurípides en su tragedia Heracles.

En Las Traquinias de Sófocles, Heracles ya estaba casado con Deyanira y ésta tenía en su poder un manto que le había entregado el centauro Neso al ser muerto por Heracles mediante un flechazo envenenado con la sangre de la hidra de Lerna. Este manto se lo obsequió engañosamente Neso a Deyanira con el pretexto de que le ayudaría a recuperar a Heracles si alguna vez fluctuaba su amor hacia ella. Así que, esperando Deyanira a Heracles en Traquis, se entera de que Heracles ha conquistado Ecalia sólo con el fin de conseguir a la joven Yole. Por consiguiente, Deyanira, evocando las palabras del centauro, decide enviar el manto a Heracles para volver a gozar de su amor, desconociendo la trampa del equinoide. De tal modo que, cuando Heracles se echa sobre los hombros el mortífero manto, comienza a abrasarse en un dolor exacerbado. En el momento en que Deyanira se da cuenta de su equivocación se suicida infligiendo un grandísimo dolor a su hijo Licas que ha sido testigo de toda la situación y, además, partícipe. Seguramente la obra recibe el nombre de Las Traquinias porque los acontecimientos narrados debieron suceder en Traquis.

La siguiente obra de la saga de Heracles ya no tiene como protagonista a Heracles sino a Yolao ${ }^{28}$ y a Demofonte ${ }^{29}$ y se titula Los Heraclidas, de Eurípides. Yolao y Alcmena comandan al resto de los hijos de Heracles en busca de la muerte de Euristeo, bajo la protección del rey ateniense, Demofonte. El oráculo asegura la victoria heraclídea si se realiza el sacrificio de una virgen. Esta virgen es Macaria, otra hija de Heracles, quien decide voluntariamente entregarse a la causa. Al final de la obra, y a pesar de las muchas lagunas, se cuenta cómo atrapan a Euristeo y Alcmena lo conduce a la muerte para vengar a su hijo.

Eurípides nos proporciona tres obras sobre la temática de la saga de Heracles, mientras que Sófocles, tan sólo una Las Traquinias. Cada obra tiene una localización distinta puesto que Heracles era un héroe que continuamente estaba viajando, conquistando ciudades y desposando a jóvenes bellas. Así, 
Alcestis se desarrolla en Feras, Heracles en Tebas, Las Traquinias, en Traquis y Los Heraclidas en Maratón.

\section{La Saga de Medea.-}

La historia de Medea es una de las más impactantes de la literatura griega y, en este caso, de la tragedia. Solamente tenemos una obra que trata el tema de Medea pero, estamos convencidos de que hubo muchísimas más y, seguramente, también muy buenas, pero el azar es como es y no ha querido que las podamos encontrar para disfrutarlas.

Medea habitaba en la Cólquide, junto con su padre Eetes, hasta que llegó Jasón con sus Argonautas ${ }^{30}$ a robar el vellocino de oro ${ }^{31}$ por orden de Pelias. Medea se enamoró perdidamente de Jasón y ayudó al robo y a la huida, dejándolo todo por él. Cuando ya están asentados en Corinto y con dos hijos, Jasón, como rey, con su reina Medea, es cuando comienza la Medea de Eurípides.

$\mathrm{Y}$ es que es normal que esté tan dolida y afligida Medea, ya que Jasón, el hombre por quien todo lo había dado, tiene la intención de desposarse con la hija de Creonte, además el pedagogo de los niños dice que Creonte quiere expulsar de la tierra de Corinto a los pequeños de Medea. Medea, que finge ante Creonte con crueles intenciones en su interior, discute con Jasón. Medea consigue la benevolencia y la hospitalidad de Egeo, rey de Atenas. Pero cuando ya había planificado todo, envenena a la mujer con la que Jasón pretende desposarse y a su padre, quien, al verla consumirse, se arroja sobre su cuerpo envenenándose también. Para concluir su plan, asesina a sus dos hijos, mostrándole a Jasón sus cuerpos exangües y se escapa volando sobre el carro del sol.

Así es tratado el mito de Medea en la tragedia, de manera efímera, pero, sin embargo, es una de las más grandiosas tragedias conservadas, sobre todo, por el tratamiento de la psicología femenina en Eurípides. Se podría decir que tanto Medea como Electra son dos grandes exponentes del pensamiento femenino, así como también Antígona.

\section{La Saga de Teseo.-}

Incluimos también esta saga de Teseo porque aparece en cuatro tragedias griegas; tres de las cuales ya hemos analizado: Edipo en Colono de Sófocles, Las Suplicantes de Eurípides y Heracles de Eurípides. Cronológicamente, la cuarta tragedia, que queda, trata sobre unos acontecimientos anteriores a todos éstos. La leyenda de Teseo va estrechamente unida a la de Heracles, pues, con él, conquistó el vellocino de oro, combatió contra las amazonas y con él acabó dando muerte a diversos monstruos. Es hijo de Egeo, precisamente el rey del 
que acabamos de hablar en la tragedia de Medea. De él recibió el trono. De Teseo es bien conocido que mató al Minotauro de Creta, saliendo del laberinto gracias al hilo que le dio Ariadna, hija de Minos y Pasífae, a quien se la llevó supuestamente para desposarla pero a la que abandonó en la isla de $\mathrm{Naxos}^{32}$. Después de luchar contra las amazonas, de una de ellas tuvo un hijo, Hipólito, pero la repudió y casó con Fedra, hija de Minos. Y aquí es precisamente donde nace el mito que nos cuenta Eurípides en su Hipólito:

La acción se sitúa en Trecén, donde había sido enviado Hipólito por su padre. Allí se dirigen Teseo y Fedra para purificarse por la muerte de Palante. Para colmo de males, Fedra, por voluntad de Afrodita, queda profundamente enamorada de Hipólito y es presa de un amor sin medida y sin salida. La nodriza de Fedra decide que, antes de que su señora muera de hambre por el amor que la consume, es mejor revelarle esa pasión que la nubla al propio Hipólito. Éste, totalmente indignado acusa a Fedra de libidinosa y licenciosa, así como a todo el género femenino y, Fedra, al escuchar tales palabras se ahorca, sosteniendo en sus manos una falaz acusación contra Hipólito por haberla forzado. Teseo destierra a Hipólito al leer tal carta y, éste, indignado por aquel oprobio se marcha en un carruaje. Teseo pide a los dioses que se desboquen los caballos de aquél para que se haga justicia y Poseidón actúa favorablemente para él. Sin embargo, cuando Hipólito está agonizante, Artemisa en persona, relata la verdad a Teseo que se lamenta una y otra vez por haber sido tan crédulo, pero Hipólito, justo antes de fallecer, lo perdona.

En esta tragedia, vemos cómo el Teseo al que estábamos acostumbrados, como juez de los asuntos de los demás y hombre bueno, se ve enredado en una trama totalmente trágica de la que tiene difícil escapatoria. Actúa correctamente al no matar a su hijo Hipólito, sin embargo, deseaba su muerte con tantísimas ganas que el dios le concedió la gracia. Un hombre pío como este héroe ateniense sufre uno de los mayores dolores en su vida al conocer la tremebunda verdad y cómo ha sido engañado por la mujer que amaba.

Por último, sólo nos queda reseñar que nos han quedado por tratar cuatro tragedias: Prometeo encadenado de Esquilo, Ión de Eurípides Las Suplicantes de Esquilo y Los Persas de Esquilo. Las hemos excluido conscientemente pues hemos considerado que el tema mítico no era tan sustancial como lo es en las otras tragedias analizadas ${ }^{33}$. En el caso de Prometeo encadenado sí hay mucha sustancia mítica pero lo hemos obviado porque no entronca prácticamente con el argumento mitológico de ninguna otra tragedia, aunque en alguna otra ocasión podremos retomar el tema y analizarla in extenso.

Creemos que estas breves reflexiones servirán para dejar clara la relación interna de las tragedias, el lugar de desarrollo de sus argumentos y su autoría; aspectos que, en muchas ocasiones, presentan dificultades de interpretación y de comprensión. 
${ }^{1}$ Queremos dedicar este breve trabajo a la memoria de la Profesora María Luisa Picklesimer, excelente profesora y experta en Mitología Griega y Latina.

${ }^{2}$ Para los diferentes aspectos de los mitos griegos y de la mitología, en general,cf.principalmente: J. P. Vernant, Mito y pensamiento en la Grecia antigua, Barcelona, 1973; G. Schwab, Las más bellas leyendas de la Antigüedad Clásica, Barcelona 1974; C. Falcón et alii, Diccionario de mitología clásica, Madrid 1980; J. Bermejo, Mito y parentesco en la Grecia arcaica, Madrid, 1980; G. S. Kirk, La naturaleza de los Mitos Griegos, Barcelona, 1984; M. Müller, Mitología comparada, Barcelona, 1988; T. Bulfinch, The Golden Age of Myth $\Xi^{\circ}$ Legend. Ware, Hertfordshire, 1993; P. Diel, El Simbolismo en la Mitología Griega, Barcelona, 1995; J. C. Bermejo, Grecia arcaica: La Mitología, Madrid, 1996; J. C. Bermejo y F. Díez Platas, Lecturas del mito griego, Madrid, 2002; R. Graves, Los mitos griegos, Barcelona 2005; R. L. Fox, El Mundo Clásico. La epopeya de Grecia y Roma. Barcelona 2005. Para los aspectos históricos, cf. principalmente: E. Will et alii, El Mundo griego y el Oriente I. El siglo V, Madrid, 1997; E. Will et alii, El Mundo griego y el Oriente II. El siglo IV y la época helenística, Madrid, 1998; F. J. Gómez Espelosín, Historia de Grecia Antigua, Madrid, 2001.

${ }^{3}$ Para el teatro griego en general y las tragedias griegas cf. principalmente, H. C. Baldry, The Greek Tragic Theatre, Londres, 1971; G. Devereux, Tragédie et poésie grecques. Etudes ethnospsychanalitques, París, 1975; O. Taplin, Greek Tragedy in Action, Cambridge, 1978; J. D. Romilly, La Tragedie grecque, París, 1982; S. Goldhill, Reading Greek Tragedy, Cambridge, 1986; C. R. Beye (ed.), La tyragedia greca. Guida storica e crítica, Roma-Bari, 1988; J. P. Vernant y P. Vidal-Naquet, Mito y Tragedia en la Grecia Antigua. Madrid, 1987-1989; A. Iriarte, Democracia y tragedia: la era de Pericles, Madrid, 1996.

${ }^{4} \mathrm{El}$ wánax o Fánax era el jefe o "rey" de cada ciudad griega en época micénica; Agamenón lo era de Micenas y Menelao de Esparta.

${ }^{5}$ Descendientes de Príamo, hijo de Laomedonte, padre de Héctor y Paris, pero cuyo nombre original era Podarces.

${ }^{6}$ Descendientes de Ilo, hijo de Tros y Calírroe, de quien proviene el otro nombre de Troya: Ilión.

${ }^{7}$ Descendientes de Tros, hijo de Erictonio y Astíoque, quien le da nombre a la ciudad de Troya.

${ }^{8}$ Cf. Esquilo, Tragedias, Biblioteca Gredos, Madrid, 2006 (traducción de B. Perea); Sófocles, Tragedias, Biblioteca Gredos, Madrid, 2006 (traducción de A. Alamillo), Madrid, 2008; Eurípides, Tragedias I, II y III, Biblioteca Gredos, Madrid, 2006 (traducción de A. Medina, J. A. López Férez y J. L. Calvo), Madrid, 2008: para los autores y sus obras, vid. J. Alsina et alii. Obras completas de Esquilo, Sófocles y Eurípides, Madrid 2004.

${ }_{9}^{9}$ Se le prometió la mujer más bella en el famoso juicio de Paris y, al no concedérsele, la raptó.

${ }^{10}$ Dicho episodio lo vemos con detalle en la Ifigenia en Áulide, de Eurípides.

${ }^{11}$ Por causa de una saeta, que disparó el propio Paris.

${ }^{12}$ Es la primera región del Hades descrita en la Odisea, donde las almas de los héroes vagan abatidas entre espíritus menores que gorjean a su alrededor como murciélagos. Cf. principalmente, Homero, Odisea, Biblioteca Gredos, Madrid, 2006 (traducción de J. M. Pabón), cap. XI, pp. 170 ss.; vid. también, M. I. Finley, El mundo de Odiseo, Méjico, 1961; F. Rodríguez Adrados, et alii, Introducción a Homero, Madrid, 1964.

${ }^{13}$ Según otras versiones, también es llamada Hécabe.

${ }^{14}$ Hay alguna versión en la que Poliméstor es sobornado por Agamenón para matar a Polidoro pero el rey tracio no puede matar a un niño al que había jurado proteger y asesina a su propio hijo Deífilo engañando a los mensajeros de Agamenón. Años más tarde, Polidoro indaga y descubre la verdad, entonces ciega y mata a Poliméstor por haber asesinado a su propio hijo a cambio de un soborno.

${ }^{15}$ Uno de nosotros (Héctor Pastor) tuvo la oportunidad de ver la representación escénica de esta obra en la ciudad romana de Baelo Claudia. Representación que fue llevada a cabo por el grupo de teatro PHERSU de la Universidad de Cádiz.

${ }^{16}$ Según otras versiones, Agamenón tuvo una hija llamada Laódice, no Electra, que es la que 
más conocemos hoy día.

${ }^{17}$ En otras versiones hemos visto a Pirro como hijo de Aquiles.

${ }^{18}$ Hemos inventado este epíteto para Neoptólemo porque mató cruelmente a Príamo, padre de Héctor.

${ }^{19}$ Realmente la patria de Agamenón, donde era rey, tras morir su padre Atreo.

${ }^{20}$ Ese nombre se lo puso el pastor corintio Melibeo porque sus pies estaban deformados por las heridas hechas con el clavo. Para las diferentes versiones de este mito, cf. principalmente, J. Bermejo, Mito y parentesco en la Grecia arcaica. Op. Cit. pp. 86 ss.

${ }^{21}$ También se menciona a Peribea como madre adoptiva de Edipo.

${ }^{22}$ En otras versiones era hija del perro Ortro y la Quimera.

${ }^{23}$ Éstos eran Polinices, Tideo, Adrasto, Capaneo, Hipomedonte, Anfiarao y el arcadio Partenopeo.

${ }^{24}$ Cicerón enumera hasta 6 personajes diferentes con el nombre de Heracles, mientras que Varrón menciona nada menos que a 44 Heracles distintos.

${ }^{25}$ Sirvió voluntariamente por haber matado a Ífito en un ataque de locura. Se cuenta que Ónfale lo vestía de mujer con collares y pulseras para entretenerse.

${ }^{26}$ Supuestamente Heracles llegó allí dispuesto a realizar su octavo trabajo: apoderarse de las yeguas de Diomedes.

${ }^{27}$ Por ser hijo de Zeus que la traicionó en uno de sus arrebatos amorosos con Alcmena.

${ }^{28}$ Fue auriga de Heracles y, también, el hermanastro de su padre. En este caso concreto, comparte el nombre con el hijo de Heracles, que es precisamente el protagonista de la obra.

${ }^{29}$ Hijo de Teseo y, por tanto, rey de Atenas cuando su padre falleció.

${ }^{30}$ La historia es contada en Las Argonáuticas de Apolonio de Rodas. El tema es de sobra conocido por lo que lo omitimos en este trabajo.

${ }^{31}$ Crisómalo, sobre el que volaron Hele y Friso, cayendo Hele al mar. De ahí el nombre Helesponto.

${ }^{32}$ Se cuenta que allí se casó con ella el dios Dioniso o, según otras versiones, se suicidó.

${ }^{33}$ Ión es un personaje mitológico menos importante que Medea o Heracles, pero que también hay que tener en cuenta. 


\title{
LA Figura de Heracles en Algunos AUTORES del Siglo IV D.c. ${ }^{1}$
}

\author{
Alberto J. Quiroga Puertas \\ Universidad de Granada
}

La profesora María Luisa Picklesimer siempre prestó una gran atención y esfuerzo, tanto en su labor docente como investigadora, a distintos episodios mitológicos protagonizados por Heracles, figura central del imaginario cultural mediterráneo ${ }^{2}$. La omnipresencia de Heracles en todos los campos de la cultura de varias de las civilizaciones que surgieron en el Mediterráneo hace que cualquier intento por condensar en un trabajo la relevancia de este héroe-dios sea una tarea tan irreal como ciclópea ${ }^{3}$. Es por este motivo por el que las siguientes páginas se centrarán en el análisis del uso del mito de Heracles que hicieron algunos autores a lo largo del siglo IV d.C., un periodo en el que hubo importantes cambios en el panorama político, cultural y religioso cuando el cristianismo pasó a ser religio licita y algunas prácticas paganas empezaron a ser perseguidas y prohibidas.

En este marco histórico, la mitología griega devino en un complejo y polisémico código cultural del que, con distintos propósitos, autores paganos y cristianos hicieron uso. Así, en relación con su empleo en diversos ámbitos a lo largo de la Antigüedad Tardía, Salustio, autor de la obra Sobre los dioses y el

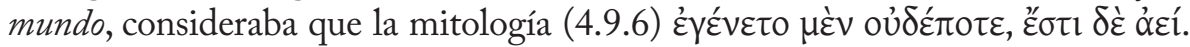
En este contexto cultural y religioso, las alusiones literarias a los diversos pasajes mitológicos protagonizados por Heracles se correspondieron con distintas actitudes políticas y religiosas. El uso de Heracles en la personificación de virtudes, la alegoría moral y la ejemplificación de actitudes religiosas demuestra que su figura gozaba de gran predicamento en el siglo IV d.C., hecho también atestiguado por su presencia en numerosas representaciones teatrales, artísticas, así como en elementos arquitectónicos ${ }^{4}$. Como recuerda G. K. Galinsky, el mito de Heracles representaba una serie de valores universales que fácilmente podían acomodarse a cada época: "man choosing between good and bad, man

${ }^{1}$ Este artículo se ha realizado gracias a la concesión de un contrato Ramón y Cajal de la Secretaría de Estado de Universidades e Investigación del Ministerio de Educación y Ciencia de España, y se enmarca en el Proyecto de Investigación "Diversidad cultural, paz y resolución de conflictos en el cristianismo antiguo (HUM2009-12679-C02-01)", dirigido por el Dr. Fernández Ubiña, y en el Grupo de Investigación HUM 404 "Tradición y Pervivencia de la Cultura Clásica”, dirigido por el Dr. Calvo Martínez.

2 Picklesimer 1981, 1992. Para la importancia de la figura de Heracles en la cultura del mediterráneo, Bernardini-Zucca 2005.

${ }^{3}$ De entre los intentos por acercarse a la figura de Heracles desde un punto de vista diacrónico y multidisciplinar, Galinsky 1972 sigue siendo la referencia. Sobre el estatus de dios y/o héroe de Heracles, Conti 2009, Deacy 2005 y Stafford 2005.

${ }^{4}$ Belayche 2004 19-20; Karivieri 2001. 
struggling for a decent fate in a hostile universe, man fighting for justice, order and peace, man succumbing to the power of love and death, to name only a few examples -all these are themes that have occupied men's minds and fired their imagination throughout history. The implications of the Herakles myth were, and are, anything but anachronistic ${ }^{5}$. No extraña, por lo tanto, que en un periodo de drásticos cambios a todos los niveles, como fue la Antigüedad Tardía, Heracles continuara siendo un objeto de comparación o un referente alegórico.

\section{La figura de Heracles en autores paganos.}

Los numerosos episodios mitológicos que giran en torno a Heracles, así como las numerosas fuentes y tradiciones paralelas que los transmitieron, constituyeron un buen filón argumentativo en las piezas retóricas del siglo IV d.C.El autor que recurrió a Heracles con mayor frecuencia en las composiciones literarias de este periodo fue el profesor de retórica y sofista Libanio de Antioquía, autor conocido por su defensa del paganismo y de los ideales insertos en la paideia clásica que aún se enseñaba en la Antigüedad Tardía ${ }^{6}$. En su amplia obra (se conservan sesenta y cuatros discursos, más de mil quinientas cartas y abundantes ejemplos de ejercicios de clase y declamaciones) se pueden distinguir dos usos principales de la figura de Heracles, uno meramente literario y otro fuertemente apegado a un trasfondo político-religioso ${ }^{7}$.

En lo que respecta a las referencias de carácter literario, Libanio se limita a revivir episodios tradicionales del mito de Heracles y emplearlos como materia argumentativa. Así sucede con la mención al relato del héroe ante la encrucijada de dos caminos - uno que representaba la Virtud y otro el Vicio ${ }^{8}$, y que en este caso sirvió a Libanio para ejemplificar la correcta decisión del emperador Juliano cuando decidió seguir con su educación y tomar el camino de la paideia clásica en lugar de dejarse seducir por los placeres carnales y sensuales

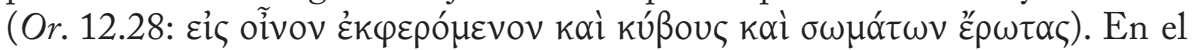
epílogo de esa misma pieza dirigida a Juliano, el sofista recurre nuevamente a Heracles como parte de su discurso propagandístico a favor del emperador Juliano y pide al dios Cronos que alargue el año del consulado de Juliano como

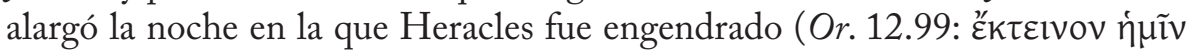

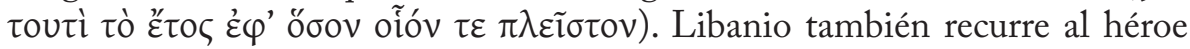
griego cuando defiende su sistema educativo y se complace en decir que de su

\footnotetext{
${ }^{5}$ Galinsky 1972185.

${ }^{6}$ Los trabajos de referencia sobre Libanio siguen siendo Cribiore 2007, López Eire 1996, Malosse 2002, Schouler 1984, Wintjes 2005.

${ }^{7}$ Una enumeración de las apariciones de Heracles en la obra de Libanio, Schouler 1984 716719. Respecto al uso de la mitología en la obra del sofista, véase también Schouler 1984 746-775.

${ }^{8}$ El relato original de Jenofonte en Mem.2.1.21-34. Sansone 2004 estudia hasta qué punto el relato de Jenofonte es fiel al de Pródico. Un estudio de la suerte de este relato en la literatura clásica griega, Staffordf 2005 y Waites 1912.
} 
escuela ha salido tal número de alumnos que han llegado hasta los confines del

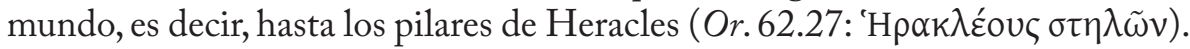

Además de servir como material para discursos, declamaciones y progymnásmata ${ }^{9}$, las virtudes que representaba Heracles también aparecen en las epístolas de Libanio como un referente cultural habitual en la correspondencia entre las elites culturales de la Antigüedad Tardía. De este modo, Heracles vino

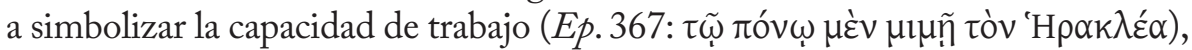

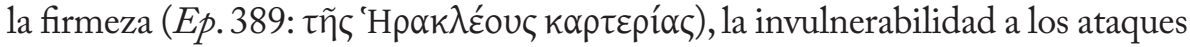

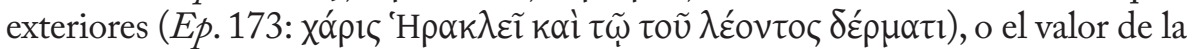

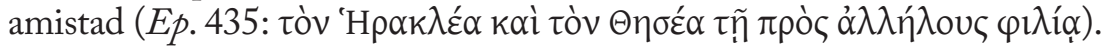

En cuanto a su uso político-religioso, Heracles sirvió a Libanio como ejemplo argumentativo o elemento de comparación cuando se trataba de defender su ideario pagano. Nótese en este sentido cómo Libanio emparenta a los primeros pobladores de su Antioquía natal con los Heraclidas (Or. 11.56-57;91 $)^{10}$, enfatizando así los orígenes paganos de una ciudad vital en la predicación cristiana tanto en los comienzos del cristianismo (de hecho, fue en Antioquía donde, según los Hechos de los Apóstoles, 11.26, los seguidores de

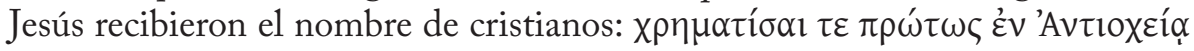

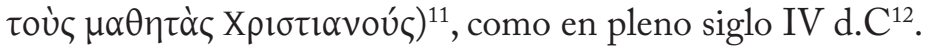

En un mismo tono político-religioso hay que leer los numerosos ejemplos en los que Libanio asimiló la imagen del emperador Juliano a la de Heracles (Or. 13.28, 48; 14.70; 15.36, 47; 18.39) ${ }^{13}$. Tras la llegada al poder de Juliano y su política de reformas para restablecer la cultura pagana como la dominante, el sofista antioqueno se sintió más confiado al exponer su ideario y volcó su retórica en elogios a la política del emperador ${ }^{14}$. La campaña del César Juliano en la Galia, por ejemplo, dio pie a que Libanio no sólo comparara a éste con Heracles por haber sido capaz de domeñar a los galos, sino que implícitamente Constancio II, a la sazón el emperador que había designado César a Juliano y que lo había enviado a pacificar la zona, es transformado en Euristeo, el rey de Corinto que encomendó a Heracles sus doce tareas (Or. 12.44): "y en aquel momento recogió los frutos de su educación, a pesar de que, como Heracles, respondía a un hombre inferior [i.e., Constancio-Euricleo]". Este discurso tuvo una clara vocación propagandística con

${ }^{9}$ Lib., Decl. 2.1.9; 4.2.82, 84; 11.1.35; 12.2.10, 17, 47, 50; 13.1.59; 15.1.32; 16.1.67, 68; 17.1.59; 18.1.17,35; 19.1.26; 21.1.13; 22.1.27; 23.1.7; 23.1.75; 29.1.8; 30.1.9; 33.1.13, 18; 43.2.70-71; 49.2.50; Prog. $2.1 .1 ; 2.8 .1 ; 2.15 .1 ; 2.23 .1 ; 2.24 .1-2 ; 2.31 .1 ; 3.1 .18 ; 3.2 .2 ; 3.3 .8 ; 7.1 .8 ; 7.3 .12 ; 8.2 .19 ; 8.3 .4 ; 8.8 .14$; 9.2.3; 9.5.3; 10.2.2; 11.6.8; 11.19.6; 11.21.2; 11.29.5; $12.13 ; 12.14 ; 12.15 ; 12.16 .2 ; 12.26$.

${ }^{10}$ Saliou 1999-2000.

${ }^{11}$ Zetterholm 2003 94-96.

12 Maraval 1995.

${ }^{13}$ La fortuna de la asimilación entre el emperador reinante y Heracles pervivió hasta época bizantina, como demuestra el proemio del Encomio al Emperador Anastasio de Procopio de Gaza.

${ }^{14}$ Sobre la compleja relación entre Libanio y Juliano, Bouffartigue 2002 y Malosse 1995. 
el objetivo de justificar el alzamiento y proclamación como emperador de Juliano frente a Constancio $\mathrm{II}^{15}$, por lo que la alusión a Heracles se explica por la capacidad del héroe para representar la legitimación del poder ${ }^{16}$. Como ha señalado $\mathrm{M}^{\mathrm{a}}$. J. Ponce, "Como la Gigantomaquia, el mito de Heracles/Hércules fue tomado de la imaginería política griega. En el mundo griego Heracles había servido durante mucho tiempo como prototipo de conquistador invencible y en el pensamiento estoico y cínico se había tomado como ejemplo de virtus" ${ }^{17}$.

Tampoco hay que olvidar que Heracles fue adorado como un dios pagano en Antioquía (tal y como relata Juan Malalas: 246.13-19), y numerosos objetos de arte aún lo representaban en los siglos $V-V^{18}$. Su figura persistió como un símbolo del helenismo cultural y religioso en la Antigüedad Tardía, como demuestra la narración de los últimos instantes de vida de Juliano: según escribe Libanio en un pasaje tan dramático como simbólico, el emperador fue herido en una refriega en su campaña persa, pero pudo llegar a su tienda, donde murió sobre una piel de león (Or. 18.269: кo

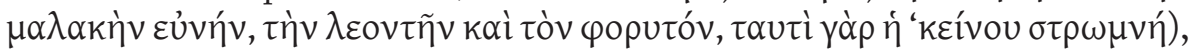
atributo mítico de Heracles y que simbolizaba en este caso la hercúlea tarea que había emprendido Juliano en su incursión en territorio persa ${ }^{19}$.

Con todo, no fue Juliano el único emperador que Libanio comparó con Heracles. Siguiendo la preceptiva retórica imperial que recomendaba evocar la figura de Heracles cuando se elogiaba al emperador ${ }^{20}$, el sofista asimiló a Teodosio I con Heracles con motivo de un discurso de agradecimiento por haber perdonado a la ciudad de Antioquía tras la revuelta de las estatuas acaecida en el año $387^{21}$. En su discurso 20, Al emperador Teodosio tras la reconciliación,

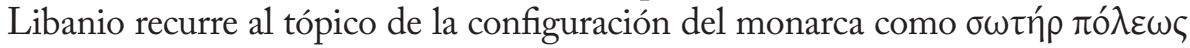
y elabora su argumentación a partir de un conocido pasaje mitológico (Or. 20.8): "En efecto, se dice que Asclepio rescató de la muerte a una sola persona [i.e., Hipólito] y Heracles a una sola mujer [i.e., Alcestis]. En cambio tú lo has hecho con una ciudad entera a la que cualquiera que hable con razón diría que la has resucitado"22. Algo más adelante, Libanio continúa con su elogio yuxtaponiendo

${ }^{15}$ González Gálvez 2001 26-28.

${ }^{16}$ Hekster 2005.

${ }^{17}$ Ponce 1998229.

${ }^{18}$ Takács 2000 204-205.

${ }^{19}$ Un pasaje similar sobre la simbología de la piel de león como elemento heleno en territorio

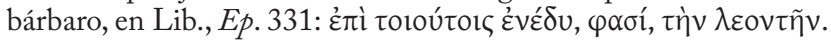

${ }^{20}$ Men. Rh. 370, 23-24; 372, 2; 422,23. También Cizek 1975 297: "The panegyrics and histories of Hellenistic dynasts and of later Roman emperors are followed by the evocation of most significant mythological and historical motifs, rhetorically expressed according to the exigencies of the genre".

${ }^{21}$ Browning 1952, Paverd 1991.

${ }^{22}$ Respecto a este pasaje, vid. Schouler 1984 718: "La douzième a en effet un caractère bien particulier, puisqu'il s'agit de la katabasis dans 1'Hadès. C'est l'exploit préféré de Libanios. Le sophiste le tient pour le plus grand des douze travaux, et le mentionne plus souvent que les autres". 
la seguridad que producía saber que Teodosio cumpliría de forma correcta con su trabajo (Or. 20.34): “Cuando Heracles iba a hacer algún trabajo, por voluntad propia o incluso cuando era enviado, cualquiera que conociera bien su naturaleza sería un adivino si, impulsado a predecir por las anteriores acciones de Heracles, dijera que tendría éxito en sus trabajos".

La lectura de los pasajes en los que Libanio compara a Juliano y a Teodosio con Heracles no provoca en el lector la sensación de estar ante un alarde de innovación literaria. De hecho, ya durante el periodo de la tetrarquía Heracles había cobrado gran protagonismo como símbolo imperial ${ }^{23}$. Sin embargo, es precisamente esa falta de originalidad en la composición retórica la que debe dar la medida exacta de la importancia de la figura de Heracles en el ámbito de la retórica epidíctica tardía: el auditorio esperaba que, en algún momento de la declamación, el héroe griego apareciera como trasunto mitológico del emperador.

Por su parte, el emperador Juliano hizo uso de la figura de Heracles en sus escritos con fines religiosos y apologéticos, aunque también es posible encontrar pasajes inocuos y meramente literarios en sus obras encomiásticas a Constancio II y a la emperatriz Eusebia, como la alusión a las columnas de Heracles (51d), a la encrucijada de caminos que conducen a la virtud o al placer (56d), o la presencia de Heracles en la fundación de Macedonia (106c) ${ }^{24}$, región de la que era originaria Eusebia. Igualmente, al inicio de su epístola a Temistio, Juliano asume la comparación con Heracles y con Dionisio porque ambos fueron tanto regentes

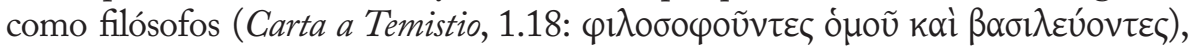
confirmando así su apego a un modelo de emperador de raigambre clásica personificado en un dios pagano y en un semi-dios o héroe como era Heracles ${ }^{25}$.

Los emperadores inmediatamente anteriores a Juliano emplearon a Heracles como una figura que podía representar una interpretación del paganismo atenuada que fuera capaz de aglutinar algunos sectores del cristianismo ${ }^{26}$. Juliano, sin embargo, se alejó de este uso conciliador y adoptó a Heracles como uno de los ejes centrales de su teología de corte pagano. La mayoría de los autores modernos ha coincidido al señalar que el sentir religioso de Juliano estaba impregnado del henoteísmo imperante y pretendía crear un sistema religioso de evidentes paralelos con el cristianismo de su tiempo ${ }^{27}$.

En esta clave hay que leer pasajes como el de su discurso 7, en el que aleccionaba al filósofo cínico Heraclio sobre el correcto uso e interpretación

${ }^{23}$ Rees 2005.

${ }^{24}$ Chuvin 1991 recoge numerosas tradiciones sobre las fundaciones de ciudades en las que participó Heracles.

25 Sobre la relación de Dionisio y Heracles con el concepto de Herrscherideal en Juliano, Stenger 2009 65-66, 159.

${ }^{26}$ Mallingly 1952132

${ }^{27}$ Ramos Jurado 1998 221; Taeger 1960 658-660 
de los mitos. A este respecto, cuando relataba el episodio mitológico en el que Heracles atravesaba el mar en una copa de oro ${ }^{28}$, Juliano intercala un comentario que, sin lugar a dudas, pretende hacer mofa del relato en el que Jesús andaba sobre las aguas (Mateo 14.22-32), al tiempo que aleccionar sobre una lectura correcta de la mitología (Or. 7.219d): "por los dioses, creo que no fue en una copa, sino que pienso que Heracles anduvo sobre el mar como si se tratara de tierra firme". Como ha afirmado P. Athanassiadi ${ }^{29}$, el emperador Juliano vio en Heracles una figura cuyo arraigo en el imaginario cultural popular era muy poderoso y que se prestaba a una asimilación fácil con otras figuras monoteístas o henoteístas.

De este modo, M. Simon considera que el emperador Juliano empleó la figura de Heracles como resultado final de la combinación de las tendencias religioso-filosóficas de su tiempo y de una lectura alegórica de la mitología griega con el objetivo de crear una réplica de Cristo: "quoi qu'il en soit, on peut, semble-t-il, tenir pour assuré que si la figure d'Hercule a pris un tel relief dans la théologie de Julien, c'est dans une large mesure à cause de ses affinités avec celle du Christ, et sous l'influence non seulement de tout le courant de pensé païenne des siècles précédentes, mais aussi de la christologie: Hercule, ici, est vraiment une réplique païenne du Christ" ${ }^{30}$. Es necesario tener esto en cuenta al leer el pasaje en el que el emperador diserta sobre los elementos

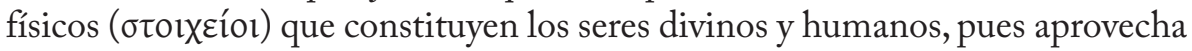
la naturaleza humana y divina de Heracles para exponer su ideario (Or. 7.219d-220a). Asimismo, las alusiones a la ayuda que Heracles recibe de la diosa Atenea (Or. 5.179a; Or. 7.219d) han sido también interpretadas como un paralelismo entre los binomios Jesús-Virgen María/Heracles-Atenea ${ }^{31}$.

La obra retórica del filósofo y orador Temistio incluye varios pasajes en los que Heracles es tomado como ejemplo moral. Así, en la oración fúnebre dedicada a su padre, el también filósofo Eugenio, Temistio invoca a Heracles como el

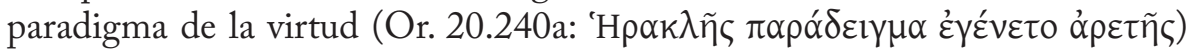
ya que considera que sus trabajos liberaron a toda la tierra de tiranos opresores

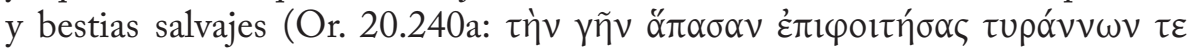

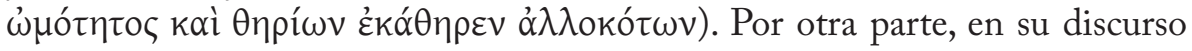
34 , una defensa ante aquellos que le recriminaban la incompatibilidad entre el ser filósofo y haber aceptado puestos oficiales en la administración imperial, Temistio compara al emperador Teodosio con el Heracles $\kappa \alpha \lambda \lambda i ́ v \bar{i} \kappa o \varsigma$ en virtud de su capacidad de vencer e impartir justicia, mientras que él mismo se asimilaba a Iolao, sobrino de Heracles y compañero de muchas de sus

\footnotetext{
${ }^{28}$ Apollod., Bibliotheca, II 107, 119.

${ }^{29}$ Athanassiadi 1992, 132-133.

${ }^{30}$ Simon 1955 149. También Aune 1990 y Stenger 200965.

${ }^{31}$ Simon 1955 144-146.
} 


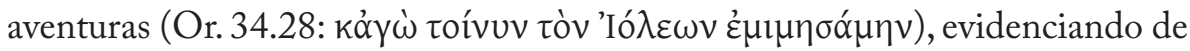
esta manera la connivencia con la política emprendida por Teodosio.

Sin embargo, el tratamiento de la figura de Heracles en Temistio destaca especialmente cuando el filósofo trata en profundidad el tema de la amistad en

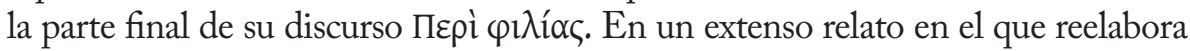
la historia contada por el sofista Pródico y transmitida por Jenofonte ${ }^{32}$, Temistio adopta una visión alegórico-filosófica del episodio: una vez que Heracles ha

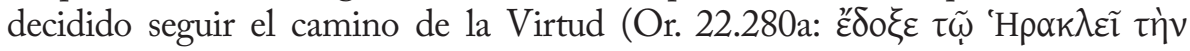

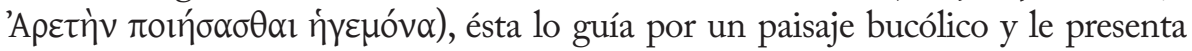

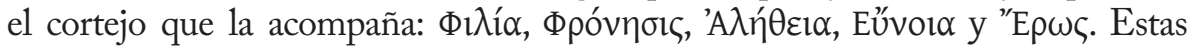
personificaciones, localizadas en el idílico marco de un florido prado en el que el agua es dulce, se oponen en este relato de Temistio a las malas compañías que habría

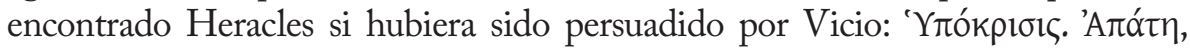

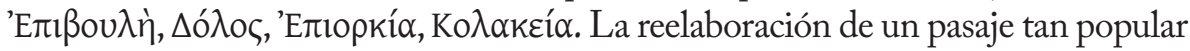
y su fuerte matiz alegórico se conjugan, en esta ocasión, para perseguir el objetivo que Temistio se propuso al componer este discurso: disertar sobre la amistad desde una perspectiva filosófica con un tono divulgativo (Or. 22.264c-266b) $)^{33}$.

De la obra de Eunapio de Sardes se pueden rescatar dos ejemplos significativos del empleo literario-político de Heracles en el siglo IV d.C. En un pasaje de su fragmentaria Historia ${ }^{34}$, Eunapio trae a colación la reputada amistad entre el hijo de Alcmena y Teseo ${ }^{35}$, si bien matizando que Teseo obtuvo

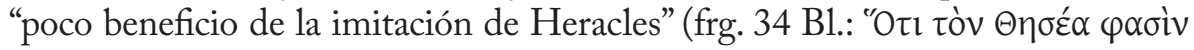

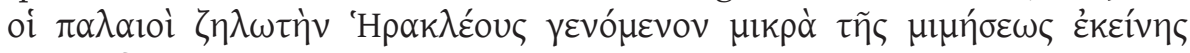

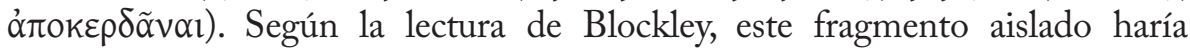
referencia a la relación entre el usurpador Procopio ${ }^{36}$ (en el papel de Teseo en este pasaje) y el emperador Juliano como trasunto de Heracles ${ }^{37}$. La alusión a la amistad entre ambos se justifica en virtud del parentesco entre Procopio y la dinastía constantiniana a la que Juliano pertenecía, y el escaso ( $\mu$ $\kappa$ ò) beneficio que esto le reportó alude a la derrota de Procopio ante el emperador Valente, quien lo mandó ejecutar tras sofocar su sublevación durante los años 365-366.

La otra alusión a Heracles en la obra de Eunapio se da en su Vidas de filósofos y sofistas. En este caso, se trata de un pasaje habitual en su obra: la inquina que uno de los filósofos o sofistas elogiados en esta obra biográfica de Eunapio se gana por

${ }^{32}$ En la reelaboración del episodio de Temistio hay reminiscencias de Dión Crisóstomo, Or. I.66 ss.

${ }^{33}$ Penella 2000 16-18.

${ }^{34}$ Esta obra pretendió ser la continuación de la Crónica de Dexipo (vid. Focio Bibl. Cod. 77). Para una compilación de la obra fragmentaria de Eunapio, Blockley 1983.

35 Un episodio de esta amistad en Picklesimer (1992).

${ }^{36}$ Blockley 1975 55-61. Un breve pero detallado estudio en http://www.roman-emperors. org/procopis.htm\#2.

${ }_{37}$ Blockley 1983137. 
parte de los consejeros de algún emperador o monarca ${ }^{38}$.El filósofo elogiado en esta ocasión es Sópatro de Apamea, quien provocó los celos de la corte del emperador Constantino por su sabiduría y capacidades. En este contexto, Eunapio compara a los altos cargos acólitos al emperador con los Cercopes, criaturas simiescas que intentaron robar a Heracles sus armas cuando éste era esclavo de Ónfale ${ }^{39}$. En el pasaje de Eunapio, los Cercopes cercanos al emperador Constantino confabulaban contra Sópatro por ingresar recientemente en el cortejo imperial a pesar de ser un

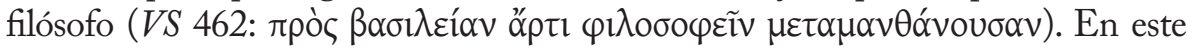
caso, la comparación de tintes peyorativos que cae sobre los acólitos al emperador sirve para ensalzar la figura de Sópatro como un Heracles filósofo ${ }^{40}$.

Por último, no podían faltar referencias a tan importante referente cultural y mitológico en el sofista Himerio, cuyo tratamiento de la figura de Heracles se aleja de las implicaciones políticas y religiosas vistas hasta ahora, enmarcándose en un contexto meramente literario dirigido hacia dos aspectos primordiales. Por un lado, Himerio, al resaltar el origen de algunos de sus nuevos alumnos, alude a Heracles como ilustre ancestro de los nativos de la región de Misia (Or. 26.8-

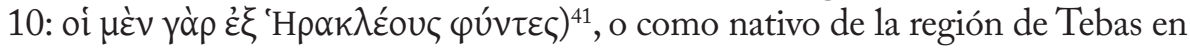
una pieza en la que el sofista personifica, muy anacrónicamente, el papel de un

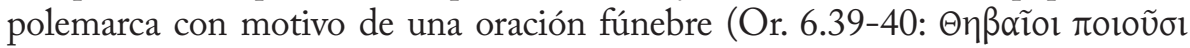

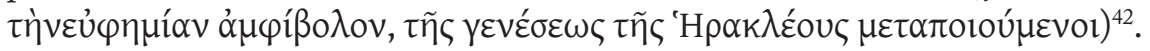

Por otro lado, Heracles aparece frecuentemente como elemento principal de un binomio de personajes mitológicos a imitar, como es el caso de la admonición para emular al joven Iolao dirigida a los nuevos estudiantes que acudían a su escuela

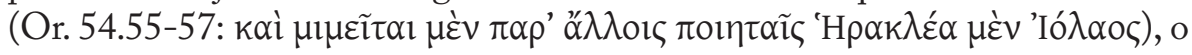
a aquellos que trabaron amistad con el procónsul de Asia Nicómaco (Or. 43.21:

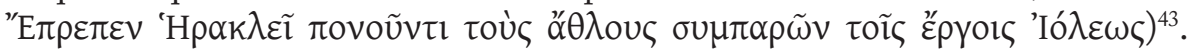
Igualmente, la legendaria amistad entre Heracles y Teseo es comparada con la que, según Himerio, mantuvieron el prefecto Salustio y el emperador Juliano

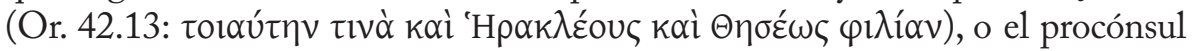
de Grecia, Hermógenes, y el innominado emperador al que prestó servicio (Or.

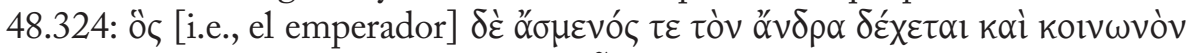

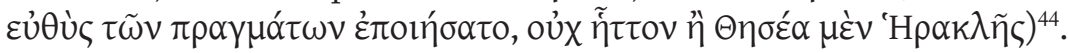

La figura de Heracles en autores cristianos.

${ }^{38}$ Véase el caso del monarca persa Sapor II, VS 465-466.

${ }^{39}$ Apollod., Bibliotheca, II.131-131; D.S. 4.31.7.

${ }^{40}$ Rappe 2000 287-291.

${ }^{41}$ Apollod., Bibliotheca., 1.117.

${ }^{42}$ Para las aventuras de Heracles en Tebas, vid. Schouler 1984716.

${ }^{43}$ Apollod., Bibliotheca, 2.70, 78-80, 127.

${ }^{44}$ Para las numerosas conjeturas acerca del nombre del emperador al que se refiere Himerio, Penella 2007 209-210. 
En un trabajo de 1995, el gran historiador W.H.G. Liebeschuetz declaró que en la Antigüedad Tardía "mythology and Christianity enjoyed a reasonably peaceful coexistence, comparable to their coexistence in the Renaissance (...) Christians could accommodate themselves to the purely literary use of myth ${ }^{45}$. En efecto, las elites culturales cristianas de la Antigüedad Tardía se educaron en un sistema educativo en el que el aprendizaje de los textos clásicos y los progymnásmata retóricos estaban impregnados de figuras mitológicas. En el caso que nos ocupa, los más que evidentes paralelos entre las historias de Heracles y Jesús ${ }^{46}$ provocaron que la figura del héroe griego sirviera, en ocasiones, como punto de referencia para determinados autores cristianos, ya fuera para exponer una postura conciliatoria o, como en la mayor parte de los escritos cristianos, para burlarse de la idiocia de la mitología pagana empleando una crítica de tipo racionalista o evemerista.

Basilio de Cesarea, por ejemplo, en su obra $A$ los jóvenes, sobre el provecho de la literatura clásica reproduce (si bien, como advierte el propio autor, no con las palabas exactas de Pródico, sino quedándose con el espíritu del episodio, 5.6: ”Ехعı

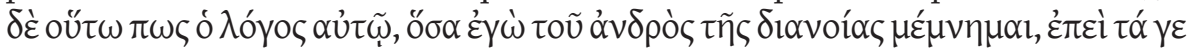

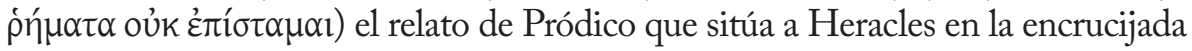
de la Virtud y del Vicio. Nuevamente, ambos conceptos son representados

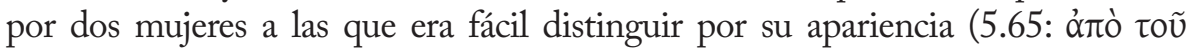

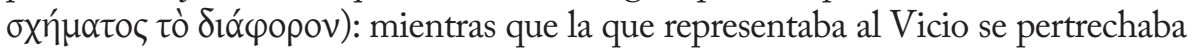

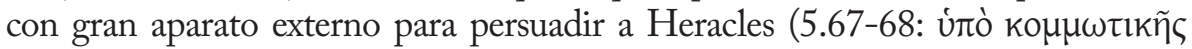

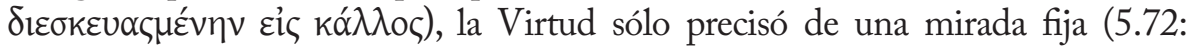

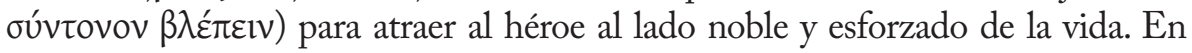
este sentido, como bien apunta N.G.Wilson ${ }^{47}$, el hecho de que la Virtud aparezca

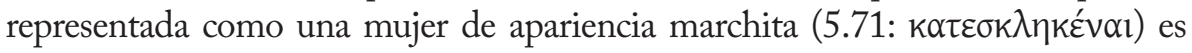
una novedad respecto al relato de Jenofonte (Mem. II.1.21-22) que contribuye a subrayar el carácter moral y sacrificado que Basilio pretendía transmitir.

Un uso de la figura de Heracles totalmente opuesto se encuentra en el Encomio de Constantino de Eusebio de Cesarea. Con el objetivo de probar la fatuidad de los dioses paganos, Eusebio alude al comportamiento licencioso de algunas figuras mitológicas, como es el caso del episodio en el que Heracles acaba rendido de tanto

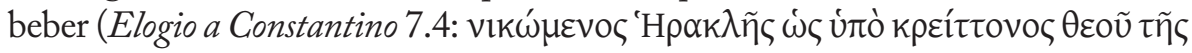
$\left.\mu \varepsilon^{\theta} \eta{ }^{4}\right)^{48}$, o hace una lectura evemerística de la religión pagana afirmando que los griegos consideraron dioses y héroes a varios mortales, como Dionisio, Heracles,

${ }^{45}$ Liebeschuetz 1995193.

${ }^{46}$ Aune 1990, Pfister 1935 y Simon 1955 siguen siendo los trabajos de referencia en este aspecto.

${ }^{47}$ Wilson 197555.

${ }^{48}$ Hay varios mosaicos conservados procedentes de Antioquía y Gaza que representan la escena entre Heracles y Dionisio en un certamen para determinar quién bebía más, Dobbins 2000 53, 55; Kondoleon 2000 68-70; Talgman 2004 221, 228. 


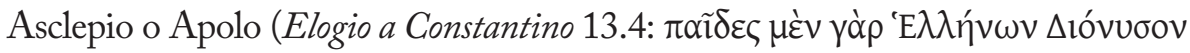

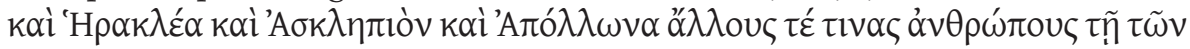

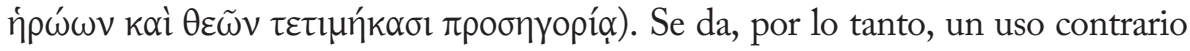
al que los oradores y panegiristas paganos otorgaron a la figura de Heracles en sus composiciones encomiásticas dedicadas a los emperadores, ya que Eusebio prioriza el elemento polemista y no compara una figura de evidentes reminiscencias paganas como era Heracles con el emperador Constantino, responsable de la conversión del cristianismo en religio licita.

La misma línea crítica-argumentativa continúa en otra obra de Eusebio, la Preparación al Evangelio. Eusebio, en primer lugar, refuta el origen heleno de Heracles y lo hace descender de linaje egipcio (Preparación al Evangelio 2.1:

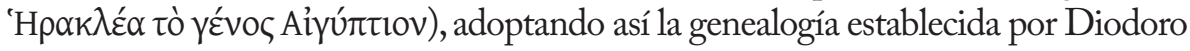
Sículo (Bibliot., I.24). Además, Eusebio recurre, como es frecuente en su afán polemista contra el paganismo, al argumento de la antiquitas, afirmando así que Moisés vivió mucho antes que Heracles (Preparación al Evangelio 10.9-12). Como se puede apreciar fácilmente, Eusebio pretende racionalizar la imagen de Heracles, convertirlo en un mortal deificado por la tradición literaria griega y así banalizar su imagen e importancia. Para ello, Eusebio insiste en la lectura evemerística ${ }^{49}$ de algunos de los pasajes mitológicos más importantes de Heracles (los doce trabajos, su relación con Euristeo, las implicaciones de su catasterización) para reducirlos al absurdo (Preparación al Evangelio 3.13), con la intención final de eliminar cualquier intento de asimilación entre el Heracles humano y la figura divina de Jesucristo. Sobre este aspecto en particular, Galinsky ha afirmado que "the only new element in the church fathers' denigration of the hero was their belief that Herakles, like the other Olympian deities, was a devilish creation. Herakles bore the brunt of their attack because, for a long time, he appeared as paganism's direct rival of Christ who was, in spite of the many similarities between the two life stories, the exact opposite of Christ: the man who became god, in contrast to the god who became man"50.

En el contexto del enfrentamiento cultural entre paganismo y cristianismo algunos pasajes mitológicos en los que intervenía Heracles fueron empleados de forma irónica. Tómese como ejemplo la peroración de la segunda invectiva de Gregorio Nacianceno contra el emperador Juliano. El teólogo cristiano juega con el significado de la palabra $\sigma \tau \eta ́ \lambda \eta$, empleada habitualmente con el sentido de "columna" pero que también puede significar "hito, monumento"; así,

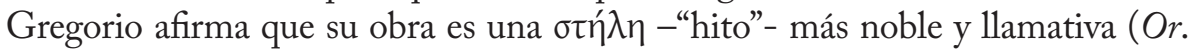

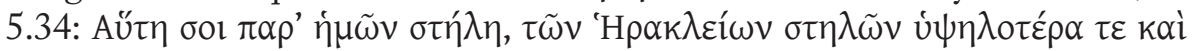

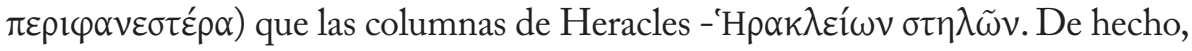
en opinión de Jean Bernardi, el uso de $\sigma \tau \eta ́ \lambda \eta$ sería una réplica irónica al empleo

\footnotetext{
${ }^{49}$ Gaeta 1954 230-232

${ }^{50}$ Galinsky 1972189.
} 
del mismo vocablo por parte de Libanio en su discurso con motivo del consulado

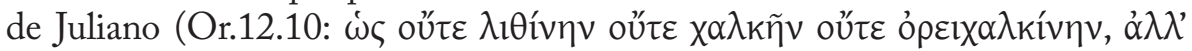

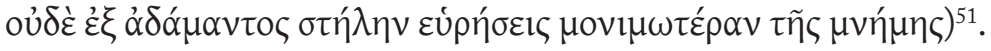

En esa misma obra, Gregorio contrapone la magnificencia de la Creación del dios cristiano (Or. 5.31) con las incongruencias y desmanes del panteón griego ${ }^{52}$, entre las que condena que Heracles sea adorado como un dios, cuando en ocasiones

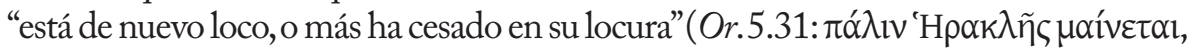

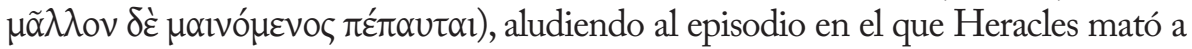
sus propios hijos tras un ataque de locura intermitente inducido por Hera ${ }^{53}$.

A pesar de que se adoptaron íntegramente algunas peripecias de la figura de Heracles en el entorno cristiano (véase la epístola 156 de Gregorio Nacianceno,

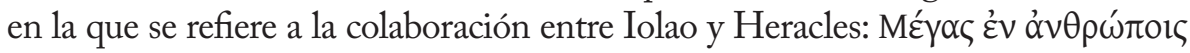

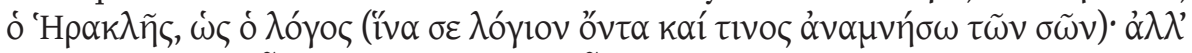

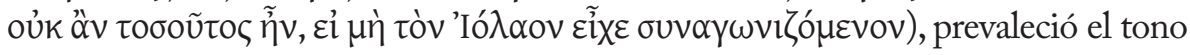
polemista e irónico en la obra de Gregorio. De esta manera, en su primera invectiva contra el emperador Juliano se pregunta quiénes son los paganos para enseñar

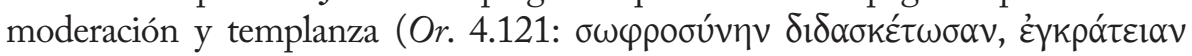

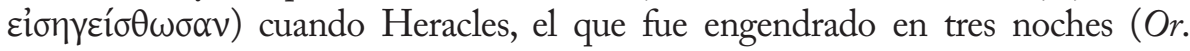

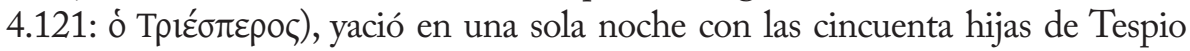

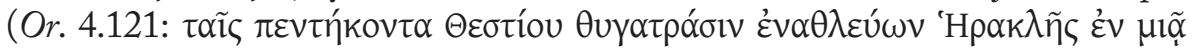
$v \cup \kappa \tau i)$, hazaña que Gregorio califica sarcásticamente como el decimotercer trabajo

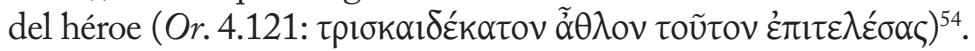

Los numerosos pasajes que narran episodios de Heracles evidencian la capacidad polimorfa y proteica de este héroe-semidios para representar muy diferentes atribuciones a lo largo de la antigüedad clásica. Ya fuera como un exemplum virtutis, ya como el paradigma de los errores del paganismo, Heracles pervivió como un referente cultural capaz de adaptarse a un nuevo periodo en el que el cristianismo se fue implantando como forma cultural imperante. Para gran parte de los autores paganos del siglo IV D.C., Heracles permaneció como un personaje que se adaptaba a las necesidades literarias de la época. Los discursos de Himerio, Libanio y la producción encomiástica del emperador Juliano atestiguan un uso retórico destinado a elogiar al emperador de turno. Temistio y los escritos filosóficos de Juliano, por otra parte, apuntan a un uso religioso y alegórico dentro del paganismo. Impregnando de ironía esa misma línea alegórica y filosófica, los autores cristianos se mofaron de Heracles por ser una figura ambivalente, cuyas representaciones y usos simbolizaron la mutabilidad y el cambio en el ambiente religioso y cultural de la Antigüedad Tardía.

\footnotetext{
${ }^{51}$ Bernardi 1983381.

${ }^{52}$ Gaeta 1954 232: "L'esegesi cristiana del mito, nei primi secoli, fece di Ercole un segno di contraddizione".

${ }^{53}$ Lugaresi 1997242.

${ }^{54}$ Sobre el recurso a este pasaje en algunos autores cristianos, Bernardi 1983289.
} 


\section{Bibliografía}

-P. Athanassiadi (1992), Julian: an intelectual biography. London: Routledge

-D.E. Aune (1990), "Heracles and Christ: Heracles imagery in the Christology of Early Christianity", en D.L. Balch-E. Ferguson-W. Meeks, W. eds., Greeks, Romans and Christians. Essays in Honor of Abraham J. Malherbe. Minneapolis, Fortress Press 3-19

-N. Belanche (2004), "Pagan Festivals in Fourth-Century Gaza”, en B. Britton Ashkelony-A. Kofsky, eds., Christian Gaza in Late Antiquity. LeidenBoston, Brill 5-22

-J. Bernardi (1983), Grégoire de Nazianze. Discours 4-5. Contre Julien. Paris, CERF

-P. Bernardini-R. Zucca (2005), Il Mediterraneo di Herakles: studi e ricerche. Roma, Carocci

-R.C. Blockley (1975), Ammianus Marcellinus. A study of his Historiography and Political Thought. Bruxelles, Latomus

-R.C. Blockley (1981-1983), The Fragmentary classicizing historians of the later Roman Empire: Eunapius, Olympiodorus, Priscus and Malchus. Liverpool, Cairns

-J. Bouffartigue (2002), "L'image politique de Julien chez Libanios", Pallas 60 175-189

-R. Browning (1952), "The riot of A.D. 387 in Antioch. The role of the theatrical Claques in the Late Empire", JRS 42 13-20

-P. Chuvin (1991), Mythologie et géographie dionysiaques. Recherches sur loeuvre de Nonnos de Panopolis. Clemont-Ferrand, Adosa

-A. Cizek (1975), "The function of the heroic myth in the encomium" en A.M. Hakkert, ed., Actes de la XIIe Conférence Internationale d'études classiques EIRENE. Bucarest, Academiei Republicii Socialiste Romania 295-305.

-S. Conti (2009), "Da eroe a Dio: la concezione teocrática del potere in Giuliano", AT 17 119-126

-R. Cribiore (2007), The School of Libanius in Late Antique Antioch. Princeton, Princeton University

-S. Deacy (2005), "Herakles and his "girl". Athena, heroism and beyond", en L. Rawlings-H. Bowden, eds., Herakles and Hercules. Exploring a GraecoRoman divinity. Swansea, The Classical Press of Wales 37-50

-J. Dobbins (2000), “The Houses of Antioch”, en C. Kondoleon, ed., Antioch: The Lost Ancient City. Princeton, Princeton University Press 50-61

-F. Gaeta (1954), “L' avventura di Ercole”, Rinascimento 5 227-260 
-G. Galinsky (1972), The Herakles Theme. Oxford, Basil Blackwell

-O. Hekster (2005), "Propagating power. Hercules as an example for secondcentury emperors", en L. Rawlings-H. Bowden, eds., Herakles and Hercules. Exploring a Graeco-Roman divinity. Swansea, The Classical Press of Wales205-221

-A. Karivieri (2001), "Mythological Subjects on Late Roman lamps and the Persistence of Classical Tradition", en J. Fleischer-J. Lund-M. Nielsen, eds., Late Antiquity. Art in Context. Copenhagen, Museum Tusculanum Press179-198

-C. Kondoleon (2000), "Mosaics of Antioch”, en C. Kondoleon, ed., Antioch: The Lost Ancient City. Princeton, Princeton University Press 63-77

-W. Liebeschuetz (1995), "Pagan Mythology in the Christian Empire", International Journal of the Classical Tradition 2:2 193-208

-A. López Eire (1996), Semblanza de Libanio. Ciudad de México, Universidad Nacional Autónoma de México

-L.Lugaresi (1997), Gregorio di Nazianzo. La morte di Giuliano l'Apostata. Orazione $V$. Firenze, Nardini Editore

-P.L. Malosse (1995), “Les alternances de 1'amitié: Julien et Libanios”, RPH 69:2 249-262

-P.L.Malosse (2002), “Orientation bibliographique sur Libanios”, Pallas 60 251-257

-P. Maraval (1995), "Antioch et l'Orient”, en J.-M. Mayeur-alii, eds., Histoire du Christianisme, vol. II. París, Desclée 903-920

-H. Mattingly (1952), “Jovius and Herculius”, HThR 45:2 131-134

-M.W. Padilla (1998), The Myths of Herakles in Ancient Greece. Survey and Profile. Maryland, University Press of America

-F. van der Paverd (1991), St. John Chrysostom. The homilies on the statues, Roma, Institutum Orientorum Studiorum.

-R. Penella (2000), The Private Orations of Themistius. Berkeley, University of California Press

-R.Penella (2007), Man and the Word. The Orations of Himerius. Berkeley, University of California Press

-F. Pfister (1935), "Herakles und Christus", Archiv für Religionswissenschaft 34 42-60

-Ma. L. Picklesimer Pardo (1981), La ascendencia indoeuropea de Herakles. Granada, Tesis Doctoral

-Ma . L. Picklesimer Pardo (1992), “Teseo, Herakles, y el cinturón de la amazona”, Florentia Iliberritana 3 503-516 
-M.J. Ponce (1998), "Menandro rétor y el discurso imperial” Habis 29 221-232

-E.A. Ramos Jurado (1998), "Mito y religión en la filosofía griega a finales del mundo antiguo", en J.L.Calvo Martínez, ed., Religión, magia y mitología en la antigüedad clásica. Granada, Editorial Universidad de Granada 221-237

-S. Rappe (2000), "Father of the Dogs? Tracking the Cynics in Plato's Euthydemus", CPh 95:3 282-303

-R. Rees (2005), "The Emperors' new names: Diocletian Jovius and Maximian Herculius", en L. Rawlings-H. Bowden, eds., Herakles and Hercules. Exploring a Graeco-Roman divinity. Swansea, The Classical Press of Wales 223-239

-C. Saliou (1999-2000), “Les fondations d'Antioche dans l'Antiochikos (Or. XI) de Libanios", Aram 11-12 357-388

-D. Sansone (2004), "Heracles at the Y", JHS 124 125-142

-B. Schouler (1984), La tradition hellenique chez Libanios. Paris, Les Belles Lettres

-M. Simon (1955), Hercule et le Christianisme. Paris, Les Belles Lettres

-E. Stafford (2005), "Vice or Virtue? Herakles and the art of allegory", en L. Rawlings-H. Bowden, eds., Herakles and Hercules. Exploring a GraecoRoman divinity. Swansea, The Classical Press of Wales 71-96

-J. Stenger (2009), Hellenische Identität in der Späntatike: pagane Autoren und ibr Unbehagen an der eigenen Zeit. Berlin-New York, W. de Gruyter

-F. Taeger (1960), Charisma. Studien zur Geschichte des Antiken Herrscherkultes. Sttutgart W. Kohlhammer Verlag

-S.A. Takács (2000), "Pagan Cults at Antioch", en C. Kondoleon, ed., Antioch: The Lost Ancient City. Princeton, Princeton University Press 198-216

-R. Talgman (2004), "The Ekphrasis Eikonos of Procopius of Gaza: the depiction of mythological themes in Palestine and Arabia during the Fifth and Sixth centuries", en B. Britton Ashkelony-A. Kofsky, eds., Christian Gaza in Late Antiquity. Leiden-Boston, Brill 209-234

-M.C. Waites (1912) "Some Features of the Allegorical Debate in Greek Literature", Harvard Studies in Classical Philology 23 1-46

-J. Wintjes (2005), Das Leben des Libanius. Rahden, Leidorf

-N.G. Wilson (1975), Saint Basil on Greek Literature. London, Duckworth

-M. Zetterholm (2003), The Formation of Christianity in Antioch. A social-scientific approach to the separation between Judaism and Christianity. London and New York, Routledge 


\title{
Mitología y Religión Romana EN LAS ACUÑACiones HISPANAS DEL SUR PENINSULAR ${ }^{\mathrm{I}}$
}

\author{
Ildefonso David Ruiz López \\ Universidad de Granada
}

\section{Introducción}

Los estudios sobre mitología y religión romanas siempre han contado con el interés de los investigadores del mundo clásico, que han intentado analizar y dar una explicación a los mitos y rituales religiosos a través de la Historia, la Antropología, la Lingüística o la Psicología. El investigador cuenta con una abundante cantidad de materiales y documentos clásicos para intentar explicar el complejo fenómeno cultural del mito o las manifestaciones religiosas asociadas al mundo romano. Además de las importantes aportaciones realizadas por la Arqueología o el estudio de las fuentes clásicas, también la Numismática intenta dar una explicación a la plasmación de muchos de estos mitos, creencias y rituales en las representaciones iconográficas que aparecen en las monedas.

En este trabajo vamos a realizar un estudio de los principales elementos iconográficos con relación a la mitología y religión romana que aparecen en las monedas del sur peninsular.

\section{Contexto histórico y monetario en el sur peninsular}

El espacio que nos ocupa estuvo poblado desde muy antiguo por gran cantidad de pueblos y culturas, como la fenicia o la ibérica, que tenían sus propias creencias y manifestaciones religiosas. Pero en el año 218 a. C. se produjo un acontecimiento de vital importancia para la historia de la península Ibérica, como fue el desembarco de las tropas romanas en Ampurias con el propósito inicial de cortar las líneas de abastecimiento cartaginesas a Aníbal, que se encontraba en Italia logrando sus primeras victorias, y de ayudar a los indígenas a expulsar a los cartagineses de la Península, su principal centro económico y humano. Precisamente esta abundancia de recursos con la que contaba la península Ibérica, especialmente de minerales y riquezas agropecuarias, provocará que el senado romano, una vez terminada la Segunda Guerra Púnica, decida consolidar sus posiciones en estos territorios. Para ello se inicia un proceso de conquista y anexión que durará, como consecuencia de una fuerte resistencia de los pueblos del interior y de una mala administración de algunos gobernadores romanos, casi dos siglos.

Durante este periodo en Hispania, nombre con el que los romanos denominaban los territorios que controlaban en la península Ibérica, 
se produjo una progresiva aculturación -en mayor o menor medida- de los territorios que iban siendo conquistados y su evolución hacia formas y modos de vida eminentemente romanos, lo que conocemos como "romanización" 2 . Este concepto se entiende como el proceso por el cual los distintos pueblos de la península Ibérica asimilaron las estructuras políticas, sociales, económicas, ideológicas, culturales y religiosas romanas. Cuando los romanos llegaron a la Península, se encontraron con comunidades que tenían panteones diversos (griego, fenicio e indígena), y, ya desde los inicios, Roma intentó un proceso de sincretismo y asimilación religiosa entre los dioses romanos y los locales. La difusión de la religión romana estuvo muy vinculada a la expansión de los derechos de ciudadanía romana o latina. Sin embargo, la mayor parte de las ciudades estipendiarias siguieron venerando a sus dioses tradicionales ${ }^{3}$.

En cuanto al contexto monetario, podemos decir que, pese a que contamos con la presencia de numerario con anterioridad a la llegada de los romanos a la península Ibérica (algunos ejemplares griegos, fenicios y cartagineses), no será hasta la Segunda Guerra Púnica y sobre todo durante el periodo romano-republicano cuando se extienda el uso de la moneda. Además de la gran cantidad de moneda romano-republicana que comienza a llegar para la explotación de la Provincia Hispania Ulterior, durante estos dos siglos más de doscientas ciudades hispanas van a emitir moneda.

En sus primeras emisiones las ciudades del sur peninsular recibieron por parte de Roma una cierta libertad en cuanto a la escritura, tipología y metrología que debían utilizar, por lo que al principio muchas de ellas acuñaron con escritura, tipología y metrología propias de los hábitos culturales de la ciudad (fenicios, ibéricos, etc.). Una de las pocas limitaciones que Roma va a imponer va a ser la de emitir moneda de plata, pese a encontrarnos en un territorio con ricas minas de este metal. La mayoría de las emisiones del sur de la Península se van a producir en las zonas más urbanizadas, con mayores riquezas mineras, fértiles valles fluviales, importantes puertos costeros o principales vías de comunicación, que serán, a su vez, las zonas en las que encontramos una mayor circulación monetaria.

Con el final de la guerra sertoriana, Roma decide limitar y unificar las emisiones hispánicas, por lo que comienza a desaparecer la escritura indígena a favor de la latina, la metrología se va adaptando progresivamente al patrón romano y en la tipología abundan cada vez más los emblemas metropolitanos. De hecho, se puede ver cómo la representación de dioses romanos como Júpiter, Apolo, Mercurio o Vulcano adquiere mayor presencia en las acuñaciones de estas cecas. Por todas estas limitaciones muchas cecas dejarán de emitir y sólo perdurarán aquéllas que tenían mayores circuitos económicos. 
A partir de la reforma monetaria de Augusto, la mayoría de cecas hispanas dejan de emitir moneda y sólo encontramos pocas ciudades que lo hagan, pues para poder acuñar moneda en este periodo debía pedirse un permiso al senado romano y éste sólo lo concedía a aquellas ciudades que poseían el estatuto de colonia o municipio (Acci, Carteia, Romula, Italica, Colonia Patricia, Sagunto, Tarraco, Celsa, Osca...). La característica principal de estas cecas es que ya utilizaban escritura, tipología y metrología propiamente romanas. El cierre de los talleres monetarios hispanos se sitúa a finales del reinado de Calígula, con quien ya se constata un descenso significativo en el número de cecas en funcionamiento.

Pasemos a continuación a describir las principales representaciones iconográficas con elementos de la mitología y la religión romana que aparecen en las acuñaciones del sur de la península.

\section{Cecas con iconografía mitológica o religiosa romana}

Abdera: ciudad de origen fenicio situada en la desembocadura del río Adra, en Almería, concretamente en el Cerro de Montecristo. Emitió tres series monetales, las dos primeras en época republicana y la tercera en época de Tiberio.

En general vemos cómo la iconografía de esta ceca presenta similitudes con otras cecas fenicias como Gadir, Malaka o Sks, con representaciones de la triada púnica: Ba'al-Hammon, Melkart y Tanit. Sin embargo, en las series II (V.81.2-4) y III (V.124.1-3) observamos la presencia de un gran templo tetrástilo de época romana, aunque todavía pervive un sustrato púnico en el sol que aparece dentro del tímpano. En la tercera serie, en la que aparece la cabeza de Tiberio, vemos cómo dos de las columnas del templo son sustituidas por dos atunes, posiblemente también en alusión de un dios local protector de las pesquerías y salazones.

Abla: ciudad púnica entre los bastetanos, situada en el interior de la provincia de Almería, en un punto estratégico que unía Urci con Acci. Esta ciudad sólo acuña una escasa serie en bronce, posiblemente en el siglo I a. C., con el topónimo púnico 'lbt'.

Aunque en los duplos y en algunas mitades aparece la representación de Melkart con clava, en otras mitades aparece en anverso una posible representación de cabeza de Vulcano con bonete y detrás unas tenazas (V.120.1), y en los hemicalcos una posible cabeza de Mercurio -que también podría pertenecer a Chusor o Ptah-. En los reversos de los hemicalcos también encontramos la presencia de un caduceo junto a la leyenda neopúnica de la ciudad. La representación de Vulcano está en clara relación con los trabajos 
de minería que se desarrollaban en la zona, mientras que la representación de Mercurio o Hermes se identifica con el importante papel de la ciudad en la comercialización y exportación del mineral de la zona.

Brutobriga: ciudad portuguesa situada entre Santarém y Abrantes. Esta ciudad fue fundada por el cónsul Décimo Junio Bruto Galaico hacia el año 135 a. C. en el contexto de las guerras lusitanas. Emitió una única serie de bronces con muy buena factura y una cronología de la segunda mitad del siglo II a. C.

Aunque en la iconografía de la única emisión de esta ceca (V.118.1) no encontremos representaciones religiosas en sí, sí tenemos elementos de referencia hacia la fundación de la ciudad, algo que en estos momentos también tendría una implicación religiosa, ya que haría referencia al nacimiento de dicha ciudad y a su protección. En los anversos de los ases de esta serie aparece una cabeza masculina y la leyenda $T \cdot M A N L I V S T \cdot F \cdot S E R G L A$, lo que ha dado lugar a diversas interpretaciones, pues para algunos autores será una representación de la cabeza de Pompeyo mientras que para otros sería el legatus propraetore Titus Manlius Sergianus, quien se habría encargado de la refundación de la ciudad en época postcesariana ${ }^{4}$. La nave que aparece en el reverso podría hacer alusión a la gente de la costa a la que asentó allí Decimo Junio en su fundación.

Carbula: oppidum situado en Almodóvar del Río, Córdoba, que emitió tres series de bronce desde mediados del siglo II a. C. hasta principios del siglo I a. C.

En las tres series de esta ceca vemos elementos con clara alusión al dios Apolo, pues en todos los reversos de los duplos, ases y semises aparece la lira como elemento principal del reverso junto al topónimo de la ciudad. Además, en los ases (V.113.2-3) y semises de la tercera serie, acuñada a principios del siglo I a. C., observamos una cabeza apolínea con tirabuzones (fig. 1). E1 peinado con tirabuzones que presenta el dios Apolo en esta ceca, así como en Salpesa, Castulo u Obulco, es similar al encontrado en denarios romanos como el de L. Piso Frugi (RRC. 240 de 90 a. C.) o Mn. Fontei (RRC. 353 de 85 a. C.). En el resto de emisiones, en anverso aparecen, en los duplos (V.113.1) de la serie I una cabeza masculina con creciente y en los ases (V.113.4) y semises (V.113.5) de la serie II, una cabeza femenina con moño (Tanit) similar a la que aparece en cecas como Ulia y Obulco.

Carmo $^{5}$ : fue una de las ciudades más importantes de la Turdetania. La ciudad se asienta sobre una meseta escarpada en el extremo septentrional de la región de Los Alcores sevillanos, en el término de Carmona. Su ceca emitió cinco series de bronce, que van desde la primera mitad del siglo II a principios del siglo I a. C. 
En esta ciudad encontramos varios elementos iconográficos con clara alusión a la mitología y a la religión romana. Entre ellos tenemos varias muestras de cabezas femeninas con casco muy similares a la representación de Roma, como por ejemplo en los ases de la serie II, grupo 2 (V.100.2) o en los ases de la serie II, grupo 1 (V.100.3), en los que del casco surgen incluso las alas y los mechones de pelo. Además, observamos la representación de una cabeza de Mercurio con petaso y detrás caduceo en los ases de la serie II, grupo 3 (V.100.1); y en los cuadrantes de la serie I, grupo 2 (V.100.8) y de la serie II, grupo 3 (V.100.7) aparece en anverso cabeza de Mercurio y en reverso caduceo (fig. 2). Aunque tradicionalmente se ha aceptado que esta cabeza masculina con petaso se trataría de Mercurio, también podríamos entender que se trata de una asimilación de un dios púnico a este dios romano. Este hecho podría pasar igualmente en cecas como Carteia, Ilipula Halos o Urso. Por otra parte, encontramos en los ases de la serie III (V.101.8-12) una representación de Hércules como dios protector de la vegetación y de la agricultura que para Rodríguez Mérida ${ }^{6}$ sería de Juno Sospita, por considerar que la cubierta que tiene el personaje sería una piel de cabra. Lo mismo piensa este autor en los casos similares de Searo y Callet. Sin embargo, nosotros creemos que se trataría de una piel de león, como en otras representaciones de Hércules que encontramos en esta ceca, en las que aparece con un atributo muy propio de este dios como es la maza (V.101.6). Otras posibles representaciones de Hércules, aunque en este caso sin leonté ni maza sino con delfín, serían las de la serie IV grupo 1 (v.101.1-4). Para terminar, diremos que existen unas posibles representaciones de cabeza de Marte, dios de la guerra, en los ases de la serie I (V.100.4-6), en los que encontramos una cabeza masculina con casco de penacho, aunque sin una clara atribución, pues para algunos autores se trataría de una Tanit en su faceta guerrera o de un dios indígena asimilado. Por último, una representación de cabeza con casco frigio podría referirse bien a Cibeles, o bien, en el caso de ser una divinidad púnica, a una Tanit con gorro lusitano.

Castulo: la ciudad ibero-romana de Castulo se sitúa en la actual Cazlona, a unos siete kilómetros de Linares, Jaén. Durante el periodo ibérico fue una de las ciudades más importantes de la Península Ibérica, y durante el periodo romano, aunque pierde cierta relevancia, contó con una de las cecas más prolíficas de Hispania. Esta ciudad emitió diez series en bronce, con una cronología entre el año 220 y el 45 a. C., cuyas piezas tuvieron una amplia dispersión y circulación, tanto en la provincia Hispania Ulterior como fuera de este territorio.

La ceca de Castulo mantuvo durante mucho tiempo en sus acuñaciones su iconografía y escritura ibéricas, aunque en sus últimas emisiones, ya en el siglo I a. C. observamos una influencia romana en su iconografía y escritura. En lo que respecta a la iconografía, encontramos la presencia del mito del rapto de 
Europa junto a tipologías de época anterior (fig. 3). También encontramos ya nombres de magistrados monetales con grafía latina, lo que nos hace pensar que los grupos oligárquicos de la ciudad al principio pactan con Roma el control del gobierno local y poco a poco comienzan a latinizarse. El mito del rapto de Europa lo encontramos en los reversos de los ases de la serie IX (V.71.14), acuñados entre los años 80 y 45 a. C. La representación de este mito consistiría en un toro corriendo a derecha y encima figura femenina, que reproduciría el tema clásico en el que Europa es raptada por un toro blanco que sería JúpiterZeus. Además, en los semises de esta misma serie (V.71.8-13) observamos la presencia de un toro parado que también se asocia a esta legendaria princesa fenicia amada por Júpiter.

Celte: oppidum prerromano localizado en la ciudad de Peñaflor, Sevilla. Emite una sola serie en bronce con la característica especial de que en sus monedas aparece tan sólo el nombre del étnico CELTITAN.

En la única emisión de esta ceca encontramos cabeza femenina laureada o diademada en anverso y un gran jabalí sobre punta de lanza en el reverso (V.116.1). No se sabe a ciencia cierta si la cabeza podría representar alguna divinidad, pudiendo ésta corresponder a Ataecina, deidad hispana con clara vinculación a la Proserpina romana, o en opinión de otros autores, a una Astarté o Tanit. Lo que sí sabemos que tendría un cierto carácter de simbolismo religioso es el jabalí, que ya aparece en representaciones del sur de Italia como en la ciudad de Arpi (Foggia Apulia). El jabalí en Hispania también ha sido adorado como un animal funerario por excelencia, relacionado con la clase sacerdotal y que podría evocar a una divinidad del mundo céltico. El jabalí, además de en esta ceca, aparece también en las de Asido, Ilipula Halos, Lascuta, Lastigi, Obulco, Ostur o un tipo que presenta jabalí y clava encima. Relación con el mundo céltico también podría tener la lanza que aparece debajo del jabalí, que podría asociarse al dios celta Lug.

Cerit: ciudad situada en la sierra de Gibalbín, en las cercanías de Jerez de la Frontera, Cádiz. Emitió dos series en bronce con una cronología de la primera mitad del siglo I a. C.

En la primera emisión de esta ceca (V.103.1) encontramos en anverso cabeza radiada con moño detrás, que estaría más en consonancia con la tipología púnica, no perteneciendo a Helios como algunos autores apuntan. Sin embargo, ya en la segunda emisión (V.103.2) observamos una cabeza laureada que presentaría influencias romanas. Este paso de lo púnico a lo romano podemos verlo también en el uso de patrones metrológicos, pues los pesos de la primera emisión son eminentemente púnicos, mientras que en la segunda emisión ya se utiliza el as semiuncial romano, muestra de los efectos 
de la romanización que sufrieron las comunidades púnicas asentadas en la zona costera.

Colonia Carteia ${ }^{7}$ : ciudad de origen fenicio situada en el Cortijo del Rocadillo, en San Roque, Cádiz. Fue una ciudad que contó con una excelente posición estratégica que le permitió desde muy pronto ser una de las principales potencias comerciales de la zona del Estrecho, tal como demuestra, por ejemplo, el hecho de ser la ciudad del sur peninsular que más emisiones acuñó, en concreto treinta, en el periodo que va del año 130 a. C.al 15 d. C. Las primeras veinticinco series corresponden al periodo republicano y las cinco restantes al imperial.

Sin duda alguna, una de las cecas que más elementos referidos a divinidades y símbolos religiosos romanos va a incluir en su iconografía va a ser la de Carteia. Entre sus representaciones tenemos aquellas referidas a Júpiter-Saturno (varios ejemplos en V.126, 127 y 129), que aparece junto a símbolos como el haz de rayos, delfín y proa de nave. Este es uno de los tipos más repetidos en esta ceca y aparece en veinticinco de sus treinta series. También contamos con varias representaciones de Neptuno-Poseidón, como la que aparece con cabeza barbada y diademada llevando tridente y con delfín en el reverso (V.128.10) o la que aparece de pie, con tridente y delfín y apoyando la pierna sobre una roca, con figura femenina torreada en el reverso (V.129.2). Esta figura femenina torreada también es una representación muy frecuente en esta ceca, y podría corresponder a una representación de Cibeles, pues aunque la cabeza torreada se suele interpretar como la Tyche de la ciudad, en el caso de Carteia parece tomado de la amonedación romana. En esta ceca suele aparecer junto a los cupidos, que navegan sobre un delfín (V.128.11-13), con tridente que simbolizaría la adhesión de la colonia al dios del mar (V.129.1), junto a clava, arco y carcaj (V.128.1), junto a timón (V.128.5-7 y 14), junto a delfín (V.128.8), junto a pescador (fig. 4), que podría representar el recuerdo de algún mito local (V.128.9 y 129.3-4), junto a haz de rayos (V.129-1) y junto a Neptuno en pie (V.129.2). Otra posible representación relativa a una deidad sería la cabeza femenina galeada, que se ha asociado a Minerva (V.127.10 y 129.7). Una representación que aparece en cuatro series sería la de Hércules con piel de león y al que puede acompañar delfín (V.126.3), clava (V.129.6 y una inédita de Chaves) o proa (V.129.13). También encontramos la representación de un busto de Victoria con cabeza desnuda, que mira a la derecha y tras cuyo hombro se deja ver un ala (V128.3). Por último, encontramos una cabeza con peinado de tirabuzones, que se ha identificado con Apolo por la lira que aparece en el reverso (V.128.4). Este instrumento musical, más que una lira, podría ser, por su forma, una vieja cítara llamada phorminx. 
Por lo que respecta a los símbolos de clara influencia romana que aparecen en esta ceca, tenemos un haz de rayos, que aparece sin alas junto a la cabeza de Júpiter-Saturno (V-126.1 y 4) o junto a una cabeza de Mercurio (V.126.2) y con alas junto a cabeza femenina torreada (V.129.1). Un petaso alado, posible símbolo asociado al dios Mercurio, aparece junto a haz de rayos (V.126.2). El delfín es un símbolo que aparece con bastante frecuencia, junto a JúpiterSaturno (V-126.5-6 y 9-13 y V.127.4, 8-9, 12-14), junto a Hércules (V.126.3) o junto a cabeza femenina torreada (V.128.8) También puede aparecer junto a un tridente (V.124.5) o montado por un Cupido (V.128.11-13). Otro símbolo que aparece con bastante frecuencia es la cornucopia sobre haz de rayos (V.126.7) o sola (V.128.3). Dos símbolos marítimos que aparecen en esta ceca son el timón, junto a cabeza torreada (V.128.5-7 y 14), junto con delfín y tridente (V.129.5) y con cabeza galeada (V.129.7), y la proa, junto a cabeza de Júpiter-Saturno (V.126.1-3, 5-8 y 14 y 129.9-12). Por último, encontramos la presencia del caduceo en dos reversos, uno alado con anverso de cabeza femenina torreada (V.127.2) y otro con anverso con petaso alado (V.129.8).

Colonia Iulia Gemella Acci: colonia de derecho latino proyectada por César como colonia tras la batalla de Munda pero que tras los idus de marzo no pudo ser concluida hasta época de Augusto. Durante el principado esta ciudad pasó a estar bajo el control de la Tarraconense. La ceca acuñó cinco emisiones, dos con Augusto, dos con Tiberio y una durante el reinado de Calígula.

En la iconografía de esta ceca prevalecen emblemas claramente imperiales, y muestra de ello es la presencia en los anversos de las piezas de cabezas de emperadores como Augusto, Tiberio y Calígula y en los reversos de miembros de la familia imperial como Germánico y Druso. Además de las famosas insignias militares que aparecen en los reversos, y a veces en los anversos de estas monedas, encontramos varios símbolos religiosos o sacerdotales en los reversos de los semises de la segunda, cuarta y quinta emisiones. Estos símbolos sacerdotales indican la presencia de augures, arúspices y pontífices que habrían sido en un principio los encargados de la fundación de la colonia y que serán después los encargados del culto de la ciudad. Así, en la serie II encontramos símbolos como el apex y el simpulum, y en la IV y V el apex, el lituus y el simpulum. En cuanto al significado de estos símbolos sacerdotales, el simpulum de la serie II haría alusión al acceso de Augusto al puesto de Pontífice Máximo en el año 12 a. C.y en los restantes al acceso a dicho puesto de Tiberio y de Calígula. En cuanto al lituus o bastón de forma curva, era un elemento distintivo que se utilizaba para delimitar el espacio sagrado de la ciudad. Por último, el apex o gorro flamíneo era una especie de tocado que presentaban los sacerdotes de la ciudad. 
Colonia Iulia Romula Hispalis: antiguo oppidum localizado en la actual Sevilla, al que posteriormente Julio César, hacia el año 45 a. C., otorga el estatuto de colonia. Fue una de las ciudades más importantes de la Turdetania junto a Corduba y Gades. Emite una serie durante el reinado de Tiberio.

Como todas estas cecas hispano-romanas de emisiones tardías, la Colonia Iulia Romula Hispalis va a presentar una iconografía eminentemente romana, pues para emitir en estos momentos haría falta pedir un permiso del Senado, que éste solo otorgaba a aquellas ciudades que poseían el estatuto de colonia o municipio y que utilizaban escritura, tipología y metrología propiamente romanas. En la única serie de esta ceca podemos observar que en los dupondios (V.167.2), junto a la cabeza de Augusto del anverso, aparece un haz de rayos y estrella, que sería símbolo de poder de este emperador. Bajo la cabeza de Livia que aparece en el reverso de estas monedas aparece también un orbe y un creciente, que junto a los símbolos que aparecen en los cuadrantes (V.167.1) como cornucopia, timón y globo, la identifican como Cibeles-Magna Mater, Dea Caelestis y Venus, posiblemente en alusión a algún culto local pre-imperial. Por último, habría que destacar la presencia de la leyenda PERM DIVI AUG $C O L R O M$, fórmula con la que se hace alusión a que se ha conseguido el permiso para acuñar, o el escudo que aparece en los reversos de los semises (V.167.4) que se referiría a los triunfos militares de Germánico.

Colonia Iulia Traducta: ciudad posiblemente situada en la actual Tarifa, Cádiz, fue fundada por Augusto entre los años 33 y 27 a. C. con población procedente de las ciudades norteafricanas de Tingi y Iula Constantia Zilil. Acuña dos emisiones durante el periodo de Augusto, quizá entre los años 12 y 2 a. C.

En estas dos emisiones, con una clara prevalencia de la iconografía romana, vemos que en los anversos y en algún reverso aparecen personajes romanos como Augusto o Cayo y Lucio. En cuanto a los elementos religiosos que aparecen en las monedas de esta ceca, tenemos la presencia del simpulum, que haría alusión al acceso de Augusto al puesto de Pontífice Máximo en el año 12 a. C.; el lituus o bastón de forma curva, distintivo del augur, que le servía para señalar un espacio sagrado; la jarra ritual de sacrificio; el aspergillum, que era un símbolo del pontificado y que se utilizaba para esparcir el líquido purificador sobre el altar o los asistentes a la ceremonia; la pátera, un pequeño plato de bronce utilizado en las ceremonias religiosas; o el gorro flamíneo o apex, tocado que presentaba el sacerdote encargado del culto. Finalmente, también observamos otros elementos como el racimo de vid, la espiga o el atún, aunque éstos serían más bien símbolos de la cultura púnica.

Colonia Pax Iulia: ciudad lusitana localizada en la actual Beja, en Portugal. Se desconoce si fue fundada por César o por Augusto. Su ceca acuñó una única 
serie de ases durante el principado de Augusto, quizá como conmemoración de la visita del Emperador o con motivo de la fundación de la colonia.

En los anversos de esta emisión aparecerá una cabeza de Augusto, mientras que en los reversos de los ases encontramos una figura con claras referencias religiosas, que podría simbolizar una Felicitas sentada sosteniendo un caduceo y una cornucopia (V.167.1-2), y en los reversos de unos posibles dupondios aparece la figura de pie, sosteniendo ambos elementos.

Corduba Colonia Patricia ${ }^{8}$ : ciudad localizada en la actual Córdoba, en un punto estratégico del valle medio del Guadalquivir. Durante la etapa romana fue capital de la provincia Hispania Ulterior en el periodo republicano y capital de la Baetica en el Imperio. En el año 46 a. C. los hijos de Pompeyo otorgaron a la ciudad el estatuto de colonia, pasando a denominarse la ciudad a partir de este momento como Colonia Patricia. Algunos autores atribuyen este estatuto colonial a Julio César o al propio Augusto. Emitió cinco series en bronce, cuatro durante el periodo republicano con el topónimo CORDUBA y una en época augustea con el nombre de Colonia Patricia.

En esta ceca hay que diferenciar por un lado aquellas emisiones republicanas y por otro lado la imperial. Dentro de las primeras, debemos mencionar que la cabeza femenina (V.118.1-4) que aparece se ha asociado a Juno, aunque la mayoría de autores ha venido reconociendo en esta figura la cabeza de Venus, pues en ella encontramos una diadema al estilo helenístico y detrás de su oreja penden dos rizos (fig. 5). Apoyaría esta teoría la presencia en el reverso de un Eros o Cupido de pie alado mirando a la izquierda, desnudo, llevando una cornucopia en su mano izquierda y una antorcha en la derecha. Se trataría, por tanto, de la única representación de la diosa Venus que encontramos en Hispania ${ }^{9}$. Por otra parte, en la serie acuñada durante el principado de Augusto encontramos, además de la representación de la cabeza de Octavio, varios símbolos sacerdotales como el apex y el simpulum de los semises (V.165.4 y 6) o la pátera, el aspergillum, la jarra y el lituus de los cuadrantes (V.165.7-8). El significado de estos símbolos sacerdotales ha sido ya descrito en otras cecas anteriores. Por último, en los dupondios de esta serie hallamos un águila entre dos insignias militares (V.165.2).

Ilipula Halos: aunque la localización de esta ciudad es controvertida, se piensa que la ciudad que emitió las piezas que presentan en anverso Cabeza de Mercurio con petaso alado y caduceo y en reverso Jabalí (fig. 6) podría tratarse de la localizada en el Cortijo de Repla, en los Corrales a $20 \mathrm{~km}$. de Osuna, Sevilla.

Como podemos ver, en las monedas acuñadas por esta ceca encontramos bastantes influencias de la iconografía romana, como son la cabeza de Mercurio 
con petaso y caduceo, que aparecen en los anversos, o el jabalí, que aparece en el reverso y que, como ya dijimos en el caso de la ceca de Celte, es un símbolo con un claro componente religioso y funerario.

Iptuci: ciudad púnica en la zona turdetana situada sobre una alta colina en Cabezo de Hortales, en Prado del Rey, Cádiz. Emitió dos series en bronce durante el siglo I a. C. con leyenda en escritura libiofenicia.

La iconografía de las dos series de esta ceca habrá que diferenciarlas en dos grupos, por un lado aquellas piezas que presentan en anverso cabeza masculina barbada y diademada (V.93.1-2), que algunos interpretan como una representación del dios romano Júpiter, aunque nosotros nos inclinamos a pensar que sería una representación del dios púnico Ba’al-Hammon (fig. 7); y por otro lado aquellas monedas que presentan en anverso cabeza de Melkart con piel de león (V.93.3-4), y que, en este caso, pensamos que se trataría también de una representación púnica, la más primigenia, que lo representaría como protector del mundo agrario más que como un guerrero.

Irippo: sin una localización determinada, se piensa que esta ciudad pudo situarse en un espacio comprendido entre el río Guadalquivir y el río Guadalete, y dentro del triángulo compuesto por los municipios sevillanos de Lebrija por el oeste, El Coronil por el este y San Juan de Aznalfarache por el norte. Emitió dos series en bronce con una cronología del siglo I a. C.

Como ya dijimos anteriormente refiriéndonos a otras cecas, las monedas de Irippo presentan en anverso una cabeza masculina que algunos autores identifican con Augusto. En el reverso de la primera serie (V.110.1 y 3-6) vemos la representación de una divinidad femenina sedente con posible influencia romana, que sostiene en su mano izquierda una cornucopia y en la derecha una piña. Esta figura podría hacer referencia a una deidad protectora de la agricultura como la Fortuna o la Felicitas (fig. 8). Para algunos investigadores esta figura tendría influencias púnicas, por lo que podría corresponder a una Astarté o Tanit, pues la piña, en muchas representaciones norteafricanas, aparece relacionada con esta deidad. Además, junto a la silla de esta divinidad encontramos la presencia de un quemaperfumes, un elemento muy cercano al ámbito religioso. La segunda serie de esta ceca presenta monedas híbridas, con anverso de la ceca de Irippo y reverso de la de Osset. La cabeza del anverso es muy tosca, y en reverso encontramos figura femenina desnuda con racimo de uvas en la mano derecha, que no sabemos si correspondería a una divinidad romana o a una Tanit púnica.

Laelia: esta ciudad puede ser localizada en el Cerro de la Cabeza en Olivares, Sevilla, en el Aljarafe sevillano y junto al río Guadiamar. Emite tres 
series en bronce con una cronología entre la primera mitad del siglo II a. C. y el siglo I a. C.

En las unidades de la serie I de la ceca de Laelia encontramos en anverso una cabeza femenina con casco muy similar a la representación de Roma (V.103.4 y 6). En los semises de la serie II (V.103.9) encontramos una cabeza masculina que parece estar radiada, por lo que podría corresponder a una representación de Helios. Sin embargo, esta interpretación presenta todavía muchas dudas. También llaman la atención los semises de la serie III (V.103.2), en los que aparece una cabeza masculina con laurea, que a veces se ha identificado con Augusto. La laurea será muy usada en el mundo romano, y en algunos casos concretos tiene una lectura claramente religiosa.

Lastigi: esta ciudad está localizada en el despoblado de Los Merineros, cerca del municipio de Aznalcóllar, en Sevilla. Emite tres series en bronce con una cronología desde la segunda mitad a finales del siglo II a. C.

En los ases, semises, cuadrantes y sextantes de la serie I de esta ceca (V.104.1-4) encontramos en los anversos una cabeza galeada con cimera rodeada de gráfila vegetal, que algunos investigadores interpretan como una posible representación bien de Marte, bien de una divinidad púnica como una Tanit guerrera. La cabeza que aparece en los anversos de la serie II quizá podría corresponder a una representación de Hércules-Melkart, aunque sin atributos.

Malaka: antigua ciudad fenicia fundada por los tirios, con una gran importancia comercial en el periodo prerromano. Durante la época romana fue una ciudad federada y no alcanzará el estatuto de municipium hasta época flavia. La ceca emite siete series monetales en bronce, con una cronología desde finales del siglo III a. C. hasta finales del siglo I a. C.

En la primera emisión de la ceca de Malaka (V.87.12-13) observamos en anverso una cabeza imberbe tocada con un petaso y en reverso una estrella, que aún hoy tiene una difícil interpretación. Sin embargo, las cabezas masculinas barbadas y tocadas con bonete cónico o cilíndrico que aparecen en las siguientes tres series siempre se han interpretado como representaciones de HephaistosVulcano (V.85.1, 6-7, 86.6-7, 10-15, 87.1-8, 14-15), debido sobre todo a las tenazas que aparecen detrás. Las tenazas siempre se han considerado símbolo de esta divinidad asociada a la metalurgia, aunque Mora Serrano se ha planteado que en este caso, más que ser símbolo de una divinidad harían alusión a la importancia del comercio de metales en esta ciudad (posible representación de la divinidad púnica Ba'al-Hammon). Por tanto, las interpretaciones como Hephaistos o Vulcano sólo tendrían un carácter sincrético, más teniendo en cuenta que las representaciones tienen un estilo más helenístico que romano. En cuanto a las representaciones de los reversos de estas tres series, 
encontramos un busto radiado de frente, que siempre se ha asociado al dios Helios-Sol (V.85.1, 6-7, 86.6-7, 10-15, 87.1-8, 14-15). En este caso, Mora Serrano también plantea que esta representación podría hacer alusión al culto a un dios púnico (Tanit-pnè-Ba’al) al que se habrían incorporado elementos estilísticos romanos más en consonancia con las corrientes culturales y artísticas del momento. En la quinta y sexta emisiones encontramos representación en anverso de una cabeza imberbe de Cabiro (V.85.9-13), que siguiendo la línea argumental anterior podría pertenecer a un dios púnico, al igual que puede suceder con las representaciones de Cabiro-Dioscuro (V.85.8) que aparecen en los semises de la serie VII, que podrían corresponder a divinidades púnicas como Ba'al-Hammon o Reschef-Melkart. Finalmente, en los reversos de los cuadrantes de las series $\mathrm{V}$ y VI encontramos la representación de un templo tetrástilo (V.85.4 y 86.1-4), que haría alusión al templo de Malaka en el que se rendiría culto a los dioses de la ciudad. Pensamos que en Malaka, desde época púnica, se rendía culto a su tríada de dioses: Ba’al-Hammon, Melkart y Tanit, pero que en algún momento, como consecuencia de la romanización, este culto se habría sincretizado con el romano, dando lugar a un tipo de representaciones de dioses púnicos pero con atributos romanos, como vemos por ejemplo en el caso de Vulcano-Hephaistos.

Municipim Salacia Urbs Imperatoria: factoría fenicia situada en la fachada atlántica de Portugal, localizada en la hoz del río Sado, en Santa Maria do Castelo, Alcácer do Sal, Distrito de Setúbal. Emite nueve series en bronce entre la segunda mitad del siglo II a. C. y mediados del siglo I a. C., las primeras ocho con escritura sudlusitana, en las que se lee el topónimo ke.t.o.u.i.bo.n. En la última serie aparece la abreviatura del topónimo latino Salacia Urbs Imperatoria. A esta ciudad César le concedió el estatuto privilegiado de municipio con derecho latino, y posteriormente, con Sexto Pompeyo, se le añade el cognomen latino.

En las primeras emisiones sudlusitanas de esta ceca vamos a encontrar en los anversos representaciones de Melkart-Hércules con dos tipologías diferentes, una con leonté y clava, al estilo gaditano, y otra con cabeza barbada y laureada, más al estilo africano. A estas representaciones acompañan en reverso bien dos atunes o bien dos delfines, y en medio la leyenda sudlusitana. Por lo que respecta a la serie IX, en la que aparece el topónimo IMP SAL (V.84.9-11) encontramos en anverso una cabeza masculina barbada con tridente detrás que presenta similitudes con el Neptuno representado en la ceca de Carteia. A esta divinidad acompañan en reverso dos delfines en las unidades y uno en las mitades.

Municipium Firmum Iulium Sexi: antigua fundación fenicia constatada arqueológicamente en el siglo VIII en el Cerro de San Cristóbal, en Almuñécar, 
en la costa granadina. En época romana, en esta ciudad se establecieron varias factorías de salazones, como la de El Majuelo, y así en época de César obtendrá un estatuto privilegiado de municipium, pasando a denominarse Firmun Iulium. La ceca emite seis series en bronce, que irían desde finales del siglo III a. C. hasta un periodo posterior a César, posiblemente después del año 49 a. C., pues ya aparece su estatus de municipium.

El tipo más frecuente en los anversos de las monedas de esta ceca será la cabeza de Melkart-Hércules, al principio con cabeza desnuda y clava, aunque después tomará importancia la representación del tipo gaditano, más helenizada, con leonté y clava. Sin embargo, la tercera emisión presenta una mezcla de elementos púnicos y romanos. Así, en las unidades de esta serie encontramos en anverso, bien cabeza de Melkart barbado, bien una cabeza femenina galeada que se podría interpretar como de Minerva o Marte, pero que creemos que podría pertenecer mejor a una Astarté-Tanit galeada (V.82.9). Este último grupo presentará en reverso una proa, posible alusión a la faceta marítima de la ciudad. Además de en las unidades, observamos esta cabeza femenina galeada también en mitades y en cuartos, presentando en reverso las primeras un toro (V.82.10) y las segundas un delfín (V.82.12). La serie $\mathrm{V}$ de esta ceca también presentará esta cabeza galeada en los anversos de sus mitades, que muestran en reverso un atún (V.83.12-13), y en sus cuartos, que muestran en reverso una cornucopia (V.83.14-15).

Municipium Gades $^{10}$ : antigua ciudad fenicia fundada por los tirios en el año 1104 a. C. Primitivamente la ciudad ocupaba una pequeña isla al norte de la actual Cádiz, llamada Aphrodisias o Insula Iuninis, aunque en época romana Balbo el Menor amplió la ciudad hacia la isla vecina de Kotinoussa, además de hacia la isla vecina de León, en la que se creó una Antípolis y un astillero (Portus Gaditanus) en la costa de la bahía. Esta ciudad emite siete series monetales, de las que seis son en bronce y una en plata, con una gran cantidad de grupos y piezas y una importante circulación monetaria. Las series más antiguas pertenecen al siglo III a. C. y la última serie se acuña ya en época imperial, durante el principado de Augusto, y en ella aparecen nombres de personajes ilustres como Agripa, Balbo, Tiberio, Augusto o Cayo y Lucio.

La iconografía por excelencia de esta ceca será la representación de Melkart-Herakles-Hércules en anverso y atún o atunes con diferentes leyendas púnicas en reverso. En algún caso el atún será sustituido por un delfín. Como en la mayoría de cecas estudiadas hasta ahora, la iconografía recibirá diversos tratamientos dependiendo del momento histórico y de las corrientes culturales imperantes. Las representaciones de la cabeza del anverso en la mayoría de las ocasiones harán referencia a un Melkart de origen púnico, que con el paso del tiempo adquirirá atributos del Herakles griego como son la piel de león y la 
maza, para, finalmente, adoptar la tipología de un Hércules más romanizado. En determinados cuartos (V.9.7 -serie I-, V.10.19-22 -serie III- y V.10.17-18, 20-21, 23 y 25-29 -serie IV-) y octavos (V.9.8-9) aparecen representaciones de un Helios de frente, aunque quizá fuera más probable que se tratara de una divinidad indígena local. En cuanto a las representaciones de delfín que hallamos en las piezas de esta ceca, éstas se asocian al dios Apolo Delfinios y son símbolo de protección para navegantes y de buenos augurios. Estos delfines aparecen en los octavos de la serie I (V-9.10-11), en los cuartos de la serie IV junto a cabeza de Helios (V.10.17 y 25-29), en las mitades de la serie VI junto a cabeza de Melkart (V.74.7-8), en los cuartos de la serie VI (V.74.9-13) y en los octavos de la serie VI junto a cabeza de Melkart (V.10.16 y 74.14). El tridente que muchas veces aparece atravesando a los delfines de los cuartos de la serie VI o tendido entre las unidades de esta serie (V.74.4) podría hacer alusión a la deidad de Neptuno o Poseidón, pues este símbolo ha venido utilizándose para hacer referencia a esta divinidad y está asociado con la faceta marítima de esta ciudad. Por lo que respecta al caduceo que aparece en las unidades de la serie VI (V.74.3) entre las colas de dos delfines, podría estar relacionado con la divinidad de Mercurio y hacer referencia a la actividad del comercio, prioritaria en esta ciudad.

Sin embargo, la mayor cantidad de elementos iconográficos relacionados con el mundo religioso romano la encontramos en la serie VII, junto a representaciones de personajes romanos. Entre estos elementos contamos con gran variedad de símbolos sacerdotales como los que aparecen en la serie VII-A (V.75.1-2 y 4-5), en la que encontramos, junto a cabeza de Hércules, elementos alusivos al pontificado de Balbo del año 19 a. C. como son el simpulum, un hacha (no siempre) y un cuchillo. En la serie VII-B encontramos tres tipos de anverso: en uno tenemos cabeza de Melkart, en otro el templo tetrástilo (V.77.4), que en algunas ocasiones también aparecería en los reversos y que representaría el templo del Hércules gaditano, y en un tercer tipo aparece Cabeza de Augusto. En cuanto a los reversos de este grupo, también encontramos tres tipos: el fulmen alado atributo de Júpiter (V.76.1 y 3-4 y 77.4), el templo tetrástilo (77.4-5) y las cabezas opuesta de Cayo y Lucio Césares (V.77.6-7). En la serie VII-C encontramos en los anversos cabeza de Melkart, cabeza de Agripa o Agripa sentado en una silla curul y vestido con toga (V.79.1). En los reversos siempre se representa el acrostolio (V.76.5-7 y 78.1-2 y 4-6), una especie de espolón que adornaba las naves antiguas y que posiblemente hiciera referencia a las obras de mejora del puerto de la ciudad realizadas por Agripa. Finalmente, en la serie VII-D encontramos en reverso cabeza de Melkart o cabeza de Tiberio y en los reversos sólo el símbolo sacerdotal del simpulum (77.1 y 3 y 79.2-5), en alusión al pontificado de Tiberio, que también aparece en las monedas de Iulia Traducta, Colonia Patricia y Acci. 
Finalmente, hay una moneda de Gades de atribución dudosa, que representa en anverso cabeza de Melkart y en reverso un ara o un altar de Hércules, del que salen cuatro ramas y alrededor del cual encontramos la leyenda latina $C O L A G A D$ y la leyenda púnica ' $g d r$. La autenticidad de esta pieza ha sido cuestionada desde su publicación por Gómez Moreno, aunque la mayoría de los autores consideran que es falsa o que podría tratarse de una pieza retocada de la ceca de Lascuta.

Municipium Italica: primera fundación romana en Hispania, en el año 206-205 a. C., creada por legionarios heridos en la batalla de Ilipa y localizada en la actual Santiponce, Sevilla. Hasta el principado de Augusto no emitió sus primeras monedas, en las que ya aparece como municipium civium romanorum de Italica. La primera emisión, realizada en bronce, tiene una cronología posterior al año 27 a. C., y las dos restantes son de época de Tiberio.

Uno de los principales aspectos que nos gustaría resaltar de esta ceca es que se adapta ya a la iconografía imperial, por lo que encontramos en el reverso de la mayoría de las piezas representaciones de bustos del emperador o de miembros de la familia imperial. Del mismo modo aparecen también representados en las piezas varios temas alusivos a la mitología referente al origen de Roma. Así, encontramos la representación de una loba alimentando a Rómulo y a Remo (V.168.5) (fig. 9), la representación de la figura de Dea Roma, de pie con coraza y casco, lanza en la mano derecha y un escudo a su lado (V.168.1), o la representación del Genius Populi Romani de pie con toga, pátera en mano derecha y varios objetos (alguno podría ser un cuerno) en la mano izquierda, con un globo terráqueo a sus pies (V.168.2). Por otro lado, también encontramos la representación del signo zodiacal Capricornio (V.168.4), en alusión al momento de la concepción de Augusto. Encima de este signo aparece cornucopia, entre las patas un globo y debajo un timón, todos ellos atributos de la Dea Fortuna. Estos elementos también aparecerán en la ceca de Romula. Otro elemento que llama la atención es la presencia de la figura de Livia con los atributos de la diosa Ceres (V.168.6-7), pues aparece sentada con un cetro en el brazo izquierdo y espigas en la mano derecha. Por otro lado, debemos destacar la presencia de un ara dedicada a la Providentia Augusta (V.168.8-9) y que, por tanto, alude también a la divinización del Emperador. Finalmente encontramos representaciones de tipo militar, como en la que aparecen Germánico y Druso como dos soldados de pie llevando una lanza (V.168.10) o en la que aparecen las insignias militares junto a un águila legionaria y el vexillum (V.168.11-12).

Municipium Iulia Constantia Osset: ciudad turdetana localizada en el Cerro de Chaboya, en San Juan de Aznalfarache, Sevilla, junto al Guadalquivir, 
hecho que le permitió ser puerto fluvial en la antigüedad. En época de César la ciudad adquiere el estatuto de municipio y pasa a denominarse Iulia Constantia Osset según cita Plinio. Su ceca emitió tres series en bronce, con una cronología desde mediados del siglo II a. C. hasta el siglo I a. C.

En esta ceca observamos varios elementos iconográficos que pueden tener relación con la cultura romana. Uno de los más llamativos es la figura femenina galeada que aparece en los anversos de los cuadrantes de la serie II (V.111.2) y que es muy similar a la representación de la diosa Roma. Estas piezas tendrán en su reverso una cornucopia y un racimo de uvas. Un segundo elemento sería la presencia de la cabeza masculina en los anversos de los ases de la serie III (V.111.7-10), que muchos autores atribuyen a Augusto. El tercer elemento que quisiéramos comentar es la presencia en los reversos de las series I y III (V.111.1, 3-4 y 6-10) de una figura femenina de pie con un racimo de uvas en su mano y que en algunas ocasiones aparece también con cornucopia. Esta figura, aunque se ha planteado que represente alguna divinidad romana o a un genio -existen dificultades para aclarar si es una representación masculina o femenina-, creemos que podría asociarse mejor con divinidades púnicas como Astarté-Tanit. Por lo que respecta a las cabezas barbadas de los anversos de la serie I (V.111.1, 3-4 y 6), parecen tener una clara relación con el dios púnico Ba'al-Hammon. Finalmente, como ya dijimos al estudiar la ceca de Irippo, existe un tipo de moneda híbrida entre las cecas de Irippo y Osset (V.111.12), en la que se observa una figura femenina sentada que podría corresponder a una divinidad romana o a una Tanit púnica.

Municipium Liberalitas Iulia Ebora: ciudad lusitana localizada en la actual Évora, en el Alto Alentejo, en Portugal. Probablemente recibió el estatuto de municipium durante el periodo de César o Augusto. Acuñó una única emisión de bronces durante el principado de Augusto.

En los dupondios de esta única emisión de Ebora (V.165.1) encontramos en los reversos cuatro símbolos sacerdotales: el aspergillum, la jarra, el simpulum y el cuchillo. Varios de estos símbolos ya han sido descritos anteriormente. Referirnos tan sólo a que el simpulum alude al pontificado de Augusto del año 12 a. C. y que el cuchillo se utilizaría para el sacrificio. Finalmente, en los anversos de estas monedas siempre aparece la cabeza de Augusto y la referencia al permiso para poder emitir.

Municipium Pontificiense Obulconense ${ }^{11}$ : esta ciudad iberorromana se localiza con toda seguridad en Porcuna, al oeste de la provincia de Jaén, dentro de la depresión del Guadalquivir y entre las campiñas de Jaén y Córdoba. En la antigüedad fue una ciudad turdetana denominada i.po.l.ka. En época romana, Julio César, o quizá Augusto, le concede el estatuto de municipio de 
derecho latino, pasando a denominarse Municipium Pontificiense Obulconense. La ceca emite seis series en bronce muy abundantes y con una cronología que iría desde finales del siglo III a. C. hasta el siglo I a. C., seguramente hasta época cesariana. Sus series presentan una gran variedad de grupos y sus piezas tuvieron una amplia dispersión.

En la mayoría de las emisiones de esta ceca encontramos en anverso una cabeza femenina con moño y collar, acompañada a veces de creciente y astro, que siempre se ha identificado con una divinidad agraria, astral y de la fertilidad y que se piensa que sería Tanit. Esta teoría estaría apoyada en la presencia de un arado, un yugo, espiga, creciente y astro en los reversos. Sin embargo, encontramos que en la sexta emisión (V.97.12-15, 98.1, 4 y 6 y 173.3) aparece una cabeza apolínea con o sin creciente que se ha identificado con Apolo. Estas piezas tendrían en su reverso símbolos agrarios en los ases y toros en los semises. En unos cuadrantes muy escasos (V.98.6) se ha encontrado que junto a la cabeza apolínea aparece una lira y un pequeño creciente. Por último, en unos semises de la serie IV (V.97.1-7) localizamos en anverso o en reverso un águila con las alas extendidas, símbolo de poder y triunfo.

Onuba Aestuaria: esta ciudad se localizaría en la actual Huelva, aunque algunos autores la han situado en las cercanas Gibraleón, Niebla o Trigueros. Según las fuentes clásicas este oppidum se encontraba situado dentro del conventus Hispalensis en la zona del estuario del río Tinto. La ceca emitió cinco series en bronce con una cronología de principios del siglo I a. C.

La cabeza femenina galeada con cimera que aparece en el anverso de los ases de las tres últimas series podría corresponder a una representación del dios Marte romano (V.102.1-2 y 4). Para aquellos que defienden que se trata de una iconografía más púnica tendríamos una representación de la diosa Tanit guerrera. Idéntica interpretación podrían tener los anversos de los semises de la serie III (V.102.3). Por otra parte, los anversos de los ases de la serie I (V.102.5) podrían corresponder a una representación del dios Melkart-Hércules, aunque en este caso con cabeza desnuda y sin barba.

Orippo: localizada en el Cerro de Torre de los Herberos, entre Coria del Rio y Dos Hermanas, junto al Guadalquivir y próxima al encauzamiento del río Guadaíra. En la antigüedad fue puerto fluvial y mansio en la vía Augusta. Su ceca emitió cuatro series en bronce, con una cronología que iría desde la primera mitad del siglo II a. C. hasta el siglo I a. C.

En esta ceca encontramos varias representaciones alusivas a temas religiosos. La primera sería la cabeza masculina que aparece en los anversos de los ases de la serie I, que podría hacer referencia a una divinidad púnica como Ba'al-Hammon, aunque posiblemente corresponda a Melkart-Hércules. 
La cabeza femenina que aparece en los anversos de los ases de las otras tres series, casi sin duda corresponde a una representación de la diosa púnica Tanit (V.110.3-5). A esta identificación ayudaría la presencia del racimo de uvas que aparece delante. Finalmente, el toro que aparece en el reverso de todas las piezas será un símbolo de Ba'al-Hammon, que para mucha de esta gente se identifica con el dios Saturno romano (V.110.1-5).

Sacili Martialium: ciudad túrdula junto al Guadalquivir y que se encuentra localizada en las cercanías del Carpio en el Cortijo de Alcorrucén, en Pedro Abad, Córdoba. La ceca emite tres series en bronce con una cronología de mediados del siglo II a. C.

Aunque se ha especulado mucho con que la cabeza masculina barbada que aparece en los anversos de las monedas de esta ceca (V.113.1-5) pudiera corresponder a una representación de Sileno o Dionisio, por la corona de pámpanos de vid que porta, creemos más lógico pensar que se trataría de una representación de un dios indígena africano, por el parecido con representaciones de cecas de esta zona. La presencia del caballo y del elefante tampoco queda clara, aunque parece tener clara relación con la iconografía púnica, aunque el elefante pasó en época romana a representar un emblema étnico.

Salpesa: aunque tradicionalmente se ha identificado con el cortijo de Facialcázar, recientemente se ha situado en la zona de Casa Coria, en el yacimiento denominado Cerro el Casar, a unos $10 \mathrm{~km}$. de Utrera y próximo a El Coronil, dentro de la provincia de Sevilla. La ceca emite dos series en bronce con una cronología de mediados del siglo I a. C.

En los anversos de los ases de esta ceca aparece una cabeza apolínea con tirabuzones rodeada de una gráfila vegetal. Aunque parece clara su asociación con el dios Apolo, el anverso de la primera serie (V.114.1) parece tener rasgos femeninos, por lo que podría asociarse a cierto tipo de divinidades indígenas femeninas como las que aparecen en la ceca de Obulco, aunque con rasgos claramente apolíneos. Sin embargo, la presencia en el reverso de esta primera emisión de objetos claramente relacionados con Apolo nos ayuda a establecer esta asociación. Entre dichos objetos observamos una lira, atributo musical de este dios, un arco y un carcaj, atributos que representan su faceta de cazador y el trípode, atributo de su poder de adivinación. En el reverso de los ases de la segunda serie (V.114-2) aparece una cabeza masculina con gorro o diadema que presenta atada en el cuello quizás una piel. Algunos investigadores lo han asociado a una representación de MelkartHércules o alguna deidad indígena sincretizada.

Ulia Fidentina: ciudad túrdula situada en lo alto de un monte en la localidad de Montemayor, provincia de Córdoba. El poblado ibérico recibe el 
nombre turdetano Ulia, que significaría "monte", y posteriormente, en época de César, adquiere el cognomen FIDENTIA, posiblemente debido a la fidelidad al bando cesariano durante las guerras civiles. La ceca emite cuatro series de bronce con una cronología que iría desde la primera mitad a mediados del siglo II a. C.

La iconografía de esta ceca será similar en sus cuatro series, presentando en los anversos cabeza femenina con moño y collar y una palma, y en los reversos unas palmas de vid entrelazada que forman una cartela en la que se incluye el topónimo de la ceca. Se ha hablado mucho sobre una posible relación de la cabeza femenina con la diosa romana Diana ${ }^{12}$, a lo que contribuye la presencia de un gran creciente lunar debajo de dicha figura, que, como sabemos, en muchas ocasiones aparece como un tipo iconográfico de esta diosa. Sin embargo, muchos autores ven en esta iconografía relaciones con una divinidad indígena ibérico-turdetana de culto a la luna, muy similar a la que aparece en los ases de Obulco. Esta divinidad indígena estará relacionada con la fecundidad y la prosperidad agrícola. Representaciones de estos cultos a la fecundidad y fertilidad serían la luna y el creciente del anverso y las ramas y pámpanos de vid del reverso.

\section{Otras posibles representaciones de iconografía mitológica y religiosa romanas.}

En este último apartado vamos a incluir algunas representaciones algo más confusas o de cecas de difícil adscripción que no hemos podido detallar individualmente en apartados anteriores. En primer lugar, me gustaría hacer referencia a las monedas que presentan un jinete lancero, como en los casos de las que aparecen en las cecas de Carissa, Ilipla, Ituci, Laelia, Lastigi u Olontigi, que en algunas ocasiones se han identificado con los dioscuros romanos o con guerreros ibéricos que aparecen en las amonedaciones de la Citerior. Sin embargo, nos inclinamos a pensar que esta iconografía respondería más a representaciones de origen púnico o norteafricano, como parecen indicar el resto de elementos iconográficos que los acompaña, y quizás podría tratarse de una Tanit guerrera.

Además de las posibles representaciones de Marte que ya han sido contempladas, pensamos que algunas cabezas masculinas galeadas, como las que aparecen en piezas de las cecas de Turirecina (V.93.1-3), Caura (V.108.13) y Lascuta (V.92.2), podrían también corresponder a esta deidad, aunque no podemos estar seguros. En la pieza de la ceca de Lascuta aparece en reverso un elefante, que como hemos dicho anteriormente podría tener también una simbología religiosa en el mundo romano.

Elementos iconográficos alusivos al culto dionisiaco tenemos en varias cecas vistas anteriormente, aunque también podemos verlos en otras como las 
de Baicipo (V.120.11) o Acinipo (V.105.1-14). En esta última ceca también aparecen una espiga y una palma, por lo que creemos que más que un culto dionisiaco se confirmaría un culto a la triada púnica (vid=Ba'al-Hammon, espiga $=$ Melkart y palma=Tanit $)$.

Referencias a una posible representación de Hércules las encontramos en muchas cecas, entre las que tenemos la de Lascuta (varias de V.92) o la de Carissa (V-117.1-2), ambas con clava. Sin embargo, como ya hemos dicho anteriormente, en la mayoría de las ocasiones harían más alusión a representaciones iconográficas fenicias de Melkart.

Continuando con las representaciones de bustos, una de las tipologías más frecuentes en la numismática hispana es la cabeza desnuda diademada, que en ciertas ocasiones, por su ausencia de atributos, es difícil atribuir a una determinada divinidad. Esto podría suceder en acuñaciones como las de Iliturgi (V.106.2) o Urso (V.112.1-8). Dentro de esta línea, podríamos entender que las monedas de Asido con cabeza masculina barbada diademada que aparecen con haz de rayos y cornucopias podrían relacionarse, a partir de estos atributos, con el dios Júpiter, aunque también podría corresponder a Hércules o a Ba'alHammon. A Melkart o a Hércules también podrían corresponder cabezas masculinas como las que aparece en la ceca de Bailo (V.91.1), Callet (V.106.12), Cumbaria (V.114.1-5), Ilse (108.5), Nabrissa (V.116.1-2), Oba (V.90.1-4), Searo (V.106.1-2), Sisipo-Detumo (V.114.5) y Vesci (V.91.1-5). Todas estas posibles iconografías de Hércules responderían más a su faceta de protector del mundo agrario que a la de guerrero.

Entre las divinidades femeninas debemos destacar la aparecida en la ceca de Bora (V.115.1-2), que aparece velada y que podría corresponder a Juno, no sólo por el velo, sino por llevar también un cetro. A Juno, aunque en este caso a una Juno Sospita se ha dicho que podrían pertenecer unas monedas de Callet (V.106.1-2) y de Searo (V.106.1-2), aunque como ya dijimos en el caso de una moneda de Carmo, a la que también se atribuía correspondencia con Juno Sospita, pensamos que en realidad se trataría de representaciones de un Hércules como dios protector de la vegetación y de la agricultura, pues lo que se intentaba ver como una piel de cabra sería un leonté. Representaciones con referencia a la cabeza de Roma podrían ser las cabezas galeadas que encontramos en cecas como Carissa (V.117.5 y 7-10), Sisipo-Detumo (V.114.13) y Ventipo (V.116.1). Dentro de esta iconografía encontramos muchos tipos de representaciones: aparecen diferentes tipos de casco, rostros más o menos estilizados o incluso en algunas, les salen pequeños rizos del cabello.

Además, contamos con dos tipos de piezas con clara influencia de la religión romana pero que no corresponden a ninguna ceca en concreto. Uno de ellos es el denominado tipo Sacerdos, en el que encontramos en anverso cabeza viril y en reverso una pátera, una jarra ritual y la leyenda $S A C E R D O S$ (fig. 10), 
y otro es el denominado tipo templo, en el que se representa un templo que podría corresponder al del Hércules gaditano. Por último, debemos añadir que en las acuñaciones hispánicas son muy utilizadas alrededor del tipo principal las laureas, elementos que tendrían una clara lectura dentro del ámbito religioso del mundo romano.

\section{Análisis general}

Como hemos podido observar a lo largo del estudio de elementos de la iconografía romana en diferentes cecas del sur peninsular, las representaciones de dioses, de sus atributos o de ciertos elementos religiosos varían dependiendo de la ceca que los utiliza o del periodo en el que se producen las acuñaciones. También debemos tener en cuenta que en muchos casos las representaciones no responden tanto a iconografías romanas como a una plasmación de diferentes divinidades indígenas bajo un prisma iconográfico romano. En esta línea, tenemos varios ejemplos de cabezas galeadas que han sido interpretadas dependiendo de sus rasgos, con representaciones de Marte o Minerva y que en realidad podrían tratarse de representaciones indígenas de la diosa púnica Tanit en su faceta guerrera. Estas representaciones aparecen en cecas como Caura, Carmo, Lascuta, Lastigi, Onuba, Turirecina o Sexi. Otro caso sería el de las figuras femeninas que aparecen portando en sus manos racimos de uva, espigas, piña o palma y que se han identificado con personificaciones romanas como Felicitas, Fortuna, Abundancia o figuras alusivas al culto dionisiaco y que más bien podrían representar a una Astarté o Tanit agrícola, relacionada con la fertilidad y la fecundidad de los campos. Esto podemos verlo en cecas como Acinipo, Baicipo, Irippo, Orippo u Osset. Casos similares sucederían con el Vulcano de Malaka o el Júpiter de Iptuci, que corresponderían en realidad a representaciones del dios púnico Ba’al-Hammon. También se han relacionado con el dios romano Júpiter algunas figuras masculinas barbadas de la ceca de Asido que en realidad podrían corresponder a representaciones de Melkart o Hércules, aunque pocas veces la representación de Melkart, que se sincretizó desde muy temprano con Hércules, ha sido asociada a otras divinidades romanas. Lo que sí sucederá con el Melkart de origen púnico será que con el paso del tiempo adquirirá atributos del Herakles griego como son la piel de león y la maza, para, finalmente, adoptar la tipología de un Hércules más romanizado.

Por otra parte, la población hispana, que, como ya dijimos en el contexto histórico, contaba con panteones muy diversos como el griego, el fenicio o el indígena, pronto asimiló el nuevo panteón romano, en muchos casos llegando a un proceso de sincretismo y asimilación entre los dioses romanos y los locales. Asimismo, tenemos constancia de un buen conocimiento de las divinidades romanas por parte de la población autóctona, pues en 
representaciones monetales de las cecas de Carteia, Carbula, Salpesa u Obulco se plasman ya desde mediados del siglo II o inicios del siglo I a. C. las cualidades musicales y de vaticinio del dios Apolo mediante la representación de la lira y del trípode. Finalmente, podemos decir que incluso las ciudades hispanas llegaron a transformar algunos de los atributos divinos para utilizarlos con fines propagandísticos. Así, por ejemplo, la presencia del haz de rayos, uno de los símbolos característicos del dios Júpiter, en cecas como Italica, Hispalis o Gades sería utilizado para representar la fuerza y el poder del Emperador Augusto, ya que el haz de rayos no forma un tipo por sí solo sino que iría delante de la cabeza del Divus Augustus Pater.

\section{Conclusiones}

Para terminar, podemos decir que pese a que en este trabajo hemos intentado incluir todas y cada una de las posibles representaciones con algún tipo de referencia hacia la mitología y la religión romanas, somos conscientes de que en la mayoría de las ocasiones dichas representaciones aludirían a dioses indígenas, a los que a veces se habría incorporado algún atributo romano, ya fuera por la tipología imperante o por una cierta deferencia al poder romano. A este respecto también tendría un importante papel el proceso de romanización y de sincretización que lleva a cabo Roma en la Península Ibérica. En casos en los que verdaderamente las cecas copian y reproducen tipologías romanas, tampoco debemos pensar que esto signifique necesariamente que se haya producido un profundo arraigo de una divinidad entre la población autóctona, o que existiese un culto a ella en esta ciudad. Muchas veces asistimos a la incorporación de tipologías romanas en muchas cecas por cuestiones meramente históricas y políticas, o bien como un proceso de copia de modelos tipológicos que para ellos tendrían un cierto prestigio. Este intento de reproducir iconografías romanas lleva a estas ciudades en muchos casos a mezclar figuras y atributos, máxime cuando se intenta hacer una fusión con otras divinidades indígenas, por lo que en muchas ocasiones encontramos piezas con iconografías tan variadas que cuesta, en muchas ocasiones, asociar a un determinado panteón religioso. Pero ya a partir de la reforma monetaria de Augusto las cecas que acuñan moneda debían poseer el estatuto de Colonia o Municipium, siendo comunidades plenamente romanas, por lo que la iconografía, así como la escritura que utilizan, pueden considerarse romanas a todos los efectos, y les sirven para plasmar sus propias creencias y religión. 


\section{Bibliografía}

AGHION, I., BARBILLON, C. y LISSARRAGUE, F. (1997), Guía iconográfica de los héroes y dioses de la antigüedad, Madrid.

ALFARO ASINS, C. (1988), Las monedas de Gadir/Gades, Madrid.

ARÉVALO GONZÁLEZ,A. (1997), "Las acuñaciones ibéricas meridionales, turdetanas y de Salacia en la Hispania Ulterior", en Historia Monetaria de Hispania Antigua, p. 213.

ARÉVALO GONZÁLEZ, A. (1999), La ciudad de Obulco: sus emisiones monetales, Sigüenza.

ARÉVALO GONZÁLEZ, A. y CAMPO DÍAZ, M. (1998), "Las emisiones romanas y sus imitaciones en Hispania durante la República", en Historia Monetaria de Hispania Antigua, pp. 318-334.

BELTRÁN MARTÍNEZ, A. (1980), "La significación de los tipos de las monedas antiguas de España y especialmente los referentes a monumentos arquitectónicos y escultóricos”, Numisma 162-164, pp. 123-152.

BLÁZQUEZ MARTÍNEZ, J. M. (1996), España Romana, Madrid.

CAMPO, M. y MORA SERRANO, B. (1995), Las monedas de Malaca, Madrid.

CHAVES TRISTÁN, F. (1973), Las monedas de Itálica, Sevilla.

CHAVES TRISTÁN, F. (1977), La Córdoba bispano-romana y sus monedas, Sevilla.

CHAVES TRISTÁN, F. (1978), "Livia como Venus en la amonedación de Colonia Rómula”, Acta Numismática VIII, pp. 89-95.

CHAVES TRISTÁN, F. (1979), Las monedas hispano-romanas de Carteia, Barcelona.

CHAVES TRISTÁN, F. (1980), "Numismática antigua de la Ulterior", Numisma 162-164, pp. 99-122.

CHAVES TRISTÁN, F. (1997), "Amonedación de las cecas latinas de la Hispania Ulterior" en Historia Monetaria de Hispania Antigua, pp. 233317.

CHAVES TRISTÁN, F. (2001), "La ceca de Carmo", en CABALLOS, A. (ed. lit.), Carmona Romana: II Congreso de Historia de Carmona (Carmona, 1999), Carmona, pp. 339-362.

CHAVES TRISTÁN, F. y MARÍN CEBALLOS, Ma C. (1981), "Numismática y religión romana en Hispania", en La Religión romana en Hispania: Symposio organizado por el Instituto de Arqueología "Rodrigo 
Caro" del C.S.I.C. (Madrid, 1979), pp. 25-46.

CHAVES TRISTÁN, F. y MARÍN CEBALLOS, Ma C. (1982) "El elemento religioso en la amonedación hispana antigua”, en Actes du IXéme Congrés International Numismatique (Berne, 1979), Luxemburgo, vol. I, pp. 657671.

ESCUDERO Y ESCUDERO, F.DE A. (1981), "Los templos en las monedas antiguas de Hispania", Numisma 168-173, pp. 153-203.

GARCÍA-BELLIDO, M.P. (1991), “Las religiones orientales en la Península Ibérica: documentos numismáticos I”, AEspA 64, no 163-164, pp. 3781.

GARCÍA-BELLIDO, M. P. y BLÁZQUEZ CERRATO, C. (2001), Diccionario de cecas y pueblos hispánicos. Vol. I. Introducción a la numismática antigua de la peninsula Ibérica. Vol. II. Catálogo de cecas y pueblos que acuñan moneda, Madrid.

GONZÁLEZ ROMÁN, C. (1981), Imperialismo y romanización en la Provincia Hispania Ulterior, Granada.

GONZÁLEZ ROMÁN, C. (2002), Ciudad y privilegio en Andalucia en época romana, Granada.

MANGAS MANJARRÉS, J. (1995), De Aníbal al Emperador Augusto. Hispania durante la República romana, Madrid.

MONTENEGRO DUQUE, A., BLÁZQUEZ MARTÍNEZ, J. M. y SOLANA SAINZ, J. M. (1986), España Romana, Madrid.

MORA SERRANO, B. (1981), "Sobre el templo en las acuñaciones malacitanas”, Jábega 35, pp. 37-42.

RIPOLLÈS ALEGRE, P. P. (1998), "Las acuñaciones cívicas de la península Ibérica (44 a. C.- 54 d. C.)", en Historia Monetaria de Hispania Antigua, pp. 335-395.

RODRÍGUEZ CORTÉS, J. (1991), Sociedad y religión clásica en la Bética romana, Salamanca.

RODRÍGUEZ MÉRIDA, J. A. (1992), "Representaciones de Juno Sospita en monedas de Callet, Carmo y Searo", Boletín del Museo Arqueológico Nacional X (1-2), pp. 39-44.

RUIZ LÓPEZ, I. D.(2010), La circulación monetaria en el surpeninsular durante el periodo romano-republicano, Universidad de Granada, Granada.

SÁEZ BOLAÑO, J. A. y BLANCO VILLERO (1996), Las monedas de la Bética Romana. Vol. I: Conventus Gaditanus, San Fernando.

SÁEZ BOLAÑO, J. A. y BLANCO VILLERO (2001), Las monedas de la Bética Romana. Vol. II: Conventus Hispalensis, San Fernando. 
TUÑON DE LARA, M., TARRADELL, M. y MANGAS, J. (1983), Introducción. Primeras culturas e Hispania romana, Barcelona.

VÁZQUEZ HOYS, A. Ma (1993), "La religión romana en la Bética y el sustrato prerromano", en Actas del I Coloquio de Historia Antigua de Andalucia (Córdoba, 1988), Córdoba, vol. II, pp. 189-197.

VÁZQUEZ HOYS, A. Ma (1995), Diana en la religiosidad hispanorromana. I (Las fuentes. Las diferentes diosas), Madrid.

VILLARONGA i GARRIGA, L. (1994), Corpus Nummum Hispaniae ante Augusti Aetatem, Barcelona.

VIVES y ESCUDERO, A. (1926), La Moneda Hispánica, Madrid. (abreviado en las referencias de las piezas como V.) 
Iconografías mitológicas y religiosas más destacadas en las cecas del sur peninsular $^{13}$
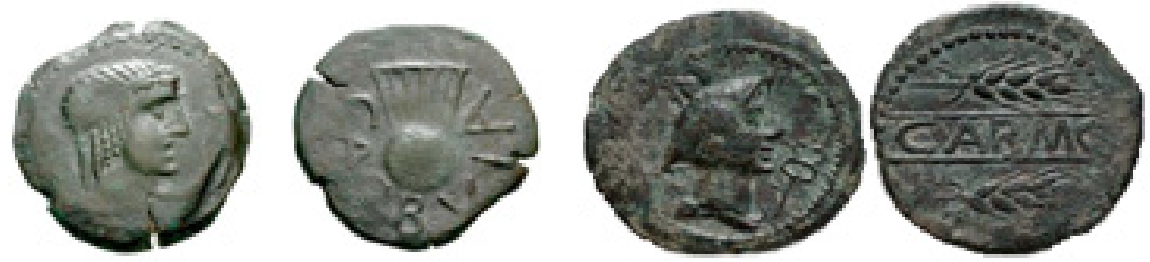

1. As de Carbula (Apolo)

2. As de Carmo (Mercurio)
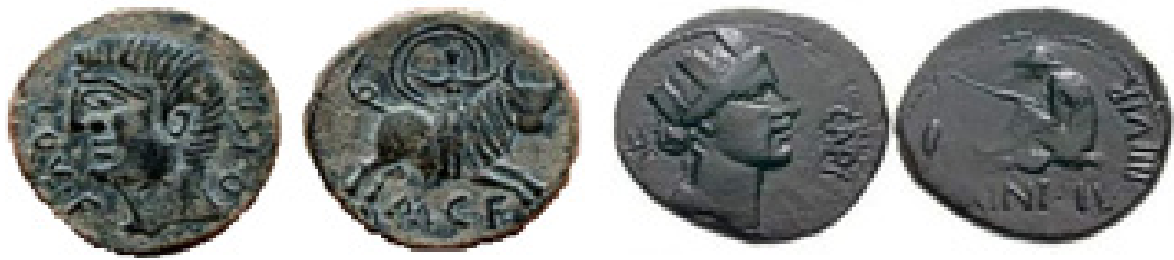

3. As de Castulo (Rapto Europa)

4. Semis de Carteia (Cibeles)
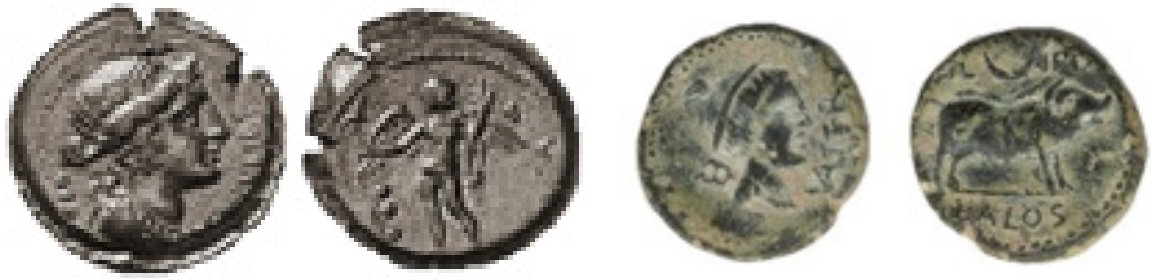

5. Cuadrante de Corduba (Venus)

6.Duplo de Ilipula Halos (Mercurio y jabalí)
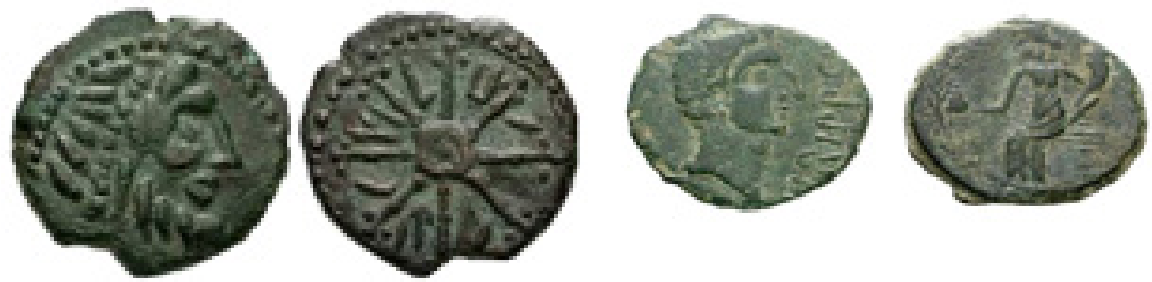

7. Mitad de Iptuci (Júpiter?)

8. Mitad de Irippo (Fortuna o Felicitas) 
Ildefonso David Ruiz López
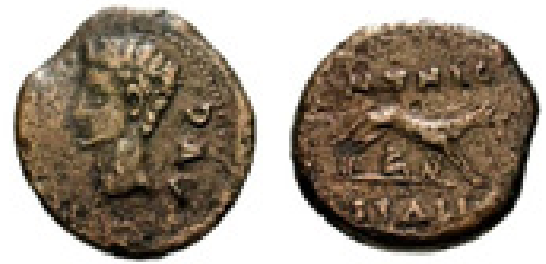

9. Semis de Itálica (Loba con gemelos) 10. Semis tipo Sacerdos 
${ }^{1}$ Este trabajo se inserta dentro de las líneas de investigación seguidas durante la realización de mi tesis doctoral, Circulación monetaria en el sur peninsular durante el periodo romanorepublicano, y que pude desarrollar gracias a la concesión de un beca FPU por parte del Ministerio de Educación y Ciencia y al apoyo del grupo de Investigación HUM-215 "Arqueología e Historia de la Hispania Meridional en época Romana y Visigoda" del Departamento de Historia Antigua de la Universidad de Granada.

${ }^{2}$ Cf. C. GONZÁLEZ ROMÁN (1981); M. TUÑ̃N DE LARA, M. TARRADELL y J. MANGAS (1983), pp. 199-286; A. MONTENEGRO DUQUE, J. M. BLÁZQUEZ MARTÍNEZ y J. M. SOLANA SAINZ (1986), pp. 39-269; J. MANGAS MANJARRES (1995); J. M. BLÁZQUEZ MARTÍNEZ (1996), pp. 28-139; C. GONZÁLEZ ROMÁN (2002), pp. 13-166.

${ }^{3}$ Cf. J. MANGAS MANJARRES (1995), pp. 130-141.

${ }^{4}$ GARCÍA-BELLIDO, M. P. y BLÁZQUEZ CERRATO, C. (2001), vol. II, p. 68.

${ }^{5}$ CHAVES TRISTÁN, F. (2001), pp. 339-362.

${ }^{6}$ RODRÍGUEZ MÉRIDA, J. A. (1992), pp. 39-44.

${ }^{7}$ CHAVES TRISTÁN, F. (1979), pp. 17-34.

${ }^{8}$ CHAVES TRISTÁN, F. (1977), pp. 48-56 y 92-98.

${ }^{9}$ CHAVES TRISTÁN, F. (1978), p. 89; CHAVES TRISTÁN, F. y MARÍN CEBALLOS, Ma C. (1981), p. 41.

${ }^{10}$ ALFARO ASINS, C. (1988), pp. 35-47.

${ }^{11}$ ARÉVALO GONZÁLEZ, A. (1999), 63-72.

${ }^{12}$ VÁZQUEZ HOYS, A. Ma (1995), pp. 187-188.

${ }^{13}$ Las monedas que aquí presentamos se han extraído de www.tesorillo.com y monedahispanica.com. 


\title{
De regresso à Lesbos de Safo \\ Atardecer en Mitilene de A. Pociña
}

\author{
Maria Fátima de Sousa e Silva \\ Universidade de Coimbra
}

\section{O círculo de Safo numa versão contemporânea}

O esboço da escola de Safo, em Atardecer en Mitilene, exige a definição de um cenário, espacial e humano. $\mathrm{Na}$ ficção, o círculo de Lesbos obedece, como sua fonte inspiradora, a uma tradição e às diferentes leituras a que, ao longo dos séculos, foi sujeita. Colaboram nessa imagem elementos prévios à acção a lista das personagens e uma extensa rubrica de cena inicial -, estabelecendo a moldura conveniente aos episódios seguintes, em que o mesmo desenho se aprofunda.

O mundo essencialmente feminino da escola revela, em primeiro lugar, uma hierarquia, onde a mestra, de idade madura ('entre cuarenta y cincuenta años', 2)1, se destaca das 'chicas jóvenes' que vivem em sua casa. É certo que essas donzelas, tal como as companheiras de Safo referidas nos poemas, têm individualidade, nomes precisos - Telesipa, Mégara, Gôngila, Irana, Girina, Filénis $^{2}$ - e uma personalidade que a peça se encarregará de revelar, por autonomia ou contraste. Mas, neste momento de apresentação inicial, o autor sublinha, a par do ascendente que separa mestra e discípulas, um conjunto de traços que as harmonizam como grupo, ou diríamos, em consideração ao contexto dramático, como coro. Os traços referidos são concretos e visuais, de acordo com as exigências de cena, mas também referenciais do universo feminino. Com incidência maior evidenciam-se os trajos, túnicas leves e de cores claras, branca a de Safo, e, por contraste, coloridas as restantes, rosa, verde, azul; depois os penteados, cabelo preso o da mestra, cingido por uma simples fita, soltos os das jovens, mas enfeitados, com maior exuberância, de fitas, grinaldas e flores ${ }^{3}$. Não é tanto a beleza, um factor individual, que se valoriza, a distinguir cada uma destas mulheres; o tom que se acentua é colectivo e respira elegância, jovialidade e festa. A harmonia dos coloridos pastel, em torno do branco que ilumina Safo, prepara-nos para uma coreografia, onde à mestra cabe o papel de corifeia ${ }^{4}$.

Antes, porém, de imprimir ao grupo feminino movimento, importa atentar numa última personagem, o Porteiro, o único elemento anónimo e dissonante do conjunto, porque masculino, figura secundária e muda, em oposição à actividade e à alegria feminina e contagiante que o cerca. $\mathrm{O}$ seu papel, confinado à cena final e a uma obediência aparentemente passiva e tácita às ordens que recebe da senhora da casa, é ambíguo. É que, discretamente, ele 
traz, num gesto dissimulado ${ }^{5}$, a permeabilidade indesejada entre dois mundos. Quando, já no êxodo, todas as mulheres se vão aos poucos retirando, uma cumplicidade se esboça com Filénis, que fica para trás, dissidente do grupo que se afasta (24): 'La última es Filenis: cuando va llegando a la puerta aparece el Portero, que le hace una señal disimulada, como para verse después'. Para a jovem, a promessa de um encontro culmina uma ânsia afirmada em todos os momentos, numa infracção às regras da casa; mas o Porteiro mascara, sob uma obediência muda, a invasão de um reduto das Musas pelo impulso lascivo e pedestre de um homem. Cabe-lhe por isso representar a fronteira entre o masculino e o feminino, ou mais ainda, entre o universo de Safo e aquele outro para além do seu mundo. É o que afirmam as últimas palavras da peça, que lhe são dirigidas pela senhora (24): 'por la mañana tendré que decirte algo. Hay unas reglas que no pueden romperse de ninguna manera en la casa de Safo de Mitilene'.

Repetindo uma estratégia já usada em Medea en Camariñas ${ }^{6}$, A. Pociña produz uma fusão de tradições (antes Cólquida e Galiza, agora Mitilene e Córdoba), aproximando espaços distintos - Lesbos e Andaluzia -, que no entanto partilham um sentimento de comunidade cultural em torno de uma bacia mediterrânica aglutinadora. $\mathrm{O}$ traço chave da sobreposição é o pátio, o coração social da casa e um espaço aberto à luz do sul, em Mitilene 'semejante a los de Córdoba'. Definido o rectângulo essencial que a palavra sugere, o cenário enche-se de cor; caiadas de fresco as paredes de uma brancura imaculada, o quadro recebe pinceladas de verde que marcam as múltiplas floreiras, repletas do tom agressivo dos gerânios. Neste pintar activo de que as discípulas se encarregam - 'Telesipa, subida en un banco, está dándole una pasada a la cal (...); otra, Gongila, en un escaño bajo, pinta de verde uno de los soportamacetas', 2 - vai contida uma sobreposição feliz entre o primeiro movimento de cena e a criação material de um cenário. Na perspectiva humana, o movimento inicial é de discordância, expressa nas relações e actividades dissonantes das discípulas. Cabe a Safo a iniciativa de promover aproximação e harmonia; com o progressivo abandono das diversas tarefas, todas se acomodam em torno do pólo aglutinador que é a mestra, para as jovens o paradigma. Embora finalmente imóveis, porque sentadas em bancos baixos em redor de uma Safo que se destaca num assento mais alto, as jovens são também, para o enquadramento da cena, um contributo sugestivo; constituem a imagem humana da casa, dentro de uma hierarquia, que continua dominante, entre mestra e discípulas ${ }^{7}$.

G. Lanata ${ }^{8}$ especula sobre a natureza e sentido da experiência poética de que Safo é catalisadora ${ }^{9}$, aplicando ao círculo que a rodeia as designações vinculativas de thiasos e hetaireia ${ }^{10}$ (cf. Safo frs. 126, 142). É como a hetairai, a 'companheiras', que Safo (fr. 160; cf. Suda S 107) se dirige ao destinatário e ouvintes dos seus poemas ${ }^{11}$. E Lanata recorda ainda que moisopólos (fr. 150), 
qualificativo que se aplica à 'casa' onde Safo vive e compõe, se não limita ao sentido de 'casa das poetas', mas parece sugerir um grupo dedicado ao culto das Musas. Mais do que as Piérides, no entanto, é Afrodite a divindade com maior proeminência na poesia de Safo, deusa detentora do título de hetaira, encarnação do amor que, como nenhum outro motivo, caracteriza a sua criação. Regressando à prática grega das fórmulas de juramento, sintoma de coloquialismo, não é por acaso que, em Pociña, Telesipa, cansada da tarefa de caiar, se lastima (2): 'no puedo más, por Afrodita'; ou que Safo, a recusar o desejo das discípulas de ouvir um dos seus poemas, afirma peremptória (4): 'No, por las Musas todas'. Estes brados, que brotam com espontaneidade de simples gestos do quotidiano, ganham em certos momentos de Atardecer en Mitilene maior consistência, obrigando a pensar que ao autor não é estranho o sentido cultual que Afrodite e as Musas poderão ter em $\mathrm{Safo}^{12}$.

Particularmente sugestivo é o fr. $2^{13}$, uma invocação de Afrodite que pretende promover a epifania da deusa e um contacto directo com $\mathrm{Safo}^{14}$. $\mathrm{Da}$ distância de Creta, que a deusa venha ao recinto que lhe é sacro em Mitilene, onde maçãs e rosas, o aroma dos incensos e a suavidade das brisas que agitam ao de leve as ramarias dão ao lugar uma tonalidade cultual. Esse é o reduto doce e tranquilo que propicia o amor, dádiva da deusa ${ }^{15}$. Fica-nos a sensação de que, ao criar o cenário da sua peça - o pátio onde mestra e discípulas se reúnem e a que não falta luz e o colorido das flores -, Pociña como que dessacraliza o ambiente que Safo construiu, adiando a recordação da deusa em cena para um outro enquadramento.

Em Atardecer en Mitilene, Afrodite é projectada não tanto como deusa misteriosa que comparece numa moldura sacra, mas como divindade inspiradora da arte e seu objecto de preferência. A par da poesia, Pociña introduz a pintura como uma arte privilegiada no círculo de Safo. Com uma fluidez sugestiva, permite até um progresso a partir de uma pintura elementar - a que restaura paredes, articulada também com a criação do cenário - até uma verdadeira techne, que isola Gôngila como a discípula apta para a arte de 'pintar, pero de verdad' (3). Como motivo, a discípula toma um tema que sabe preferido na escola (5): 'Voy a pintar un nacimiento de Afrodita, la diosa que tanto amas, surgiendo de las olas del mar de Chipre'. Numa cena feliz, que suspende este acto criador, Pociña, como Aristóteles, harmoniza as duas artes, pintura e poesia. Gôngila sabe qual o enquadramento que pretende: o azul do mar e o branco da espuma que nasce do golpe das águas contra as rochas. Ao seu projecto falta, porém, a alma, a que a imagem da deusa trará ao quadro, imagem indefinida que o seu talento não alcança. Nem se trata de pormenores superficiais, como saber se Afrodite será representada nua ou vestida; a dificuldade está em dar forma plástica a um espírito, que a poesia é mais apta a configurar; por isso a jovem se propõe enfrentar os materiais, tábua e tintas, com os versos que Safo 
dedicou a Afrodite nos lábios (fr. 1, o único que se conserva completo). É este o pretexto que introduz a recitação de alguns versos $(1-4,25-28)$ do famoso poema ${ }^{16}$. Afrodite é retratada não tanto em tom de respeito sacro, quanto como símbolo da agitação e instabilidade emotiva próprias da paixão, sempre forte e imprevisível; trata-se, portanto, de converter em mito uma emoção. Os dois epítetos que caracterizam a deusa no apelo que lhe é dirigido - poikilóthron, 'de trono policromo', e dolóplokos, 'tecedeira de intrigas', 1-2 - ambos hápax de Safo, são disso mesmo a prova. A policromia encarna a insegurança, ao mesmo tempo que a competência de tramar intrigas pode sugerir o sorriso irónico de uma deusa soberana (fr. 2. 14). A Safo de Pociña recorda do poema a parte final, de satisfação e apaziguamento, de uma divindade que, se favorável, tem para os corações atormentados a dádiva superior da tranquilidade (6) ${ }^{17}$. Assim abertura e fecho do poema conciliam características à partida incompatíveis, reunidas numa mesma Afrodite: força e debilidade, persistência e inconstância, angústia e prazer, ou seja, as contradições próprias do amor.

No plano humano, o das relações interpessoais entre mestra e discípulas, é incontornável, na versão espanhola, a noção de homo-erotismo de que a poetisa de Lesbos ficou como eterno símbolo ${ }^{18}$. Importa, no entanto, sublinhar a visão, compartilhada pela cultura arcaica e clássica na Grécia, de que o processo de crescimento e aprendizagem resulta do acompanhamento de um erastês, 'um amante', mais velho e experiente, junto de um erómenos, 'o amado', mais jovem e imaturo; à relação, que tem muito de idealizado e muito de objectivo, também não é estranha uma componente física ${ }^{19}$. Assiste a Safo o mérito de ter produzido a primeira configuração literária de um erotismo feminino.

Este lado pedagógico ${ }^{20}$ e cultural do homo-erotismo tem, no texto de Pociña, um papel fundamental. Trata-se de um acto voluntário, assumido conscientemente pelo oikos, o de delegar na escola de Safo a formação das suas pupilas; consciente das responsabilidades que lhe estão incumbidas, Safo pode dizer, em tom reprovador (5): 'No es para eso para lo que os han enviado a mi casa vuestras familias'. Esse objectivo é adiante enunciado em pormenor e feito para promover um claro avanço social, sem rupturas declaradas nem hostilidade quanto à convenção do comportamento feminino; bem pelo contrário, trata-se da aquisição de uma competência que apetreche a mulher para o bom exercício da sua função tradicional (7): 'hacer de ti una mujer como dicen que es debido, culta, elegante, sobre todo dueña ejemplar de su casa. Y además, a ser posible, amante ideal y fiel a su marido'21. É claro, no entanto, que o círculo de Safo, com o seu programa dirigido ao espírito, promove a qualidade de vida feminina e a quebra de uma subserviência que a amesquinhava. Girina, uma das discípulas, encarna os resultados deste outro percurso pedagógico (7). Sobre ela impende o compromisso de um casamento tradicional, com um noivo desejado pela família, aplaudido pelo pai e aceite por si mesma com uma passividade cega ${ }^{22}$. 
Em Lesbos, Girina viveu a experiência única de abrir os olhos do espírito, de perceber quanto era vazio o padrão de vida que antes faria a sua felicidade. Ao entusiasmo pelo que parecia um projecto de realização feminina, sucedeu-se o desencanto penoso perante o que passou a ser o retrato da frustração que espera a mulher (11): 'Yo regreso a mi casa, para casarme con mi Eucarión, para encerrarme en otra casa, que dirán que es la mía de verdad, y cuidarla, y reñirla todo el dia a las esclavas perezosas, y criar uno, o dos, o três niños, hasta que se me deforme la tripa y me cuelguen las tetas hasta las rodillas'. É verdade que o mundo real prossegue fora das paredes do reduto que Safo construiu para si e para as companheiras. Mas a frustração espera-as no regresso a casa. Nada voltará, mesmo assim, a ser simplesmente o que era dantes. Uma memória, ainda que fugaz, há-de ficar desse contacto com os dons das Musas. Assim o reconhece Girina (13): 'Me acordaré de todas vosotras cuando me la canten el día de mi boda. Y después la aprenderé yo misma, y la cantaré pensando en ti, Irana, cuando esté en mi casa, tejiendo en las tardes interminables de la primavera'.

Que metodologia seguia este círculo de Safo para levar a cabo essa missão pedagógica? Pociña integra no seu plano dramático algumas estratégias. A primeira parece ser uma saudável emulação, um espírito competitivo entre as discípulas, que incentiva a arete de cada uma ${ }^{23}$. Nas simples tarefas do quotidiano, como retocar a pintura da casa, por exemplo, é estimulado o empenho e o esmero. Mégara é desse princípio um modelo, tal como o acentua Gôngila (3): 'Lo tuyo ya se sabe, siempre la primera, siempre la niña ejemplar'. Ao mesmo tempo, do mesmo modo que à arete masculina, no campo de batalha, com todo o seu sentido competitivo, é associada, como factor de moderação, a philia, a solidariedade, igual factor pode imprimir às relações femininas um carácter de sintonia, que vai buscar ao par harmonioso de Heitor e Andrómaca ${ }^{24}$ o seu paradigma mitológico: 'Que nadie le toque un pelo a Telesipa. Que ella se pone a pintar, tú a pintar; que le da por cantar, tú segunda voz; que ella se queja de algo, tú que pobrecilla ....

Mas a emulação pode criar o ciúme e as dissidências entre os talentos 'do exército' de Mitilene, como em Tróia Aquiles confrontou Agamémnon. Associado à capacidade de cada uma está o desejo de agradar à mestra, o que faz do círculo um campo de luta cultural, em nome de uma time que se quer ver reconhecida (6): 'Porque dije antes que la voy a pintar en honor a ti es por lo que se enfurece. Son celos, nada más que celos. Te querería toda para ella, solo para ella'.

Pela mestra as discípulas nutrem uma admiração entusiástica e devota - 'Es admiración, es admiración, es reverencia. Es amor a tus poesias', 4 -, que tem no seu génio poético a razão principal. Algo divino transparece desta mulher, tocada pelo além, no surgir diário da intimidade do quarto, qual 'Aurora de 
dedos rosados'. É portanto o culto das Musas o que sobretudo as une, e a admiração gerada não se espera que seja apenas contemplativa, mas pró-activa; mais do que elogios, Safo deseja das discípulas que lhe sigam o exemplo e a imitem no talento ${ }^{25}$. Este objectivo tem por trás um princípio de imitação, do mesmo modo que, mais tarde, os sofistas o praticaram; o processo é indutivo, provém da consideração das criações da mestra como de um modelo a seguir. Por solicitação das companheiras, Safo repete os seus poemas, sobretudo aqueles por todas reconhecidos como rasgos de génio; é o caso de 'Se parece a un dios', repetido entre elas 'en mil ocasiones', até à saturação (4). Girina resume o processo de aprendizagem de forma expressiva (7): 'Cuando llegué aquí, a Mitilene, estaba todo claro, porque en realidad no tenía claro nada. Aquí descubrí lo que se oculta en tu corazón, Safo, y en los de todas vosotras; y aprendí tus versos, y los de Irana, y sus hermosas canciones al son de la lira. Escuché vuestros relatos de amor, los de todas, los reales y los inventados'. Do convívio com esses poemas, repetidos e imitados, as jovens assimilam uma cultura e interiorizam, em conformidade, padrões de comportamento.

Como exercício alternativo, Safo propõe, como mote, o seu poema de criação recente, quatro versos apenas de introdução, que as discípulas devem completar: 'Yo os digo una nadería cortita que pensé ayer por la noche, y vosotras buscáis una continuación'. O processo é oral, uma récita espontânea e improvisada, que pede uma sequência no mesmo tom, uma espécie de skolion no feminino. No seu entusiasmo pelo paradigma, Mégara apressa-se a responder ao desafio, mas fá-lo de modo passivo, limitando-se a colar nos versos propostos como 'de esta noche', outros de Safo, que tem no ouvido. $O$ resultado falseia a coerência, não é coeso na estrutura, embora o tema - a descrição dos astros - convide à associação. Ao mesmo tempo que ficciona a metodologia praticada na escola 'ao vivo', Pociña sugere o processo que pôde criar intervenções espúrias sobre os versos genuínos de Safo, que o tempo e a distância se encarregaram de multiplicar. Irana responde ao mesmo desafio com maior criatividade ${ }^{26}$; Safo reconhece-se na beleza dos versos que a jovem propõe para completar o seu mote; pode até usar-lhe as palavras, pessoais sem dúvida ainda que com uma marca de escola, para uma autocrítica: o reconhecimento de alguma falta de criatividade inovadora na tendência, talvez excessiva, para o modelo convencional do epitalâmio (5): 'Le estamos dando demasiada entrada a hombres hermosos en nuestros versos'.

Além de um relacionamento cultural e artístico, o convívio entre mulheres aprofunda emoções ou sentimentos; surge o homo-erotismo de que tradicionalmente Lesbos é referência. Esse é um relacionamento aceite por Pociña como natural na escola (14): 'Dónde está escrito que no puede querer, amar, gozar, una mujer con una mujer, o un hombre con un hombre?' Este enunciado serve de introdução ao episódio de amor entre Safo e uma 
das discípulas, Átis, que a personagem de Pociña reconhece como um dos tópicos de vários dos seus poemas. Como primeira qualidade, a amada respirava elegância e encanto, como boa discípula do círculo. Por isso vê-la se tornou uma fonte de inspiração para amor e poesia, apenas duas fases de um só processo. A tradição deste episódio é sujeita por Pociña, na presença dramática de Safo, a um esclarecimento cabal27. O episódio de Átis (cf. Safo fr. 131 ${ }^{28}$ enquadra-se, em Atardecer en Mitilene (15), como uma história dentro da história, que Safo narra a pedido das suas ouvintes. Marca-a, desde o início, a mão incerta do destino - 'Atis llegó a mi casa por verdadera casualidad', 15 - e o capricho de Eros. Na ficção como na realidade, Safo assume-se como a primeira poeta capaz de analisar as suas próprias emoções, centradas sobretudo no amor e no ódio. $\mathrm{O}$ interesse peculiar da sua poesia reforça-se pelo ambiente feminino que se instala, de onde os homens são excluídos. Depois de diluídos os antecedentes que enquadravam Átis - uma mãe pobre, abandonada, frágil, que desapareceu sem deixar rasto -, a jovem surge como mulher e objecto de paixão. Incorporando a arte de Safo, Pociña sintoniza amor com poesia. Uma primeira impressão, ainda difusa, ficou gravada num fragmento (49): 'Pequeña me parecías y desgarbada'. Pouco a pouco, um conjunto que não exprimia um ideal de beleza foi-se desmembrando em múltiplos atractivos: 'ojos imensos, lábios finos e bien debujados, dientes blancos, manos finas, pechos pequeños y redonditos' (16). À tomada de consciência, seguiu-se um crescendo de amor 'cada dia que pasaba iba descubriendo en ella algo admirable' - e de intimidade - 'cuanto me hicieron gozar aquellas manos!'.

Só o ciúme, porém, foi capaz de dar a um fascínio crescente um impulso final. Vê-la com outra mulher, Andrómeda ${ }^{29}$, uma rival, transformou um vago interesse em fogo da paixão. É deste misto de amor e ciúme - o mesmo que anima o famoso carme 31, o que celebrizou Safo no círculo como o retrata Pociña - que nasce o clímax da experiência amorosa da mestra, que é também o clímax da versão espanhola da história (16): 'Sólo soñaba con ir al atardecer a tumbarme con ella en la suave arena a la orilla del mar, lejos de todas vosotras' (cf. Safo fr. 126). A poesia, que servira como voz da paixão e do ciúme, serve também como grito de ódio e despedida (fr. 55): 'Y muerta yacerás, y no habrá un día ni un recuerdo de ti ni nunca en el futuro: porque no participas de las rosas de Pieria ${ }^{30}$. É a condenação de uma jovem dotada que, seduzida por argumentos fúteis e rasteiros, abandona escola, amor, poesia e perde, com esse passo, direito à excelência do convívio com as Musas. Um silêncio eterno, o do apagamento total, há-de rematar-lhe a vida. Dentro da agitação social que abalou Mitilene em finais do séc. VII a. C., fazem sentido as marcas de invectiva que não são raras na poesia de Safo.

O afastamento e a ruptura são, de resto, o desfecho esperado para todas as paixões que o convívio espiritual no círculo de Safo fomenta. Um dia virá 
em que a família recebe de volta a sua filha, discípula dilecta da mestra, para a confiar a um noivo e rentabilizar, na vida, a formação obtida na escola. Foi o caso de Anactória (17). A partida é dolorosa, a saudade amarga, mas algum refrigério resulta de um quadro de felicidade (17; cf. 19-20): 'La causa es hermosa. La marcha de Atis, en cambio, es quizá la historia más triste de toda mi existencia' ${ }^{31}$.

O círculo de Andrómeda representa, no texto de Pociña, a escola entre todas rival da de Safo. Do mesmo modo que esta centraliza o espírito do seu grupo, outro tanto se passa com Andrómeda, de forma que a competição se torna também um confronto pessoal. A adoração que as discípulas nutrem por Safo contrasta com o desprezo que lhes merece Andrómeda, 'la bruja' (14). Uma natural concorrência entre escolas leva a denegrir a falta de talento da adversária (17): 'En el círculo de Andrómeda no se cultivan los versos y las canciones, porque la pobre es negasa para la poesía y la música’. No concreto, esta falta de aptidão para os dons do espírito reflecte-se num sentido do que seja amor, a verdadeira alavanca da criatividade poética. $\mathrm{O}$ círculo de Andrómeda converte-se num prostíbulo, onde, em vez dos arroubos de sentimento, domina um erotismo brutal (18): 'Su mayor defecto reside en su terrible ignorancia, en su carencia absoluta de cualquier tipo de educación'. Em redor da fortaleza feminina que lhe circunda a escola, rondam os homens, noite alta, numa denúncia de que o verdadeiro sentido do grupo foi adulterado (19). Por todas estas características, o círculo de Andrómeda não merece a confiança das famílias para a suprema missão de educar as suas filhas, para a principal missão que as espera, o matrimónio. A rivalidade entre os dois grupos concretiza-se com a transferência de Átis, discípula dilecta de Safo, para a escola rival. E o contraste entre o projecto dos dois círculos tem em Átis uma imagem palpável. Jovem, fresca, natural no círculo de Safo, tornou-se, por intervenção de Andrómeda, numa boneca artificial, falsa, grotesca (16): 'Llevaba los lábios tiznados de manteca encarnada, y los ojos encarbonados y, no sé como, los pechos inflados como las antiguas mujeres minoicas'. Esta imagem de decadência, própria de um universo onde a espiritualidade cedeu ao mais elementar artificialismo, ditou a Safo um poema (fr. 57) de insulto e condenação. À falsidade da beleza sucedeu-se, em cadeia inevitável, a falsificação do sentimento. O que Andrómeda sentiu por Átis foi capricho ('se encaprichó de Atis', 17), talvez até o desejo torpe de atingir a rival, Safo. As suas armas foram o suborno, presentes, promessas, uma retórica falsa de sedução. E, por natural consequência, adveio a quebra da inspiração e o divórcio das Musas, situadas num universo bem distinto e inacessível à vileza de sentimentos e propósitos. Assim Andrómeda, que a tradição identificava com detentora de outra escola feminina em Lesbos, ganha um perfil concreto na ficção de Pociña. 
Em conclusão: Atardecer en Mitilene promove harmonia entre duas perspectivas na leitura do círculo de Safo: a que faz dela a guia de um grupo de intelectuais em formação, ao mesmo tempo que, sob essa mesma escola, deixa entrever uma teia de relações que põem em evidência o tradicional homoerotismo de Lesbos.

\section{A criação poética no círculo de Safo}

Num reduto onde Afrodite e as Musas têm um lugar de eleição e em que a actividade literária não parece alheia a um objectivo de culto, não surpreende que a arte seja vista como fruto de uma inspiração concedida pelos deuses aos seus eleitos ${ }^{32}$. Com rigor, os versos de Safo 'salen divinos a la primera' (3), perfeitos e irrepreensíveis para quem os escuta, concebidos 'por milagre', no que Pociña designa por 'éxtasis artístico'. À poeta, na versão moderna, não falta a consciência de uma técnica, que é preciso apurar. Antecipando o que viria a ser a norma horaciana, Safo recomenda um distanciamento crítico, que só o tempo pode trazer - 'nunca debe una poeta lanzar nada al viento sin antes haberlo revisado como es debido', 3 -, e um trabalho minucioso de polimento, como o que exige ao escultor a brutalidade genuína do mármore. Seduzida por essa arte única de Safo, a sua primeira audiência - as discípulas que a rodeiam - consciencializa-se do que constitui os seus méritos essenciais. Entre todos destaca-se o laconismo, aquele dom inimitável de dizer 'sólo en dos versos lo que nosotras no conseguiríamos con doscientos' (4), e a extraordinária eufonia da linguagem.

Se à inspiração que bafeja Safo não falta o toque divino, é também certo que a natureza, os impulsos genuínos, os sentimentos têm, no produto final, um contributo decisivo; porque antes de exercitar as discípulas na composição poética, a mestra alerta-as para a expressão genuína das paixões, como uma espécie de diagnóstico de um estado de espírito. Conhecer-lhe os poemas de amor é ser capaz de identificar o mesmo amor quando ele surja. Por isso a poesia de Safo tendeu a ser lida como uma representação biográfica, e a capacidade de usar a própria vida como inspiradora dos seus poemas a sua mais relevante inovação ${ }^{33}$. É certo que algum desse labor foi posto ao serviço do círculo e das aspirações das discípulas, destinadas, após a aprendizagem, ao casamento e à constituição de família. $\mathrm{O}$ epitalâmio, como canto de celebração nupcial entoado pelas amigas da noiva, tornou-se uma convenção poética capaz de celebrar esse ritual de passagem, do tempo de formação feminina para a plenitude da sua condição (cf., e. g., frs. 27, 30, 105, 107, 113, 114, 194). Dentro da cultura grega, o epitalâmio passou a alegrar as bodas e a homenagear noivas e famílias de todo o Egeu, sobretudo as que viam distinguidas 'con un poema de la más grande de las poetas' (12). Mas mesmo a mais distinta das criadoras não era imune ao desgaste de modelos, ainda que capaz de dar-lhes 
o seu toque especial (por exemplo, adaptar a descrição do noivo, um elemento incontornável do género, a cada caso concreto). Com o seu talento, a poeta pode derramar beleza sobre a mediocridade do concreto. Assim, embora Eucarião, o noivo de Girina, seja 'moreno, moreníssimo! Como la pez negra!' (14) - de resto entendido como um atributo da masculinidade -, Safo pode beneficiarlhe os traços: 'Deja lo más alto que un hombre alto. Así, en la oscuridad de la alcoba, podré imaginarlo distinto, tal como lo habéis concebido vosotras dos'.

No entanto, não é esse tipo de criação programada o que constitui a excelência da escola. A essa tendência natural, a Safo de Pociña opõe uma crítica (5): 'Últimamente nos estamos pasando con tantos epitalamios. (...) Le estamos dando demasiada entrada a hombres hermosos en nuestros versos. Quizá también en nuestras existências. Es preciso retornar de nuevo a nosotras mismas'. Dignas e desejáveis são as composições genuínas, que surgem espontaneamente a compasso com o próprio explodir dos sentimentos, como sua verbalização rigorosa ${ }^{34}$. Paixão, ciúme, ódio são tão poderosos quanto os próprios deuses na promoção do êxtase artístico. A poesia configura-se então como a sua análise e descrição minuciosa. Mas faz parte do talento colorir ou transformar a realidade com os recursos inesgotáveis da poesia ${ }^{35}$.

É típico da produção de Safo recorrer à simbologia, e os astros são manifestamente um recurso da sua preferência. A noite, por exemplo, com o seu silêncio e sombras, é uma moldura bela para o desenho da solidão e do abandono amoroso (4; cf. fr. 168B Voigt): 'Ya se ha puesto la luna y las Pléyades; mediada es la noche, pasando ya la hora, y yo me estoy durmiendo sola'. Mas não é menos próprio, dentro de uma linha tradicional, recorrer ao mito; Fáon pode ser deste motivo o paradigma por excelência. 'Brilhante' de seu nome, o belo barqueiro de Afrodite tinha por dom 'volver locas de amor a todas las mujeres que lo veían' (10). Tornou-se, por isso, símbolo de uma paixão irresistível, a quem nem mesmo Safo (fr. 211) fora capaz de resistir, tanto quanto o afirmam os seus versos ${ }^{36}$. Não se trata de mais do que de um arroubo poético (11): 'Pues ya vés, aquí la tenemos, sana y entera, sentada con nosotras y tan feliz: al final no se ha lanzado desde las peñas, y menos todavía desdeñada por el gran estúpido'. Ao mesmo tempo que desfaz o mito do suicídio de Safo, Pociña, através da voz de Filénis, desfaz uma ilusão que envolve Fáon, o apaixonado, por trás de um brilho aparente simplesmente 'un individuo blandengue, mantecoso, engreído, fátuo’. O poema a Fáon é portanto o produto da arte, daqueles que transforma uma realidade mesquinha num quadro ofuscante de luz e de beleza.

Filénis tem, na peça, o papel de contraponto do amor poético, subtil e virtual que se cria e se exprime em verso no círculo de Safo. Auxilia assim na sua caracterização, por flagrante contraste. Esta é uma visão do amor obediente às Musas e faz sentido dentro de um convencionalismo artístico. Em vez 
da natureza, espontânea ou até brutal, o mundo de Safo 'se reduce a chicas educadas, bien peinadas, bien vestidas, bien habladas, de andar modoso, que bordan, pintan, recitan, cantan ...' (10). Inadaptada a este universo de artifício, Filénis respira outro mundo, aquele em que 'existen esos seres que son los hombres'. Pela sua sensibilidade áspera, concreta, Filénis faz-se ouvir como uma voz dissidente (pelas companheiras, as suas palavras são sentidas como impertinências (7) ou insolências (10)). O amor com que sonha centra-se num homem, forte, vigoroso, másculo. E tem a objectividade de um projecto claro: anseio por um herói viril, do tipo de Páris, que foi capaz de levar Helena a trair todos os seus - marido, filha e pais amados - e a provocar a guerra de Tróia $(8)^{37}$. É na imagem épica da Ilíada que Filénis busca o paradigma; reconhece nos guerreiros aqueus os verdadeiros kaloi kai agathoi, 'hermosos, fuertes y valientes' (10), ainda que os sinta presas de um universo de guerra e de carnificina que já não é aquele em que se move. Não é a honra conquistada no campo de batalha o que lhe suscita apreço, mas a capacidade de um homem belo para se tornar, no acto de amor, herói vitorioso. E apesar de toda a divergência com Safo, há entre as duas uma assonância que se impõe: aquela que a mestra reconhece no poema 16 , de que a beleza de uma parada militar, ou a pujança da cavalaria ou de uma armada, empalidece perante o fulgor irresistível da paixão ${ }^{38}$. O poema é, portanto, a celebração de um sentimento profundo, detentor de uma enorme beleza e superior aos valores masculinos cantados na épica; mas, ao tomar Helena como paradigma de alguém que abandonou casa e família em nome do amor, parece ser também a defesa de uma nova forma de entender a condição feminina, colocando o prazer da satisfação emocional acima da estrita fidelidade conjugal que a tradição recomendava, mau grado os conflitos inerentes. Nesse sentido, está em perfeita consonância com a imagem que Pociña estabelece do círculo de Safo e dos critérios que o regulam, onde o choque entre a moral social e as novas aspirações que a educação do espírito suscita é evidente.

O desfasamento entre as duas expressões do amor - amor ideal versus amor real - tem o seu clímax, na versão de Pociña, num momento central: aquele em que, por insistência das discípulas, é repetido o famoso carme 31 sobre os sintomas do amor e do ciúme. Este tem sido reconhecido como uma primeira e exímia descrição de um sentimento pessoal. A felicidade sublime vê-a uma Safo ciumenta naquele mortal que agora cativa a paixão de uma sua favorita. Esse prazer reservado aos deuses - 'Igual a los dioses me parece el hombre' - é de natureza contemplativa - 'se sienta, te escucha' (9); a vida dentro do quadro está na jovem - que 'dulcemente habla' e 'ríe seductora' -, que finalmente ambos contemplam com sentimentos díspares, 'o homem' com um enlevo divino, Safo com um sofrimento mortal. A ironia é profunda e resulta da doçura da fala e da sedução do riso, que exprime uma cumplicidade íntima e excluidora da amante 
preterida. Esta é, no dizer de F. Brasete ${ }^{39}$, 'uma situação ficcional que coloca, num nível diferente, um eu que fala de um par imaginado, imobilizado pela palavra poética num tempo e espaço indefinidos'. Esta interpretação corrente é incluída por Pociña na forma como as discípulas podem relembrar o poema; nessa perspectiva (9), entendem-no como uma descrição fiel, inspirada na vida, que identifica um mal de amor: 'cuando sientas esas sensaciones al observar a una persona, estate segura de que la amas' ${ }^{40}$. Ainda que expressa em termos concretos, a subtileza dos sintomas alinhados pelo famoso poema sofre, na leitura de Filénis, uma tradução para outro registo, mais consentâneo com uma outra sensibilidade que lhe cabe assumir na peça (9-10): 'A mí me pasa cuando tengo un hombre encima y sabe manejarme, y me domina, me hace sentir dolor y placer, y me hace lanzar gritos, y me conduce al final a las cumbres del gozo'.

Sob forma dramática, Atardecer en Mitilene utiliza vários processos para recriar o ambiente que a tradição atribuiu ao círculo de Safo em Lesbos. O cenário é perfeitamente mediterrânico, o de uma ilha grega do Egeu, nas suas cores, natureza e paladares. $\mathrm{O}$ contexto, aquele que os testemunhos antigos construíram: um grupo destinado a formar filhas de boas famílias para cumprirem a missão que a sociedade grega lhes atribuía, o matrimónio e a maternidade. Mas para o cumprimento deste propósito a escola de Lesbos programou uma estratégia que extrapolou o universo feminino da tradição: mais do que estimular as tarefas próprias da mulher - manter o asseio da casa, preparar refeições -, Safo dirigiu ao espírito o seu maior empenho, usando a poesia como um instrumento formativo de grande valor. Mitilene tornou-se assim um núcleo inovador de cultura e arte. Por fim, numa peça que dá corpo a todo um conjunto de testemunhos recriando uma realidade a que não falta ficção, Pociña faz ouvir a voz da própria Safo nas traduções magníficas com que reproduz alguns dos mais emblemáticos dos seus poemas. 
${ }^{1}$ As citações são feitas por uma versão policopiada do texto, datada de 2009 e amavelmente cedida pelo autor.

${ }^{2}$ Os nomes das jovens são inspirados nas destinatárias dos poemas de Safo ou na tradição em sua volta. É o caso de Gôngila, referida pela Suda s. u. Safo (S 107; cf. frs. 22. 10, 95. 4); de Mégara, aludida também pela Suda e pelo fr. 68a de Safo; de Telesipa, mencionada na Suda; de Girina pelo fr. 82; de Irana pelos frs. 91, 135. Os frs. de Safo são citados por E. Lobel, D. Page, Poetarum Lesbiorum Fragmenta, Oxford University Press, 1963.

${ }^{3}$ É frequente, na poesia de Safo, a menção de elementos de adorno feminino, de que claramente Pociña acompanha a sugestão; cf., e. g., frs. 81, 92, 94. 12-13, 98, 101.

${ }^{4}$ C. Calame, 'Sappho's group: an initiation into womanhood', in E. Greene (ed.), Reading Sappho. Contemporary approaches, Berkeley and Los Angeles, 1996, 117, estabelece nos mesmos termos a relação entre a mestra - a corifeia - e as discípulas - suas coreutas.

${ }^{5}$ Dissimulado mas não inesperado. Já antes Safo manifestara suspeitas sobre uma conivência entre Filénis, uma das suas discípulas, e o Porteiro (5) nos seus encontros fugazes nas lidas da casa.

${ }^{6}$ Este texto de A. Pociña foi publicado em A. Pociña e A. López (2007), Otras Medeas: nuevas aportaciones al estudio literario de Medea, Granada: 175-197.

${ }^{7}$ Não deixa de ser sugestiva a semelhança que existe entre este quadro e, por exemplo, o relatado por Platão no Protágoras 15 b-c, onde um grupo de jovens, curiosos de saber, se dispõem em volta de Hípias, um sofista da moda.

8 'Sappho's amatory language', in Greene 1996: 14 sqq.

9 D. Yatromanolakis, 'Alcaeus and Sappho', in The Cambridge Companion to Greek Lyric, Cambridge, 2010, 216, sintetiza as diversas hipóteses sobre o papel de Safo no seu círculo: como educadora; responsável por um culto; regente de um coro de raparigas; poetisa que produzia para um grupo feminino. E lembra como todas estas interpretações provêm, com todas as dúvidas que as condicionam, da representação de Safo na ficção literária. Sobre o tipo de relação existente entre Safo e o seu círculo, vide ainda A. Lardinois, 'Subject and circumstance in Sappho's poetry', TAPhA 124, 1994, 57-84.

${ }_{10}$ Calame, in Greene 1996: 113 fala de um grupo com a função de iniciar jovens na vida social e de promover a passagem da adolescência para a maturidade das suas pupilas. Thíasos é uma palavra nunca usada nos frs. que nos restam de Safo, embora the tenha sido aplicada por vários comentadores (vide A. L. Klinck, 'Sappho's company of friends', Hermes 136. 1, 2008, 24-25). Equivaleu a 'festa, cortejo festivo', e designou na época clássica sobretudo os ritos dionisíacos. A ideia de que o grupo fosse uma hetaireia, uma espécie de clube de adultos, foi defendida por H. N. Parker, 'Sappho schoolmistress', TAPhA 123, 1993, 309-351; e contestada por Lardinois 1994: 76, com base no argumento de que uma hetaireia, entendida na versão masculina, constituía um grupo politicamente activo e com representação pública, o que não era o caso do círculo de Safo. Na verdade, ainda que sujeitos a um esclarecimento ou precisão, ambos os vocábulos têm mesmo assim alguma propriedade se aplicados ao círculo de Safo.

${ }^{11}$ A Suda fala de mathetriai, 'discípulas' (253 Voigt). Pociña opta por fórmulas de tratamento mais genéricas, que talvez não captem as nuances que os termos gregos comportam; 'chicas' ou 'muchachas' são os vocativos que a sua Safo usa para com as companheiras, que lhe retribuem com o de 'señora' ou 'maestra'.

${ }_{12}$ Também Calame, in Greene 1996: 118 salienta, como típico da poesia coral arcaica, um carácter performativo, e a execução dos poemas actos de culto em contextos de ritual. Entre os estudiosos de Safo, a possibilidade de que o seu círculo tivesse uma função religiosa continua a ser muito discutida. A participação, com epitalâmios, nos rituais de casamento é o único contexto indiscutível para essa vinculação.

${ }^{13}$ Vide J. R. C. Martyn, 'Sappho and Aprodite', Euphrosyne 18, 1990, 204-208, que avalia o sentido sacro dos diversos elementos que delineiam este reduto que aguarda a vinda de Afrodite.

${ }^{14}$ Para Martyn 1990: 205, este poema representa 'uma sesta altamente sensual, num dia quente de primavera, disfrutada por um par de amantes'. Para Page 1955: 40-43, a epifania de Afrodite seria meramente subjectiva, a marcar o prazer erótico que anima o par. Sobre esta controversa questão, vide ainda Klinck 2008: 15-29. 
${ }^{15}$ Ch. Segal,'Eros and incantation: Sappho and oral poetry', Arethusa 7.2,1974, 140 valoriza o modo como a poesia de Safo privilegia 'situações de encontro' e a sua tendência para evocar Afrodite e a trazer à presença de quem fala nos seus poemas; a este processo poético não é alheio, na opinião de Segal, um toque de magia.

${ }^{16}$ Uma análise minuciosa deste poema foi feita por D. Page, Sappho and Alcaeus, Oxford University Press, 1955, 3-18; C. M. Bowra, Greek Lyric Poetry, Oxford University Press, ${ }^{2} 1961$, 198-205. Sublinha Bowra o tom de invocação ritual na abertura de um poema que é sobretudo a expressão de um apelo pessoal; vide ainda K. Stanley, 'The role of Aphrodite in Sappho Fr. 1', GRBS 17. 4, 1976, 305-321; J. C. B. Petropoulos, 'Sappho the sorceress. Another look at fr. 1 (LP)', Zeitschrift fur Papyrologie und Epigraphik 97, 1993, 43-56.

${ }^{17}$ Afrodite é, no texto de Pociña, o árbitro da paixão realizada. Não lhe falta capricho, nem tão pouco generosidade. Parece reconhecer-se à deusa uma identidade própria, como que uma sobreposição de Afrodite que é desejo com os anseios distintos de cada coração humano (14): 'Se Afrodita la conduce por ese camino: pués hágase su voluntad. Lo importante es que la chipriota te ponga ante los ojos el objecto de tus deseos, sea hombre o mujer'; (17), 'Pero Afrodita dejó de escuchar mis plegarias y de serme propicia demasiado pronto'. Garantida a sua protecção a existência decorrerá feliz (20): 'Afrodita nos inspirará algún recurso, estoy segura. Sé con toda seguridad que no nos fallará en este apuro'.

${ }^{18}$ Também a questão do homo-erotismo praticado em Lesbos é polémica; vide, e. g., A. L. Klinck, "'Sleeping in the bosom of a tender companion"', Journal of Homosexuality 49, 2005, 193-208.

${ }^{19}$ A aplicação a Safo deste paradigma masculino tem sido motivo de muita controvérsia.

${ }^{20}$ Sobre a intervenção pedagógica do círculo de Safo, vide Calame, in Greene 1996: 117120. Klinck 2008: 18-19 assinala quanto são escassas as indicações dadas pela poesia de Safo nesta matéria. Mas não deixa de reconhecer o papel que a arte, privilegiada na escola, pode ter na preparação para a vida, mesmo que se não trate de um programa ou curriculum pedagógico stricto sensu. De uma forma mais enérgica, H. N. Parker, 'Sappho schoolmistress', $T A P h A 123$, 1993, 314 repudia a ideia de 'uma escola' de Safo, e acentua que nunca nos poemas é usada a palavra 'ensinar', associando-se a uma corrente que vem já de Page, 1955.

${ }^{21}$ Projecto semelhante ditou a vinda de Filénis para a escola (10): 'Mi padre y mi madre me han mandado contigo para hacerme una mujer elegante, distinguida, como corresponde a las gentes de su clase'.

${ }^{22}$ Gôngila partilha com Girina a mesma dificuldade, a de deixar um oásis de arte, elevação e elegância, para regressar à mediocridade de um programa de vida previsto (20). Na mãe, Gôngila vê o exemplo instituído: uma vontade débil face à do marido, uma incapacidade de opinar mesmo sobre os assuntos de família; ' $y$ se alguna vez la tienen, tanto peor para ellas, porque su opinión vale menos incluso que la de un criado hombre'.

${ }^{23}$ As nuances estabelecidas por Pociña sobre os méritos ou deméritos particulares de cada discípula sugerem o tom, elogioso ou reprovador, de vários fragmentos de Safo no que se refere a diversas companheiras; cf., e. g., frs. 55, 56, 57, 71.

${ }^{24}$ Sobre o motivo de Heitor e Andrómaca como um quadro de referência para afectos solidários (Pociña 3), cf. Safo fr. 44. Trata-se de uma narrativa, em tom épico, das bodas do famoso casal troiano.

${ }^{25}$ A. Lardinois, 'Lesbian Sappho and Sappho of Lesbos', in J. Bremer (ed.), From Sappho to De Sade. Moments in the history of sexuality, London and New York, 1989, 26 enumera o que podem ter sido alguns aspectos da vivência destes grupos. As jovens participavam em coros como parte da sua educação, como estímulo à noção de disciplina e de prazer estético. Dança e música substituíam, na escola, as tarefas domésticas aprendidas em casa.

${ }^{26}$ Irana corporiza na peça a discípula mais talentosa e mais próxima da mestra. Cf. p. 12, onde Girina se lhe dirige nestes termos: 'Las Musas te colmen de sus dones y te conviertan en la más egregia de las poetas discípulas de Safo'.

${ }^{27}$ Da mesma forma que, em Medea en Camariñas, a amada de Jasão e matricida de Corinto tem oportunidade de comentar ou corrigir as versões que o mito disseminou sobre os episódios da sua vida, também a Safo é dada, neste caso, igual oportunidade. 
${ }^{28} \mathrm{O}$ fr. 49, dedicado a Átis, fala do afecto de alguém mais velho por uma menina. Uma referência à memória de Átis é feita no fr. 96. 15-16, que descreve a dor da separação agora que Átis abandonou Mitilene para regressar à sua terra natal, a Lídia (vide R. Hague, 'Sappho's consolation for Atthis, fr. 96 LP', AJPh 105. 1, 1984, 29-36); o fr. 131 trata justamente da fuga de Átis para a casa de Andrómeda.

${ }^{29}$ Safo dirige a Andrómeda o seu fr. 57 e refere-a nos frs. 131, 133a. Andrómeda foi frequentemente identificada como detentora de uma escola rival da de Safo, mas esta possibilidade é apenas hipotética. Parker 1993: 318 defende que não se pode ir mais longe do que imaginar Andrómeda uma rival de Safo no amor, e não alguém com uma escola concorrente.

${ }^{30}$ De acordo com Yatromanolakis 2010: 218, este teria sido um poema dirigido por Safo contra uma dama rica da cidade.

31 Vide Safo fr. 16. 15-20 sobre Anactória (cf. Suda S 107; Max. Tyr. 18. 9). Ainda que ausente, ela continua a fascinar Safo com o seu andar gracioso e face brilhante; perante o seu encanto, até o fulgor dos carros e da infantaria lídia empalidece. Lardinois 1994: 60 fala de um 'eu' (16. 4) que pode não se identificar com Safo, e de uma Anactória que Ovídio, Heroides 15. 18-19, identificou com uma das discípulas amadas por Safo, o que pode colocar também dúvidas. E será que os sentimentos expressos são autobiográficos ou simples ficção poética? Neste poema, valores femininos, de sensibilidade e beleza, são opostos aos masculinos, de violência e de combate. Sobre a interpretação deste poema, vide G. Koniaris, 'On Sappho, fr. 16 (LP)', Hermes 95, 1967, 257-268; C. Brown, 'Anactoria and the Chariton amarygmata: Sappho fr. 16, 18 Voigt', QUCC 32 (61). 2, 1989, 7-15; H. C. Fredricksmeyer, 'A diachronic reading of Sappho fr. 16 LP', TAPhA 131, 2001, 75-86; E. Dodson-Robinson, 'Helen's “judgment of Paris" and Greek marriage ritual in Sappho 16', Arethusa 43, 2010,1-20.

32 J. P. Hallett, 'Sappho and her social context: sense and sexuality', Signs 4. 3, 1979, 447 considera que esta ideia de que a inspiração de Safo era um toque divino - que lhe valeu o título de $10^{\text {a }}$ Musa $(A P 7.14,9.66,571)$ - adveio da sua condição particular de mulher. Pela sua natureza diferente, pareceu desapropriado aplicar-se-lhe a noção de uma exigência técnica ou de uma prova competitiva, própria do poeta homem.

${ }^{33}$ Sobre a vida de Safo, o que sabemos provém de três fontes: os seus poemas, os diversos testimonia de autores da Antiguidade; e o contexto histórico, de onde se pode inferir alguns elementos sobre a sociedade em que Safo viveu. Os fragmentos são um primeiro manancial de informação; há os que aludem, por exemplo, a familiares, os irmãos (fr. 5), a filha Cleis (frs. 98, 132). Entre os autores tardios - Ovídio, Heroides 15 é neste aspecto relevante - surgiram referências variadas, de veracidade duvidosa, à biografia de Safo. Deu-se nome aos seus familiares; fez-se de Mitilene o cenário da sua vida (finais do séc. VII a. C.); retratou-se a mulher frágil, pequena, não muito dotada de beleza; atribuiu-se-lhe uma tendência homo-erótica responsável por muitos dos seus poemas; romanceou-se-lhe o suicídio - projectada no mar a partir do rochedo de Lêucade, 'a Rocha Branca' -, por incompatibilidade com Fáon, 'Brilhante', objecto da sua paixão.

${ }^{34}$ Assim o exprime Pociña quando diz (16): 'Creedme, no fue una ilusión poética que me haya inventado'; (14): 'Tenía un encanto divino, y yo la ame de verdad. Lo dije más de una vez en mis versos, con sinceridad'. Yatromanolakis 2010: 216 reconhece, em vários fragmentos de Safo, esta mesma sugestão: de que se trata de um grupo de mulheres que entoavam canções a respeito de experiências íntimas.

${ }^{35}$ Segal 1974: 139 identifica, bem a propósito, a poesia de Safo com 'uma forma básica (...) de comunicar conhecimento acerca dos deuses, da sociedade e da natureza da vida humana'.

${ }^{36}$ É expandida por Ovídio, Heroides 15 a ficção acerca da paixão de Safo por Fáon (cf. Men. fr. 258K; Ath. 13. 596b). Em nome desse amor não correspondido, Safo perdeu lira e voz, ou seja, a própria identidade. Restou-lhe o suicídio. Lembra M.Williamson, 'Sappho and Pindar in the nineteenth and twentieth centuries', in The Cambridge Companion to Greek lyric, Cambridge, 2010,356, que, à luz da interpretação romântica a que este mito foi sujeito, se encontrou para o salto do rochedo outros sentidos; porque antes de o consumar, Safo produziu o seu poema mais belo, o salto pode representar, mais do que desespero, um rasgo de ousadia, de libertação e de afirmação poética. Sobre as implicações dos amores de Safo e Fáon, vide Lardinois 1989: 22-23. 
O mesmo Lardinois 1994: 60 n. 14 valoriza o facto de Fáon ser uma figura do mito, próxima de Afrodite, e de a confissão de amor por Fáon feita no poema, que poderia ser, por exemplo, proferida pela deusa, acabar sendo erradamente tomada como autobiográfica. Vide também G. Nagy, 'Phaethon, Sappho's Phaon, and the White Rock of Leukas', HSCPh 77, 1973, 137-177.

${ }^{37}$ Embora não se refira a um poema concreto, é evidente que Pociña pensa no fr. 16 de Safo (vv. 6-10).

${ }^{38}$ Vide Martyn 1990: 210.

39 'Homoerotismo feminino na lírica grega arcaica: a poesia de Safo', in R. A. Ramos, M. C. Fialho, N. Simões Rodrigues, A sexualidade no mundo antigo, Lisboa, 2009, 321.

${ }^{40}$ Este famoso poema tem sido objecto de múltiplas interpretações e discussões. Vários aspectos são particularmente controversos: se a composição é um epitalâmio; quem é o homem que se interpõe entre as duas mulheres; se se trata de Safo e de uma discípula; se o ciúme faz parte deste quadro ou se se trata apenas dos sintomas constantes na paixão. De uma bibliografia extensa recordamos apenas alguns títulos: G. Wills, 'Sappho 31 and Catullus 51', GRBS 8. 3, 1967, 167-197; M. Lefkowitz, 'Critical stereotypes and the poetry of Sappho', GRBS 14. 2, 1973, 113-123; Ch. Segal, 'Eros and incantation: Sappho and oral poetry', Arethusa 7. 2, 1974, 139-160; V. di Benedetto, 'Intorno al linguaggio erotico di Saffo', Hermes 113. 2, 1985, 145-156; O. Tsagarakis, 'Broken hearts and the social circumstances in Sappho's poetry', RhM 129. 1, 1986, 1-17. 

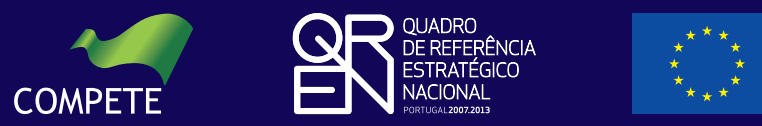